UNIVERSIDADE DE SÃO PAULO

FACULDADE DE EDUCAÇÃO

JOSÉ RICARDO ORIÁ FERNANDES

O BRASIL CONTADO ÀS CRIANÇAS:

VIRIATO CORRÊA E A LITERATURA ESCOLAR

PARA O ENSINO DE HISTÓRIA (1934-1961) 
UNIVERSIDADE DE SÃO PAULO

FACULDADE DE EDUCAÇÃO

JOSÉ RICARDO ORIÁ FERNANDES

\section{O BRASIL CONTADO ÀS CRIANÇAS: \\ VIRIATO CORRÊA E A LITERATURA ESCOLAR \\ PARA O ENSINO DE HISTÓRIA (1934-1961)}

Tese apresentada ao Programa de Pós-Graduação em Educação da Faculdade de Educação da Universidade de São Paulo para obtenção do título de Doutor em Educação.

Área de Concentração: História da Educação e Historiografia

Orientador: Prof ${ }^{a}$ Dra. Circe Maria Fernandes Bittencourt 
Autorizo a reprodução e divulgação total ou parcial deste trabalho, por qualquer meio convencional ou eletrônico, para fins de estudo e pesquisa, desde que citada a fonte.

Catalogação na Publicação

Serviço de Biblioteca e Documentação

Faculdade de Educação da Universidade de São Paulo

371.34(81) Fernandes, José Ricardo Oriá

F363b O Brasil contado às crianças : Viriato Corrêa e literatura escolar para o ensino de História (1934-1961) / José Ricardo Oriá Fernandes ; orientação Circe Maria Fernandes Bittencourt. São Paulo : s.n., 2009.

363 f. il., grafs. tabs.

Tese (Doutorado - Programa de Pós-Graduação em Educação. Área de Concentração : História da Educação e Historiografia) - - Faculdade de Educação da Universidade de São Paulo.

1. Corrêa, Viriato, 1884-1967 2. Livros didáticos - História - Brasil 1930-1960 3. Educação escolar - História - Brasil 4. História - Estudo e ensino 5. Identidade nacional I. Bittencourt, Circe Maria Fernandes, orient. 
FOLHA DE APROVAÇÃO

José Ricardo Oriá Fernandes

O BRASIL CONTADO ÀS CRIANÇAS:

VIRIATO CORRÊA E A LITERATURA ESCOLAR

PARA O ENSINO DE HISTÓRIA (1934-1961)

Tese apresentada ao Programa de PósGraduação em Educação da Faculdade de Educação da Universidade de São Paulo para obtenção do título de Doutor em Educação.

Área de Concentração: História da Educação e Historiografia

Aprovado em:

\section{Banca Examinadora}

Prof Dr.

Instituição: Assinatura:

Prof Dr.

Instituição: Assinatura:

Prof Dr.

Instituição: Assinatura:

Prof Dr.

Instituição:

Assinatura:

Prof Dr.

Instituição: Assinatura: 
Aos meus pais, Francisco Antonio Fernandes e Maria Nila Oriá, pelo apoio e estímulo constantes em minha vida pessoal e profissional.

Aos doze sobrinhos-netos, representantes da infância brasileira do séc. XXI, a quem Tio Ricardo, tomando o exemplo de Viriato Corrêa, conta essa história. 


\section{AGRADECIMENTOS}

O processo de escrita de uma tese é uma das tarefas mais complexas e, muitas vezes, permeada por sobressaltos que afligem a mente do doutorando. A proximidade do prazo de entrega, com o respectivo depósito da tese, deixa-nos aflitos e achando que sempre está faltando alguma coisa a ser escrita, algum autor a ser mencionado, uma citação que poderia explicar melhor aquela passagem do texto. Para completar essa situação, às vezes, em que pese a importância dos mais modernos recursos tecnológicos à nossa disposição, ocorrem problemas na área da informática que nos deixam atônitos e tensos com a possível perda de arquivos do trabalho.

Nesse momento, é sempre bom poder contar com a ajuda dos amigos que, muitas vezes, em meio a dúvidas e incertezas desse processo, nos oferecem o ombro para nos ouvir pacientemente acerca de nossas inseguranças e socorrer-nos quando preciso for.

E, embora a tarefa de elaboração de uma tese seja um trabalho individual e solitário, ela está permeada de idéias e conceitos de outros, resultado de todos esses anos de aprendizagem como pesquisador e professor de História em diferentes níveis de ensino. Sempre acreditei que a vida, a exemplo da História, é um processo de construção coletiva. Nesse sentido, essa tese traz consigo também a "marca" de algumas pessoas que foram importantes em minha trajetória profissional e intelectual. Assim, deixo consignados meus sinceros agradecimentos a todos que, direta ou indiretamente, contribuíram para a conclusão dessa tese, em especial:

À Circe que, mais do que orientadora, foi a amiga e interlocutora que há anos vem se dispondo a trocar idéias acerca da melhoria da qualidade do ensino de História em nosso País;

À Câmara dos Deputados, instituição na qual exerço, atualmente, o cargo efetivo de consultor legislativo da área de educação e cultura, possibilitando-me o afastamento em tempo integral, indispensável para um trabalho de pesquisa desta natureza; 
Aos colegas de trabalho da Consultoria Legislativa, sobretudo aqueles que sempre acreditaram que eu era capaz de produzir esta tese: Helena Heller, Hermínia Munhoz, Heloísa Lobo, Beatriz Rezende e Ricardo Rodrigues;

Aos leitores de Cazuza que deram depoimentos interessantes sobre as memórias de leitura em sua vida escolar: Edmilson Caminha, Cláudia Neves, Luís Henrique Cascelli e Rosa Mossri. Espero que gostem do que escrevi nesse trabalho;

Aos colegas pesquisadores do projeto temático LIVRES, pelo convívio e troca de experiências nesses anos do doutorado, com um carinho especial para Rozélia Bezerra;

Aos professores Maria Helena Capelato e Nelson Schapochnick, pelas valiosas críticas e sugestões por ocasião do exame de qualificação. Espero tê-las incorporado ao presente trabalho;

Aos funcionários do Centro de Memória da Academia Brasileira de Letras (ABL), especialmente a Luis Antonio de Souza e Alice Façanha, da Biblioteca dos Acadêmicos Lúcio de Mendonça, pela presteza no fornecimento de informações e dados para esta pesquisa;

Ao diretor editorial da Companhia Editora Nacional (CEN), Sr. Nicolau Youssef, que abriu as portas dessa instituição e à Sra. Tânia Andrade, responsável pela preservação e administração do Arquivo Histórico da CEN;

À historiadora e conterrânea Isabel Lustosa, da Fundação Casa de Rui Barbosa, que facilitou o acesso do pesquisador ao importante acervo do Museu da Literatura Brasileira dessa renomada instituição, depositária da correspondência de Viriato Corrêa a Ribeiro Couto;

Aos amigos Fábio Carvalho, Leonardo Lemos, Aledio Ferreira, Gilberto Ramos e Wellington Oliveira, que, em diferentes momentos, me acolheram em suas respectivas residências, tornando mais amena e prazerosa minha estada em São Paulo; 
Ao amigo Paulo Knauss, pela hospitalidade e convívio na "Cidade Maravilhosa", quando de minha pesquisa em instituições culturais do Rio de Janeiro;

Às tias Lúcia Oriá, Maria do Carmo Oriá, Cleonice Oriá e Irismar Oriá (in memoriam), pelas orações e estímulo indispensáveis à conclusão deste trabalho;

À Lina Mendes, pela correção do vernáculo e revisão da tese;

À Eliana Spinelli Luciano, pelo excelente e paciente trabalho de editoração da tese em tempo hábil. 
Eu venho das dunas brancas

Da onde eu queria ficar Deitando os olhos cansados

Por onde a vida alcançar

Meu céu é pleno de paz

Sem chaminés ou fumaça

No peito enganos mil

Na terra é pleno abril

Aldeia, aldeota

Estou batendo na porta

Pra lhe aperrear

Pra lhe aperrear

Eu sou a nata do lixo

Eu sou do luxo da aldeia

Eu sou do Ceará

(TERRAL, Ednardo)

Ando devagar

Porque já tive pressa

E levo esse sorriso

Porque já chorei demais

Hoje, me sinto mais forte,

Mais feliz, quem sabe

Eu só levo a certeza de que muito pouco sei

Enada sei

[…]

Cada um de nós

Compõe a sua história

E cada ser em si

Carrega o dom de ser capaz

De ser feliz

(TOCANDO EM FRENTE, Almir Sater) 


\section{RESUMO}

FERNANDES, José Ricardo Oriá. O Brasil contado às crianças: Viriato Corrêa e a literatura escolar para o ensino de História (1934-1961), 2009. 363 f. Tese (Doutorado) - Faculdade de Educação, Universidade de São Paulo, São Paulo, 2009.

A pesquisa trata da produção literária infantil de Viriato Corrêa (1884-1967) dedicada ao ensino de História para alunos da escola primária, a partir da análise da obra História do Brasil para crianças (1934). Fundamenta-se nos pressupostos da História Cultural articulada à História da Educação, baseando-se em análises referentes aos conceitos de disciplina escolar e livro didático. A obra de Viriato é pesquisada em suas articulações com as propostas para o ensino de História na escola primária, cujo objetivo, a partir da década de 1930 até o início dos anos 60, era a construção de uma identidade nacional patriótica. Nessa perspectiva, analisa a concepção de História do autor e a especificidade da narrativa por ele criada, em uma obra que se tornou didática, mas que, igualmente, se insere no âmbito da literatura infantil. Analisa também a produção didática de História que circulava na escola primária, comparando-a com esse livro de leitura, que foi bastante lido pela infância brasileira, tornando-se um best-seller, com 28 edições, grandes tiragens e tendo circulado durante cinqüenta anos no mercado editorial brasileiro. A narrativa de Viriato Corrêa está calcada na idéia de História como "mestra da vida", a partir das "lições do vovô" (personagem criado pelo autor) - que possui experiência e foi partícipe de alguns momentos de nossa história -, na transmissão para as crianças de um conhecimento histórico que valoriza os grandes fatos e heróis nacionais de nosso passado. $\mathrm{O}$ autor segue a tradição do gênero didático "livro de leitura", ao incorporar valores cívicos e patrióticos, mas contempla também fatos pitorescos, curiosos e, até mesmo, anedóticos - uma "história vistosa" -, objetivando despertar nas crianças o interesse e o gosto pela história pátria. Finalmente, a pesquisa aborda a produção da obra de Viriato Corrêa junto à Companhia Editora Nacional (CEN), demonstrando a importância dos diversos agentes que participam da elaboração e difusão do livro, bem como enfatiza os aspectos de sua materialidade na construção de uma leitura para o público infantil. Nessa perspectiva, esta tese incorpora o debate historiográfico sobre as autorias do livro escolar, destacando o papel do ilustrador e do editor na composição de uma relação entre textos e imagens para tornar o livro um artefato cultural mais vendável.

Palavras-Chave: História da educação escolar - Ensino de História - Escola primária História da edição escolar - Livro didático - Identidade nacional. 


\begin{abstract}
FERNANDES, José Ricardo Oriá. Brazil told for children: Viriato Corrêa and the school literature for the teaching of history (1934-1961), 2009. $363 \mathrm{f}$. Thesis (Ph.D.) - School of Education, University of São Paulo, São Paulo, 2009.

The research deals with the childhood literary production of Viriato Corrêa (1884-1967), dedicated to the History teaching for students of elementary school, from the analysis of the work History of Brazil for children (1934). It is based on assumptions of Cultural History articulated to the History of Education, based on analysis concerned to the concepts of discipline and school textbook. Viriato's work is studied in its relations with the proposals for the teaching of History in elementary school, which goal, from the 1930s until the early $60 \mathrm{~s}$, was the creation of a patriotic national identity. From that perspective, it analyses the author's History conception and specificity of the narrative created by him in a work that became didactic, but that, also, inserts itself in the field of childhood literature. It also analyzes the didactic production of History that circulated in the elementary school, compared with that reading book, which was really read by Brazilian childhood, becoming a bestseller with 28 editions, great print runs and having circulated for fifty years in the Brazilian publishing market. The narrative of Viriato Corrêa is based on the idea of History as a "master of life", from the "Pop's lessons" (character created by author), who has experience and has been participant in some moments of our history, in the transmission of a historical knowledge to children, which highlights the major events and national heroes of our past. The author follows the tradition of didactic gender "book reading" to incorporate civic and patriotic values, but also includes picturesque facts, curious, and even anecdotal - a "flash history", aiming to arouse in children the interest and taste for patriotic History. Finally, the research deals with the production of Viriato Corrêa's work near the National Publishing Company (CEN), demonstrating the importance of the various agents involved in the preparation and distribution of the book, and emphasizes the aspects of its materiality in the construction of a reading for the childhood public. At this perspective, this thesis incorporates the historiographical debate about the authorship of the school book, highlighting the role of the illustrator and the editor in the composition of a relationship between texts and images in order to make the book a cultural artefact more salable.
\end{abstract}

Keywords: History of school education - History teaching - elementary school - history of school publishing - textbooks - national identity. 


\section{LISTA DE ILUSTRAÇÕES}

Figura 1 Boletim de Ariel (mensário crítico-bibliográfico), 1934.

Figura 2 A menina do narizinho arrebitado - capa. Primeiro livro infantil de Monteiro Lobato. 45

$\begin{array}{llr}\text { Figura } 3 \quad \text { Coração - capa. } & 80\end{array}$

$\begin{array}{llr}\text { Figura } 4 \quad \text { Coração - capa. } & 80\end{array}$

Figura 5 Le Tour de La France par deux enfants - capa. Clássico da literatura infantil ocidental. 82

Figura 6 Cazuza: memórias de um menino de escola. $\quad 84$

Figura 7 Cazuza - capa adotada a partir da $2^{\mathrm{a}}$ até a $41^{\mathrm{a}}$ edição. 86

$\begin{array}{lll}\text { Figura } 8 \text { Cazuza. } & 88\end{array}$

$\begin{array}{lll}\text { Figura } 9 \quad \text { Cazuza - capa. } & 90\end{array}$

Figura $10 \quad$ Por que me ufano do meu Paiz - capa. 97

Figura $11 \quad$ Contos Pátrios - capa. $\quad 99$

$\begin{array}{llr}\text { Figura } 12 \text { A Patria Brazileira - capa. } & 100\end{array}$

Figura 13 A Patria Brazileira em formato de "livro-prêmio". 101

Figura 14 Dedicatória contida no livro-prêmio A Patria Brazileira. 101

$\begin{array}{ll}\text { Figura 15 Através do Brasil-capa. } & 104\end{array}$

Figura 16 Viriato Corrêa (à esquerda), nas ruas do Rio de Janeiro (s/d). 110

Figura 17 Viriato Corrêa quando jovem (s/d). 112

Figura $18 \quad$ Gaveta de Sapateiro - capa. $\quad 114$

Figura 19 Era uma vez - capa. Primeiro livro infantil de Viriato Corrêa, em parceria com João do Rio. 116

Figuras 20 No paiz da bicharada - capa. $\quad 117$

Figura 21 No paiz da bicharada - contracapa. $\quad 117$

Figuras 22 A macacada e No reino da bicharada. 118

e 23

Figura 24 Marquesa de Santos, de autoria de Viriato Corrêa, com Dulcina de Moraes. 123

Figura 25 Posse de Viriato Corrêa na ABL (1938). 125

Figura 26 Divulgação dos livros infantis de Monteiro Lobato e Viriato Corrêa, na contracapa de 132 outros livros escolares.

Figura 27 Exemplares do Boletim NOVIDADES, da Companhia Editora Nacional. 134

$\begin{array}{lll}\text { Figura } 28 & \text { Contracapa do livro de leitura O Tesouro da Criança. } & 138\end{array}$ 
Figura 29 Histórias da nossa História - capa. $\quad 143$

Figura $30 \quad$ O Brasil dos meus avós - capa. $\quad 144$

Figura 31 Bahú Velho - capa. $\quad 145$

Figura $32 \quad$ Terra de Santa Cruz - capa. $\quad 146$

Figura 33 Contos da História do Brasil - capa. 149

Figura 34 Meu Torrão (contos da história pátria) - capa. 150

Figura 35 A Bandeira das Esmeraldas - capa. $\quad 151$

Figura $36 \quad$ As belas histórias da História do Brasil - capa. 152

Figura 37 Curiosidades da História Brasileira (para crianças). 153

Figura $38 \quad$ História da Liberdade no Brasil-capa. 154

Figura 39 Viriato em sessão de autógrafos do livro História da Liberdade no Brasil, rodeado de 156 crianças (s/d).

Figura 40 Viriato discursando na Academia Brasileira de Letras (s/d). 158

$\begin{array}{llr}\text { Figura } 41 \quad \text { Charge } & 161\end{array}$

Figura 42 Viriato Corrêa (1884-1967, s/d). 164

Figura 43 Benedito Carneiro de Bastos Barreto - Belmonte (1897-1947). 172

$\begin{array}{lll}\text { Figura } 44 \text { História do Brasil para crianças (capa e contracapa) } & 178\end{array}$

Figura 45 História do Brasil para crianças - Capa (reprodução em tamanho original - 15 x $21 \mathrm{~cm}) . \quad 179$

Figura 46 História do Brasil para crianças - Contracapa (reprodução em tamanho original - 15 x $21 \mathrm{~cm}$ ). 180

Figura 47 História do Brasil para crianças - Verso da falsa página de rosto do livro. 181

Figura $48 \quad$ História do Brasil para crianças. 183

Figura 49 História do Brasil para crianças - Índice. 184

Figura 50 História do Brasil para crianças - Índice. 185

$\begin{array}{llr}\text { Figura } 51 \quad \text { História do Brasil - capa. } & 188\end{array}$

Figuras 52 História do Brasil para crianças - capa e contracapa de Belmonte. 188

$\begin{array}{lll}\text { E } 53 & & \\ \text { Figura } 54 & \text { História do Brasil para crianças - Ilustração colorida de Belmonte. }\end{array}$

Figura 55 História do Brasil para crianças - Ilustração colorida de Belmonte. 189

Figura 56 Ficha do Departamento Editorial da CEN - 1935. 191

Figura 57 Catálogo da CEN (1935, p. 62). 193

Figura 58 Catálogo da CEN, 1935 (destaque para o livro História do Brasil para crianças). 194 
Figura 59 Divulgação dos livros de Viriato Corrêa na contracapa do livro Nosso Brasil.

Figura 60 Assinatura da criança na página de rosto ("cicatriz" ou "marca" de leitura).

Figuras 61 História do Brasil para crianças.

e 62

Figura 63 Livro didático de História Sagrada - capa (Ed. FTD).

Figura 64 Pequena História do Brasil para uso da infância brasileira - capa.

Figura 65 Primeiras lições de Historia do Brasil: perguntas e respostas (Edições FTD, s/d).

Figura 66 Resumo da história do Brazil desde seu descobrimento até....(1500-1840).

Figura 67 Nossa Pátria - capa.

Figura 68 História do Brasil - capa.

Figura 69 Historia da Civilização Brasileira para a escola primária - capa.

Figura 70 História do Brasil para crianças (reprodução em tamanho original).

Figura 71 A contadora de histórias - capa do primeiro livro infantil colorido, publicado no Brasil.

Figura 72 História do Brasil para crianças.

Figura 73 História do Brasil para crianças - capa.

Figura 74 História do Brasil para crianças - contracapa.

Figuras 75, História do Brasil para crianças

76 e 77

Figura 78 História do Brasil para crianças - parte da contracapa.

Figura 79 História do Brasil para crianças - lombada.

Figura 80 História do Brasil para crianças - capítulo "Na Colina do Ipiranga".

Figura 81 "Independência ou Morte!" - Quadro a óleo pertencente ao acervo do Museu Paulista.

Figura 82 História do Brasil para crianças.

Figura 83 Quadro “República 1889”.

Figura 84 História do Brasil para crianças.

Figura 85 História do Brasil para crianças.

$\begin{array}{llr}\text { Figura } 86 & \text { História do Brasil para crianças. } & 278\end{array}$

Figura 87 História do Brasil para crianças. 281

Figura 88 História do Brasil para crianças - Ilustração da $1^{\text {a }}$ até a $11^{\text {a }}$ edição. 284

Figura 89 História do Brasil para crianças. 285

Figura $90 \quad$ História do Brasil para crianças. 287

Figura 91 “Domingos Jorge Velho e seu ajudante de campo Antonio Fernandes de Abreu”, 1903.287 
Figura 92 A cidade de ouro. $\quad 289$

Figura $93 \quad$ História do Brasil para crianças. $\quad 291$

Figura 94 História do Brasil para crianças. Capítulo “Cidades que eram aldeias”. 294

Figura 95 História do Brasil para crianças. Capítulo “Costumes dos nossos avós”. 295

Figura 96 História do Brasil para crianças. Tiradentes como alferes. 299

Figura 97 Tiradentes na contracapa do livro $\quad 300$

Figura 98 História do Brasil para crianças. Tiradentes assemelhando-se a um “Cristo cívico" 301

Figuras 99 Osório e Caxias - heróis militares. 304

e 100

Figuras História do Brasil para crianças. Imagens de D. Pedro II. 307

$\begin{array}{lll}101 \text { e } 102 & & 310\end{array}$ 


\section{LISTA DE TABELA E QUADROS}

Tabela 1. Edições e tiragem de História do Brasil para crianças (Arquivo CEN)

Quadro 1. Currículo escolar do curso primário (1946)

Quadro 2. Currículo escolar e História do Brasil para crianças (1934)

Quadro 3. Exame de admissão e História do Brasil para crianças.

Quadro 4. Estilo comparativo entre dois livros escolares

Quadro 5. Imagens dos sujeitos históricos privilegiados em $H B C$. 


\section{LISTA DE ABREVIATURAS}

$\mathrm{ABE}$

$\mathrm{ABEH}$

ABL

ANPUH

BLD

BNDE

BPB

CBL

CEALE

CEDES

CEN

CNLD

COLTED

DIP

EME

EMMANUELLE

FAE

FENAME

FEUFMG

FEUSP

FNDE

$\mathrm{HBC}$

HISTELEA

IBEP

IHGB

INEP

INL

LIVRES

MANES

MEC

PLIDEF
Associação Brasileira de Educação

Associação Brasileira de Ensino de História

Academia Brasileira de Letras

Associação Nacional de História

Biblioteca do Livro Didático da Faculdade de Educação (FEUSP)

Banco Nacional do Desenvolvimento Econômico

Biblioteca Pedagógica Brasileira

Câmara Brasileira do Livro

Centro de Estudos da Alfabetização e Letramento (FEUFMG)

Centro de Estudos Educação e Sociedade

Companhia Editora Nacional

Comissão Nacional do Livro Didático

Comissão do Livro Técnico e do Livro Didático

Departamento de Imprensa e Propaganda

Estatuto, funções e história do manual escolar, Portugal

Banque de Doneés Emmanuelle - INRP, França

Fundação de Assistência ao Estudante

Fundação Nacional de Material Escolar

Faculdade de Educação da Universidade Federal de Minas Gerais

Faculdade de Educação da Universidade de São Paulo

Fundo Nacional de Desenvolvimento da Educação

História do Brasil para crianças

Historia social de la enseñanza de la lectura y la escrita en Argentina

Instituto Brasileiro de Edições Pedagógicas

Instituto Histórico e Geográfico Brasileiro

Instituto Nacional de Estudos e Pesquisas Educacionais

Instituto Nacional do Livro

Banco de Dados Livros Escolares, Brasil

Centro de Investigación MANES - Manuales Escolares, Espanha

Ministério da Educação

Programa do Livro Didático para o Ensino Fundamental 
PNBE

Programa Nacional Biblioteca na Escola

PNLA Programa Nacional do Livro Didático para a Alfabetização de Jovens e Adultos

PNLD Programa Nacional do Livro Didático

PNLEM Programa Nacional do Livro Didático para o Ensino Médio

PNLL Plano Nacional do Livro e da Leitura

SBAT Sociedade Brasileira de Autores Teatrais

SBHE Sociedade Brasileira de História da Educação

SNT Serviço Nacional de Teatro

UECE Universidade Estadual do Ceará

UFC Universidade Federal do Ceará

UNESCO Organização das Nações Unidas para a Educação, a Ciência e a Cultura UNICAMP Universidade de Campinas

USAID Agência Norte-Americana para o Desenvolvimento Internacional USP Universidade de São Paulo 
19 PARTE: A LITERATURA ESCOLAR PARA A INFÂNCIA BRASILEIRA:

LIVROS DE LEITURA E ENSINO DE HISTÓRIA 39

CAPÍTULO 1 - HISTÓRIA DO BRASIL PARA CRIANÇAS: QUE LIVRO É ESSE?.40

1.1 Literatura escolar e literatura infantil: aproximações e separações 44

1.1.1 Primeiros livros para crianças no Brasil .47

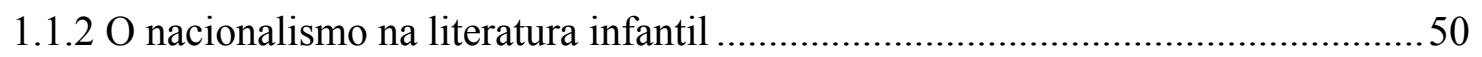

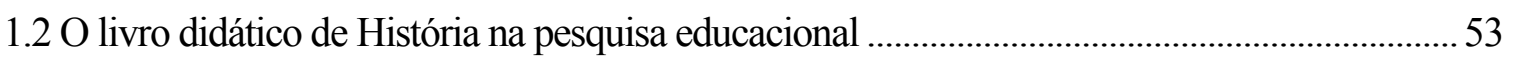

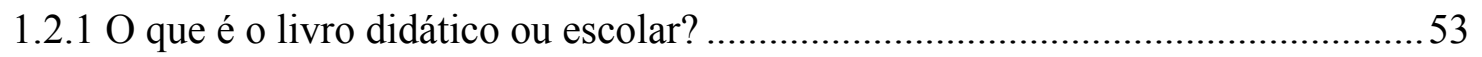

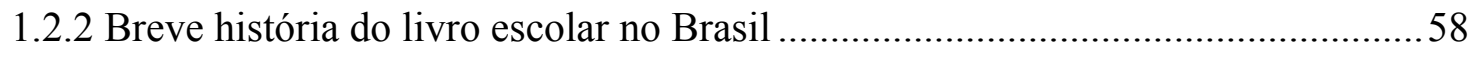

1.2.3 O livro didático de História: debates e pesquisas .................................................66

\section{CAPÍTULO 2 - A PÁTRIA IMPRESSA: OS LIVROS DE LEITURA E A FORMAÇÃO}

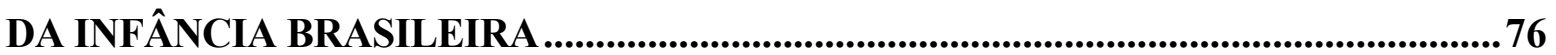

2.1 Livros estrangeiros "fazem a cabeça" das crianças: do Coração ao Cazuza ............................... 77

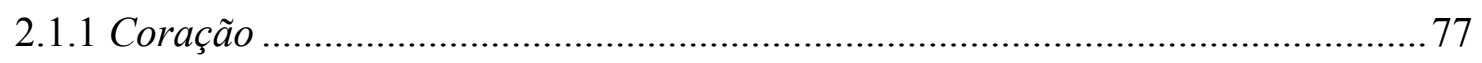

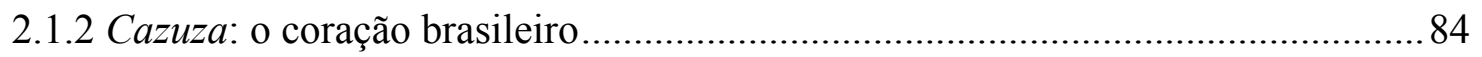

$2.2 \mathrm{O}$ ufanismo patriótico na literatura escolar............................................................................................. 94

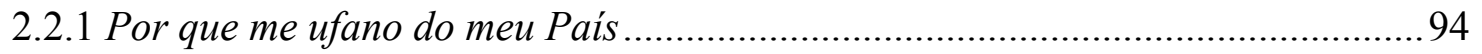

2.2.2 Contos Pátrios e A Pátria Brasileira .................................................................... 98

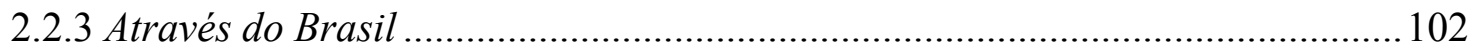

2 ${ }^{\mathrm{a}}$ PARTE: VIRIATO CORRÊA E A COMPANHIA EDITORA NACIONAL..........105

\section{CAPÍTULO 3: A COMPANHIA EDITORA NACIONAL E A LITERATURA}

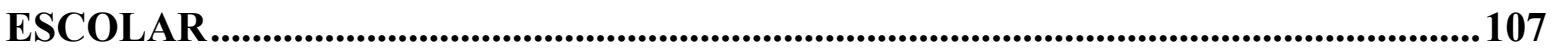

3.1 O autor: Viriato Corrêa e a "vulgarização" da História ............................................................. 108

3.2 Os editores: Monteiro Lobato e Octalles Ferreira ........................................................................... 125

3.3 A Biblioteca Pedagógica Brasileira: Fernando de Azevedo e Viriato Corrêa............................ 134

3.4 Viriato Corrêa e a escrita da história para crianças..................................................................... 141 


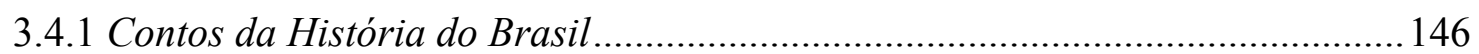

3.4.2 Outros livros infantis com temática histórica .................................................. 150

3.5 A consagração do autor: o ingresso na Academia Brasileira de Letras .................................... 159

\section{CAPÍTULO 4: HISTÓRIA DO BRASIL PARA CRIANÇAS: PROCESSO DE}

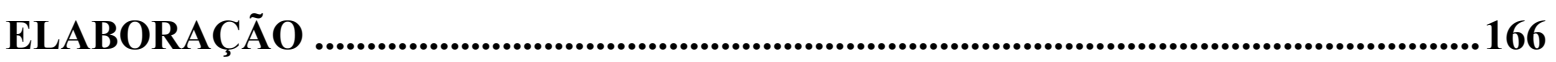

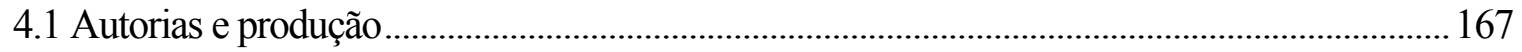

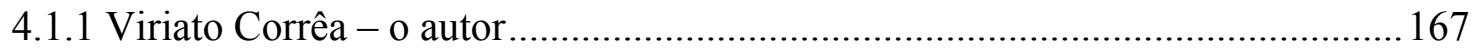

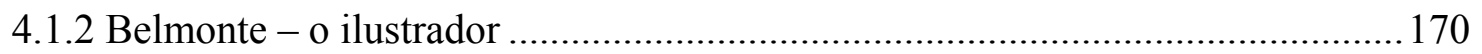

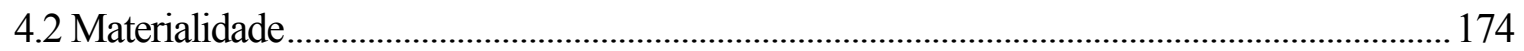

4.2.1 O livro em suas primeiras edições ............................................................... 175

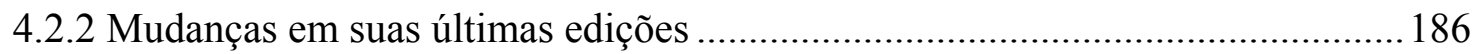

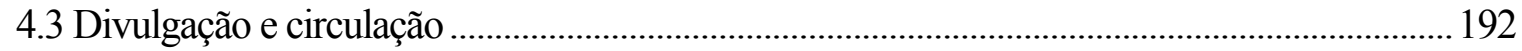

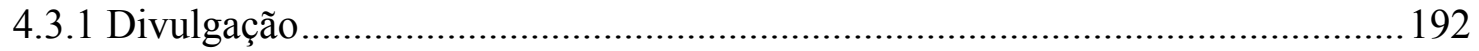

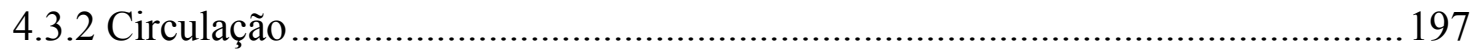

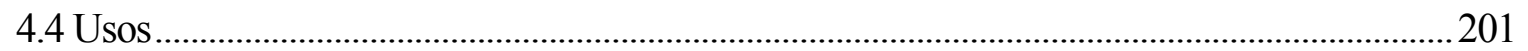

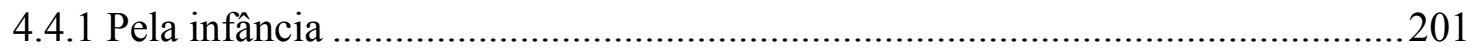

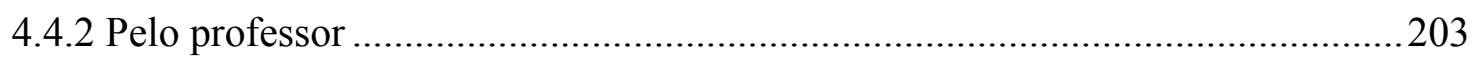

$3^{\text {a }}$ PARTE: HISTÓRIA DO BRASIL PARA CRIANÇAS E O ENSINO PRIMÁRIO206

CAPÍTULO 5: O ENSINO DE HISTÓRIA NA ESCOLA PRIMÁRIA (1934-1961).209

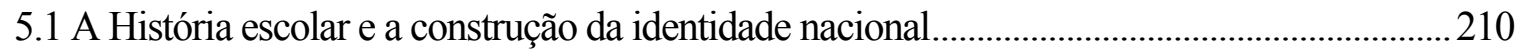

5.1.1 O IHGB e a produção didática no século XIX ……………………...................2212

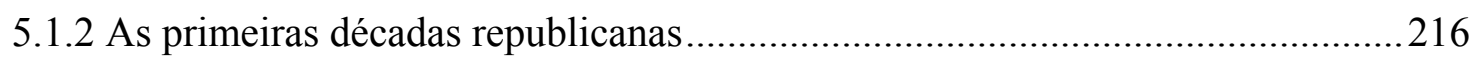

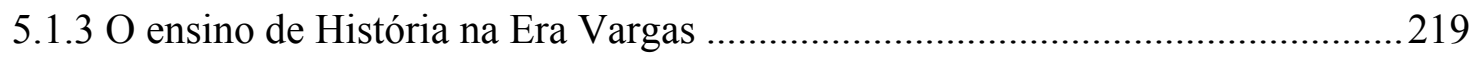

5.1.4 $\mathrm{O}$ ensino de História na segunda metade do século XX....................................222

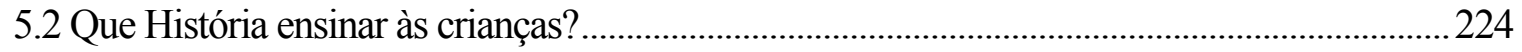

5.2.1 Currículos, programas e métodos de ensino .....................................................224

5.2.2 O ensino da História no Brasil: relatos e críticas ..............................................2229

5.3 A escrita da história para crianças: outros livros didáticos ...........................................................2. 234

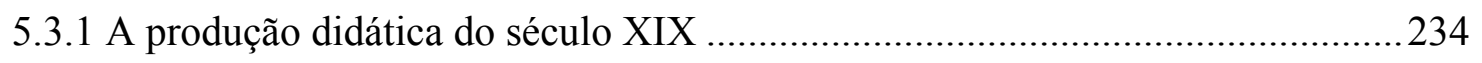

5.3.2 Os livros de maior circulação no século XX ...................................................238 


\section{CAPÍTULO 6 - HISTÓRIA DO BRASIL PARA CRIANÇAS: ENTRE TEXTOS E}

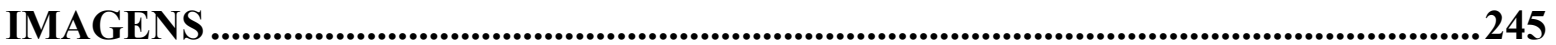

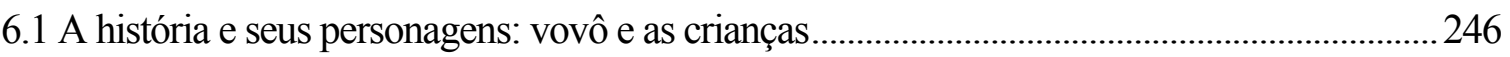

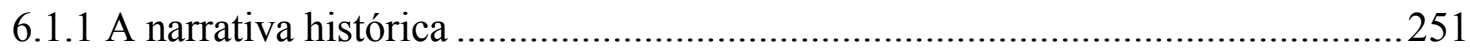

6.1.2 A iconografia em História do Brasil para crianças ...........................................255

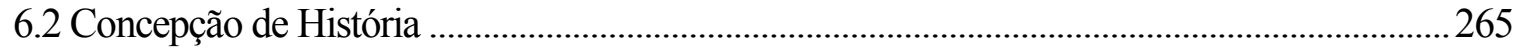

6.2.1 A história de chinelo: entre o pitoresco e o anedótico.......................................265

6.2.2 O ufanismo patriótico: “Sem história não há pátria!’” ......................................268

6.3 Temas de História do Brasil para crianças ....................................................................................2. 270

6.3.1 O mito fundador de nossa História: a democracia racial.................................2270

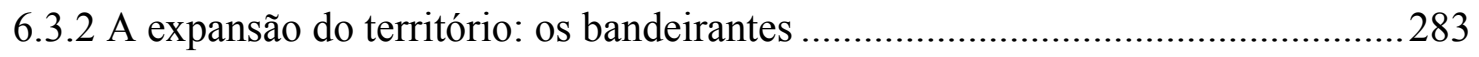

6.3.3 A defesa do território e o sentimento nativista ...............................................290

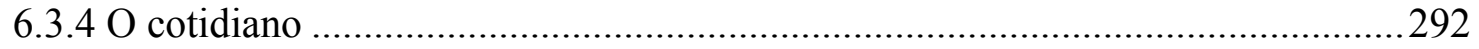

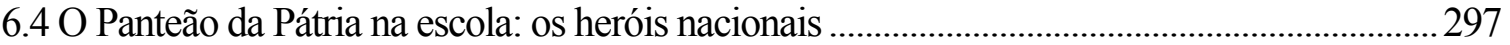

6.4.1 Tiradentes: o herói por excelência..................................................................297

6.4.2 D. Pedro II: “o reinado do homem pacifico".........................................................305

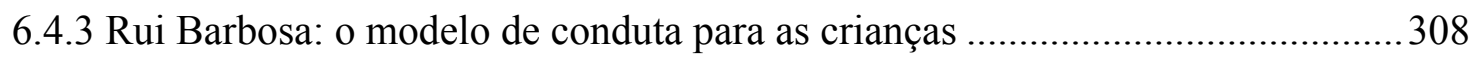

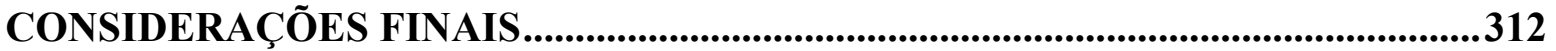

REFERÊNCIAS BIBLIOGRÁFICAS .....................................................................318

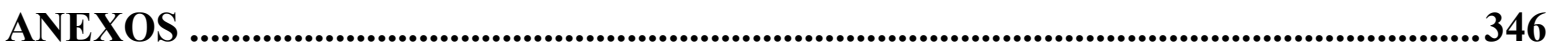




\title{
INTRODUÇÃO
}

Um trabalho de pesquisa reflete e diz muito sobre a trajetória pessoal e intelectual de seu autor. No meu caso, não poderia ser diferente. Estando no segundo ano do curso de Licenciatura em História, na Universidade Estadual do Ceará (UECE), fui convidado para substituir uma professora de História do Colégio Marista Cearense, instituição de ensino em que havia estudado o $1^{\circ}$ e $2^{\circ}$ graus - terminologia educacional usada na época, para o ensino fundamental e ensino médio, respectivamente.

Diante de um grupo de irrequietos adolescentes, cursando a $7^{\mathrm{a}}$ série, o que fazer para tornar o ensino de História mais interessante e próximo da realidade concreta desses alunos? Debatia-me com a falta de interesse da turma e da diminuta carga horária destinada às aulas de História Geral (2 aulas semanais), em meio a um conteúdo assustador, para ser ministrado no ano letivo de 180 dias (da Pré-história até o final da Idade Média). Tarefa quase impossível!

Estava, portanto, numa situação muito semelhante à do professor de História da obra de Moacyr Scliar:

\begin{abstract}
Gostava de ensinar, de modo que arranjei um emprego como professor num colégio público. O salário era baixo, a escola pobre em recursos, mas o que mais me chateava era o fato de que os alunos não davam a mínima para a disciplina. Para que a gente precisa saber dos egípcios, perguntavam, dos faraós, esse caras já morreram há tanto tempo. Eram uns chatos aqueles alunos, e eu já estava ficando com raiva deles e querendo mandar tudo à merda. Antes de largar o colégio, porém, decidi fazer uma última tentativa. Bolei uma brincadeira, uma encenação na qual cada aluno deveria representar um personagem histórico. Para minha surpresa, a coisa entusiasmou a garotada. Era o assunto do dia, na escola: reis, condes, generais, os alunos não falavam de outra coisa. Os outros professores, admirados, me cumprimentavam pela idéia (SCLIAR, 2007, p. 8, grifo nosso).
\end{abstract}

O texto acima remete-nos a um problema fundamental que perpassa a história do ensino de História e com que todo professor depara-se algum dia, em meio a uma crise existencial que coloca em xeque sua profissão de educador: Para que estudar história? Qual a utilidade do conhecimento histórico na escola? Por que estudar o passado, como dizem os 
alunos, se vivemos no presente, estamos no "aqui e agora" e o que interessa é o que eu vou ser no futuro?

Marc Bloch, na sua obra Apologia da História ou o oficio de historiador, revela alguns possíveis entendimentos sobre tais questionamentos.

- "Papai, então me explica para que serve a história." Assim um garoto, de quem gosto muito, interrogava há poucos anos um pai historiador [...] para um escritor, elogio mais belo do que saber falar, no mesmo tom, aos doutos e aos escolares. [...] Decerto, mesmo que a história fosse julgada incapaz de outros serviços, restaria dizer, a seu favor, que ela entretém (BLOCH, 2001, p. 41-3, grifo nosso).

Assim, pus-me na tentativa de mostrar aos meus jovens alunos a importância da História para sua formação integral, com todos os jargões a que temos direito: o estudo do passado ajuda-nos a compreender melhor o presente"; "a história objetiva formar cidadãos críticos e conscientes de seu papel como sujeitos históricos que somos"; "quem não conhece seu passado histórico está fadado a cometer os mesmos erros no presente".

Procurei tornar o ensino de História interessante, mediante a realização de aulas mais criativas e participativas, com o auxílio de recursos pedagógicos da época: projetor de slides, retroprojetor, músicas, filmes etc. Se consegui relacionar métodos de ensino e conteúdos pedagógicos para solucionar o problema não sei. Mas pelo menos tenho a consciência de que fiz muito esforço para tornar as aulas de História menos chatas e cansativas, para "entreter" esses alunos em meio a uma fase difícil e complexa de suas vidas - a adolescência.

Posteriormente, na minha atividade docente, sempre questionei o livro didático adotado pela escola e, muitas vezes, escolhido pela supervisão pedagógica, sem a participação direta do professor. Considerava o livro apenas um recurso a mais e utilizava outros materiais didáticos que o complementassem, na preparação de minhas aulas e para o uso com os alunos. Criticava a literatura escolar da época por não acompanhar os avanços teórico-metodológicos da História e por manter os mesmos conteúdos que se repetiam há décadas, com exercícios que induziam o aluno a apenas memorizar o passado. 
Da crítica passei à ação. Por que não tentar escrever um livro didático destinado às séries iniciais do ensino fundamental? À época, já fazia parte de um grupo de estudos sobre o ensino de História que nasceu com a organização do núcleo regional do Ceará, da Associação Nacional de História (ANPUH), da qual fui diretor no início dos anos 90. Pela ANPUH e com o apoio do Curso de História da Universidade Federal do Ceará (UFC), realizou-se o seminário intitulado Um lugar na escola para a história local (1989). A partir daí, foi constituído um grupo de trabalho para a elaboração de um livro de História do Ceará para crianças.

Muito trabalho nos esperava. A principal dificuldade era adequar o conhecimento histórico produzido na academia a um universo de alunos na faixa etária dos 7 aos 11 anos de idade. Novas pesquisas sobre a História do Ceará estavam sendo produzidas, oriundas dos cursos de pós-graduação, e queríamos que o livro incorporasse novas temáticas, que deveriam contemplar uma história de caráter mais social e não meramente político-administrativo tão comum aos livros escolares de história local.

Durante três anos, escrever, ler e reescrever cada capítulo foi uma tarefa incansável de três professores: Simone Sousa, Zenilde Amora e eu. Como escrever história para uma criança do ensino fundamental que não a induza ao simples exercício da memorização de datas-fatos-nomes? Como escrever numa linguagem coloquial, sem ser simplificadora na abordagem dos fatos históricos? Como usar uma linguagem que não infantilizasse a criança? Como superar a abordagem tradicional dos "círculos concêntricos", presente na maioria dos livros didáticos de Estudos Sociais, que acarretavam um conhecimento histórico atemporal ou apenas contemporâneo? Esses devem ser os questionamentos de todos os professores que se aventuram na árdua tarefa de se dedicar à escrita da história para crianças.

O livro Construindo o Ceará foi publicado pela Fundação Demócrito Rocha, no ano de 1993, e hoje já se encontra na sua $5^{\text {a }}$ edição, após reformulações e atualizações necessárias a um livro didático e às exigências do mercado editorial que, muitas vezes, impõe aos autores uma série de determinações cujo objetivo maior é vender o produto "livro". E eu era, então, um autor de livro didático, uma obra vista como de segunda categoria, sem fornecer prestígio à vida acadêmica. Será que sempre foi assim? Afinal, quem são os autores das obras escolares? 
Na década de 1930, um escritor maranhense, bacharel em Direito e jornalista radicado na cidade do Rio de Janeiro, resolveu escrever um livro de História do Brasil dedicado à infância. Seu nome, Viriato Corrêa (1884-1967). O que o motivou a escrever o livro História do Brasil para crianças, que logo se tornou um best-seller editorial, com tiragens anuais em torno de cinco mil exemplares?

Viriato Corrêa publicou nove livros infanto-juvenis ${ }^{1}$ que abordavam a história nacional, em meio à sua obra mais conhecida - Cazuza: memórias de um menino de escola-, de 1938, considerada um clássico da literatura infantil nacional. Nesta tese de doutoramento, tomo como referência básica o livro História do Brasil para crianças, de 1934, pelos motivos a seguir expostos.

História do Brasil para crianças foi o primeiro livro de Viriato Corrêa que tratou, em 59 capítulos, de grande parte da História do Brasil (da chegada dos portugueses à Proclamação da República), assemelhando-se, portanto, aos conteúdos propostos pelos programas curriculares e presentes nos livros didáticos da época. Essa obra de Viriato foi concebida para integrar a Biblioteca Pedagógica Brasileira (BPB), Série Literatura Infantil (vol. 18), coordenada por Fernando de Azevedo, para a Companhia Editora Nacional (CEN), juntamente com outros livros de Monteiro Lobato e adaptações de livros infantis estrangeiros feitos por este.

História do Brasil para crianças circulou durante 50 anos no mercado editorial brasileiro (28 edições, chegando à casa dos 150 mil exemplares vendidos). E, embora tenha sido enquadrado como um livro de "literatura infantil", recebeu a chancela do Governo Federal, mediante o registro n 966 da Comissão Nacional do Livro Didático do MEC, o que permitiu sua adoção nas escolas públicas de todo o País.

Até o final da década de 1960, o livro era indicado por especialistas e educadores como leitura complementar para o aluno ou sugestão de leitura nos manuais de Didática direcionados à formação do professor da escola primária.

\footnotetext{
${ }^{1}$ São nove livros infanto-juvenis de Viriato Corrêa que abordam a história nacional, a saber: Contos da História do Brasil (para uso das escolas) (1921); A Descoberta do Brasil (1930), História do Brasil para crianças (1934), Meu Torrão (contos da história pátria) (1935), História de Caramuru (1939), A Bandeira das Esmeraldas (1945), As belas histórias da História do Brasil (1948), Curiosidades da História do Brasil (para crianças) (1952) e História da Liberdade no Brasil (1962).
} 
Essa obra foi se tornando o centro dos meus questionamentos pela sua singularidade na história dos livros didáticos: como situar essa produção na história da edição escolar brasileira? Trata-se de uma obra de literatura infantil ou de um livro de leitura? Pode ser considerado um livro didático face ao seu uso e no contexto de um conceito mais amplo do que seja esse objeto da cultura escolar, conforme as concepções de Alain Choppin (1993) e Augustín Escolano (2001)?

As análises sobre livros didáticos têm se multiplicado nos últimos anos, com abordagens diversas e tais perspectivas levaram-me a aprofundar estudos que pudessem contribuir para a compreensão desse polêmico material da cultura escolar. Qual a história de uma obra singular, em meio a uma profusão de "gêneros didáticos" destinados ao ensino de História? Qual a trajetória de seu autor? Como o livro História do Brasil para crianças foi produzido? O que o difere dos demais manuais didáticos do período, adotados na escola primária?

Embora tome como fonte de pesquisa um dos livros infantis de Viriato Corrêa, o presente trabalho não tem como escopo uma análise literária da produção do autor. A pesquisa sobre a história de História do Brasil para crianças insere-se na área de História da Educação, com abordagens que integram a história das disciplinas ${ }^{2}$, do livro didático e dos currículos e programas escolares de História para o ensino primário.

Graças ao repertório da História Cultural, hoje as tendências das pesquisas em História da Educação articulam-se aos problemas dos saberes pedagógicos e das práticas escolares e da constituição da cultura escolar (JULIA, 2001). Trabalhos de franceses, ingleses e espanhóis, notadamente, possibilitaram o dimensionamento de conceitos fundamentais para a história de uma educação escolar. A história das disciplinas escolares (CHERVEL, 1990) e do currículo escolar (GOODSON, 2008) tem sido abordada em uma perspectiva histórica, de modo a possibilitar a compreensão das permanências e mudanças do saber escolar. O peso da “tradição escolar" explica a relação existente entre o ensino de História e a constituição da

\footnotetext{
${ }^{2}$ Para a análise da história das disciplinas escolares, tomo como referência os trabalhos de André Chervel. Para esse historiador da educação, as disciplinas escolares não são meras vulgarizações ou simplificações de determinadas ciências, com a finalidade de ensiná-las ao público jovem. A Pedagogia, neste caso, apenas contribuiria, com seus métodos de ensino, para adequar o conteúdo científico à assimilação e aprendizagem dos alunos. Segundo Chervel, a história das disciplinas escolares, ao contrário, esforça-se por demonstrar que a escola não se define como um espaço que tem como função a simples transmissão do conhecimento e iniciação de uma determinada ciência. As disciplinas escolares são criações originais do sistema escolar, com a finalidade de cumprir sua função de educar e formar intelectualmente os alunos (CHERVEL, 1990).
} 
identidade nacional. Mas será que a História escolar tem exclusivamente esse objetivo? Que outros componentes curriculares também contribuem para esse fim? Qual o papel do livro didático como instrumento privilegiado da cultura escolar ocidental, nesse processo de se forjar uma dada identidade nacional?

No âmbito da História do Brasil, as décadas de 1930 e 1940 têm sido analisadas na perspectiva de uma educação fortemente centrada na constituição de uma identidade nacional. Nesse sentido, o recorte temporal da pesquisa toma como data-limite o ano de 1934, quando Viriato Corrêa publicou o livro História do Brasil para crianças, considerado verdadeiro best-seller para a época. Na década de 30 do século passado, o País passava por mudanças sociais, políticas, econômicas e, principalmente, educacionais, com a implementação de reformas pautadas no ideário da "Escola Nova" e a recém-criação do Ministério da Educação e Saúde (1931), que trouxe uma série de mudanças institucionais e legais, com tendências de uniformização do ensino secundário, mas também da escola primária. Os livros didáticos tendiam a exercer essa uniformização, tanto que foi criada, em 1938, a Comissão Nacional do Livro Didático (Decreto-Lei $n^{0} 1.006$, de 30/12/1938), que tinha, entre outras, a função de "examinar os livros didáticos que lhe forem apresentados, e proferir julgamento favorável ou contrário à autorização de seu uso" (art. 10, a).

A pesquisa termina em 1961, ano da promulgação da primeira Lei de Diretrizes e Bases da Educação Nacional (Lei no 4.024, de 1961) e da obtenção de reconhecimento do referido livro pelo MEC como manual didático, de acordo com a legislação vigente, que estabelecia regras para o uso do livro nas escolas públicas de todo o País.

Outra pergunta é o porquê da escolha de Viriato Corrêa para uma análise do ensino de História na escola primária. Há três motivos principais: o primeiro refere-se à identificação do autor com a obra de um escritor que se preocupou com o ensino e divulgação da história para crianças, através da produção de vários livros infantis sobre fatos do passado nacional. $\mathrm{O}$ segundo refere-se ao esquecimento a que ficou relegada a obra infanto-juvenil de Viriato, comparada com a de outros escritores do mesmo período (Monteiro Lobato, por exemplo). Acrescente-se a isso, o pouco interesse acadêmico pela rica produção literária de Viriato, constando, até a presente data, apenas dois trabalhos oriundos de programas de pós-graduação 
no País e que se detiveram tão-somente na sua obra mais conhecida - Cazuza ${ }^{3}$. O terceiro motivo é de ordem pessoal, pois em minha memória de vida escolar tive contato com um dos livros de Viriato Corrêa.

Todos trazemos na lembrança a recordação de livros infantis que nos marcaram. Marcel Proust tem toda razão ao afirmar que "Talvez não haja na nossa infância dias que tenhamos vivido tão plenamente como aqueles que pensamos ter deixado passar sem vivê-los, aqueles que passamos na companhia de um livro preferido" (PROUST, 2003, p. 9). Já Ítalo Calvino $^{4}$ (2007, p. 10-1), ao analisar a importância dos clássicos, afirmou com muita propriedade que:

Os clássicos são livros que exercem uma influência particular quando se impõem como inesquecíveis e também quando se ocultam nas dobras da memória, mimetizando-se como inconsciente coletivo ou individual.

Por isso, deveria existir um tempo na vida adulta dedicado à revisitar as leituras mais importantes da juventude. Se os livros permaneceram os mesmos (mas também eles mudam, à luz de uma perspectiva histórica diferente), nós com certeza mudamos, e o encontro é um acontecimento totalmente novo.

A geração brasileira que viveu a infância ou passou pelos bancos escolares entre os anos de 1930 a 1960 teve, com certeza, contato com algum livro de Viriato Corrêa.

Quando eu era menino e estudava em Taperoá, tirei boas notas e ganhei de minha
mãe as obras completas de Monteiro Lobato, que incluíam a História do mundo
para crianças. Eu me apaixonei. Diante da minha animação, ela me deu História do
Brasil para crianças, de Viriato Corrêa. Aos dez anos, minha mãe me trouxe do
sertão para Pernambuco, fiquei interno num colégio aqui no Recife. Na época, para
passar do primário para o ginasial, havia um exame chamado admissão. As matérias
eram Matemática, Português, História do Brasil e Geografia, com prova escrita e
oral. Quando eu respondi a uma pergunta de História do Brasil, o professor -
Antonio Gonçalves de Castro - disse: "A sua resposta está certa, mas você
respondeu da maneira de quem conhece História da Civilização", como se chamava
História Geral. Eu, que era meio convencido, retruquei: "Mas eu conheço". O
professor começou a rir e a me fazer novas perguntas, comigo acertando todas.
Entusiasmado, ele chamou os outros para assistir meu exame. Tudo isso eu devia à

${ }^{3}$ Os trabalhos a que me refiro são: FERRO, Maria do Amparo Borges. Literatura Escolar e História da Educação: cotidiano, ideário e práticas pedagógicas. Tese de Doutoramento. Faculdade de Educação, Universidade de São Paulo (USP), 2000 e PENTEADO, Ana Elisa de Arruda. Literatura Infantil, História e Educação: um estudo da obra Cazuza, de Viriato Corrêa. Dissertação de Mestrado. Faculdade de Educação, Universidade Estadual de Campinas (UNICAMP), 2001.

${ }^{4}$ Para o escritor italiano, "um clássico é um livro que nunca terminou de dizer aquilo que tinha a dizer" (2007, p.11). 
leitura de Dumas, Viriato Corrêa e Monteiro Lobato. Iniciei-me na História com leituras agradáveis. É isso que os historiadores atuais estão perdendo - e eu estou reclamando muito (SUASSUNA, 2004, p. 51-52, grifo nosso) ${ }^{5}$.

As memórias literárias da professora Hilda Lontra na escola primária de São Francisco do Sul, Santa Catarina, também fazem menção a História do Brasil para crianças, embora ela mesma não tenha lembrado o nome de seu autor, atribuindo a Monteiro Lobato a autoria:

\begin{abstract}
Nessa época, ganhei de uma tia rica, com quem dizem assemelho muito, a obra de Monteiro Lobato História do mundo para crianças. Adorei. Devorei. Queria mais, e vieram Viagem ao Céu e Aritmética da Emília. Lembro-me de também haver lido História do Brasil para crianças, mas hoje, vasculhando o acervo lobatiano, penso que tenha inventado esse livro. Imaginação fértil ainda tinha. Nunca gostei do Jeca Tatu, de quem tive notícias por intermédio do Biotônico Fontoura; as ilustrações imitavam a Mazzaropi ou era este que imitava aquele, personagem real de um Brasil sujo e feio que eu desconhecia (LONTRA, 2006, p. 77).
\end{abstract}

Tudo isso nos mostra que, de Taperoá, no interior da Paraíba, ao município de São Francisco do Sul, em Santa Catarina, o livro História do Brasil para crianças circulou nas mãos de várias crianças por esse Brasil afora.

Meu primeiro contato com a obra de Viriato Corrêa deu-se de forma diferente. Não foi através do clássico Cazuza ou de História do Brasil para crianças.

Já adolescente, aos quinze anos, aluno da primeira série do $2^{\circ}$ grau do Colégio Marista de Fortaleza, eis que me deparo com o comovente texto de Viriato Corrêa. Estudávamos a história do Primeiro Reinado e o movimento de resistência ao governo imperial, que ficou conhecido como Confederação do Equador (1824), e o professor de História chamava-se, a exemplo do "pai da história", Heródoto. O livro didático adotado e de uso obrigatório ${ }^{6}$ para todos os alunos era de autoria do historiador pernambucano Armando Souto Maior - História do Brasil, da Companhia Editora Nacional (CEN).

\footnotetext{
${ }^{5}$ Hoje, Ariano Suassuna é "imortal" e ocupa a mesma cadeira de n ${ }^{\circ} 32$ da ABL, que já fora de Viriato Corrêa.

${ }^{6}$ Geralmente, as escolas particulares exigiam de todos os alunos a compra de material didático, sendo o livro componente obrigatório e de uso pessoal do aluno. A falta do livro didático em aula acarretava, muitas vezes, para o aluno a impossibilidade de assistir à aula do professor e merecia advertência comunicada aos pais na agenda do aluno. Na prática, o livro didático tornava-se importante elemento da cultura escolar.
} 
No capítulo sobre a Confederação do Equador, havia uma leitura suplementar intitulada "A morte do Padre Mororó"?

\begin{abstract}
A execução do Padre Gonçalves Inácio de Albuquerque Mororó deu-se na manhã dia 30 de abril de 1825 . Um espetáculo novo para a cidade de Fortaleza - pela primeira vez o povo cearense ia assistir ao fuzilamento de um sacerdote. A cidade acordou vibrando. Ainda não havia nascido o Sol, e já as ruas estavam cheias de rumores. Um toque de clarim aqui, um rufar de tambores além. Quando acabou de amanhecer, abriu-se no céu um maravilhoso sol de festa. Detalhe curioso em nossa história: todos os mártires liberais do Brasil morrem em dias de sol festivo. Como que é uma homenagem da Natureza: o céu se enfeita para iluminar-lhes a morte.

É na praça do quartel que o padre vai ser fuzilado. São sete horas da manhã. Gente, muita gente. Já não cabe na praça uma cabeça de alfinete. Um clarim soa limpidamente na manhã luminosa.

O Padre Mororó aparece escoltado. É uma surpresa para o povo. O Padre Mororó que a cidade inteira conhecia não era o homem que ali estava. $O$ Padre era um homem belo, forte, desenvolto e moço. E o Padre Mororó que ali estava era um homem de cabeça branca, rugas no rosto, envelhecido [...]

Chega-se ao lugar do suplício. O Padre é posto na coluna da morte. Um soldado traz a venda para the atar nos olhos.

— Não - diz o condenado. - Eu quero ver como é isto.

Vem outro soldado para colocar-lhe no peito a pequena roda de papel vermelho que vai servir de alvo aos atiradores.

— Não é necessário - diz Mororó. - Eu mesmo farei o alvo.

E cruza as duas mãos sobre o coração e grita, fortemente, arrogantemente, para os praças:

- Camaradas, o alvo é este!

E com um ar de riso, como se aquilo fosse uma brincadeira:

—E vejam lá! Tiro certeiro, que não me deixe sofrer muito!

Dois segundos, cinco segundos. Um minuto.

- Fogo! - grita o Comandante da Brigada.

Troam os tiros. Mororó tomba, morrendo. A seus pés tinham caído três dedos de sua mão direita, decepados pelas balas" (MAIOR, 1965, p. 277-279).
\end{abstract}

A narração de Viriato sobre aspectos do fuzilamento de Mororó ficaram marcados na minha memória. O historiador francês Marc Ferro tem toda a razão ao afirmar que a história que aprendemos nos bancos escolares permanece indelével em nossas mentes e corações:

\footnotetext{
7 A exemplo de Frei Caneca, em Pernambuco, Padre Mororó foi um dos principais líderes do movimento revolucionário no Ceará, tendo sido fuzilado pela forças imperiais no Largo da Pólvora, juntamente com outros rebeldes que pretendiam a implantação de uma República no Nordeste brasileiro. Após o fuzilamento, esse espaço ficou conhecido como "Praça dos Mártires". Em meados do séc. XIX, em meio ao processo de remodelação da cidade de Fortaleza, a Praça foi apropriada pelas elites locais e transformado em Passeio Público. Hoje, dada a sua significação histórica para o Ceará e a beleza arquitetônica de seu estilo eclético, o Passeio Público é tombado pelo patrimônio histórico e artístico nacional.
} 
Não nos enganemos: a imagem que fazemos de outros povos, e de nós mesmos, está associada à História que nos ensinaram quando éramos crianças. Ela nos marca para o resto da vida. Sobre essa representação, que é para cada um de nós uma descoberta do mundo e do passado das sociedades, enxertam-se depois opiniões, idéias fugazes ou duradouras, como um amor... mas permanecem indeléveis as marcas de nossas primeiras curiosidades, das nossas primeiras emoções (FERRO, 1983, p. 11, grifo nosso).

Quase trinta anos se passaram e, somente quando pesquisava a obra de Viriato Corrêa, deparei-me novamente com o mesmo texto lido na adolescência. Então fiquei sabendo que "A morte do Padre Mororó” era um excerto de seu último livro dedicado às crianças e aos jovens brasileiros. Trata-se de História da Liberdade no Brasil, de 1962, publicada pela Editora Civilização Brasileira ${ }^{8}$.

A partir daí, analisando-se a biografia de Viriato Corrêa, constata-se que ele foi um dos autores mais lidos pela infância brasileira, a exemplo de Monteiro Lobato, e sua produção literária para o mundo infantil era centrada na abordagem de fatos de nossa história. Antes de História da Liberdade no Brasil, Viriato já havia publicado dezenas de livros infantis que tematizavam a história pátria. Um deles - o de maior sucesso entre a garotada e reconhecido oficialmente como livro didático - foi História do Brasil para crianças. É esse livro a fonte principal desta tese, em que analiso o ensino de História para crianças entre os anos 30 a 60 do século passado.

Posso afirmar também que este trabalho tem suas origens em meados dos anos 60 do século passado, marcado por uma infância povoada de contação de histórias de livros infantis pela minha irmã Paula Sandra. Destacavam-se aí a coleção de capa dura vermelha intitulada $O$ Mundo da Criança e revistas de quadrinhos, para ler e distrair-me, em meio às crises de bronquite asmática que me afastavam dos brinquedos e brincadeiras no quintal de casa. Eram essas as únicas leituras autorizadas para além dos livros didáticos da escola, segundo os critérios pedagógicos de minha irmã mais velha, Ana Maria Oriá, professora primária, que me alfabetizou.

\footnotetext{
${ }^{8}$ Esse livro teve grande repercussão à época, tendo servido de inspiração para que os sambistas da Escola de Samba Acadêmicos do Salgueiro fizessem seu enredo baseado nessa obra, para o carnaval de 1967. Era a primeira vez que um acadêmico e escritor vivo recebia uma homenagem de sambistas carnavalescos. Em 1974, o livro teve mais uma edição, patrocinada pelo Instituto Nacional do Livro (INL), o que evidencia as contradições do governo militar brasileiro, ao publicar, em pleno regime de exceção sob o império da censura, um livro sobre a história da liberdade no Brasil.
} 
Mais tarde, na escola, tive contato com os primeiros livros infanto-juvenis que abordavam a história. $\mathrm{O}$ primeiro deles, para mim o mais marcante e que despertou o interesse pelo passado histórico de nosso País, foi As aventuras de Tibicuera, de Érico Veríssimo. Era leitura obrigatória da disciplina Língua Portuguesa, com preenchimento de ficha de leitura, contendo o resumo do enredo da obra, principais personagens e vocabulário com o significado das palavras novas. Lobato também foi companheiro amigo, nas leituras de $O$ Minotauro e $A s$ aventuras de Hans Staden. Interessante agora observar que todos esses livros que li e de que gostei deram-se por intermédio da disciplina de Língua Portuguesa e não de História. Ao ensino de História estava reservado apenas o livro didático, cujo nome infelizmente não recordo, e resumos e estudos dirigidos colocados no quadro-negro, para serem memorizados para as argüições e exames bimestrais.

A questão relativa ao ensino de História no Brasil sempre foi objeto de interesse de educadores, especialistas e, até mesmo, do governo. Intelectuais das mais variadas correntes ideológicas já propuseram mudanças para o ensino dessa disciplina escolar. No final do séc. XIX, o então Deputado Federal Rui Barbosa, ao oferecer parecer sobre a reforma da instrução primária no âmbito da Câmara dos Deputados, fez considerações sobre a didática e a metodologia do ensino de História.

Thaís Fonseca analisou a produção historiográfica sobre o ensino de História e constatou que há "uma sólida tradição de estudos sobre as metodologias de ensino, os currículos e os manuais didáticos, presente no Brasil desde o início do século XX" (FONSECA, 2007, p. 11). Ela cita os trabalhos pioneiros do Prof. Jonathas Serrano (Methodologia da História na aula primária, 1917, Livraria Francisco Alves, e Como se ensina História, 1935, Edições Melhoramentos), nos quais já se discutiam problemas ainda hoje atinentes ao ensino da disciplina História, bem como o uso de novos recursos, como o cinema e a iconografia, na sala de aula.

Apesar de restrito ao ensino de História na escola secundária, não se pode esquecer também o trabalho de Guy de Hollanda, autor do clássico Um quarto de século de programas e compêndios de História para o ensino secundário brasileiro (1931-1956, INEP, 1957). 
No final da década de 1960, a historiadora Miriam Moreira Leite escreveu o livro Ensino da História no primário e no ginásio (Cultrix, 1969), ainda hoje obra de referência para os pesquisadores que se dedicam à história da História ensinada.

No início dos anos 80 do século $\mathrm{XX}$, em meio à crise do regime militar e no bojo do processo de redemocratização do País, assistiu-se a um intenso debate sobre a função social do conhecimento histórico na escola, no contexto da luta pela extinção dos Estudos Sociais e pelo retorno da História ao currículo escolar do ensino de $1^{\circ}$ e $2^{\circ}$ graus. Essa discussão levou à necessidade de reformulação curricular em alguns estados brasileiros, sobretudo Minas Gerais, São Paulo e Rio de Janeiro (BITTENCOURT, 1998), e à publicação de trabalhos que merecem ser citados, dada sua repercussão junto ao professorado: Repensando a História (Marco Zero, 1984), coletânea de textos sobre o ensino da disciplina, organizada pelo Prof. Marcos Silva (USP); O ensino de História: revisão urgente (Brasiliense, 1986), com a proposta de um ensino temático para a disciplina, de autoria de Conceição Cabrini e outros, e o caderno do Centro de Estudos Educação e Sociedade (CEDES, n $\left.^{\circ} 10\right)$, intitulado A prática de ensino de História, organizado pela Prof ${ }^{a}$ Ernesta Zamboni (UNICAMP).

Vale ressaltar o trabalho da Associação Nacional de História (ANPUH), que abriu seus quadros ao ingresso de professores da escola básica, possibilitando, assim, maior aprofundamento das discussões sobre o ensino de História, o que resultou na criação, em 1997, do Grupo de Trabalho (GT) - Ensino de História. A ANPUH tem, nos últimos anos, publicado números especiais, com dossiês temáticos sobre o ensino de História ${ }^{9}$.

Os anos finais do século XX foram contemplados com a publicação de livros oriundos, em grande parte, das dissertações e teses dos programas de pós-graduação em História e/ou Educação, que passaram a tomar como objeto de pesquisa o ensino de História em suas múltiplas abordagens, e das coletâneas de textos de autores de diferentes universidades, versando sobre o assunto. Nesse contexto, não podemos deixar de assinalar os seguintes livros: Caminhos da História ensinada (Papirus, 1993), de Selva Guimarães Fonseca; O saber

\footnotetext{
${ }^{9}$ História em quadro-negro: escola, ensino e aprendizagem (Revista Brasileira de História ${ }^{\circ}$ 19, São Paulo: ANPUH/Editora Marco Zero, setembro de 1989/fevereiro de 1990); Memória, História e Historiografia: Dossiê Ensino de História (Revista Brasileira de História n 25/26. São Paulo: ANPUH/Editora Marco Zero, setembro de 1992/agosto de 1993) e Ensino de História: novos problemas (Revista Brasileira de História $\mathrm{n}^{\circ}$ 36, São Paulo: ANPUH/Humanitas Publicações, 1998). Não podemos deixar de registrar o esforço dos professores da Universidade Estadual de Londrina (UEL) que, através de seu Laboratório de Ensino de História, vêm publicando a revista História \& Ensino, importante espaço para a discussão de relatos de experiência de professores e pesquisas acadêmicas da área.
} 
histórico na sala de aula (Contexto, 1997), organizado pela Prof ${ }^{\mathrm{a}}$ Circe Bittencourt; $A$ História no centro do debate: as propostas de renovação do ensino de História nas décadas de setenta e oitenta (Cultura Acadêmica, 2000), do Prof. Jaime Cordeiro, e A História prescrita e disciplina nos currículos escolares: quem legitima esses saberes (EDUSF, 2000), de Maria do Carmo Martins.

Não se pode deixar de registrar a existência de dois importantes fóruns de discussão sobre o ensino de História. Trata-se do Seminário Perspectivas do Ensino de História, realizado desde 1988, e o Encontro Nacional dos Pesquisadores de História, o último tendo sido realizado nesse ano de 2008 e culminado na criação da Associação Brasileira de Ensino de História (ABEH), cuja função, entre outras, é congregar profissionais que atuem e/ou pesquisem o ensino de História, em todas as suas perspectivas e em todos os níveis de escolaridade.

Em que pese a profusão de trabalhos e livros sobre o ensino de História nos últimos anos, numa perspectiva histórica constata-se que a maioria deles concentra-se em abordagens que priorizam o ensino médio e as últimas séries do ensino fundamental. Grande parte das pesquisas sobre a história da História ensinada, muitas delas já transformadas em livros (GASPARELLO, 2004), tem se restringido a análises que priorizam apenas o ensino de História no nível secundário (ou ensino médio, hoje), a partir da experiência escolar do Colégio Pedro II, que, durante muito tempo de nossa história educacional, serviu de parâmetro para a elaboração dos programas de ensino da escola secundária brasileira.

Poucos trabalhos dedicaram-se à análise do ensino de História para crianças ${ }^{10}$. Talvez isso se deva ao fato de que, durante mais de vinte anos na história da educação brasileira, o ensino de História para crianças tenha sido dado de forma fragmentária, diluído em conteúdos

\footnotetext{
${ }^{10}$ Entre esses trabalhos, podemos citar: BITTENCOURT, Circe M. F. Pátria, Civilização e Trabalho: o ensino de História nas escolas paulistas (1917-1939). São Paulo: Loyola, 1990, que dedica um capítulo à análise do ensino de História na escola primária e as dissertações de mestrado CARVALHO, Anelise M. M. Pregadores de idéias, animadores de vontades: livros didáticos nos anos 1930-40. São Paulo: Pontifícia Universidade Católica (PUC-SP), 1992 e PIRES, Veríssimo Lopes. O Ensino de História nas escolas primárias (19401950). São Paulo: Faculdade de Educação, Universidade de São Paulo (USP). 1996. Mais recentemente, no âmbito do Grupo Memória, História e Educação, vinculado à Faculdade de Educação da UNICAMP, estão sendo produzidos trabalhos significativos que remetem a uma discussão do ensino de História nas séries iniciais do Ensino Fundamental, sobretudo no que se refere à construção de tempo na infância (DE ROSSI, Vera Lúcia Zabongi e ZAMBONI, Ernesta (orgs.). Quanto tempo o tempo tem! Campinas, SP: Alínea, 2003) e à formação de professores para esse nível de ensino (ver Histórias e Memórias do Grupo de Pesquisa In: ZAMBONI, Ernesta et al. (orgs.) Memórias e Histórias da Escola. Campinas, SP: Mercado de Letras, 2008).
} 
de Estudos Sociais e Educação Moral e Cívica, o que contribuiu, sem sombra de dúvida, para o desinteresse dos pesquisadores no estudo desse ensino nessa faixa etária.

Nosso trabalho, pois, pretende contribuir para ampliar a historiografia da educação brasileira, ao propor uma análise do ensino de História na escola primária, entre as décadas de 1930 a 1960, tomando como referência os livros escolares do escritor Viriato Corrêa, sobretudo História do Brasil para crianças.

Para a elaboração deste trabalho, uma longa trajetória de pesquisa foi necessária, sobretudo no que se refere à procura das fontes principais, no caso, os livros infantis de Viriato Corrêa. Como muitos deles já se encontram esgotados e não circulam mais no mercado editorial brasileiro, tivemos que recorrer aos sebos ${ }^{11}$, numa tentativa de buscar 0 maior número de edições possíveis para, segundo Choppin (2004), proceder a uma análise precisa da história da edição de um livro escolar.

Sendo considerado uma produção menor e de uso descartável pelo aluno e o professor, construir a história do livro didático no Brasil tem sido tarefa hercúlea, em um país que ainda não aprendeu a preservar sua memória histórica escolar. Até mesmo as editoras não têm o costume de preservar todas as edições de um mesmo livro didático, alegando, muitas vezes, a falta de espaço adequado para acondicioná-los. Outras nem sequer permitem o acesso do pesquisador a seu acervo histórico (arquivo e biblioteca). No nosso caso, tivemos sorte, pois, à época da pesquisa, existia o Arquivo Histórico da Companhia Editora Nacional (CEN), que nos abriu as portas, viabilizando o trabalho. Mesmo assim, apenas para citar exemplo concreto, a editora não dispunha de todas as edições do livro História do Brasil para crianças, nem tampouco de todos os volumes da obra de Viriato Corrêa. A maior parte dos livros de Viriato foi encontrada em sebos, sobretudo os localizados na cidade do Rio de Janeiro, talvez pelo fato de que o autor tenha passado grande parte de sua vida nessa cidade.

$\mathrm{Na}$ construção da história desse livro escolar, tivemos, muitas vezes, que proceder como um arqueólogo à procura de vestígios de uma cultura material extinta. Assim,

\footnotetext{
${ }^{11}$ Particularmente, considero os sebos verdadeiros espaços de memória da leitura. Em um país que ainda não aprendeu a preservar, de forma eficaz, seu patrimônio histórico, ficaria difícil, para não dizer impossível, a pesquisa na área da história das edições escolares no Brasil. Sobre a importância dos sebos ou alfarrábios para a história das práticas de leitura, consultar DELGADO, Márcia Cristina. Cartografia Sentimental de sebos e livros. Belo Horizonte: Autêntica, 1999 e SECCHIN, Antonio Carlos. Guia dos Sebos das cidades do Rio de Janeiro e São Paulo. $3^{\text {a }}$ ed., Rio de Janeiro: Nova Fronteira, 2001.
} 
recorremos a outras fontes, em bibliotecas e centros de pesquisa, localizados no Rio de Janeiro e São Paulo.

$\mathrm{Na}$ análise de História do Brasil para crianças, foi dada especial atenção, além dos conteúdos, aos seguintes aspectos: materialidade (capa, tipo de encadernação, formato, ilustrações etc.), prefácio e dedicatória (quem escreve e legitima o autor), sumário, o papel da autoria (autor e ilustrador), dos editores (divulgação da obra), entre outros. Como o referido livro não mais circula no mercado editorial desde meados da década de 1980, os exemplares adquiridos em sebos pertenceram a crianças. Numa exploração indiciária, tal como nos sugere Ginsburg (1989), fiz análise das "marcas" deixadas pelo leitor nos livros (assinatura, dedicatória, riscos e rabiscos, anotações nas páginas). $\mathrm{O}$ uso de mais de uma edição do mesmo livro permite, segundo Choppin (2004), o estudo da história da edição escolar, ao mostrar também as modificações feitas pelo autor/editor na obra, no decorrer do tempo.

Além dos livros didáticos de Viriato Corrêa, utilizamos outros manuais escolares de História que foram amplamente usados na escola brasileira, em especial os de autoria de Rocha Pombo ${ }^{12}$, um dos autores mais adotados no ensino primário, durante várias décadas.

O ritual de ingresso da Academia Brasileira de Letras ${ }^{13}$ exige que escritores mais antigos façam a recepção do autor ingressante, mediante discurso em que se mostra a relevância da obra desse autor, justificando, assim, sua entrada no quadro dos "imortais". Por sua vez, o novo acadêmico faz também um discurso em que discorre sobre o patrono e os membros que o antecederam na cadeira que irá ocupar.

Assim, o Centro de Memória da $\mathrm{ABL}^{14}$ dispõe, em seus anais, dos discursos e falas de Viriato Corrêa, por ocasião de sua posse na cadeira de $n^{0} 32$, bem como outros em que ele recepciona novos acadêmicos. Na hemeroteca desse centro, consultei a seção de recortes de

\footnotetext{
${ }^{12}$ Estou me referindo ao livro Nossa Pátria: narração dos fatos da História do Brasil, através da sua evolução, com muitas gravuras explicativas, editado em 1917 e que circulou até o final dos anos 60, numa edição revista e atualizada pelo Prof. Lourenço Filho, com o seguinte título POMBO, Rocha. Pequena História do Brasil: Nossa Pátria. 85a ed. São Paulo: Melhoramentos, 1967.

${ }^{13}$ Sobre os rituais da ABL, consultar EL FAR, Alessandra. A Encenação da Imortalidade: uma análise da Academia Brasileira de Letras nos primeiros anos da República (1897-1924). Rio de Janeiro: Editora FGV, 2000.

${ }^{14}$ O Centro de Memória da ABL fica localizado na cidade do Rio de Janeiro (RJ) e dispõe de acervo com importantes documentos que mostram a trajetória intelectual do acadêmico Viriato Corrêa. Livros, discursos, fotos, jornais de época e homenagens póstumas estão disponíveis ao pesquisador. $\mathrm{Na} A B L$, obtive cópias de todos os discursos proferidos por Viriato e por seus sucessores na cadeira de $\mathrm{n}^{\mathrm{o}} 32$.
} 
jornais, obtendo informações relevantes acerca da vida e da inserção do autor no meio intelectual carioca, tais como reportagens, entrevistas, convites para palestras realizadas pelo mesmo em escolas e associações culturais, lançamentos de seus livros e repercussão de sua obra na imprensa local.

Recorri, também, a diários e relatos memorialistas de outros escritores que conviveram com o autor e prestaram depoimentos sobre sua vida e obra literária, entre os quais cito seus conterrâneos Humberto de Campos e Josué Montello, o crítico literário João Ribeiro, o escritor Moacyr Scliar e o biógrafo G. Hércules Pinto. Os relatos de escritores renomados da literatura sobre aspectos da sua própria vida escolar foram também usados, pois neles há indicações de leituras que lhes influenciaram a formação. Muitas dessas leituras permitiramme concluir que se tratava de "cânones literários escolares".

Outro suporte documental importante para o trabalho foi a correspondência trocada entre Viriato Corrêa e o escritor Ribeiro Couto. Essas cartas revelam o trabalho intelectual do autor e as disputas internas para o ingresso na $\mathrm{ABL}$ e estão depositadas no Museu de Literatura Brasileira da Fundação Casa de Rui Barbosa.

O Arquivo Histórico da Companhia Editora Nacional (CEN) disponibilizou catálogos, mapas e contratos de edição - material esse valioso para a análise de aspectos referentes à cadeia de produção dos livros de Viriato Corrêa (produção, edição, divulgação e circulação). Os mapas de edição e os contratos de edição/reedição dos livros foram importantes para verificar a repercussão da obra do autor no mercado editorial brasileiro.

Fonte documental importante para quem se dedica à história da educação escolar é a legislação educacional, que nos permitiu ver as mudanças curriculares ocorridas no ensino primário e o lugar da disciplina História neste contexto normativo. No período analisado (1934-1961), ocorreram importantes reformas educacionais nos estados, respaldadas pelo movimento escolanovista e, posteriormente, no âmbito federal, com a criação do Ministério da Educação e Saúde (1931), tendo à frente os ministros Francisco Campos e Gustavo Capanema, e com a posterior edição da “Lei Orgânica do Ensino Primário” (1946).

Procurando pistas e indícios, a fim de mostrar a importância de um livro escolar para o ensino de História, utilizei, também, da leitura de manuais de didática e de metodologia do 
ensino dessa disciplina, direcionados à formação do professor primário. O objetivo era verificar até que ponto esses livros faziam indicação de História do Brasil para crianças ao professor, como sugestão para a preparação de suas aulas ou como leitura complementar do aluno.

A tese está dividida em três partes, com dois capítulos cada, que se interligam. O Capítulo 1 procura esclarecer a natureza e o caráter do livro História do Brasil para crianças, ou seja, é ele um livro infantil, didático ou de leitura? O que levou esse livro a ter ampla aceitação junto ao público infantil e a ter circulado durante cinqüenta anos no mercado editorial brasileiro? Faço também uma análise da história do livro didático no Brasil e do atual estado da pesquisa desse importante objeto da cultura material escolar, em especial, os manuais de História.

Como História do Brasil para crianças possui características similares aos livros de leitura existentes em nossa literatura escolar desde a segunda metade dos oitocentos, o Capítulo 2 trata de alguns desses livros, que se tornaram leituras emblemáticas da infância brasileira, verdadeiros cânones literários escolares. Nesse sentido, nossa análise recai sobre as seguintes obras: Por que me ufano do meu país (1900), de Afonso Celso; Contos Pátrios (1904) e A Pátria Brasileira (1909), da dupla Coelho Neto e Olavo Bilac; Através do Brasil (1914), de Manuel Bonfim e Olavo Bilac, e Cazuza (1938), de Viriato Corrêa. Constata-se, pois, que Viriato deixou-se influenciar por esse tipo de literatura escolar, ao possuir, como esses autores, embora com matizes variados, uma visão ufanista de nosso País.

Grande parte da produção literária de Viriato Corrêa, sobretudo a de cunho infantojuvenil, deu-se no âmbito da Companhia Editora Nacional (CEN). Nesse sentido, o Capítulo 3 da segunda parte da tese objetiva mostrar o papel da autoria do livro História do Brasil para crianças, no qual se inclui, além de Viriato, o ilustrador Belmonte. É dado destaque à interlocução estabelecida pelo autor com nomes do movimento escolanovista (Fernando de Azevedo, Anísio Teixeira, Paulo de Albuquerque Maranhão), bem como a importância dos editores (Monteiro Lobato e Octalles Ferreira) na divulgação da obra. No Capítulo 4, analiso a materialidade desse artefato cultural "livro didático", tomando como referência algumas edições de História do Brasil para crianças. 
A última parte, em dois capítulos, pretende analisar os fatores que levaram História do Brasil para crianças a ter tanta aceitação junto ao público infantil, ao ponto de se transformar em livro escolar com parecer favorável e respectivo registro da Comissão Nacional do Livro Didático (CNLD), do MEC. Isso se deve, em grande parte, ao fato de que os temas do currículo escolar de História da escola primária estão presentes no livro de Viriato. No Capítulo 6, daremos ênfase ao conteúdo do livro propriamente dito, numa análise crítica de seu texto, narrativa, concepção de história do autor e iconografia.

A escrita de uma tese é um trabalho demorado, mas extremamente gratificante, sobretudo para quem gosta do que faz e escolheu, como Viriato Corrêa, escrever História por prazer. No momento em que escrevo essa Introdução que, para os manuais de metodologia do trabalho científico, deve ser a última a ser redigida, vêm-me à mente as palavras proferidas pela historiadora Emília Viotti da Costa, quando de uma homenagem, aos quarenta anos de edição do clássico Da Senzala à Colônia:

Toda obra de história é ao mesmo tempo uma visão do passado e um retrato do presente, um diálogo a partir do presente entre o historiador, suas inquietações, seus projetos, de um lado, e os traços deixados pelo passado, de outro. A obra também é expressão das tendências da historiografia, dos debates teóricos, metodológicos e das lutas políticas existentes na época de sua elaboração. Por essa razão toda a obra histórica ilumina tanto o passado quanto o presente, tanto a história quanto a historiografia. Quando deixa de ter valor por sua interpretação do passado, passa a valer como documento que lança luz sobre o tempo em que foi escrita. Ela é ao mesmo tempo expressão de uma época e de um indivíduo, obra pessoal e coletiva (COSTA, 2008, p. 54). 
1 ${ }^{\text {a }}$ PARTE: A LITERATURA ESCOLAR PARA A INFÂNCIA BRASILEIRA: LIVROS DE LEITURA E ENSINO DE HISTÓRIA 
CAPÍTULO 1 - HISTÓRIA DO BRASIL PARA CRIANÇAS: QUE LIVRO É ESSE?

[...] o historiador não é aquele que fala do passado. Ele se serve do que sabe do passado para falar do presente, para compreender o que se passa hoje

(Marc Ferro) $^{15}$

O homem constrói casas porque está vivo, mas escreve livros porque se sabe mortal. Ele vive em grupo porque é gregário, mas lê porque se sabe só

(Daniel Pennac) $^{16}$

${ }^{15}$ FERRO, Marc; JEAMMET, Philippe e GUILBERT, Daniele. Que herança terão nossos filhos? São Paulo: Edições Loyola, 2001, p. 31.

${ }^{16}$ PENNAC, Daniel. Como um romance. Porto Alegre, RS: LP\&M; Rio de Janeiro: Rocco, 2008, p. 150. 
Em dezembro de 1934, a CEN publicou, nos principais jornais e periódicos da época, uma propaganda em que incentivava os pais a presentearem seus filhos com livros infantis da editora:

\footnotetext{
FAÇA SEU FILHO VIVER NO MELHOR DOS MUNDOS: O MUNDO DOS LIVROS

Dificilmente poderá V.S. dar um presente que proporcione à criança tanto prazer e utilidade como o livro. O livro a conserva atenta, ocupada e alegre, prestando também um grande auxílio nos estudos. Dê-lhe, porém, somente o que há de melhor na Literatura Infantil, que são as edições da Companhia Editora Nacional.

Até hoje no Brasil não apareceram melhores livros para as crianças que os da EDITORA NACIONAL, porque são os mais bem escritos, os mais bem traduzidos, os mais fartamente ilustrados (BOLETIM ARIEL, 1934, p. 1, grifo nosso).
}

Após a chamada, a propaganda editorial relacionava dezenove títulos de volumes já publicados. A sua maioria era constituída por livros de Monteiro Lobato (1882-1948) ou clássicos infantis por ele traduzidos. Isso se justifica, em parte, pelo fato de que o autor era um dos fundadores da CEN e conhecido do público infantil desde a década de 1920, quando lançou seu primeiro livro infantil - A menina do narizinho arrebitado. Lobato notabilizou-se também pela tradução de clássicos infantis, a exemplo de Alice no país das maravilhas, de Lewis Carroll, Contos de Andersen e Contos dos Irmãos Grimm, entre outros.

$\mathrm{Na}$ mesma relação, constava o livro História do Brasil para crianças, de Viriato Corrêa (1884-1967), publicado neste mesmo ano de 1934.

A estratégia de lançar livros à época do Natal já fazia parte do marketing editorial usado por Monteiro Lobato, que passou a ser também adotado pela Companhia Editora Nacional (CEN) (HALLEWELL, 1985). 


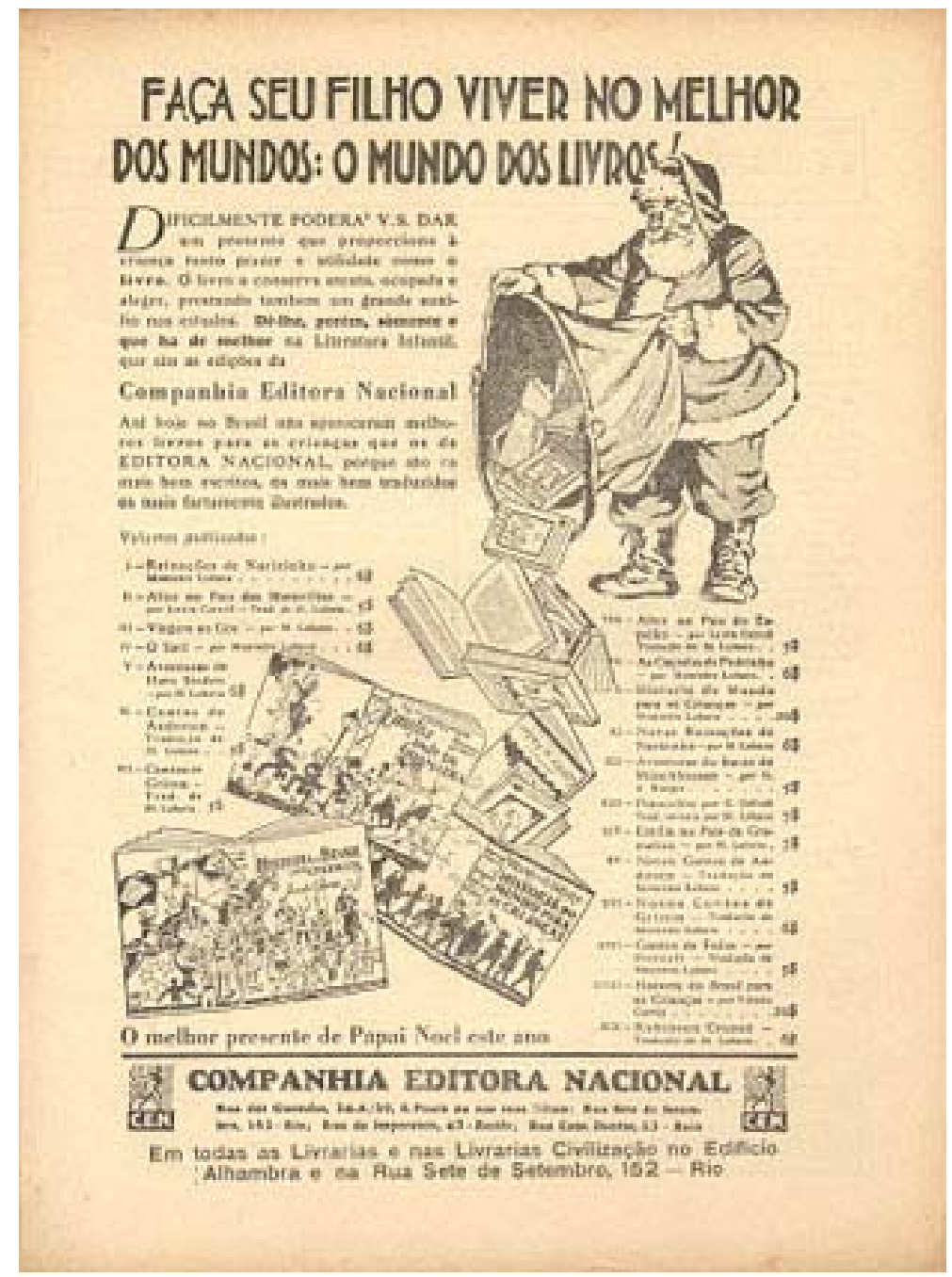

Figura 1 - Boletim de Ariel (mensário crítico-bibliográfico), 1934. Fonte: Acervo Centro de Memória da ABL.

O destaque maior da propaganda está na figura de Papai Noel, que despeja vários livros infantis de seu saco de presentes. A partir dessa ilustração, percebem-se, nitidamente, os títulos de três livros, a saber: Emília no país da gramática, História do mundo para crianças, ambos de Monteiro Lobato, e História do Brasil para crianças, de Viriato Corrêa.

Apesar de ter sua sede em São Paulo, a CEN possuía filiais no Rio de Janeiro, em Recife e em Salvador, o que bem demonstra a sua tentativa de ser realmente, como a propaganda afirma, uma "EDITORA NACIONAL", presente em outros pontos do território brasileiro, além do eixo Rio-São Paulo. Isso nos leva a concluir que o livro História do Brasil para crianças, além de outros de autoria de Monteiro Lobato, teve circulação nacional, podendo ter chegado às mãos de crianças de todo o País. 
Considerando que História do mundo para crianças já havia sido lançado no ano anterior, os dois grandes lançamentos do Natal de 1934 foram Emília no país da gramática, de Monteiro Lobato, e História do Brasil para crianças, de Viriato Corrêa.

Em pouco tempo, História do Brasil para crianças tornou-se um best-seller entre o público infanto-juvenil. O trabalho de divulgação da própria editora contribuiu para esse sucesso:

\begin{abstract}
HISTÓRIA DO BRASIL PARA CRIANÇAS - se há um livro que vai contribuir poderosamente para vulgarizar e tornar atraente a História do Brasil é esse que escreveu Viriato Corrêa. Ele pôs a história pátria ao nível das crianças, mas com tanta fidelidade e tamanha arte de fixar o essencial, que acaba interessando também os adultos. Livro delicioso, admiravelmente ilustrado por Belmonte, de um extraordinário alcance educativo e destinado a realizar por si só, nas escolas, uma grande obra de brasilidade e de espírito nacional. Grosso volume com 59 ilustrações de páginas solidamente cartonado. $4^{\mathrm{a}}$ edição, $20^{\circ}$. Milheiro........10\$000 (Catálogo Geral CEN, 1935, p. 30, grifo nosso).
\end{abstract}

Esse livro surgiu no mercado editorial como parte integrante de uma coleção, a BPB, na série Literatura Infantil, coordenada pelo educador e intelectual Fernando de Azevedo (1894-1974) ${ }^{17}$. Posteriormente, no início da década de 1960, História do Brasil para crianças recebeu o registro da Comissão Nacional do Livro Didático (CNLD), do Ministério da Educação, o que permitiu sua adoção como livro escolar, podendo circular e ser usado em salas de aula de todo o País.

Como, então, caracterizar História do Brasil para crianças? É um livro de literatura infantil? Um livro de leitura? É mais um livro didático, como os demais que circularam no período?

\footnotetext{
${ }^{17}$ Fernando de Azevedo (1894-1974): bacharel em Direito, foi professor de Latim, Psicologia e Educação Física em várias instituições. Integrou o movimento de renovação da educação a partir dos anos 20 e foi diretor da Instrução Pública do Distrito Federal (1927-1930), onde promoveu ampla reforma educacional. Em 1931, coordenou, no âmbito da Companhia Editora Nacional, a Biblioteca Pedagógica Brasileira. Em 1932, foi responsável pela redação do "Manifesto dos Pioneiros da Educação Nova", juntamente com outros 25 educadores e intelectuais de renome nacional. Participou também da fundação da Universidade de São Paulo (1934), chegando, posteriormente, a exercer o cargo de Diretor da Faculdade de Filosofia, Ciências e Letras e de professor catedrático de Sociologia. Entre suas inúmeras obras, destaca-se A Cultura Brasileira (1943), livro escrito como introdução ao Censo de 1940 e considerado uma referência bibliográfica importante para os estudos de História da Educação. Foi eleito para a ABL no ano de 1967, na cadeira 14, anteriormente ocupada por Carneiro Leão (FÁVERO; BRITTO,1999).
} 


\title{
1.1 Literatura escolar e literatura infantil: aproximações e separações
}

Tradicionalmente, os livros de autoria de Viriato Corrêa são considerados como pertencentes ao gênero "literatura infanto-juvenil". A própria Companhia Editora Nacional coloca, ainda hoje, os livros de Viriato nessa categoria, em seus catálogos de divulgação e no sítio da editora na internet ${ }^{18}$.

No Brasil e em outros países ocidentais ${ }^{19}$, é muito difícil estabelecer diferenças marcantes entre a literatura escolar e a literatura infantil. Em virtude de nossa formação histórico-social, com um passado escravocrata e exclusão de amplos setores da cultura letrada, muitas crianças tinham acesso ao livro, seja ele de leitura, didático ou infantil, apenas nos bancos escolares. A partir da expansão da escola primária, nas primeiras décadas republicanas, com o ensino da leitura houve o desenvolvimento da literatura infantil e o crescimento do mercado editorial brasileiro, que passou a se interessar pela demanda desse segmento da população e atender a ela (ARROYO, 1968; RAZZINI, 2005).

Leonardo Arroyo mostra as relações estreitas entre literatura escolar e literatura infantil, nos primórdios da República.

\begin{abstract}
O estudo do desenvolvimento da educação entre nós mostra que somente com a fundação de escolas, formação de professores, advento de livros de texto, possibilitou-se o aparecimento de uma literatura, a escolar, intimamente ligada à literatura infantil propriamente dita. Ou melhor, aquela é a gênese desta na perspectiva do nosso processo de formação. [...] O desenvolvimento do ensino, a abertura de escolas, criaram condições no país para o aparecimento do livro especialmente dedicado à infância. Este nasceu nos bancos escolares vinculados ao sistema de educação, mas logo se tornou independente (ARROYO, 1968, p. 65, grifo nosso).
\end{abstract}

Para elucidar melhor a questão, Arroyo cita o exemplo de Monteiro Lobato. Lobato havia publicado seu primeiro livro destinado às crianças em 1920 - A menina do narizinho

\footnotetext{
${ }^{18}$ Hoje a Companhia Editora Nacional integra, com muitos de seus títulos, a Editora IBEP (Instituto Brasileiro de Edições Pedagógicas), cujo sítio na internet é www.ibep-nacional.com.br.

19 Jean Glénisson adota o conceito de M. Soriano para quem a terminologia "littérature de jeunesse" inclui as obras destinadas a uma ampla faixa etária que vai desde a infância até a adolescência (GLÉNISSON, 1985).
} 
arrebitado $^{20}$. Numa estratégia de marketing e com o objetivo de que o livro chegasse a um maior número de crianças, na capa da segunda edição Lobato colocou, de forma bem nítida, a expressão "segundo livro de leitura para uso das escolas primárias", e distribuiu gratuitamente às escolas e grupos escolares do estado de São Paulo um total de 500 exemplares. Ao visitar as escolas, o então presidente do estado, Washington Luís, percebeu que "em todas as escolas havia um livrinho de leitura, extraprograma, muito sujinho e surrado, que era o preferido da criançada" (BARBOSA, 1982, p. 51). Autorizou, então, seu Secretário de Interior, Alarico Silveira, a adquirir quantidade suficiente do livro para distribuí-lo a todos os alunos do estado. O livro tornou-se, assim, um verdadeiro best-seller infantil.

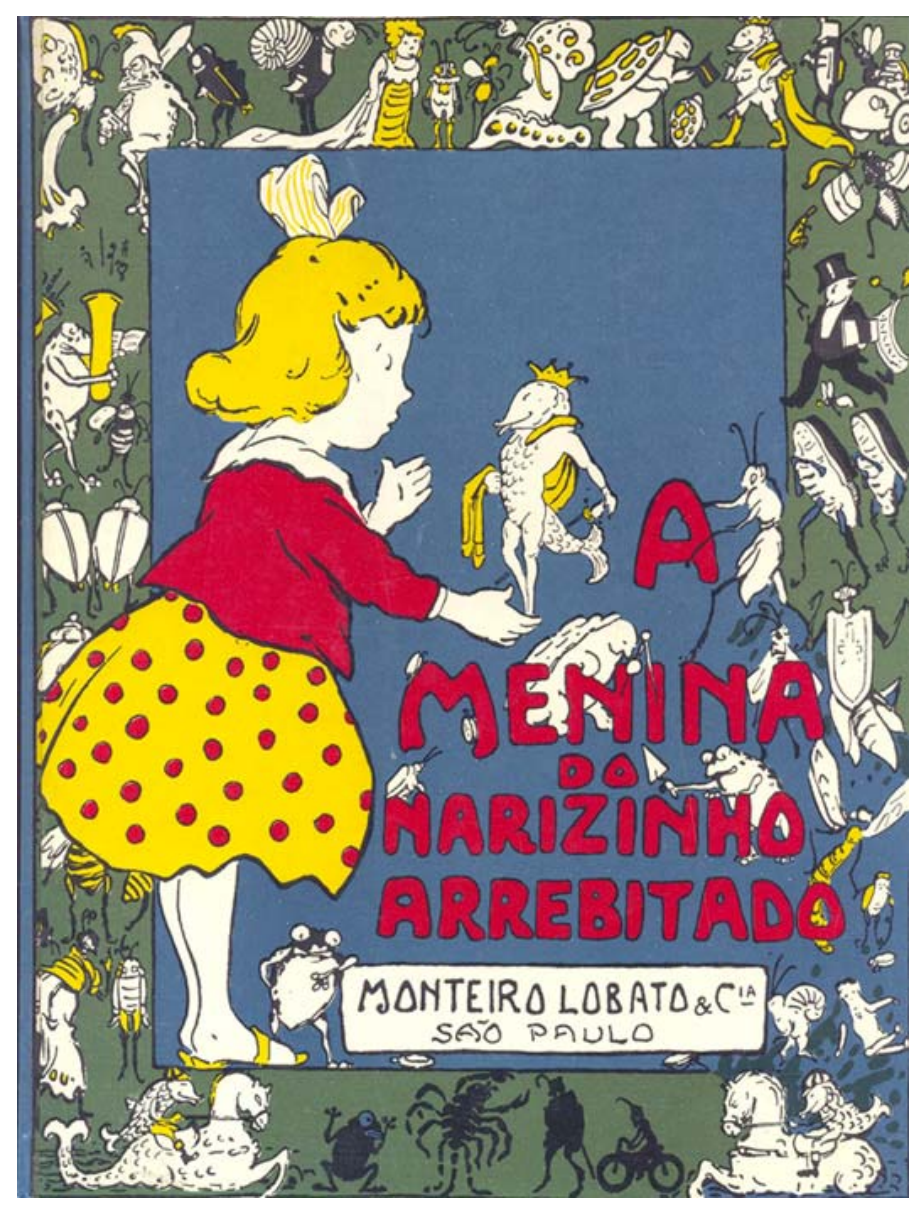

Figura 2 - A menina do narizinho arrebitado - capa. Primeiro livro infantil de Monteiro Lobato.

Fonte: LOBATO, 1920.

\footnotetext{
${ }^{20}$ A menina do narizinho arrebitado, livro de figuras por Monteiro Lobato com desenhos de Voltolino, teve uma tiragem inicial de 50.500 exemplares - número surpreendente para a época em que as tiragens não ultrapassavam três mil exemplares. Em menos de um ano, a tiragem esgotou-se (LOBATO, Monteiro. A menina do narizinho arrebitado. Monteiro Lobato \& Cia, 1920. Edição fac-similar em comemoração ao centenário de nascimento de Monteiro Lobato. São Paulo: Metal Leve, 1982).
} 
Outro exemplo paradigmático da aproximação entre literatura escolar e literatura infantil são os livros de caráter didático de Monteiro Lobato, que produziu ou fez adaptações de livros estrangeiros à realidade brasileira (DEBUS, 2004; EDREIRA, 2001). Nesse rol, enquadram-se os livros História do mundo para crianças $(1933)^{21}$, Emília no país da gramática (1934), História das invenções (1935) ${ }^{22}$, Aritmética da Emília (1935), Geografia da Dona Benta (1935), O poço do Visconde (1937) e Serões de Dona Benta (1937).

Em carta endereçada ao amigo Oliveira Viana, Lobato fez algumas considerações sobre seu primeiro livro infantil que abordou, de forma lúdica e recreativa, o ensino da Língua Portuguesa e da Gramática:

\begin{abstract}
A minha Emília está realmente um sucesso entre as crianças e os professores. Basta dizer que tirei uma edição inicial de 20.000 e o Octales está com medo que não agüente o resto do ano. Só aí no Rio, 4.000 vendidas num mês. Mas a crítica não percebeu a significação da obra. Vale como significação de que há caminhos novos para o ensino das matérias abstratas. Numa escola que visitei a criançada me rodeou com grandes festas e me pediram: 'Faça a Emília no país da aritmética'. Esse pedido espontâneo, esse grito d'alma da criança está indicando um caminho? (LOBATO apud NUNES, 1986, p. 96).
\end{abstract}

Nessa mesma carta, teceu, também, críticas sobre o livro escolar destinado às crianças:

O livro como o temos tortura as pobres crianças - e no entanto poderia diverti-las, como a gramática da Emília o está fazendo. Todos os livros podiam tornar-se uma pândega, uma farra infantil. A química, a física, a biologia, a geografia prestam-se imensamente porque lidam com coisas concretas. O mais difícil era a gramática e a aritmética. Fiz a primeira e vou tentar a segunda. O resto fica canja. $\underline{\mathrm{O} \text { Anísio }}$ Teixeira acha que é toda uma nova metodologia que se abre. Amém (LOBATO apud NUNES, 1986, p. 96, grifo nosso).

\footnotetext{
${ }^{21}$ O livro História do mundo para crianças (1933) tem sua origem no livro Child's history of the world, do professor norte-americano Virgil Mores Hillyer. Segundo Edreira, "não é um livro pequeno, pelo contrário, é o segundo mais extenso do autor, compondo 78 capítulos. Conta a vida humana desde a pré-história até a Segunda Guerra Mundial." (EDREIRA, Marco Antonio Branco. Monteiro Lobato e seus leitores: livros para ensinar, ler para aprender. Revista Brasileira de História da Educação. Campinas, $1^{\circ}$ número, p. 31, 2001). Para abrasileirar a obra, Monteiro Lobato inseriu os personagens do Sítio do Pica-pau Amarelo na narrativa. Posteriormente, esse livro teve tradução e adaptação para o português, sob a responsabilidade do escritor Godofredo Rangel (HILLYER, V.M. Pequena história do mundo para crianças. Tradução e adaptação de Godofredo Rangel. $3^{\mathrm{a}}$ ed., São Paulo: Companhia Editora Nacional, s/d.).

${ }^{22}$ História das invenções foi outra adaptação feita por Monteiro Lobato à obra História das invenções do homem: o fazedor de milagres, do escritor norte-americano Hendrick Van Loon.
} 
Tendo como interlocutor o educador Anísio Teixeira (1900-1971), Lobato aproximava-se do ideário da Escola Nova, que pretendia tornar a criança um sujeito ativo no processo de aprendizagem. Surgia, assim, uma literatura infantil que, com propostas de mudanças nos métodos, tencionava tratar dos conteúdos do currículo escolar, tornando-os menos áridos e mais interessantes para as crianças brasileiras ${ }^{23}$. Isso viabilizou, de certa forma, o sucesso desse autor junto ao público infanto-juvenil, consagrando-o, perante os críticos literários, como o fundador da moderna literatura infantil brasileira (LAJOLO, 2001).

Foi esse o mesmo caminho escolhido por Viriato Corrêa, quando se propôs a escrever o livro História do Brasil para crianças.

\subsubsection{Primeiros livros para crianças no Brasil}

O aparecimento da literatura infantil no mundo ocidental está ligado à ascensão da burguesia e à emergência de um novo sujeito histórico dentro do contexto da família nuclear a criança. A partir do século XVIII, a sociedade burguesa caminhou para a consolidação de um sentimento de infância (ARIÈS, 1981). A preocupação com a criança, não mais vista como um adulto em miniatura, mas um ser com características próprias, fez surgir também a necessidade de se produzirem livros para esse segmento da população.

Embora as primeiras obras publicadas para o público infantil já existissem na Europa desde meados do séc. XVII (Fábulas, de La Fontaine, editadas entre os anos de 1668 e 1694, e os Contos da Mamãe Gansa, de Charles Perrault, de 1697), a literatura infantil brasileira só surge no início do século XX, com o advento da República e de uma preocupação marcante de modernizar o País, em meio a um passado escravocrata e à exclusão de amplos segmentos da sociedade que não tinham acesso à cultura escrita.

\footnotetext{
${ }^{23}$ Cecília Meireles (1901-1964) menciona que esse tipo de literatura infantil de "instrução amena" já era conhecido na Europa desde a segunda metade do séc. XIX, quando o escritor Jean Macé publicou o livro História de um bocadinho de pão (1861). A partir de cartas endereçadas a uma menina, o escritor conseguiu explicar os órgãos e funções do corpo humano. Usava a literatura para ensinar História Natural, como então se dizia na época. O livro fez muito sucesso e foi traduzido para a língua portuguesa, chegando inclusive ao Brasil (MEIRELES, 1984). Segundo Tambara, o livro teve a seguinte tradução: MACE, João. História de um bocadinho de pão - cartas a uma menina acerca da vida do homem e dos animais. Obra adotada pela Inspetoria Geral de Instrução Pública. Rio de Janeiro: R.L. Garnier, 1892 (TAMBARA, 2003).
} 
É bem verdade que já circulavam no Brasil, desde a instalação da Impressão Régia (1808), alguns livros infanto-juvenis traduzidos de autores estrangeiros (ZILBERMAN, 1997). É o caso das obras Contos seletos das mil e uma noites, As aventuras do celebérrimo Barão de Münchhausen, Robinson Crusoé e As viagens de Gulliver (todas elas traduzidas por Carlos Jansen ${ }^{24}$ ). Para meninas, a leitura recomendada eram os livros da Condessa de Ségur, entre os quais podemos citar Os desastres de Sofia e As meninas exemplares. Mesmo assim, a circulação desses livros infanto-juvenis, na sua maioria em edições portuguesas, era bastante precária, irregular e restrita a um grupo seleto de crianças dos setores mais abastados da sociedade brasileira.

O bibliófilo Rubens Borba de Moraes, ao estudar as publicações da Impressão Régia, apontou o livro Leitura para meninos (contendo huma collecção de historias moraes relativas aos defeitos ordinários às idades tenras, e hum dialogo sobre a Geografia, Chronologia, Historia de Portugal, e Historia Natural) ${ }^{25}$ como o primeiro livro infantil publicado em terras brasileiras:

\begin{abstract}
A literatura infantil surge em 1818, com uma obra que fez sucesso, pois foi reimpressa em 1821, 1822 e 1824. É um 'livro de leitura', como se dizia antigamente: Leitura para meninos [...] A obra saiu anônima, mas é de José Saturnino da Costa Pereira, irmão de Hipólito da Costa. Entre muitas obras que deixou, encontram-se outras do mesmo gênero publicadas mais tarde. Foi o primeiro autor brasileiro de livros infantis (MORAES, 1993, p. 29).
\end{abstract}

Esse primeiro período da literatura infantil brasileira também foi "marcado pelo transplante de temas e textos europeus adaptados à linguagem brasileira" (LAJOLO; ZILBERMAN, 1986, p. 17). Exemplo disso foi a obra do escritor Figueiredo Pimentel, que compilou várias histórias infantis da cultura européia e publicou pela Livraria Quaresma os

\footnotetext{
${ }^{24}$ Carlos Jansen (1823-1889) nasceu na Alemanha, mas veio muito jovem para o Brasil e dedicou-se às atividades do jornalismo e do magistério. Nessa atividade, percebeu que no Brasil faltavam livros de histórias para os alunos e, então, passou a traduzir alguns clássicos da literatura infantil ocidental. Segundo Zilberman, Carlos Jansen, Figueiredo Pimentel e Olavo Bilac são os precursores da literatura infantil brasileira (ZILBERMAN, 2005).

${ }^{25}$ Por veicular conteúdos de diferentes disciplinas (Geografia, Cronologia, História Natural e História de Portugal), além de preceitos morais, considero que esse seja o primeiro livro de leitura publicado no Brasil. Essa modalidade de livro - o de leitura - vai ser seguida por autores como Abílio César Borges (1824-1891) - o "Barão de Macaúbas", Felisberto de Carvalho (1850-1898), entre outros, sendo bastante difundido nas escolas brasileiras até a década de 1960.
} 
seguintes livros: Contos da carochinha, Histórias da avozinha, Contos de fadas e Histórias da baratinha.

Em meio à tradução de clássicos para a leitura da infância brasileira, surgem críticas de educadores e intelectuais preocupados com a importância do hábito de leitura desde a mais tenra idade para a formação do cidadão, "formação que, a curto, médio e longo prazo, era o papel que se esperava do sistema escolar que, então, se pretendia implantar e expandir." (LAJOLO; ZILBERMAN, 2002, p. 28).

Nesse contexto, a escola era vista como importante instituição na consecução de tal tarefa - a formação não mais do súdito do Império, mas de um novo cidadão comprometido com o ideário republicano. Assim, no Brasil, a literatura infantil dependeu do processo de escolarização da criança, o que a colocou em uma posição complementar em relação à educação. Isso justifica, de certo modo, a existência de livros infantis que circularam tanto fora como dentro do espaço escolar. Segundo Lajolo e Zilberman (1986, p. 19), “a escola é fundamental enquanto destinatária prevista para estes livros, que nela circulam como leitura subsidiária ou como prêmio para os melhores alunos."

Seguindo a tradição francesa (GLENISSON, 1995), naquela época algumas escolas brasileiras distribuíam livros de literatura infantil como prêmio aos melhores alunos que se destacavam no ano letivo escolar. Os livros-prêmio (livres de prix), como eram conhecidos, geralmente recebiam um tratamento editorial diferenciado quanto à sua materialidade (capa dura, letras douradas, tamanho maior etc.). Essa modalidade de livros teve bastante repercussão no mercado editorial francês (PRÉVOST, 1979). 


\subsubsection{O nacionalismo na literatura infantil}

$\mathrm{Na}$ sua tese de doutoramento, Marisa Lajolo cita o exemplo da obra de Olavo Bilac e Coelho Neto, Contos Pátrios (1904) ${ }^{26}$, editado pela Livraria Francisco Alves, como livro de leitura que circulou amplamente pela escola brasileira. Contos Pátrios, nesse sentido, pode tanto ser um livro de literatura infantil, como um livro escolar, dependendo da forma como foi utilizado, na sala de aula ou fora do espaço escolar. Observa-se, pela dedicatória em livros infantis encontrados em sebos, que os pais e familiares costumavam presentear as crianças com livros em datas especiais (aniversário, primeira eucaristia, Natal etc.).

Para Lajolo (1982), Olavo Bilac e outros intelectuais do período (João Ribeiro, Coelho Neto, Alberto de Oliveira e Manoel Bomfim) foram responsáveis pela criação de uma literatura escolar, na medida em que assumiram "a educação como uma de suas grandes bandeiras." (LAJOLO, 1982, p. 14).

A autora considera que Contos Pátrios, juntamente com outros (ver Capítulo 2), inaugura nova fase da produção de livros para crianças - a do nacionalismo na literatura infantil. São obras de cunho ufanista, que procuravam desenvolver nos pequenos leitores o sentimento de amor à Pátria, mediante a exaltação das riquezas naturais do Brasil e do conhecimento de sua história, através do exemplo edificante dos "filhos ilustres" da terra.

Ao veicular fatos de nossa história, nos quais emergia quase sempre a figura de heróis nacionais, esse tipo de livro pretendia inculcar nas crianças o patriotismo. Antes, porém, fazse necessário definir esse gênero da literatura escolar, que foi bastante usado na escola brasileira - o chamado livro de leitura.

Segundo Circe Bittencourt (1993), "livro de leitura" é um tipo específico de leitura para a infância, que deveria fornecer conhecimentos variados e incentivar o gosto pela leitura. Além disso, esses livros deveriam veicular preceitos morais e cívicos indispensáveis à

\footnotetext{
${ }^{26}$ Essa obra foi feita sob encomenda, a pedido do editor Francisco Alves, que pretendia publicar um livro de educação moral e cívica para crianças. Foi o próprio Francisco Alves que sugeriu o título - Contos Pátrios (CONY, 2004). Ainda hoje, esse livro circula no mercado com a seguinte edição: BILAC, Olavo e COELHO NETO. Contos Pátrios: educação moral e cívica (para as crianças). Belo Horizonte: Livraria Garnier, 2001. Biblioteca de Autores Célebres da Literatura Infantil.
} 
formação da criança e estar de acordo com os programas de ensino. Nessa fase nacionalista da literatura infantil brasileira, esses livros de leitura dedicavam especial atenção aos conteúdos de História do Brasil.

Começaram a ser escritas histórias sobre as tradições brasileiras, informações sobre costumes indígenas, heróis nacionais e seus feitos. Biografias de figuras da história nacional engrossaram, freqüentemente, o repertório desta literatura. Os livros de leitura que se constituíram como mais representativos na divulgação da história nacional foram os de Olavo Bilac, especialmente Contos Pátrios e Através do Brasil (BITTENCOURT, 1993, p. 214).

Para Batista (2002), o livro de leitura, além da sua dimensão formativa, funcionava, muitas vezes, como livro único em sala de aula, razão pela qual trazia um conjunto de conhecimentos vinculados aos conteúdos programáticos do currículo escolar e era objeto de aprendizagem dos alunos.

Particularmente, a grande maioria desses livros de leitura veiculava conteúdos de História do Brasil, razão pela qual considero que a construção do saber histórico escolar davase por intermédio de outras obras, e não apenas através dos livros didáticos dessa disciplina.

É bom ressaltar que esse tipo de literatura escolar de cunho nacionalista perdurou durante muitos anos no mercado editorial brasileiro: "[...] do ufanismo de Afonso Celso, Olavo Bilac e Júlia Lopes de Almeida para o de Viriato Corrêa, Murilo Araújo, Tycho-Brahe, entre outros, não há solução de continuidade, apenas a adaptação às novas circunstâncias." (LAJOLO, ZILBERMAN, 1986, p.163).

Assim, livros infantis com temática histórica vão se constituir numa modalidade de literatura escolar bastante utilizada pelo mercado editorial brasileiro, durante grande parte do período republicano (notadamente até os anos 1950), pois tinham público certo e garantido: alunos do ensino primário em fase de aprendizagem escolar da leitura e da escrita.

Ainda na década de 1930, o próprio Ministério da Educação e Saúde Pública promoveu um concurso para premiar as melhores obras de literatura infantil (GOMES, 2003). O vencedor foi o escritor gaúcho Érico Veríssimo (1905-1975), com o livro As aventuras de 
Tibicuera que são também as aventuras do Brasil. O livro narra a História do Brasil relatada pelo índio que dá nome à obra, como o próprio autor assim explica, na introdução: "aqui estão as aventuras de Tibicuera, contadas por ele próprio. O herói narra sua espantosa viagem que começou numa taba tupiniquim antes de 1500 e terminou num arranha-céu de Copacabana em 1937.” (VERÍSSIMO, 1947, p. 9).

Outro importante autor de nossa literatura que se dedicou à escrita da história para crianças foi o alagoano Graciliano Ramos (1892-1953). Ele escreveu o livro Pequena História da República ${ }^{27}$, em pleno Estado Novo (1937-1945). Enquanto os demais livros escolares da época apenas abordavam os fatos históricos até o início da República, o autor narrou, de forma crítica e bem-humorada, a história recente do País:

\begin{abstract}
Os homens maduros de hoje eram meninos. O sr. Getúlio Vargas, no sul, montava em cabos de vassoura; o sr. Ministro da Guerra comandava soldadinhos de chumbo; o sr. Ministro da Educação vivia longe da escola, porque ainda não existia.

Nesse tempo, o chefe de governo, o sr. D. Pedro II, Imperador, dispunha de longas barbas respeitáveis e nas horas de ócio estudava hebraico, língua difícil, inútil à administração e à política. Todos os homens notáveis e idosos eram barbudos, conforme se vê em qualquer História do Brasil de perguntas e respostas (RAMOS, 1981, p. 135, grifo nosso).
\end{abstract}

Com receio da censura e possível repressão política ao autor, que, em outra ocasião, já havia sofrido na prisão, o livro só foi publicado na década de 50. Embora pouco conhecida dos leitores e estudiosos da literatura escolar, Pequena História da República "continua sendo exemplar, pois o escritor oferece uma visão crítica e audaciosa de importante período da trajetória nacional, nem sempre suficientemente estudado." (ZILBERMAN, 2005, p. 40).

Parto do pressuposto de que o ensino de História, através de seus conteúdos e temas, não está restrito aos livros didáticos propriamente ditos, nem tampouco ao espaço da sala de aula. A construção do saber histórico também se dá por outras vias, tais como os meios de comunicação (jornal, rádio, cinema, televisão), a comemoração de datas cívicas, a visita a museus, o estudo do meio com a observação dos bens culturais pertencentes ao patrimônio

${ }^{27}$ O livro Pequena História da República encontra-se atualmente publicado no interior de outro livro de Graciliano Ramos, Alexandre e outros heróis, também dedicado ao universo infantil, em que o autor recorre à tradição folclórica brasileira, para narrar as aventuras do personagem-título (RAMOS, Graciliano. Alexandre e outros heróis. $20^{\mathrm{a}}$ ed. Rio de Janeiro: Record, 1981). 
histórico e, mais recentemente, com os novos suportes de informação (internet, CD-rom, multimídia, DVD, audiolivro, entre outros).

Entretanto, nos anos 30 do século passado, dispúnhamos apenas do jornal, do rádio, do cinema e de revistas como meios de comunicação. Desse modo, o conhecimento de temas de história por parte da infância brasileira dava-se principalmente na escola, e o livro didático exercia um papel importante nesse contexto, razão pela qual muitos intelectuais brasileiros, desde o início dos tempos republicanos, dedicaram-se à escrita da história para crianças, seja através de livros de leitura, ou de livros de literatura infantil que tematizavam a história pátria.

É nesse contexto que se insere o livro História do Brasil para crianças, de Viriato Corrêa, publicado pela Companhia Editora Nacional e que circulou no mercado editorial brasileiro durante cinqüenta anos (1934-1984).

\subsection{O livro didático de História na pesquisa educacional}

\subsubsection{O que é o livro didático ou escolar?}

O que vem a ser o livro didático ou escolar? Qual o papel do livro didático nos dias de hoje, em pleno mundo globalizado e com o advento de novos suportes de informação e tecnologia? Há quem advogue até mesmo o fim do livro como o conhecemos, com o surgimento desses recursos da cultura digital. Outros afirmam que o impresso conviverá durante muito tempo com outros suportes e possibilidades de leitura (ZILBERMANN, 2001; LEN, 2007).

No âmbito educacional, pesquisas atuais demonstram que, mesmo com o advento de novas tecnologias de informação e comunicação, a exemplo do CD-rom, recursos multimídia, internet, livros eletrônicos (e-books), audiolivros, o livro impresso ainda reina soberano no 
espaço da sala de aula ${ }^{28}$. É ele, muitas vezes, o único recurso de que dispõe o professor na preparação de suas aulas, sendo, portanto, o definidor do próprio currículo escolar.

Em que pese o aparecimento de novas tecnologias de informação, os educadores são unânimes em afirmar que o livro didático ainda exerce um papel preponderante no desenvolvimento do processo ensino-aprendizagem nas escolas brasileiras, sobretudo nos estabelecimentos da rede pública de ensino, caracterizados pela carência de outros materiais de ensino. Tanto assim é, que essas escolas são contempladas pelo maior programa de distribuição de livros didáticos do mundo (BITTENCOURT, 2004; HÖFLING, 2006), gerenciado pelo Fundo Nacional de Desenvolvimento da Educação do Ministério da Educação (FNDE-MEC). Trata-se do Programa Nacional do Livro Didático (PNLD) ${ }^{29}$, que distribui livros das diferentes disciplinas curriculares aos alunos regularmente matriculados nas escolas públicas do ensino fundamental em todo o País e, mais recentemente, o Programa Nacional do Livro Didático para o Ensino Médio (PNLEM), destinado às escolas de ensino médio.

Assim, no Brasil, país de gritantes desigualdades sociais, onde a grande maioria da população não tem acesso aos mais elementares direitos de cidadania, não se torna exagero dizer que a maior parte dos cidadãos só tem acesso, muitas vezes, em toda sua vida, ao livro didático. Oferecido pelo governo federal, numa política mais ampla de universalização do ensino básico, o livro didático não pertence ao aluno, uma vez que deverá devolvê-lo ao final do ano letivo escolar para que outro educando possa dele fazer uso.

$\mathrm{Na}$ verdade, é consenso entre os historiadores da educação que se torna quase impossível termos uma definição concisa e, ao mesmo tempo, completa do que seja o livro didático, também conhecido como manual escolar.

\footnotetext{
${ }^{28}$ Sobre o papel dos novos suportes de informação e tecnologia na educação brasileira, consultar RÖSING, Tânia M. K (org.). Do livro ao CD-Rom: novas navegações. Passo Fundo, RS: EDIUPF, 1999.

${ }^{29}$ Para uma análise desse programa de distribuição do livro didático pelo governo federal no contexto das políticas educacionais nos últimos anos, consultar BATISTA, Antônio Augusto Gomes. Recomendações para uma política pública de livros didáticos. Brasília: Ministério da Educação, Secretaria de Educação Fundamental, 2001; SPOSITO, Maria Encarnação Beltrão. A avaliação de livros didáticos no Brasil - por quê? In: SPOSITO, Maria Encarnação Beltrão (org.). Livros Didáticos de História e Geografia: avaliação e pesquisa. São Paulo: Cultura Acadêmica, 2006; HÖFFLING, Eloísa de Mattos. A trajetória do Programa Nacional do Livro Didático do Ministério da Educação no Brasil. In: FRACALANZA, Hilário; MEGID NETO, Jorge (orgs.). O Livro Didático de Ciências no Brasil. Campinas: Editora Komedi, 2006.
} 
A historiografia da educação registra a dificuldade terminológica para designar este material de ensino-aprendizagem - o livro didático. Nos países ibero-americanos de idioma espanhol, usam-se, principalmente, três substantivos para indicar o nível mais geral e amplo: livro, texto e manual, seguidos ou não do adjetivo "escolar". Na língua portuguesa ocorre algo similar, sendo utilizadas as seguintes denominações: livros didáticos, textos didáticos, manuais escolares, livros para crianças, entre outros, para um nível mais geral, e catecismos, manuais de civilidade, livros de leitura, compêndios, entre outros, para os tipos mais específicos. No Brasil ${ }^{30}$, a expressão mais usada para designar esse artefato cultural é "livro didático". No presente trabalho, uso tanto a expressão "livro didático", quanto "livro escolar", por considerá-las sinônimas.

Tomando como referência a evolução histórica do livro escolar espanhol, o professor Augustín Escolano (2001) classifica a obra didática em sete modalidades, a saber:

a) livros de iniciação: obras destinadas a ensinar as técnicas elementares da leitura e escrita;

b) séries cíclicas: textos de diferentes níveis de complexidade que expõem os conteúdos de forma graduada;

c) modelos enciclopédicos: textos sintéticos que procuram reunir em um só volume toda a cultura escolar;

d) livro-guia: são todos aqueles que se anunciam como manual, curso, programa de uma determinada disciplina escolar;

e) livro de consulta: livro auxiliar que complementa os textos básicos;

f) livro ativo: como os cadernos de atividades, fichas de exercícios, em que o aluno intervém diretamente (OSSENBACH; RODRIGUEZ, 2001, p. 18).

Escolano (2001) considera também que o livro didático é um espaço de memória e objeto, por excelência, da cultura escolar ocidental. Segundo ele, hoje o livro didático constitui uma fonte de primeira linha da nova historiografia da educação. Objeto essencial da cultura da escola tradicional, o manual não é somente um elemento material de auxílio ao trabalho docente e aos alunos, como também representa todo um modo de conceber e praticar o ensino.

\footnotetext{
${ }^{30}$ Nos países de língua inglesa, usa-se a expressão textbook ou school book. Já na Espanha e países latinoamericanos de língua espanhola, a terminologia mais usada é manuales escolares. O mesmo ocorre na França manuel scolaire.
} 
O historiador francês Alain Choppin (1992), por outro lado, classifica os livros escolares em duas grandes categorias: os destinados especificamente ao uso escolar e os que adquirem essa dimensão somente pelo uso que a escola faz deles. Os primeiros, ele os denomina de livros escolares stricto sensu, dentre os quais se distinguem quatro tipos:

a) os manuais, que seriam as obras utilitárias de uma classe, concebidas com a intenção de servir como suporte escrito ao ensino de uma determinada disciplina escolar;

b) as edições clássicas ou leituras escolhidas, compostas de obras clássicas da literatura e da cultura, com comentários e anotações adequadas para o uso escolar;

c) as obras de referência, integradas por dicionários, atlas, enciclopédias, compilação de documentos etc;

d) as obras paraescolares, que compreenderiam um conjunto heterogêneo de obras destinadas a resumir, reforçar e exercitar os conteúdos educativos trabalhados pela instituição escolar.

De difícil conceituação, o livro escolar possui algumas características que o singularizam entre os demais. Com base nos mais recentes estudos sobre a literatura escolar (CHOPPIN, 1993; JOHNSEN, 1996; ESCOLANO, 2001), podemos elencar algumas características do livro didático que o diferenciam dos demais impressos, incluindo também, neste caso, o manual direcionado à formação do professor:

a) intencionalidade, por parte do autor e/ou editor, de ser expressamente destinado ao uso escolar;

b) sistematização na exposição dos conteúdos;

c) adequação para o trabalho pedagógico, ajustando-se a um determinado nível de complexidade e a um determinado nível de maturidade intelectual e emocional dos alunos;

d) regulamentação dos conteúdos, sua extensão e tratamento dos mesmos, segundo o currículo escolar ou programa oficial;

e) intervenção estatal administrativa e política, seja através de leis e normas que selecionam, hierarquizam e excluem saberes e valores, seja através da necessidade de autorização expressa ou implícita para a publicação, circulação e uso do livro escolar (OSSENBACH; RODRIGUEZ, 2001, p. 20).

Segundo Circe Bittencourt (2004), o livro didático é um objeto de "múltiplas facetas": ora é visto como um produto cultural, ora como uma mercadoria ligada ao mercado editorial e, como tal, sujeito à lógica do sistema capitalista; outras vezes é encarado como um suporte 
de conhecimentos e de métodos das várias disciplinas curriculares e, sobretudo, como veículo de valores ideológicos ou culturais.

Sendo o livro didático um objeto multifacetado, segundo Alain Choppin (2004), podemos ver nele várias funções: função referencial, curricular ou programática (o livro didático constitui uma referência para a definição de currículos e programas); função instrumental (o livro didático acaba por impor métodos de aprendizagem); função ideológica ou cultural (o livro didático veicula valores); e função documental (o livro didático é fonte e objeto de pesquisa para a História da Educação).

Aspecto importante de seu caráter peculiar é o fato de que o livro didático conta com uma multiplicidade de atores envolvidos em cada uma das etapas de seu processo de produção, desde sua concepção pelo autor que, por sua vez, é influenciado pelos programas e currículos oficiais emanados do poder público, até o uso que dele fazem professor e alunos. Não nos esqueçamos, também, de que, na história do livro escolar, esse artefato cultural era, muitas vezes, destinado ao uso do professor, como guia de suas atividades docentes, utilizando trechos dele retirados ou ditando-os para os alunos. Com o passar dos tempos, tornou-se também objeto de uso do aluno, no desenvolvimento de seu processo de aprendizagem.

Choppin (1993) faz outra importante consideração acerca do livro escolar e sua íntima relação com a constituição da identidade nacional. Diz ele:

\footnotetext{
Os manuais escolares foram, durante muito tempo, reservados para a formação das elites e até, aproximadamente, o fim do século XVIII, eles contribuíram para assegurar a coesão cultural européia. Entretanto, ao longo do século XIX, a formação dos estados nacionais foi acompanhada da constituição dos respectivos sistemas escolares que objetivavam generalizar um ensino popular e uniforme. Assim, a maior parte dos estados nacionais procuraram constituir uma produção escolar nacional, conforme as opções políticas, os valores ideológicos e a língua que o poder pretendia promover. Ainda hoje, o manual escolar é visto como um produto nacional, tal qual a moeda ou o selo de um determinado país (CHOPPIN, 1993, p.5, grifo nosso).
}

Outro dado importante relativo ao estado da arte da pesquisa sobre o livro didático como fonte e/ou objeto de estudo da cultura escolar é a dimensão transnacional de seus 
estudos, adquirida nos últimos anos, bem como o diálogo que se estabeleceu entre os pesquisadores, a partir dos colóquios e seminários realizados em diversas partes do mundo.

Hoje, o historiador da educação, interessado na pesquisa sobre as edições escolares, dispõe de importantes bancos de dados sobre produção didática em diferentes países, entre os quais podemos citar: EMMANUELLE (Banque de Doneés Emmanuelle - INRP, França), MANES (Centro de Investigación MANES - Manuales escolares, Espanha), EME (Estatuto, funções e história do manual escolar, Portugal), HISTELEA (Historia social de la enseñanza de la lectura y la escrita en Argentina) e LIVRES (Livros Escolares, Brasil), vinculado ao Centro de Memória da Educação da Faculdade de Educação da USP (FEUSP) ${ }^{31}$.

Não se pode esquecer o papel do George Eckert Institute for International Textbook Research, com sede em Hannover, Alemanha, que, desde 1951, realiza pesquisas sobre a produção didática em países-membros da UNESCO (PINGEL, 1999).

\subsubsection{Breve história do livro escolar no Brasil}

Durante muito tempo, criou-se falso consenso, a partir de uma visão reducionista, de que “[...] o livro didático não tem uma história própria no Brasil. Sua história não passa de uma seqüência de decretos, leis e medidas governamentais que se sucedem, a partir de 1930, de forma aparentemente desordenada, e sem a correção ou a crítica de outros setores da sociedade [...].” (FREITAG et al., 1989, p. 11).

A partir dos anos 90, com novos trabalhos e pesquisas sobre a literatura escolar, resultantes dos programas de pós-graduação no País (BITTENCOURT ${ }^{32}, 1993$ e MUNAKATA, 1997), pode-se afirmar que a história do livro didático no Brasil está intimamente ligada à própria história da formação do estado nacional.

\footnotetext{
${ }^{31}$ No Brasil, podemos citar, também, o banco de dados e acervo de cartilhas escolares, organizado pelo CEALE (Centro de Estudos da Alfabetização e Letramento), vinculado à Faculdade de Educação da Universidade Federal de Minas Gerais (UFMG).

${ }^{32}$ A tese de doutorado de Circe Bittencourt representou um marco no estado da arte da pesquisa da história do livro didático no País, sendo referência obrigatória nos estudos posteriores. Depois de quinze anos, essa tese foi recentemente publicada (BITTENCOURT, Circe. Livro didático e saber escolar (1810-1910). Belo Horizonte: Autêntica Editora, 2008, Coleção História da Educação).
} 
Face à instalação tardia de tipografias no País, o que se deu somente com a vinda da Família Real para o Brasil (1808) e a criação da Impressão Régia, a edição de livros escolares surgiu para atender a demanda das escolas de ensino superior recém-instaladas, em especial da Academia Real Militar, criada por D. João VI, em 1810. Conforme acentua Rubens Borba de Moraes (1993, p.26),

[...] não bastava criar a Academia e nomear os lentes; era preciso ter livros para os alunos. Surgia no Brasil o problema do livro didático. Para resolvê-lo, a Impressão Régia publicou uma série de manuais franceses 'para uso dos alumnos', como consta em suas páginas de rosto. O empenho do governo em resolver o problema é tão patente, que, em 1809, antes mesmo de fundar a Academia Militar, já se providenciara a abertura de chapas para as gravuras dos ELEMENTOS DE GEOMETRIA e se publicara o TRATADO DE TRIGONOMETRIA, ambas as obras de Legendre. [...] Os alunos não ficavam, portanto, sem livros de texto logo no início do curso. À medida que iam passando de ano para ano, novos livros iam sendo publicados.

Nesse período, foram editados cerca de dezessete livros didáticos para essas escolas de nível superior. Pode-se afirmar, portanto, que os primeiros livros escolares publicados no País datam das décadas iniciais dos oitocentos. Podemos, por outro lado, estabelecer uma periodização para a história do livro escolar no Brasil, através de sua divisão em fases, como veremos.

A primeira fase da história do livro escolar no Brasil, entre os anos de 1810 e 1882 , caracterizou-se pela tradução de livros estrangeiros e adaptações. As editoras mais importantes do período que se instalaram no País pertenciam a livreiros estrangeiros, a exemplo dos irmãos Laemmert e Louis Baptiste Garnier, que montaram seus negócios de "mercadores de livros" na então Capital, nos anos de 1833 e 1846, respectivamente (SENNA, 2006).

Nesse período, muitos livros escolares, embora publicados até mesmo por editoras nacionais, eram impressos no exterior: 
O Brasil imprimiu muitos livros na Europa, principalmente em Portugal e na França - pela Livraria Garnier, por exemplo. A empresa Garnier foi fundada em 1833, em Paris, pelos irmãos Auguste e Hyppolite com o nome de Librarie Garnier Frères. Um terceiro irmão, Baptiste Louis Garnier, chegou ao Rio de Janeiro em 1844 e em 1846 instalou ali uma filial, a B.L. Garnier, que imprimia suas edições tanto dentro como fora do país. Foi a Garnier que introduziu o formato francês (in octavo) no Brasil e começou a empregar revisores e investir nas coleções de autores como José de Alencar e Machado de Assis. No total, a Garnier publicou cerca de 665 obras de autores nacionais, bem como muitas traduções feitas por autores brasileiros (MINDLIN \& ANTUNES, 2007, p. 86).

Não podemos esquecer de registrar que, nesse período, face à dimensão continental do País, surgiram também editores regionais que tiveram papel importante na difusão do livro escolar, sobretudo nas províncias do Norte (Maranhão, Pernambuco e Bahia) e no Rio Grande do Sul (TAMBARA, 2002). Estou me referindo, particularmente, às tipografias de Belarmino de Mattos e de José Maria Corrêa de Frias, em São Luis do Maranhão.

Frias foi considerado por muitos um excelente editor, tal a qualidade gráfica dos livros por ele publicados (HALLEWELL, 1985). Foi também responsável pela edição do Livro do Povo (1861), de autoria de Antonio Marques Rodrigues ${ }^{33}$, manual de leitura amplamente usado nas escolas primárias das províncias do norte e nordeste do Brasil, que, em menos de dois anos, teve duas edições, num total de 10 mil exemplares (RODRIGUES, 1865), número bastante expressivo para a época.

\begin{abstract}
Até 1861, as maiores edições que se fizeram no Maranhão eram de mil exemplares, e essas muito poucas. O Sr. Antônio Marques Rodrigues é que veio abrir o caminho às grandes edições com o seu inestimável Livro do Povo [...] pela primeira vez se viu no Brasil um livro publicado no Império contendo 208 páginas e vendendo-se por 320 réis! E tão bem recebida foi essa completa novidade que, vendendo-se hoje por 500 réis, por ter recebido aumento de páginas e sido ilustrado com grande número de gravuras, conta quatro edições de que tem extraído 16 mil exemplares em quatro anos, e vai entrar na quinta, que é de dez mil exemplares, ornada com cerca de 110 estampas (FRIAS, 2001, p. 46).
\end{abstract}

\footnotetext{
${ }^{33}$ Antonio Marques Rodrigues era inspetor da Instrução Pública da Província do Maranhão. Seu Livro do Povo é considerado, hoje, uma obra didática rara, produzida fora do eixo econômico do Império, onde se concentrava o comércio livreiro e editorial do País. "O livro está dividido em duas grandes partes: a primeira contém preceitos da moral cristã, através dos ensinamentos da vida de Jesus Cristo, com gravuras. A segunda parte contém assuntos os mais diversos, desde noções de higiene, ciências naturais, passando pelo estudo dos astros e animais, máximas e sentenças, até algumas páginas de História do Brasil. Com recomendação expressa dos bispos do Maranhão e da Bahia, em pouco tempo, tornou-se livro de leitura obrigatória nas escolas das províncias do Amazonas, Pará, Maranhão, Piauí, Ceará, Paraíba e Pernambuco. [...] Os estudiosos da história da educação consideram que Antonio Marques Rodrigues teve um papel fundamental no desenvolvimento do ensino primário na segunda metade do séc. XIX, sendo considerado, portanto, um dos primeiros autores a se preocupar com a popularização do livro escolar, mediante a distribuição gratuita e preço módico do Livro do Povo" (FERNANDES, 2007, p. 201).
} 
Embora circulassem livros escolares pelas diferentes províncias do País, o relato do viajante estrangeiro ao sul da Bahia revela a precariedade de nossas escolas e a quase total ausência de material para o aprendizado.

[...] A venda era mantida por um homem instruído, que também mantinha uma escola. Quando entramos, fomos saudados pelo animado murmúrio das crianças, que recitavam em coro a lição num cômodo contíguo. Fomos até lá e deparamos com dez ou doze meninos sentados em bancos, decentemente trajados, todos lendo juntos em voz alta. Seus livros não passavam de cartas comerciais recebidas pelo seu mestre e tratando de vários assuntos relativos aos seus negócios, sendo cada folha protegida de maneira que manuscritos tão preciosos não sofressem com o manuseio dos meninos. O professor via-se forçado a se valer desse recurso porque não dispunha de livros, e dessa forma seus alunos aprendiam a ler textos manuscritos antes dos impressos. Algumas cartas eram quase incompreensíveis e muito mal escritas, e na minha opinião teriam confundido qualquer escrivão do Registro Público. Parecia-me espantoso que, numa época em que os impressos já eram tão comuns, e em que havia tantos jornais e gazetas em circulação, ainda não se tivesse cogitado da publicação de livros de ensino elementar. Prometi ao professor informar-me no Rio sobre livros desse tipo e, se os encontrasse, enviar-lhe um suprimento deles, o que ele considerou a melhor dádiva que eu lhe poderia fazer (WALSH, 1985, p. 54, grifo nosso).

As impressões de viagem de estrangeiros sobre a realidade social do País no séc. XIX foram reforçadas pelo Relatório de Ensino, de 1852, escrito pelo poeta maranhense Gonçalves Dias (1823-1864), que, entre outros aspectos, constatou que: “[...] um dos defeitos é a falta de compêndios: no interior porque não os há; nas capitais porque não há escolha, ou foi mal feita; porque a escola não é suprida, e os pais relutam em dar os livros exigidos, ou repugnam aos mestres os admitidos pelas autoridades.” (MOACYR, 1939, p. 525).

Até meados do séc. XIX, na falta de livro escolar, o ensino das primeiras letras serviase de outros impressos, tais como a Constituição do Império, o Código Criminal, os evangelhos, catecismos e opúsculos contendo um resumo da História do Brasil.

A segunda fase da história do livro escolar no Brasil coincidiu com o fim do regime monárquico e os primeiros anos da República, com uma produção editorial de livros cujos autores eram predominantemente integrantes das academias científicas e literárias, dos institutos históricos, das escolas politécnicas e militares e do Colégio Pedro II (BITTENCOURT, 2004). Isso se explica pelo fato de que a atividade do magistério era, em grande parte, exercida por esses intelectuais, já que não havia ainda uma profissionalização do 
educador, o que vai ocorrer somente a partir dos anos 30 do séc. $\mathrm{XX}$, com a criação dos primeiros cursos de formação de professores, no âmbito das faculdades de Filosofia, Ciências e Letras.

Destacam-se, nesse período, como editoras de livros escolares, a Livraria Francisco Alves (1854), a Melhoramentos (1915) e a Companhia Editora Nacional (1925).

Sabe-se que o poder instituído sempre exerceu o controle sobre a produção e circulação do livro escolar no Brasil. Ainda no Império, a autorização para circulação e adoção do livro escolar ficava a cargo dos Conselhos da Instrução Pública ${ }^{34}$, ligados diretamente aos governos provinciais. Em se tratando de livros escolares de religião disciplina obrigatória durante o Império - catecismos, livros de história sagrada ou até mesmo livros de leitura que veiculassem conteúdos acerca da doutrina cristã, além de estarem de acordo com os programas curriculares oficiais, deveriam ter a chancela da autoridade eclesiástica competente.

O Imprimatur, assinado e datado pelas autoridades religiosas locais da edição, visível na contracapa do livro, representava a censura e a forma de interferência no texto dos autores em relação à produção didática. A edição de qualquer livro destinado às escolas católicas dependia dessa chancela (BITTENCOURT, 2004, p. 487).

Em 1938, no contexto da política educacional do Estado Novo (1937-1945), surgiu a primeira legislação federal que estabelecia regras para a edição, publicação e circulação do livro didático no Brasil (Decreto-Lei $\mathrm{n}^{\circ}$ 1.006, de 30/12/38). Através desse ato normativo, o governo federal criou a Comissão Nacional do Livro Didático (CNLD), que emitia um registro de autorização para a circulação do livro em todo o território nacional.

\footnotetext{
${ }^{34}$ Segundo Francisca Maciel, “[...] no final do século XIX, os livros literários já eram avaliados pelos membros do Conselho da Instrução Pública, órgão responsável pela análise dos livros e materiais didáticos, nas provínciasEstados. Caberia aos membros do Conselho indicar os livros que cada governo iria adquirir e distribuir para os alunos pobres das escolas públicas brasileiras.” (MACIEL, 2008, p. 9).
} 
Durante o Estado Novo, o governo federal relacionava os textos aprovados, numa tentativa de padronizar a instrução nacional. A Comissão Nacional do Livro Didático ordenou que, após o dia $1^{\circ}$ de janeiro de 1940, todos os livros didáticos fossem submetidos à aprovação do Ministério da Educação e Saúde Pública antes de serem utilizados nas escolas públicas. Era considerado conteúdo inadmissível: críticas ao regime, desrespeito à tradição nacional, incitamento à luta de classes, ofensa ao sentimento religioso e pessimismo ou dúvida quanto ao potencial futuro da raça brasileira (NAVA, 2007, p. 109).

Posteriormente, o Decreto-Lei $n^{\circ} 8.460$, de 26/12/1945, consolidou a legislação sobre as condições de produção, importação e utilização do livro didático, delegando - e restringindo - ao professor a escolha do livro a ser usado pelos alunos:

Os poderes públicos não poderão determinar a obrigatoriedade de adoção de um só livro ou de certos e determinados livros para cada grau ou ramo de ensino, nem estabelecer preferência entre os livros didáticos de uso autorizado, sendo livre aos professores do ensino primário, secundário, normal e profissional a escolha de livros para uso dos alunos, uma vez que constem da relação oficial das obras de uso autorizado (Art. $5^{\circ}$, grifo nosso).

Um terceiro período teve início nos anos 60 do século passado, quando ocorreu uma expansão escolar evidenciada através do aumento do número de matrículas, advindo da nova Lei de Diretrizes e Bases da Educação Nacional (Lei no 4.024, de 1961), o que contribuiu para o crescimento do mercado editorial brasileiro. "Como conseqüência, em meados de 1968, já estavam à venda, no Brasil, cerca de 2.500 títulos didáticos distribuídos entre os três níveis, publicados por cerca de sessenta editoras.” (PAIXÃO, 1996, p. 157).

Nesse período, destacam-se, no mercado de livros didáticos, as editoras do Brasil, Ática e Saraiva, entre outras já consolidadas nacionalmente (Melhoramentos, Agir, Francisco Alves, Nacional e Ao Livro Técnico).

Em 1966, em convênio com a Agência Norte-Americana para o Desenvolvimento Internacional (USAID), o MEC criou a Comissão do Livro Técnico e do Livro Didático (COLTED), que tinha "a finalidade de incentivar, orientar, coordenar e executar as atividades do Ministério da Educação e Cultura relacionadas com a produção, a edição, o aprimoramento e a distribuição de livros técnicos e de livros didáticos" (art. $1^{\circ}$ do Decreto ${ }^{\circ}$ 59.355/66). 
Após denúncias de irregularidades, o MEC criou uma comissão de inquérito para apurá-las e, em 1971, extinguiu o COLTED, transferindo para o Instituto Nacional do Livro (INL) as atribuições pela execução da política do livro didático (OLIVEIRA et al., 1984).

A partir dos anos 70 do século passado, no contexto do regime militar (1964-1985), o governo federal assumiu de forma mais eficaz e centralizadora a política do livro didático no País. Foram criados programas de distribuição do livro para as escolas, dentre os quais podemos citar:

- PLIDEF (Programa do Livro Didático para o Ensino Fundamental), criado pelo governo federal em 1971, sob a responsabilidade do Instituto Nacional do Livro (INL). O INL, já criado em 1937, podia também estabelecer com o Ministério da Educação o sistema de co-edição de livros com as editoras nacionais;

- FENAME (Fundação Nacional de Material Escolar), que, com a extinção do INL, em 1976, passou a ser responsável pela execução do programa do livro didático;

- FAE (Fundação de Assistência ao Estudante), criada em 1983, substituindo a FENAME e incorporando o PLIDEF. Foi extinta em 1997, e a política de execução do programa do livro didático foi transferida para outra instância do MEC - o Fundo Nacional de Desenvolvimento da Educação (FNDE).

O quarto e último período iniciou-se com a criação do Programa Nacional do Livro Didático (PNLD), em 1996, e a conseqüente adoção de um amplo sistema de avaliação desse material escolar. $\mathrm{O}$ governo passou a interferir na qualidade do material a ser enviado às escolas e utilizado por professores e alunos, o que provocou ampla repercussão no mercado editorial brasileiro, com a publicação do "Guia de Livros Didáticos".

Esse guia, publicado pelo MEC, é distribuído às escolas para que os professores possam escolher o livro didático a ser usado em sala de aula, e contém resenhas das obras e coleções de livros aprovados por pareceristas de diferentes universidades brasileiras.

No processo de avaliação dos livros didáticos das diferentes disciplinas curriculares, alguns critérios gerais e comuns são seguidos pelos especialistas. Assim, 
uma obra didática não pode conter erros conceituais; anunciar uma proposta metodológica e executar outra; apresentar recursos - texto, imagens, exercícios que sejam inadequados à faixa de escolarização pretendida; conter textos ou imagens que levem à discriminação, preconceitos ou que veiculem propaganda ou proselitismo religioso e conter erros graves de edição e revisão (GEBRIM, 2004, p.203).

Mediante o êxito e a consolidação do PNLD, e no contexto da política educacional de universalização da educação básica, o MEC criou um programa de distribuição de livros escolares para os alunos do ensino médio da rede pública. Trata-se do PNLEM - Programa Nacional do Livro Didático para o Ensino Médio. ${ }^{35}$

Esse último período da história das edições escolares no Brasil foi também marcado, até a presente data, pela internacionalização do mercado editorial, com a venda de editoras nacionais a grupos estrangeiros, notadamente espanhóis (CASSIANO, 2007).

Segundo Ferreira \& Franco (2008), a venda de livros didáticos correspondeu a cerca de $41 \%$ de todo o mercado de livro do Brasil no ano de 2006. É um mercado altamente lucrativo e com forte tendência à concentração em grandes grupos empresariais ${ }^{36}$. Hoje, constata-se também a existência dos chamados "sistemas de ensino", que produzem e editam seus próprios materiais de ensino, incluindo os livros didáticos.

Originários dos cursos pré-vestibulares, nascidos em geral na década de 1970 , os
sistemas de ensino passaram a produzir materiais didáticos que pretendiam cobrir
todo o programa das disciplinas do currículo escolar. Assim, através de modelos
fechados adquiridos pelas escolas, esses sistemas fornecem coleções de livros e
materiais, modelos de avaliação e suporte pedagógico às escolas que os adquirem.
Sem entrar no mérito das vantagens e desvantagens que os sistemas de ensino
apresentam, o que é preocupante é o fato de passarem ao largo de qualquer
avaliação. Trata-se de um número significativo de livros e apostilas que não contam

\footnotetext{
${ }^{35}$ Além dos programas citados, destinados ao ensino regular, o MEC possui, sob a gerência do FNDE, dois outros programas de distribuição gratuita do livro escolar. O Programa Nacional do Livro Didático para a Alfabetização de Jovens e Adultos (PNLA), criado em 2007, que tem como objetivo contribuir para a erradicação do analfabetismo no País, mediante a distribuição, a título de doação, de livros didáticos às entidades parceiras, que trabalham com alfabetização de pessoas maiores de quinze anos. Com o objetivo de fomentar a prática da leitura na escola, entre professores, alunos e comunidade, o MEC também vem desenvolvendo, desde 1997, o Programa Nacional Biblioteca na Escola (PNBE), que distribui, aos estabelecimentos públicos do Ensino Fundamental e Médio, livros de literatura infanto-juvenil, de pesquisa e obras de referência (dicionários, atlas histórico e geográfico, entre outros).

${ }^{36}$ Hoje, o mercado editorial de livros escolares concentra-se nas seguintes empresas: o Grupo Saraiva, formado pelas editoras Saraiva, Atual e Formato; o Grupo Abril, que congrega as editoras Ática e Scipione; as Editoras IBEP e a Companhia Editora Nacional; a Editora FTD, dona da Editora Quinteto; a Editora do Brasil e o Grupo espanhol Prisa-Santillana, dono das editoras Moderna, Objetiva e Salamandra (CASSIANO, 2007).
} 
com nenhum tipo de avaliação que possa atestar sua qualidade e pertinência (FERREIRA \& FRANCO, 2008, p. 8, grifo nosso).

Nos últimos anos, o governo federal tem envidado esforços para a implementação de uma política nacional do livro, que enseje o direito ao livro e à leitura, como mecanismos de inclusão social, a uma parcela maior de brasileiros, sobretudo dos estratos sociais mais baixos. Em pleno século XXI, dados do Ministério da Cultura apontam para uma situação desalentadora no que se refere ao acesso ao livro e às práticas de leitura dos brasileiros:

\footnotetext{
Cerca de $10 \%$ dos brasileiros apresentam analfabetismo absoluto, situação comparável com a de populações da Europa Central durante o século XIX. O índice nacional de leitura, por sua vez, é de 1,8 livro per capita por ano, resultado inferior à média de 2,4 livros da Colômbia e de 7 livros na França. Embora seja o equipamento cultural mais espalhado pelo Brasil, as bibliotecas estão desigualmente distribuídas entre as regiões. Dos mais de 600 municípios que nunca receberam uma biblioteca, 405 ficam no Nordeste, e apenas dois no Sudeste. No que se refere ao mercado editorial, o preço médio do livro é bastante elevado para o poder aquisitivo das classes C, D e E. Por conta desses fatores, $73 \%$ dos livros estão concentrados nas mãos de apenas $16 \%$ da população (MinC, 2007, p. 43).
}

$\mathrm{Na}$ tentativa de reverter esse quadro sociocultural, o governo federal promulgou a Lei $\mathrm{n}^{\mathrm{o}} 10.753$, de $30 / 10 / 2003$, que instituiu a política nacional do livro e criou, através de uma portaria interministerial, envolvendo as pastas da Educação e da Cultura, o Plano Nacional do Livro e da Leitura (PNLL). Sua finalidade básica é "assegurar a democratização do acesso ao livro, o fomento e a valorização da leitura e o fortalecimento da cadeia produtiva do livro como fator relevante para o incremento da produção intelectual e o desenvolvimento da economia nacional." (art. $1^{\circ}$. Portaria $\mathrm{n}^{\circ} 1442$, de 2006).

\subsubsection{O livro didático de História: debates e pesquisas}

É fato inconteste o papel central que o livro didático exerce na instituição escolar desde o advento da modernidade. Isso se deve, em grande parte, ao fato de que a escola é uma instituição social que lida com o conhecimento historicamente produzido e acumulado por várias gerações. Nesse sentido, conforme acentua Magda Soares, 
[...] na escola, o saber, para ser ensinado, aprendido, avaliado, sofre um processo de seleção, segmentação progressivas, é, em síntese, didatizado, escolarizado. Nesse sentido, o livro didático instituiu-se, historicamente, bem antes de programas e currículos mínimos, como instrumentos para assegurar a aquisição dos saberes escolares, isto é, aqueles saberes e competências julgados indispensáveis à inserção das novas gerações na sociedade, daqueles saberes que a ninguém é possível ignorar (SOARES, 1996, p. 54).

Apesar da centralidade do livro didático no processo educativo, só muito recentemente é que ele tem recebido a devida atenção dos pesquisadores e cientistas sociais.

Durante muito tempo, o livro didático foi considerado um livro "menor", descartável e efêmero no contexto do mercado editorial, o que contribuiu para a dificuldade de preservar esse objeto cultural ao longo da história. Nisso reside, em grande parte, uma outra dificuldade para o pesquisador do livro escolar, pois, muitas vezes, ele não dispõe de todas as edições que lhe permitam fazer a história de uma determinada obra didática. Nem mesmo as editoras têm o costume de guardar todas as edições de um mesmo livro escolar, alegando, muitas vezes, falta de espaço para acondicioná-los. Nesse contexto, muita coisa se perdeu no decorrer do tempo, comprometendo sobremaneira a história da edição escolar no Brasil.

A visão que o aluno tem do livro escolar colabora para que ele seja descartável, material para se consumir e jogar fora, expurgar se preciso for, como um ato de rebeldia, conforme depoimento a seguir transcrito:

\footnotetext{
Um antigo costume juvenil é o de queimar textos didáticos. Quando concluí meu ensino médio, o primeiro ato consumado, além das assinaturas nas camisas, foi queimar os livros de estudo, o que não deixou de me impressionar, pois os professores avalizavam a prática com seus sorrisos [...].

Em junho de 2001, houve um caso escandaloso nas areias da praia La Victoria, em Cádiz, onde centenas de estudantes se reuniram para fazer uma grande fogueira. Entre risos e gritos, lançaram todos os seus livros didáticos, incluindo alguns de leitura obrigatória. Dessa forma, nem sequer alguns clássicos da literatura espanhola se salvaram do que deveria ser, unicamente, um ato de fim de curso.

Um dos rituais secretos de Harvard consiste em que, no final do curso, se queimem os livros do último ano. Desaparecem habitualmente dessa forma dezenas de manuais didáticos (BAÉZ, 2006, p. 303-5).
}

Embora o livro didático seja considerado o "primo pobre da literatura, texto para ler e botar fora, descartável porque anacrônico" (LAJOLO; ZILBERMANN, 1999, p. 120), ele é o 
grande filão da indústria editorial brasileira. Segundo a Câmara Brasileira do Livro (CBL), desde a década de 1990, os livros didáticos são predominantes na produção das editoras nacionais (GATTI, 2005). Dados mais recentes indicam que o governo federal é o principal comprador de livros didáticos, tendo adquirido 121 milhões de exemplares em 2007, número bastante expressivo, se levarmos em conta que o brasileiro consome, em média, 2,5 livros por ano $^{37}$ (SOUSA, 2007).

A recente pesquisa sobre Retratos da Leitura no Brasil (AMORIM, 2008) revela que, após a Bíblia (45\% dos leitores), são os livros didáticos ou aqueles indicados pela escola os mais lidos pelos brasileiros (34\%).

Hoje, com os aportes teóricos da História Cultural, o objeto "livro didático" constitui elemento essencial para a investigação científica, no âmbito da História da Educação, especialmente nos campos da história das disciplinas escolares, história dos currículos e programas, história da leitura, bem como no estudo da cultura material escolar ${ }^{38}$, através de suas práticas e representações.

Tudo isso nos leva a considerar que a História da Educação Brasileira não pode prescindir das pesquisas acerca do uso do livro escolar, pois ele é, muitas vezes, revelador do alcance das políticas públicas do setor e da própria situação do ensino no País.

Assim, um olhar sobre o livro didático no Brasil pode levar-nos a uma história do nosso ensino, das práticas escolares, da transformação das disciplinas ao longo do tempo, tudo isso determinado e explicado pela evolução das políticas culturais, sociais e, conseqüentemente, educacionais (SOARES, 1996, p. 56).

A partir da década de 60 do século passado, as pesquisas sobre o livro didático iniciaram-se no meio acadêmico, denunciando-lhe o caráter ideológico, ao trazer, subjacentes aos textos e imagens, preconceitos e estereótipos acerca de determinados segmentos sociais, bem como valores da sociedade capitalista. Nessas abordagens, o livro didático era visto

\footnotetext{
${ }^{37}$ Esse dado demonstra um crescimento em relação às informações do Ministério da Cultura (ver p. 66).

${ }^{38}$ A cultura escolar, segundo Dominique Julia, compreende "um conjunto de normas que definem saberes a ensinar e condutas a inculcar e um conjunto de práticas que permitem a transmissão desses saberes e a incorporação desses comportamentos, normas e práticas ordenadas de acordo com finalidades que podem variar segundo as épocas." (JULIA, 2001, p. 10).
} 
como mero portador e veiculador de um sistema de valores, de uma ideologia, de uma cultura, vinculada às classes historicamente dominantes.

O grande clássico e referência para todos os trabalhos que se seguiram foi a obra de Umberto Eco e Mariza Bonazzi, Mentiras que parecem verdades, traduzida em diversos idiomas. No Brasil, o livro As Belas Mentiras: a ideologia subjacente aos textos didáticos, de Maria de Lourdes Deiró Nosella, fez escola, sendo ainda hoje referência em qualquer bibliografia sobre livro didático ${ }^{39}$.

No tocante ao ensino de História, dois livros tornaram-se emblemáticos na historiografia e tiveram repercussão no Brasil como referencial teórico das pesquisas sobre a literatura escolar. Comment raconte l'histoire aux enfants à travers le monde entier $(1981)^{40}$, de Marc Ferro, que analisou o conteúdo ideológico dos manuais didáticos em diversas partes do mundo. O outro livro, organizado por Henri Moniot e intitulado Enseigner l'histoire: des manuels à la mémoire (1984), foi o resultado de um colóquio sobre os manuais escolares de História e a memória coletiva, realizado na Universidade de Paris VII, no ano de 1983.

A partir deles, as pesquisas sobre a literatura escolar para o ensino de História passaram a ter duas vertentes principais: as análises versavam sobre a ideologia dos livros, denunciando o caráter discriminatório contra alguns segmentos sociais, ou sobre as relações entre a produção historiográfica acadêmica e os conteúdos veiculados nos livros didáticos.

Nessa vertente, podemos citar a tese da pesquisadora da Fundação Carlos Chagas, Maria Laura P. B. Franco, intitulada O Livro didático de História no Brasil: a versão fabricada (1982), na qual a autora faz uma análise do tratamento dado ao "povo" e à "violência" em movimentos insurrecionais do Período Regencial (1831-1840) e de como são veiculados nos livros de História do Brasil destinados ao antigo ensino de $2^{\circ}$ grau, hoje denominado ensino médio.

\footnotetext{
${ }^{39}$ Para um levantamento completo da bibliografia sobre o livro didático, consultar BIBLIOTECA CENTRAL. Catálogo Analítico - Que sabemos sobre livro didático. Campinas: Editora da UNICAMP, 1989.

Mais recentemente, consultar MUNAKATA, Kazumi. Brasil. Apéndice Bibliográfico. In: OSSENBACH, Gabriela; RODRIGUEZ, Miguel Somoza. Los manuales escolares como fuente para la historia de la educación em América Latina. Madrid: Universidad Nacional de Educación a Distancia, 2001.

${ }^{40}$ Esse livro recebeu o seguinte título na edição brasileira: FERRO, Marc. A manipulação da História no ensino e nos meios de comunicação. São Paulo: IBRASA, 1983.
} 
O livro da antropóloga Norma Abreu Telles é outro trabalho dentro dessa mesma orientação metodológica. Cartografia brasilis ou esta história está mal contada (1984) procura denunciar a concepção etnocêntrica presente na maioria dos livros escolares da década de 1980.

A partir dos anos 90 do século passado, com as contribuições teóricas advindas da obra de Henry-Jean Martin (1992), Roger Chartier (1999; 2001) e Robert Darton (1990; 1992), que inovaram os estudos acerca da história da leitura no mundo ocidental, houve mudanças de abordagens nas pesquisas relacionadas ao livro didático.

Hoje, os trabalhos estão mais direcionados a questões relativas ao uso e apropriação do livro didático por alunos e professores, às práticas de leitura, à questão da autoria, à sua materialidade física, entre outros. Assim, segundo Choppin (2004), a história da edição escolar constitui, hoje, um dos campos mais promissores da História da Educação e novas questões colocam-se para os historiadores, tais como: a relação entre livro didático e a formação de professores; o livro didático e sua interferência no currículo escolar; o uso do livro didático por parte do aluno; sua utilização na educação não-formal; a linguagem e imagem utilizadas nos livros didáticos; o perfil sociológico dos autores; o papel das mulheres na elaboração e difusão dos saberes escolares.

Por sua vez, as pesquisas educacionais voltaram-se para o interior da escola, não mais vista como mero aparelho ideológico do Estado, a serviço da classe burguesa, mas como um lugar de produção cultural. A escola produz, assim, um saber que é diferente daquele produzido na academia, mas nem por isso menos importante e que deve ser levado em consideração pelo historiador da educação, quando investiga a relação entre livro didático, disciplina escolar e programas curriculares (CHERVEL, 1990; GOODSON, 2008, JULIA, 2001). São todos eles partes integrantes da cultura escolar. Vale ressaltar, também, que o conhecimento histórico produzido no interior da sala de aula por alunos e professores tem objetivos e fundamentos epistemológicos diferentes daqueles que regem a produção do conhecimento histórico na academia e instituições de pesquisa.

Nesse contexto, a partir do final dos anos 1990, foram publicados importantes trabalhos historiográficos que tomaram como objeto ou fonte de pesquisa o livro didático de História, resultado, em grande parte, de dissertações de mestrado ou teses de doutorado no 
âmbito dos programas de pós-graduação em Educação e/ou História. Aliás, segundo levantamentos bibliográficos, a grande maioria dos trabalhos acadêmicos sobre literatura didática versa sobre a análise dos livros de História e Língua Portuguesa (SILVA, 2008).

Alguns trabalhos tomaram como eixo norteador o problema da autoria do livro escolar e sua repercussão no ensino de História. É o caso, por exemplo, dos livros de Selma Rinaldi de Mattos $^{41}$ (2000) e Patrícia Santos Hansen ${ }^{42}$ (2000), que abordaram, respectivamente, a produção didática de Joaquim Manuel de Macedo e João Ribeiro, como importantes autores de livros destinados ao ensino da História do Brasil.

Ainda nesse contexto das autorias do livro didático de História, temos o trabalho recém-publicado do Prof. Ciro Flávio de Castro Bandeira de Melo. Senhores da história e do esquecimento: a construção do Brasil em dois manuais didáticos da História na segunda metade do século XIX (2008) analisa dois manuais que tiveram ampla adoção na escola secundária brasileira, durante a segunda metade do século XIX - Lições de História do Brasil (1861), de Joaquim Manuel de Macedo, e História do Brasil - curso superior (1900), de João Ribeiro.

Pode-se citar, ainda, o livro Construtores de identidades: a pedagogia da nação nos livros didáticos da escola secundária brasileira (2004), da historiadora Arlette Medeiros Gasparello, que analisou os livros escolares adotados no Colégio Pedro II, modelo e paradigma de instrução secundária para todo o País.

Já o professor Décio Gatti Júnior, no livro A escrita escolar da História: livro didático e ensino no Brasil (2004), dedicou-se à análise da produção didática para o ensino de História em um período mais recente (1970-1990), ressaltando as mudanças ocorridas, seja no âmbito das políticas públicas para o livro didático, seja nas reformulações conceituais da literatura escolar dessa disciplina.

Nos anos mais recentes, importantes dissertações e teses de pesquisadores do projeto temático Educação e Memória: organização de acervos de livros didáticos (BITTENCOURT,

\footnotetext{
${ }^{41}$ MATTOS, Selma Rinaldi de. O Brasil em lições: a história como disciplina escolar em Joaquim Manuel de Macedo. Rio de Janeiro: Acess Editora, 2000.

${ }^{42}$ HANSEN, Patrícia Santos. Feições \& Fisionomia: A História do Brasil de João Ribeiro. Rio de Janeiro: Acess Editora, 2000.
} 
2007) foram defendidas, revelando que essas pesquisas incorporaram novas análises e abordagens do repertório da História Cultural, entre as quais podemos citar:

- A produção didática de história em quadrinhos: Julierme e a História para a escola moderna (1969-1975), dissertação de mestrado defendida na Faculdade de Educação da USP, em 2005, sob a orientação da Prof ${ }^{a}$ Dra. Circe Bittencourt, de autoria de Júlio Maria Neres, que fez uma análise do uso da história em quadrinhos na literatura escolar dos anos 70 , tomando como referência a obra do professor Julierme, publicada pela Editora IBEP.

- Os intelectuais e a produção da série Resumos Didáticos da Companhia Melhoramentos de São Paulo (1918-1937) de Marcos Antonio Oliveira. Tese de doutorado defendida na Faculdade de Educação da USP, em 2006, sob a orientação da Prof ${ }^{a}$ Dra. Circe Bittencourt, em que o autor analisa o papel dos historiadores ligados aos institutos históricos na produção de livros escolares de história regional, destinados à formação de professores das antigas escolas normais.

- Entre as coisas do mundo e o mundo dos livros: prefácios cívicos e impressos escolares no Brasil republicano. Tese de doutorado defendida na Faculdade de Educação da USP, em 2008, sob a orientação do Prof. Dr. Nelson Schapochnik, de autoria de Cleber Santos Vieira. O autor toma diversos momentos-chave da história republicana do País para fazer análise dos prefácios em livros de leitura, de moral e civismo e de Organização Social e Política do Brasil (OSPB), ao tempo em que empreende uma história do civismo como prática pedagógica e disciplina escolar.

- A coleção Sérgio Buarque de Holanda: livros didáticos e ensino de História, de José Cássio Másculo. Tese de doutorado defendida no Programa de Estudos PósGraduados em Educação da PUC-SP, em 2008, sob a orientação do Prof. Dr. Kazumi Munakata. Nessa tese, o autor revela a preocupação do historiador Sérgio Buarque de Holanda ${ }^{43}$ com o ensino de História na escola básica, ao coordenar

\footnotetext{
${ }^{43}$ Embora pouco divulgado no meio acadêmico, o historiador Sérgio Buarque de Holanda foi também autor de livros didáticos, juntamente com Octávio Tarquínio de Sousa: HOLANDA, Sérgio Buarque de; SOUSA, Octávio Tarquínio de. História do Brasil ( $3^{\mathrm{a}}$ série do ciclo ginasial). Rio de Janeiro: Editora José Olympio, 1940.
} 
uma equipe de professores que produziu uma coleção de três livros didáticos editados pela Companhia Editora Nacional, no início dos anos $1970^{44}$.

Analisando essa nova produção historiográfica, constata-se que a maior parte dos trabalhos produzidos enfoca a literatura didática para o ensino de História, destinada ao antigo curso ginasial e secundário. Há uma carência de pesquisas na análise da produção escolar destinada às crianças. Meu trabalho pretende, de certa forma, contribuir para a discussão acerca do ensino de História na escola primária brasileira, tomando como contraponto a obra escolar do escritor e bacharel Viriato Corrêa.

Para efeito de pesquisa, tomei como referência fundamental a orientação metodológica dos trabalhos de Alain Choppin adotados pelo projeto temático Educação e Memória: organização de acervos de livros didáticos, da Faculdade de Educação da Universidade de São Paulo (FEUSP), que revela uma compreensão mais ampla do que seja o livro didático. Assim, considero que

livros escolares (livros didáticos) são todas as obras cuja intenção original é explicitamente voltada para o uso pedagógico e esta intenção é manifestada pelo autor e editor. Nesta concepção se inserem, além dos livros didáticos mais comuns, também denominados de compêndios ou manuais escolares, as obras conhecidas como paradidáticas, coletâneas de literatura produzidas para as escolas, e ainda atlas, dicionários especialmente editados para uso pedagógico (GUIA LIVRES, 2005, p.7).

Esta mesma posição é partilhada por outros centros de pesquisa, a exemplo do MANES, da Espanha, que também considera "manual o livro destinado especificamente aos professores ou alunos e de emprego sistemático na escola, com vista à aprendizagem de matérias incluídas no currículo escolar" (MANES, 2007, p. 37).

Nesse sentido, considero que os livros infantis de Viriato Corrêa são também livros didáticos, uma vez que muitos deles foram produzidos com finalidades estritamente educativas, tendo sido adotados por escolas em várias partes do País. É o caso, por exemplo,

\footnotetext{
44 A Coleção Sérgio Buarque de Holanda foi publicada pela Companhia Editora Nacional e contou com a participação de outros professores da Universidade de São Paulo (USP), na década de 1970. Era constituída pelos seguintes títulos: História do Brasil: das origens à independência (Vol. 1), História do Brasil: da independência aos nossos dias (Vol. 2) e História da Civilização (MÁSCULO, 2008, p. 39).
} 
de seu primeiro livro, intitulado Contos da História do Brasil (para uso das escolas), de 1921. Nele, o autor expressou o motivo que o levou a escrevê-lo - o apelo dos professores do Rio de Janeiro que queriam um livro para a leitura cívica das crianças na escola.

Outros livros de Viriato receberam o aval das instâncias educacionais competentes, a exemplo de História do Brasil para crianças (1934). Muitos outros foram indicados em Manuais de Didática e Metodologia do Ensino e serviram como leitura complementar à formação do professor da escola primária.

Hoje, seguindo a moderna nomenclatura do mercado editorial, os livros escolares de Viriato Corrêa seriam enquadrados no gênero didático "paradidático",45, pois são livros com conteúdos temáticos de uma determinada disciplina, no caso, a História do Brasil.

Respondendo à questão inicialmente proposta neste capítulo: Como, então, caracterizar História do Brasil para crianças? É um livro de literatura infantil? Um livro de leitura? É mais um livro didático como os demais que circularam no período?, concluo afirmando que História do Brasil para crianças surge como livro de literatura infantil em 1934 e, face a seu uso na escola e posterior registro na Comissão Nacional do Livro Didático (CNLD) do MEC, em 1961, ele se torna um livro didático. Considero também que, mesmo tendo surgido no âmbito de uma coleção de literatura infantil, ao lado de várias obras de Monteiro Lobato, Viriato, ao escrever esse livro, tinha pretensões pedagógicas, como veremos mais adiante.

Há também outro aspecto que revela que o livro em discussão pode ser considerado um manual didático. Trata-se da intencionalidade do editor, manifesta no catálogo da própria editora que pretendia que o livro chegasse também às escolas. "Livro delicioso, [...], de um extraordinário

\footnotetext{
${ }^{45}$ Considero que o termo "paradidático" é mais um gênero didático para designar livros complementares ao estudo de uma determinada disciplina escolar. Para MUNAKATA (1997), paradidático é um termo tipicamente brasileiro, uma vez que, segundo ele, não existe a utilização desse termo em outros países. "[...]a Ática foi a criadora o termo paradidático e dos primeiros livros destinados a auxiliar o ensino de Língua Portuguesa com obras já existentes da literatura clássica, porém, acompanhadas de suplemento de atividades para o aluno e de outro especialmente para o professor, que trazia todas as respostas prontas, além de orientação metodológica e didática - outra grande invenção da editora." (MELO, 2006, p. 122). Para Melo, o livro paradidático difere do didático tanto em seu conteúdo quanto na sua materialidade. "[...] os livros têm formatação diferente do livro didático, possuem poucas páginas bem ilustradas e coloridas, apresentando apurado cuidado gráfico e uma nova diagramação, e se aproximando do formato da literatura infanto-juvenil. Do ponto de vista do conteúdo, são livros temáticos normalmente de acordo com o currículo escolar, trabalhados em forma de narrativas/ficção, em cuja maioria se sobressai a preocupação pedagógica às intenções estéticas e/ou literárias.” (MELO, 2006, p. 122).
} 
alcance educativo e destinado a realizar por si só, nas escolas, uma grande obra de brasilidade e de espírito nacional.” (CEN, 1935, p. 30).

As vinte e oito edições de História do Brasil para crianças, durante cinqüenta anos de circulação no mercado editorial brasileiro, consagraram-no como um verdadeiro best-seller, "fazendo corações e mentes" das crianças e adolescentes acerca do passado histórico nacional. Depois de Cazuza, outro clássico da literatura infantil de Viriato Corrêa, História do Brasil para crianças foi o livro mais lido pela infầncia brasileira entre os anos 30 e 60 do século XX. 
CAPÍTULO 2 - A PÁTRIA IMPRESSA: OS LIVROS DE LEITURA E A FORMAÇÃO DA INFÂNCIA BRASILEIRA

Aos poucos, num sebo e em outro, fui refazendo parte de minha biblioteca de então: [...] Apanho um volume: é a trigésima edição de Cazuza, de Viriato Corrêa, obra concluída pelo autor justamente no ano em que nasci-1937. Folheio-a com a mesma sensação que tive pela primeira vez, a de descobrir um Brasil que eu não conhecia, o Brasil do Maranhão, o Brasil do

Pata Choca, do Padre Zacarias, de Luís Gama. O Brasil do professor Câncio dizendo - numa época em que o ufanismo era

a tônica: "Somos um país pobre, um povo pobre... Mas justamente porque a terra não é a mais doce, nem a mais generosa, nem a mais rica é que é maior o valor de nossa gente". Humildes livros, bravos livros

(Moacyr Scliar) $^{46}$

\footnotetext{
${ }^{46}$ SCLIAR, Moacyr. Memórias de um aprendiz de escritor. Memórias de um menino apaixonado por livros. $2^{\mathrm{a}}$ ed. São Paulo: Cia Editora Nacional, 2005, p. 26. Este mesmo trecho encontra-se em seu mais novo livro: SCLIAR, Moacyr. O Texto, ou: a vida. Uma trajetória literária. Rio de Janeiro: Bertrand Brasil, 2007.
} 


\subsection{Livros estrangeiros "fazem a cabeça" das crianças: do Coração ao Cazuza}

A cientista política Lúcia Lippi, ao analisar a questão nacional nas primeiras décadas da República, mostra que "os livros escritos para crianças pelos mais ilustres intelectuais da época, quase todos acadêmicos, fornecem as posições mais sintéticas, já que nesses textos eles se obrigam a explicitar claramente os pontos de vista e as posições que assumem frente à nacionalidade" (OLIVEIRA, 1990, p. 141).

A emergência do nacionalismo não foi fenômeno social exclusivamente brasileiro, mas ocorreu em várias partes, a partir do séc. XIX, como característica marcante da história contemporânea (HOBSBAWN, 1989; GUIBERNAU, 1997; ANDERSON, 2008). Um nacionalismo patriótico fez-se presente na escola de várias formas, mas, sobretudo, com o desenvolvimento de uma literatura escolar que se ampliou no período inicial do regime republicano. A literatura didática do período corresponde à que Choppin denomina de "livrosinstituição"47 - livros de ampla circulação, com várias edições, que foram lidos por crianças e jovens em idade escolar e veiculavam valores morais, cívicos e patrióticos - imprescindíveis ao fortalecimento de uma identidade da Nação.

\subsubsection{Coração}

Na Itália, por exemplo, a partir de seu processo de unificação, Edmundo de Amicis ${ }^{48}$ escreveu a obra Cuore. Libro par I ragazzi (1861). Na França, o livro Le Tour de la France

\footnotetext{
${ }^{47}$ Essa expressão foi usada por Alain Choppin na sua conferência de abertura no Simpósio Internacional Livro Didático: História e Educação, realizado na Faculdade de Educação da Universidade de São Paulo (FEUSP), entre os dias 5 e 8/11/2007. Na referida conferência, Choppin citou o livro infantil brasileiro As reinações de Narizinho, de Monteiro Lobato, como exemplo de "livro-instituição".

${ }^{48}$ Edmundo de Amicis (1846-1908) escritor italiano, militar, jornalista, monarquista moderado, tornou-se, depois de 1890, um ardente socialista. Suas obras estão centradas em três focos: a pátria, os jovens em processo de escolarização e a população pobre.
} 
par deux enfants: devoir e patrie (1877) constitui outro exemplo de "livro-instituição" ou "lugar de memória"49 da república francesa (OZOUF, 1997).

Desses livros estrangeiros, o de maior sucesso junto às crianças e jovens brasileiros foi Cuore, do escritor italiano Edmundo de Amicis (1846-1908). O livro narra, em forma de diário, a vida escolar do menino Enrico, na época do Risorgimento (pós-unificação da Itália), e seu conceito fundamental é o de educar a mente e o coração dos jovens com exemplos de virtude, de abnegação e de coragem, além de difundir valores morais, cívicos e patrióticos. No prefácio, em sua última edição nacional, há uma explicação acerca dos propósitos do autor: "Este livro é particularmente dedicado aos meninos das escolas primárias, que têm entre nove e treze anos, e poder-se-ia intitular: História de um ano escolar, escrita por um aluno de terceiro ano, duma escola primária da Itália.” (DE AMICIS, 1974, p. 8).

Esse livro fez sucesso no mundo todo, com traduções em vinte e cinco idiomas ${ }^{50}$ e adaptações para a televisão e o cinema italianos (BASTOS, 2004). No Brasil, a tradução mais conhecida é a do escritor João Ribeiro, pela Livraria Francisco Alves, em 1891, embora já houvesse traduções portuguesas circulando em escolas brasileiras.

\begin{abstract}
Somente na Itália mais de um milhão de exemplares do Cuore foram vendidos. Numerosas traduções em diversos idiomas apareceram desde fins do século passado até o presente. Livro de leitura escolar e, ao mesmo tempo, obra clássica da literatura infantil, Cuore conquistou também as crianças brasileiras e exerceu sensível influência sobre nossos autores de livros de leitura, conforme se pode constatar nas obras de Romão Puiggari e Arnaldo de Oliveira Barreto, Bilac, Júlia Lopes de Almeida, Scaramelli e outros (PFROMM NETO, 1974, p. 174, grifo nosso).
\end{abstract}

Coração foi lido por várias gerações de brasileiros e citado também por muitos autores consagrados da literatura, em suas memórias de infância, a exemplo de Humberto de Campos, Manuel Bandeira, Paulo Mendes Campos e Pedro Nava, entre outros.

\footnotetext{
${ }^{49}$ Para Pierre Nora "Os lugares de memória nascem e vivem do sentimento que não há memória espontânea, que é preciso criar arquivos, que é preciso manter aniversários, organizar celebrações, pronunciar elogios fúnebres, notariar atas, porque essas operações não são naturais. [...] Os lugares de memória são, antes de tudo, restos" (NORA, 1993, p. 13). Na obra organizada pelo historiador francês, há alusão a outro livro escolar considerado também "lugar de memória" - o Petit Lavisse, ao qual ele denomina "evangelho da República" (NORA, 1997, p. 239).

${ }^{50}$ Particularmente, além das edições brasileiras, tive acesso a duas traduções: uma para o espanhol (DE AMICIS, Edmundo. Corazón: diário de um niño. Buenos Aires: Ediciones Peuser, 1947) e outra para a língua inglesa, ainda em circulação (DE AMICIS, Edmundo. Cuore: a heart of a boy. Dufon Editions, Inc., 2005).
} 
José Lins do Rego, no romance autobiográfico Doidinho, fez menção a esse livro escolar, na voz de um personagem - o estudante Carlinhos:

Seria para mim uma vitória abandonar aqueles cadernos amarelos. Mas o meu grande ideal de aluno estava no Coração. [...] E como era diferente a escola de lá da do professor Maciel! Distribuíam prêmios, os professores falavam manso, não existiam palmatórias. O nosso colégio não se parecia com as escolas da Itália. [...] Todo esse livro delicioso me chamava para as suas páginas (REGO, 1980, p. 30-1).

Monteiro Lobato, por outro lado, tinha opinião diversa. Em carta endereçada a seu amigo Godofredo Rangel, datada de 1916, Lobato indagava:

Que é que nossas crianças podem ler? Não vejo nada. Fábulas assim seriam um começo da literatura que nos falta. Como tenho um certo jeito para impingir gato por lebre, isto é, habilidade por talento, ando com idéia de iniciar a coisa. É de tal pobreza e tão besta a nossa literatura infantil, que nada acho para a iniciação de meus filhos. Mais tarde, só poderei dar-lhes o Coração, de De Amicis - um livro tendente a formar italianinhos [...] (LOBATO, 1956, p. 104-5, grifo nosso).

Por sua vez, Viriato Corrêa, em vários depoimentos à imprensa, afirmou que esse livro de leitura serviu de inspiração para que ele escrevesse um outro clássico da literatura infantil nacional - Cazuza: memórias de um menino de escola (1938).

Quando li o "Coração", de De Amicis, já era homem formado, e achei o livro uma obra-prima, embora contivesse dois graves defeitos para a criança brasileira: era muito triste e fazia amar a Itália - disse-nos o escritor (acadêmico) Viriato Corrêa, evocando a origem de seus livros infantis e da obra didática, que vem publicando ininterruptamente desde 1908 (CORRÊA, 1960¹).

\footnotetext{
${ }^{51}$ A ausência de mais informações se deve ao fato do trecho ter sido extraído de um recorte de jornal sem data
} (n.a.) 


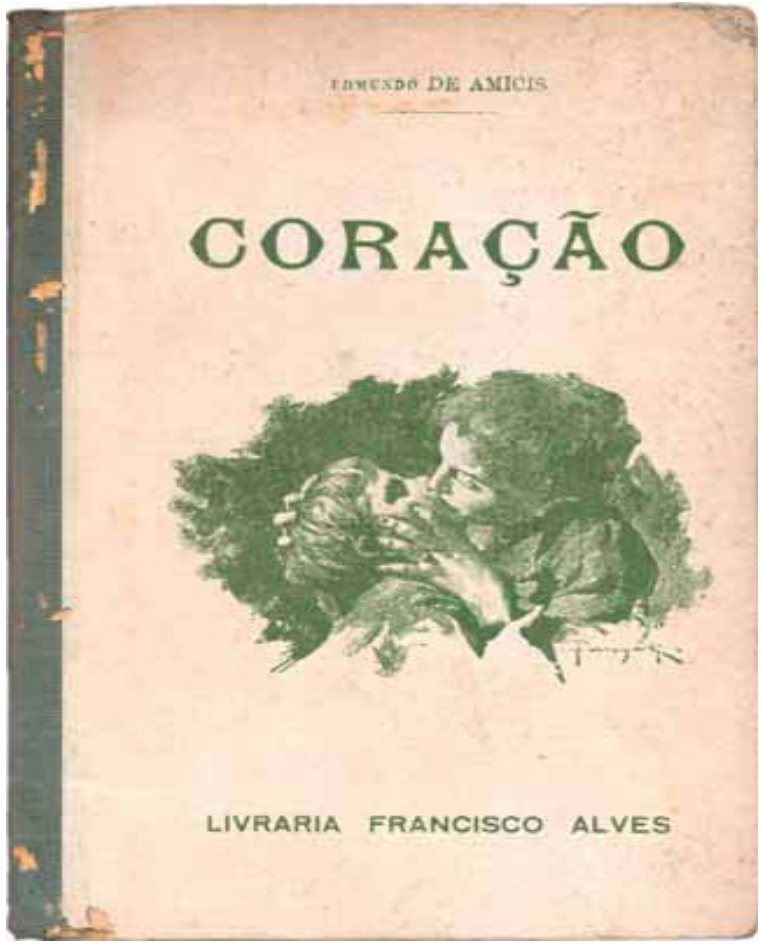

Figura 3 - Coração - capa.

Fonte: DE AMICIS, 1891.

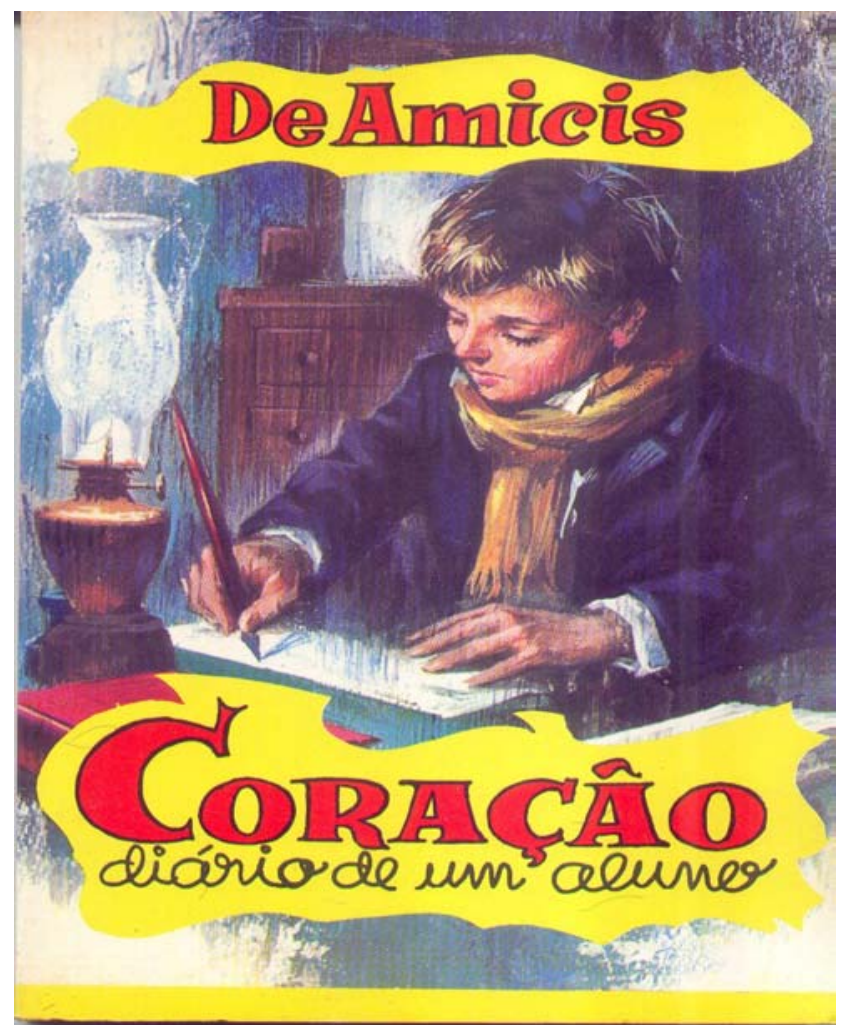

Figura 4-Coração - capa.

Fonte: DE AMICIS, 1982. 
Já o livro Le Tour de la France par deux enfants serviu de inspiração para a elaboração de um livro de leitura nacional - Através do Brasil, de Olavo Bilac e Manoel Bomfim. Esse livro francês, de autoria da escritora Augustine Fouillé ${ }^{52}$, é considerado um dos maiores sucessos da literatura escolar ocidental de todos os tempos, com centenas de edições, chegando a atingir a marca de 6 milhões de cópias vendidas na Europa. O livro narra a viagem de dois jovens órfãos - Julien e André - por diferentes regiões francesas e, a exemplo do Cuore, visava a desenvolver nos jovens um forte sentimento de patriotismo, a partir do conhecimento da geografia e da história francesas.

\begin{abstract}
Cada capítulo desse "livro de leituras correntes para o curso médio, com mais duzentas gravuras instrutivas para as aulas de ciências" era uma verdadeira "lição" (de história, de geografia, de ciências, é claro, mas sobretudo lição de moral), trazida pelas peripécias de uma viagem através da França. André e Julien descobriam os monumentos, as paisagens, as técnicas de trabalho e construíam, no decorrer do tempo, uma nova representação do mundo: variedade do seu país, dureza dos tempos, solidariedade dos homens. Por meio desse périplo educativo, o autor mostrava que $\mathrm{o}$ amor à pátria poderia proporcionar à moral escolar uma unidade ainda mais indiscutível do que a religião cristã. Fazendo a volta da França, as duas crianças aprenderam a ter coragem e confiança, mesmo na adversidade, a assumir um destino coletivo. Dessa forma, 'tornaram-se' francesas, quer dizer, solidárias com um solo, uma língua, com uma história (HÉBRARD, 1999, p. 62-3, grifo nosso).
\end{abstract}

Registre-se que esse livro surge no contexto em que a França havia sido duramente derrotada pela Alemanha e perdido partes importantes de seu território - a Alsácia e a Lorena. A autora pretendia, pois, elevar a auto-estima dos seus compatriotas franceses e resgatar a consciência nacional, profundamente abalada pela derrota de 1871 .

Vê-se que esse livro de leitura, bastante usado na escola primária francesa, difundiu a pedagogia republicana, calcada no amor à Pátria, no culto aos que desapareceram na guerra e no exemplo dos grandes homens.

Recentemente, a antropóloga Michele Petit, ao analisar os hábitos e práticas de leitura dos jovens, cita depoimento de um agricultor francês acerca de suas memórias de leitura, o que bem atesta como esse livro formou várias gerações de crianças francesas, durante a primeira metade do século XX:

\footnotetext{
${ }^{52}$ Escritora francesa, esposa do filósofo Alfred Fouillé, usou, nessa obra, o pseudônimo de G. Bruno. Logo no prefácio de sua obra, a autora adverte: "La connaissance de la patrie est le fondement de toute véritable instruction civique." (BRUNO, 2006, p. 4)
} 
Lembro de meus avós. Meu avô lia para mim A volta da França por duas crianças. Havia uma grande lareira, nem me lembro se tinha eletricidade, e depois do jantar minha avó colocava no fogo uma grande panela com vinho e tomilho e punha a ferver. Com mel. E ele nos contava... não sei por que, talvez porque eu fosse jovem, mas ele lia bem - a gente vivia aquelas histórias à medida que ele contava, sabe? Com meu irmão, quando a gente fala dessa Volta da França... conforme eles davam a volta da França, e curiosos, podíamos vê-la... isso devia ser por volta de 1945-46 (PETIT, 2008, p. 21-2).

Já a historiadora Haroche, ao mostrar a formação dos sentimentos coletivos dos franceses no final do séc. XIX, aponta o livro de História da França, de Ernest Lavisse, que foi escrito em 1876 e que, segundo ela, enquadra-se nos mesmos propósitos da pedagogia republicana, ao contribuir também para o fortalecimento do nacionalismo patriótico.

Lavisse faz parte dos republicanos franceses que, abalados pela derrota de 1871, pretendem, pela escolha dos temas de reflexão, das narrativas edificantes, do ensino da história, fabricar uma consciência nacional nutrida pelo amor da pátria. Ernest Lavisse insiste, como outros, sobre o dever da doação de si: na pátria, ele vê um país cujas crianças preferirão morrer a viver sob o jugo do estrangeiro (HAROCHE, 2002, p. 90).

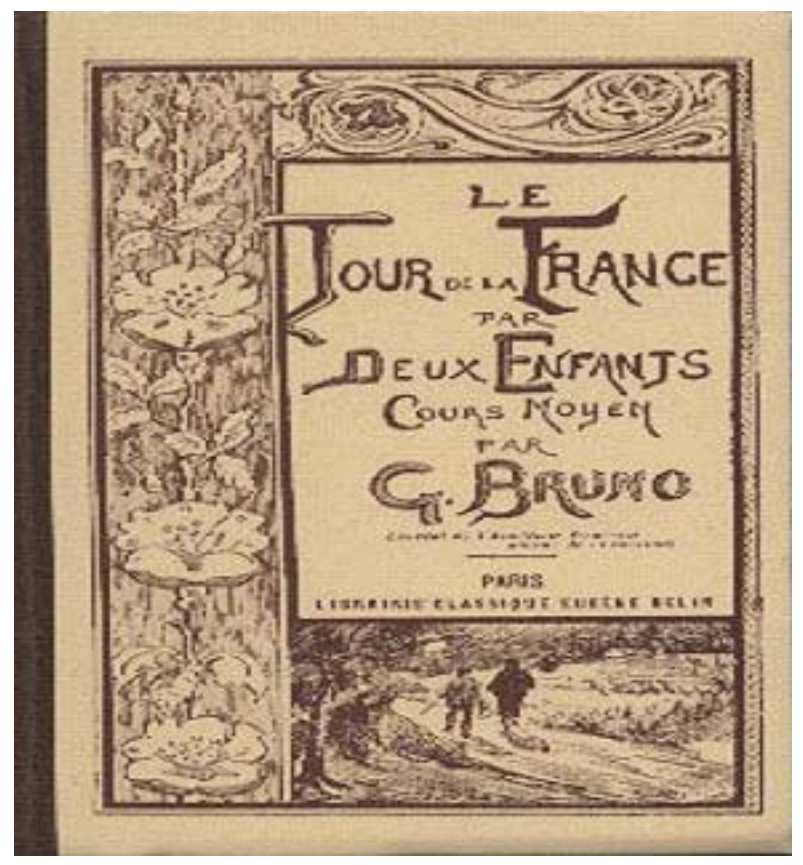

Figura 5 - Le Tour de La France par deux enfants capa. Clássico da literatura infantil ocidental.

Fonte: BRUNO, 2006. 
No Brasil, quais livros poderiam ser considerados "livros-instituição"? Que leituras promovidas na escola brasileira constituíram-se em "cartilhas da nacionalidade" 53 ? Alguns livros de leitura constituíram-se símbolos da nacionalidade e, de certa forma, influenciaram a produção literária de Viriato Corrêa: Por que me ufano do meu País (Affonso Celso, 1900), Contos Pátrios (Olavo Bilac e Coelho Neto, 1904), A Pátria Brasileira (Olavo Bilac e Coelho Neto, 1909) e Através do Brasil (Olavo Bilac e Manoel Bomfim, 1910).

$\mathrm{Na}$ primeira década da República, o escritor e crítico literário José Veríssimo preconizava que uma das tarefas mais urgentes no campo educacional brasileiro seria a reforma do livro escolar, sobretudo o chamado "livro de leitura". Dizia ele: "cumpre que ele seja brasileiro, não só feito por brasileiros que não é o mais importante, mas brasileiro pelos assuntos, pelo espírito, pelos autores trasladados, pelos poetas reproduzidos e pelo sentimento nacional que os anime.” (VERÍSSIMO, 1906, p. 6).

A iniciativa da produção dessa literatura por parte de diferentes intelectuais foi uma característica do período. Vários intelectuais que pertenciam ao IHGB e passaram a formar o seleto grupo da $\mathrm{ABL}^{54}$, foram responsáveis pela escrita de livros escolares adotados nas escolas primárias e lidos pela infância brasileira nas primeiras décadas republicanas. Destaque especial deve ser dado a algumas produções didáticas de membros da ABL que se tornaram verdadeiros cânones literários escolares.

Defino cânone literário escolar ${ }^{55}$ como o livro que teve adoção contínua na escola, com sucessivas edições e tiragens consideráveis de exemplares, tendo sido leitura obrigatória de várias gerações de crianças e jovens. Um dos sinais ou indícios (GINSBURG, 1989) para se constatar a existência do cânone literário escolar é o depoimento de autores em livros de memórias e autobiografias.

\footnotetext{
${ }^{53}$ Algumas cartilhas de alfabetização, destinadas à aprendizagem da leitura e da escrita de crianças, tornaram-se verdadeiros impressos da nacionalidade. É o caso da Cartilha do povo, de Lourenço Filho, que, publicada em 1928 pela Editora Melhoramentos, circulou até a década de 60, com mais de 2 mil edições (MACIEL; FRADE, 2003).

${ }^{54}$ A ABL foi criada em 1897, no Rio de Janeiro, por um grupo de intelectuais (Machado de Assis, Silvio Romero, Affonso Celso, Olavo Bilac, Coelho Neto, entre outros), nos moldes de sua congênere francesa (PIZA, 2003; RODRIGUES, 2003).

${ }^{55}$ Ver OLIVEIRA, Luiz Eduardo M. de. Entre a História Cultural e a Teoria Literária: rumo a uma história dos cânones escolares no Brasil. In: Revista Brasileira de História da Educação, Sociedade Brasileira de História da Educação (SBHE), nº 8, jul./dez. 2004.
} 


\subsubsection{Cazuza: o coração brasileiro}

Quando se fala o nome de Viriato Corrêa, a primeira associação que se faz é relacionálo ao seu livro de maior sucesso, Cazuza: memórias de um menino de escola, um clássico da literatura infantil lido por várias gerações de brasileiros que passaram pelos bancos escolares de outrora, sobretudo entre as décadas de 40 e 70 do século passado.

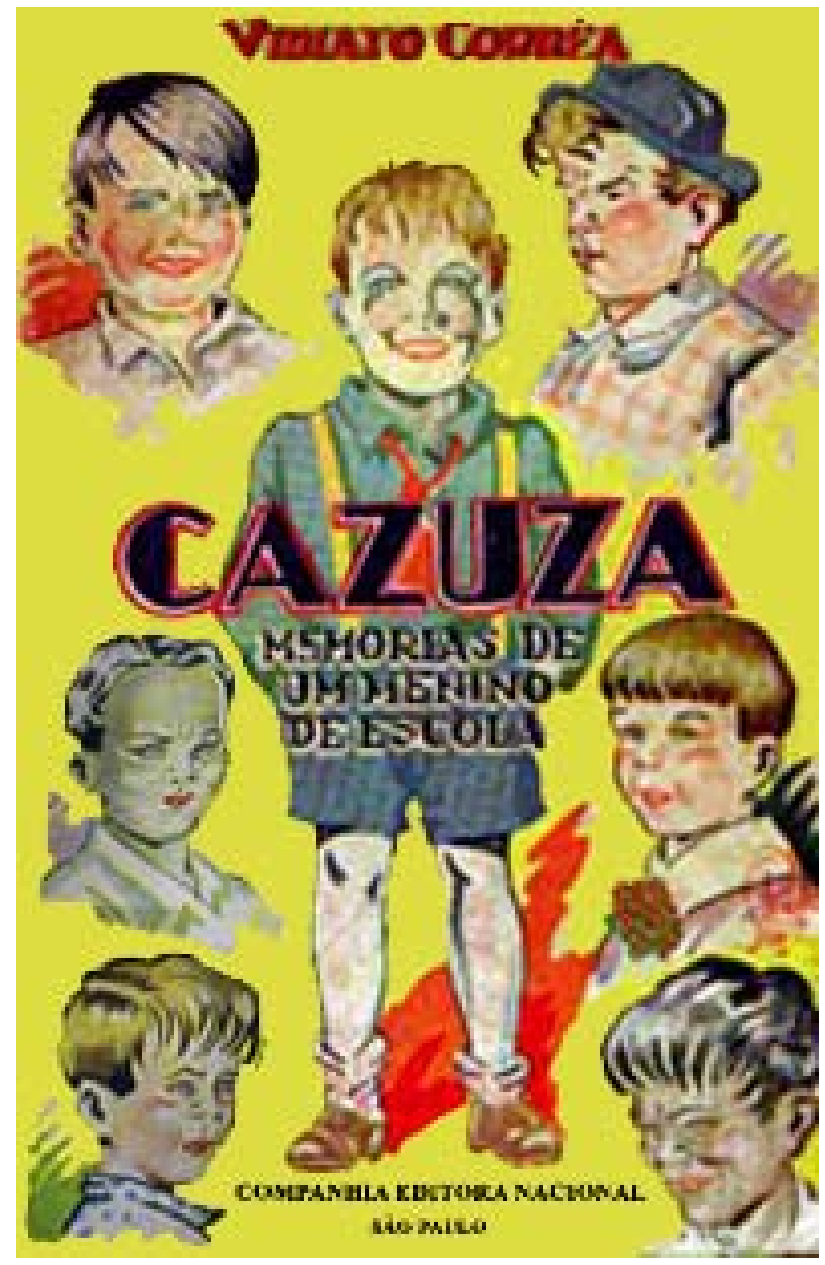

Figura 6 - Cazuza: memórias de um menino de escola. Fonte: CORRÊA, $1^{\mathrm{a}}$ edição, 1938.

O livro foi lançado em 1938 pela Companhia Editora Nacional e, atualmente, encontra-se em sua $42^{a}$ edição (2004). "Continuamente reeditado, apesar de mais de meio século de vida, Cazuza é livro que não envelheceu" (COELHO, 2006, p. 840). Com setenta anos de circulação no mercado editorial brasileiro, Cazuza é um verdadeiro cânone literário escolar ou um "livro-instituição". 
Em carta endereçada a seu amigo e editor Ribeiro Couto ${ }^{56}$, Viriato fez importante revelação: “[...] Estou a trabalhar num outro livro infantil. O título ainda não achei. É um livro, não digo nos moldes, mas nas intenções do Coração, de Amicis, mas um Coração verde e amarello, bem brasileiro, bem nosso. Deverá estar concluído em abril, para sair lá pelo Natal." (CORRÊA, $1936^{57}$, grifo nosso).

Cazuza é uma espécie de romance autobiográfico ou romance de formação ${ }^{58}$. O livro, ao narrar os fatos da infância do autor no Maranhão, mostra o cotidiano escolar na segunda metade do séc. XIX, fazendo críticas ao modelo de ensino da época (uso da palmatória, sabatinas, castigos físicos e morais). É o próprio autor que assim afirmou:

Pensei, então, em fazer um livro que inspirasse amor ao Brasil e fosse lido com agrado pelas crianças. Levei mais de dez anos pensando nisto. Fazia e desfazia planos. Afinal, depois de várias tentativas, resolvi fazer um livro que saísse de dentro de mim, fosse eu mesmo... E assim, surgiu o 'Cazuza', que é a minha vida de criança, com os meus companheiros, as nossas brigas, as nossas festas... Tôdas as figuras do livro viveram comigo - arremata o escritor maranhense: o livro fez sucesso porque escrevi com sinceridade [...] (CORRÊA, 1960).

Além de ter sido o maior sucesso editorial do autor, o próprio Viriato considera Cazuza seu melhor livro infanto-juvenil.

\footnotetext{
${ }^{56}$ Ribeiro Couto (1898-1963), juntamente com Octalles M. Ferreira e Getúlio M. Costa, eram diretores da Editora Civilização Brasileira S.A., filiada à Companhia Editora Nacional de São Paulo, que editou os principais livros de Viriato Corrêa.

${ }^{57}$ Carta de Viriato Corrêa a Ribeiro Couto, de 13.1.1936 - Arquivo Museu da Literatura Brasileira, Fundação Casa de Rui Barbosa, Rio de Janeiro-RJ.

${ }^{58}$ Terminologia usada para designar o livro em que o protagonista, na narrativa do autor, vivencia, no decorrer do enredo, um processo de aprendizagem, geralmente através de uma viagem. Nesse sentido, Através do Brasil e Cazuza são exemplos paradigmáticos de "romances de formação".
} 


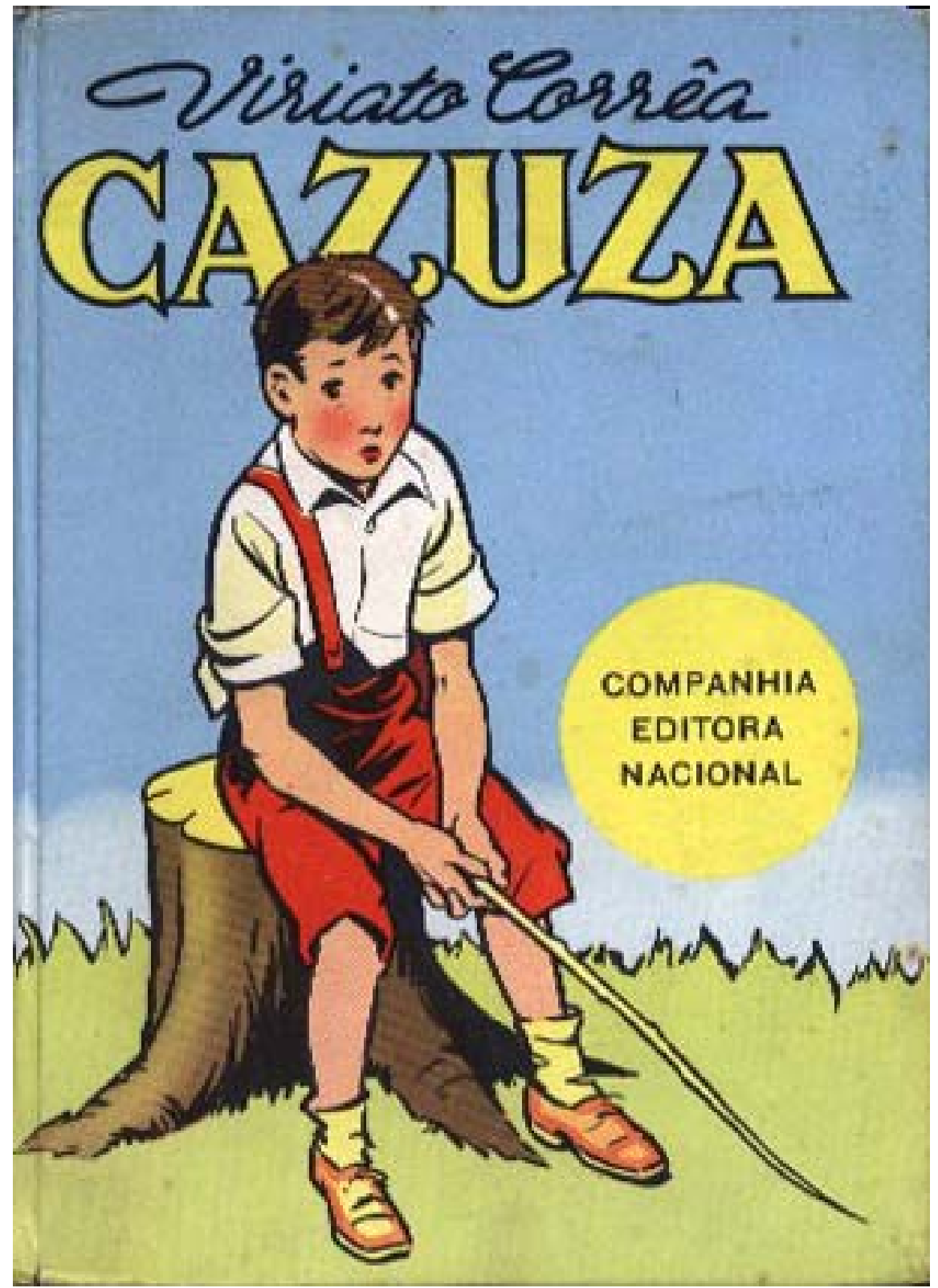

Figura 7 - Cazuza - capa adotada a partir da $2^{\mathrm{a}}$ até a $41^{\mathrm{a}}$ edição. Fonte: CORRÊA, 1982.

Um dos aspectos mais importantes do livro Cazuza é o fato de ele ser revelador da cultura escolar brasileira do século XIX, ao mostrar as práticas pedagógicas desenvolvidas em sala de aula e os saberes a serem aprendidos pelos alunos.

Em várias de suas passagens, o autor mostra o cotidiano de uma escola rural do nordeste brasileiro. A primeira delas é a decepção de Cazuza ao se deparar com as condições materiais da escola do povoado. 
A escola ficava no fim da rua, num casebre de palha com biqueiras de telha, caiado por fora. Dentro unicamente um grande salão, com casas de marimbondo no teto, o chão batido, sem tijolo.

De mobiliário, apenas os bancos e as mesas estreitas dos alunos, a grande mesa do professor e o quadro-negro arrimado ao cavalete.

A minha decepção começou logo que entrei (CORRÊA, 2004, p. 31-2).

O modelo de escola tradicional impunha aos alunos algumas práticas pedagógicas, entre as quais podemos citar o estudo da lição em voz alta, a realização de sabatinas e argüições e os exercícios de caligrafia.

Após o exercício de escrita ia-se "estudar a lição".

$\mathrm{O}$ estudo era gritado, berrado. Cantava-se a lição o mais alto que se podia, numa toada enfadonha.

Um inferno aquela barulheira. Trinta, quarenta, cinqüenta meninos gritando coisas diferentes, cada qual esforçando-se em berrar mais alto. E quando, já cansados, íamos diminuindo a voz, o professor reclamava energicamente, da sua cadeira:

- Estudem!

E a algazarra recrudescia.

Aquela mesma coisa, semanas inteiras, meses inteiros.

Nada, nada que despertasse o gosto pelo estudo (CORREAA, 2004, p. 39, grifo nosso).

Outra prática pedagógica bastante usada nas escolas de outrora era o exercício de caligrafia:

Nas antigas escolas roceiras, os exercícios de caligrafia se aprendiam vagarosamente. Levava-se de janeiro a dezembro não fazendo outra coisa senão cobrir pauzinhos e raramente a criança conseguia assinar o nome em menos de dois anos (CORRÊA, 2004, p. 57, grifo nosso).

Segundo o autor, tudo era motivo para castigo naquela escola.

Por uma falta pequenina ficava-se de pé, no centro da sala ou à porta da rua. Se a falta era maior, punha-se a criança de joelhos, no meio da sala.

A escola inteira falava horrorizada de dois suplícios que eu ainda não tinha tido ocasião de presenciar.

Um deles era ficar o aluno de joelhos sobre grãos de milho.

O outro, a 'orelha de burro'. À cabeça do menino colocavam-se duas enormes orelhas de papelão e fazia-se o desgraçado passear pelas ruas, vaiado pelos companheiros (CORRÊA, 2004, p. 39). 
No entanto, o mais temido de todos os castigos era a palmatória, usada geralmente por ocasião das sabatinas.

Nos dois anos e meio que alisei os bancos da escola da povoação, não houve para mim dia pior do que aquele da sabatina da tabuada. [...]

A sabatina de tabuada era, realmente, o grande pavor dos meninos do meu tempo.

O professor chamava quinze, vinte, trinta alunos, colocava-os de pé, em fila, conforme a ordem de chamada, e fazia-lhes perguntas.

A resposta devia ser dada imediatamente, em quatro ou cinco segundos. [...]

Quem acertava ia buscar a palmatória em cima da grande mesa e dava um bolo em cada companheiro.

$\underline{\text { Se, de ponta a ponta, todos erravam, o professor é quem dava os bolos de ponta a }}$ ponta (CORRÊA, 2004, p. 71, grifo nosso).

Um das imagens do livro é bastante esclarecedora quanto às práticas pedagógicas da escola freqüentada por Cazuza, no povoado de Pirapemas, interior do Maranhão.

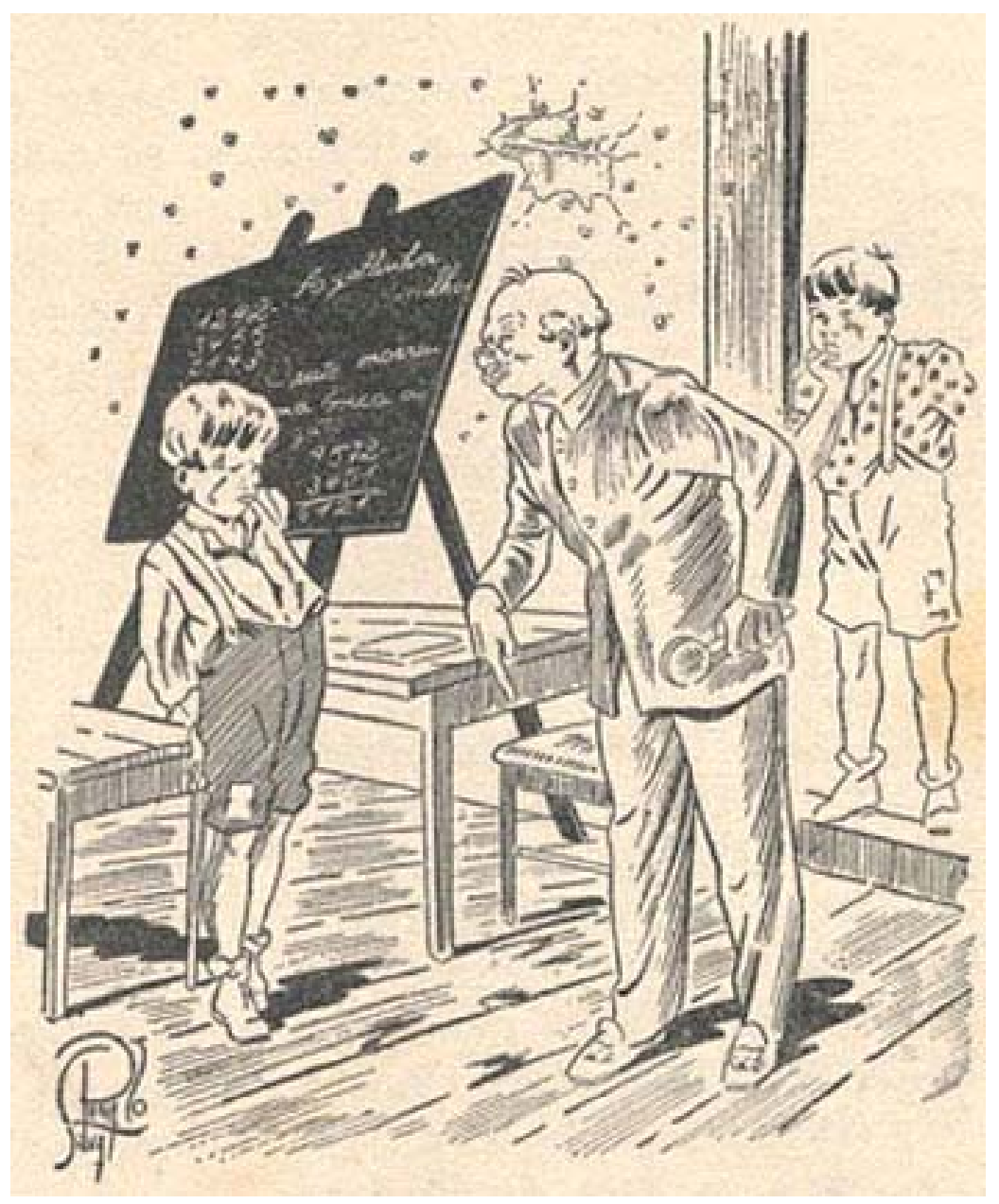

Figura 8-Cazuza.

Fonte: CORRÊA, 30ª ed., 1982, p. 45. 
Primeiramente, analisemos as condições materiais da escola: mobiliário bastante rústico (quadro-negro sobre um cavalete, uma simples mesa do professor com respectiva cadeira e bancos de madeira) e parede esburacada.

Há três imagens de pessoas: o professor com olhar carrancudo e palmatória na mão; o aluno sendo repreendido pelo mestre. Outro menino encontrava-se já de castigo ao pé da porta. Observa-se também que se trata de uma aula de Aritmética (como se chamava antigamente a disciplina Matemática, na escola primária), com conteúdos programáticos relacionados às quatro operações fundamentais. Era muito comum o professor realizar argüições em que se avaliava o domínio dos alunos na memorização da tabuada. Aqueles que não respondiam corretamente às perguntas do professor eram duramente advertidos e colocados de castigo. O mais temido por todos era a palmatória. "[...] A palmatória de lá trabalha na mão da gente... O Hilário me disse que bolo de palmatória dói mais do que bolo de chinela" (CORRÊA, 2004, p. 30).

Ao relembrar os primeiros anos de estudo numa escola do interior do Maranhão, Viriato Corrêa denunciava e fazia críticas a esse modelo de ensino tradicional, que usava métodos pedagógicos ultrapassados e ameaçava os alunos com punições severas. Ao fazer

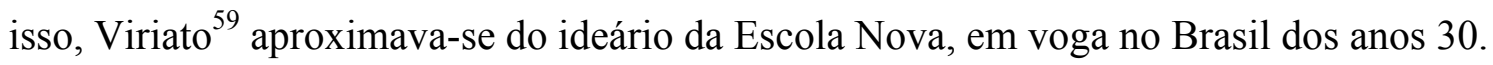

\footnotetext{
${ }^{59}$ Além de Fernando de Azevedo, com quem vai estabelecer interlocução ao escrever para a coleção de Literatura Infantil da Biblioteca Pedagógica Brasileira (BPB), Viriato fala, em seus depoimentos a jornais, sobre a amizade que tinha com Paulo Maranhão (que o convence a escrever o livro História do Brasil para crianças) e Anísio Teixeira, ambos ligados ao movimento da Escola Nova no Brasil.
} 


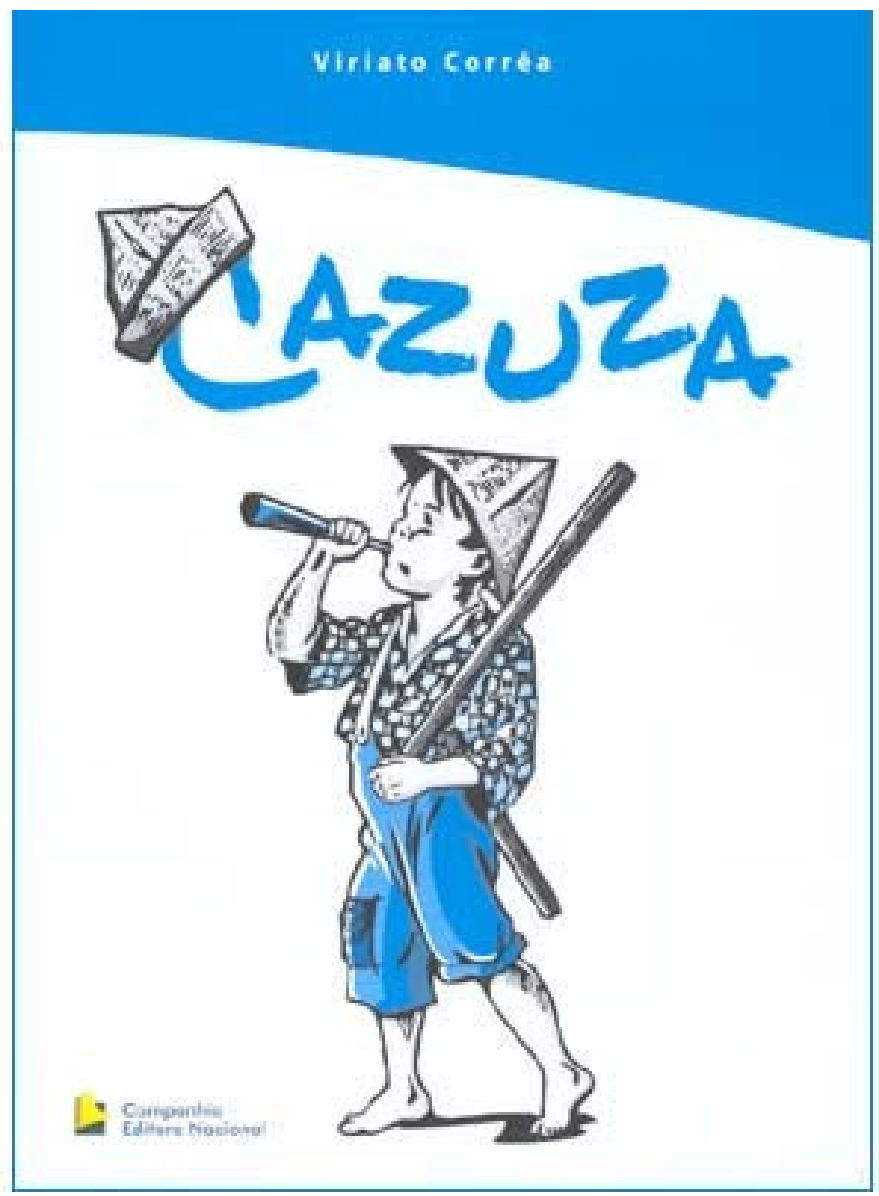

Figura 9-Cazuza - capa.

Fonte: CORRÊA, 42 a edição, 2004

O romance de formação Cazuza traz, em suas páginas, fatos relacionados à História do Brasil, e seu objetivo maior é inculcar nas crianças determinados valores morais, cívicos e patrióticos. E, apesar de não ser um manual didático de História, o livro cita alguns personagens e fatos históricos que deveriam servir de inspiração para que os alunos seguissem seus exemplos edificantes, em prol da Nação brasileira. Vejamos alguns deles:

Em uma das aulas, o Prof. João Câncio propõe aos alunos o seguinte tema para redação - "A bandeira nacional". O mestre faz uma advertência aos alunos: "Não quero frases: quero idéias. Ninguém se preocupe com palavras bonitas; preocupe-se, porém, com bonitos pensamentos." (CORRÊA, 2004, p. 182).

No dia seguinte, o professor disse que todas as composições estavam ruins e leu uma delas para toda a turma. Ao final, fez algumas críticas sobre as idéias expostas pelos alunos nas redações. Disse ele que 
todas exaltam a extensão do território, a beleza dos campos, das florestas, dos mares, das montanhas etc., etc. [...] exaltar estas coisas é ter da pátria uma noção inteiramente errada. É ter da pátria a noção de coisa material, que tem corpo, que se toca e que se pega. Ora, pátria não é isso (CORRÊA, 2004, p.183).

\section{O Prof. Câncio prosseguiu:}

[...] não existem pátrias físicas, ou melhor, pátrias não se medem pela extensão territorial. Brilho de céus, beleza de campos e mares, riquezas e tamanho da terra, são obras da natureza para as quais o homem não concorreu com uma parcela do seu esforço. E pátria é, principalmente, o esforço digno de seus filhos. [...]

- Pátria não é natureza, não é o território. É o homem. Se o homem é pequeno, ela é insignificante; se o homem é grande, ela é grandiosa. [...]

- O Brasil não é o volume das águas do Amazonas. Não é a Mantiqueira, com seus picos coroados de nuvens. Nem os campos de Mato Grosso, verdes, intermináveis. Nem a cachoeira de Paulo Afonso, cheia de espuma e de ruído. Nem a Guanabara. Nem o Corcovado. Nem o Pão de Açúcar. Nada disso é trabalho nosso (CORRÊA, 2004, p. 184, grifo nosso).

Floriano, um dos alunos da turma, indagou ao professor o que era, então, o Brasil, e ele respondeu:

- Pergunta você que é o Brasil? É tudo que temos feito em prol do progresso, da moral, da cultura, da liberdade e da fraternidade. O Brasil não é o solo, o mar, o céu que tanto cantamos. É a história de que não fazemos caso nenhum (CORRÊA, 2004, p. 185 , grifo nosso).

Nesse sentido, embora ainda persista na obra uma visão ufanista da nossa história, caudatária da contribuição de outro importante livro de leitura ${ }^{60}$, Cazuza aponta para outra direção: somos uma grande Nação devido ao trabalho e dedicação de grandes homens que, com seu exemplo e abnegação, fizeram a história desse País.

Que grandes homens são esses? Ao relacionar personagens de nossa história, Viriato Corrêa criou uma galeria dos heróis nacionais, com destaque para os fatos históricos que protagonizaram. Para ele, o Brasil é:

\footnotetext{
${ }^{60}$ Refiro-me ao livro de leitura Por que me ufano do meu País (1900), de Affonso Celso.
} 
- a obra de seus construtores, ou melhor, daqueles que o tiraram do nada selvagem e o fizeram terra civilizada;

- o trabalho dos jesuítas (Nóbrega e Anchieta);

- a coragem dos defensores do seu solo (Estácio de Sá, Mem de Sá e Araribóia na expulsão dos franceses do Rio de Janeiro; Jerônimo de Albuquerque na expulsão dos franceses no Maranhão; os patriotas pernambucanos na expulsão dos holandeses do Nordeste);

- a obra dos bandeirantes (Antonio Raposo, Fernão Dias Paes Leme, Borba Gato, Bartolomeu Bueno);

- o esforço de sua gente para tirar da terra os bens que a terra dá a quem trabalha;

- é a cana-de-açúcar;

- $\quad$ é o esplendor das minas de ouro;

- $\quad$ é o café, que engrandeceu São Paulo, Rio de Janeiro, Minas e Espírito Santo e que atualmente é a nossa maior riqueza;

- $\quad$ é o algodão, a riqueza do Nordeste; o cacau, a riqueza da Bahia, e a borracha, a riqueza da Amazônia;

- é sua indústria pastoril;

- é o trabalho obscuro dos negros nos campos de criação e de lavoura, nas minas, nos trapiches e nas fábricas;

- $\quad$ é tudo que se fez para que tivéssemos liberdade (Tiradentes e a Inconfidência Mineira; Domingos José Martins e Padre Roma na Revolução de 1817; José Bonifácio e Joaquim Ledo, na Independência; Frei Caneca e Padre Mororó, na Confederação do Equador; José do Patrocínio e Joaquim Nabuco, na defesa da Abolição da Escravatura; Silva Jardim, Benjamin Constant e Deodoro da Fonseca, na proclamação da República);

- $\quad$ é a obra dos patriotas da Regência (Padre Feijó e Duque de Caxias);

- $\quad$ é o gênio inventivo de Bartolomeu de Gusmão produzindo a Passarola;

- são os grandes vultos das ciências (Teixeira de Freitas, Rui Barbosa e Varnhagen), das letras (Gonçalves Dias e Castro Alves) e das artes (Pedro Américo, Vítor Meireles e Carlos Gomes) (CORRÊA, 2004, p. 185-7).

Por fim, o Prof. Câncio sintetizou sua explanação, dizendo de forma enfática:

Em vez de exaltarmos os céus azuis, as montanhas verdes, os rios imensos, exaltemos os homens que realizaram as obras em favor da nossa indústria e do nosso comércio. Exaltemos Mauá e Mariano Procópio, que construíram as nossas primeiras estradas de ferro; Barbacena, que fez navegar, nos nossos rios, o primeiro barco a vapor. [...]

Num país, a beleza da paisagem, o fulgor do céu, a extensão dos rios, as próprias minas de ouro, são quase nada ao lado da inteligência, da energia, do trabalho, das virtudes morais de seus filhos. [...] E é essa energia, esse trabalho, essa inteligência, essas virtudes morais que a nossa bandeira representa (CORRÊA, 2004, p. 187, grifo nosso).

Assim, a bandeira nacional, símbolo da Pátria, encarna a própria identidade da Nação, pautada na ideologia do trabalho de seus filhos ilustres - os brasileiros patriotas. 
Além dos fatos históricos mencionados, há um capítulo sobre o ex-escravo e abolicionista Luiz Gama, bem como sobre a participação "heróica" dos "Voluntários da Pátria”, na Guerra do Paraguai (1864-1870).

Em um dos últimos capítulos do livro, intitulado "A obra dos brasileiros", fica mais nítida a concepção de pátria e de história que o autor pretendia passar às crianças. Mais uma vez, o Prof. João Câncio fez uma grande preleção:

[...] Quando thes dei o tema "A bandeira nacional", todos erraram a verdadeira noção da pátria louvando a grandeza territorial do país em vez de louvar a grandeza moral e o esforço da gente. [...] A culpa não é de vocês, é de quem lhes ensina noções falsas. Para muita gente, patriotismo é elogiar as nossas coisas mesmo quando elas não merecem elogios. É um erro. O verdadeiro patriotismo é aquele que reconhece as coisas ruins do seu país e trabalha para melhorá-las. [...]

- É necessário que vocês, desde pequeninos, saibam disso, para que, desde pequeninos, pensem em engrandecer o Brasil.

Cazuza pergunta:

- Então não há glória nenhuma em ser brasileiro?

O Prof. João Câncio responde:

- Devemos ter orgulho de ser brasileiros, porque a obra que estamos realizando no mundo é obra que ninguém realizou.

E dirigindo-se ao mapa-múndi, apontou:

- O Brasil está aqui. Fica, como vocês estão vendo, entre o Equador e o trópico de Capricórnio. Entre o trópico e o Equador, não houve, até hoje, na história, povo nenhum que fosse um grande povo, povo nenhum que pudesse realizar uma grande civilização. É a própria natureza, o próprio clima que o impedem. No entanto, nós, os brasileiros, com quatro séculos apenas, já temos um maravilhoso começo de civilização. Pode-se dizer que ontem saímos do estado selvagem e já fazemos parte dos povos civilizados. [...]

- Tenhamos orgulho de ser brasileiros (CORRÊA, 2004, p. 209-11, grifo nosso).

Concluo, afirmando que a visão ufanista que Viriato Corrêa tem da história do País coaduna-se com os preceitos do Estado Novo (1937-1945), que pretendia difundir a idéia de que o Brasil estava no caminho certo rumo ao progresso. A ideologia do trabalho, presente em Cazuza (1938), serviu para sedimentar o sentimento de identidade nacional propagado pelo governo Vargas, através de suas instituições educacionais e culturais ${ }^{61}$.

\footnotetext{
${ }^{61}$ Para uma análise mais completa da política educacional e cultural do Estado Novo, ver SCHWARTZMAN, Simon et al. Tempos de Capanema. Rio de Janeiro/São Paulo: Paz e Terra/EDUSP, 1984.
} 


\title{
2.2 O ufanismo patriótico na literatura escolar
}

\subsubsection{Por que me ufano do meu País}

Em 1900, por ocasião das comemorações alusivas aos quatrocentos anos do descobrimento do Brasil, o Conde Affonso Celso ${ }^{62}$, um dos fundadores da ABL e membro do IHGB, escreveu Por que me ufano do meu País, dedicado a seus filhos, Affonso Celso e Carlos Celso:

\begin{abstract}
As páginas que aí vão - escrevi-as para vós, meus filhos, ao celebrar nossa Pátria o quarto centenário do seu descobrimento. [...] Consiste a minha primordial ambição em vos dar exemplos e conselhos que vos façam úteis à vossa família, à vossa nação e à vossa espécie, tornando-vos fortes, bons e felizes. Se de meus ensinamentos colherdes algum fruto, descansarei satisfeito de haver cumprido a minha missão. Entre esses ensinamentos, avulta o patriotismo (CELSO, 1997, p. 25).
\end{abstract}

Para desenvolver o sentimento de patriotismo, o autor fez uma explanação laudatória das riquezas e potencialidades do País e apontou os onze motivos de nossa suposta superioridade nacional. São eles:

1. Grandeza territorial: o Brasil é um dos mais vastos países da Terra;

2. Beleza incontestável, evidenciada através do Rio Amazonas, da Cachoeira de Paulo Afonso, das reservas florestais, da Baía da Guanabara e dos pampas do Sul;

3. Riquezas naturais abundantes: ouro, diamantes, gado, fosfato, águas minerais etc;

4. Variedade e amenidade do clima;

5. Ausência de calamidades que costumam afligir a humanidade: ciclones, terremotos, furacões, inundações, vulcões;

6. População resultado da "fusão de três dignas e valorosas raças" (CELSO, 1997, p. 226);

7. Qualidades do caráter nacional: somos um povo ordeiro, pacífico, serviçal, sensível, sem preconceitos;

\footnotetext{
${ }^{62}$ Affonso Celso (1860-1938), filho do monarquista Visconde de Ouro Preto, bacharel em Direito, filiado ao Partido Liberal, defendeu a abolição da escravatura e o regime republicano. Foi eleito deputado com apenas 22 anos e obteve quatro mandatos consecutivos. Foi membro da ABL e do IHGB.
} 
8. O Brasil nunca sofreu humilhações de outros povos e nações, nem foi vencido;

9. O Brasil sempre manteve uma relação cordial e de respeito com os outros países;

10. O País constitui-se num vasto campo de estudo para os pesquisadores;

11. O Brasil possui uma história admirável, "relacionada com os mais notáveis acontecimentos da espécie humana, escasseiam guerras civis e efusões de sangue, sobejando feitos heróicos, formosas legendas, preclaras figuras, luminosos exemplos." (CELSO, 1997, p. 226).

Logo no início, após o título na página de rosto, há a expressão em língua inglesa "Right or wrong, my country" (certo ou errado, meu país) -, o que já revela o sentimento patriótico que o autor quer passar às crianças e jovens. O que nos causa estranheza é o fato de que, em pleno período de afirmação da nacionalidade, em meio às comemorações dos 400 anos do Brasil, o autor use uma expressão em inglês; além disso, era a língua francesa o idioma falado pela elite letrada do País nessa época.

Na concepção do autor, o Brasil estaria predestinado ao progresso. A partir dele, cunhou-se a palavra "ufanismo", para designar um sentimento ingênuo e conservador de amor à pátria.

A visão do país como um "paraíso tropical" é, ainda hoje, bastante presente no imaginário brasileiro e parece ter suas raízes nesse livro de leitura, presente na formação de várias gerações, conforme atesta José Murilo de Carvalho, ao citar pesquisa nacional ${ }^{63}$ na qual $60 \%$ dos brasileiros entrevistados têm muito orgulho do Brasil e a principal razão desse orgulho reside na exuberância de nossa natureza.

“A visão edênica da nova terra foi reiterada muitas e muitas vezes pelos portugueses, brasileiros e estrangeiros, até se tornar um importante ingrediente do 'imaginário nacional'. Tornou-se o mito edênico brasileiro ${ }^{64}$." (CARVALHO, 2003, p. 402).

\footnotetext{
${ }^{63}$ Pesquisa Vox Populi, publicada em revista semanal, de circulação nacional, com a matéria intitulada " $O$ Brasileiro segundo ele mesmo" (Revista VEJA, 01.12.1996).

${ }^{64}$ Sobre a visão edênica do Brasil desde a chegada dos portugueses ao país, consultar o clássico: HOLANDA, Sérgio Buarque de. Visão do paraíso: os motivos edênicos do descobrimento e colonização do Brasil. São Paulo: Brasiliense, 1992.
} 
Por que me ufano do meu País é um livro de leitura, mas que, como os demais, possui conteúdos históricos que merecem ser analisados. Affonso Celso registra alguns fatos históricos e personagens de nossa história, a saber: o papel dos jesuítas, que garantem a presença do catolicismo em nossa formação cultural; o quilombo de Palmares, que ressalta o papel do negro na formação étnica; a expulsão dos holandeses em defesa do território nacional, e as bandeiras, responsáveis pela expansão territorial.

É importante destacar que todos esses conteúdos históricos integram também o livro História do Brasil para crianças (1934), de Viriato Corrêa. São temas, aliás, que vão perpassar, durante muito tempo, os currículos e programas de ensino da História do Brasil na escola primária. Nesse período - e até a década de 1960 - não há livro didático que não cite esses conteúdos, que se tornam uma verdadeira "vulgata histórica".

Affonso Celso, por outro lado, refutou o discurso racial presente no debate acadêmico do séc. XIX e exaltou nossa miscigenação racial e os atributos das três raças na formação do caráter nacional. Vê-se, na obra, um prenúncio da teoria da democracia racial, posteriormente elaborada por Gilberto Freyre em Casa-Grande e Senzala (1933).

$\mathrm{Na}$ verdade, segundo Oliveira (2003), esse livro de leitura toma como herói nacional não um personagem histórico, mas a própria natureza exuberante e exótica, motivo de orgulho de todos os brasileiros, já que diferencia nosso país dos demais.

Por que me ufano do meu País deu início à fase nacionalista da literatura escolar brasileira que, a exemplo de Viriato Corrêa, com Cazuza (1938), terá outros seguidores, embora com matizes diferenciados.

Em 1997, por ocasião do centenário da Academia Brasileira de Letras, Por que me ufano do meu País mereceu uma reedição, cuja introdução, escrita pelo "imortal” João de Scantimburgo, revela ser esse livro um cânone literário escolar:

Lembro-me com nitidez da compra que fiz, numa das tipografias da cidade de Rio Claro, no interior de São Paulo, do livro Por que me ufano do meu País. Estava eu no quarto ano do grupo escolar Joaquim de Sales, e a simpática, bela - para a minha saudade daqueles tempos que, desgraçadamente, não voltam mais - professora o indicou aos alunos. Devíamos lê-lo e dois de nós, alunos, seríamos escolhidos para 
comentá-lo perante a classe. [...] No grupo escolar, onde se aprendiam as primeiras letras, mas sob ensino sério, fazíamos incursões em algumas obras de autores consagrados. Esse o meu contato inicial com o livro de Affonso Celso, de quem eu nunca ouvira falar e nem sabia quem era. A diligente professora nos informou que se tratava de grande nome das Letras, fora fundador da Academia Brasileira de Letras, escrevera numerosos livros, romances, poemas, história e outros gêneros. Affonso Celso erigiu-se para mim, diante de mim, como um mito. Encantado com o livro, que fascinara o menino da escola primária, vi-o logo, na minha confusa inteligência como um dos notáveis escritores, dos quais já tinha conhecimento, ao menos, dos nomes. Não podia avaliar-lhe a dimensão, mas o considerava uma eminência literária, e o Por que me ufano do meu País, se me impôs como um breviário de patriotismo. Estava ali, nas suas páginas, pouco mais de duzentas, todo o Brasil resumido, convocando-nos para amá-lo e servi-lo (CELSO, 1997, p. 11-2, grifo nosso).

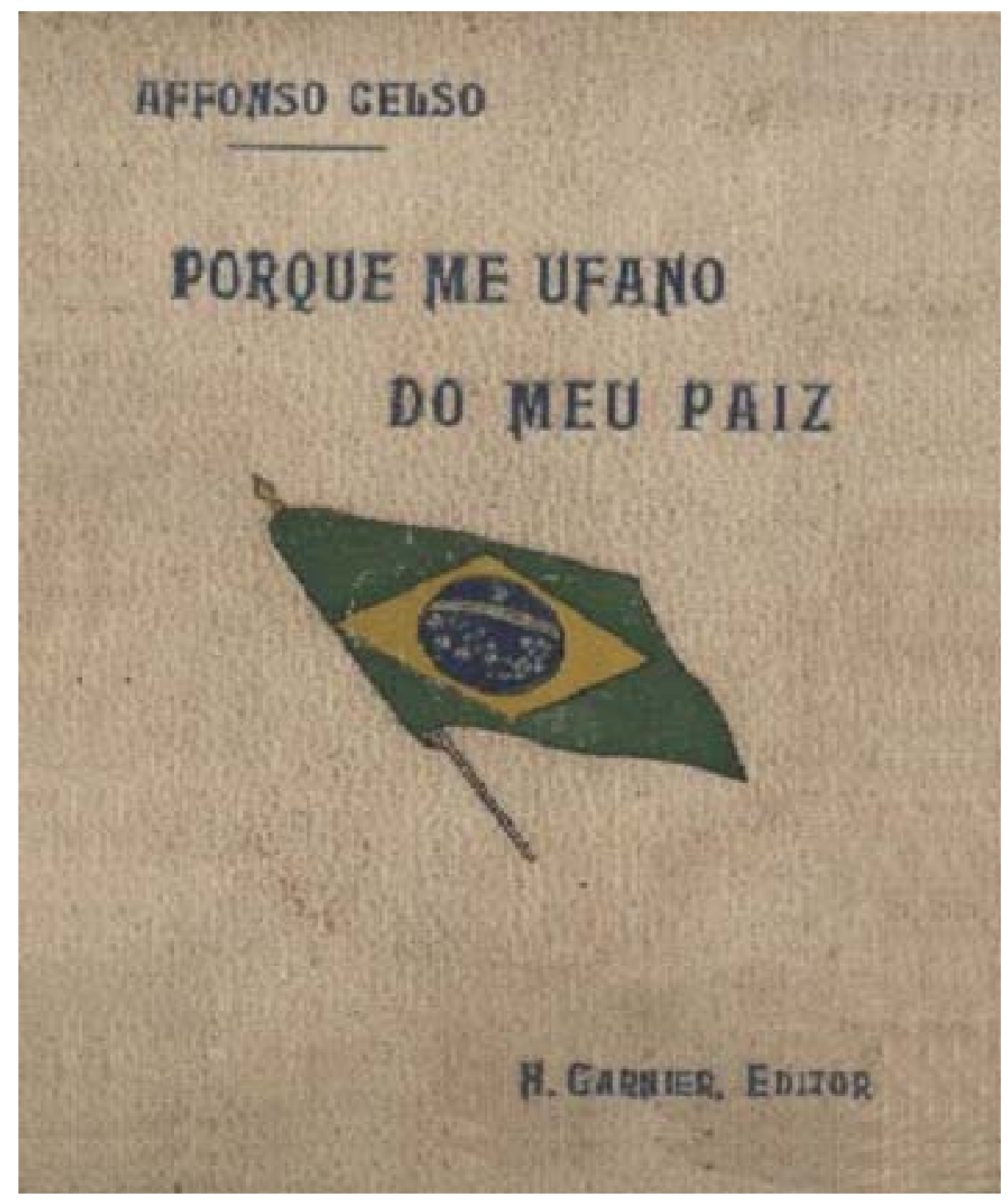

Figura 10 - Por que me ufano do meu Paiz - capa.

Fonte: CELSO, 1900. 
Outro indício de que Por que me ufano do meu País tornou-se obra canônica na escola brasileira é o fato de que, até a década de 1950, as antologias ou seletas escolares para os exames de admissão incluíam textos extraídos dessa obra. É o caso, por exemplo, do livro Seleta Brasileira: pequena antologia da cultura brasileira (curso de admissão), de autoria do educador Theobaldo Miranda Santos, que, logo na primeira unidade, traz o texto de Affonso Celso sobre a grandeza do rio Amazonas - "uma das maravilhas da natureza, o maior rio do mundo! [...] o Mar Doce.” (SANTOS, 1951, p. 9).

\subsubsection{Contos Pátrios e A Pátria Brasileira}

Também na década de 1910, os poetas parnasianos Olavo Bilac ${ }^{65}$ e Coelho Neto ${ }^{66}$, movidos pelo nacionalismo, escreveram obras que passaram a ser amplamente adotadas pelas escolas primárias de todo o País, a saber: Contos Pátrios (1904) e Pátria Brasileira (1909).

O livro Contos Pátrios surgiu de uma encomenda feita pelo editor Francisco Alves aos poetas Olavo Bilac e Coelho Neto. A história da escrita e posterior edição desse livro é bastante reveladora dos primórdios da indústria editorial brasileira e do papel de Francisco Alves como um dos primeiros editores de livros escolares (BRAGANÇA, 2006).

\footnotetext{
${ }^{65}$ Olavo Bilac (1865-1918) é a grande figura literária da Belle Époque carioca, tendo também se dedicado às questões sociais e educacionais de seu tempo. Foi diretor interino do Pedagogium, Instituto de Pesquisas Educacionais criado em 1890, e inspetor de ensino, na gestão de Manoel Bomfim, da Instrução Pública do Distrito Federal. Envolveu-se também em campanhas cívicas pela instrução primária, pelo serviço militar obrigatório e criou a Liga da Defesa Nacional.

${ }^{66}$ Coelho Neto (1864-1934), escritor maranhense, foi parceiro de Bilac na edição de livros escolares. Membrofundador da $\mathrm{ABL}$, dedicou-se a vários gêneros literários, tendo recebido o título de "Príncipe dos prosadores brasileiros". Foi Deputado Federal em dois mandatos consecutivos e secretário-geral da Liga de Defesa Nacional.
} 


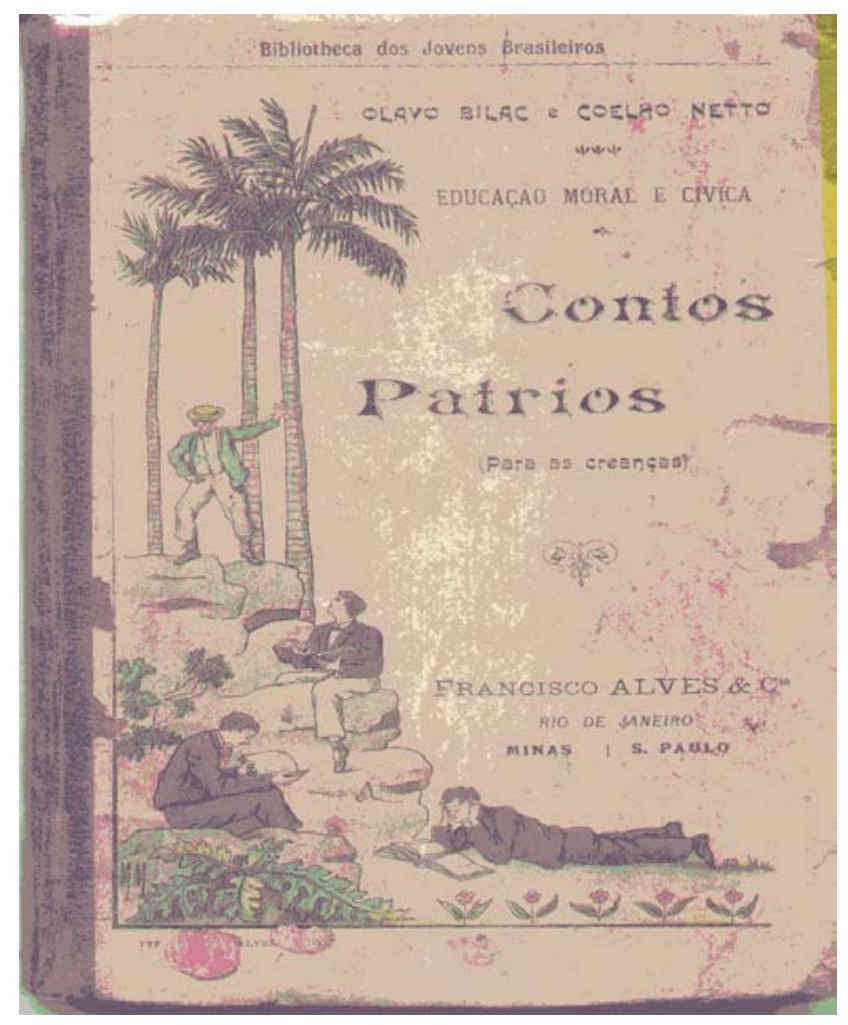

Figura 11 - Contos Pátrios - capa.

Fonte: BILAC e COELHO NETTO, s/d.

Bilac encontrava-se em difícil situação financeira, tendo empenhado até mesmo as jóias de sua mãe para conseguir se manter. No entanto, não tendo resgatado as cautelas, as peças seriam leiloadas; com a proximidade do leilão, tinha uma semana para resgatá-las ou então as perderia.

Sem dinheiro para resgatá-las, Bilac e Coelho Neto recorrem ao editor Francisco Alves para conseguir algum adiantamento por algum livro.

De imediato, o livreiro se dispôs a ajudá-los, mas quis saber se tinham algum original pronto. Não, não tinham. Fugindo da polícia de Floriano, Bilac havia guardado alguns sonetos esparsos, insuficientes para um livro. Coelho Neto, por sua vez, também não tinha nada na gaveta.

Alves, então, lhes fez uma proposta: pagaria quatro contos de réis, metade ali, naquela hora, e metade contra a entrega dos originais, no final da semana. Queria um livro de contos sobre episódios da História do Brasil, temas cívicos para alunos dos ginásios. Contos Pátrios seria um bom título - sugeriu.

Era uma segunda-feira e o leilão aconteceria na sexta. Os dois, Bilac e Coelho, se entreolharam. O prazo era bastante curto, mas não tinham outra saída. Aceitaram a encomenda e passaram os três dias seguintes, virando noite após noite, até que, no dia combinado, os originais estavam nas mãos de Francisco Alves.

O livro vendeu 105 mil exemplares, um absoluto sucesso em comparação a toda e qualquer referência da época. E até o dia de sua morte, em 29 de junho de 1917, todos os anos, pelo Natal, o livreiro Alves enviava 1 conto de réis para Coelho Neto e outro para Bilac, como lembrança dos Contos Pátrios, que eles escreveram em colaboração (LEE, 2006, p. 179-80, grifo nosso). 
O sucesso de Contos Pátrios motivou a dupla a escrever outros livros escolares. $A$ Pátria Brasileira (1909) foi outro livro de leitura destinado à leitura cívica dos alunos das escolas primárias, como consta na capa do livro, que integrou a Biblioteca dos Jovens Brasileiros organizada pela editora Francisco Alves. Diferentemente de Contos Pátrios, esse livro traz como conteúdo textos históricos que contemplam basicamente o programa da disciplina História para o curso primário.

Em pequenos textos, sem atividades ou questionário ao final dos capítulos, esse livro de leitura abarca vasto período de nossa história - desde a expansão marítimo-comercial européia, que resultou no "descobrimento" da América e do Brasil (dois capítulos do livro), até o advento da República, com o texto "Quinze de Novembro".

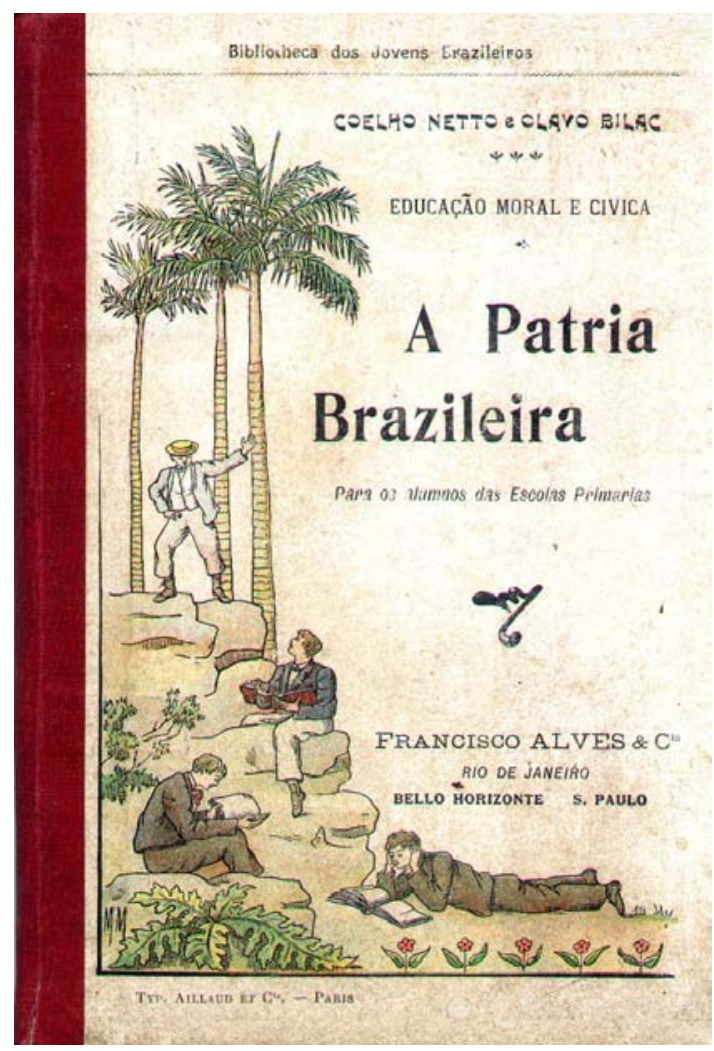

Figura 12 - A Patria Brazileira - capa.

Fonte: BILAC e COELHO NETTO, 1910.

No final do livro, os autores fazem uma exortação patriótica às crianças e jovens brasileiros, elucidativa de sua concepção de história e de como deveria ser o ensino da disciplina História, para aquele segmento: 
Damos aqui por finda a nossa empreza. Aballançamo-nos a leva-la a termo sem vaidade, porque não trazemos novos subsídios à história nem nos alongamos tanto pelos episodios quanto devêramos; muitos e admiráveis deixamos de parte, por não caberem em um livro cujo principal intuito é despertar nas almas jovens o amor da pátria.

Para tornar a leitura mais agradável procuramos revestir os factos de uma forma amena que não enfastiasse os leitores. D'aqui partireis para o estudo da verdadeira história nacional; neste livro ha apenas quadros de exemplos; e não vos deveis limitar às suas linhas escassas, porque ha ainda muitas e grandes bellezas a conhecer do copioso documentário da nossa vida social e política.

Ide por diante, buscai conhecer a vossa pátria, para que, vendo-a tão grande como é, façais por vos tornardes dignos d'ella (COELHO NETO; BILAC, 1910, p.282-3, grifo nosso).

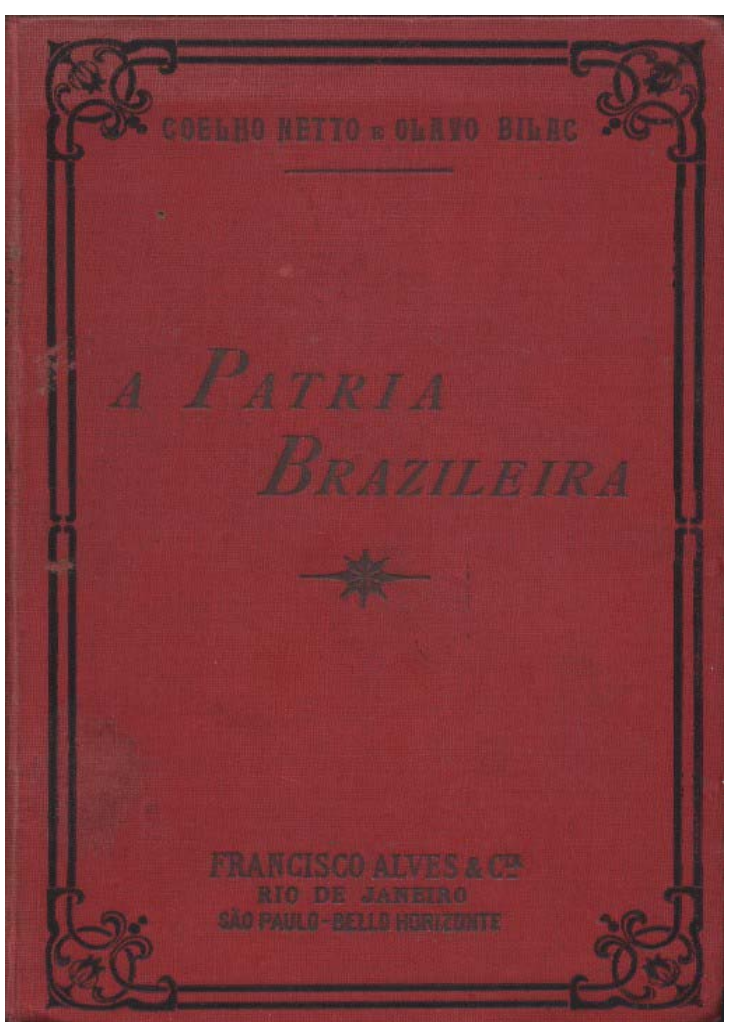

Figura 13 - A Patria Brazileira em formato de "livro-prêmio".

Fonte: BILAC e COELHO NETTO, 10ª edição, 1916.

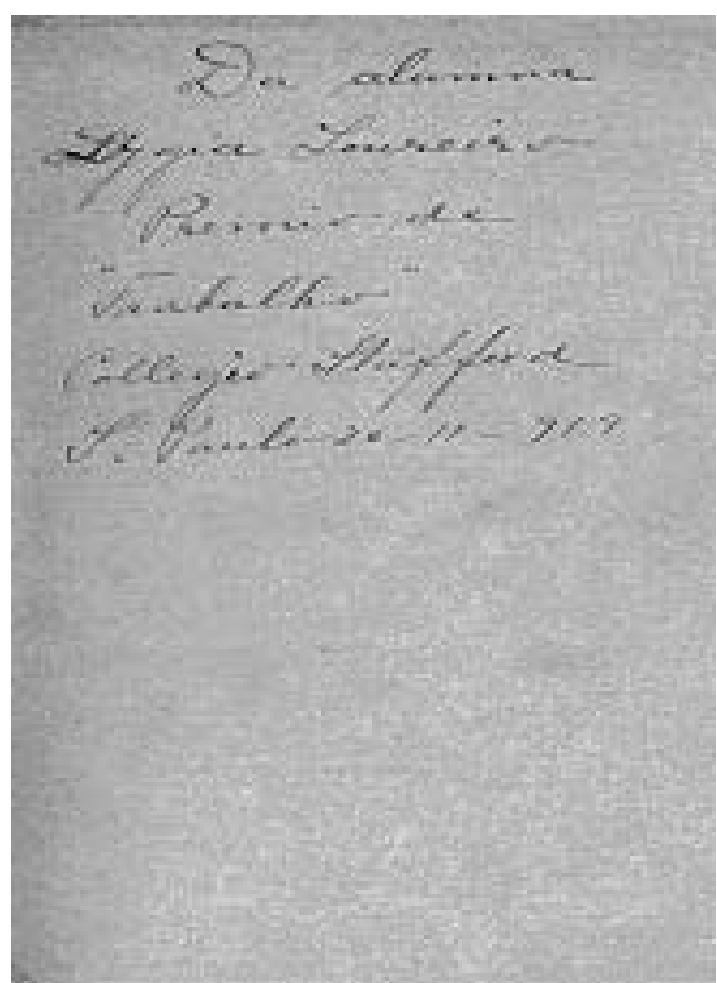

Figura 14 - Dedicatória contida no livro-prêmio A Patria Brazileira.

Fonte: BILAC e COELHO NETTO, $10^{\mathrm{a}}$ edição, 1916. 
Coelho Netto, a exemplo do Conde Affonso Celso, escreveu outro livro com pretensões pedagógicas e ufanistas, não tão conhecido como os dois anteriores que escrevera com Bilac, mas que merece nossa análise, por fazer uma síntese do nacionalismo patriótico. Trata-se do Breviário Cívico (1921), dedicado a seus filhos Emanuel, Georges, Paulo e João: "meus filhos, achareis condensada nos breves capítulos deste livrinho, toda a doutrina com que vos preparei o coração para o culto da virtude e para o amor da Pátria" (COELHO NETTO, 1957, p.7).

E conclui, citando o célebre verso de seu amigo Olavo Bilac: "Ama com fé e orgulho a terra em que nasceste.” (BILAC apud COELHO NETTO, 1957, p.7).

No Breviário Cívico, além dos valores cívico-patrióticos e de preceitos morais fundados na doutrina cristã, há conteúdos históricos, quando o autor aborda as datas nacionais que a escola deve comemorar ${ }^{67}$. Para Coelho Netto,

\footnotetext{
Assim como amamos a terra da Pátria devemos prezar a sua história, que é o celeiro eterno onde se recolhem as colheitas de heroísmo dos que passaram a vida semeando exemplos. [...]

Assim é na História que a Pátria se concentra e resguarda como na Bíblia vive e perpetua-se a tradição cristã (COELHO NETTO, 1957, p.15).
}

\subsubsection{Através do Brasil}

Foi outra obra de Olavo Bilac, com o escritor sergipano Manoel Bomfim ${ }^{68}$, que se tornou também um cânone literário escolar, sucesso de vendas sem precedentes na indústria editorial brasileira. Trata-se de Através do Brasil: prática da língua portuguesa. Narrativa.

\footnotetext{
67 "As datas nacionais são as que relembram um culto tradicional da Humanidade ( 2 de novembro), as que comemoram um acontecimento de interesse universal ( $1^{\circ}$ de janeiro, 14 de julho, 12 de outubro); e as que, particularmente, se referem à nossa história, tendo influído no progresso e na civilização da Pátria Brasileira (24 de fevereiro - promulgação da Constituição da República; 21 de abril - Martírio de Tiradentes; 3 de maio de 1500 - Descobrimento do Brasil; 13 de maio de 1888 - Abolição da escravidão; 7 de setembro de 1822 Independência do Brasil e 15 de novembro - Proclamação da República)" (COELHO NETTO, 1957, p. 99).

${ }^{68}$ Manoel Bomfim (1868-1932), médico e escritor sergipano, propôs uma nova análise sociológica dos problemas brasileiros. Exerceu importantes cargos educacionais no início da República: diretor-geral do Pedagogium, diretor da Instrução Pública do Distrito Federal e diretor da Escola Normal do Rio de Janeiro. Foi Deputado Federal pelo Estado de Sergipe e um dos fundadores da revista infantil "Tico-Tico", em 1905. Além de Através do Brasil, escreveu outros livros escolares em co-autoria com Bilac: Livro de Composição (1899) e Livro de Leitura (1901).
} 
Impresso em Paris, como de costume, e lançado pela Livraria Francisco Alves em 1910, o livro fez sucesso nas escolas. Inspirado no livro francês Le Tour de la France par deux enfants, narra as aventuras dos irmãos Carlos e Alfredo em busca do pai.

Carlos e Alfredo são dois jovens que fogem do colégio interno, na cidade do Recife, à procura do pai, que suspeitam estar morto. Na viagem, são mostradas a paisagem do território, os costumes, as tradições e os tipos característicos de diversas regiões do País - o sertanejo, o caboclo, o gaúcho. No caminho, conhecem Juvêncio, também jovem, forte e sagaz, conhecedor da região e considerado um protótipo do bom e valente sertanejo, a quem compete mostrar as especificidades do território brasileiro em sua rica diversidade. Com um bom final, os jovens descobrem que o pai está vivo, depois de terem percorrido diversas regiões.

A procura do pai é, de certa forma, a tentativa de conhecer melhor o País e, com isso, desenvolver o amor à pátria, pois se ama mais intensamente aquilo que se conhece. Nesse sentido, nessa obra, a tríade "Pai, País e Pátria" confunde-se na mesma história, cujo objetivo é também desenvolver o sentimento de patriotismo nas crianças e jovens.

A exemplo do seu inspirador francês, Através do Brasil teve sucessivas edições, "fazendo a cabeça" de gerações de brasileiros. Com 66 edições, foi o livro de leitura mais utilizado durante cinqüenta anos nas escolas brasileiras (BOTELHO, 2002).

Por que me ufano do meu País e Através do Brasil são dois exemplos paradigmáticos de livros de leitura que constroem a identidade nacional a partir de uma visão edênica e idílica do país. Segundo Oliveira (2003), talvez por influência de Manuel Bomfim - um de seus autores - o livro Através do Brasil dialoga com o pensamento de Euclides da Cunha, ao mostrar os valores do sertanejo e do sertão. 


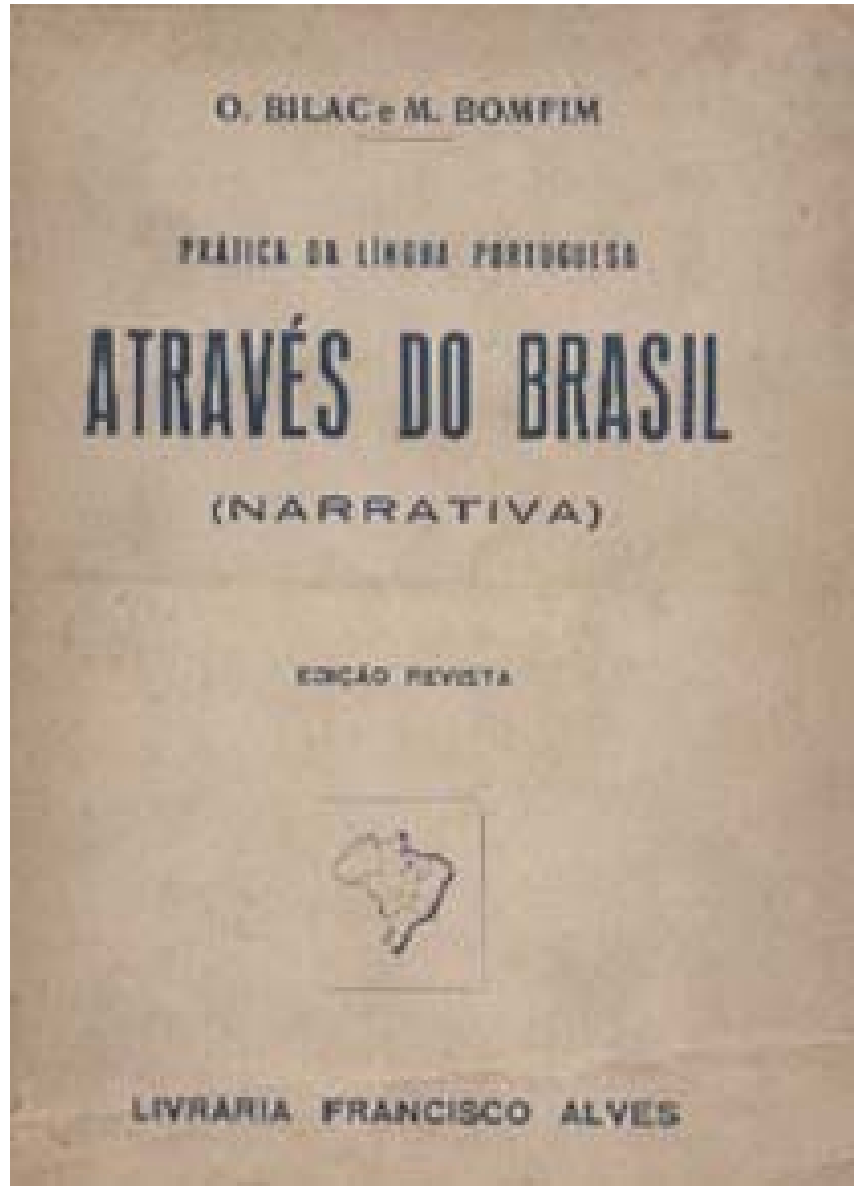

Figura 15 - Através do Brasil - capa.

Fonte: BILAC e BOMFIM, 1918.

Por se constituir num locus da produção literária destinada ao uso das escolas, seja através de manuais didáticos ou livros de leituras e antologias escolares, a ABL, a exemplo de outras instâncias da sociedade, é, por excelência, um "lugar de memória" da educação em nosso País.

Outros membros da ABL como Sylvio Romero (A História do Brasil ensinada pela biografia de seus heróis. Livro para as classes primárias, 1890), João Ribeiro (História do Brasil, 1900), Afrânio Peixoto (Minha Terra, minha gente, 1915), Rocha Pombo (Nossa Pátria, 1917) produziram livros didáticos destinados ao ensino de História para a escola primária e secundária. Todos eles pertenceram aos quadros da $\mathrm{ABL}$, o que reforça a tese de que a segunda fase da literatura escolar brasileira contou com a autoria de renomados intelectuais que faziam parte de academias literárias e científicas, a exemplo do IHGB e da ABL. Viriato Corrêa é, portanto, um desses intelectuais que se dedicou à escrita de livros escolares para as crianças. 
2a PARTE: VIRIATO CORRÊA E A COMPANHIA EDITORA NACIONAL 
Em 1938, após quatro tentativas frustradas, o escritor maranhense radicado no Rio de Janeiro, então capital da República, viu finalmente seu sonho realizado: Viriato Corrêa foi eleito para a cadeira de $n^{\circ} 32$ da Academia Brasileira de Letras. Era a primeira vez que um escritor de livros infanto-juvenis ingressava no quadro dos "imortais" da ABL.

Quem foi Viriato Corrêa? Qual a relação entre sua obra literária e o ensino de História? O que o levou a escrever crônicas históricas e contos infantis, mesmo não sendo historiador ligado aos quadros do IHGB, nem tampouco professor de História em escolas de ensino primário ou secundário? Por que se interessou em escrever para crianças livros que abordavam o passado nacional? Na trajetória intelectual de homem de letras, quais seus parceiros e interlocutores nesse processo de "vulgarização" (aqui entendida como divulgação) da História?

Esses são os questionamentos que pretendo responder no Capítulo 3, dando destaque à produção do autor no âmbito da Companhia Editora Nacional, que publicou os principais livros infantis de Viriato Corrêa.

No Capítulo 4, a ênfase recai sobre o processo intelectual de elaboração do livro História do Brasil para crianças, seus aspectos materiais e o papel de outros agentes na produção e divulgação desse livro. 
CAPÍTULO 3: A COMPANHIA EDITORA NACIONAL E A LITERATURA ESCOLAR

Dos diversos instrumentos utilizados pelo homem, o mais espetacular é, sem dúvida, o livro. Os demais são extensões de seu corpo. O microscópio, o telescópio são extensões de sua visão; o telefone é extensão de sua voz; em seguida, temos o arado e a espada, extensões de seu braço. O livro, porém, é outra coisa: o livro é extensão da memória e da imaginação. ${ }^{69}$

(Jorge Luís Borges)

Os livros não matam a fome, não suprimem a miséria, não acabam com as desigualdades e com as injustiças do mundo, mas consolam as almas, e fazem-nas sonhar

(Olavo Bilac) $^{70}$

${ }^{69}$ BORGES, Jorge Luis. O Livro In: Cinco visões pessoais. $4^{\mathrm{a}}$ ed., Brasília: Editora da UnB, 2002, p. 13.

${ }^{70}$ DIMAS, Antonio. Bilac, o jornalista. São Paulo: Imprensa Oficial, 2006, p.187. 


\title{
3.1 O autor: Viriato Corrêa e a "vulgarização" da História
}

\begin{abstract}
O povoado em que nasci era um dos lugarejos mais pequenos, mais pobres e mais humildes do mundo. Ficava à margem do Itapicuru, no Maranhão, no alto da ribanceira do rio.

Uma ruazinha apenas, com umas vinte ou trinta casas, algumas palhoças espalhadas pelos arredores e nada mais. Nem igreja, nem farmácia, nem vigário. De civilização a escola, apenas (CORRÊA, 2004, p. 17, grifo nosso).
\end{abstract}

Assim, Viriato Corrêa inicia sua narrativa autobiográfica em Cazuza, retratando a terra natal. Manuel Viriato Corrêa Baima do Lago Filho ${ }^{71}$ nasceu em 23 de janeiro de $1884^{72}$, no povoado de Pirapemas, a meio caminho das cidades de São Luís e Caxias, estado do Maranhão. Era filho de Manuel Viriato Corrêa Baima e de Raimunda Nonato da Silva Baima.

Fez seus primeiros estudos na escola pública do povoado. Ainda criança, aos nove anos de idade, Viriato ficou órfão de pai. A família viu-se em situação de penúria, mas, mesmo assim, sua mãe envidou esforços para que o primogênito continuasse os estudos em São Luís. Na capital, foi matriculado no Colégio São Luís, tendo, depois, ingressado no Liceu do Maranhão, onde completou o curso secundário.

Sua veia literária já se fazia presente aos dezesseis anos, quando escreveu os primeiros contos e poesias para o jornal do Liceu, $O$ Estudante, usando o pseudônimo de Milton Larebel. No início do século XX, continuar os estudos em nível superior, para quem se interessava pelas humanidades, significava ingressar nos cursos jurídicos de Recife ou de São Paulo - tidos como os dois principais centros culturais do país, afora a capital do Rio de Janeiro.

Com a ajuda financeira do avô, o velho Manuel Corrêa, Viriato mudou-se para Recife, em 1900, a fim de cursar a Faculdade de Direito, sob a promessa de que realmente se dedicaria à ciência jurídica e não à vida literária:

\footnotetext{
${ }^{71} \mathrm{O}$ nome Manuel é uma corruptela de Emanuel, que significa na linguagem bíblica "Deus conosco". Segundo Pinto (1966), como os dois filhos do casal morreram após o nascimento, foi dado ao terceiro filho o nome de Manuel, pois era tradição local colocar esse nome ao recém-nascido que sobrevivesse, batizando-o com urgência.

${ }^{72}$ Há divergências quanto à data certa de nascimento do autor. Seu biógrafo menciona a data de 23 de janeiro de 1882 (PINTO, 1966, p. 12). Nos anais da ABL e no Dicionário Literário Brasileiro, está registrado o ano de 1884 (MENEZES, 1978, p. 203).
} 
Nas vésperas de Viriato seguir para Pernambuco, o velho o chamou para uma conversa reservada. A sós deu-lhe vários conselhos, fez-lhe diversas recomendações, lembrou que D. Mundica (sua mãe), sendo pobre, não lhe podia fazer uma mesada superior a $50 \$ 000$. Vendo, entretanto, que essa quantia era pequena, ele se propunha a juntar outra de $100 \$ 000$ mensais.

Antes que Viriato estourasse de alegria, o avô cortou o entusiasmo nascente com uma condição:

- Quero, porém, que você me prometa uma coisa.

Intrigado, não sabendo onde estaria o pensamento de seu querido e austero vovô, falou desconfiado:

- Pois, não...

- Quero que me prometa que nunca, sob pretexto nenhum, escreverá versos. Estude seu Direito, se achar que não poderá deixar de escrever sua literatura, que a escreva, com todos os demônios, mas nada de poemas. Se souber que você enveredou por esse caminho, suspenderei a mesada. Combinado?

Que poderia fazer o jovem poeta, senão concordar?

$[\ldots]$

Com a pensão e os estudos garantidos, Viriato escrevia cada vez mais, porque o que ele perseguia era a fama. Queria ser um nome neste país de literatos. Não lhe pagavam o que escrevia? Isso era o que menos importava. Que o deixassem publicar seus contos, porque o resto, certamente viria depois. O que não desejava era perder a oportunidade de ver sempre seu nome nas colunas dos jornais (PINTO, 1966, p. 36-7).

Aos dezenove anos, publicou seu primeiro livro de contos - Minaretes (1903). E, sob o pretexto de terminar o curso jurídico na capital do País, Viriato mudou-se para o Rio de Janeiro, onde passou a ter contato com a geração boêmia que marcou a intelectualidade brasileira no começo do século XX.

[...] nesse fim de tarde chuvosa de 1903, Viriato desembarcou na cidade encantada. Sem tempo para nada ver, foi em busca de uma pensão onde morar. Cansado de tanto andar, deitou-se e dormiu. Na manhã seguinte, bem cedo, foi para rua. Havia duas coisas por que ansiava. Conhecer a cidade e ver, se possível, falar aos grandes vultos das letras.

A enorme fascinação do homem da província é a capital, a corte. Viriato, como tal, era fascinado. Mas, onde estavam os grandes da literatura?

Indagando aqui, acolá, disseram-lhe que eles se concentravam na livraria Garnier, à Rua do Ouvidor. E, perguntando aqui a um, além a outro, foi esbarrar lá. Teve a primeira decepção. Ali não estava nem um deles porque era muito cedo.

Não viu os grandes, mas viu o gênio do século e ficou enormemente contente. Porque Santos Dumont enchia a cidade com seu chapéu desabado e sem modéstia (PINTO, 1966, p. 48).

Viriato chegou num momento de crescente ebulição na Capital Federal. A cidade do Rio de Janeiro passava por transformações urbanas importantes, levadas a cabo pelo Prefeito Pereira Passos, com o apoio expresso do presidente da República, Rodrigues Alves. Era o famoso "bota-abaixo", que resultou na derrubada de cortiços e moradias populares, afastando 
a população mais pobre do centro da. Queriam transformar o Rio de Janeiro numa "Paris nos trópicos", dotando-a de equipamentos urbanos condizentes com o ideário do progresso e da modernidade, projeto tão caro às elites políticas e intelectuais.

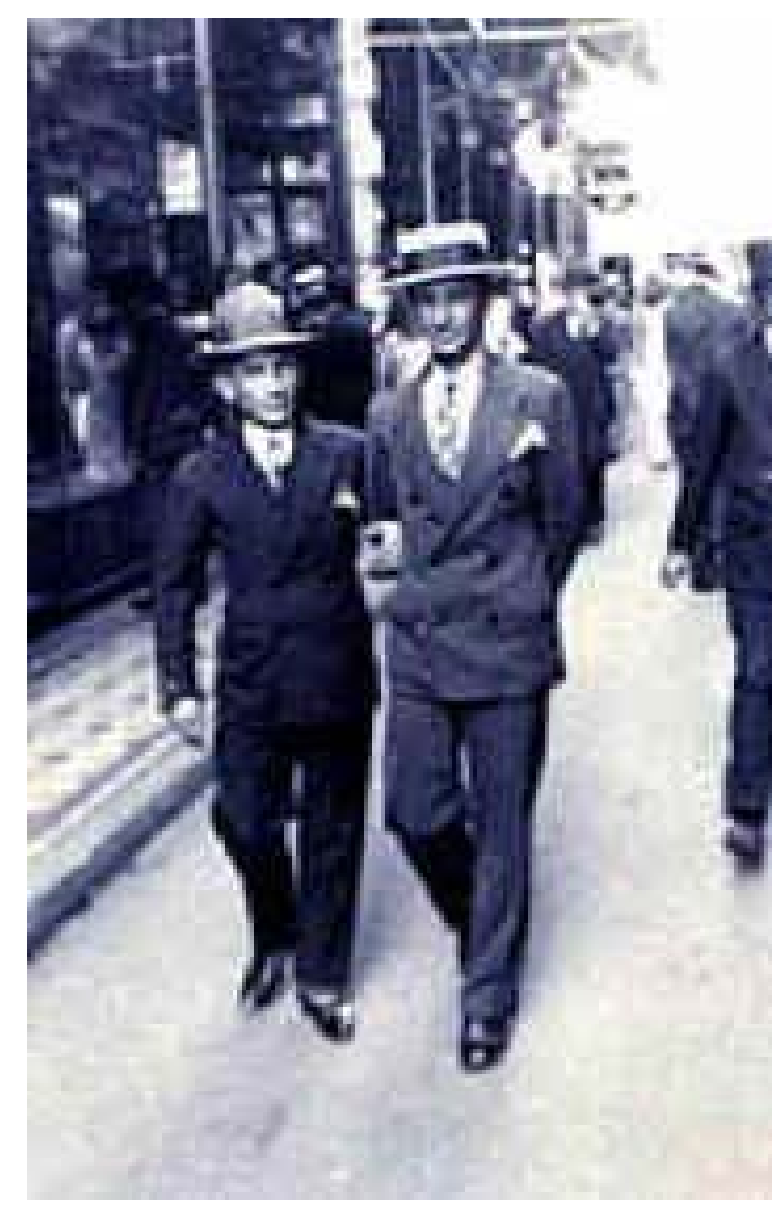

Figura 16 - Viriato Corrêa (à esquerda), nas ruas do Rio de Janeiro (s/d).

Fonte: Acervo Centro de Memória da ABL.

Nas livrarias e cafés da cidade, Viriato teve contato com importantes nomes da literatura nacional, a exemplo de José do Patrocínio, Olavo Bilac e o próprio Machado de Assis. A chamada "República das Letras" era constituída por um grupo de intelectuais, escritores e jornalistas que circulavam nos cafés, salões e livrarias da então capital da República, no período que ficou conhecido como a Belle Époque brasileira ${ }^{73}$.

\footnotetext{
${ }^{73}$ Sobre este período de nossa história cultural, ver SEVCENKO, Nicolau. Literatura como missão: tensões sociais e criação cultural na Primeira República. $2^{\mathrm{a}}$ ed. São Paulo: Companhia das Letras, 2003; BROCA, Brito. A Vida literária no Brasil. 1900. $4^{\mathrm{a}}$ ed. Rio de Janeiro: José Olympio Editora, Academia Brasileira de Letras, 2004 e NEEDELL, Jeffrey D. Belle Époque Tropical: sociedade e cultura de elite no Rio de Janeiro na virada do século. São Paulo: Companhia das Letras, 1993.
} 
A República das Letras situava-se nas passarelas de nomes Rua do Ouvidor, Rua Gonçalves Dias, Avenida Central, nos palacetes da Tijuca, de Santa Tereza, do Flamengo, em cujos cenários forjava-se uma forma de interação social com regras bem definidas. Os salões, as conferências pagas, o colunismo social nas revistas e jornais, as casas de comércio, os cafés, as tertúlias e os grêmios mais as livrarias cumpriam a função social de palco para uma mis en scène literária. Freqüentar esses lugares era buscar a construção de uma identidade que associava livreiros, autores e leitores à civilidade e os distinguia da massa iletrada que compunha grande parte da população (LEÃO, 2001, p. 119).

Logo ao chegar à cidade do Rio de Janeiro e por influência e prestígio de seu amigo Medeiros e Albuquerque ${ }^{74}$, Viriato Corrêa obteve colocação na Gazeta de Notícias, iniciando, portanto, uma profícua carreira jornalística que se estenderia por longos anos.

Luiz Edmundo, cronista da época, em sua obra $O$ Rio de Janeiro do meu tempo, menciona a participação de Viriato no início da carreira jornalística:

Paulo Barreto, cronista maravilhoso, que a cidade, mais tarde, ama e consagra, criador de reportagens sensacionais, como as das Religiões do Rio, que transformam por completo a feição rotineira da "Gazeta", ainda não se revelou. Já faz parte, porém, da redação, onde escreve a crônica de teatros, ao lado de Viriato Corrêa, que chegou do Recife a fim de bacharelar-se aqui (EDMUNDO, 1957, p. 924, grifo nosso).

\footnotetext{
${ }^{74} \mathrm{O}$ próprio Viriato assim se refere ao grande amigo e incentivador: "Eu fui criança no Maranhão; rapaz na Faculdade do Recife; em casa de Medeiros e Albuquerque me fiz homem. Medeiros foi o mais doce, o mais carinhoso, o maior dos meus amigos. Preocupava-o meu destino como o destino de um filho. O seu grande desejo, desejo que ele não escondia de ninguém, era ver-me aqui na Academia, sentado entre vós" (CORRÊA, Viriato. Discurso de posse do Sr. Viriato Corrêa, em 29 de outubro de 1938. In: Revista da Academia Brasileira de Letras. Anais de 1938. Julho a dezembro. Rio de Janeiro. Ano 31, vol. 56, p. 116). Antes de morrer, Medeiros e Albuquerque escreveu uma carta que, após sua morte, deveria ser levada ao conhecimento do presidente da $\mathrm{ABL}$ - Ramiz Galvão. Na carta, Medeiros registrava que seu voto à sua sucessão seria a favor de Viriato Corrêa. Ramiz Galvão não considerou o pedido do acadêmico e deu fim à carta, ignorando por completo o "voto póstumo" (Cf. MONTELLO, Josué. Pequeno Anedotário da Academia Brasileira de Letras. São Paulo: Livraria Martins Editora, s/d).
} 


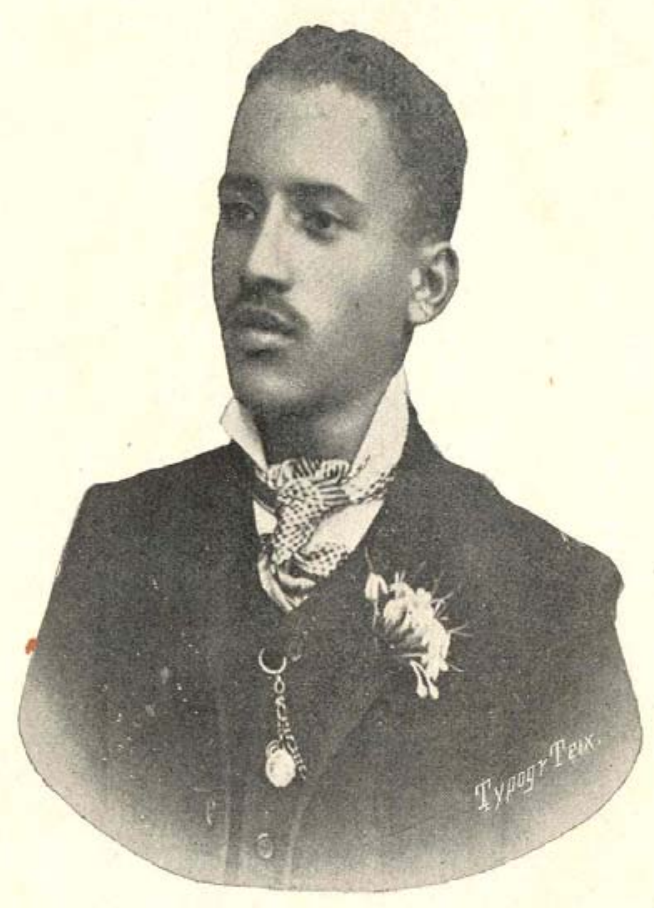

Figura 17 - Viriato Corrêa quando jovem (s/d).

Fonte: Acervo Centro de Memória da ABL.

Viriato também escreveu em outros importantes jornais da capital, tais como Correio da Manhã, Jornal do Brasil e a Folha do Dia. Colaborou também em revistas de época, a exemplo de Careta, Ilustração Brasileira, Cosmos, A Noite Ilustrada, Para Todos, O Malho.

Um dos aspectos marcantes da sociabilidade da República das Letras era a realização de conferências semanais - idéia trazida da Europa por Medeiros e Albuquerque. Assim, os intelectuais como Coelho Neto, Olavo Bilac, João do Rio, Alberto de Oliveira, Alcindo Guanabara, entre outros, proferiam palestras sobre os mais diferentes assuntos. Viriato Corrêa, embora jovem, participou como conferencista em uma dessas reuniões, palestrando sobre o tema "Poetas do sertão". Em outra ocasião, falou sobre o tema "Casar é bom", o que lhe valeu uma réplica de seu mentor intelectual Medeiros e Albuquerque - "Mas não casar é melhor..."

Na década de 1920, já era conhecido no meio jornalístico local. Seu ingresso no Jornal do Brasil foi noticiado com destaque, na edição de 10 de fevereiro de 1925, quando passou a escrever uma coluna semanal neste periódico. 
Inicia hoje a sua colaboração nesta folha o Sr. Viriato Corrêa. Trata-se de um dos mais brilhantes escriptores do Brasil contemporâneo. E certamente nenhum de nossos leitores deixará de conhecer as suas chronicas leves e finas ou os seus contos sertanejos, tão cheios da saudade da terra selvagem, tão impregnados dessa doce poesia da recordação.

[...] a mais importante de suas actividades tem sido, sem dúvida, a de jornalista. Viriato escreve novellas, pequenos contos, narra episódios históricos, atravez de chronicas jornalísticas, com uma leveza, uma graça, um encanto particulares. [...] Os leitores do Jornal do Brasil hão de agradecer-nos a satisfação que ora havemos de dar, offerecendo-lhes, cada semana, uma página de Viriato Corrêa (grifo nosso). ${ }^{75}$

E, no âmbito das redações desses jornais, surgiriam muitos dos seus escritos, posteriormente transformados em livros. Foi o caso, por exemplo, de Gaveta de Sapateiro, originalmente uma coluna semanal de crônicas históricas, no Jornal do Brasil, na qual usava o pseudônimo de Frei Caneco ${ }^{76}$. Por sugestão dos próprios leitores, os textos dessa coluna converteram-se em livro homônimo, com o seguinte título - Gaveta de Sapateiro: miudesas desarrumadas da Historia Nacional (1932).

${ }^{75}$ Jornal do Brasil, Rio de Janeiro, 10.2.1925.

${ }^{76}$ Viriato Corrêa usou outros dois pseudônimos: Tibúrcio da Anunciação na revista Careta e Pequeno Polegar no jornal A Noite. 


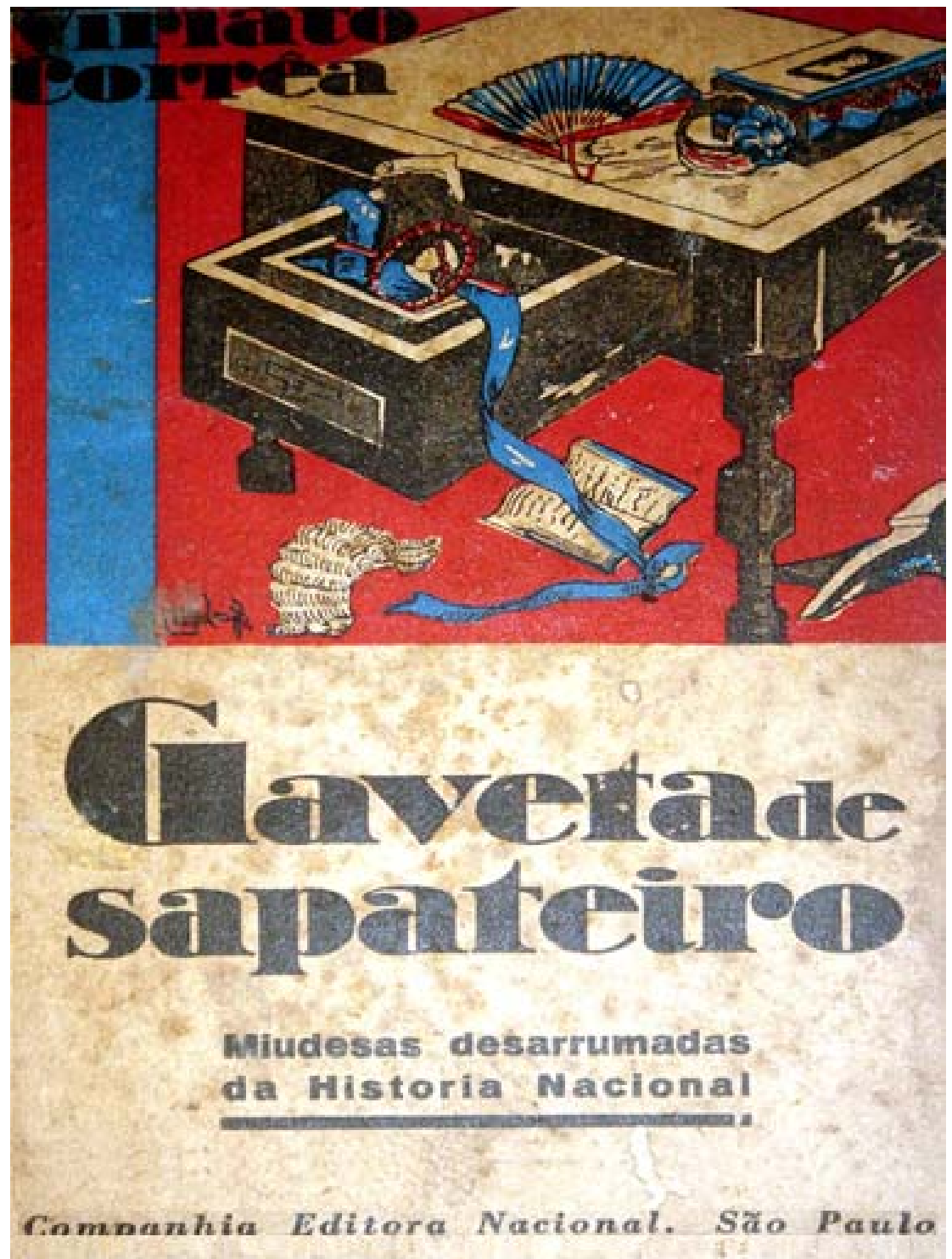

Figura 18 - Gaveta de Sapateiro - capa.

Fonte: CORRÊA, 1932.

Já o primeiro livro infantil escrito por Viriato Corrêa deu-se em parceria com o escritor Paulo Barreto ${ }^{77}$, o famoso cronista carioca João do Rio. Era uma vez... contos infantis foi lançado em 1908, pela Livraria Francisco Alves.

\footnotetext{
77 Segundo Nelson Schapochnik, "João Paulo Alberto Coelho Barreto, dito João do Rio, foi um dos mais inquietos e notáveis escritores da Belle Époque carioca. Volátil e versátil, ele experimentou um multifário conjunto de textos que incluíam a reportagem, a entrevista, a crônica, a conferência, a dramaturgia, o romance e o conto, publicando-os nos mais distintos órgãos da imprensa [...]" (SCHAPOCHNIK, 2004, p. 13).

Segundo seu biógrafo, depois de Medeiros e Albuquerque, "outro grande amigo que o escritor conquistou foi Paulo Barreto. Quando aqui chegou, o homem mais elegante da cidade - que comprava suas estranhas camisas em Londres e Paris e mandava cortar seus ternos, especialmente os fraques, no mais caro e famoso alfaiate do Rio - fazia furor com suas roupas e com suas crônicas sobre as "Religiões do Rio", sob o pseudônimo de João do Rio [...] Viriato se afeiçoou a ele e, até a sua morte, recebeu do cronista da cidade as mais carinhosas atenções e amizade que resistia a todas as provas." (PINTO, 1966, p. 53-4). Foi João do Rio quem apresentou Viriato a Machado de Assis, e sua morte, em 1921, despertou no maranhense o desejo de disputar uma vaga na ABL. Foi a primeira vez que Viriato concorreu; não tendo obtido êxito, no entanto.
} 
A escrita desse primeiro livro infantil revela o quanto era difícil a situação do autor para ter uma obra publicada no início do século XX:

[...] em 1908, Viriato começou a pensar em ir ao Maranhão. Sentia saudades da terra, da família, porém, como chegar lá, se não possuía nem o dinheiro das passagens de ida e volta? Sim, porque não arredaria o pé daqui se não tivesse garantida a viagem de retorno. Entretanto urgia consegui-lo. Como? E naquela teimosa procura de dinheiro, um dia, em conversa com Paulo Barreto, surgiu a idéia salvadora. Se os dois escrevessem um livro para crianças por exemplo? Para Viriato não era difícil porque muitas histórias escrevera no Fafazinho. Paulo, na pior das hipóteses, entraria com seu nome que, por si só, era uma garantia de venda. Estabelecido o acordo, meteram mãos à obra e, dentro de pouco estava feito o livro que tomou o nome de "Era uma vez..." Estava escrito. E agora? Como publicá-lo, se de novo se repetia o problema do dinheiro? Onde arranjá-lo para publicação? Era um círculo vicioso de endoidar.

Os bolsos dos dois autores viviam sempre vazios porque o que ganhavam com suas literaturas era o bastante para sua subsistência.

E, sem solução melhor, aceitaram a que menos desejavam, que era a de vender seus direitos autorais. Resolutos, dirigiram-se à Livraria Francisco Alves e venderam o livro pela importância de 3:000\$, que foram divididos irmãmente. E cada um se apossou, com infinita alegria, de 1:500\$, embora Viriato tivesse escrito muito mais que seu parceiro. Mas, isso não tinha a menor importância para eles. O que lhes interessava era mais um livro na rua e uns níqueis no bolso para gastar o mais rapidamente possível.” (PINTO, 1966, p. 62, grifo nosso).

Por esse lançamento, no contexto da incipiente literatura infantil brasileira, Viriato Corrêa tem sido considerado por muitos estudiosos como um dos precursores desse gênero literário no País.

O pendor para escrever às crianças Viriato desenvolveu trabalhando no jornal Gazeta de Noticias, pois nesse periódico passou a colaborar na seção infantil "Fafazinho". Viriato foi também colaborador da Tico-Tico - considerada a primeira revista de quadrinhos brasileira e a de maior sucesso e longevidade, dedicada ao público infantil (VERGUEIRO \& SANTOS, 2005). 


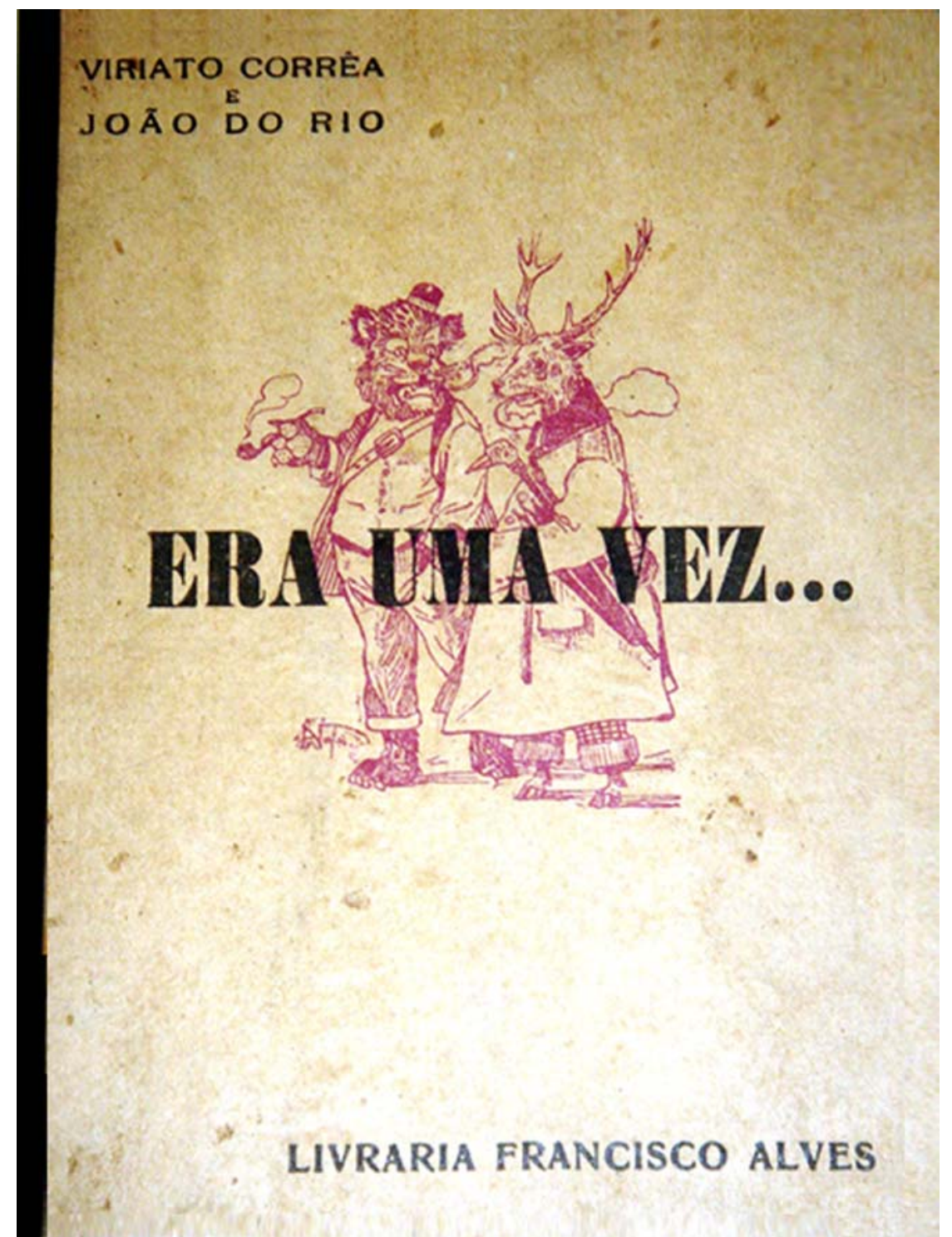

Figura 19 - Era uma vez - capa. Primeiro livro infantil de Viriato Corrêa, em parceria com João do Rio.

Fonte: CORRÊA, DO RIO, 1908.

Antes de se dedicar à escrita da história para crianças, Viriato escreveu outros livros para a gurizada, todos eles pela Companhia Editora Nacional, entre os quais podemos citar: Varinha de condão (1928), Arca de Noé (1930), A Macacada (1931), Os meus bichinhos (1931), No reino da bicharada (1931), Quando Jesus nasceu (1931) e Bichos e bichinhos (1938). 


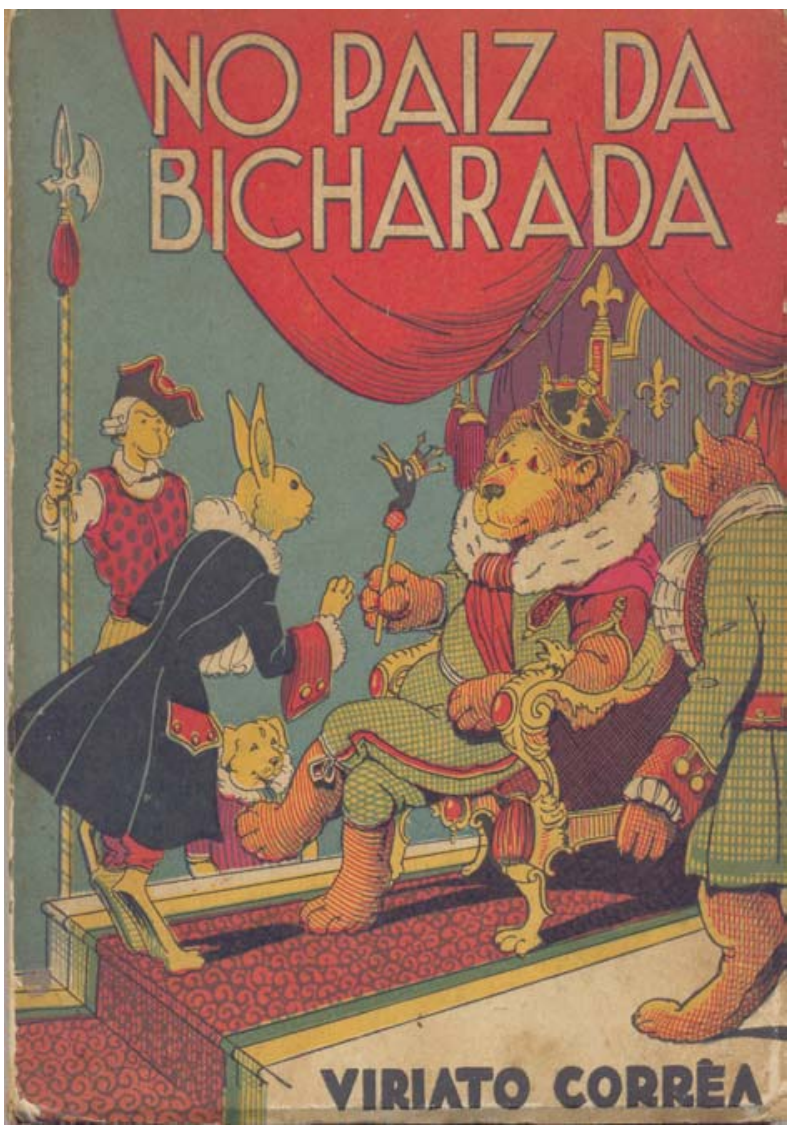

Figura 20 - No paiz da bicharada - capa.

Fonte: CORRÊA, 1937.

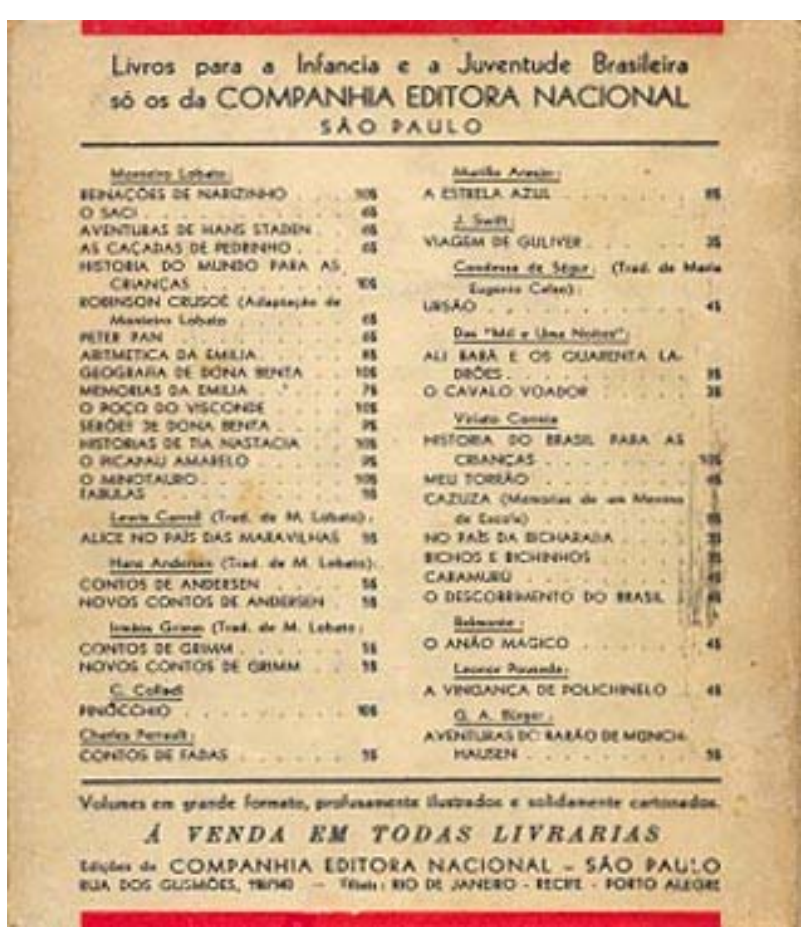

Figura 21 - No paiz da bicharada - contracapa.

Fonte: CORRÊA, 1937. 

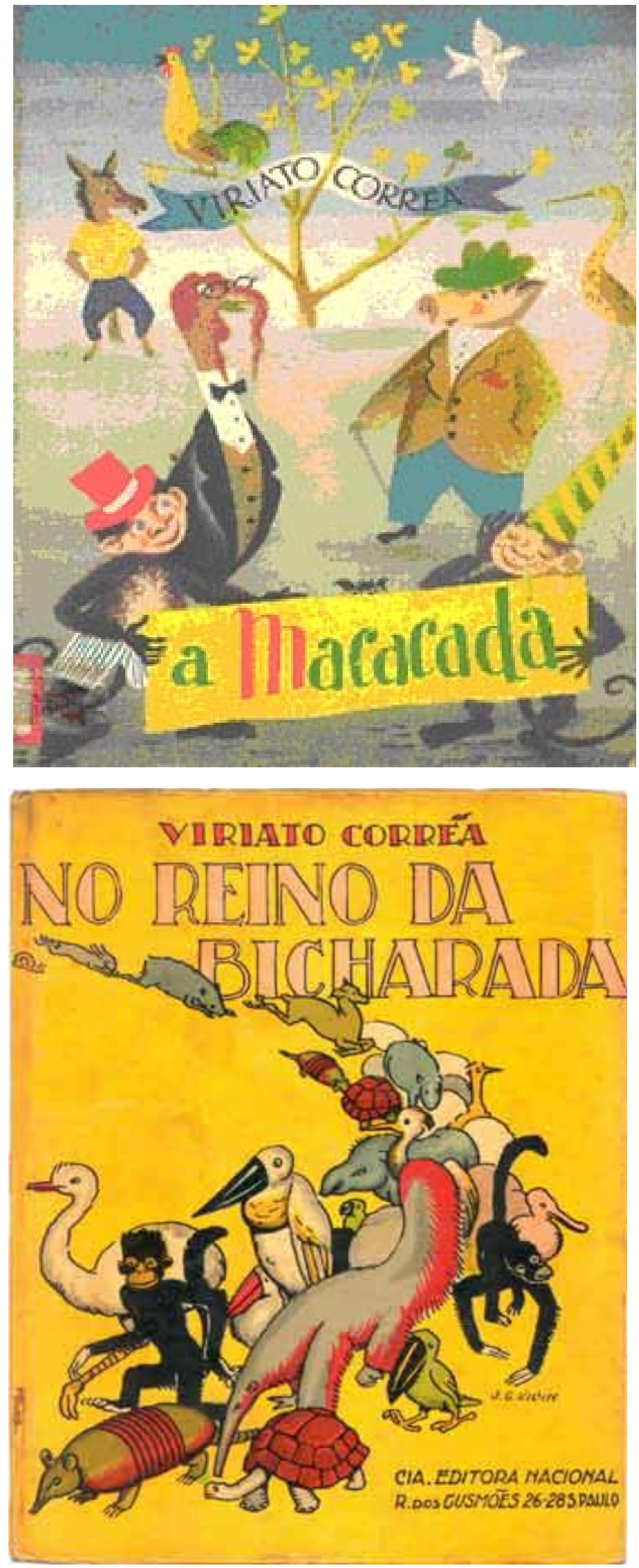

Figuras 22 e 23 - A macacada e No reino da bicharada. Fonte: CORRÊA, 1931. 
No entanto, apesar de tantos títulos de ficção, Viriato consagrou-se no campo da narrativa histórica, ao lado de outro grande escritor do período - o paulista Paulo Setúbal (1893-1937). E, enquanto Paulo Setúbal dedicou-se ao romance histórico, Viriato escreveu contos e crônicas históricas, ajudando, assim, como ele mesmo dizia, a "vulgarizar" a história pátria.

A temática histórica passou a ser destaque em sua produção literária. Escreveu neste gênero mais de uma dezena de crônicas históricas, entre as quais se destacam Histórias da nossa história: crônicas e contos históricos (Monteiro Lobato \& Cia, 1921), Terra de Santa Cruz (1921), Brasil dos meus avós (1927), Bahú velho: roupas antigas da historia brasileira (1927), Gaveta de Sapateiro: miudezas desarrumadas da historia nacional (1932), Alcovas da Historia (cantinhos, esceninhos e recesso da vida histórica do Brazil) (1934), Mata Galego: história da noite das garrafadas e outras histórias (1934), Casa de Belchior (1936) e O País do pau de tinta (1939).

Escreveu também um romance histórico, em que retratou o movimento de rebelião ocorrido no período regencial (1831-1840) de nossa história - Balaiada: romance do tempo da regência (1927). No prefácio desse romance, Viriato mostra-nos o porquê de ter dedicado grande parte de sua produção literária à divulgação da história ao grande público, com o objetivo de torná-la menos árida e mais atraente ao leitor-comum.

\footnotetext{
No Brasil, é veso velho acusar-se o povo de desconhecedor de nossa história.

$\mathrm{Na}$ verdade o desconhecimento existe. A accusação, porém, é que não tem razão de ser.

O desconhecimento toma proporções tão grandes que, a não ser a tão falada viagem de Cabral, a restauração pernambucana, o martyrio de Tiradentes, a trasmigração da família real portugueza, o 7 de setembro, o 7 de abril, a guerra do Paraguay, o 13 de maio, a Republica, mais uma ou outra data culminante, e isso mesmo mal e muito mal, tudo mais se desconhece, quando não seja totalmente, de tal maneira que é mesmo que desconhecer (CORRÊA, 1927, p. 7).
}

Mostrou, também, que a culpa pelo desconhecimento de nossa história não é do povo, mas dos próprios historiadores, que não sabem divulgá-la. 
Mas, quem tem menos culpa disso, quem menos deve se accusado, é o povo. $\underline{A}$ culpa é dos elementos intellectuaes do paiz, a culpa é dos próprios historiadores.

[...]

Queremos que o publico se interesse pela nossa historia quando, até agora, ella quasi só existe em forma de documentos, soterrada na poeira dos archivos ou enjaulada nesta ou naquella monographia massuda, neste ou naquele compendio detestável.

$[\ldots]$

Entre nós, raros são os livros de sciencia que se podem ler. Abra-se um compendio de direito, de historia, de medicina, seja do que for, e ficar-se-á de cabeça ardendo na difficuldade de comprehender que diabo o autor quis dizer nos seus períodos.

É tudo confuso, graniticamente impenetrável, desorganizado, desconchavado, torcicoloso, uns em estilo grosso de mestre-escola, outros em estilo engalanado pelo pernosticismo tropical (CORRÊA, 1927, p. 7-8, grifo nosso).

\section{Mais uma vez, Viriato fez críticas à forma como a história era escrita pelos próprios}

historiadores, o que, segundo ele, contribuía, para o desprezo que a população a ela atribuía:

Em historia do Brasil, particularmente, essa coisa chega ser liquidante. Os taes grandes mestres da nossa historia, os que, no passado, formam o primeiro plano do saber histórico nacional, são simplesmente illegíveis.

É, na verdade, um trabalho penosissímo terá a gente que ler os Jaboatão, os Pedro Tasques, os Madre-Deus, os Rocha Pitta, os Berredo, os Raphael de Jesus, os Balthasar Lisboa, os Fernandes Pinheiro, os Pereira da Silva etc, etc.

São paginas horrendas, indigestas, desattraentes, atulhadas fabricas de bocejos, que fazem a gente ferrar no somno logo aos primeiros períodos. Muitas dellas são copiosas de informações, profundas de saber, mas tão mal expostas, tão mal apresentadas que acabam por deixar no leitor a dolorosa impressão de que a história brasileira é um immenso fardo de enfaro e de coisas desinteressantes (CORRÊA, 1927, p. 9, grifo nosso).

Nem mesmo Varnhagen escapou à sua crítica:

Mesmo o maior delles todos, o mais illustre, o mestre dos mestres - o grande Varnhagen, erudito, rigoroso na pesquisa da verdade, com aquella autoridade rara em affirmar os factos, com aquelle admirável talento de pesquisador, mesmo Varnhagem é massudo, é enfadonho (CORRÊA, 1927, p. 9).

Para Viriato, o problema do desconhecimento de nossa história por parte do povo, não está na existência de temas difíceis à compreensão, mas sim, na forma como eles são tratados pelos historiadores: 
Não há assumptos que não sejam capazes de interessar o povo, mesmo os mais áridos e os mais ásperos. A questão é que elles lhes venham às mãos de forma insinuante e encantadora, com esses doces de 'vitrine' de confeitaria, muitas vezes, detestáveis de gosto, mas de aparencia tão bonita, que despertem o appetite e fazem água na bocca de quem os admira.

Nos nossos grandes historiadores tem faltado, e lamentavelmente, esse factor de attracção indispensável nas coisas intellectuaes (CORRÊA, 1927, p. 9-10, grifo nosso).

No contexto dessa tarefa de divulgação da história nacional, foi um dos escritores que usou o rádio ${ }^{78}$, principal veículo de comunicação da época ${ }^{79}$. No âmbito das comemorações do Estado Novo dos cento e cinqüenta anos da morte de Tiradentes e como forma de reforçar o culto ao herói nacional, Viriato Corrêa escreveu uma novela radiofônica sobre Tiradentes. Essa novela foi irradiada pela primeira vez, por iniciativa do Departamento Nacional de Propaganda (DNP), na Hora do Brasil do dia 21 de abril de 1939, e pôde ser transmitida por todas as emissoras do País, independentemente do pagamento de direitos autorais.

Viriato Corrêa teve também um programa de rádio intitulado Histórias de chinelo:

Há oito anos, a Rádio Nacional e, agora, a Rádio Ministério da Educação, mantêm no ar o programa "histórias de chinelo", de Viriato Corrêa, que já criou mais de 3 mil histórias infantis. Todo esse volume de obras, Viriato não tinha pensado em editar em livros. E ele explica: É tanta coisa, que não sei por onde começar. ${ }^{80}$

Seu maior trabalho de divulgação histórica, no entanto, deu-se na produção literária de cunho infantil, ao criar a figura do vovô que conta histórias às crianças, na sua chácara, embaixo de árvores. As "lições de história do vovô" estão presentes em livros como História do Brasil para crianças (1934), As belas histórias da História do Brasil (1948) e

\footnotetext{
${ }^{78}$ A partir dos anos 1930, o rádio se tornou o principal veículo de comunicação de massa do país e o governo entendeu o seu alcance junto ao público, razão pela qual Getúlio Vargas usou-o como instrumento de propaganda política (Cf. D’ÂNGELO, Newton. Ouvindo o Brasil: o ensino de História no rádio - décadas de 1930/40. Revista Brasileira de História, v. 18, n. 36, São Paulo, 1998).

${ }^{79}$ Viriato Corrêa teve sua peça teatral $\dot{A}$ Sombra dos Laranjais adaptada para a televisão brasileira em novela homônima da Rede Globo, em 1977 (CORRÊA, 1977, p. 6). Na década de 1970, em correspondências existentes no acervo histórico da CEN, constatou-se que, face ao sucesso editorial de Cazuza, havia o interesse por parte da Editora e do jornalista Roberto Freire em transformá-lo em filme, chegando-se até a iniciar as negociações com a viúva do autor acerca dos direitos autorais da conversão da obra para o cinema.

80 "Viriato vai ver sua História da Liberdade no samba do Salgueiro", Diário de Notícias, Rio de Janeiro-RJ, 19.08.1966.
} 
Curiosidades da História Brasileira (para crianças) (1952), entre outros, como veremos mais adiante.

Deve-se destacar, ainda, que, na sua atividade jornalística, Viriato dedicou-se à crítica teatral, no jornal $A$ Manhã, a partir de 1941. Foi também professor de História do Teatro, na Escola Dramática do Rio de Janeiro, além de escrever cerca de 30 peças, entre dramas e comédias, que focalizam ambientes rurais e urbanos, vinculando-se à tradição do teatro de costumes. Suas peças lançaram grandes nomes da dramaturgia nacional, como Dulcina de Moraes e Procópio Ferreira, e, com importantes nomes do teatro, como Chiquinha Gonzaga, Raul Pederneiras, Bastos Tigre, fundou, em 1917, uma das primeiras associações de defesa dos direitos autorais: a Sociedade Brasileira de Autores Teatrais (SBAT), ainda hoje em pleno funcionamento.

Viriato dedicou-se também à vida pública, tendo sido eleito Deputado Estadual, em 1911, e Deputado Federal (1927), ambos os mandatos como representante do estado do Maranhão. No entanto, por ser amigo pessoal de Washington Luís e contrário ao movimento revolucionário de 30, que pôs fim à chamada República Velha (1889-1930), Viriato foi preso em 1930 permanecendo um mês na Casa de Correção. Sofreu perseguições políticas, não mais retornando ao mundo político-partidário. A partir de então, passou a dedicar-se inteiramente à vida jornalística e literária. 


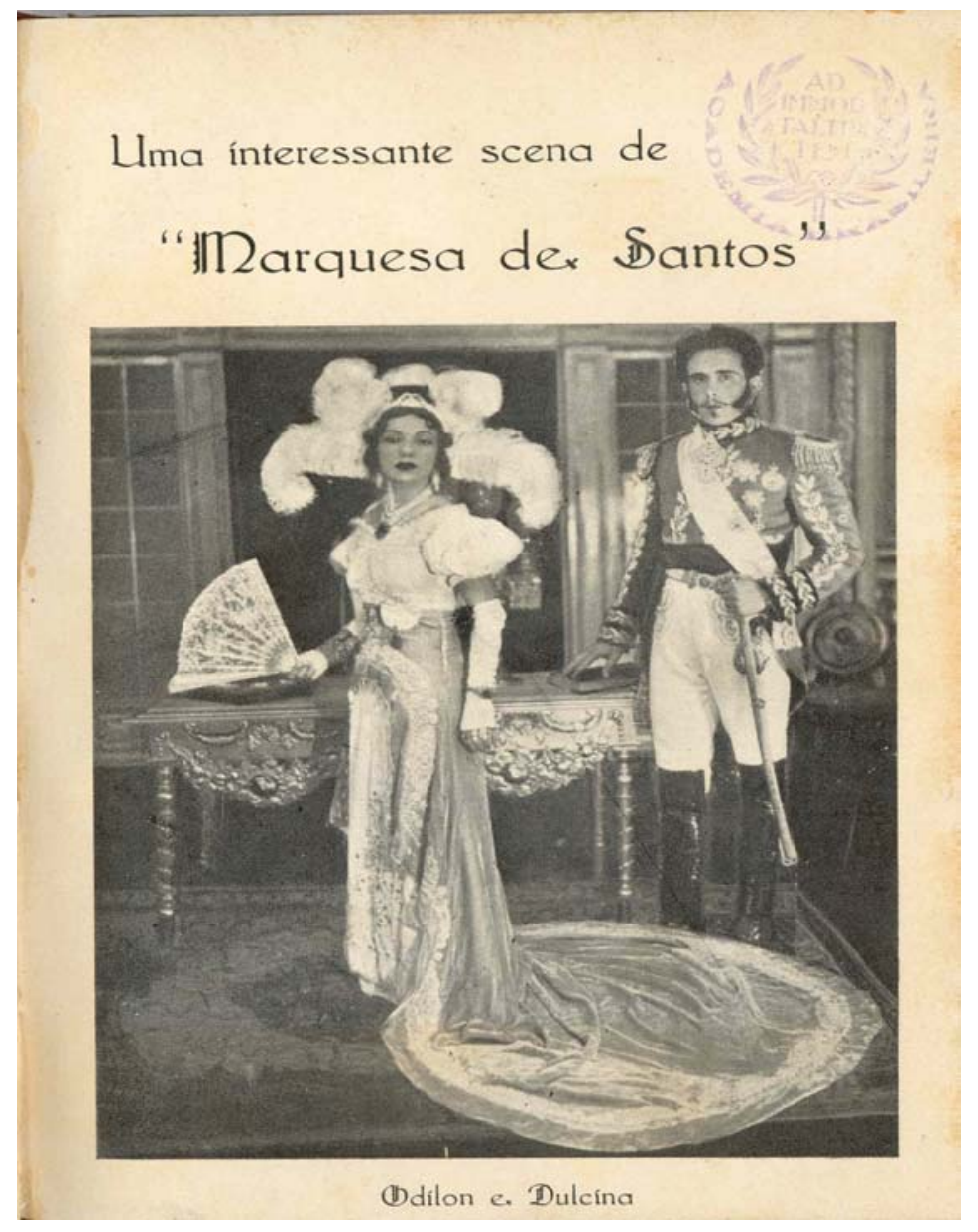

Figura 24 - Marquesa de Santos, de autoria de Viriato Corrêa, com Dulcina de Moraes.

Fonte: Acervo Centro de Memória da ABL.

$\mathrm{Na}$ medida em que produzia seus livros de crônicas históricas e de literatura infantil, Viriato sempre demonstrou uma verdadeira obsessão para ingressar no quadro dos imortais da ABL.

As cartas a seu editor e amigo pessoal Ribeiro Couto revelam a obstinação e a persistência para alcançar a tão sonhada imortalidade ${ }^{81}$ :

\footnotetext{
${ }^{81}$ Segundo Alessandra El Far, a ABL inspirava-se no modelo da Academie Française, criada pelo Cardeal Richelieu em 1635, e pretendia, portanto, adotar os mesmos preceitos, entre eles o "estatuto da imortalidade": "Desde sua fundação em 1897, a Academia frisava sua preocupação de trabalhar pela glória e imortalidade dos homens de letras. Além de zelar pela língua e pela literatura brasileira, salientava, através dos inúmeros discursos de seus membros, sua tarefa de garantir a memória daqueles que dela faziam parte. Se os políticos, advogados, cientistas, engenheiros e médicos eram constantemente lembrados por seus feitos, os romancistas, poetas e cronistas, por suas qualidades ímpares, mereciam igual admiração [...]. Todos aqueles que pertencessem aos quadros da associação nascente seriam qualificados de imortais, tendo seu nome e sua obra enaltecidos pelos demais e lançados à posteridade nas sucessivas sessões ordinárias e celebrativas.” (EL FAR, 2000, p. 120).
} 
Meu querido Ribeiro Couto,

[...] Eu, meu caro Ribeiro, estou neste momento com a preocupação de entrar para a Academia. A verdade, porém, é que a tarefa é penosa. A Academia é difficílima.

Difficílima por tudo principalmente pelo que há de aulicismo e de inconstância lá dentro.

Como as meninas românticas que sonham com noivados com príncipes, a Academia só deseja príncipes nas suas cadeiras [...]

- Meu caro Ribeiro, eu continuo trabalhando, isto é, escrevendo ininterruptamente com a coragem que Deus me deu. Este mez saem dois livros meus: MEU TORRÃO (contos patrióticos da História do Brasil para creanças) e CASA DE BELCHIOR, chrônicas históricas.

Fiz duas peças que o Procópio vae montar. Estou com vários livros na gaveta, já promptos. Estou trabalhando num livro do gênero do CORAÇÃO de Amicis, vou escrever a vida dos grandes homens do Brasil (para creanças) e já entreguei ao Instituto Histórico o MISTÉRIO DA PROCLAMAÇÃO (história do primeiro dia da República) que deve dar umas seiscentas páginas da Revista do Instituto.

A minha sina é trabalhar, produzir. Se um dia a Academia achar que isso merece o premio de uma de suas cadeiras, contente me irei sentar naquella que me for offerecida; se porém, ella nunca se lembrar de tal coisa, eu viverei com o consolo de ter cumprido, para a minha geração e para meu paiz, o meu dever de homem trabalhador (23.11.1935, grifo nosso).

Rio, 13-2-1937.

Meu caro Ribeiro Couto,

$[\ldots]$

Esta carta vai dizer-te que não sou candidato à vaga do Alberto de Oliveira [...] Eu não ia bater-me com o Oliveira Vianna e nem appareci em campo. Só quem está tendo a coragem de concorrer com elle é o Ozório Dutra, mas o Ozório perdeu totalmente o senso de oportunidade. A intoxicação acadêmica perturba-lhe o juízo.

Meu caro Ribeiro: o que me falta é um expressivo apoio para a minha candidatura, assim como o Oliveira Vianna tem o Taunay e o Alcântara. Tu, meu caro Ribeiro, é que me está faltando aqui!

Na próxima vaga vou apresentar-me pela última vez. Terei pela prôa o Zé Maria Bello e Cassiano Ricardo.

Se perder apagarei o sonho de immortalidade e me recolherei ao silêncio, como as solteironas se recolhem aos seus suspiros..... Porque, a respeito da Academia, meu caro Ribeiro, eu já estou ficando "tia".

Estou trabalhando loucamente num livro de creança. [...]

Escreve-me. Teu velho amigo Viriato (grifo nosso).

Outras vezes, dirigia-se a Ribeiro Couto, para solicitar seu apoio e voto à tão pretendida e sonhada vaga na Academia, que o tornaria "imortal".

Meu caro Ribeiro Couto.

[...] O Setúbal morreu hoje pela manhã em São Paulo. Hoje, à tarde, telegrafei-te fazendo a comunicação de minha candidatura à vaga do pobre Setúbal [...]

Agora morre um prosador. E um prosador de coisas históricas e do mesmo gênero histórico que eu exploro. Não há no Brasil dois escriptores mais queridos no gênero e na maneira do que Setúbal e Viriato.

Espero, portanto, que votes em mim (4.5.1937, grifo nosso). 
A correspondência trocada entre Viriato Corrêa e Ribeiro Couto é reveladora dos meandros na escolha dos membros que deveriam integrar a Academia Brasileira de Letras, ao tempo em que mostra o processo de elaboração de seus livros dedicados ao universo infantil, que priorizavam a temática histórica.

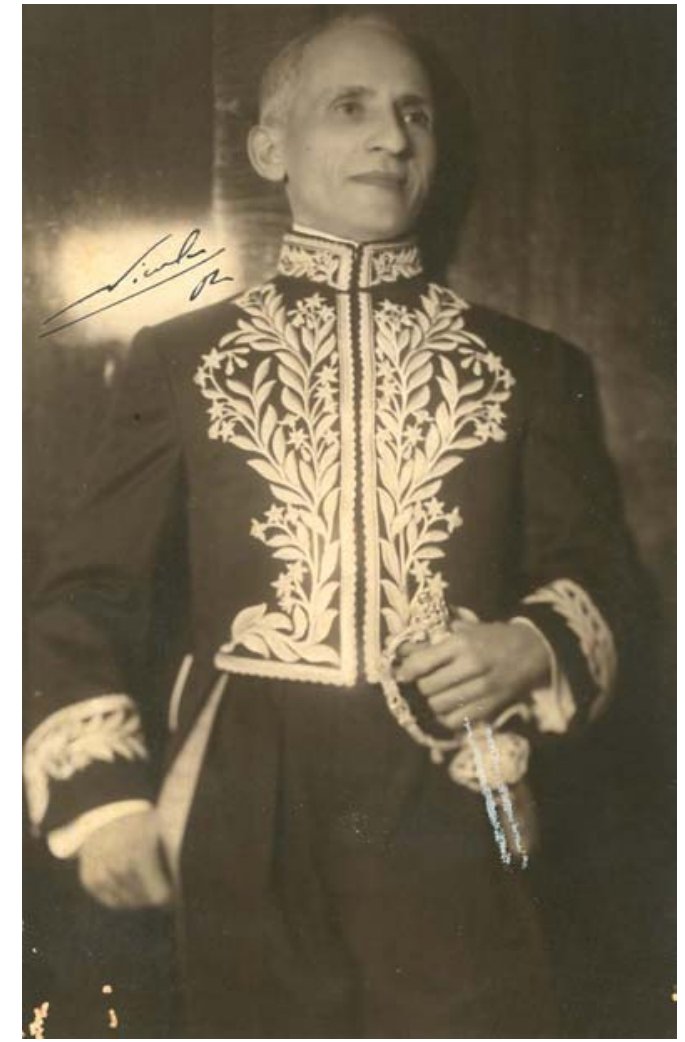

Figura 25 - Posse de Viriato Corrêa na ABL (1938).

Fonte: Acervo Centro de Memória da ABL.

\subsection{Os editores: Monteiro Lobato e Octalles Ferreira}

A produção literária de Viriato Corrêa dá-se praticamente a partir dos anos 20 do século passado, época de conturbações sociais, políticas e culturais no País. Essas mudanças inseriram-se no contexto de crise da Primeira República (1889-1930), marcada por revoltas armadas, campanhas presidenciais tumultuadas, em meio às reivindicações de novos atores sociais que apareciam na cena política nacional.

A incipiente industrialização, como decorrência dos efeitos da $1^{\text {a }}$ Guerra Mundial fez surgir uma classe operária e uma burguesia empresarial; as mulheres passaram a reivindicar maior participação na sociedade, através do direito ao voto e do acesso às instâncias de poder; 
jovens militares - os tenentes - contestavam o modelo político vigente, que consideravam obsoleto e viciado, sobretudo por ocasião das eleições, com denúncias de fraudes e corrupção; intelectuais modernistas pretendiam uma nova estética cultural genuinamente nacional, cujo ápice se deu no emblemático ano de $1922^{82}$ - em meio às comemorações do centenário de nossa emancipação política.

Essas manifestações também se fizeram presentes no campo educacional. Em 1924, um grupo de intelectuais publicou, no Anuário do Brasil, um estudo colegiado feito em torno das questões que afligiam a República ${ }^{83}$. Uma das questões mais críticas foi tratada pelo educador pernambucano Carneiro Leão (1887-1966) no seu ensaio "Os deveres das novas gerações brasileiras”. Dizia ele:

Acredito que, nesta época de civilização de base científica, onde tudo se procura fazer pela cultura, a educação é a maior necessidade do país. [...]

É mister convençam-se todos, no Brasil, de que as questões de educação não são simplesmente pedagógicas, porém, nacionais, na mais alta expressão do termo. Interessam ao futuro do país, ao desenvolvimento de suas forças vivas. [...]

A questão primordial é convencermo-nos de que o nosso problema máximo é a educação integral, desde a formação do individuo físico - sadio, inteligente, capaz até a organização cívica, política e social, passando pela preparação profissional e técnica, literária e científica (LEÃO, 1990, p. 16; p. 20, grifo nosso).

Assim, Carneiro Leão imputava às novas gerações de brasileiros o dever máximo de cuidar da educação do País, uma vez que, até o presente momento, o governo republicano não fora capaz de melhorar a situação educacional da Nação cujos cidadãos, em sua maioria, não tinham acesso à instrução formal.

Conforme acentua Jorge Nagle (1983), desde as décadas iniciais da República já havia um clima de entusiasmo generalizado em torno da educação, pois muitos intelectuais viam-na como a solução para os graves problemas sociais brasileiros, acentuados, principalmente, pelos

\footnotetext{
${ }^{82} \mathrm{O}$ ano de 1922 é bastante emblemático para se entender a crise por que passava o País. Nele ocorreram importantes fatos históricos: Semana de Arte Moderna; Fundação do Partido Comunista; Revolta Tenentista dos 18 do Forte de Copacabana; Exposição Universal comemorativa do centenário da Independência do Brasil (ver SANDES, Noé Freire. A invenção da nação: entre a monarquia e a república. Goiânia: Editora UFG, 2000).

${ }^{83}$ Esse estudo foi resultado de um "inquérito por escritores da geração nascida com a República" (Anuário do Brasil. RJ: 1924), com o título À Margem da História da República, organizado por Vicente Licínio Cardoso. Dele participaram expressivos nomes da intelligentsia nacional: A. Carneiro Leão, Celso Vieira, Gilberto Amado, Jonathas Serrano, José Antonio Nogueira, Nuno Pinheiro, Oliveira Vianna, Pontes de Miranda, Ronald de Carvalho, Tasso da Silveira, Tristão de Athayde e Vicente Licínio Cardoso.
} 
alarmantes índices de analfabetismo, que atingia cerca de $80 \%$ da população do País. E, já que a primeira constituição republicana estabelecia o direito de voto apenas aos alfabetizados, isso colocava outro problema para a recente República do Brasil, em que apenas 20\% de seus habitantes estavam aptos para exercer o direito de cidadania política (CARVALHO, 2001).

Em função disso, “os anos de 1920 e 1930 foram marcados por tentativas de reformar a escola primária, em grande medida lideradas por um grupo de educadores e intelectuais pertencentes ao movimento 'escolanovista' no Brasil" (OLIVEIRA, 2006, p. 28). Segundo esses intelectuais, a regeneração da Nação se daria pela escola primária universalizada a todos. Era preciso diminuir o analfabetismo e garantir a escolarização a amplas parcelas da população. Só assim, o País ingressaria na tão almejada modernidade (HERSCHANN \& PEREIRA, 1994; DE LORENZO \& COSTA, 1997).

Nesse sentido, reformas educacionais foram implementadas em alguns estados brasileiros por renomados educadores: em São Paulo (Sampaio Dória, 1920); Ceará (Lourenço Filho, 1922); Bahia (Anísio Teixeira, 1924); Minas Gerais (Francisco Campos, 1926) e Distrito Federal (Fernando de Azevedo, entre 1927 e 1930). Vale destacar também a fundação, em 1924, da Associação Brasileira de Educação (ABE), que desempenhou a função de institucionalizar a discussão dos problemas da escolarização, mediante a realização das Conferências Nacionais de Educação (CARVALHO, 1998).

$\mathrm{Na}$ verdade, o País e, principalmente, o ambiente intelectual brasileiro, impregnavamse, então, de sentimentos nacionalistas e foi assim que os anos 20 do século passado assistiram também à modernização do parque editorial, caracterizado pelas ações empreendedoras do paulista Monteiro Lobato (1882-1948).

A primeira experiência editorial de Lobato deu-se em 1919, quando fundou a empresa "Monteiro Lobato \& Cia". Foi responsável pelo lançamento de autores novos no reduzido mercado editorial nacional, a exemplo de Ribeiro Couto, Paulo Setúbal, Oliveira Viana, entre outros. Ele mesmo se proclama um "editor revolucionário", que abriu as portas para gente nova, uma vez que os velhos editores só queriam publicar os autores consagrados. Dizia: "Nada de velharias, medalhões, nada de acadêmicos com farda de general de opereta do tempo de Luís $\mathrm{XIV}$, armado daquela espadinha de cortar-papel. Gente nova, de paletó saco, humildade nas suas pretensões, mas gente nova" (LOBATO apud HALLEWELL, 1985, p. 246). 
Como editor, Monteiro Lobato preocupava-se com o mercado livreiro e o conseqüente acesso da população ao livro e fazia críticas a uma certa visão romântica oitocentista do livro: objeto sacralizado, cujo acesso estava reservado à elite. Em 1918, montou uma inovadora estratégia de divulgação, ao escrever carta dirigida aos comerciantes de bancas de jornais, papelarias, farmácias e armazéns de todo o território nacional, com o intuito de aumentar os pontos de venda, restritos àquela época às livrarias localizadas geralmente nas capitais. Sua carta dizia:

Vossa Senhoria tem o seu negócio montado, e quanto mais coisa vender, maior será o lucro. Quer vender também uma coisa chamada 'livros'? Vossa Senhoria não precisa inteirar-se do que essa coisa é. Trata-se de um artigo comercial como qualquer outro: batata, querosene ou bacalhau. É uma mercadoria que não precisa examinar nem saber se é boa nem vir a esta escolher. $O$ conteúdo não interessa a V.S., e sim ao seu cliente, o qual dela tomará conhecimento através de nossas explicações nos catálogos, prefácios, etc. E, como V.S. receberá esse artigo em consignação, não perderá coisa alguma no que propomos. Se vender os tais livros, terá uma comissão de 30 p.c.; se não vendê-los, no-los devolverá pelo Correio, com o porte por nossa conta. Responda se topa ou não topa (LOBATO apud HALLEWELL, 1985, p. 245).

Mas Lobato, apesar dessas inovações, continuava a dar importância ao trabalho do livreiro, pois via nele a figura de um difusor, sobretudo em um país de dimensões continentais como o nosso. Queria que esse produto chegasse às mãos de um maior número de brasileiros.

Entre os mais humildes comércios do mundo está o do livreiro. Embora sua mercadoria seja a base da civilização, pois que é nela que se fixa a experiência humana, o livro não interessa ao nosso estômago nem a nossa vaidade. Não é, portanto, compulsoriamente adquirido. - O pão diz ao homem: ou me compras ou morres de fome; - $\mathrm{O}$ batom diz à mulher: ou me compras ou te acharão feia. $\mathrm{E}$ ambos são ouvidos. Mas se o livro alega que sem ele a ignorância se perpetua, os ignorantes dão de ombros, porque é próprio da ignorância sentir-se feliz em si mesma, como o porco com a lama. E, pois o livreiro vende o artigo mais difícil de vender-se.

Qualquer outro lhe daria maiores lucros; ele o sabe e heroicamente permanece livreiro. E é graças a esta generosa abnegação que a árvore da cultura vai aos poucos aprofundando as suas raízes e dilatando a sua fronde. Suprimam-se o livreiro e estará morto o livro - e com a morte do livro retrocederemos à idade da pedra, transfeitos em tapuias comedores de bichos de pau podre. A civilização vê no livreiro o abnegado zelador da lâmpada em que arde, perpetua, a trêmula chamazinha da cultura. 
Porém, apesar de sua disposição, uma série de fatores ${ }^{84}$ levou Monteiro Lobato a pedir falência em 1925. Mas ele persistiu na sua carreira de editor e, juntamente com o amigo e comerciante Octalles Marcondes Ferreira, fundou a Companhia Editora Nacional - CEN $\left(\right.$ HALLEWELL, 1985) ${ }^{85}$. Ao lado da Livraria Francisco Alves e Melhoramentos, editoras já reconhecidas no mercado, a CEN notabilizou-se, principalmente, pela edição de livros escolares e infanto-juvenis.

Para alguns estudiosos (HALLEWELL, 1985; TRAVASSOS, 1964), Monteiro Lobato é considerado o verdadeiro fundador da moderna editoração no Brasil.

Toda essa popularidade e valorização do livro de hoje se deve a Monteiro Lobato, e uma síntese histórica do livro no Brasil pode ser assim enunciada: D. João VI criou a Imprensa Nacional. Monteiro Lobato criou o livro no Brasil. O mais foi Idade Média (TRAVASSOS, 1978, p. 177).

O próprio Viriato Corrêa compartilhou dessa posição acerca do papel pioneiro e empreendedor de Lobato na indústria editorial brasileira, ao ponto de considerá-lo o "bandeirante do livro":

\begin{abstract}
Monteiro Lobato não realizou apenas uma obra literária que é das mais altas do Brasil. Não foi apenas o contista maravilhoso, o ensaísta fascinante, o homem de luta que toda a vida se bateu pelo aproveitamento das riquezas do país. Não foi apenas o maior dos escritores de crianças que já tivemos em todos os tempos. [...] Mas Monteiro Lobato tem outra obra que, sozinha, lhe daria renome imperecível. Ele foi no Brasil o bandeirante do livro.

[...]

Em cada paulista, já isto foi dito por muita gente, há sempre o potencial de um bandeirante. Não há bandeirante sem largos horizontes; sem visão do futuro não há bandeirismo. $\mathrm{O}$ amanhã venturoso sempre valeu mais para o paulista do que a atualidade risonha e tranqüila. A fatalidade de abrir caminhos novos os filhos de São Paulo desde os velhos tempos de Antonio Raposo e de Fernão Dias.

Monteiro Lobato surgiu para fazer o bandeirismo do livro com todas as qualidades dos seus antepassados $[\ldots]$
\end{abstract}

\footnotetext{
${ }^{84}$ Entre os fatores que contribuíram para o pedido de falência da Monteiro Lobato \& Cia. estão o levante tenentista de 1924, que parou a cidade de São Paulo por um mês inteiro; a seca que afligiu o estado, comprometendo o fornecimento de energia elétrica, e o fato de Lobato não ter podido honrar seus compromissos financeiros assumidos junto aos bancos para compra de máquinas mais modernas para sua editora (AZEVEDO, CAMARGOS \& SACCHETTA, 1997; LAJOLO, 2000).

${ }^{85} \mathrm{O}$ primeiro livro publicado pela CEN, com uma tiragem inicial de três mil exemplares, foi o relato do náufrago alemão Hans Staden que, em 1550, foi aprisionado pelos índios tupinambás - Meu cativeiro entre os selvagens do Brasil. Posteriormente, Lobato adaptou essa obra para a série Literatura Infantil da Biblioteca Pedagógica Brasileira, com o título As Aventuras de Hans Staden (vol. 5) (GANDRA, 2005).
} 
O bandeirante de outrora desvendou terras novas, rincões longínquos de que ninguém tinha notícia. Lobato descobria mercados novos, em lugares remotos, que todo mundo imaginava infrutíferos [...] [Ele] havia alargado as fronteiras de nossa cultura como o bandeirante antigo alargava as nossas fronteiras geográficas (CORRÊA, 1948, p. 369-71, grifo nosso) ${ }^{86}$.

Merece registro, também, o fato de que, numa época em que não havia legislação consolidada que garantisse os direitos autorais dos escritores, Lobato manteve com eles relação cordial, através do pagamento correto dos exemplares vendidos. Ao lado disso, esmerou-se no trabalho gráfico-editorial, produzindo obras bem acabadas, com capas ilustradas em cores mais vibrantes, clareza de impressão e inovação nos formatos dos livros ${ }^{87}$.

Há, no entanto, quem conteste o pioneirismo e a importância de Lobato na mudança do aspecto gráfico-visual do livro brasileiro:

[...] a atuação de Monteiro Lobato foi decisiva sim na adoção da capa ilustrada como prática comercial corrente e, por conseguinte, na sofisticação da programação visual dos livros brasileiros. Porém, não obstante sua grande importância como um dos principais modernizadores do meio editorial no Brasil, é um erro atribuir tais mudanças apenas à sua iniciativa e, pior ainda, ignorar o que foi feito à mesma época por outras editoras (CARDOSO, 2005, p. 168).

Aníbal Bragança também relativiza a atuação de Monteiro Lobato no contexto da indústria editorial brasileira, ao mostrar o papel pioneiro de Francisco Alves na edição de livros escolares, desde 1854. Ele considera que há

certo ufanismo paulista, que encontrou em Monteiro Lobato um suposto "ponto zero" da nossa indústria editorial. Grande escritor, rica personalidade, editor arrojado e inovador, Monteiro Lobato a isso aliou grande habilidade para promover suas idéias, seus produtos e a si próprio, contribuindo assim para ofuscar o trabalho dos que o precederam no campo editorial (BRAGANÇA, 1999, p. 455).

\footnotetext{
${ }^{86}$ CORRÊA, Viriato. Fala de Viriato Corrêa, na sessão póstuma em homenagem a Monteiro Lobato. In: Revista da Academia Brasileira de Letras. Anais de 1948 (julho a dezembro). Rio de Janeiro: Edições ABL, Ano 47, vol. 76.

${ }^{87}$ Segundo Hallewell (1985), Lobato adotou, em algumas edições na Monteiro Lobato \& Cia, um formato menor, semelhante a um folheto de literatura de cordel $(16,5 \mathrm{X} 12,0 \mathrm{~cm})$, com o objetivo de reduzir o preço de capa do livro.
} 
Para Bragança ${ }^{88}$, o enaltecimento de Lobato como fundador da indústria editorial brasileira insere-se em um contexto social de luta de São Paulo pela hegemonia cultural do País, cujo marco histórico foi a Semana de Arte Moderna (1922). São Paulo pretendia, também, impor-se ao Rio de Janeiro, então capital do Brasil, no plano econômico e social.

Mesmo levando-se em consideração tais aspectos, não se pode esquecer que Lobato teve também um papel destacado na luta pela nacionalização da indústria editorial brasileira: lutou pela isenção das taxas alfandegárias para a importação de papel para livro (KOSHIYAMA, 2006) e foi, também, responsável pelo lançamento de autores novos no reduzido mercado editorial brasileiro, entre eles Viriato Corrêa. É o próprio Viriato que assim se reporta: "Sou cria da casa, desde os tempos de Monteiro Lobato, que foi quem me levou para lá, editando 'Histórias da nossa História', em 1921."89 (O JORNAL, 1960).

No que se refere à literatura infanto-juvenil, ainda pesava uma crítica quanto à qualidade dos livros. Viriato Corrêa, ao relembrar os tempos de escola no interior do Maranhão, fez a seguinte denúncia:

O primeiro livro que, menino no curso primário, li fora das minhas lições, foi 'Desastre de Sofia', da Condessa de Ségur. Li-o tantas e tantas vezes que quase o decorei. E tomei paixão pela leitura. Devorei contos de fadas, tudo quanto era história que me caia nas mãos. E desordenada e gulosamente pus-me a devorar livros. E o pior é que eram livros ruins (CONDE, 1961).

Monteiro Lobato fez questão de imprimir um novo formato e concepção na publicação de livros infantis e de leitura ${ }^{90}$, rompendo com a edição de livros que, segundo ele, não interessavam à criança brasileira pelo seu conteúdo, abordagem e apresentação gráfica. Neste sentido, Lobato aproximou-se do ideário escolanovista, ao retratar o universo infantil de

\footnotetext{
${ }^{88}$ Outro erro em relação à história editorial do País é colocar Francisco Alves como editor estrangeiro ao lado de Garnier e Laemmert. Embora tenha nascido em Portugal, Alves instalou-se no Rio de Janeiro e obteve cidadania brasileira. Aqui desenvolveu seu trabalho de livreiro e editor, tendo sido responsável pela edição de importantes livros didáticos. Ao morrer, deixou em testamento sua fortuna para a ABL, o que bem demonstra sua dedicação e amor às coisas do Brasil (BRAGANÇA, 2006).

${ }^{89}$ Viriato Corrêa passou a limpo a História do Brasil: fórmula simples. "O Jornal”, Rio de Janeiro, 17.12.1960.

${ }^{90}$ Para reforçar o papel de inovação da literatura infanto-juvenil brasileira atribuído a Monteiro Lobato, sua data natalícia - 18 de abril - é consagrada ao "Dia Nacional do Livro Infantil", através da Lei no 10.402, de 8 de janeiro de 2002 (ORIÁ, 2007).
} 
forma diferenciada e colocar os interesses da criança como objeto de preocupação dos educadores.

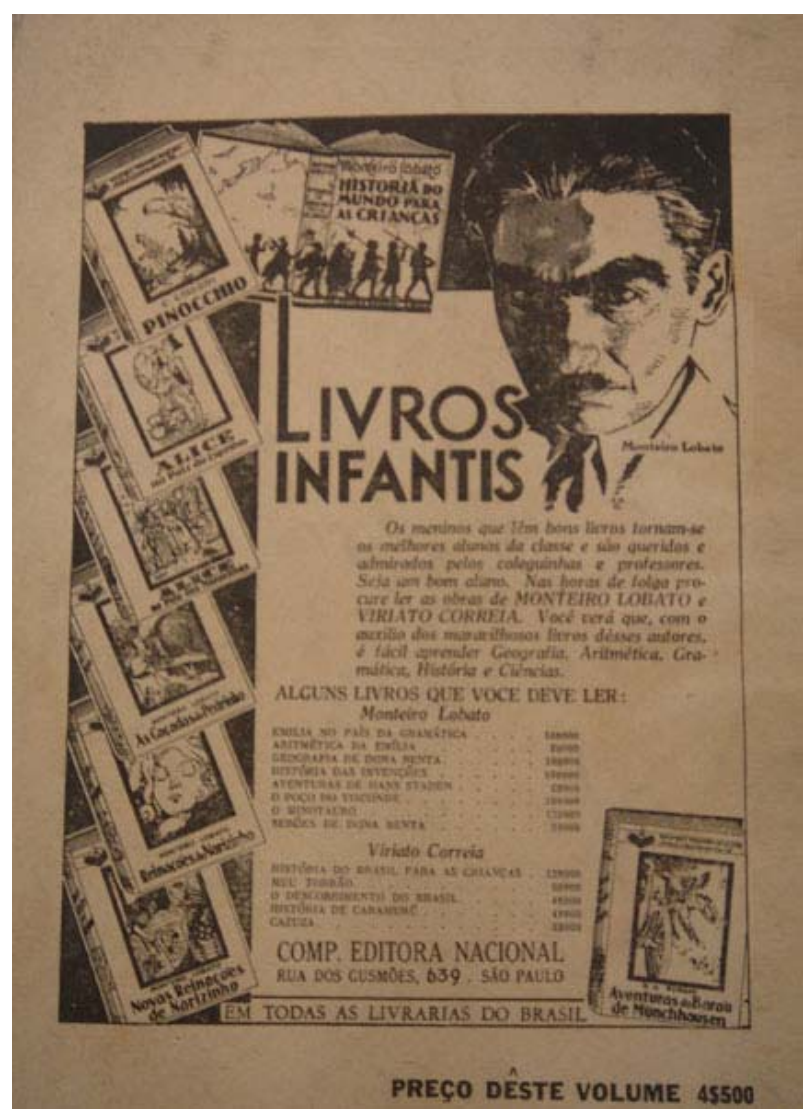

Figura 26 - Divulgação dos livros infantis de Monteiro Lobato e Viriato Corrêa, na contracapa de outros livros escolares.

Fonte: Acervo CEN.

No período em que esteve à frente da editora Monteiro Lobato \& Cia. e, posteriormente, da Companhia Editora Nacional, Lobato foi responsável pelo lançamento de, no mínimo, cinqüenta novos escritores, até então desconhecidos do público. Esse fato, por si só, já o consagra como um grande editor, se não pioneiro, pelo menos moderno e sintonizado com as questões de seu tempo.

A reunião de Monteiro Lobato e Octalles Ferreira ${ }^{91}$ em um mesmo projeto editorial foi assim retratada pela historiadora Eliana Dutra:

\footnotetext{
${ }^{91}$ Enquanto Monteiro Lobato era o idealizador, Octalles Ferreira era quem, de fato, realizava as tarefas editoriais e comerciais: "Possuindo um cérebro privilegiado, aliado a uma extraordinária capacidade executiva, tornou a sua empresa na maior organização editorial do país, sendo ele o editor de melhor visão que o Brasil produziu até esta data [...]. O nome de Octalles Marcondes Ferreira não aparece aqui incidentalmente, mas sim, porque foi ele a alma executora, não só da Companhia Monteiro Lobato como da Companhia Editora Nacional." (TRAVASSOS, 1964, p. 99-100).
} 
A criação da Companhia Editora Nacional não apenas vai se beneficiar dessa inovadora experiência acumulada pelos dois sócios no empreendimento anterior, como vai ser herdeira de um projeto, de inspiração iluminista, acalentado por setores da intelectualidade republicana brasileira dos anos 10 e 20, dos quais Lobato foi parte integrante, e que convencidos de que o país além de pouco alfabetizado era "alérgico aos livros", contavam em civilizar a nação através de um poder pedagógico e transformador dos livros.

Para "inundar o país de livros" como queria Monteiro Lobato, a Companhia Editora Nacional vai se valer de uma fórmula editorial e grande sucesso que marcou a paisagem oitocentista francesa, expandindo-se da França para o mundo: as coleções (DUTRA, 2004, p. 6).

Entre as coleções da Companhia Editora Nacional avulta, pelas suas características e abrangência das obras publicadas, a Biblioteca Pedagógica Brasileira, dirigida por Fernando de Azevedo. E, a fim de atender segmentos específicos da população, a Companhia Editora Nacional publicou outras importantes coleções, tais como: Biblioteca das Moças, considerado um sucesso absoluto de vendagem e leitura da geração de mulheres até os anos 1960 e a Coleção Paratodos:

$\mathrm{Na}$ coleção Paratodos, a Nacional editava traduções de romances, romances históricos, policiais e de ficção científica, trazendo para os leitores muitos autores consagrados da literatura universal e traduzidos por importantes brasileiros. Indicados para o leitor como 'literatura sã', as obras da coleção Paratodos ganhavam capas coloridas e modernas para a época, inovando na apresentação dos livros [...] (GANDRA, 2005, p. 75). 


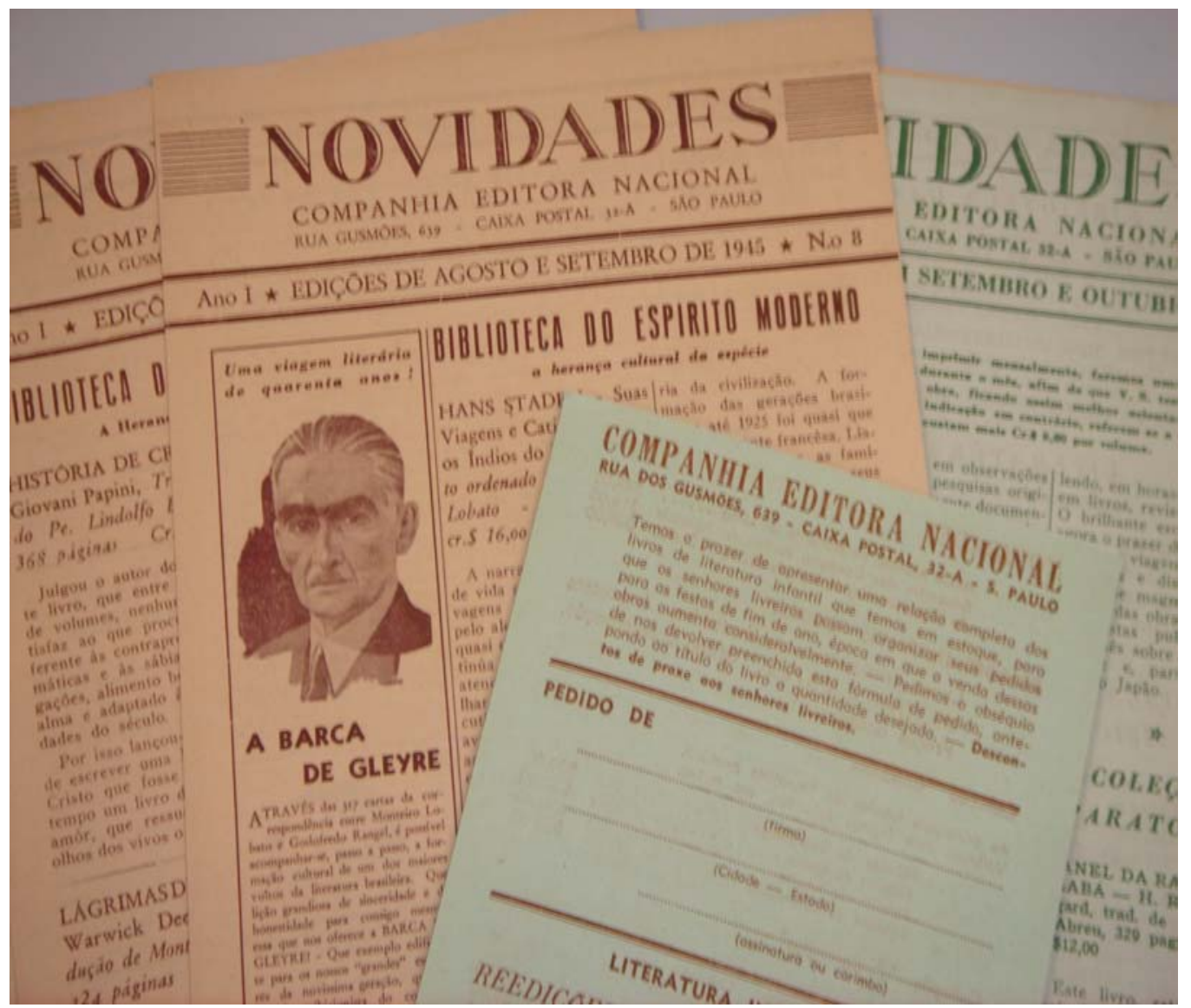

Figura 27 - Exemplares do Boletim NOVIDADES da CEN.

Fonte: Acervo CEN.

\subsection{A Biblioteca Pedagógica Brasileira: Fernando de Azevedo e Viriato Corrêa}

Em 1931, a CEN criou seu mais ambicioso projeto editorial, a Biblioteca Pedagógica Brasileira, convidando para a direção o educador escolanovista Fernando de Azevedo ${ }^{92}$. A CEN aproximava-se, assim, do movimento de renovação educacional do País, cujo marco foi o lançamento do Manifesto dos Pioneiros da Educação Nova (1932) ${ }^{93}$. Assim, esse projeto editorial de tamanha envergadura representou, de certa forma, a incorporação do ideário da Escola Nova no mercado editorial brasileiro.

\footnotetext{
92 Fernando de Azevedo dirigiu a Biblioteca Pedagógica Brasileira até 1951, quando foi substituído pelo historiador Américo Jacobina Lacombe. Mais dados biográficos desse educador podem ser encontrados no seu livro de memórias: AZEVEDO, Fernando de. História de minha vida. Rio de Janeiro: Livraria José Olympio Editora, 1971.

93 Apesar de ser custeada pelos próprios signatários, foi a CEN que publicou o Manifesto dos Pioneiros da Educação Nova e, dada sua abrangência nacional, com filiais em pontos estratégicos do País, encarregou-se da distribuição dos volumes em todo o território brasileiro.
} 
Ao analisar a Coleção Atualidades Pedagógicas, uma das séries da BPB, Rita Toledo explica por que a editora escolheu Azevedo:

[...] ao optar por Azevedo como diretor da BPB, a CEN acaba por escolher um dos representantes de uma das hostes de educadores do movimento educacional dos anos 30. Mas é preciso notar que a projeção do nome do educador estava ligada ao movimento de renovação educacional e não especificamente ao grupo que vai assinar o Manifesto dos Pioneiros da Educação Nova (1932). Talvez, a escolha do nome de Azevedo entre os diferentes educadores de projeção do período estivesse ligada ao fato de ter relações próximas a Lobato (TOLEDO, 2001, p. 64).

Vale ressaltar que a Editora Melhoramentos ${ }^{94}$ já contava com o trabalho editorial de outro importante educador do período. Manuel Bergströn Lourenço Filho (1897-1970) desempenhou desde 1926, quando substituiu o professor Arnaldo de Oliveira Barreto na direção da Biblioteca Infantil, papel importante na edição de obras pedagógicas, livros didáticos e infantis na editora (SOARES, 2007).

A Biblioteca Pedagógica Brasileira era constituída de cinco séries, a saber: Literatura Infantil, Livros Didáticos, Atualidades Pedagógicas, Iniciação Científica e a famosa coleção Brasiliana, que foi responsável pela renovação do pensamento social brasileiro e publicou, até 2005, 444 títulos de expressivos nomes da intelligentsia nacional, a exemplo de Nina Rodrigues, Sérgio Buarque de Hollanda, Florestan Fernandes e autores estrangeiros que estudaram o País, como Roger Bastide, Jacques Lambert, entre outros.

Segundo Eliana Dutra, a coleção Brasiliana foi "o maior empreendimento editorial destinado a reunir um conhecimento sistemático sobre o Brasil, ainda hoje sem equivalente na história da edição do país.” (DUTRA, 2006, p. 301). Ela foi concebida, segundo a autora, para ser uma biblioteca ideal, uma "biblioteca sem muros" "95 e uma enciclopédia do conhecimento brasileiro. Fez tanto sucesso, que serviu de exemplo para que outras empresas lançassem projetos editoriais semelhantes. Foi o caso da Editora José Olympio, que lançou em 1936 a Coleção Documentos Brasileiros, coordenada por outro intelectual, o sociólogo

\footnotetext{
${ }^{94}$ Sobre a história da empresa Melhoramentos e sua trajetória de indústria de papel a editora de livros, consultar: DONATO, Hernani. 100 Anos da Melhoramentos: 1890-1990. São Paulo: Melhoramentos, 1990.

${ }^{95}$ Expressão usada pelo historiador francês Jean-Yves Mollier para designar as edições de coleções, dicionários e enciclopédias que marcaram a cultura impressa no século XIX em toda a Europa (MOLLIER, 2008).
} 
pernambucano Gilberto Freyre, que lançou o importante livro Raízes do Brasil, do renomado historiador Sérgio Buarque de Holanda.

No entanto, aqui, interessa-me mais de perto a série Literatura Infantil, por nela estarem incluídos dois livros de Viriato Corrêa: História do Brasil para crianças, de 1934, e Meu Torrão (contos da História Pátria), de 1935.

A série Literatura Infantil era uma "collectanea de livros para crianças, em que se acham incorporadas, traduzidas por mestres, obras universalmente consagradas, de literatura infantil” (CEN, Catálogo escolar, 1935, p. 63). Essa série publicou ao todo 33 volumes, sendo que 21 livros eram de autoria de Monteiro Lobato; 8 volumes eram traduções de clássicos da literatura ocidental, a exemplo de Alice no País das Maravilhas e Contos de Fadas de Charles Perrault; 1 livro de poemas para crianças, A Estrela Azul, de Murilo Araújo, e uma tradução do clássico Aventuras do Barão de Münchhausen, de G. A. Burger, além dos dois livros de Viriato Corrêa, anteriormente mencionados.

Vale dizer que muitos desses livros que passaram a integrar a série Literatura Infantil da BPB já haviam sido publicados anteriormente. É o caso de Narizinho Arrebitado, publicado originalmente em 1920 e considerado um marco na literatura infantil brasileira e um dos primeiros best-sellers do autor Monteiro Lobato. Depois, já no âmbito da BPB, passou a se intitular Reinações de Narizinho.

Na série Literatura Infantil, merece destaque a História do mundo para crianças, publicada em 1933. O livro é uma adaptação feita por Lobato da obra do professor norteamericano e diretor da Calvert School, de Baltimore, V. M. Hillyer, intitulada Child's History of the World. De todos os livros infantis de Lobato, foi História do mundo para as crianças o que mais críticas recebeu, tendo sido censurado nas escolas católicas da época e expurgado das bibliotecas públicas infantis (PALLOTA, 2001). A obra era acusada pelas autoridades religiosas de pregar a ideologia comunista, atentar contra a moral cristã e incutir nas crianças idéias contrárias ao nacionalismo (BRASIL, 1957). 
História do mundo para as crianças foi considerada tão polêmica que causou reações negativas até fora do Brasil. Segundo Cavalheiro, o órgão oficial do Governo português pediu, e obteve, a proibição da obra em Portugal e colônias. Interpelado pelas razões de tal atitude, Monteiro Lobato responde que só encontrava explicação pelo fato de pertencer à corrente que afirma ter sido o Brasil descoberto "por acaso" [...].

Devido a tantas críticas, nas escolas oficiais e praticamente em todos os colégios católicos, é dada uma ordem absurda, chocante: os livros de Monteiro Lobato devem ser retirados das bibliotecas escolares (PALLOTTA, 2008, p. 225-6).

No ano seguinte, saiu pela Companhia Editora Nacional o livro História do Brasil para crianças, de Viriato Corrêa, na mesma série Literatura Infantil da BPB. A partir de então, a editora usou a seguinte estratégia de divulgação: colocou a imagem da capa dos dois livros e uma pequena resenha nas contracapas de outros livros escolares. Com isso, ela disponibilizava aos alunos e professores a oportunidade de conhecerem outros livros que abordavam, de forma diferenciada, a História do mundo e do Brasil para crianças, colocando, lado a lado, dois dos maiores escritores infantis da época - Lobato e Viriato.

A divulgação empreendida pela editora contribuiu, sem sombra de dúvida, para tornar esses livros best-sellers da infância brasileira. 


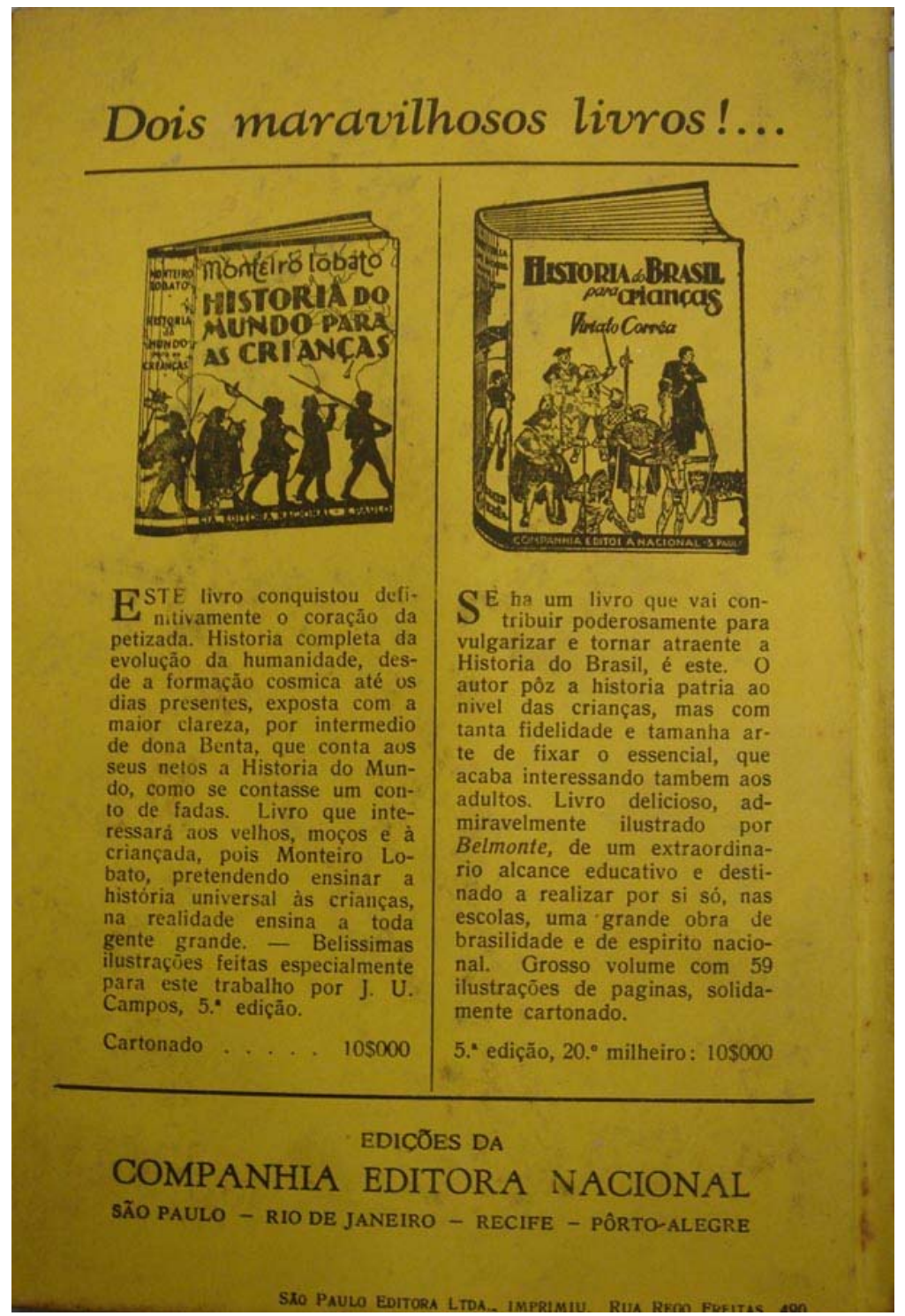

Figura 28 - Contracapa do livro de leitura $O$ Tesouro da Criança Fonte: Acervo CEN.

No decorrer dos anos 1930, a Companhia Editora Nacional foi se transformando na maior editora de livros de São Paulo. Na década de 50, por exemplo, lançou nova coleção, intitulada Brasiliana Infantil, sob a coordenação do educador Theobaldo Miranda Santos ${ }^{96}$. Essa coleção, a exemplo de sua homônima para o público adulto, pretendia ser

\footnotetext{
${ }^{96}$ No livro Contos Cívicos do Brasil, Theobaldo Miranda Santos diz que se utilizou, para a elaboração de seus textos, dos livros Meu Torrão e História do Brasil para crianças, de autoria de Viriato Corrêa, entre outros, o que nos leva a concluir, mais uma vez, que a produção didática de Viriato esteve também presente, de forma indireta, em outros livros escolares.
} 
[...] a mais moderna, a mais brasileira e a mais interessante coleção de livros de literatura infantil e escolar [...]. Trata-se de um conjunto de livros de leitura recreativa e pedagógica, destinado às crianças de todas as idades e de todas as séries escolares. A Brasiliana Infantil representa uma modesta tentativa de oferecer às crianças do Brasil livros de leitura que não sejam enciclopédias escolares e de tornar o conhecidos de nossa infância, em toda a sua beleza e esplendor, os mitos, as lendas, os heróis, os contos populares, as histórias maravilhosas, os episódios cívicos, bem como as aventuras e viagens que mais se destacam no panorama colorido e luminoso do folclore, da história e da tradição brasileira (SANTOS, 1955, p. 7)

A coleção Brasiliana Infantil compunha-se de cinco títulos, para cada uma das séries do ensino primário: Contos Populares do Brasil (vol. I - 1ª série); Histórias Maravilhosas do Brasil (vol. II - 2a série); Lendas e Mitos do Brasil (vol. III - $3^{\mathrm{a}}$ série); Contos Cívicos do Brasil (vol. IV - $4^{\mathrm{a}}$ série) e Viagens e Aventuras do Brasil (vol. V - 5ª́rie).

Em sua trajetória, a Companhia Editora Nacional, apesar de ter sido uma empresa comercial, que visava a lucros com a venda de livros, teve um compromisso com a questão educacional do País, seja na escolha de Fernando de Azevedo para coordenar a BPB, seja na publicação de importantes livros de significativos autores, seja em ações de menor alcance, mas não menos importantes, tais como a preocupação para que os professores escolhessem bem os livros didáticos a serem usados pelos alunos: em um de seus catálogos distribuído aos professores, a CEN recomendava critérios para a escolha correta do livro didático. Citando, por exemplo, as recomendações do Prof. Jonathas Serrano ${ }^{97}$, na sua obra Como se ensina História (1935), a editora fazia um alerta mostrando que o livro escolar deve ser um facilitador do processo ensino-aprendizagem:

\section{COMO SE ESCOLHE UM LIVRO DIDACTICO}

No início do anno letivo, surge para os professores e directores de estabelecimentos de ensino um problema de grande importância: escolher, dentre a profusão de livros didacticos no mercado, os que possam ser considerados como "os melhores"

No intuito de facilitar esta árdua tarefa aos nossos educadores, tentamos dar, nestas páginas, uma serie de indicações que servirão de guia na escolha de livros que realmente possam ser proveitosos no ensino.

Segundo a opinião unânime de autoridades em literatura escolar, um livro didático, para ser considerado bom, deve preencher os seguintes requisitos essenciais, quanto à substância, à forma e ao método:

$1^{\circ}$.) exatidão da matéria tratada;

$2^{\circ}$.) clareza e segurança na exposição;

\footnotetext{
${ }^{97}$ Jonathas Serrano foi membro do IHGB e professor de História do Colégio Pedro II e do Instituto de Educação do Rio de Janeiro. Publicou vários livros didáticos (Epitome de História Universal e Epitome de História do Brasil) e foi um dos primeiros autores a se preocupar com a metodologia do ensino da História (Como se ensina História, Methodologia da História, Cinema e Educação, A Escola Nova, entre outros).
} 
$3^{\circ}$.) didaticidade e método dos assuntos;

$4^{\circ}$.) perfeição tipográfica;

$5^{\circ}$.) boa apresentação material $[\ldots]$

"O Compêndio foi feito para o aluno

$\mathrm{O}$ aluno deve gostar do livro adotado em aula. Deve entendê-lo perfeitamente. O compêndio é feito para facilitar o estudo, e não para torná-lo complicado e enfadonho. $\mathrm{O}$ melhor juiz do compêndio é o próprio estudante. Livro antipático e detestado é, por força, livro malfeito. JONATHAS SERRANO. Como se ensina História" (CEN, 1935, p. 19-20).

$\mathrm{Na}$ contracapa desse mesmo catálogo, constata-se uma preocupação da Editora em vender livros novos para os alunos. A CEN faz junto aos livreiros e professores uma campanha contra a compra de livros usados em sebos, pois, segundo ela, eles poderiam trazer prejuízos para a aprendizagem dos alunos:

\section{NÃO COMPRE LIVROS DE SEGUNDA MÃO.}

O hábito de comprar livros usados é de uma enganadora vantagem: traz em si tantos prejuízos que na verdade não se realiza a intenção inicial de fazer economia.

Reparem nisso: geralmente a differença de custo é muito pequena. O livreiro, que compra baratíssimo, por preços quase irrisórios, revende sempre com ganho abusivo, revende quase pelo custo normal das livrarias comuns. Attrahido por essa pequena differença, vai o estudante comprar-lhe o livro. Compra-o pensando ter feito optimo negócio. Mas se tivesse pensado melhor, se tivesse reflectido um pouco antes de bater à porta do "sebo", ter-se-ia lembrado das innúmeras desvantagens do seu gesto. Algumas dessas desvantagens são as seguintes:

a) Compra um livro materialmente precário e, portanto, de duração ephemera.

b) Arrisca-se a adquirir um livro a que faltem páginas e páginas de matéria, inútil, portanto.

c) Traz para casa, geralmente, uma edição velha, cheia de erros, vehiculo de idéas e noções antigas, já em desuso.

d) Corre o perigo de contaminação: os livros velhos têm, para substituir-lhes a utilidade e belleza, ricas colleções de micróbios, que poderão invadir o organismo do estudante desprevenido, causando-lhe moléstias graves e benignas, desde a tuberculose até as simples erupções cutâneas.

e) Traz para casa, enfim, um objeto pouco útil, feio e porco.

Compre apenas livros novos. As edições modernas, principalmente as pedagogicas e didacticas, da COMPANHIA EDITORA NACIONAL, são baratíssimas. Não se prejudique acreditando fazer bons negócios com livros usados (CEN, Catálogo Escolar, 1935).

Até o final dos anos 1960, a CEN era uma das maiores do Brasil, sendo responsável por $55 \%$ da produção didática destinada ao ensino primário e secundário (HALLEWELL, 1985). Após a morte de seu fundador, Octalles Ferreira, em 1973, a editora vivenciou um período de crise e foi colocada à venda pelos herdeiros. A José Olympio Editora tentou adquirir a CEN com recursos do Banco Nacional do Desenvolvimento Econômico (BNDE), 
mas, no fim das negociações, as duas editoras foram incorporadas ao Governo Federal. Sem conhecer as leis do mercado editorial, a administração estatal foi desastrosa para a CEN.

Em 1980, foi adquirida pelo Instituto Brasileiro de Edições Pedagógicas (IBEP). A partir de então, o IBEP tentou redimensionar o acervo da Companhia. Prova disso é a retomada da edição da obra de Viriato Corrêa, que vem ocorrendo desde 2001 em novo formato e design contemporâneo (IBEP/CEN, 2006).

\subsection{Viriato Corrêa e a escrita da história para crianças}

Antes de se tornar, ao lado de Monteiro Lobato, um dos principais autores de livros infanto-juvenis, Viriato já era autor de crônicas históricas publicadas pela CEN.

Podemos até afirmar que a CEN teve papel importante na divulgação da história para o grande público leitor. Além de Viriato Corrêa, que se dedicou à crônica histórica e à literatura infantil com temática pautada no passado nacional, a editora publicou romances históricos do escritor paulista Paulo Setúbal, que fez muito sucesso à época.

O primeiro livro de crônicas históricas de Viriato Corrêa foi publicado pela editora de Monteiro Lobato - Histórias da nossa História (1921). O livro traz, em forma de crônicas, capítulos sobre a vida de Colombo, Chica da Silva, Manuel da Nóbrega, Joaquim Silvério dos Reis, ao lado de aspectos relacionados à vida cotidiana no Rio de Janeiro. Uma das crônicas mais interessantes é "Ponha-se na Rua", que retrata a reação da população local à criação das "aposentadorias" do governo: as solicitações das residências para acomodar a nobreza lusa recém-chegada ao Brasil. O meirinho era encarregado de colocar nas portas das casas as letras P.R (Príncipe Regente), exigindo a desocupação da residência. O povo traduziu, de forma irônica, a expressão “P.R.” por “Ponha-se na Rua!” (CORRÊA, 1923).

O prefácio dessa sua primeira obra de cunho histórico foi feito pelo historiador e seu principal interlocutor - Rocha Pombo. Nele, Pombo faz algumas considerações importantes acerca da estreita relação entre o estudo da história e a formação do civismo: 
Em toda essa aparatosa propaganda cívica que se faz hoje no Brasil, só uma forma de consolidar na alma do povo o legítimo sentimento patriótico até agora não foi utilizada. Prega-se o sagrado amor em todos os tons e por todos os modos, principalmente ensinando a vestir um uniforme, trazer uma carabina, e a marchar cantando e dando vivas. Parece inculcar-se que é só assim que se há de amar a pátria $[\ldots]$.

[...] pátria não é só a terra de nossos pais, mas a existência social de cada um de nós ligada, não apenas ao solo, mas ao passado, à grandeza moral dos nossos, da nossa gente, da nossa raça (CORRÊA, 1923, p. 9).

Rocha Pombo constata que falta à mocidade o sentimento de patriotismo indispensável à formação da nacionalidade e que "só a história é que lhe poderia dar uma noção exata do grande dever, criando-lhe o legítimo impulso de que a alma anda vazia." (CORRÊA, 1923, p. 10). E, como Viriato defende uma maior divulgação do conhecimento histórico para além dos bancos escolares:

E então - por que é que não havíamos de abrir em cada quartel, em cada associação de classe, em cada fábrica, em cada oficina, uma aula de nossa história, já que não temos instituído no seio de nossas famílias em culto dos antepassados? Decerto que não se inculca história narrada de pedagogos, seca, monótona, confusa; mas história sentida, história viva, feita dos grandes lances, das épocas fundamentais: que só assim é que há de ser história edificante, capaz de enaltecer o nosso espírito nacional (CORRÊA, 1923, p. 12, grifo nosso). 


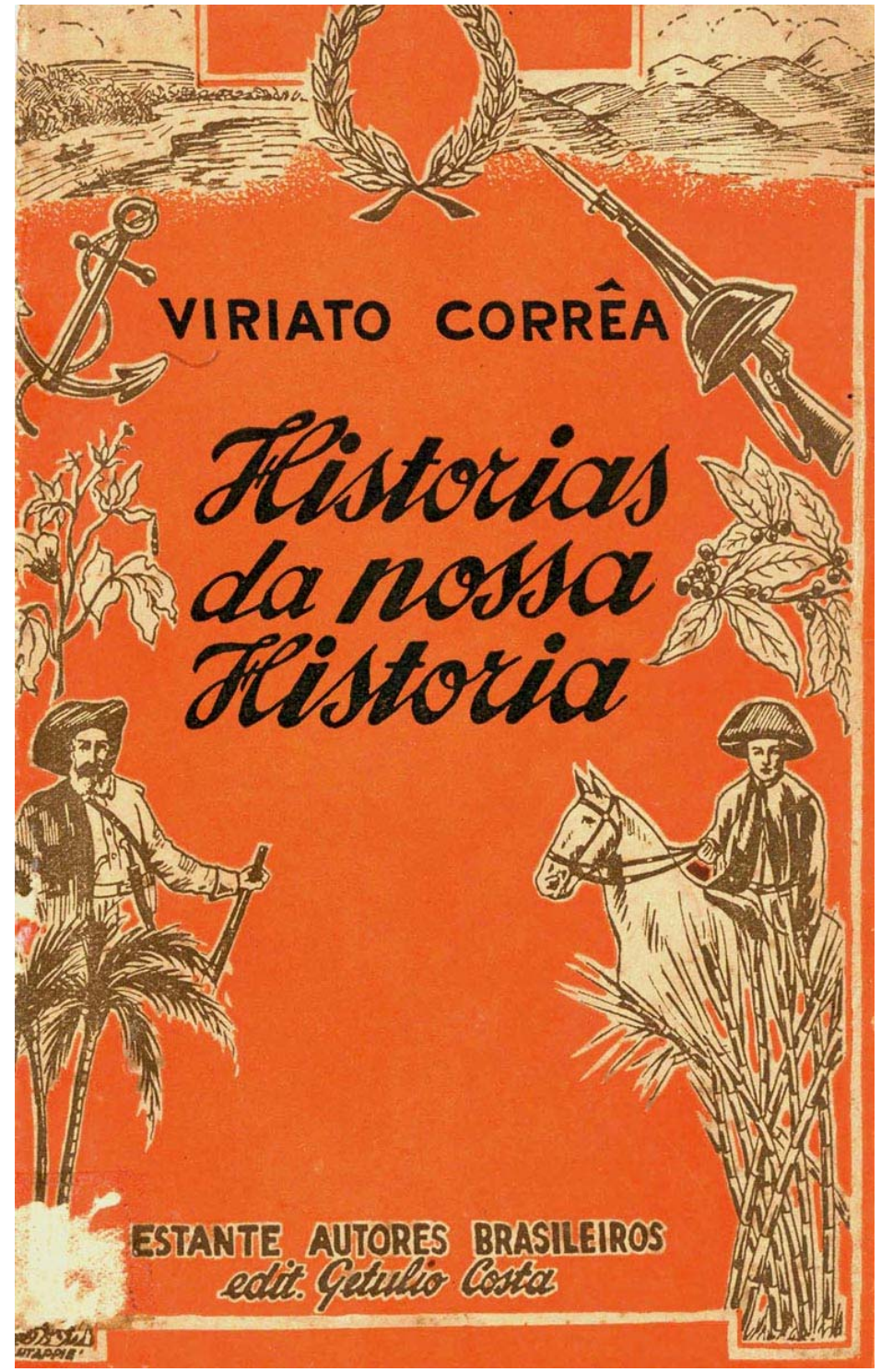

Figura 29 - Histórias da nossa História - capa.

Fonte: CORREA, 1923.

Rocha Pombo faz elogios ao trabalho de Viriato Corrêa e tece considerações sobre a sua forma de escrever história, utilizando-se da anedota, do pitoresco e da legenda: "Viriato Corrêa é um grande sabedor das nossas coisas históricas, e um sincero entusiasta das nossas tradições e das nossas lendas. É, além disso, dos mais finos e brilhantes espíritos de sua geração, sobretudo entre os que lidam na imprensa e no teatro.” (CORRÊA, 1923, p. 13-4). Considera também que esse método adotado por Viriato de "ensinar a história pela anedota e de suscitar através da legenda o interesse dos grandes fatos e dos grandes vultos" (CORREAA, 1923, p. 15) é eficaz. E prossegue: 
Dir-me-ão que a história não é isso, e que há mesmo grande risco em confundir a história com a legenda.[...] Não receio mesmo dizer que a legenda completa a história. É uma espécie de arte que diz melhor a verdade do que diria só por si a história. Basta observar que na maioria dos casos uma simples anedota pode esculpir melhor a fisionomia moral de um tipo do que os fatos de uma extensa biografia (CORRÊA, 1923, p. 15, grifo nosso).

O consagrado historiador do IHGB e autor de vários livros didáticos de História chama-o de apóstolo da nossa cultura cívica, pois considera que o seu trabalho de divulgação de nossa história pátria é muito mais edificante do que "muita festa espetaculosa de civismo de convenção [...] é ele o primeiro que se lembra de publicar um livro deste gênero, cujos assuntos foram todos hauridos em nossa história" (CORRÊA, 1923, p. 14).

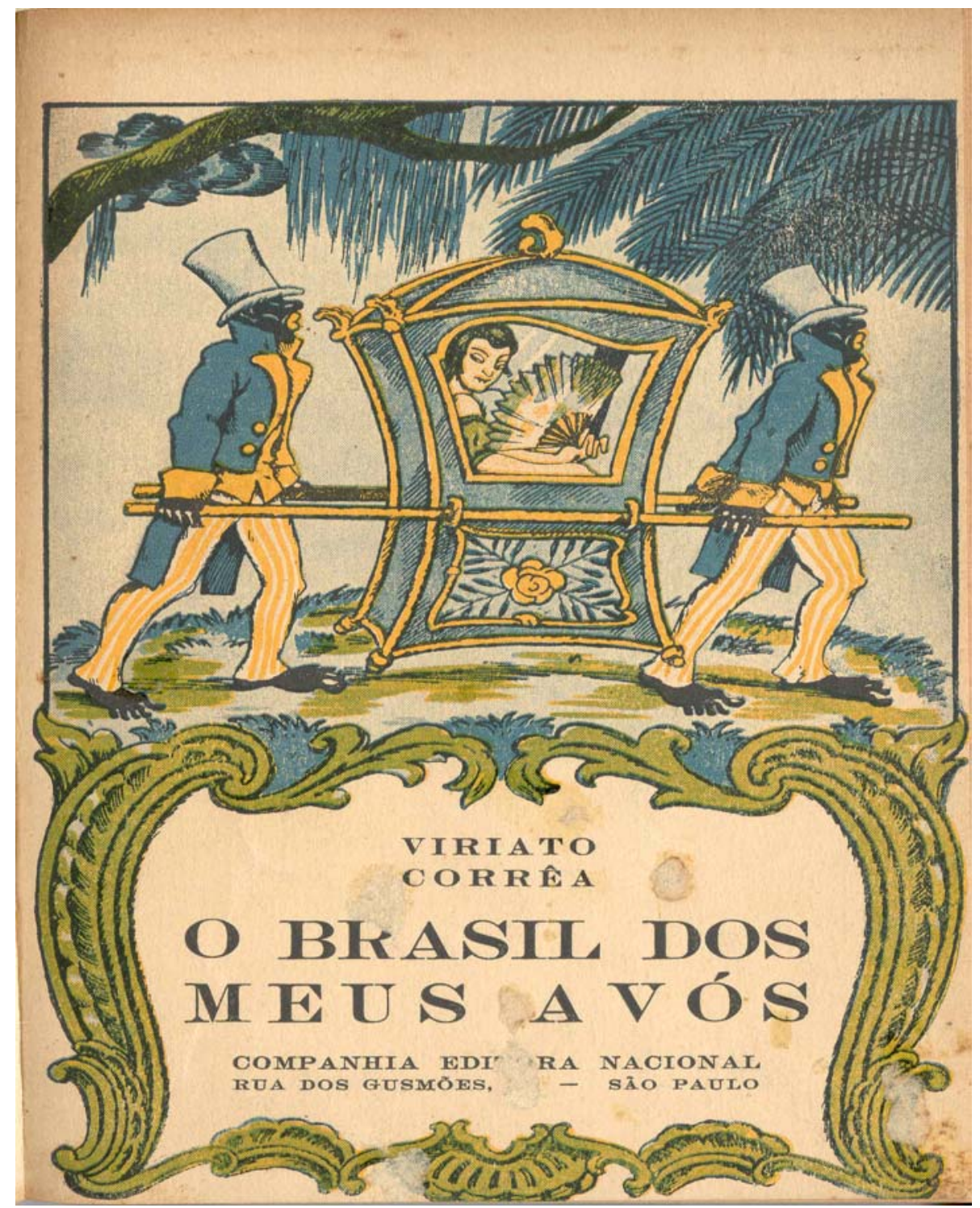

Figura 30 O Brasil dos meus avós - capa.

Fonte: CORRÊA, 1927. 
A esse primeiro livro de crônicas históricas seguiram-se outros publicados pela CEN, entre os quais podemos citar: O Brasil dos meus avós, Baú Velho, Gaveta de Sapateiro, Alcovas da História etc. Na Editora Civilização Brasileira, braço editorial da CEN no Rio de Janeiro, Viriato teve os seguintes livros publicados: Terra de Santa Cruz, O país do pau de tinta e História da liberdade no Brasil.

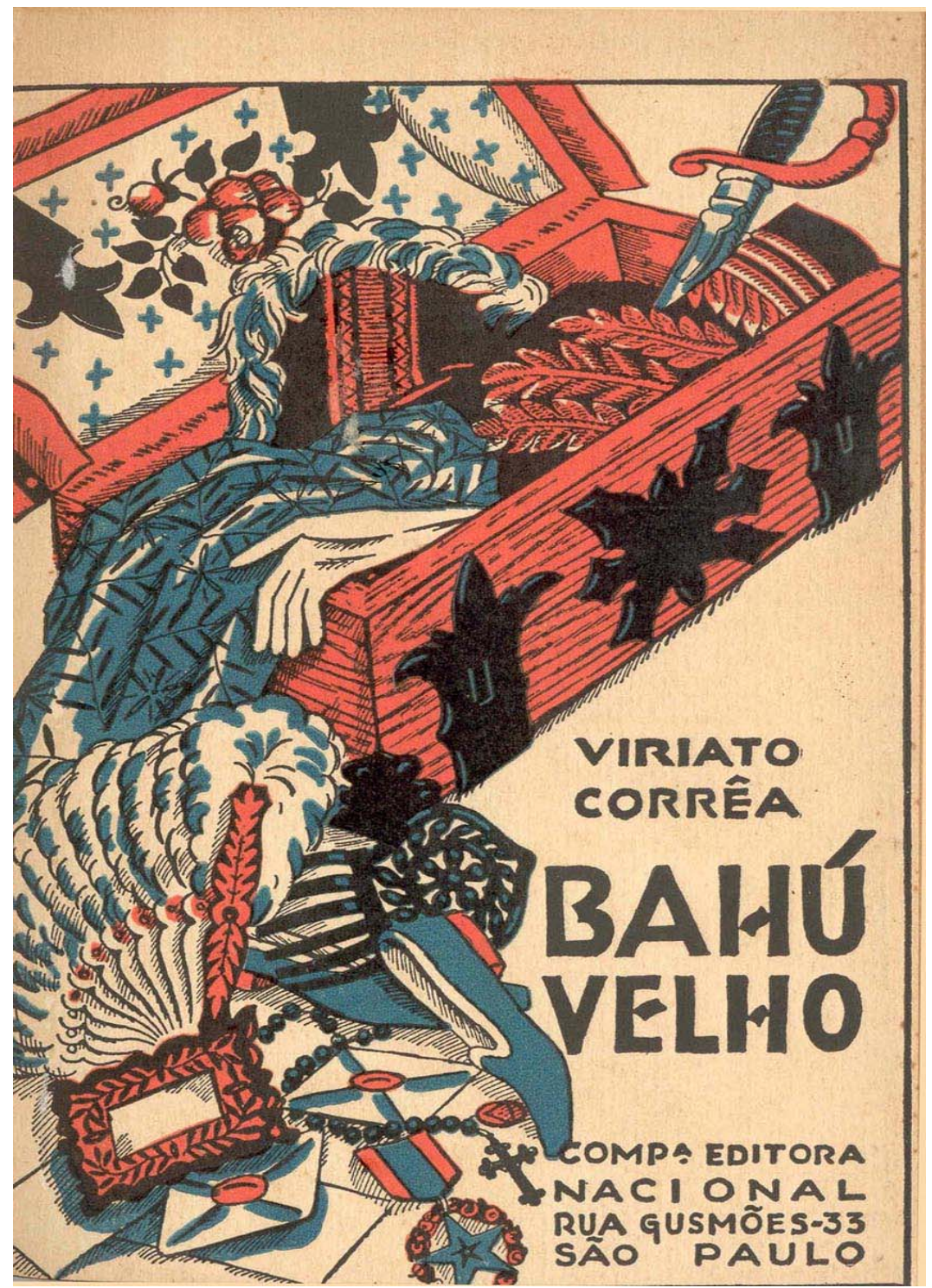

Figura 31 - Bahú Velho - capa.

Fonte: CORRÊA, 1927. 


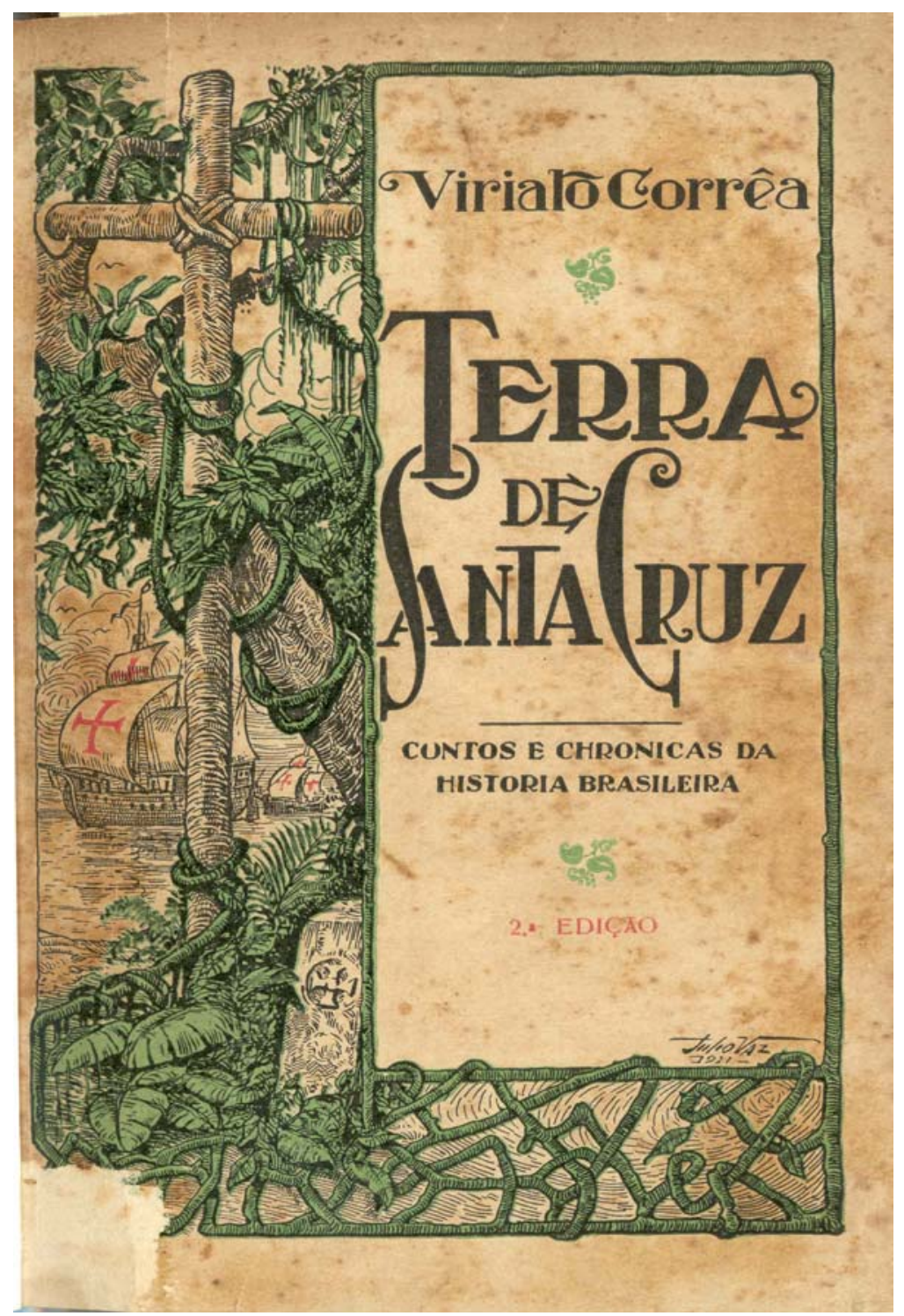

Figura 32 - Terra de Santa Cruz - capa.

Fonte: CORREAA, 1927.

\subsubsection{Contos da História do Brasil}

O primeiro livro infanto-juvenil de Viriato Corrêa com finalidades explicitamente pedagógicas foi Contos da História do Brasil (para uso das escolas), de 1921. Este livro surgiu de um apelo de professores do Rio de Janeiro, que pretendiam adotar nas escolas seus primeiros livros de crônicas históricas - Histórias da nossa História e Terra de Santa Cruz, ambos de 1921. É o próprio Viriato que assim explicita, na introdução: 
Apoz a publicação das Historias da nossa historia e da Terra de Santa Cruz, várias figuras do magistério publico carioca, por gentileza ou por amisade, manifestaram desejos de adoptar os dois livros nas escolas, para a leitura cívica das creanças (CORRÊA, 1921, p. 11, grifo nosso).

Viriato, no entanto, considerava que seus livros de crônicas não se adequavam à infância, razão pela qual se dispôs a fazer um novo livro para essa faixa etária:

Era-lhes, porém, impossível. Qualquer dos dois livros tinham páginas de algum modo ousadas, de algum modo rudes para os espíritos infantis.

A todos prometi sanar o mal, escolhendo num e noutro livro os artigos e os contos que melhor se almodassem à pureza da alma da infância. É esta a razão de ser dos Contos da Historia do Brasil (CORRÊA, 1921, p. 11, grifo nosso).

Nesse seu primeiro livro escolar, Viriato adotou a periodização seguida por Sylvio Romero (ROMERO, 1890), que divide a história nacional em séculos, a saber: século do descobrimento e da conquista; século de expansão e de resistência; século do desenvolvimento autonômico; século da Independência e século da República.

Como é um livro infantil, há necessidade de uma classificação. Boa ou má, a classificação feita na história brasileira por Sylvio Romero é a que me parece mais simples para as creanças [...] o fim deste livro é apenas dar às creanças, pela feição anedótica, o tom geral da história brasileira [...]" (CORRÊA, 1921, p. 11, grifo nosso).

Embora tenha tido apenas uma edição, o livro parece ter feito sucesso e extrapolado os limites territoriais onde foi editado, a cidade do Rio de Janeiro. Vejamos o depoimento do escritor maranhense Josué Montello:

De um momento para outro sinto que se abre na minha consciência o clarão da memória, e dou por mim a receber, como prêmio de classe, no terceiro ano da Escola Modelo, os Contos da História do Brasil, de Viriato Corrêa. Foi esse o ponto de partida de uma amizade que cresceu comigo, para acompanhar-me por toda a vida (MONTELLO, 1998, p. 909, grifo nosso). 
O livro, embora direcionado às crianças, não trazia ilustrações. Apenas a capa continha imagens alusivas a dois fatos históricos - a chegada dos portugueses ao Brasil em suas caravelas e a proclamação da Independência por D. Pedro I -, em desenho que lembra o célebre quadro de Pedro Américo, "Independência ou Morte!”, e que se tornou uma imagem canônica no ensino de História (SALIBA, 1999), reproduzida em vários livros escolares. Ambas estão adornadas por ramos de café, denotando a principal riqueza do País. Ao fundo, vê-se uma paisagem litorânea com gaivotas no ar e, ao pé da capa, a reprodução do marco do descobrimento do Brasil, existente em Porto Seguro, Bahia.

Esse primeiro livro de História para uso das escolas foi bem recebido pela crítica ${ }^{98}$ :

Não é a primeira vez que nosso conteur aplica o fecundo engenho a essa tarefa de vulgarizar, com o encanto das coisas imaginativas, a verdade da nossa história. Assim escreveu já dois livros interessantes, as Histórias da nossa História e a Terra de Santa Cruz, um e outro, acolhidos com a mais bela estima.

A estes faltava, entretanto, o caráter didático, mais apropriado à literatura escolar e infantil. Agora os novos Contos respondem cabalmente àquele propósito. São contos para gente pequena, o que não quer dizer que não o sejam também para a gente grande[...].

Os Contos da História Pátria, lindamente impressos, serão certamente adotados nas nossas escolas, onde o que falta mais é o livro, o livro como este é, que ensina, deleita, instrui, edifica e aprimora o bom gosto (RIBEIRO apud LEÃO, 1961, p. 233-4, grifo nosso).

\footnotetext{
${ }^{98}$ Em seu diário, o escritor e acadêmico maranhense Humberto de Campos acusou Viriato Corrêa de ter se apropriado de textos de Mario Behring, então Diretor da Biblioteca Nacional, ao escrever esse livro de História para crianças: " - Coitado do Viriato! - exclama, com os seus modos recolhidos o diretor da Biblioteca. Ele quer conhecer a História do Brasil mas não quer ler, estudar, pesquisar. Quer apanhar o assunto no ar, para desenvolvê-lo a seu modo. Uma vez ele me entrou por aqui, aflitíssimo. Queria que eu lhe fornecesse, de memória, alguns episódios históricos, que lhe servissem para contos. Lembrei-me que, na coleção da Kosmos, havia numerosas crônicas escritas por mim, sobre acontecimentos dramáticos da História do Brasil. Pois o nosso Viriato, com a maior sem-cerimônia, caiu na minha seara e não deixou nada! Não se deu, sequer, ao trabalho de ir às fontes citadas por mim, e isto sem a menor referência ao meu esforço. E Mário Behring ri, modesto, como quem, possuindo um celeiro cheio, não se incomoda que um pinto the devore um punhado de milho...." (CAMPOS, s/d, p. 162-3).
} 


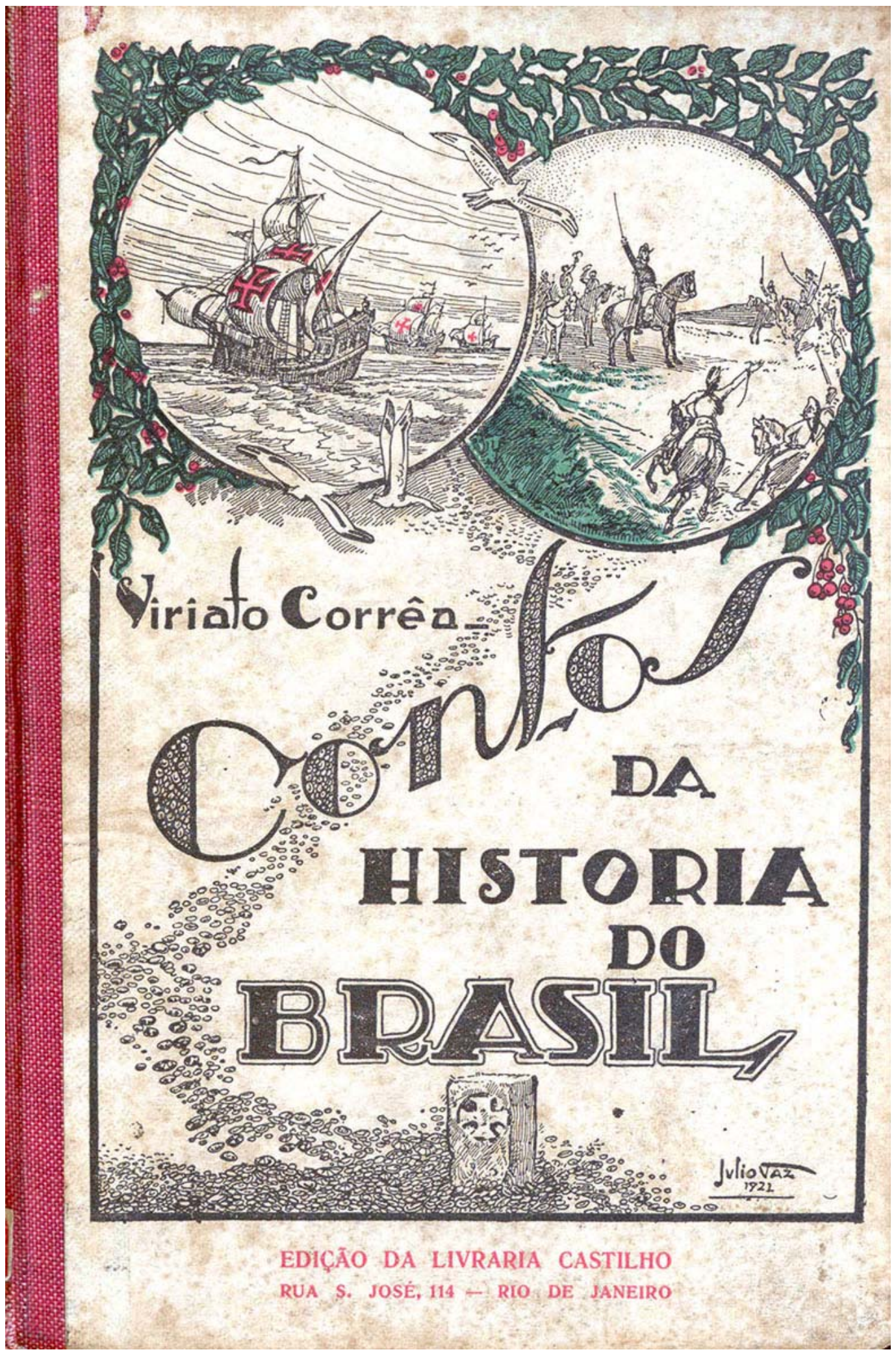

Figura 33 - Contos da História do Brasil - capa.

Fonte: CORRÊA, 1921. 


\subsubsection{Outros livros infantis com temática histórica}

Como vimos anteriormente, seu segundo livro com temática histórica foi publicado pela CEN, no contexto da coleção Literatura Infantil (Série I - $\mathrm{n}^{\mathrm{o}} 18$ ), da Biblioteca Pedagógica Brasileira. Trata-se do História do Brasil para crianças (1934).

Em 1935, Viriato publicou, também pela CEN, o livro Meu Torrão (contos da história pátria), que integrava, também, a série Literatura Infantil da BPB ( $\mathrm{n}^{\circ}$ 24). Viriato dedicou esse livro a Monteiro Lobato, cuja importância para o desenvolvimento da literatura infantil ele reconhece: "A Monteiro Lobato, mestre de todos que escrevemos para crianças" (CORRÊA, 1939, p.5).

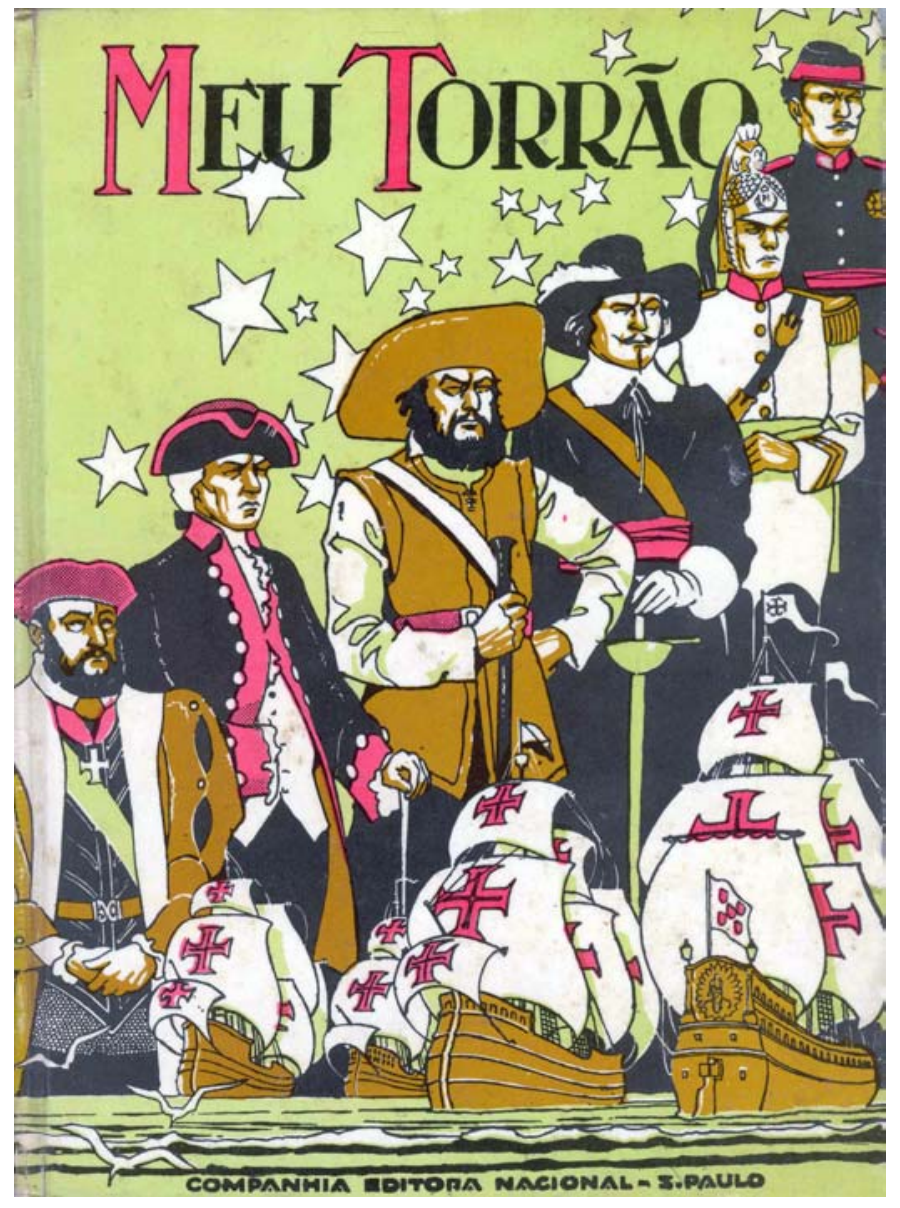

Figura 34 - Meu Torrão (contos da história pátria) - capa.

Fonte: CORRÊA, 1939. 
O livro Meu Torrão traz os seguintes fatos e personagens históricos: Anchieta, Borba Gato, Fernão Dias, Chico Dias, Chico-Rei, a guerra de Independência na Bahia, os "heróis" pernambucanos que lutaram na Revolução de 1817 e na Confederação do Equador. Mais uma vez há o destaque para a figura de Tiradentes, em um texto para dramatização dos alunos, o que revela o apreço do autor à produção teatral com temas históricos.

Em 1945, Viriato publicou outro livro infantil com abordagem histórica. A Bandeira das Esmeraldas, como o próprio título expressa, narra a epopéia dos bandeirantes paulistas, com destaque para a figura de Fernão Dias Pais - o "caçador de esmeraldas". O livro traz também duas outras partes, a saber: "História de Tiradentes" e "Nóbrega e Anchieta". Vale ressaltar que esse livro recebeu nova edição (2004) por parte da CEN-IBEP, no contexto do projeto de reedição da obra infantil de Viriato Corrêa.

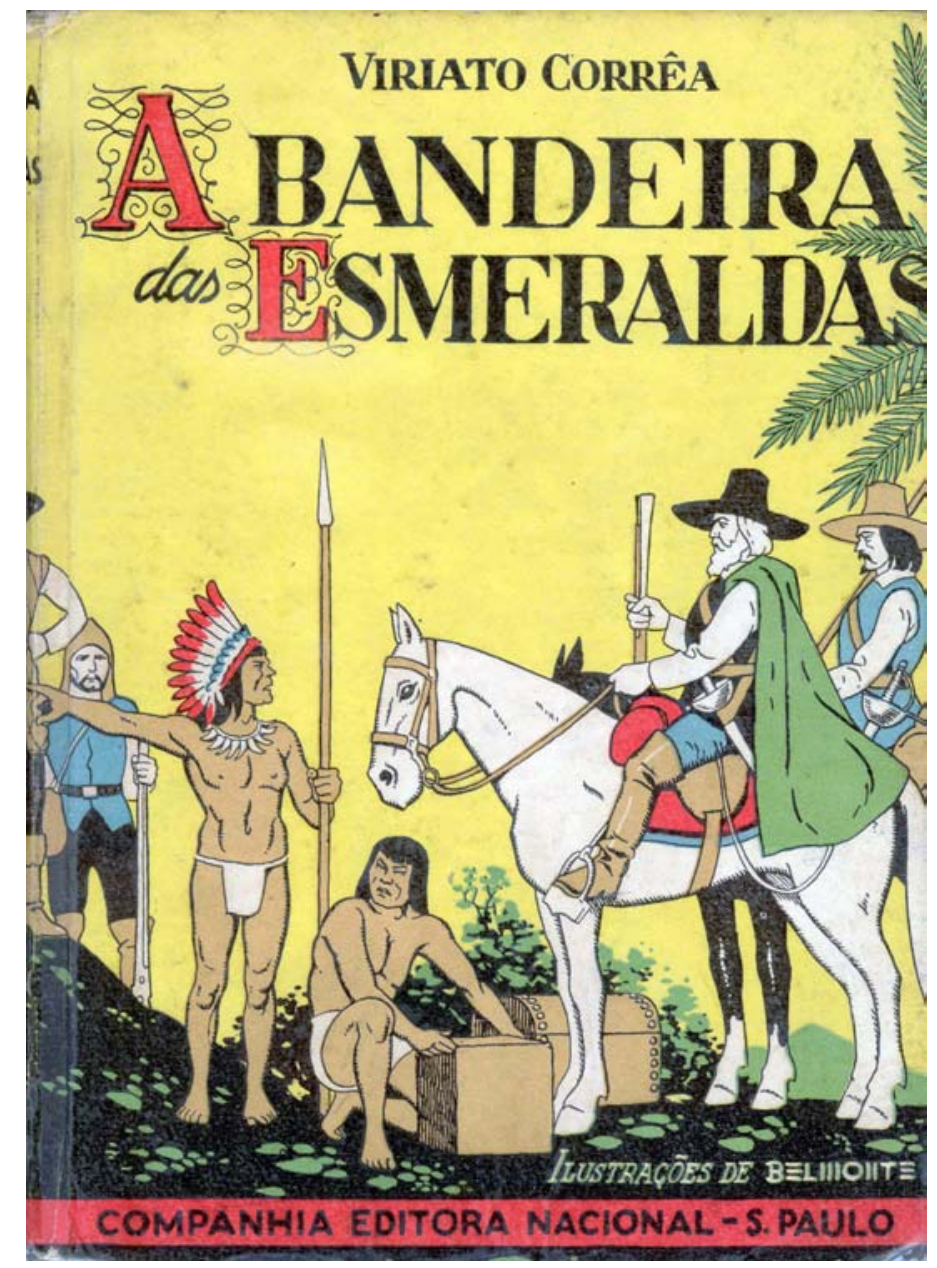

Figura 35 - A Bandeira das Esmeraldas - capa.

Fonte: CORREAA, 1945. 
Viriato havia publicado dois pequenos livros intitulados $A$ Descoberta do Brasil (1930) e História de Caramuru (1939), posteriormente reunidos no livro As belas histórias da História do Brasil, de 1948. O livro traz também dois outros capítulos que abordam os ciclos do pau-brasil e da cana-de-açúcar, em "A árvore que nos deu nome" e "Sua excelência - o açúcar", respectivamente.

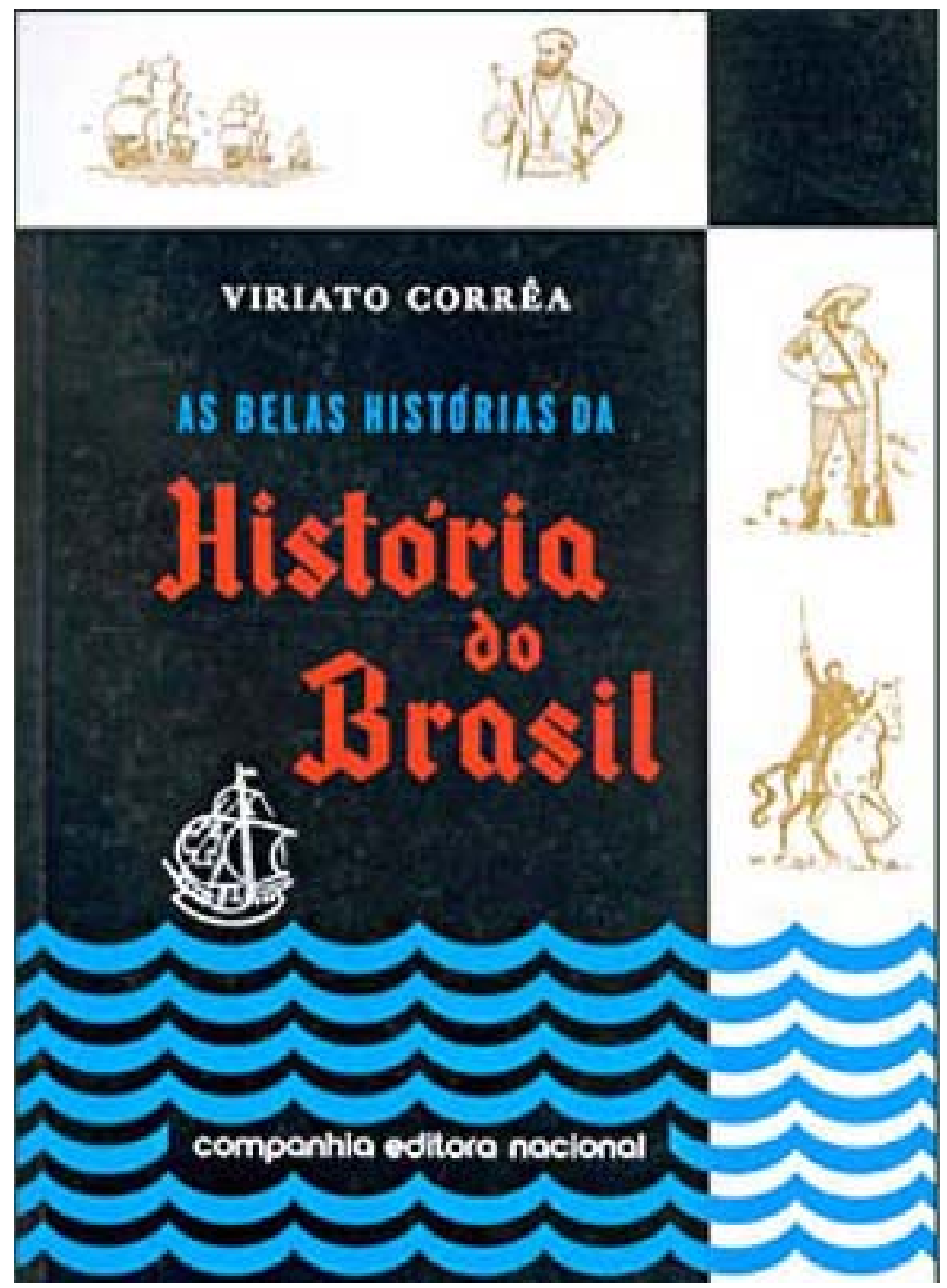

Figura 36 - As belas histórias da História do Brasil - capa. Fonte: CORRÊA, 1948.

Um dos livros mais interessantes de Viriato publicado pela CEN foi, sem sombra de dúvida, Curiosidades da História Brasileira (para crianças). Nesse livro, o autor retomou os personagens de História do Brasil para crianças. Em seis domingos, durante as férias, vovô conta pequenas histórias do Brasil, ligadas à vida cotidiana e aspectos pitorescos de nosso passado: "O namorado número um de nossa terra", "O bispo que os índios comeram", "A escola mais antiga e o mais antigo mestre-escola", "O vovô dos historiadores", "A maior 
biblioteca de outrora", "Sorvete - novidade deliciosa", "Os velhos cemitérios" e "A mais famosa das ruas" são alguns dos capítulos desse livro, ainda hoje em circulação no mercado editorial brasileiro.

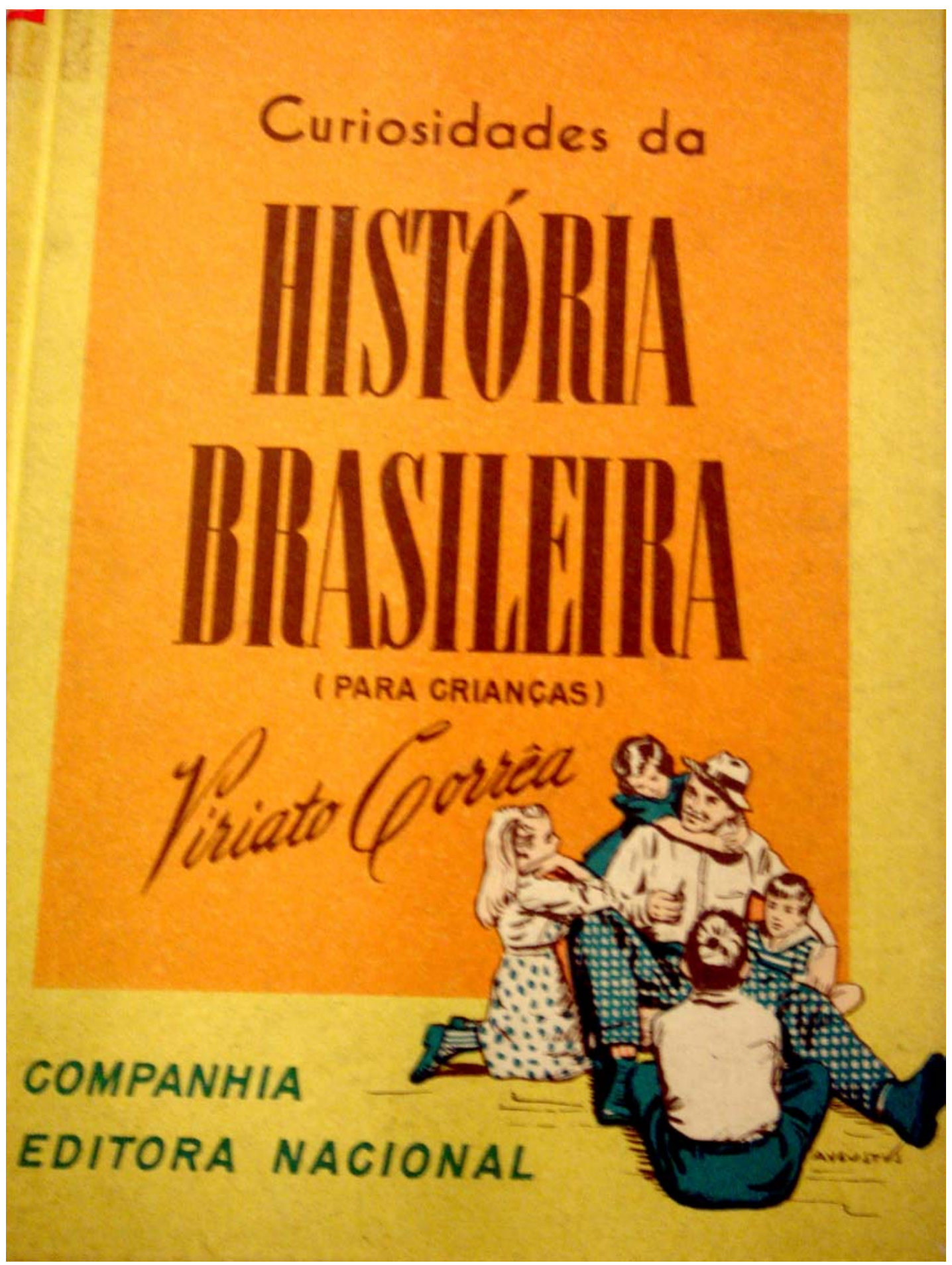

Figura 37 - Curiosidades da História Brasileira (para crianças) - capa. Fonte: CORRÊA, 1952. 
Por fim, em 1962, Viriato Corrêa publicou pela Editora Civilização Brasileira o livro História da Liberdade do Brasil. Nele, defende a idéia de que o povo brasileiro, desde colônia até o período republicano, possui uma vocação libertária e enumera diferentes revoltas, rebeliões e guerras, tais como a formação do quilombo de Palmares, a Inconfidência Mineira, a Revolta dos Alfaiates, a Confederação do Equador e o movimento de luta pela abolição dos escravos, entre outros.

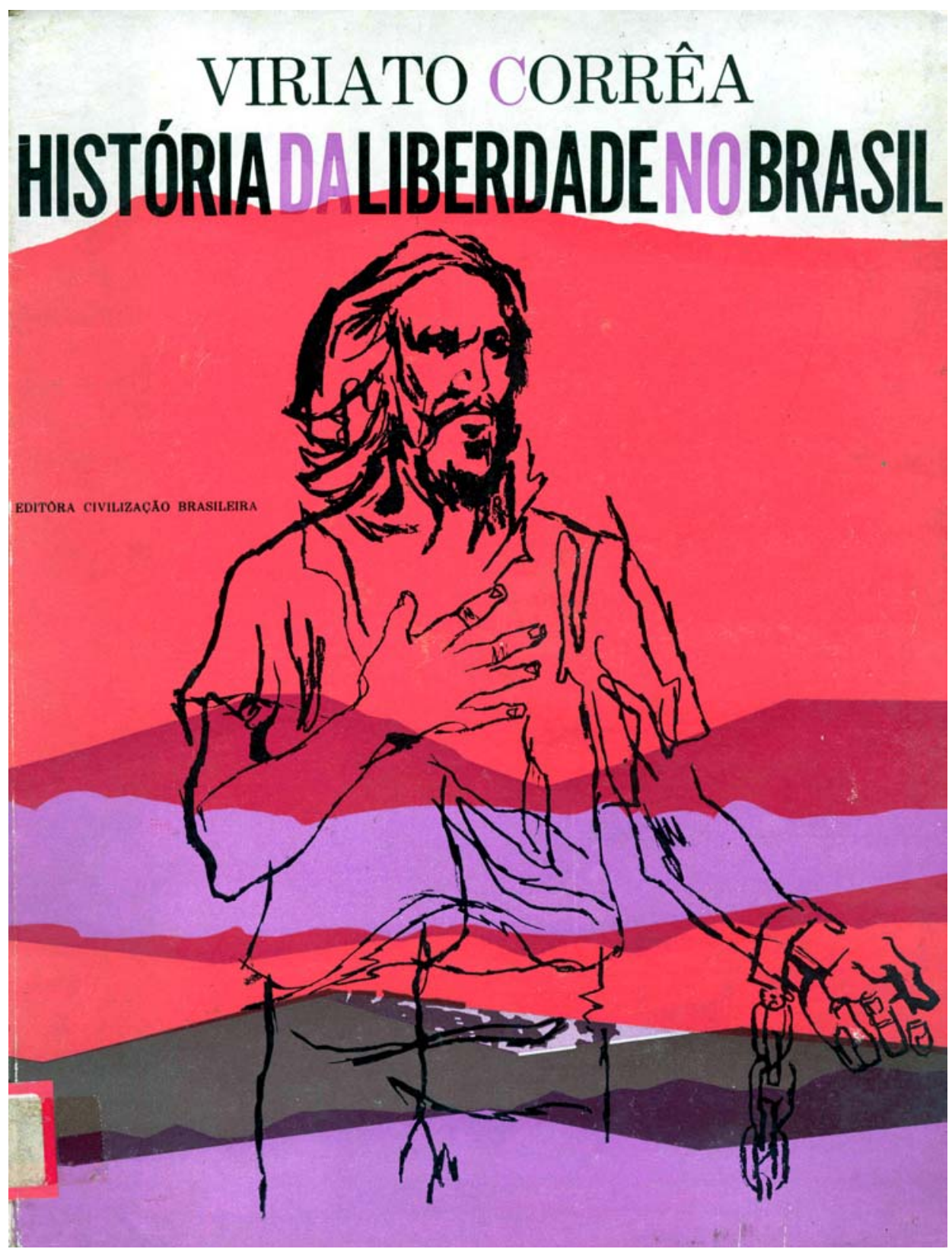

Figura 38 - História da Liberdade no Brasil - capa. Fonte: CORRÊA, 1962. 
Esse livro teve bastante repercussão à época, em dois momentos distintos. O primeiro deles quando de seu lançamento na ABL, em 1962, com a presença de alunos de escolas públicas e amplamente noticiado pela imprensa local:

Viriato Corrêa, maior escritor vivo de literatura infantil em nossa terra, lançará, oficialmente, no próximo dia 26, na ABL, seu livro História da Liberdade no Brasil. Trata-se de empreendimento editorial dos mais ousados que renova substancialmente todos os recursos da arte gráfica brasileira. A capa e as ilustrações de Eugênio Hirsch representam criações de excepcional efeito plástico, muito das quais em folha dupla. Desse modo, associou-se na mesma obra, um grande autor de literatura infantil e um artista de imensa originalidade que, como capista, revolucionou a apresentação de livros. A tiragem experimental é de $20 \mathrm{mil}$ exemplares e espera o editor Ênio Silveira uma próxima edição da ordem de $100 \mathrm{mil}$ volumes.

Viriato Corrêa falou também que o livro em questão é materialmente o mais belo livro para crianças feito no Brasil (VIANA, 1962, s.p.).

Não é de se registrar em termos formais e discretos o aparecimento de uma obra como esta História da Liberdade no Brasil, do acadêmico Viriato Corrêa, que a Civilização Brasileira acaba de publicar. E isto pelo mérito e expressão da obra em si, pelo primor de arte gráfica que ela representa e, em particular, pelo que significa no conjunto da bagagem literária do autor. Nas escolas deste país deviam-se realizar festas para assinalar o acontecimento, que diz de perto da formação cultural das novas gerações. A idéia do livro foi um achado: Viriato Corrêa se propôs a contar histórias para crianças - histórias vivas e atraentes acerca da luta em que, desde sua formação, o povo brasileiro sempre se empenhou para ter e manter a liberdade [...] (CAVALCANTI, 1962, s.p., grifo nosso).

"A História do Brasil, desde os primeiros dias de colonização, até os dias presentes é o constante esbravejar de um povo para ser senhor de si mesmo". Esta é uma das frases iniciais do acadêmico Viriato Corrêa, no seu belo livro História da Liberdade no Brasil, que a Civilização Brasileira acaba de editar. Destinado em princípio a um público de calças curtas, a verdade é que o volume de Viriato Corrêa pode (e deve) ser lido por leitores de todas as idades. Não podia ter sido mais feliz a sua idéia, de escrever uma história dos grandes movimentos que, através dos tempos, procuraram sacudir o jugo que nos prendia a Portugal, permitindo ao Brasil encontrar o próprio caminho como nação soberana e democrática. "A liberdade é vocação, é índole, é instinto nosso" - observa o autor (Livros da Semana, Correio da Manhã, 1962).

Viriato Corrêa dedicou sua vida de escritor às crianças. Criou-lhes uma literatura e talvez por isso mesmo guarde, na sua velhice, uma enorme alegria. Agora mesmo, editado pela Civilização Brasileira, vem ele com seu último livro que é também uma beleza de apresentação gráfica: História da Liberdade no Brasil. O livro foi lançado na ABL sendo Viriato saudado pelo seu conterrâneo, o romancista acadêmico Josué Montello (ENEIDA, 1962, s.p.). 


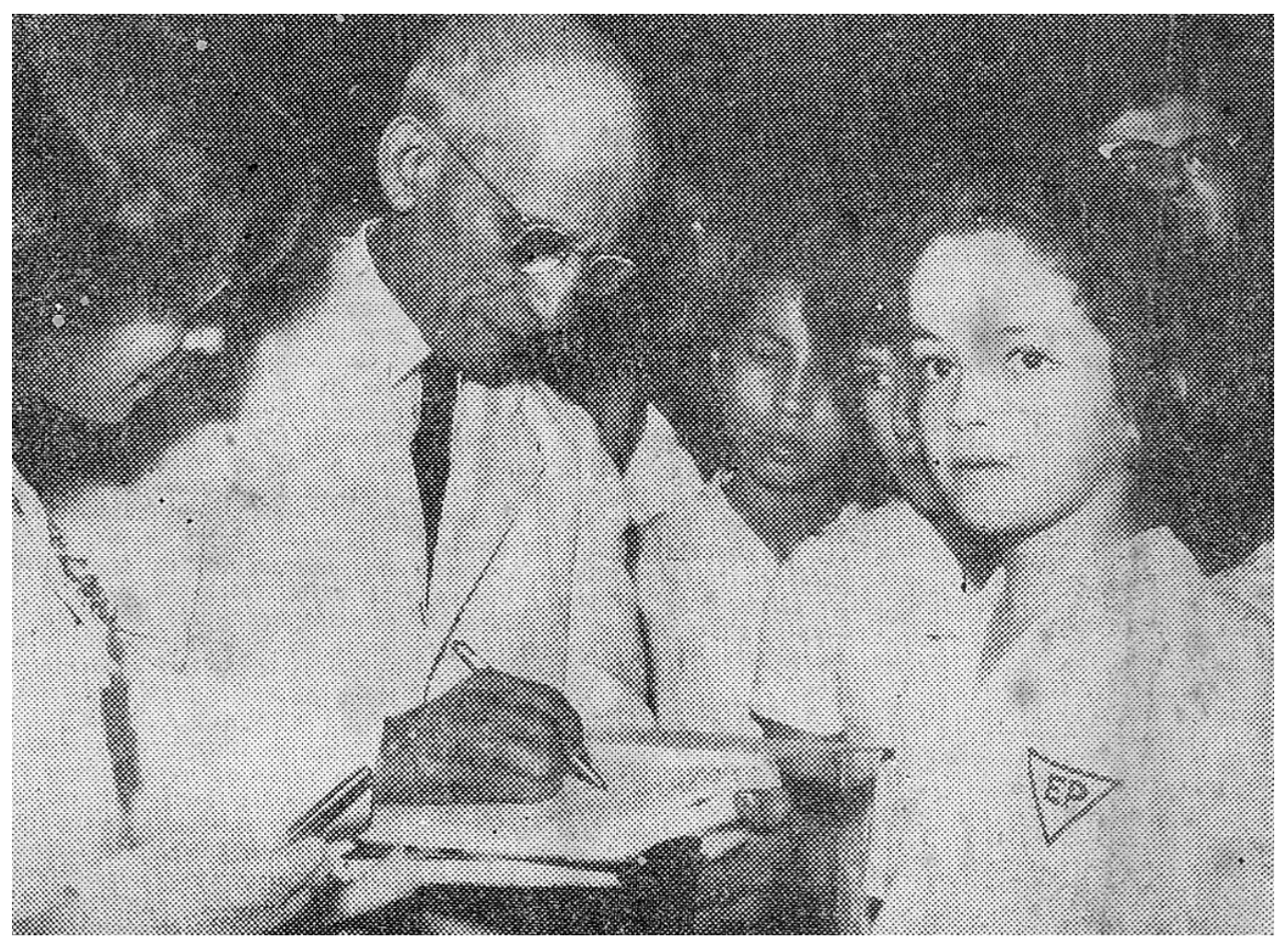

Figura 39 - Viriato em sessão de autógrafos do livro História da Liberdade no Brasil, rodeado de crianças $(\mathrm{s} / \mathrm{d})$.

Fonte: Acervo Centro de Memória da ABL.

Posteriormente o livro serviu de inspiração para que os carnavalescos da Escola de Samba Acadêmicos do Salgueiro desenvolvessem o samba-enredo para o Carnaval carioca de 1967. De autoria dos sambistas Áureo Campagnac e Aurinho da Ilha, sendo intérprete o cantor Jorge Goulart, o samba-enredo retrata os principais movimentos narrados por Viriato e tem o mesmo título do livro:

História da Liberdade no Brasil

Quem por acaso folhear a História do Brasil

Verá um povo cheio de esperança

Desde criança,

Lutando para ser livre varonil.

O nobre Amadeu Ribeiro,

O homem que não quis ser rei,

O Manoel, o Bequimão,

Que no Maranhão

Fez aquilo tudo que ele fez.

Nos Palmares,

Zumbi, o grande herói,

Chefia o povo a lutar

Só para um dia alcançar

Liberdade.

Quem não se lembra 
Do combate aos Emboabas

E da chacina dos Mascates,

Do amor que identifica

O herói de Vila Rica.

$\mathrm{Na}$ Bahia são os alfaiates,

Escrevem com destemor,

Com sangue, suor e dor

A mensagem que encerra o destino

De um bom menino.

Tiradentes, Tiradentes,

O herói inconfidente, inconfidente,

Domingos José Martins

Abraçam o mesmo ideal.

E veio o "Fico" triunfal

Contrariando toda a força em Portugal.

Era a liberdade que surgia,

Engatinhando a cada dia,

Até que o nosso Imperador

A Independência proclamou.

Ô-ô, oba, lá-rá-iá, lá-rá-iá-iá

Oba, lá-rá-iá, lá-rá-iá!

Frei Caneca, mas um bravo que partiu,

Em seguida veio o 7 de abril,

No dia 13 de maio

Negro deixou de ter senhor,

Graças à Princesa Isabel,

Que aboliu com a Lei Áurea

O cativeiro tão cruel.

Liberdade, Liberdade afinal,

Deodoro acenou,

Está chegando a hora,

E assim quando a aurora raiou,

Proclamando a República,

O povo aclamou.

Houve também repercussão na imprensa, pois era a primeira vez que um imortal tinha sua obra transformada em samba-enredo para o Carnaval carioca; estávamos em $1967^{99}$ :

O acadêmico Viriato Corrêa será homenageado com uma noite de samba autêntico, terça-feira, no Café Theatro Casa Grande, quando lançará seu livro História da Liberdade no Brasil e receberá o título de sócio honorário da Escola de Samba Acadêmicos do Salgueiro.

$\mathrm{Na}$ ocasião será também anunciado o enredo da escola para o carnaval de 67, dentro da linha de exaltação à liberdade, tendo sido convidados membros da ABL, escritores, jornalistas, artistas e sambistas das grandes agremiações. São carnavalescos da escola Fernando Pamplona e Arlindo Rodrigues.

O escritor Viriato Corrêa, que teve sua última obra - História da Liberdade no Brasil - escolhida pra tema do enredo da Escola de Samba do Salgueiro no próximo

\footnotetext{
${ }^{99}$ Com esse samba-enredo baseado no livro de Viriato Corrêa, a Acadêmicos do Salgueiro logrou o segundo lugar no desfile, ao lado da escola Império Serrano. O primeiro lugar coube à Mangueira, que apresentou o samba-enredo "O mundo encantado de Monteiro Lobato" (site oficial da G.R.E.S. Acadêmicos do Salgueiro. Fundado em 5 de março de 1953. Rio de Janeiro - RJ. Acesso em 19.11.2008).
} 
carnaval, recebeu ontem à noite em sua residência o cenógrafo Fernando Pamplona e outros representantes da Escola, a fim de tratarem da adaptação de alguns trechos do livro.

Ficou estabelecido durante o encontro que o escritor não terá qualquer participação na execução do enredo, limitando-se apenas a responder às consultas toda vez que houver uma dúvida e estudar o trabalho quando estiver concluído. O escritor informou que esta é a primeira vez que uma obra sua servirá de tema para o carnaval carioca (Viriato é enredo do Salgueiro. Jornal do Brasil, 1966, s.p.).

Segundo o também acadêmico Peregrino Júnior, Viriato encarnava o próprio ideal de

\section{liberdade:}

[...] celebridade no Brasil obedece a um plano: primeiro o nome nos jornais, depois a glória Acadêmica, depois o nome na Rua, a seguir o nome numa estátua e em último lugar, raros o têm, o nome numa ópera. Viriato desfilou na Avenida Presidente Vargas, como um herói da liberdade brasileira. Essa coisa esplêndida, essa coisa a qual todos nós devemos cultuar, que é a liberdade, sem a qual não podemos criar, não podemos trabalhar, não podemos enriquecer, não podemos ser aquela coisa grande e bela que foi Viriato Corrêa [...] (PEREGRINO JR, 1967, p.28).

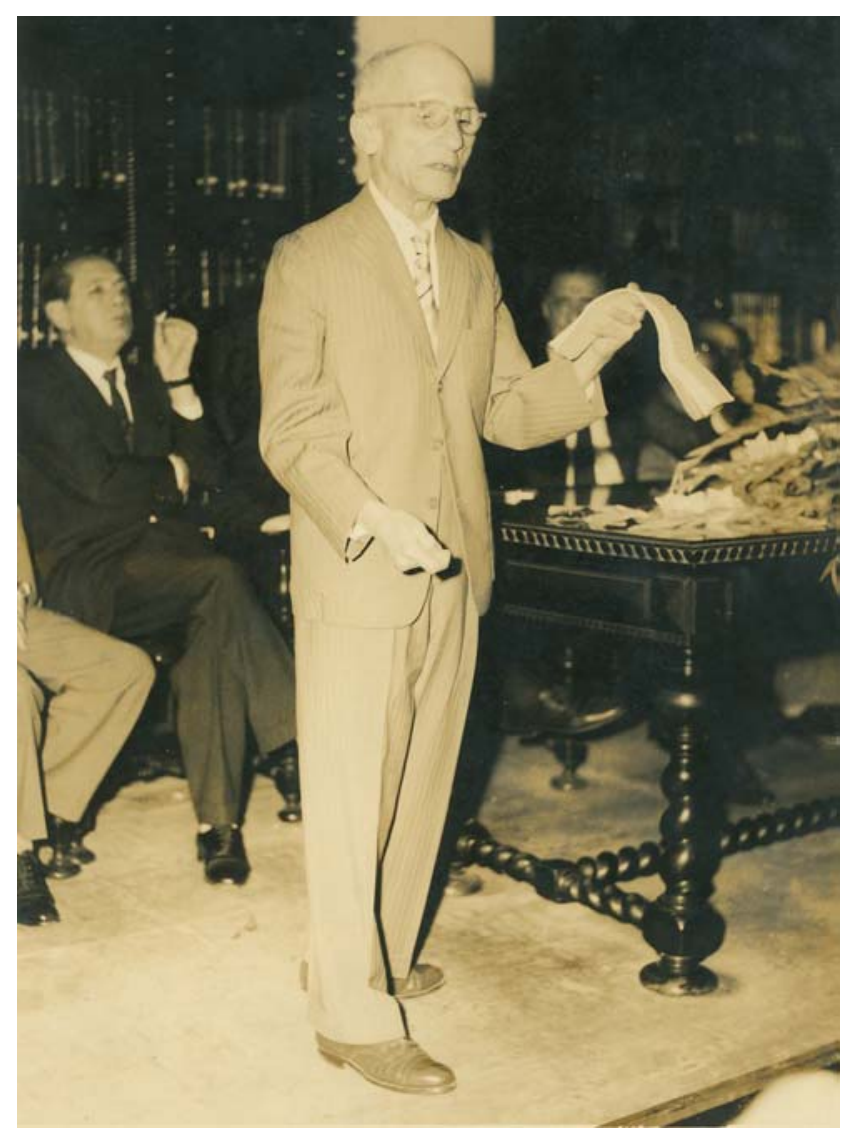

Figura 40 - Viriato discursando na Academia Brasileira de Letras (s/d).

Fonte: Acervo Centro de Memória da ABL. 


\title{
3.5 A consagração do autor: o ingresso na Academia Brasileira de Letras
}

Em 1938, após quatro tentativas frustradas, Viriato Corrêa foi eleito para a Academia Brasileira de Letras, na cadeira de número 32, criada por Carlos de Laet e cujo patrono é Araújo Porto Alegre ${ }^{100}$.

O próprio Viriato considerava que essa resistência a seu nome deveu-se ao fato de que era um escritor dedicado ao teatro de costumes e à literatura infantil - considerados gêneros literários menores, no âmbito da literatura brasileira - além de seu fenótipo - era mulato, e seria baixo e feio para os padrões estéticos da Academia ${ }^{101}$.

\begin{abstract}
A Estética do Fardão ${ }^{102}$
Há três anos era eu candidato à vaga que Medeiros e Albuquerque abrira nesta casa. E uma tarde, nas vésperas do pleito, Laudelino Freire e Benjamim Costallat palestravam na redação do Jornal do Brasil quando entrei na sala. Os dois, imediatamente, se puseram a conversar sobre a minha candidatura. Costallat começou a fazer pilhérias com a Academia e comigo. Laudelino era voto meu; estava seguro da minha eleição.

- Está eleito! Rigorosamente eleito! Assegurou.

O romancista da Guria dava muchochos de incredulidade:

- Eleito nada! Eleito com aquele tamaninho!

Laudelino escandalizou-se.

- Que tem isso? Ele fica muito bem no fardão.

- Mas o fardão não fica muito mal nele! retrucou Costallat, com a mais vasta de suas risadas.

O brilhante autor de Loucura Sentimental, sem querer ou talvez querendo, estava, com um simples gracejo, a definir um aspecto rigorosamente acadêmico.

Foi sempre dos cuidados das Academias velar pela estética dos fardões. Um trajo tão nobre precisa estar bem ajustado. O manequim que o veste deve ser um primor de manequim, bem formado, bem formoso, bem lustroso e bem gentil.

E a cautela no exame do que vai ter as honras do fardão custa, às vezes, um trabalho interminável às Academias.

O trabalho que eu dei foi longo e fatigante. Bati a estas portas de cabelos pretos e só agora, com a cabeça quase toda branca, é que as portas se me abriram.
\end{abstract}

\footnotetext{
${ }^{100}$ Sucederam a Viriato Corrêa nessa cadeira, os seguintes escritores: Joracy Camargo (1967-1973), Genolino Amado (1973-1989) e o atual ocupante Ariano Suassuna (1989 - ...).

${ }^{101} \mathrm{Na}$ imprensa local, circulava uma piada a respeito da estatura de Viriato, em torno de 1,40 de altura. O jornalista Agripino Grieco, que não gostava de Viriato Corrêa, disse certa vez que "O Sr. Viriato Corrêa saiu do Maranhão para vir sentar praça no Exército. Como não tinha o tamanho mínimo necessário para vestir farda, foi ser escritor." Jornal "O Fluminense", Niterói-RJ, 18.12.1972.

102 Um das solenidades mais importantes da ABL ocorreu quando da recepção e posse dos novos eleitos, num ritual teatral, onde todos os acadêmicos estavam vestidos do fardão e o momento mais solene da cerimônia foi a leitura do discurso do novo "imortal". Através do discurso de posse, o novo sócio elogiou o seu antecessor, ao tempo em que fez referências também ao fundador e respectivo patrono da cadeira que iria ocupar. Em seguida, um acadêmico veterano fez também um discurso recepcionando o novo "imortal", destacando sua vida e obra (EL FAR, 2000).
} 
E, por isso mesmo, é mais alto o meu desvanecimento. As conquistas, tanto de mulheres como das letras, são sempre mais saborosas quanto mais difíceis.

A luta que travei para transpor estes humbrais ilustres, a constância nessa luta, a pugnacidade na constância, a serenidade nos insucessos são as provas claras e profundas da profunda e clara estima que voto a esta casa.

E é em certa volúpia que hoje, no fastígio dos louros, eu recordo os dias procelosos das cinco investidas que fiz para me sentar entre vós, numa destas cobiçadas cadeiras azuis.

Foi o mais longo e o mais penoso trabalho de minha vida. Tão longo que vem desde os meus tempos de rapaz (CORRÊA, 1938, p. 106-7).

\title{
Embora a Academia Brasileira de Letras tenha sido fundada e presidida por um
} escritor mulato, no caso Machado de Assis, como veremos adiante, há fortes indicações de que o preconceito contra Viriato Corrêa também fosse de natureza racial ${ }^{103}$.

\begin{abstract}
Um dos seus mais ferrenhos opositores era o acadêmico-parteiro Fernando Magalhães. Ele confessou: - Não quero ver lá dentro da Academia o moleque Viriato. Magalhães o detestava, não pelo fato de Viriato ser um escritor medíocre, cuja prosa insípida, sem qualquer brilho, é um amontoado de lugares-comuns e de trivialidades. $\underline{\mathrm{O} \text { acadêmico-parteiro se opunha à entrada do cronista de } O \text { país do }}$ pau de tinta porque ele pertencia à raça negra (JORGE, 1999, p. 210, grifo nosso).
\end{abstract}

Viriato considerava-se "o mais velho namorado da Academia. Porque, o que tive, senhores, através de tantos e tantos anos pela ilustre companhia, outra coisa não foi senão um verdadeiro namoro" (CORRÊA, 1938, p. 107). E prossegue no seu discurso de posse:

[...] Meu namoro com a Academia era de tal maneira escandaloso que se tornou até um dos pratos mais ricos da zombaria nacional. De norte a sul do país o humorismo jornalístico punha-o de quando em quando à mesa, para o agrado dos leitores.

Diziam-me de mim coisas bem ridículas. Certo humorista, aludindo aos constantes insucessos das minhas eleições acadêmicas, chamou-me Romeu sem escada, Romeu que não conseguia chegar aos braços de Julieta por não ter degraus de seda para subir ao balcão do amor.

Um outro chamou-me de "tia" da Academia. "Tia" na acepção de solteirona. Realmente, não foi senão de solteirona o papel que representei com o meu namoro. $\mathrm{Na}$ janela do sonho, mais de dois lustros me debrucei à espera do noivado da imortalidade. Diante dos meus olhos passaram cortejos nupciais, carruagens engrinaldadas, de noivos felizes. Aos meus ouvidos chegaram muitas e muitas vezes rumores de festas esponsalícias que se faziam nessa sala.

\footnotetext{
${ }^{103}$ No dia da eleição para a vaga de Ramiz Galvão (14.07.1938), Olegário Mariano, já membro da ABL, amigo e um dos principais propugnadores da candidatura de Viriato, diante da iminência da confirmação da vitória do escritor maranhense, bradava para que todos ouvissem: “ - Agora é que vamos ver o moleque eleito! Ah, ah, ah! Hoje o moleque entra!” (PINTO, 1966, p. 209) Em reconhecimento ao trabalho de Olegário Mariano pela sua candidatura à $\mathrm{ABL}$, Viriato dedicou o livro Cazuza ao escritor pernambucano.
} 
E eu ficava de cabeça zonza, olho comprido, água na boca, palpitando, suspirando, desejando...

De onde em onde, queimado pela febre da esperança, eu fazia um penteado novo (um novo livro, que atirava ao público), punha pó no rosto e carmim no lábio. Mas o noivado não vinha.

Iam-se casando as minhas irmãs, iam-se casando as minhas vizinhas. E, para mim, em vez de noivo, eram os cabelos brancos que chegavam [...] (CORRÊA, 1938, p. 107-8, grifo nosso).

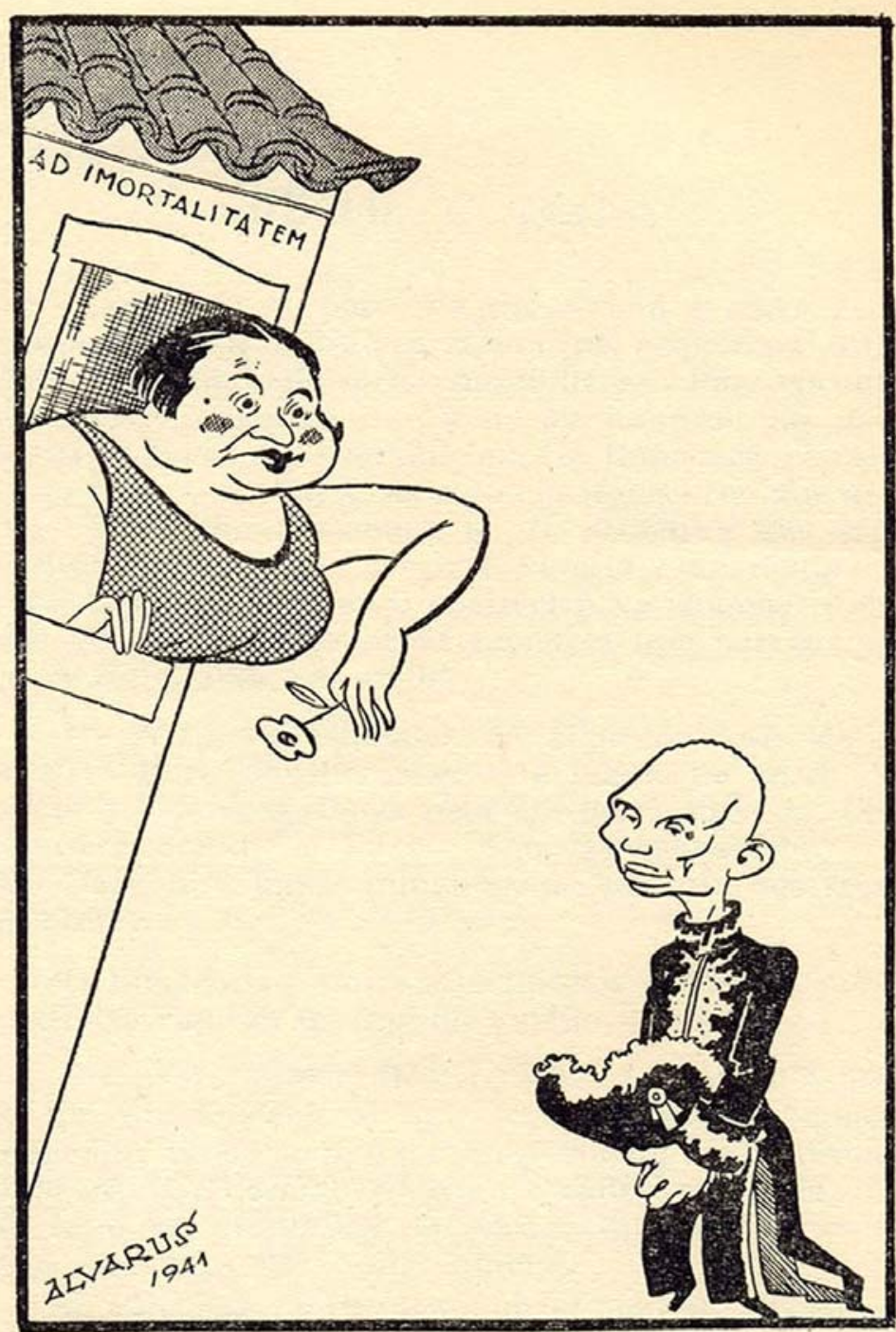

Viriato Corrêa numa "charge" de Alvarus. - Do Album "Hoje tem Espetáculo..." - Rio, 1941.

Figura 41- Charge.

Fonte - PINTO, 1966, p.9.

Seu ingresso na ABL foi, segundo ele, motivo de muitas comemorações: 
Meu caro Ribeiro Couto: Deus sabe o que faz. A minha eleição veio quando devia vir. Se viesse quando eu queria, não teria tido o sucesso que teve.

Não imaginas o barulho. Os meus sucessivos desastres tinham-se tornado um caso que o publico comentava como se comenta um fato policial, político ou social. E, por esta ou aquella razão, o publico estava ao meu lado.

A eleição foi esperada com verdadeira ansiedade. Quando se deu o resultado houve realmente uma grande sensação. As estações de radio fizeram uma barulhada excepcional: falou o Cezar Ladeira, falou o Lamartine Babo, falou o Paulo Magalhães, falou o Ary Barroso, falou o Barboza Junior, falaram vários oradores, discursando, Ribeiro, discursando. Durante uma semana varias estações de rádio fizeram horas dedicadas a mim. A imprensa despejou-se em elogios incríveis. $\mathrm{O}$ Maranhão mandou-me oferecer o fardão que, agora, está custando 12 contos.

Tudo isso, porque eu fora preterido muitas vezes. Aos olhos do publico eu era uma espécie de Tiradentes literário, isto é martyr da Academia.

O que Deus dá só chega no dia. [...] (Carta de Viriato Corrêa a Ribeiro Couto, 1938).

\section{Contraditoriamente, após todo o esforço para ingressar na ABL, Viriato demonstrou}

um certo fastio com as reuniões semanais às quintas-feiras, quando, ainda hoje, se serve um tradicional café para os acadêmicos.

[...] Finalmente, meu caro Ribeiro Couto, estou na Academia. Queres que te fale com franqueza. Ainda não achei jeito de amar aquillo. Não sei se são as velhas magoas que aquella casa me deixou no coração com as repetidas preterições, ou se é o ar enfatuado que vários dos acadêmicos (principalmente os duques) carregam no semblante. A verdade é que as reuniões de quinta-feira me deixam sempre amolecido e caceteado. E, as vezes, surpreendido pelas bobagens que ouço em plena sessão. Há acadêmicos que tem a gula da discurseira e falam a propósito de tudo, dizendo asneiras. [...] (Idem, 1938).

A vida aqui na Academia vai indo, monótona, é verdade, mas sem atritos e sem brigas. De quando em quando, para quebrar a monotonia, lá se vai um para o outro mundo. Ultimamente foram dois, como você deve saber: o Garcia e o João Luso dois excelentes homens.

Eu continuo a trabalhar, a fazer peças e livros de crianças. Acabo de ter agora um grande sucesso com "Dinheiro é dinheiro" - comédia que o Procópio levou no Serrador [...] (grifo nosso) (Carta de Viriato Corrêa a Ribeiro Couto, 1950).

Viriato Corrêa teve vida longeva ${ }^{104}$, caracterizada por farta produção literária, sobretudo a de cunho infanto-juvenil. No dia 10 de abril de 1967, aos oitenta e três anos,

\footnotetext{
${ }^{104}$ Dentre as histórias que correm pelos bastidores da ABL e que formam o folclore dessa instituição cultural, uma se refere ao fato de que a cadeira de $\mathrm{n}^{\circ} 32$ é a "cadeira dos longevos". O seu patrono Araújo Porto-Alegre morreu aos setenta e três anos; o fundador da cadeira - Carlos de Laet - faleceu aos oitenta; Ramiz Galvão, aos noventa e dois, e Viriato Corrêa morreu aos oitenta e três anos. Hoje, essa cadeira é ocupada por Ariano Suassuna, que tem 81 anos.
} 
faleceu na cidade do Rio de Janeiro, que o acolhera ainda jovem e assistira à sua profícua carreira jornalística e literária.

Neste mesmo dia, o escritor e acadêmico Josué Montello deixou registrado em seu Diário, palavras de despedida ao amigo e conterrâneo Viriato Corrêa:

Vejo imóvel para sempre, na quietude do derradeiro sono, na Academia, no Salão dos Poetas Românticos, o meu querido Viriato Corrêa, e todo o meu ser se opõe a essa imobilidade definitiva. Não, não pode ser. E é verdade. Está ali o velho amigo que, ao longo de trinta anos, ou me falava, ou me escrevia, todos os dias, vivo, esfuziante, com a réplica instantânea na ponta da língua. [...] Enquanto viveu, Viriato Corrêa soube conservar o mesmo gênio divertido. O mesmo poder de comunicação (MONTELLO, 1998, p. 908-9).

A morte de Viriato Corrêa teve bastante repercussão nos meios literários, artísticos e políticos. De diversas partes do território brasileiro chegaram condolências pelo falecimento do acadêmico, o que bem demonstra que sua obra, sobretudo a de cunho infanto-juvenil, era conhecida de muitos brasileiros.

Muitas instâncias do poder - governo, assembléias legislativas e câmaras municipais expressaram o seu voto de pesar. O então governador do Maranhão e futuro "imortal" da ABL, José Sarney, transmitiu, em nome de seus conterrâneos, um telegrama de pesar. Vários telegramas e cartas encontram-se no arquivo do Centro de Memória da ABL. Uma dessas cartas me chamou especialmente a atenção. Trata-se da carta de uma classe de normalistas, de uma Escola de Jaboticabal-SP, redigida de próprio punho, o que bem demonstra que a obra de Viriato Corrêa ${ }^{105}$ também era objeto de estudo das futuras professoras primárias da época:

Jaboticabal, 12 de abril de 1967

Exmo. Sr. Acadêmico Austregésilo de Ataíde,

DD. Presidente da Academia Brasileira de Letras.

Respeitosas Saudações.

Nós, alunas do Curso de Formação de Professôres Primários, do I. E. Aurélio Arrobas Martins, de Jaboticabal - SP, juntamente com o nosso professor de

\footnotetext{
${ }^{105}$ Viriato Corrêa era também conhecido pelos professores que atuavam no ensino primário e secundário, prova disso eram os convites que recebia para fazer palestras sobre temas da História do Brasil. Foi o caso da conferência pronunciada na Associação dos Professores Primários, intitulada $O$ Teatro de Anchieta e reproduzida no livro O País do Pau de Tinta (crônicas históricas da terra do pau-brasil). Rio de Janeiro: Civilização Brasileira S/A, 1938, p. 116-44).
} 
Português, vimos apresentar, por intermédio de V. Exa., sentidos pêsames à Academia Brasileira de Letras, pelo falecimento de Viriato Correia, escritor insigne que pertenceu com muita dignidade à Casa de Machado de Assis.

Queira receber os protestos de nosso elevado apreço e consideração.

José Paulino da Costa Neto.

Alunas do $3^{\circ}$. Normal A e do $3^{\circ}$. Normal B (Acervo Centro de Memória da ABL).

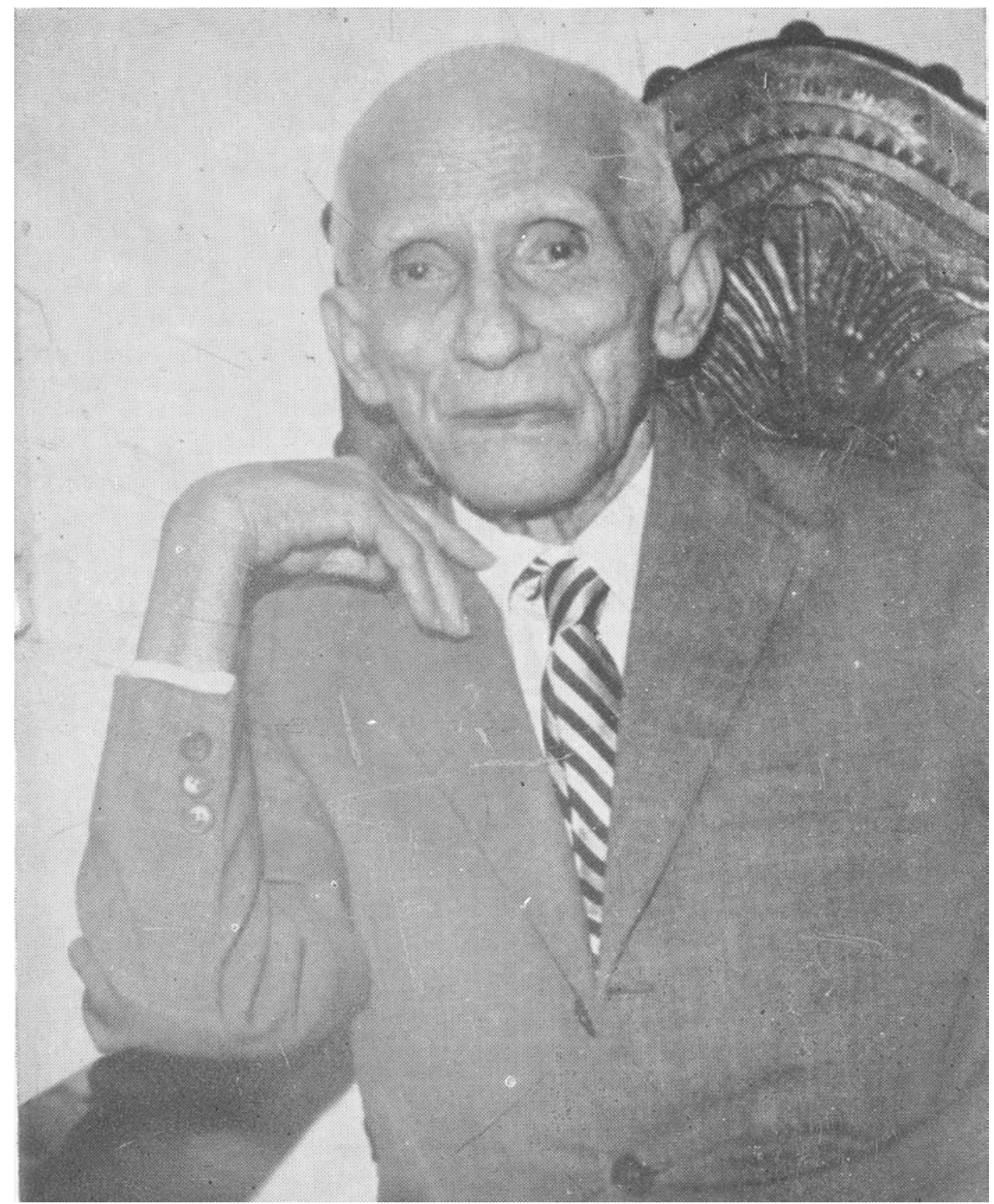

Figura 42 - Viriato Corrêa (1884-1967), s.d.

Fonte - Acervo Centro de Memória da ABL.

Há opiniões divergentes sobre a importância do papel de Viriato Corrêa nas letras nacionais a ponto de ter sido consagrado como um "imortal". Segundo muitos de seus contemporâneos, foi um notável contador de histórias, "apóstolo da cultura cívica", segundo um dos seus principais interlocutores (POMBO, 1921, p. 14). 
João Ribeiro ${ }^{106}$ elencava o nome de Viriato ao lado de historiadores renomados pertencentes aos quadros do IHGB, a exemplo de Capistrano de Abreu, Max Fleiuss, Rocha Pombo, Rodolfo Garcia, Osório Duque Estrada, Gustavo Barroso e Luiz Edmundo e tecia elogios acerca de sua obra nos principais jornais da época:

Viriato Corrêa não necessita que o recomendemos. É historiador, dramaturgo, conteur, romancista e neste momento ilustra os nossos leitores com a sua muito metódica e bem ordenada Gaveta de Sapateiro (Jornal do Brasil, 08.2.1933).

Viriato continua a encher diariamente a sua Gaveta e é provável que dentro em pouco tenhamos outra série dessas galantes historietas, que ajudam a compreender a nossa história melhor que os compêndios áridos e massudos (Jornal do Brasil, 23.3.1932, grifo nosso).

Para o crítico literário Mário da Silva Brito,

Os dois principais escritores brasileiros dedicados à literatura infanto-juvenil foram Monteiro Lobato e Viriato Corrêa. Ambos, depois que conquistaram o aplauso dos adultos, através de seus contos, romances, crônicas e breves ensaios, passaram a escrever mais para os jovens do que para a gente grande. [...] Sua primeira edição de História da Liberdade no Brasil foi de 20.000 exemplares e a segunda, que agora se lança em coedição com o Instituto Nacional do Livro, alcança a mesma cifra [...] Esse mestre indiscutido da literatura infanto-juvenil, nasceu contador de estórias. Sabia, como poucos, trazer todos suspensos de sua prosa amena e instrutiva (orelha da $2^{\text {a }}$ edição de História da Liberdade no Brasil, grifo nosso).

Para outros escritores e críticos modernos, contudo, Viriato Corrêa não mereceria figurar no panteão dos imortais, por ser "um escritor medíocre, cuja prosa insípida, sem qualquer brilho, é um amontoado de lugares-comuns e de trivialidades" (JORGE, 1999, p. 210). Para esse crítico, Viriato pretendia igualar-se a Paulo Setúbal, mas não tinha o talento literário necessário para uma obra de fôlego como a do paulista, que escreveu importantes romances históricos.

O que importa é que Viriato Corrêa já tem seu nome inscrito nos Anais da ABL, por ter sido o primeiro autor de livros infanto-juvenis a ingressar no quadro dos imortais. Se não escreveu grandes obras, ao se dedicar à crônica histórica e à produção teatral, prestou um serviço relevante de divulgação de nossa história.

\footnotetext{
${ }^{106}$ A obra crítica e literária do acadêmico João Ribeiro foi organizada por LEÃO, Múcio (Org.). Crítica. Vol. VI (Historiadores). Rio de Janeiro: Publicações da Academia Brasileira, 1961.
} 


\section{CAPÍTULO 4: HISTÓRIA DO BRASIL PARA CRIANÇAS: PROCESSO DE ELABORAÇÃO}

A questão essencial que, na minha opinião, deve ser colocada por qualquer história do livro, da edição e da leitura é a do processo pelo qual os diferentes atores envolvidos com a publicação dão sentido aos textos que transmitem, imprimem e lêem. Os textos não existem fora dos suportes materiais (sejam eles quais forem) de que são os veículos. Contra a abstração dos textos, é preciso lembrar que as formas que permitem sua leitura, sua audição ou sua visão participam profundamente da construção de seus significados. $O$ "mesmo" texto, fixado em letras, não é o "mesmo" caso mudem os dispositivos de sua escrita e de sua comunicação

(Roger Chartier) $^{107}$

107 CHARTIER, Roger. A mediação editorial. In: UNESP, 2002, p. 61-2. 


\title{
4.1 Autorias e produção
}

\subsubsection{Viriato Corrêa - o autor}

O livro História do Brasil para crianças (1934) é de autoria do escritor maranhense Viriato Corrêa (1884-1967), como já vimos anteriormente. Viriato não foi professor de História na escola primária ou secundária, nem tampouco membro do IHGB. O que o levou, então, a escrever um livro de História do Brasil dedicado ao universo infanto-juvenil? Em entrevistas concedidas aos jornais do Rio de Janeiro, Viriato fez algumas afirmações importantes que podem responder a essa questão:

\begin{abstract}
Quando criança - narra o escritor - senti grande dificuldade em aprender e não achava o mínimo interesse na História do Brasil. Adulto, comecei a meditar que todas as crianças teriam essas mesmas dificuldades, e comecei a pensar num meio de fazer a História prender a atenção dos pequenos estudantes. Por que teria que ser sempre cacete, enfadonha, dura de entrar na cabeça da gente?

Decidiu, então, "fazer uma História do Brasil para todo mundo entender" e andava bolando idéias, quando recebeu uma carta do Professor Paulo Maranhão, "líder do ensino no Brasil, que me reclamava, justamente, uma História do Brasil para crianças, achando que eu era o homem talhado para fazê-la".

- Eu, que vivo muito de estímulo alheio - comenta o escritor - lancei-me à obra, inebriado pelo trabalho. Anísio Teixeira tem razão quando diz que o livro foi feito 'sob figurino'. Assim foi, com efeito: cada capítulo escrito era passado às mãos de uma jovem professora da Escola José de Alencar, que ia lendo em classe, para os seus alunos, quando escrevi. Dessa forma, o livro foi sendo criticado pelo seu pequeno público, à medida que era feito [...]

Diante do sucesso da História do Brasil para crianças, Monteiro Lobato afirmou que Viriato Corrêa havia 'ensinado o caminho, vaticinando que teria muitos seguidores'. O livro, contudo, lançado em 1934, 'continua o único no gênero'. ${ }^{108}$ ("O Jornal”, Rio de Janeiro, 17.12.1960, grifo nosso).
\end{abstract}

O texto acima me permite fazer algumas ilações. A primeira delas refere-se às práticas pedagógicas do ensino de História existentes na maioria das escolas à época em que o livro foi escrito (década de 1930). Segundo Viriato, as aulas de História não conseguiam prender a

\footnotetext{
${ }^{108} \mathrm{Na}$ mesma linha de História do Brasil para crianças e, devido ao seu sucesso junto ao público infantojuvenil, Viriato Corrêa pretendia também escrever um livro em que contaria a história da literatura para as crianças: "Mas Viriato não pára. Continua estudando, escrevendo pesquisando a alma humana; está preparando uma História da Literatura para as crianças, continua amando suas crianças e admirando o Rio de Janeiro, a sua cidade, sua do coração" (A cidade e seus autores, O Globo, Rio de Janeiro, 06.02.1965). No entanto, seu último livro publicado foi História da Liberdade no Brasil, de 1962, editado pela Civilização Brasileira e que teve uma segunda edição em parceria com o Instituto Nacional do Livro (INL), em 1974.
} 
atenção dos alunos, por serem monótonas e enfadonhas. Certamente, o ensino da disciplina estava pautado na memorização de "datas-fatos-nomes" que levavam os alunos a "quebrarem a cabeça" para serem aprovados nos exames escolares. Ele mesmo afirma que, quando criança, não gostava de História e, quando adulto, decidiu "fazer uma História do Brasil para todo mundo entender".

Ainda segundo o depoimento do autor, o principal dado do processo de produção refere-se ao modo sui generis de sua elaboração, em se tratando de uma obra infantil. Os capítulos escritos por Corrêa foram testados por alunos da Escola José de Alencar, no Rio de Janeiro, com o auxílio de uma professora para, a partir das críticas das próprias crianças, o livro ser aprimorado até sua publicação pela Companhia Editora Nacional.

Outro aspecto importante é a menção feita a dois nomes ligados ao movimento escolanovista, Paulo Maranhão e Anísio Teixeira ${ }^{109}$, o que bem demonstra que o autor tinha interlocução com esses educadores e com o pensamento de renovação educacional que eles representavam naquele momento da história do País. Embora Viriato não tenha aprofundado a questão metodológica do ensino de História, por não ser pedagogo, viu-se sensibilizado pelas propostas de renovação do ideário escolanovista, e a aceitação da obra por Anísio Teixeira - à época o principal dirigente da Educação, na cidade do Rio de Janeiro, então Distrito Federal revela a afinidade do autor com a percepção da importância de despertar na criança o interesse pelo estudo. Foi uma obra destinada ao público infantil, que poderia agora aprender História, mesmo sem a mediação do professor.

Há, ainda, no livro, como reconhecimento ao incentivo recebido, a dedicatória ao educador Paulo de Albuquerque Maranhão ${ }^{110}$ que, segundo Viriato, foi quem o convenceu a escrever a história pátria para crianças.

\footnotetext{
${ }^{109}$ Anísio Teixeira teve um papel destacado na história da educação brasileira, como um dos principais nomes ligados ao movimento da Escola Nova e por ter implementado a reforma de educação do Distrito Federal, no período de 1931 a 1935.

${ }_{110}$ Paulo de Albuquerque Maranhão foi um dos signatários do Manifesto dos Pioneiros da Educação Nova no Brasil, em 1932 e fazia parte do grupo dirigido por Anísio Teixeira na gestão da instrução pública do Distrito Federal.
} 
A Paulo de Albuquerque Maranhão,

A sua carta, impondo-me a obrigação de escrever a história pátria para crianças, meteu-me em brios para realizar este livro.

É a você que ele pertence, a você que teve a coragem louca de acreditar que eu era capaz de realizá-lo.

Rio - agosto - 1934 (CORRÊA, 1944, p. 5).

O livro traz também uma pequena carta do escritor e historiador Rodolfo Garcia, que tece elogios à obra:

Meu caro Viriato Corrêa,

Devolvo os originais de tua História do Brasil. Se eu ainda fosse professor, ganharias uma nota ótima. Com o método adotado, conseguiste fazer um livro magnífico, não só para crianças, como ainda para a gente grande.

Deves ter ouvido muitas vezes, como eu, de ilustres cavalheiros a cândida declaração de que não gostam da História do Brasil, porque é matéria árida e desinteressante: por isso, deixam-na de lado, não a estudam, não a sabem.

À semelhança do que fizeste com as crianças, devias ter dedicado também teu livro a esses cavalheiros. Porque, estou certo que o leriam com muito prazer e sobretudo proveito.

Dispõe sempre do velho amigo e confrade.

RODOLFO GARCIA (CORRÊA, 1944, p. 7, grifo nosso).

Ao transcrever a carta elogiosa de Rodolfo Garcia ${ }^{111}$, o autor/editor utilizou-se de uma estratégia de legitimação do livro, visto ser Rodolfo Garcia historiador ligado à tradição historiográfica do IHGB e intelectual respeitado na capital do País, pois, como já dissemos, à época era Diretor da Biblioteca Nacional. O fato de Rodolfo Garcia ter lido os originais do livro antes de ser publicado oferece a chancela de um historiador renomado à obra do escritor Viriato Corrêa.

\footnotetext{
${ }^{111}$ Rodolfo Garcia (1873-1949) era membro do IHGB e assumiu a cadeira 39 da ABL, anteriormente ocupada por Rocha Pombo. Em 1930, exerceu o cargo de Diretor do Museu Histórico Nacional, em substituição a Gustavo Barroso, criando nessa instituição o "Curso de Museus". Em 1932, assumiu a direção da Biblioteca Nacional. Juntamente com Capistrano de Abreu, Garcia foi responsável pela anotação da $3^{\mathrm{a}}$ edição de "História Geral do Brasil", de Varnhagen. Foi um dos mais importantes colaboradores do "Dicionário Histórico, Geográfico e Etnográfico do Brasil", organizado pelo IHGB. Segundo José Honório Rodrigues, "Varnhagen, Capistrano de Abreu e Rodolfo Garcia formam uma trindade bendita da historiografia brasileira. É preciso atentar na função representada pelos três para bem avaliar a significação da obra por eles realizada e transmitida." (RODRIGUES, 1970, p. 155).
} 


\subsubsection{Belmonte - o ilustrador}

Para o trabalho de confecção da mercadoria "livro", participam também de seu processo de produção gráficos, digitadores, ilustradores, revisores, encadernadores, designers etc. Em se tratando de um livro infantil, em que as imagens assumem papel preponderante, o ilustrador deixa de ser um mero "prestador de serviços" e passa a ser um co-autor da obra (LINS, 2004, p. 40).

Nesse sentido, podemos também indicar na autoria da referida obra o escritor, jornalista e caricaturista Benedito Carneiro de Bastos Barreto ${ }^{112}$, Belmonte, responsável pela criação das ilustrações, incluindo a capa, que será posteriormente analisada.

Décadas depois, ao retratar sua própria infância, outro humorista e cartunista, Jaguar, enumeraria dentre seus objetos favoritos o livro História do Brasil para crianças, ilustrado por Belmonte:

\footnotetext{
Meus tempos de menino, em Santos. Meu pai era do Banco do Brasil, fomos morar lá quando eu tinha seis, sete anos [...].

Meus tesouros: uma coleção de estampas das balas Pan (que perdi num jogo de bafo-bafo), uma caneta-tinteiro Esterbrook, os livros de Viriato Corrêa (História do Brasil para crianças) e todo o Sítio do Pica-Pau Amarelo ilustrado por Belmonte. Era para mim o maior desenhista do mundo. Varava noites copiando os desenhos dele, sem poder dormir por causa da asma (JAGUAR, 2007, grifo nosso).
}

O depoimento acima revela o quanto as ilustrações ficam, muitas vezes, como marcas indeléveis na mente das crianças, ao ponto de serem lembradas quando de sua vida adulta.

Belmonte, pseudônimo pelo qual ficou mais conhecido no meio intelectual e artístico, foi

\footnotetext{
${ }^{112}$ Benedito Carneiro de Bastos Barreto (1897-1947) nasceu em São Paulo capital, e era filho de João de Carrero e Rita do Espírito Santo. Segundo a mãe, desde cedo, já mostrava pendores artísticos para o desenho, rabiscando as paredes de casa.
} 
quem deu rosto para os moradores do Sítio do Pica-Pau Amarelo, de Monteiro Lobato, e, dentre as várias versões criadas para seus livros, foram dele as que mais agradaram o público leitor. Seu Jeca Tatu pode ser considerado como a versão oficial do personagem, quase se transformando, para desespero dos mais ufanistas, em símbolo nacional. Tornou-se amigo do grande escritor de Taubaté, que em suas cartas sempre o incentivava a continuar sua carreira literária [...] (CARRAL, 1996, p. 12).

Ele também ilustrou outros quatro livros infantis de Viriato Corrêa, todos publicados pela CEN: Meu Torrão (1935), A Descoberta do Brasil (1930), História de Caramuru (1939) e $A$ Bandeira das Esmeraldas (1945).

Belmonte foi muito influenciado por outro cartunista de renome nacional - J. Carlos, considerado um dos mais importantes artistas gráficos da imprensa brasileira do século XX. Já em 1914, publicou seu primeiro desenho na Revista Rio Branco. A partir daí, não parou mais de desenhar para importantes periódicos, tais como Cosmos, Revista da Semana, Dom Quixote, Fon-Fon, entre outros. Para atender os apelos de sua mãe, que pretendia uma carreira mais sólida para o filho do que ilustrador de revistas e jornais, Belmonte iniciou a Faculdade de Medicina, mas logo viu que não era sua vocação, retornando ao desenho e à charge política.

Em 1921, foi convidado para integrar a equipe de jornalistas da Folha da Noite e sua primeira função foi substituir outro grande caricaturista da vida paulistana - Voltolino. Nesse jornal, criou o personagem "Juca Pato", um baixinho careca, lídimo representante da classe média paulistana, que protestava contra o aumento dos preços, o arrocho salarial dos funcionários, os desmandos administrativos do governo e a corrupção. Juca Pato ${ }^{113}$ fez tanto sucesso entre a população que, das páginas do jornal ganhou notoriedade, sendo seu nome usado em bares, marcas de vários produtos de uso doméstico e até mesmo como nome de cavalo de corrida.

Tinha uma enorme paixão por São Paulo, a ponto de não aceitar o convite para uma carreira internacional nos estúdios da Metro Goldwin Mayer, nos Estados Unidos, optando

\footnotetext{
${ }^{113}$ Segundo Belmonte, Juca Pato era careca de "tanto levar na cabeça" e adotava o lema pessimista "podia ser pior", que virou um verdadeiro bordão na cidade de São Paulo. Hoje, Juca Pato designa o prêmio conferido anualmente pela União Brasileira dos Escritores (UBE) ao intelectual do ano.
} 
por permanecer em sua cidade natal. Essa paixão Belmonte traduziu também em livros, o que bem mostra que ele era, no dizer de Lobato,

[...] um artista integral. Tanto caricatura com o lápis, como por meio da palavra escrita. Quero dizer que é um escritor notável - desses cujas crônicas os jornais estampam em tipo de relevo. A mesma finura de humor que mostra no desenho ressalta dos seus comentários críticos (LOBATO apud LIMA, 1963, p.1372).

Belmonte também foi escritor, além de caricaturista e ilustrador. São de sua autoria os seguintes livros: Brasil de outrora (Edições Melhoramentos, com desenhos inspirados nos quadros de Rugendas); Angústias de Juca Pato (álbum de caricaturas); O amor através dos séculos (álbum de desenhos humorísticos); Assim falou Juca Pato (crônicas humorísticas publicadas pela Companhia Editora Nacional); Idéias de João Ninguém (crônicas humorísticas publicadas pela Livraria José Olympio Editora) e um único livro infantil - $A$ Cidade de Ouro (CEN), que aborda o movimento das Bandeiras.

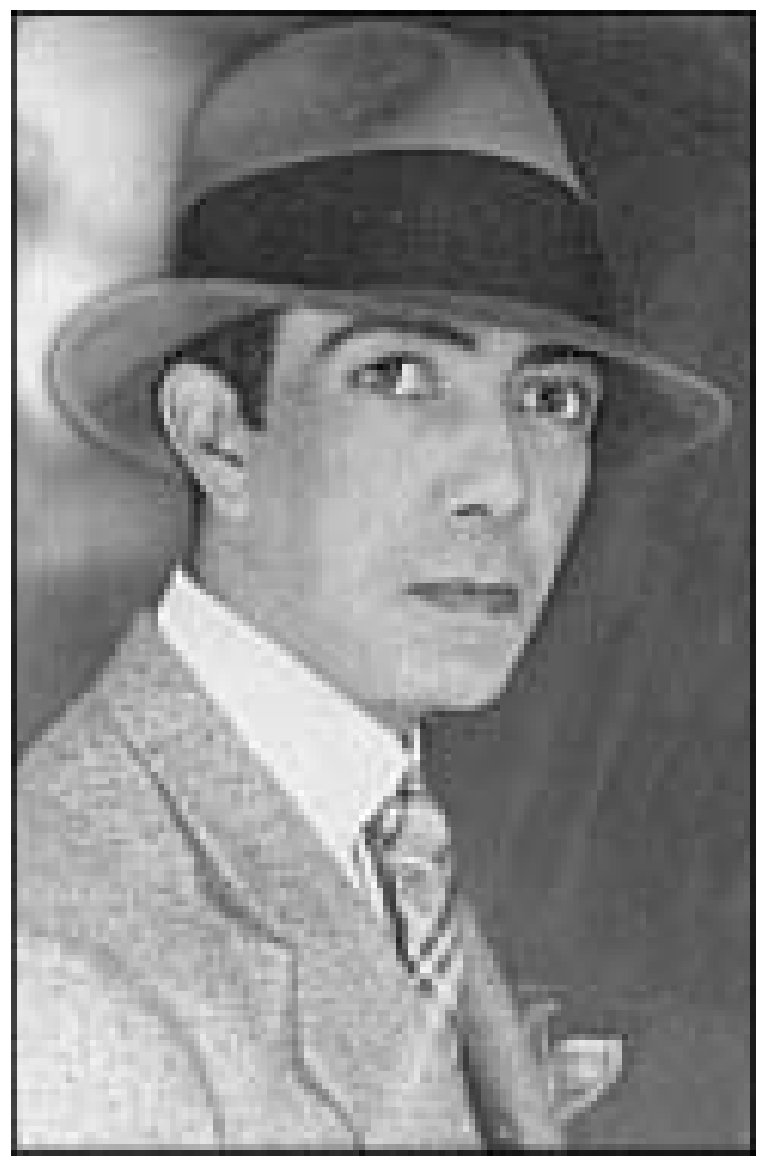

Figura 43 - Benedito Carneiro de Bastos Barreto - Belmonte (1897-1947).

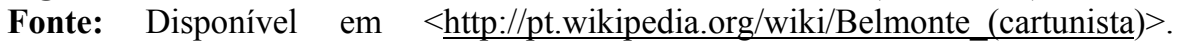
Acesso em 20/11/2008. 
Seu livro de maior sucesso, com várias edições, foi No tempo dos bandeirantes ${ }^{114}$, publicado pela Edições Melhoramentos. Segundo Fernando Carral, o livro

[...] é um retrato fiel e aprofundado dos primórdios da ocupação de nossas terras pelos desbravadores. Os desenhos e textos feitos para esse livro nos dão mostra de sua técnica impecável, assim como do rigor no levantamento histórico, evidenciados na precisão com que descreve o vestuário, a armaria e a ambientação do período retratado (CARRAL, 1996, p. 11).

Talvez por influência desse livro e por ser conhecedor do assunto, Belmonte tenha dado tanto destaque à figura do bandeirante, no rol das ilustrações do livro História do Brasil para crianças. De todo modo, segundo Herman Lima (1963), o traço de Belmonte destaca-se pelo seu esmero técnico e "cuidado histórico" na reconstituição dos fatos e personagens de nosso passado.

Para o ilustrador Rui de Oliveira, ganhador do Prêmio Hans Christian Andersen de Ilustração 2008, Belmonte foi um dos maiores ilustradores brasileiros de todos os tempos, "bastariam as charges contra o nazifascismo, durante a Segunda Guerra Mundial, para consagrá-lo como grande artista." (OLIVEIRA, 2008, p. 52).

Ainda em plena atividade da pena e do lápis, Belmonte faleceu em 19 de abril de 1947, vítima de tuberculose, na sua São Paulo natal. Pela importância de seu traço nas ilustrações do livro de História do Brasil para crianças, considero que Belmonte faz parte do processo de autoria desse livro infantil, ao lado de Viriato Corrêa.

\footnotetext{
${ }^{114}$ Fora de circulação há alguns anos, o livro No tempo dos bandeirantes teve, recentemente, uma reedição pela Imprensa Oficial do Estado de São Paulo (IMESP), na Coleção Paulística.
} 


\subsection{Materialidade ${ }^{115}$}

Além do texto de Viriato Corrêa e das ilustrações de Belmonte, o livro História do Brasil para crianças contou com a participação de outros sujeitos no seu processo de elaboração. "Livros são papéis pintados com tinta", como bem afirmou o poeta português Fernando Pessoa (2006, p. 96). E, nessa condição material, é um objeto fabricado por "técnicos especialistas": impressores, diagramadores, desenhistas, ilustradores, revisores, costuradores, capistas, encadernadores, indiciadores etc (HOUAISS, 1983). A presença desses outros sujeitos interfere na materialidade do impresso, no caso analisado, o livro escolar. Neste sentido, a materialidade do livro constitui aspecto fundamental para se conhecerem as práticas de leitura realizadas a partir desse suporte.

Como bem afirmou Enric Satué (2004, p. 17),

Fisicamente, o livro é um conjunto de folhas impressas - agrupadas em fascículos ou cadernos numerados em ordem crescente e costurados para funcionar como sanfona - inseridas, coladas e protegidas por uma encadernação ou capa. A UNESCO define-o ainda mais laconicamente: impresso não periódico que agrupa num só volume mais de 49 páginas, excluídas as capas. Quando menor chama-se opúsculo ou folheto (ou plaqueta); quando formado de mais de um volume, rotula-se obra $^{116}$.

De modo geral, um livro possui a seguinte estrutura física ${ }^{117}$ :

1. Elementos externos: sobrecapa, capa, lombada ou dorso, orelha, quarta capa ou contracapa e folha de guarda;

\footnotetext{
115 Para análise da materialidade, recorri a várias obras de referência que tratam do processo de editoração do livro: FARIA, Maria Isabel e PERICÃO, Maria da Graça. Dicionário do Livro: da escrita ao livro eletrônico. São Paulo: EDUSP, 2008; ARAÚJO, Emanuel. A construção do livro: princípios da técnica de editoração. $2^{\text {a }}$ edição revista e atualizada com o novo acordo ortográfico Rio de Janeiro: Lexikon Editora Digital; São Paulo: Fundação Editora da UNESP, 2008; HOUAISS, Antonio. Elementos de Bibliologia. São Paulo: Hucitec, 1983; LUGARINHO, Airton. No mundo dos livros. Brasília: Editora Universa, 2005; SATUÉ, Enric. Aldo Manuzio: editor, tipógrafo, livreiro. O design do livro do passado, do presente e, talvez, do futuro. Cotia, SP: Ateliê Editorial, 2004, Col. Artes do Livro, vol. 4.

${ }^{116}$ Neste trabalho, contudo, tem-se usado "obra" como sinônimo de "livro", simplesmente, mesmo de 1 só volume.

${ }^{117}$ Segundo Lugarinho, “existem partes de uma obra bibliográfica que estão presentes em praticamente todas as que são publicadas. Não existe legislação sobre esse tema, ficando aos cuidados de cada casa editorial as normas que irão ser usadas e quais as partes que estarão presentes em seus produtos." (LUGARINHO, 2005, p. 67).
} 
2. Elementos pré-textuais: falsa folha de rosto, verso da falsa folha de rosto, folha de rosto, verso da folha de rosto, dedicatória, epígrafe, agradecimentos, nota bibliográfica de autores, sumário, lista de ilustrações, lista de abreviaturas, siglas e símbolos;

3. Elementos textuais: apresentação, prefácio, introdução, texto, conclusão;

4. Elementos de apoio ao texto: citações, tabelas, quadros, figuras distribuídos ao longo do texto com a finalidade de melhorar e facilitar sua compreensão;

5. Elementos pós-textuais: posfácio, glossário, referências, apêndices, anexos e índices.

Em se tratando da produção de livros escolares, o estudo da materialidade ganha especificidades, segundo o historiador português Justino Magalhães (2008):

O manual escolar tem uma materialidade; espécime e produto autoral, editorial, mercantil, ele é mercadoria e produto industrializado e comercializado, com características próprias e que cumpre objectivos específicos nos planos científico, social e cultural. Os seus modos de produção e de circulação envolvem uma cadeia de agentes e estão condicionados por uma série de prerrogativas: dimensões autorais; técnicas e materiais de fabrico e reprodução; processos e percursos produtivos; circunstâncias e condicionalismos de comercialização, circulação,

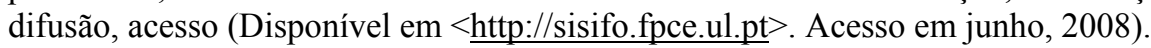

\subsubsection{O livro em suas primeiras edições}

Com base na sua $11^{\text {a }}$ edição, do ano de 1944, pertencente a meu acervo pessoal, procedo, agora, à análise da materialidade do livro História do Brasil para crianças ${ }^{118}$.

Segundo indicações constantes no referido exemplar, o livro teria pertencido a Cleópatra Luiza de Lima e Mello, já que seu nome consta na página de rosto. No referido exemplar, não há nenhuma dedicatória.

\footnotetext{
${ }^{118}$ O referido exemplar foi adquirido em sebos, uma vez que essa obra não mais circula no mercado editorial, sendo sua última edição a do ano de 1984 (28 edição). A Companhia Editora Nacional, responsável pela obra do autor, iniciou desde 2002 a reedição de alguns de seus livros, conforme matéria veiculada na imprensa nacional ("Cazuza abre projeto de reedição da obra de Viriato Corrêa”. Jornal O Estado de S. Paulo. Caderno 2. Ano XVII. 1 de junho de 2002).
} 
Um dos mais importantes aspectos da materialidade do livro diz respeito à capa. É nela que são identificados o título da obra, o nome do autor, a editora responsável pela publicação, além de eventuais ilustrações.

\begin{abstract}
A capa é parte integrante da história de qualquer livro [...]. A capa, sem dúvida, cumpre um papel no processo de envolvimento físico com o livro, pois, embora não se possa olhá-la enquanto se lê, ela o define como objeto a ser apanhado, deixado de lado e talvez conservado ao longo do tempo (POWERS, 2008, p. 7).
\end{abstract}

No caso de História do Brasil para crianças, por se tratar de um livro destinado às crianças $^{119}$, houve preocupação por parte do editor de confeccionar uma capa bastante colorida, atendendo à orientação de Monteiro Lobato: "chamei desenhistas, mandei pôr cores berrantes nas capas. E também mandei pôr figuras" (LOBATO apud HALLEWELL, 1985, p. 251). Ou como diz o próprio Viriato Corrêa, na introdução de seu livro: “Às crianças só interessa o que é vistoso. Os livros que mais lhes sabem são os livros de figuras; as figuras as coloridas; [...]" (CORRÊA, 1944, p. 8). Isso o diferenciava dos vários livros didáticos do mesmo período, que traziam capas monocromáticas, com poucas imagens. Outra diferença refere-se ao preço do livro: segundo informações contidas nos catálogos da CEN, o livro História do Brasil para crianças custava $10 \$ 000$, enquanto vários livros didáticos custavam em torno de $2 \$ 500$ a $12 \$ 000^{120}$.

O livro apresenta-se no tamanho $21 \mathrm{~cm} \mathrm{X} 15 \mathrm{~cm}$, em capa dura ou, como se dizia muito na época, em "capa cartonada". As imagens contidas na capa são, como já mencionei anteriormente, de autoria do escritor e caricaturista Belmonte. São dele também todas as 59 imagens em preto e branco, no decorrer do texto.

\footnotetext{
${ }^{119}$ No que concerne especificamente à materialidade do livro infantil, foram consultados os seguintes trabalhos: LINS, Guto. Livro Infantil?: projeto gráfico, metodologia, subjetividade. São Paulo: Edições Rosari, 2003 (Coleção Textos Design); POWERS, Alan. Era uma vez uma capa: história ilustrada da literatura infantil. São Paulo: Cosac Naify, 2008; OLIVEIRA, Rui de. Pelos Jardins Boboli: reflexões sobre a arte de ilustrar livros para crianças e jovens. Rio de Janeiro: Nova Fronteira, 2008.

${ }_{120}$ No catálogo da CEN, apareciam os seguintes livros didáticos para o ensino de História na escola primária: História da Civilização Brasileira, de Pedro Calmon, no valor de $5 \$ 000$ e Pontos de nossa História, de autoria de Veríssimo e Lourenço de Souza, no valor de $5 \$ 000$, ambos em edição cartonada. Na série II da Biblioteca Pedagógica Brasileira (BPB), referente a manuais, livros de texto e livros fontes, os livros das mais diferentes disciplinas escolares variavam de $2 \$ 500$ (Ler brincando, cartilha de Thales de Andrade) a $12 \$ 000$ (Curso elementar de História Natural, de C. de Mello-Leitão) (Catálogo CEN, 1935, p. 62; 64-65).
} 
$\mathrm{Na}$ capa, sobressaem as cores amarela, verde, azul e branca (cores nacionais), expressão da nacionalidade brasileira, com toques das cores vermelha e preta. $\mathrm{O}$ título do livro e o nome do autor estão em cor preta, com bastante destaque, bem como o nome da editora, em branco, sob uma tarja preta que perpassa toda a capa, no rodapé. Já o nome do ilustrador Belmonte aparece no pé da capa, ao lado direito, em tamanho menor. 


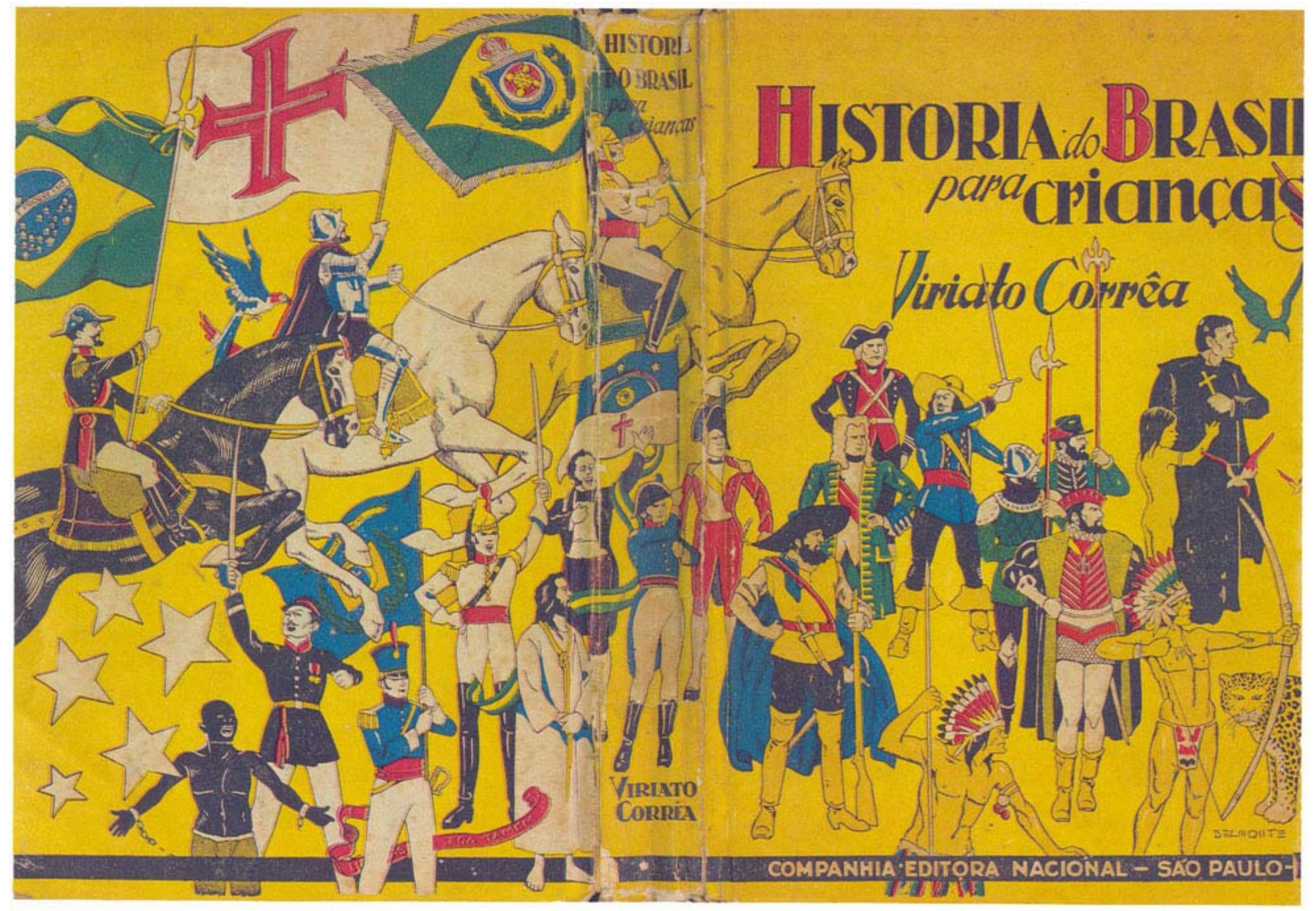

Figura 44 - História do Brasil para crianças (capa e contracapa) Fonte: CORRÊA, 11 ${ }^{\mathrm{a}}$ ed., 1944. 


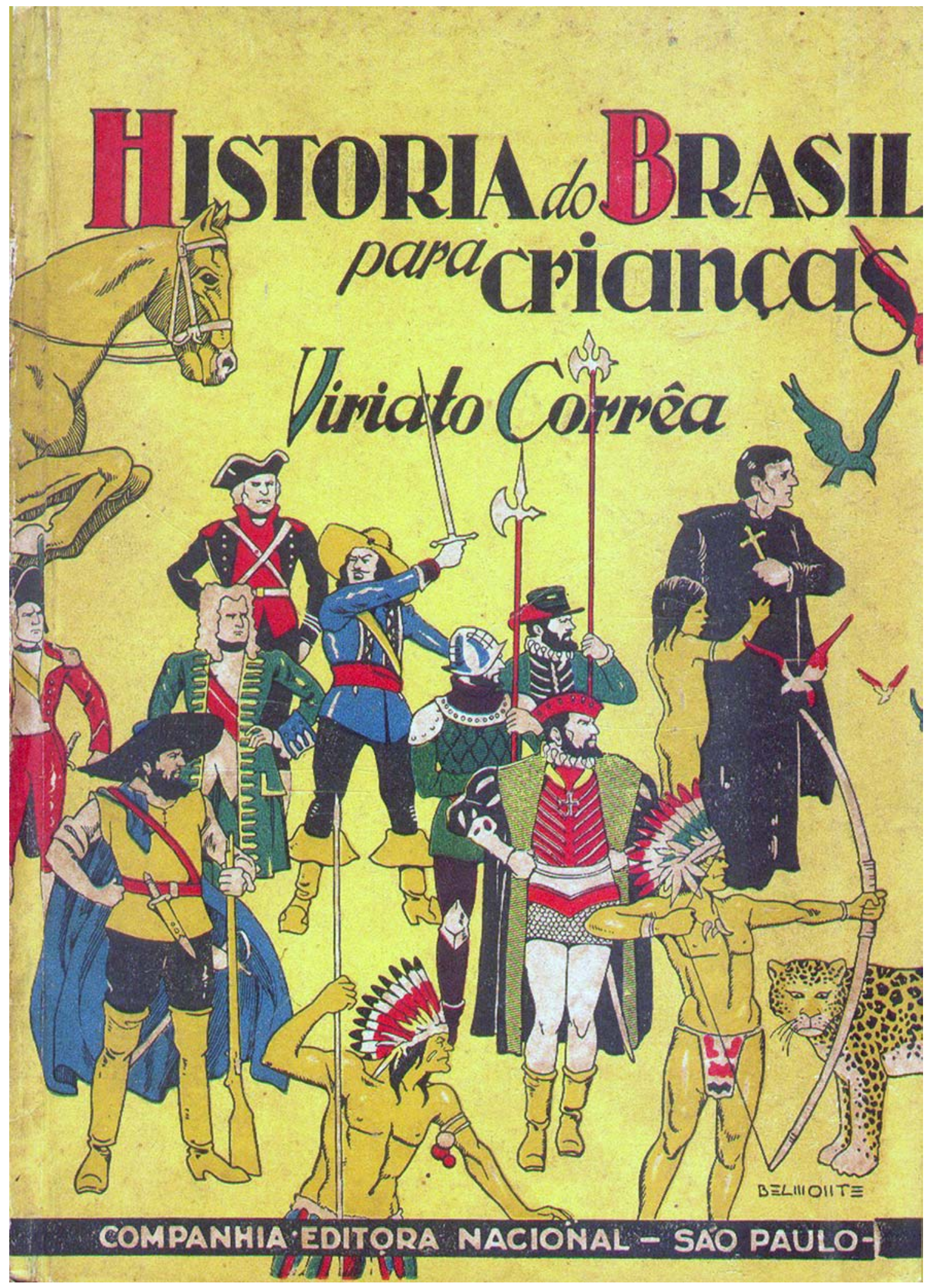

Figura 45 - História do Brasil para crianças - Capa (reprodução em tamanho original - 15 x $21 \mathrm{~cm}$ ). Fonte: CORRÊA, $11^{\mathrm{a}}$ ed., 1944.. 


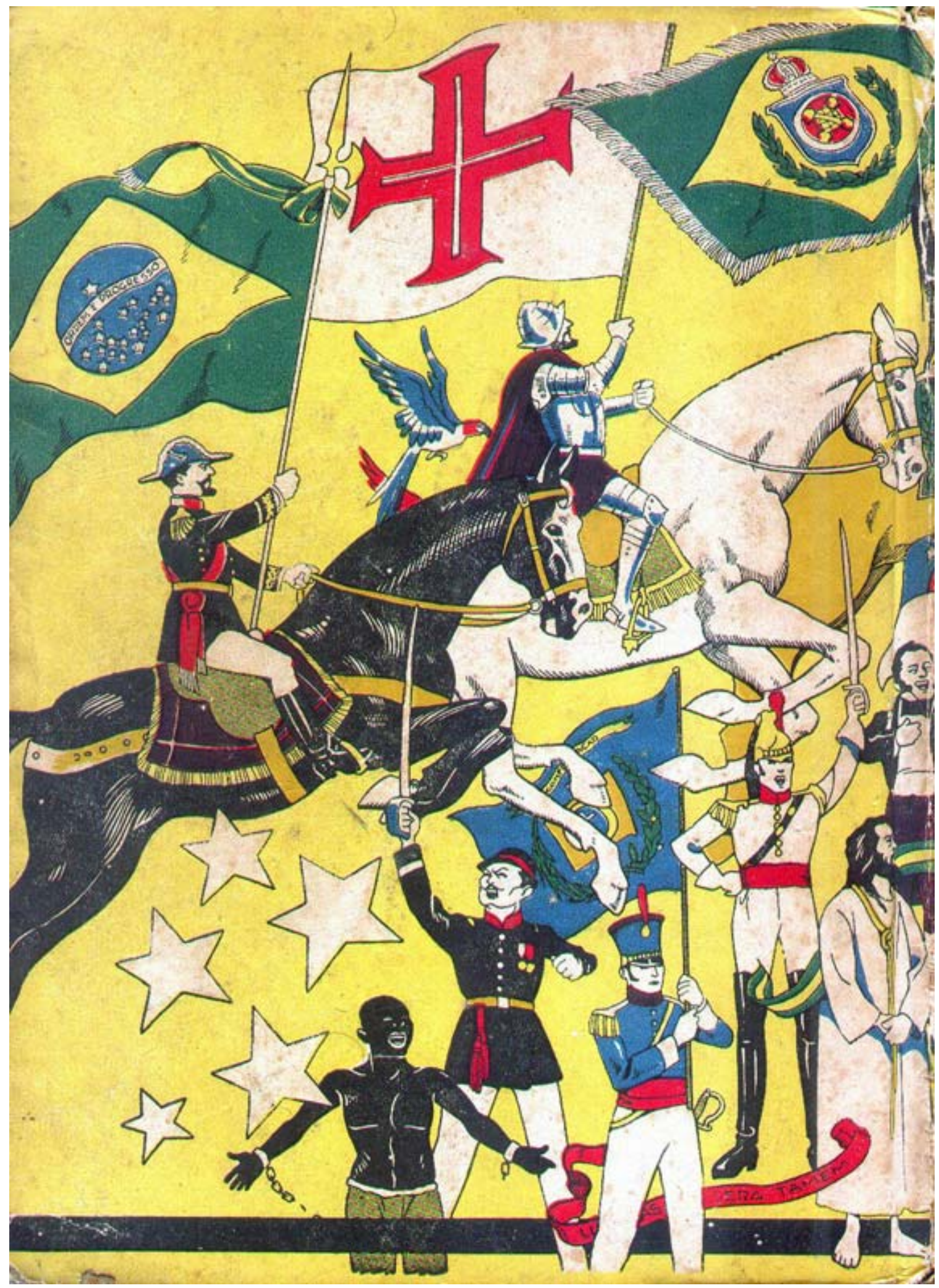

Figura 46 - História do Brasil para crianças - Contracapa (reprodução em tamanho original - 15 × $21 \mathrm{~cm}$ ). Fonte: CORRÊA, 11ª ed., 1944. 
O escritor argentino Jorge Luís Borges indaga acerca do livro para além de sua materialidade: "Que é um livro, se não o abrimos? É, simplesmente, um cubo de papel e couro, com folhas. Mas, se o lemos, acontece uma coisa rara: creio que ele muda a cada instante" (BORGES, 2002, p. 20).

Abrindo-se a capa, há a chamada "falsa página de rosto" (ante-rosto ou falso frontispício), que traz impresso apenas o título do livro - História o Brasil para Crianças.

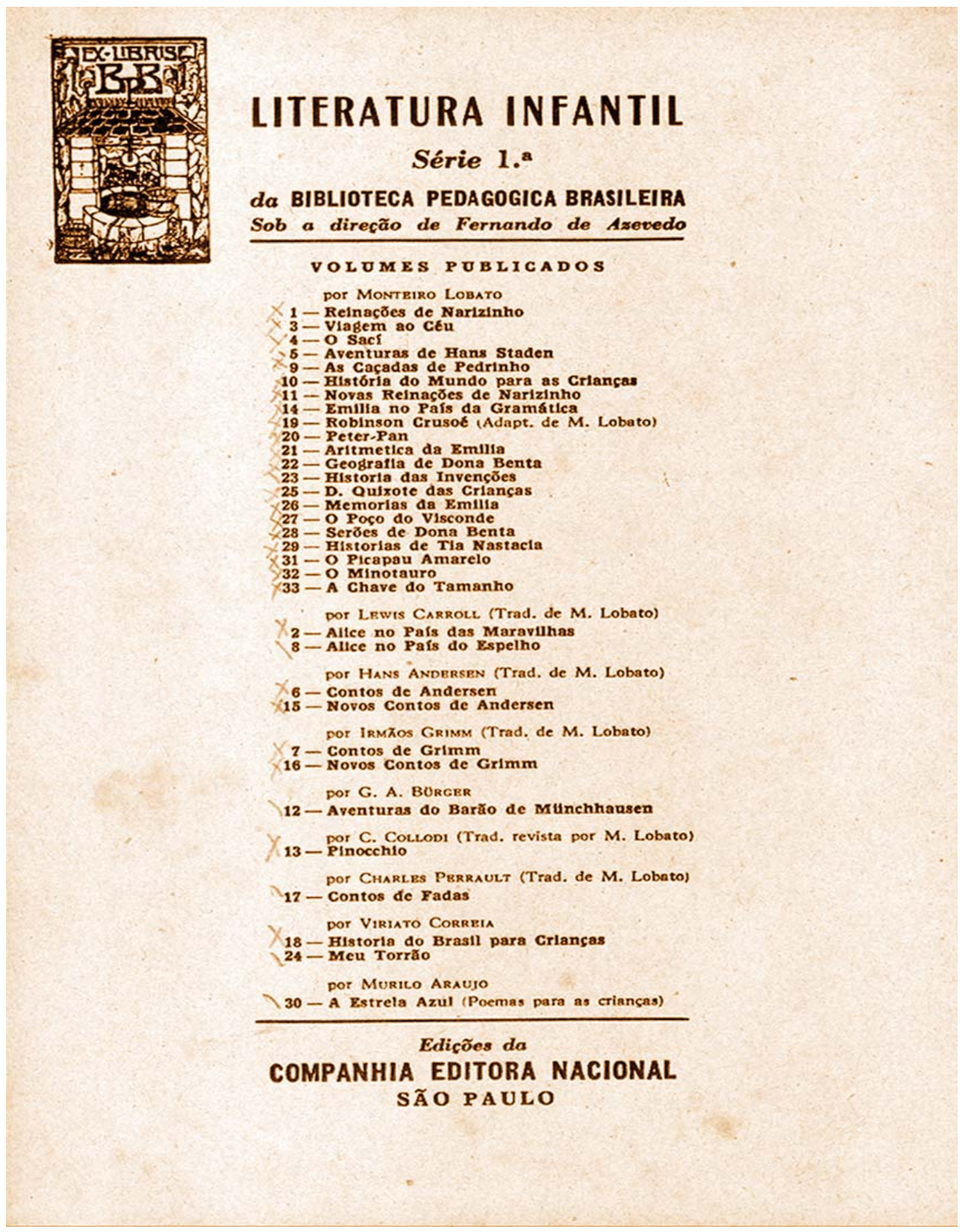

Figura 47 - História do Brasil para crianças - Verso da falsa página de rosto do livro. Fonte: CORREAA, $11^{\mathrm{a}}$ ed., 1944. 
No verso da falsa página de rosto, constam o respectivo Ex-Libris ${ }^{121}$ da Biblioteca Pedagógica Brasileira e a relação dos volumes publicados na série $1^{\mathrm{a}}$ (Literatura Infantil).

Na página de rosto ${ }^{122}$, também conhecida como "frontispício", constam as seguintes informações: no alto da página, a referência de que o livro em pauta pertence à Biblioteca Pedagógica Brasileira, sendo o vol. 18, da Série 1ª (LITERATURA INFANTIL); logo abaixo, o nome do autor - VIRIATO CORREAA - com a seguinte referência entre parênteses: Da Academia Brasileira de Letras. Ao colocar essa referência, quis o editor mostrar o local social de onde fala o autor, como forma de legitimação da obra. Como disse anteriormente, Viriato foi o primeiro autor de literatura infanto-juvenil a ingressar nos quadros da ABL.

No centro da página de rosto, encontram-se novamente o título do livro (História do Brasil para crianças) e, logo abaixo, a seguinte indicação entre parênteses: Ilustrações de BELMONTE, 11 ${ }^{a}$ EDIÇÃO. No pé da página, a logomarca da Coleção Biblioteca Pedagógica Brasileira, o nome da editora e os locais de suas filiais (COMPANHIA EDITORA NACIONAL - São Paulo - Rio de Janeiro - Bahia - Recife - Porto Alegre) e o ano da publicação (1944).

No verso da folha de rosto, constam a respectiva tiragem de cada uma das edições do livro e o número do exemplar (no caso, $\mathrm{N}^{\circ} 3.569$ ). Da primeira à nona edição, foram editados 51 mil exemplares de História do Brasil para crianças.

Na página seguinte, consta a dedicatória do autor ao seu amigo e incentivador Paulo de Albuquerque Maranhão. Em seguida, foi reproduzida a carta do historiador Rodolfo Garcia ao autor, datada de 1 de outubro de 1934, anteriormente analisada.

\footnotetext{
${ }^{121}$ No caso referido, o ex-libris servia para indicar os livros que pertenciam à Biblioteca Pedagógica Brasileira (BPB), funcionando mais como uma logomarca da coleção. "O ex-libris, sabe-se, é aquela etiqueta, colada geralmente nas primeiras folhas de um livro ou na contracapa, contendo o nome ou as iniciais do proprietário e podendo, através de uma imagem ou texto, indicar sua profissão, seus gostos, seu ideário, ou até (nem sempre) discreto lembrete a eventual surrupiador da obra. [...] Por meio dos ex-libris é que os bibliófilos, ou leitores que prezam os seus livros e se orgulham da sua biblioteca, costumam personalizar cada um dos seus volumes. Daí, justamente, a origem do nome: em latim, 'ex libris' significa 'dentre os livros de', 'da biblioteca de", (MARTINS FILHO, 2008, p. 11).

${ }^{122}$ Para Satué, a página de rosto "é o verdadeiro cartão de identidade do livro, pois nela figuram: o título completo (em corpo maior que o do ante-rosto, embora menor que o da capa), o subtítulo ou as partes, nome e sobrenome do autor e a identificação da editora (logotipo, denominação, cidade e ano de edição)." (SATUÉ, 2004, p. 18).
} 
Na página seguinte, segue uma pequena introdução do autor sobre o livro, em que ele explicita sua concepção de ensino de História para crianças:

As crianças so interessa o que é vis-
toso.
Os livros que mais thes sabem sio os livros de figuras; as figuras - as coloridas; os brinquedos - os que deslumbram os olhos; os objetos - os que lhes enchem a vista.

Na história, mesmo na da Carochinha, o que thes fere a imaginaçio é o lado aparatoso. O aspecto filosófico produz-lhes enfado e sono.

Neste livro procura-se dar à criancas apenas a superficic vistosa da história brasileira. Nada de filosofia. Nada de profundos aspectos históricos que thes possam causar bocejos.

Figura 48 - História do Brasil para crianças.

Fonte: CORRÊA, $11^{\text {a }}$ ed., 1944, p. 8.

Nas páginas 9 e 10, consta o índice com os respectivos capítulos do livro, em algarismos romanos (Cap. I, I [...] IX, X), num total de 59. O livro possui 237 páginas e 59 ilustrações em preto e branco, de Belmonte, correspondendo a uma para cada capítulo. 


\section{ÍNDICE}

CAP.

PAG

I - O contador de histórias . . . . . 11

II - O mundo antigo . . . . . . . 14

III - O louco . . . . . . . . . . . . . 18

IV - A Pindorama . . . . . . . . . 21

$\mathrm{V}$ - Na terra das palmeiras . . . . 25

VI - Plantas e bichos da Pindorama . . $\quad 29$

VII - A gente da Pindorama . . . . . . 32

VIII - O navegador espanhol . . . . . . 35

IX - O navegador portuguẽs . . . . . . 39

$X$ - O lar de Bartira. . . . . . . 45

XI - O lar de Paraguassú . : . . . 48

XIl - O lar de Maria do Espírito Santo. 51

XIII - A desgraça das capitanias . . . 54

XIV - A triste sorte de Vasco Coutinho . . $\quad 59$

XV - A cana-de-açúcar . . . . . . . 62

XVI -- As primeiras boiadas . . . . . 66

XVII - Os padres jesuitas . . . . . . . . 69

XVIII - Os fundadores da civilização brasileira $\quad \mathbf{7 4}$

XIX - As primeiras cidades . . . . . . 76

$\mathrm{XX}$ - Cidades que eram aldeias . . . . $\quad 79$

$\mathrm{XXI}$ - O Eldorado e as amazonas . . . 83

XXII - A França Antártica . . . . . 87

XXIII - O Maranhão e os franceses. . . 90

XXIV - A conquista dos holandeses . . . 95

XXV - O principe de Nassau . . . . . . . 99

XXVI - A queda dos flamengos . . . . $\quad 102$

XXVII - O primeiro ensaio . . . . . . . 105

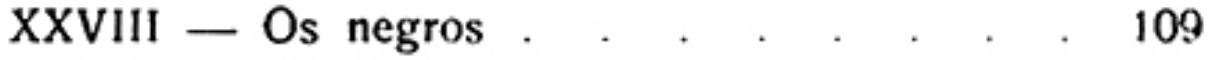

Figura 49 - História do Brasil para crianças - Índice.

Fonte: CORREAA, $11^{\mathrm{a}}$ ed., 1944, p. 9. 
CAP.

PÁG.

XXIX - Palmares . . . . . . . . . 112

XXX - Bandeiras e bandeirantes . . . . 115

XXXI - Antônio Raposo e Fernão Dias . . 119

XXXII - As minas de ouro . . . . . . 124

XXXIII - As pedras maravilhosas . . . 127

XXXIV - Paulistas e emboabas . . . . . 131

XXXV - O corsário que vencemos . . . . 135

XXXVI - O corsário que nos venceu . . . 140

XXXVII - A linha de Tordesilhas . . . . . 144

XXXVIII - O sentimento da independência . . 148

XXXIX - A figura maravilhosa de Tiradentes . 150

XL - A morte de Tiradentes . . . . . 154

XLI - Os costumes dos nossos avós . . . 158

XLII - Grandes homens . . . . . . . . 162

XLIII - A mesa brasileira . . . . . . 166

XLIV - A chegada da côrte portuguesa . . 170

XLV — Os sonhadores de 1817 . . . . 174

XLVI - O Fico . . . . . . . . . . . 179

XLVII - Na colina do Ipiranga . . . . . 183

XLVIII - A dissolução da Constituinte . . . 186

XLIX - Os republicanos de 1824 . . . . 190

L — Sete de abril . . . . . . . . . 193

LI - Nove anos de sangue . . . . . 197

LII - O reinado do homem pacífico . . . 200

LIII - A guerra do Paraguai . . . . . 204

LIV - Riachuelo e Tuiutí . . . . . . 207

LV - Um figurão da nossa história . . . 210

LVI - Ainda o figurão . . . . . . . . . 214

LVII - 13 de maio . . . . . . . . 216

LVIII - 15 de novembro . . . . . . . 220

LIX - Palavras do fim . . . . . . . . . 224

Figura 50 - História do Brasil para crianças - Índice.

Fonte: CORRÊA, $11^{\mathrm{a}}$ ed., 1944, p. 10. 
Logo após o título de cada capítulo, há uma pequena sinopse dos conteúdos que serão nele abordados. Por exemplo, no capítulo XV - A CANA-DE-AÇÚCAR, que trata da exploração desse produto no Período Colonial de nossa história, há a seguinte sinopse: “Os primeiros canaviais. Os primeiros engenhos de açúcar. As gulodices açucaradas. O luxo de Olinda" (CORRÊA, 1944, p. 62). Essa sinopse em cada capítulo assemelha-se aos itens de um programa curricular a ser seguido pelo professor, o que denota o caráter didático desse livro infantil.

No decorrer do texto e como forma de torná-lo mais didático e ao alcance do universo das crianças, encontra-se o significado de algumas palavras, ao pé da página. É o único elemento de apoio ao texto encontrado no livro.

Como na maioria dos didáticos do período, não há elementos pós-textuais (glossário, referências bibliográficas, apêndices e anexos). No verso da última página, consta o chamado "colofão", com a indicação do local e da gráfica onde o livro foi impresso (São Paulo Editora Limitada, imprimiu).

\subsubsection{Mudanças em suas últimas edições}

Geralmente, um manual escolar passa por diversas modificações no decorrer de sua vida útil. Muitas vezes, essas modificações são feitas para atender à necessidade de atualização da obra, ou às mudanças no currículo escolar e, até mesmo, aos interesses do mercado editorial, com o objetivo de torná-lo mais vendável. História do Brasil para crianças sofreu, no decorrer de cinqüenta anos de circulação no mercado editorial, algumas modificações quanto à sua materialidade.

A primeira edição do livro História do Brasil para crianças (1934) fazia parte da BPB, série Literatura Infantil (série 1ª, vol. 18), coordenada por Fernando de Azevedo. Essa primeira edição era em capa "solidamente cartonada" e continha ilustrações, em cores muito fortes, do escritor e caricaturista Belmonte. Na capa, há o registro de que o livro pertence à coleção da BPB. A partir da $4^{\mathrm{a}}$ edição (1935), o índice foi colocado no início do livro. 
Em 1939, em sua $7^{\text {a }}$ edição, foi acrescentada ao nome do autor Viriato Corrêa, entre parênteses na página de rosto, a seguinte referência: Da Academia Brasileira de Letras.

A partir da $13^{\mathrm{a}}$ edição (1946), houve a substituição, no decorrer do texto, de algumas imagens que permaneceram até a última edição.

$\mathrm{Na} 14^{\mathrm{a}}$ edição (1949), houve mudança no tamanho da capa, mas permaneceram as mesmas imagens de Belmonte. Acredita-se que essa edição constituiu-se em um "livroprêmio", dada à sua especificidade material: capa dura, tamanho maior, lombada vermelha com letras douradas.

Após a aprovação da Comissão Nacional do Livro Didático, do MEC, o livro sofreu importantes modificações (24 edição, 1961). O próprio exemplar traz o registro de autorização da referida Comissão: "Livro de uso autorizado pelo Ministério da Educação e Cultura, e registrado na Comissão Nacional do Livro Didático sob n 966" (CORRÊA, 1961, p. 4). A capa manteve-se cartonada, mas houve mudança na sua ilustração: Belmonte produziu imagens estilizadas. Eliminou-se a sinopse depois do título de cada capítulo, as ilustrações adquiriram um fundo de cor rósea e quatro delas ficaram coloridas ${ }^{123}$.

Mesmo de forma estilizada, a capa ${ }^{124}$ preserva as imagens de personagens históricos ligados ao poder instituído, como na capa anterior. Mais uma vez, o destaque é dado à figura do bandeirante, que se sobressai das demais. A ilustração parece indicar certo evolucionismo ou progresso cultural: em primeiro lugar, na contracapa, encontra-se um índio, seguido de um padre jesuíta e uma mulher indígena. Na capa, vê-se um bandeirante, uma mulher presumivelmente ligada aos setores abastados da sociedade, devido aos seus trajes, e uma figura do colonizador.

Acima do título, o desenho de um dirigível denota idéia de progresso. A inovação dessa capa reside na inclusão de duas figuras femininas, o que não havia na primeira capa.

\footnotetext{
${ }^{123}$ As ilustrações coloridas constam nos seguintes capítulos: O navegador espanhol (p. 40); A França Antártica (p. 94); Antônio Raposo e Fernão Dias (p. 128) e A figura maravilhosa de Tiradentes (p. 158).

${ }^{124}$ A capa dessa nova edição assemelha-se a capas de outros livros didáticos publicados pela CEN: SILVA, Joaquim. História do Brasil ( $1^{\mathrm{a}}$ série ginasial). São Paulo: CEN, 1961 e HERMIDA, Borges. História do Brasil. 5a série. São Paulo: CEN, 1983. (MÁSCULO, 2008, p. 60).
} 


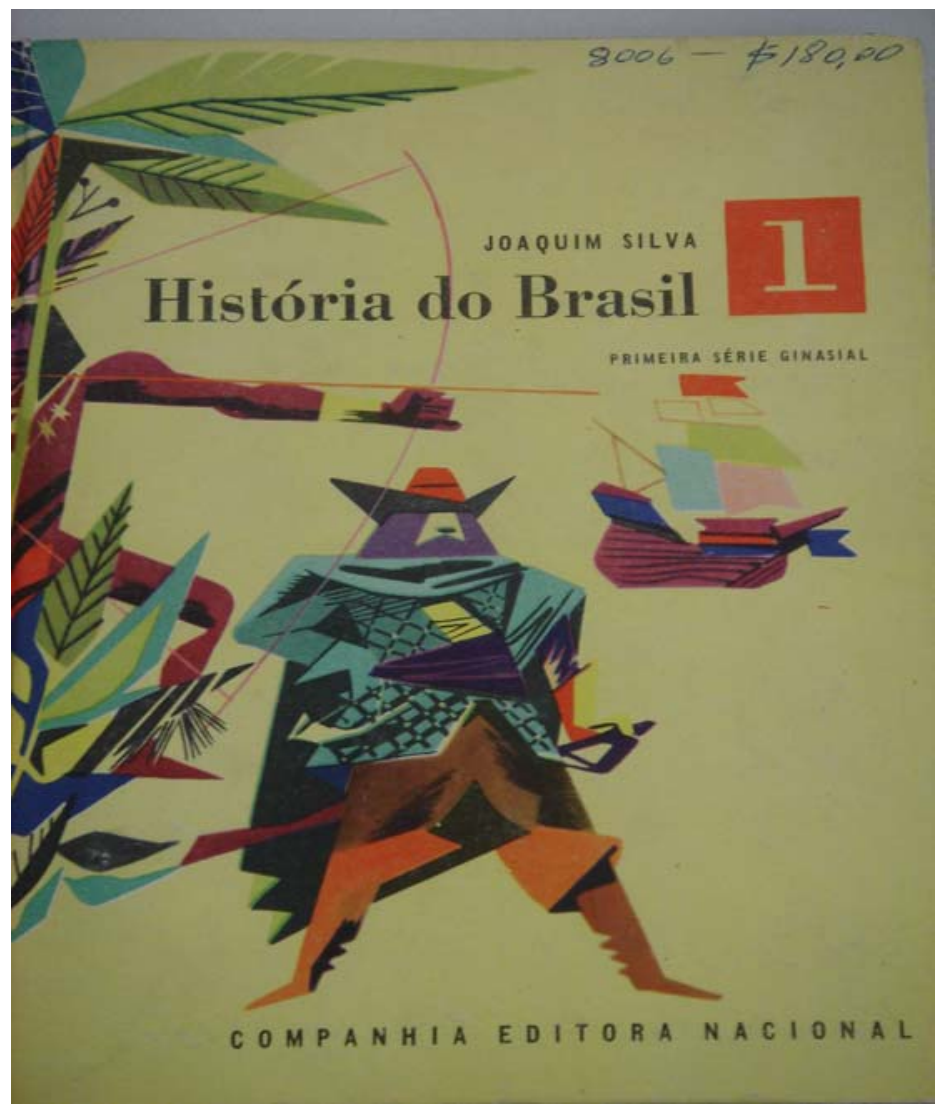

Figura 51 - História do Brasil - capa. Fonte: SILVA, 1961.
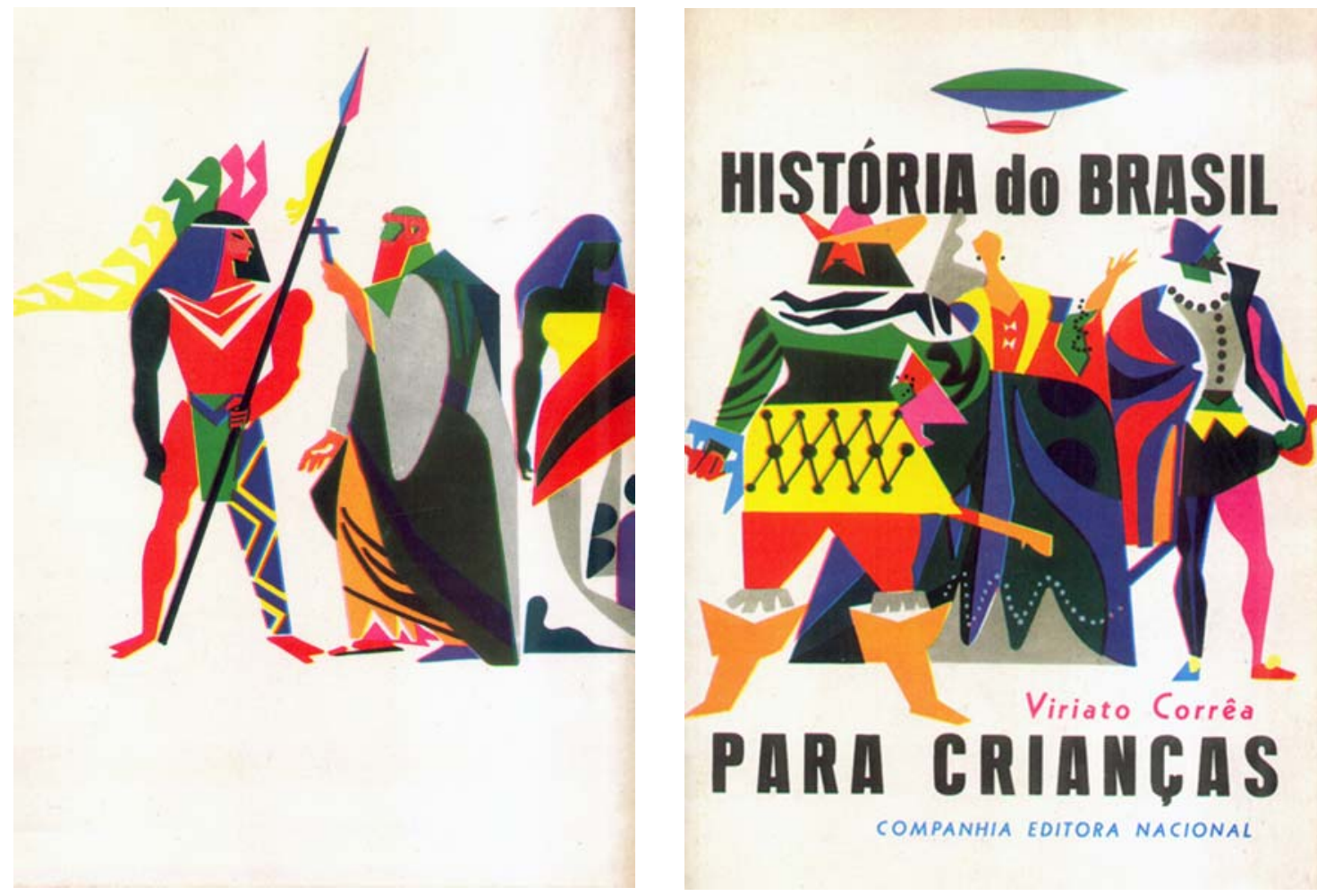

COMPANHIA EDITORA NACIONAL

Figuras 52 e 53 - História do Brasil para crianças - capa e contracapa de Belmonte. Fonte: CORRÊA, 24ª ed., 1961. 


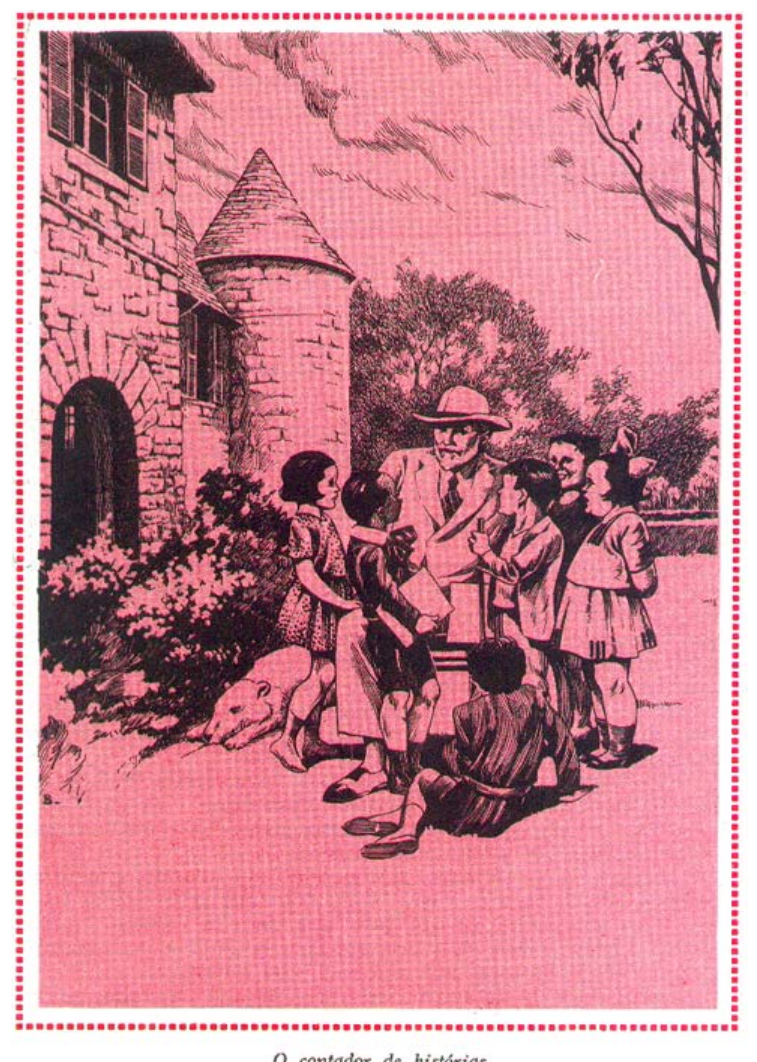

Figura 54 - História do Brasil para crianças ilustração colorida de Belmonte.

Fonte: CORRÊA, 24ª ed., 1961.

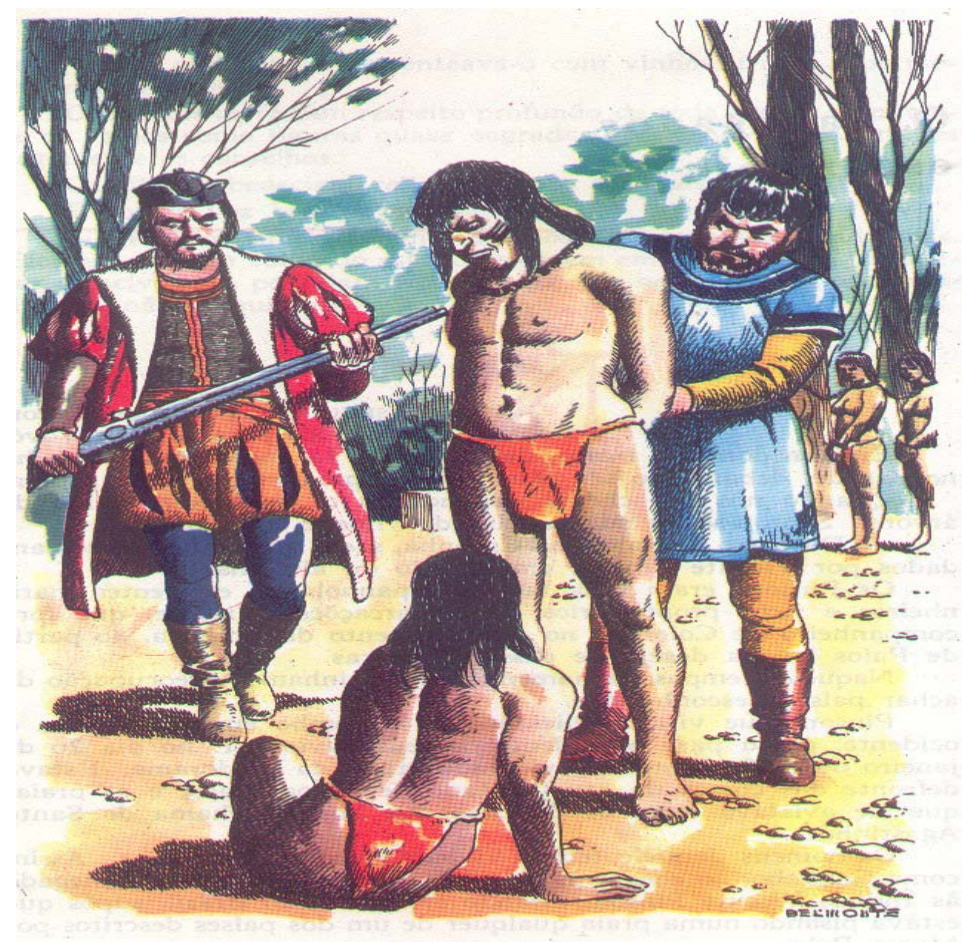

o navegador espannol

Figura 55 - História do Brasil para crianças - ilustração colorida de Belmonte Fonte: CORRÊA, 24ª ed., 1961. 
Já na $27^{\mathrm{a}}$ edição (1982), talvez como forma de ter barateado seu preço, o livro passou a circular em capa mole, também conhecida como "capa rústica", mas com as mesmas ilustrações e disposição gráfica anteriores.

A última edição de História do Brasil para crianças é do ano de 1984. O livro circulou durante cinqüenta anos no mercado editorial brasileiro, com uma tiragem bastante expressiva, num total de 154.090 exemplares, conforme tabela abaixo:

\begin{tabular}{|c|c|c|}
\hline \multicolumn{3}{|c|}{ MOVIMENTO DE EDIÇÕES } \\
\hline \multicolumn{3}{|c|}{ Obra: História do Brasil para crianças } \\
\hline \multicolumn{3}{|c|}{ Autor: Viriato Corrêa } \\
\hline Série: Infantis & & \\
\hline Data & Edicão & Tiragem \\
\hline $1 / 11 / 1934$ & $1 / 3$ & 13.000 \\
\hline $26 / 4 / 1935$ & 4 & 6.000 \\
\hline $9 / 6 / 1936$ & 5 & 6.067 \\
\hline $14 / 9 / 1937$ & 6 & 5.966 \\
\hline $27 / 4 / 1939$ & 7 & 6.000 \\
\hline $14 / 6 / 1940$ & 8 & 7.050 \\
\hline $10 / 8 / 1942$ & 9 & 7.100 \\
\hline $11 / 5 / 1944$ & $10 / 11$ & 10.105 \\
\hline $29 / 5 / 1946$ & $12 / 13$ & 10.173 \\
\hline 14/12/1949 & $14 / 15$ & 9.860 \\
\hline $10 / 12 / 1952$ & $16 / 17$ & 10.040 \\
\hline $2 / 9 / 1955$ & $18 / 19$ & 10.003 \\
\hline $2 / 8 / 1957$ & $20 / 22$ & 15.103 \\
\hline $26 / 10 / 1961$ & $23 / 25$ & 15.187 \\
\hline $29 / 8 / 1967$ & 26 & 10.056 \\
\hline $2 / 8 / 1982$ & 27 & 7.476 \\
\hline \multirow[t]{2}{*}{$30 / 1 / 1984$} & 28 & 4.904 \\
\hline & Total & 154.090 \\
\hline
\end{tabular}

Pela tabela acima, nota-se que o período de maior tiragem do livro deu-se entre os anos 40 e 60, com duas edições por ano. O livro deixou de ser editado em meados da década de 80, talvez pelas mudanças ocorridas na própria Editora, com a morte de seu fundador Octalles Ferreira e a posterior venda ao Governo Federal.

A partir dos anos 70, já se constatava um considerável declínio na venda dos livros de Viriato Corrêa, como atesta a carta da Editora enviada à viúva do autor, Maria das Dores 
Viriato Corrêa ${ }^{125}$. Nos anos de 1974, 1975 e 1976, por exemplo, o livro História do Brasil para crianças só tinha vendido o montante de 405, 697 e 72 unidades, respectivamente, embora houvesse no estoque da Editora o total de 2.071 exemplares.

Ainda no que se refere à materialidade do livro, não podemos deixar de mencionar a questão relativa aos direitos autorais. Em pesquisa realizada no acervo histórico da CEN, constatou-se que Viriato Corrêa recebia 10\% sobre a venda do livro História do Brasil para crianças.

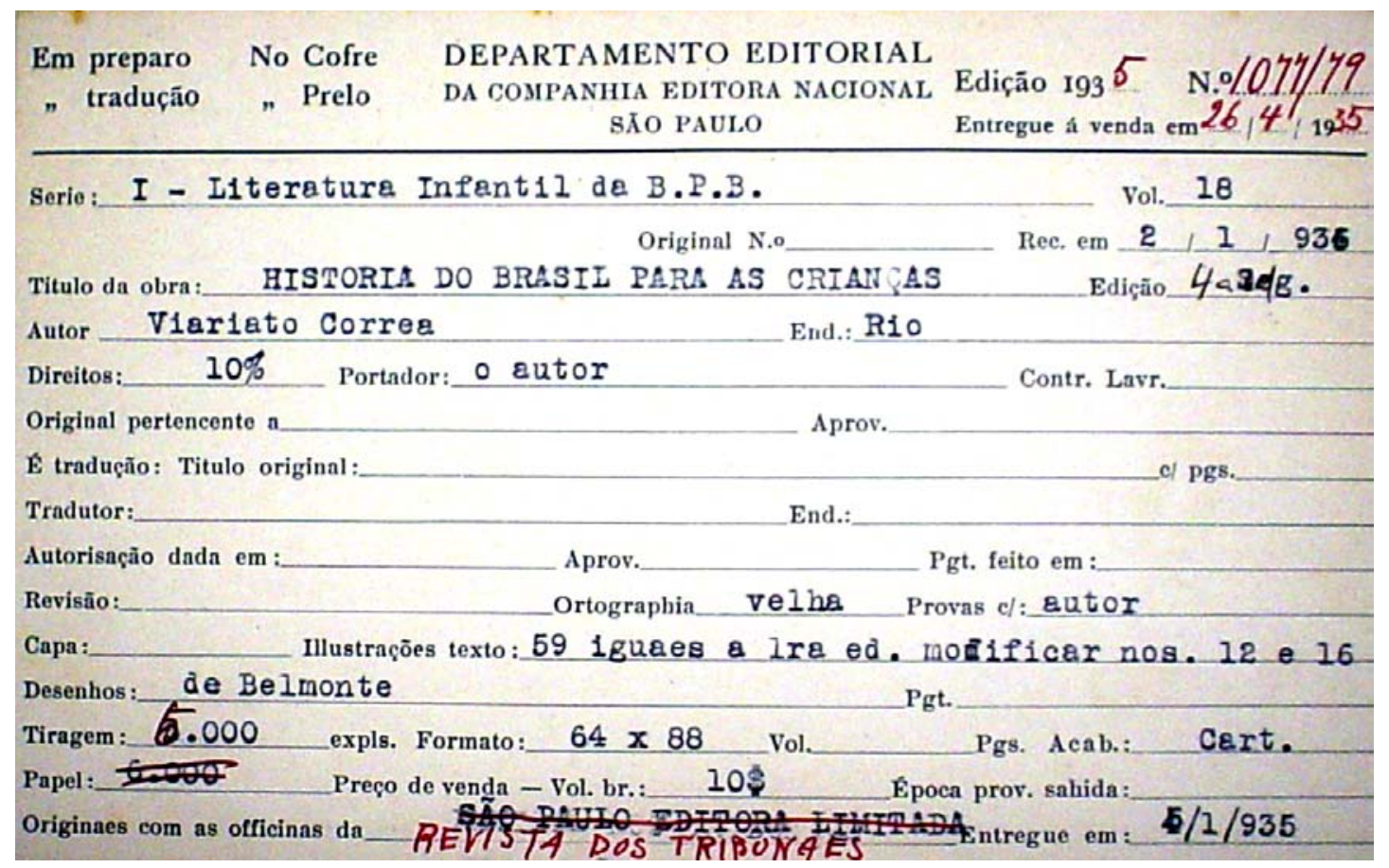

Figura 56 - Ficha do Departamento Editorial da CEN - 1935.

Fonte: Acervo CEN.

Pela ficha cadastral, constata-se também que, um ano após a sua publicação, em 1935, já estava sendo providenciada a $4^{\mathrm{a}}$ edição de História do Brasil para crianças. Para essa nova edição, a tiragem de 5 mil exemplares foi impressa na Gráfica da Revista dos Tribunais, em São Paulo, sendo o livro posto à venda no dia 26.04 .1935 , ao preço de $10 \$$. Não há informações acerca dos direitos autorais relativos aos desenhos de Belmonte para o referido livro.

\footnotetext{
${ }^{125} \mathrm{Na}$ carta, o Departamento Comercial da CEN sugere como solução para a queda na venda dos livros de Viriato que eles sejam vendidos ao valor de CR \$ 4,50 (quatro cruzeiros e cinqüenta centavos), ao invés de CR\$ 15,00 (quinze cruzeiros), tendo em vista o interesse de um comprador em adquirir todo o estoque, o que foi aceito pela viúva e beneficiária dos direitos autorais de Viriato (Arquivo Histórico CEN - Dossiê Viriato Corrêa).
} 


\subsection{Divulgação e circulação}

\subsubsection{Divulgação}

No estudo da história das práticas de leitura, Chartier (1999) chama atenção para o fato de que, no processo de produção de um livro, há dois conjuntos de dispositivos e que cada um possui suas especificidades, a saber: os procedimentos de produção do texto que dizem respeito à elaboração do texto pelo escritor, com o objetivo de produzir efeitos que garantam a boa leitura por parte do leitor; e os procedimentos de produção do livro. Esses últimos dizem respeito ao papel do editor/livreiro, que se utiliza de estratégias para seduzir o leitor, dando um suporte ao texto do autor. Assim, o editor ${ }^{126}$ recorre à utilização de cores nas capas, tipos diferenciados de letras, uso de ilustrações, melhor disposição gráfica dos capítulos etc. Como produto de mercado, o editor procura tornar o livro um objeto de venda prazeroso ao seu potencial consumidor - o leitor.

Cabe ao editor, além da publicação, a função de divulgar a obra e fazer com que circule no comércio, a fim de que possa ser adquirida e lida pelos leitores - sua finalidade última. Para os estudiosos da editoração, está implícita, na tarefa do editor, ao publicar determinado impresso, a "ação de torná-lo publicamente conhecido, isto é, difundido, distribuído, consumido e lido" (BRAGANÇA, 2005, p. 222).

No caso de História do Brasil para crianças, o editor lançou mão das seguintes estratégias de divulgação: catálogos de edição, boletim de novidades aos livreiros, publicação de resenhas em anúncios de jornais e revistas, divulgação da obra na contracapa de outros livros da própria editora. Outras formas adotadas foram a sessão de autógrafos e a realização de palestras com o autor.

\footnotetext{
${ }^{126}$ Segundo Bragança, "palavra de origem latina, editor indica-nos dois movimentos: 'dar à luz' e 'publicar'. Surge em Roma antiga para identificar aqueles que assumiam a responsabilidade de multiplicar e de cuidar das cópias dos manuscritos originais dos autores, zelando para que fosse correta a sua reprodução." (BRAGANÇA, 2005, p. 220). Para a moderna editoração, "editor possui o sentido de pessoa encarregada de organizar, i.e., selecionar, normalizar, revisar, para publicação, os originais de uma obra e, às vezes, prefaciar e anotar os textos de um ou mais autores." (ARAÚJO, 2008, p. 37).
} 
A primeira divulgação da obra deu-se com a publicação do anúncio em dezembro de 1934, já analisado no Capítulo 1, que circulou em revistas e jornais da época: "FAÇA SEU FILHO VIVER NO MELHOR DOS MUNDOS: O MUNDO DOS LIVROS" (BOLETIM ARIEL, 1934, p.1).

Nos catálogos de edição da CEN, sempre houve destaque para as obras de Viriato Corrêa e, em especial, para História do Brasil para crianças.

Somente no ano de seu lançamento, conforme o catálogo da CEN, História do Brasil para crianças vendeu cerca de 20 mil exemplares, ficando atrás apenas de História do Mundo para crianças (35 mil) e Emília no País da Gramática (25 mil), ambos de Monteiro Lobato. A CEN comemorava o feito na vendagem das referidas obras: "SÓ EM 1934! TRÊE DEGRAUS INSUPERÁVEIS".

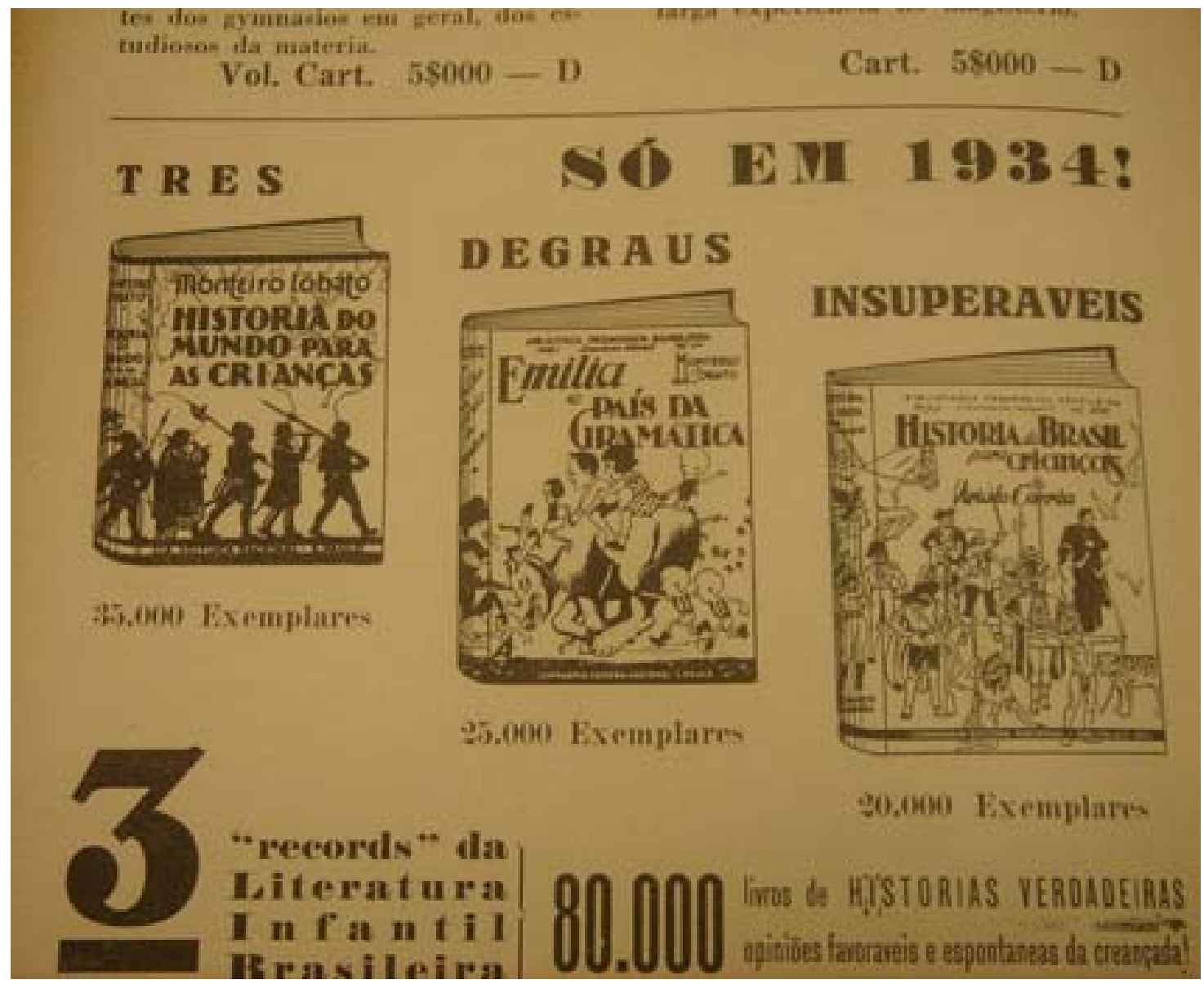

Figura 57 - Catálogo da CEN (1935, p. 62). Fonte: Acervo CEN. 
História do Brasil para crianças era considerado um dos três recordes da literatura infantil brasileira no ano de 1934 . Já em sua $4^{a}$ edição, o Catálogo da CEN trazia a seguinte resenha da obra:

HISTÓRIA DO BRASIL PARA CRIANÇAS - se há um livro que vai contribuir poderosamente para vulgarizar e tornar atraente a História do Brasil, é esse que escreveu Viriato Corrêa. Ele pôs a história pátria ao nível das crianças, mas com tanta fidelidade e tamanha arte de fixar o essencial, que acaba interessando também os adultos. Livro delicioso, admiravelmente ilustrado por Belmonte, de um extraordinário alcance educativo e destinado a realizar por si só, nas escolas, uma grande obra de brasilidade e de espírito nacional. Grosso volume com 59 ilustrações de páginas solidamente cartonado.

$4^{\mathrm{a}}$. edição, 20. Milheiro........10\$000 (Catálogo CEN, 1935, p. 30).

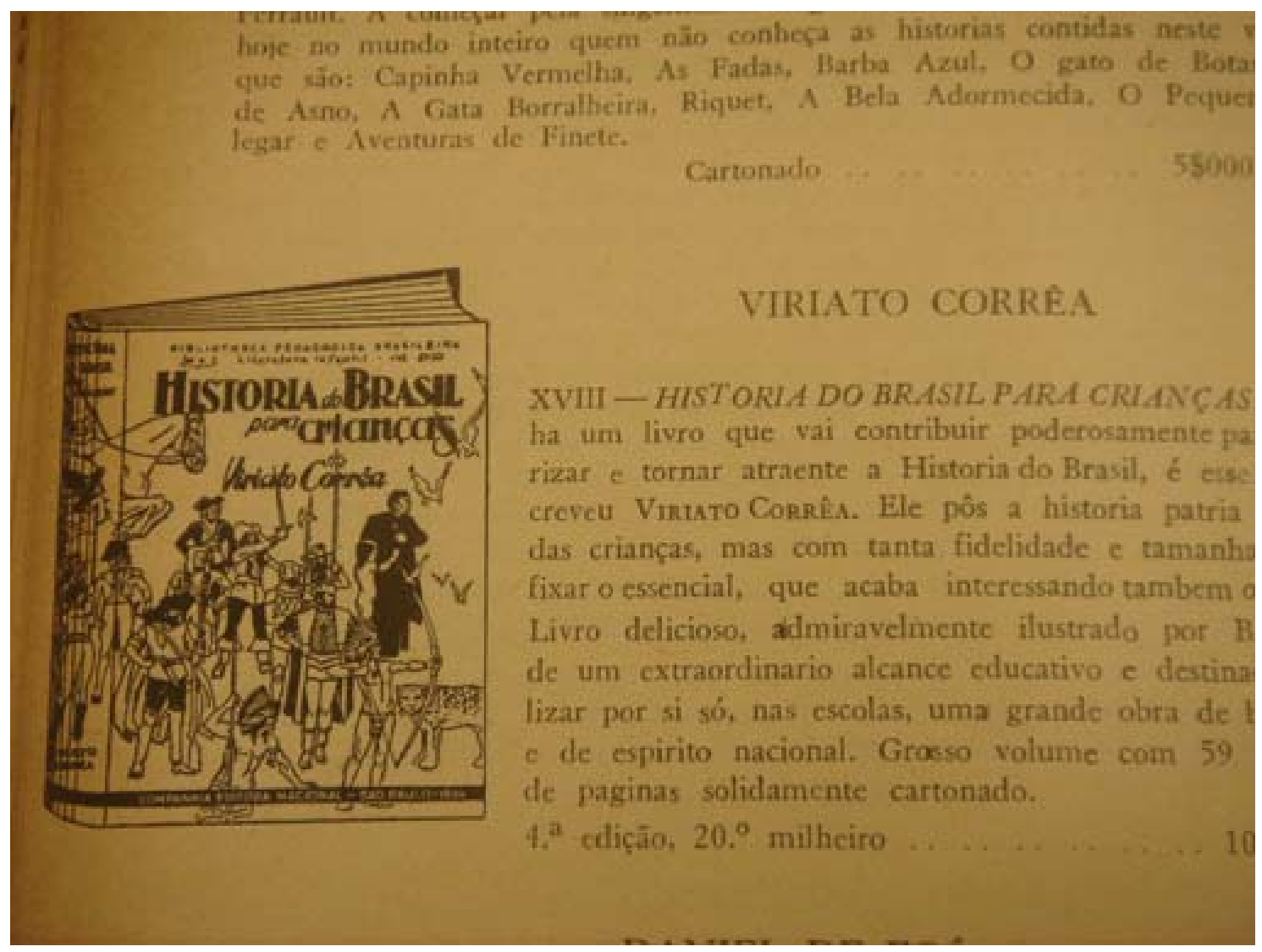

Figura 58 - Catálogo da CEN, 1935 (destaque para o livro História do Brasil para crianças).

Fonte: Acervo CEN.

No seu boletim de novidades, distribuído aos livreiros e representantes da Editora em todo o território nacional, a CEN dava mais uma vez destaque ao livro. 
HISTÓRIA DO BRASIL PARA CRIANÇAS

Viriato Corrêa - nova edição - Cr $\$ 25,00$.

Partindo do princípio de que às crianças só interessa o que é vistoso, Viriato Corrêa escreveu este livro de História do Brasil, que, despido de qualquer tintura de interpretação árida do desenrolar dos fatos históricos, é nada mais nada menos que uma deliciosa sucessão de contos, através dos quais, insensivelmente, tudo o que há de mais importante na vida do Brasil é visto e compreendido. As ilustrações de Belmonte enriquecem grandemente o trabalho (NOVIDADES, ano II, edições de abril a junho de 1946, $\left.\mathrm{n}^{\circ} .11\right)$.

Como já vimos anteriormente, era estratégia de marketing editorial da CEN lançar livros por ocasião das festas natalinas e incentivar os pais e familiares a presentearem as crianças com livros.

\begin{abstract}
Sr. Livreiro,
Aproximando-se o fim do ano, é natural que todos os comerciantes se preocupem com aquilo que oferecerão ao público para a época natalina. Realmente, é o Natal, logo seguido do Ano Novo, a ocasião oportuna para a troca de presentes entre todos que têm entre si fundos laços afetivos e, também, entre aqueles que julgam conveniente a oferta de lembranças, por quaisquer razões.

O livro - seja-nos permitido incidir num lugar-comum - é, entre os presentes realmente significativos, entre aqueles que não são uma simples 'lembrancinha', o presente mais barato, sem que seu baixo custo em comparação com o de outros artigos o deprecie. Pelo contrário, dar um livro é uma demonstração de bom gosto, carinho, vontade de ser útil.

Assim sendo, permitimo-nos, no presente Boletim, o último de 1969, chamar a atenção de V. Sa. para algumas de nossas edições em estoque (inclusive algumas bem recentes) que nos parecem apropriadas para o fim de ano e Natal.

Literatura Infantil: edições cartonadas, em prático formato, ilustradas, a preços bem acessíveis.

Viriato Corrêa: A BANDEIRA DAS ESMERALDAS, BELAS HISTÓRIAS DA HISTÓRIA DO BRASIL, Cazuza, HISTÓRIAS DA HISTÓRIA BRASILEIRA, HISTÓRIA DO BRASIL PARA CRIANCCAS, A MACACADA, MEU TORRÃO.

Thales de Andrade: SAUDADE, CAMPO E CIDADE.

V.M. Hillyer: GEOGRAFIA PITORESCA PARA CRIANÇAS, PEQUENA HISTÓRIA DO MUNDO PARA CRIANÇAS (Boletim de Novidades da CEN, novembro de 1969, grifo nosso).
\end{abstract}

Como se vê, ainda no final de década de 60, os livros de Viriato Corrêa, entre os quais História do Brasil para crianças, eram destaque da CEN, ao lado de obras de autores também consagrados, como Thales de Andrade e seu livro infantil Saudade. Essa e outras estratégias de divulgação contribuíram para o sucesso de Viriato junto ao público leitor-mirim. 
Outra forma de divulgação bastante usada pela CEN foi publicar pequenas resenhas ou chamadas desse livro na contracapa de outros livros escolares publicados pela Editora.

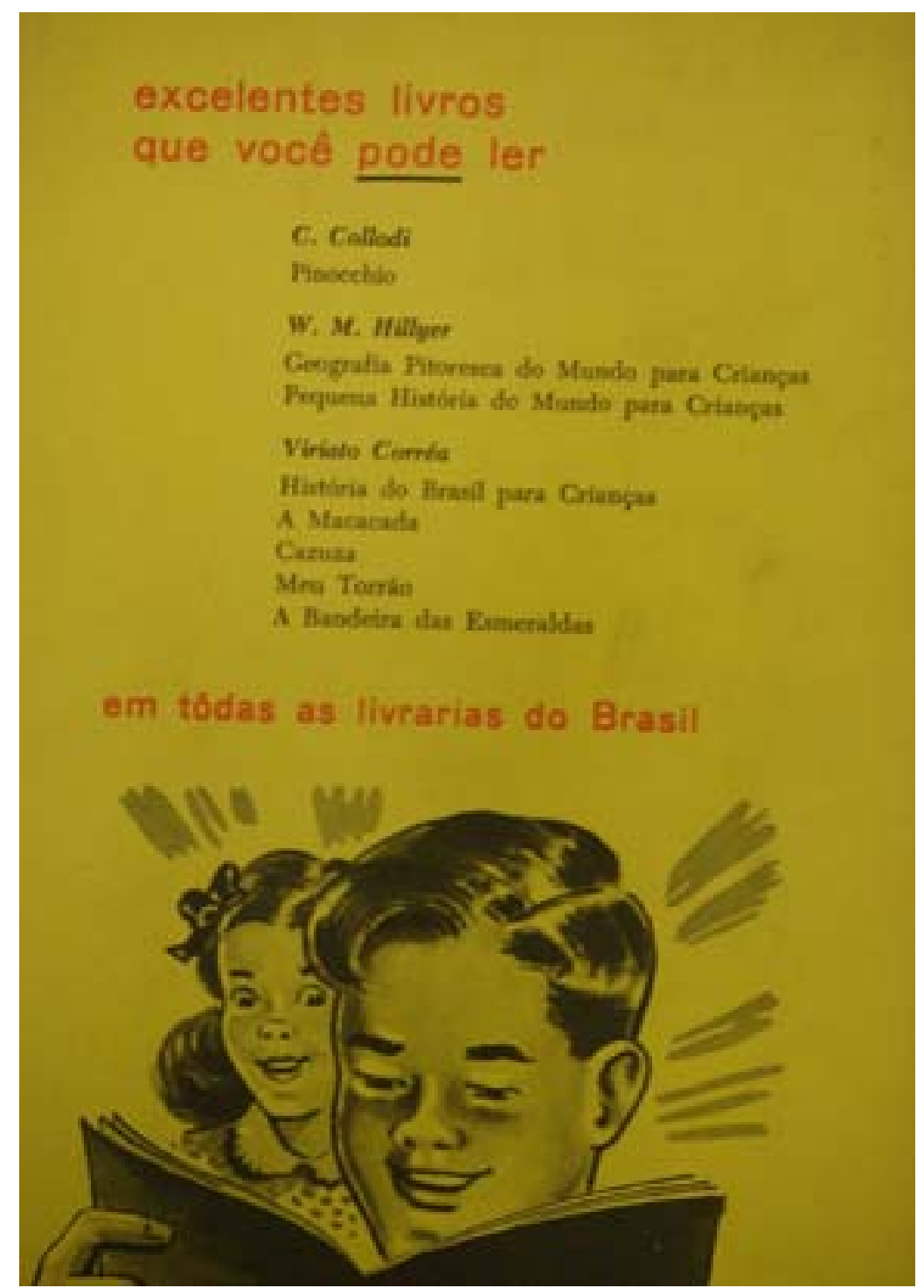

Figura 59 - Divulgação dos livros de Viriato Corrêa na contracapa do livro Nosso Brasil.

Fonte: Acervo CEN.

Resenhas do livro também eram publicadas em periódicos de circulação nacional:

O Sr. Viriato Corrêa, que logo no começo de sua carreira tanto deliciou as creanças com as suas historias destinadas ao mundo infantil, procura falar-lhes agora do nosso passado, dos nossos varões históricos, dos nossos acontecimentos gloriosos. A narração é em linguagem adequada ao publico de saias curtas e calças curtas, evidentemente o auditório a que o escriptor maranhense se dirige sempre com maior prazer. Optimanente ilustrado pelo grande desenhista Belmonte, o livro fará o regalo 
da gente miúda e é bem provável que a segunda edição não tarde a vir por ahi (BOLETIM DE ARIEL mensário crítico-bibliographico de Lettras, Artes, Sciencias, Rio de Janeiro, fevereiro de 1935, ano IV, $\mathrm{n}^{\circ} 5$, p. 46).

O lançamento ou relançamento de seus livros eram sempre noticiados pela imprensa:

Paulo de Albuquerque Maranhão, conhecedor das virtudes literárias desse fascinante contador de história que é Viriato Corrêa, dirigiu-lhe um apelo, por carta, há vários anos, no sentido de que o intelectual maranhense escrevesse a história pátria para crianças. O escritor meteu-se em brios e o livro apareceu. Com ele a História do Brasil, sem passar da realidade para a fantasia, mas escoimada de profundos aspectos de interpretação e de certas chatices tão comuns, mantendo-se na superfície vistosa dos fatos, surgiu encantatória para a garotada. Tanto que hoje, com 150 mil exemplares vendidos, é posta em sua $25^{\mathrm{a}}$. Edição pela Companhia Editora Nacional (Viriato Corrêa, Diário de Notícias, Porto AlegreRS, 27.12.1962, grifo nosso).

Após Cazuza, livro pelo qual Viriato ficou mais conhecido, História do Brasil para crianças era sempre sugerido para a leitura das crianças.

Grande parte da produção literária infantil de Viriato Corrêa, por exemplo, está sendo novamente editada pela Nacional: livros bonitos, de características marcadamente brasileiras, ilustrados a cores, e destinados a figurar com destaque nas bibliotecas da petizada. História do Brasil para crianças (vigésima quinta edição), hoje somando cerca de cento e cinqüenta mil exemplares já vendidos, é uma história gostosa, atraente, de nossa história; 'Cazuza' (11 ${ }^{\mathrm{a}}$. Edição), mais de cinqüenta mil exemplares editados. 'A Bandeira das Esmeraldas'; 'Meu Torrão'e 'A Macacada'são livros de Viriato Corrêa que a Nacional acaba de colocar nos balcões das livrarias e que representam o que há de mais sadio, atraente e instrutivo para a leitura da garotada (Viriato Corrêa, Estado de São Paulo, 17.11.1962, grifo nosso).

\subsubsection{Circulação}

Morador do Rio de Janeiro, o escritor Viriato Corrêa era bastante conhecido no meio jornalístico carioca. Os jornais locais noticiavam, em pequenas notas, o lançamento de livros do autor com respectiva sessão de autógrafos. Nessa ocasião, as crianças tinham contato direto com o autor. 


\begin{abstract}
Autografando para a Criançada
A exemplo do que fez ontem, em Copacabana, na livraria Eldorado, quando autografou suas obras infantis para a gurizada do bairro, Viriato Corrêa repetirá a sessão, na próxima semana, na Tijuca.

Como se sabe, o livro de Viriato Corrêa, a 'História do Brasil para crianças', já teve mais de 100 mil exemplares vendidos em todo o país, sendo inúmeras as suas edições (Correio da Manhã, Rio de Janeiro, 20.12.1959, grifo nosso).
\end{abstract}

A divulgação de sua obra não ficava restrita à então capital do País, conforme notícia veiculada no jornal "O Diário":

Livros de Viriato Corrêa para crianças

Depois de Monteiro Lobato é Viriato Corrêa o autor de livros para crianças de maior tiragem no Brasil. É bastante dizer que somente a sua 'História do Brasil para crianças' já atingiu muito mais de 100 mil exemplares.

A Companhia Editora Nacional lança agora para o Natal várias reedições de histórias infantis de Viriato: 'A Bandeira das Esmeraldas', quarta edição, com ilustrações de Belmonte; 'A Macacada', oitava edição, com ilustrações de Dorca; 'Cazuza', oitava edição, com ilustrações de Renato Silva; 'Meu Torrão', quinta edição, com ilustrações de Belmonte - além da vigésima segunda edição da já referida 'História do Brasil para crianças' (Jornal "O Diário", Belo Horizonte-MG, sessão No mundo dos livros, 19.12.1957, s/p, grifo nosso).

Além disso, Viriato Corrêa era sempre convidado para eventos em escolas públicas e privadas, o que o tornava conhecido das crianças. Empresas também o convidavam a ministrar palestras sobre fatos de nossa história.

Quando estive no Serviço de Educação Cívica da Prefeitura, era com satisfação imensa que ia todos os anos ouvir Viriato, na Escola Tiradentes, falando ele cada ano sobre um aspecto novo do Proto-Mártir, com erudição e entusiasmo.

Esta nota de brasilidade é um dos [traços] característicos de Viriato, tanto nos livros de história como literatura. Também nos infantis é marcante esse feitio, fazendo de Viriato um autêntico valor nacional.

Como conferencista, quando as conferências literárias empolgavam a cidade, Viriato foi um dos mais brilhantes, ao lado de Medeiros, Bilac, Neto, Alcindo, João do Rio, Alberto, Luiz Edmundo. [...] (Vida Cultural: a vida intensa de Viriato Corrêa, assinada por Nelson Costa, Correio da Manhã, Rio de Janeiro-RJ, 23.01.1959, grifo nosso).

Atendendo a um convite do Serviço de Relações Públicas do Departamento de Correios e Telégrafos (DCT), o escritor e historiador Viriato Corrêa, da Academia Brasileira de Letras, compareceu ontem, às 10 horas, à sede do Correio Geral (Rua Primeiro de Março, 64), onde contou histórias de correios para alunos das escolas públicas Argentina, Afonso Pena, Pedro Varela e Tiradentes (Colegiais ouviram 
histórias de Viriato e viram roteiro das cartas para Papai Noel, O Jornal, Rio de Janeiro-RJ, de 02.12.1960).

Está sendo realizado no Colégio São Vicente de Paulo a Semana do Livro, promoção anual da direção do estabelecimento, objetivando incentivar, nos alunos do curso primário, de admissão e ginasial, o interesse pela boa leitura. Como parte da programação [...], foi instituído um debate sobre uma obra literária. Este ano foi escolhido 'Cazuza', de Viriato Corrêa, que foi convidado para o debate. Um grupo de alunos, dividido em defesa e acusação, incumbiu-se da leitura e análise da obra, para discuti-la publicamente perante um júri de alunos e professores (Estudantes debaterão com Viriato Corrêa as histórias de Cazuza, O Globo, 13.06.1963, grifo nosso).

A própria $\mathrm{ABL}$ e outras instituições culturais, ao promoverem cursos e conferências, noticiando-as para o grande público através dos jornais locais, contribuíam, também, para a divulgação da obra.

\begin{abstract}
Cursos
Curso de Historiografia do Brasil. Realiza-se hoje, às 17:30 hs, na Academia Brasileira de Letras, a conferência do acadêmico Viriato Corrêa, sobre o tema 'Cronistas do Século XVII' (Jornal Correio da Manhã, Rio de Janeiro, 03.07.1958).

Viriato Corrêa proferiu palestra sobre a proclamação da República no âmbito do curso ' $\mathrm{O}$ que se deve saber sobre alguns aspectos da história e geografia do Rio', patrocinado pelo Instituto Histórico e Geográfico do Rio de Janeiro, no salão nobre da Escola Nacional de Belas Artes (Rio é palha seca para fogo de todo boato: Viriato Corrêa fala da proclamação da República..., Correio da Manhã, Rio de Janeiro-RJ, de 06.09.1958).
\end{abstract}

Os jornais também se encarregavam da divulgação da obra de Viriato Corrêa, noticiando a reedição de seus livros e sugerindo-os como leitura para a gurizada.

Como está chegando o Natal, um livro que recomendo para presente destinado à garotada é a História do Brasil para crianças, do acadêmico Viriato Corrêa, agora em 23 . Edição (Cia. Editora Nacional) - o que já representa um índice de qualidade e êxito. $O$ texto é o que há de melhor: afeito a este gênero de trabalho, há muitos anos, o conhecido escritor brasileiro trocou em miúdos o nosso passado, narrando fatos e focalizando figuras num leve tom de narrativa, que muito agrada ao público de menoridade. E ilustrando o texto, desenho a cores de Belmonte (CAVALCANTI, 1961, grifo nosso). 
Segundo jornalistas, Viriato Corrêa era um escritor conhecido pelas crianças das décadas de 40, 50 e 60 do século passado e querido por elas.

\begin{abstract}
Viriato Corrêa vai fazer setenta e cinco anos em janeiro. Essa honrada e laboriosa vida já não pertence somente a ele. [...]_ o nosso grande Viriato escreveu para a infância. Se eu cometesse a barbaridade de me esquecer disso, não havia fogo de purgatório que me livrasse de pecado. As crianças sabem. E quando as crianças sabem, Deus sabe. Quando Deus sabe, o melhor é proclamar alto tudo o que se tem a proclamar. $\mathrm{O}$ autor de Cazuza, História do Brasil para crianças, Histórias da nossa História é um grande amigo da infância. As crianças retribuem essa amizade com juros maravilhosos. Fora o incrível campeonato de tiragem (cento e muito mil exemplares da História do Brasil para crianças) Viriato conta com o bem querer de uma infinidade de meninos e meninas, o que não é brinquedo. Fale em Viriato Corrêa para um menino que aprecie livros e verá seu rosto se iluminar. [...] Em janeiro completará setenta e cinco anos. Merecia, não um dia de festa. Mas uma semana inteira de comemorações (BENEDETTI, 1958, grifo nosso).
\end{abstract}

Por fim, para demonstrar que Viriato Corrêa era um dos principais escritores de livros infantis e que História do Brasil para crianças foi um livro bastante lido pela infância brasileira, transcrevo a apreciação de Leonardo Arroyo, crítico literário de literatura infantil:

Dois recentes lançamentos da Editora Nacional, 'Saudade', de Tales de Andrade, e 'História do Brasil para crianças', de Viriato Corrêa, o primeiro na $55^{\mathrm{a}}$ e o segundo na $25^{\text {a }}$ edição, marcam um reencontro com a infância, com os velhos tempos do descompromisso e da descoberta permanente. São dois livros que não envelhecem e carregam aquele frescor [...]. Uma simples vista de olhos no livro de Viriato Corrêa faz-nos voltar aos bancos escolares e à alegria das ilustrações coloridas de Belmonte, quando o volume surgiu, pela primeira vez nas livrarias, em 1934. E então, já mais pela graça das narrativas do que especificamente pelos temas, a História do Brasil se tornava uma doida aventura que a imaginação acrescentava de modo considerável, imaginando mais coisas além dos próprios fatos históricos. O 'contador de histórias' de Viriato Corrêa ressurge novamente na sua imortalidade, pela magia da nova edição do seu livro.” (ARROYO, 1962, grifo nosso). 


\subsection{Usos}

\subsubsection{Pela infância}

Por ter sido inicialmente lançado como livro de literatura infantil, acredita-se que História do Brasil para crianças tenha sido leitura extensiva de grande parte das crianças brasileiras. Algumas dedicatórias encontradas em exemplares da obra levam-nos a essa conclusão, pois era muito comum à época presentear livros infantis em datas festivas ou como prêmio escolar.

A escritora Cecília Meireles (1901-1964) reporta-nos a esse momento solene que faz parte da cultura escolar - a entrega de prêmios aos melhores alunos - e que, aliás, atesta o fato de que a escola exercia papel fundamental no incentivo à prática da leitura:

Livros assim, nem os que antigamente se distribuíam como prêmios, e cujo luxo todo consistia em algumas gravuras, encadernação em percalina, com discreto arabesco, e as beiras das páginas douradas. [...] Como se tudo isso não fosse suficiente, a esses livros encantados se acrescentavam as emoções do dia de recebêlos: palanques floridos, encerramento de aulas, hinos cívicos, nome na lista dos prêmios, dedicatórias, aniversários, mesas de doce, Natal, roupa nova, maravilhosos sapatos transbordantes de presentes [...] (MEIRELES, 1984, p. 36-7).

Um dos aspectos do uso que era dado ao livro pelos alunos são as marcas deixadas por eles no corpo do texto, tais como rabiscos, indicação de datas, desenhos etc. São as "cicatrizes da leitura" de que fala Debus (2006, p. 35):

O livro carrega cicatrizes da leitura, denunciando as mãos que lhe tocaram. Rastros que são deixados pelo leitor ao longo da caminhada da leitura: marcador de páginas, fitinhas coloridas, calendário do ano passado, dobras e orelhas, vincos, riscos, registros. Marcas que delatam a fragilidade e a fatal perenidade do livro em sua feição material. 
Serie $t^{n} \quad$ LITERATURA INFANTIL BIBLIOTECA PEDAOOOICA BRASILEIRA

Vol. 18

\section{VIRIATO CORREA}

(Da Aralemia Brasileira de Lems)

\section{História do Brasil}

\section{para \\ Crianças}

Mustraçes de BELMONTE

\section{1." EDICX̃o}

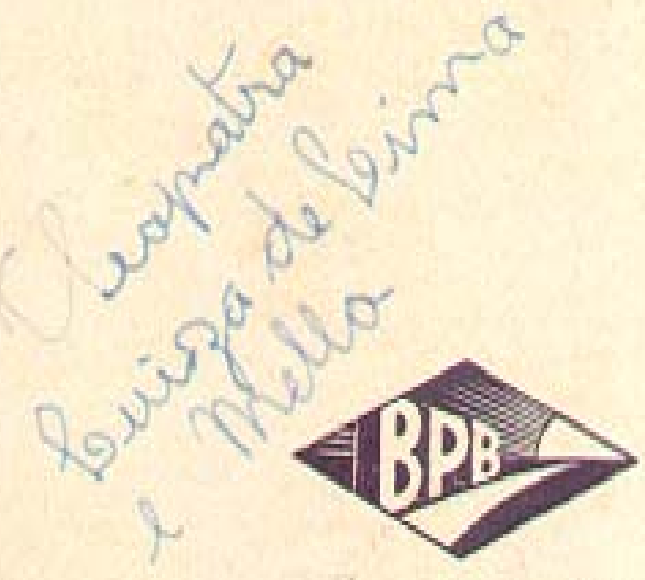

COMPANHIA EDITORA NACIONAL Swo Paub - Rio de Janeiro - Rahia - Rowle - Poro Alegre 1944

Figura 60 - Assinatura da criança na página de rosto ("cicatriz" ou "marca" de leitura). Fonte: CORRÊA, $11^{\text {a }}$ ed., 1944. 
No exemplar analisado, pertencente à Cleópatra Luiza de Lima e Mello, uma das marcas deixadas por ela, além da assinatura na folha de rosto, foi a de pintar com lápis-de-cor muitas ilustrações de Belmonte em preto-e-branco, dotando-as de um colorido particular e individualizado. Nesse momento, a leitora "ganha um espaço, assina aí sua existência de autor" (DE CERTEAU, 2005, p. 94).
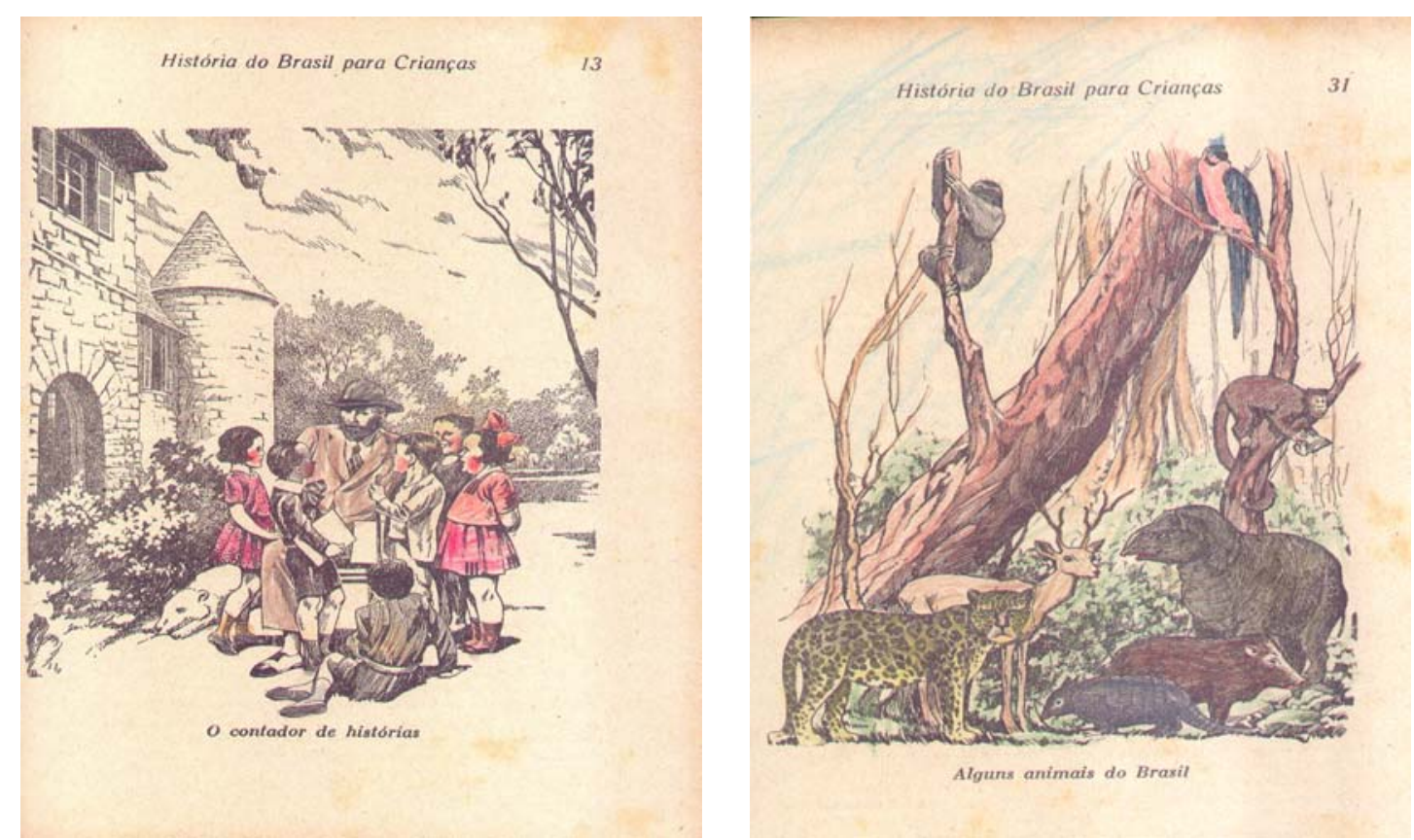

Figuras 61 e 62 - História do Brasil para crianças. Fonte: CORRÊA, $11^{\mathrm{a}}$ ed., 1944.

\subsubsection{Pelo professor}

Outro fato que nos leva a concluir que o livro foi bastante usado pela infância, sobretudo na escola, é sua indicação como bibliografia nos manuais de Didática destinados à formação do professor primário. Por ser indicado em livros de formação continuada, História do Brasil para crianças pode também ter sido leitura de muitos professores que lecionavam na escola primária da época, seja porque o livro era indicado para a leitura das crianças, seja como instrumento de apoio para preparação de suas aulas.

O livro Estudos Sociais na Escola Primária, pertencente à Biblioteca da Professora Primária, publicação oficial do Governo Federal, na gestão do Ministro da Educação e Cultura Darcy Ribeiro, trazia várias referências a livros de Viriato, na seção Sugestão de 
Bibliografia Auxiliar - 1. Assim, para o $3^{\circ}$ e $4^{\circ}$ anos escolares, eram indicados os livros História do Brasil para crianças e Curiosidades da História Brasileira (CASTRO \& GAUDENZI, 1962, p. 461), por estarem em consonância com os programas curriculares vigentes à época $^{127}$.

$\mathrm{Na}$ mesma seção, mas como sugestão de leitura e pesquisa para o professor, era indicado outro livro de Viriato Corrêa, a saber: História da Liberdade no Brasil (CASTRO \& GAUDENZI, 1962, p. 481).

A professora Dinara Leite, responsável pela disciplina Metodologia da Geografia e da História, nos cursos de aperfeiçoamento do INEP, relacionou, como sugestão, alguns livros para o aluno, entre os quais "História do Brasil para crianças - Viriato Corrêa - para o $4^{\circ} \mathrm{e}$ $5^{\circ}$ anos" (LEITE, 1959, p. 97), ao lado de obras didáticas também consagradas de autores como Rocha Pombo (Nossa Pátria), Pedro Calmon (História da Civilização Brasileira para a escola primária), Afrânio Peixoto (Minha terra e minha gente) e Osório Duque Estrada (Noções de História do Brasil).

Miriam Moreira Leite, no capítulo sobre sugestões didáticas, de seu livro de Metodologia do Ensino de História, do final da década de 60, diz textualmente que:

\begin{abstract}
Ao lado destas fontes propriamente históricas, existem livros escritos deliberadamente para proporcionar às crianças uma literatura de caráter histórico $[\ldots]$.

Com todas as restrições que se lhes possam fazer, alguns livros históricos para crianças podem ser indicados com vantagem, como As belas histórias da História do Brasil, A Bandeira das Esmeraldas e a História do Brasil para crianças, de Viriato Corrêa; ou Histórias Brasileiras para a Juventude, de Cid Franco (LEITE, 1969, p. 82-3, grifo nosso).
\end{abstract}

\footnotetext{
${ }^{127}$ No livro Prática na formação e no aperfeiçoamento do magistério primário, as autoras fazem uma recomendação expressa acerca da metodologia do ensino de História para a escola primária:"É também muito importante que a História tenha colorido para a criança. Assim, seu estudo precisa ser orientado de maneira que a criança veja o passado de nosso país como algo vivo, dinâmico e, não, frio, distante, sem interesse. Os personagens de maior destaque - Tiradentes, José Bonifácio, Mauá, Barão do Rio Branco, Oswaldo Cruz, entre outros - devem adquirir para ela sentido humano. Não nos podemos limitar a citar-lhes o nome e o acontecimento principal em que tenham tomado parte. Há livros, como Meu Torrão, de Viriato Corrêa, que muito favorecem esse trabalho de humanizar, para as crianças, os vultos do passado." (PINHEIRO \& PINHEIRO, 1969, p. 368, grifo nosso).
} 
Para finalizar, não se pode esquecer que os livros de Viriato Corrêa constavam como indicação bibliográfica em vários programas curriculares da escola primária de alguns estados brasileiros. É o caso, por exemplo, do programa do ensino primário elementar, estabelecido pela Secretaria de Educação do Estado de Minas Gerais ${ }^{128}$. No referido programa, o livro História do Brasil para crianças foi sugerido na bibliografia tanto no programa de Língua Pátria, como no de História e Moral e Civismo.

128 SECRETARIA DA EDUCAÇÃO DO ESTADO DE MINAS GERAIS. Programas (ensino primário elementar). $3^{\text {a }}$ ed., Belo Horizonte: Imprensa Oficial, 1961, p. 130; 188. 
3ª PARTE: HISTÓRIA DO BRASIL PARA CRIANÇAS E O ENSINO PRIMÁRIO 
Entender como o livro História do Brasil para as crianças insere-se no contexto da escola primária brasileira e interfere na construção do saber histórico escolar é o objetivo desta terceira parte de nosso trabalho. Nesse sentido, irei analisar os currículos e programas escolares de História para a escola primária ${ }^{129}$ e de que forma os conteúdos desses programas estão presentes na obra de Viriato Corrêa.

Considero que o livro História do Brasil para crianças possuía certa ambigüidade quanto ao uso que dele foi feito: ao mesmo tempo em que foi um livro de literatura infantil e, nesse caso, pôde ser lido pela criança sem a mediação do professor (uso extra-escolar); foi também um livro de leitura para o estudo de História na escola primária, uma vez que contemplava o currículo oficial da época (até a década de 1960) - uso escolar. Razão pela qual História do Brasil para crianças foi o único livro de Viriato Corrêa a receber o parecer favorável e respectivo registro ( $n^{\circ}$ 966) da Comissão Nacional do Livro Didático (CNLD), podendo ser adotado nas escolas de todo o País, a partir de 1961.

Essa ambigüidade fez-se presente também no estilo e linguagem usados pelo autor. Para fugir do modelo tradicional de narrativa histórica, presente na maior parte dos livros didáticos, e para tornar prazerosa a leitura, Viriato optou por recorrer à tradição oral, em que 'vovô' torna-se um contador de histórias, relembrando o passado por ele vivido.

Diferentemente dos manuais didáticos de História, Viriato Corrêa, em sua narrativa, não se preocupa com a organização cronológica. O livro também não possui atividades em forma de exercícios ou questionários como os manuais didáticos de perguntas e respostas que se constituíram numa modalidade bastante usada na escola brasileira.

Viriato parece indicar que, para se fazer uma História para a infância brasileira, não é necessária a enumeração de fatos e datas organizadas cronologicamente, como nas demais obras de História que, muitas vezes, induzem as crianças apenas à memorização. Aqui, além de tudo, a narrativa histórica dava-se em um ambiente fora da escola, numa chácara aprazível e com um diálogo que se estabelecia entre o vovô e as crianças. Assim, através desse livro, Viriato possibilitava às crianças o acesso, fora do espaço escolar, à História, que deixa de ser vista apenas como mais uma disciplina do currículo escolar.

\footnotetext{
${ }^{129}$ O Ensino Primário - também chamado Escola Elementar e Ensino Elementar - é compreendido como aquele ofertado a crianças de 7 a 12 anos.
} 
Neste capítulo, analiso, aliás, como a constituição da disciplina escolar "História" esteve ligada à própria formação do Estado nacional brasileiro, na tentativa de se forjar uma dada identidade nacional, dando ênfase ao ensino primário, seu currículo escolar, métodos de ensino e produção didática para uso das crianças na escola. E, no capítulo final, a análise recai sobre as características de estilo da narrativa, relacionando textos e imagens do livro História do Brasil para crianças. 
CAPÍTULO 5: O ENSINO DE HISTÓRIA NA ESCOLA PRIMÁRIA (1934-1961)

“ESTUDO ERRADO

[…]

Quase tudo que aprendi, amanhã eu já esqueci Decorei, copiei, memorizei, mas não entendi Quase tudo que aprendi, amanhã eu já esqueci Decorei, copiei, memorizei, mas não entendi Decoreba: esse é o método de ensino Eles me tratam como ameba e assim eu num raciocino Não aprendo as causas e conseqüências, só decoro os fatos Desse jeito até História fica chato

Eu gosto dos professores e eu preciso de um mestre Mas eu prefiro que eles ensinem alguma coisa que preste - O que é corrupção? Pra que serve um deputado? Não me diga que o Brasil foi descoberto por acaso!

Não me faça decorar as capitanias hereditárias!!

Vamos fugir dessa jaula! "Hoje eu tô feliz" (matou o presidente?) Não. A aula Matei a aula porque num dava

Eu não agüentava mais. $[\ldots] "$ 


\title{
5.1 A História escolar e a construção da identidade nacional
}

Desde a formação do Estado nacional brasileiro, após a emancipação política de Portugal (1822), a história serviu como elemento de afirmação de nossa identidade nacional e seu ensino já estava previsto em uma das primeiras leis do País ${ }^{130}$. Trata-se da Lei de 15 de outubro de 1827, que "manda crear escolas de primeiras letras em todas as cidades, villas e logares mais populosos do Império”. Esse dispositivo legal previa, em seu art. $6^{\circ}$, que:

\begin{abstract}
Os professores ensinarão a ler, escrever, as quatro operações de arithmetica, pratica de quebrados, decimaes e proporções, as noções mais geraes de geometria pratica, a grammatica da lingua nacional, e os princípios de moral christã e da doutrina da religião catholica e apostólica romana, proporcionados à comprehensão dos meninos; preferindo para as leituras a Constituição do Império e a Historia do Brazil (grifo nosso).
\end{abstract}

Mesmo de forma indireta, já havia, por parte do poder constituído, o interesse para que os súditos do Império desenvolvessem a prática de leitura e conhecessem os princípios da Carta Constitucional e elementos de nossa história.

Circe Bittencourt, ao analisar a trajetória do ensino de História em nosso País, sintetiza a questão: “[...] o ensino de História do Brasil está associado, inegavelmente, à constituição da identidade nacional. Nacionalismo patriótico, cultos a heróis nacionais e festas cívicas são alguns dos valores que, na escola, se integram ao ensino da História do Brasil [...]." (BITTENCOURT, 2003, p. 185).

Neste sentido, os historiadores são unânimes em afirmar que o ensino de História no Brasil esteve atrelado ao processo de formação do estado nacional, envolvendo, também, a participação de importantes instituições acadêmicas e culturais, que viam, na educação, fator

\footnotetext{
${ }^{130}$ O historiador Américo Jacobina Lacombe (1909-1993) defende a posição de que o ensino da História começou no Brasil no período colonial, nos colégios jesuíticos. Ele cita também o fato de que, no século XVII, iniciou-se o ensino de História Pátria e Geral, sendo adotado nos colégios brasileiros o compêndio do padre italiano Antônio Maria Bonucci (Lisboa, 1706) - Epitome cronológico, genealógico e histórico (LACOMBE, 1973). Considero que essa análise é polêmica levando em conta as análises de Annie Brutter sobre a História ensinada nas escolas nos séculos XVII e XVIII, momento anterior à sua constituição como disciplina escolar e voltada para a constituição da identidade nacional (BRUTER, Annie. Um exemplo de pesquisa sobre a história de uma disciplina escolar: a História ensinada no século XVII. In: História da Educação, ASPHE/FaE/UFPel, Pelotas, n. 19, p. 7-21, abr. 2006).
} 
decisivo para a inserção do Brasil no concerto das nações civilizadas (NADAI, 1988; ABUD, 1998; ZAMBONI, 2003; BITTENCOURT, 2007).

No entanto, esse fenômeno social não é particularidade do Brasil, mas configura-se como elemento recorrente na segunda metade do século XIX. Tal constatação é também compartilhada por historiadores estrangeiros:

Desde la incorporación misma de la historia a la escuela, la relación entre su enseñanza y la formación de identidad há sido fuerte y estrecha. Precisamente la historia se estableció en la escuela, entre finales del siglo XIX y comienzos del XX, como um instrumento ideológico de carácter doctrinal para fortalecer los Estados nacionales (CARRETERO, GONZALEZ, 2004, p. 174, grifo nosso).

Ao se estudar a relação entre o ensino de História e a configuração da identidade nacional, é preciso levar em consideração algumas questões. Em primeiro lugar, é importante ressaltar que o conceito de identidade nacional esteve sempre associado à constituição de um sentimento nacionalista e a uma concepção de povo. Por outro lado, o conceito de identidade nacional não é a-histórico. Assim, a identidade nacional forjada no período monárquico não é a mesma que se desenvolveu durante as primeiras décadas republicanas, nem tampouco aquela dos períodos ditatoriais de nossa história. Por último, é importante salientar que a constituição da identidade nacional não foi papel exclusivo do ensino de História em nosso País. Outras disciplinas escolares, a exemplo da Geografia, da Língua e da Literatura, tiveram também um papel destacado nesse processo.

Conforme Albuquerque, a segunda metade dos oitocentos é um momento crucial, pois foi durante esse período que se formulou uma suposta identidade para o país recém-criado.

O século XIX marca, portanto, o momento de construção simbólica e discursiva da nacionalidade brasileira. É o momento em que se institui grande parte do imaginário que nós utilizamos para nos definir e para nos dizer. É neste século, também, que muito daquilo que consideramos ser a nossa história, os fatos principais de nosso processo histórico, foram definidos e descritos. Muitos dos mitos que continuamos a repetir sobre nós mesmos e sobre nossos vizinhos foram aí elaborados. Este século marca não só o nascimento do Brasil enquanto Estado, mas também enquanto um conjunto de sentidos, de significados, de símbolos, de eventos, que nos vão dizer e nos tornar visíveis. [...] Dentre as instituições que vão se dedicar a construir e definir o que seria o Brasil, e traçar um projeto para o País, está o IHGB, fundado em 1838, 
e que congregava as mais expressivas figuras intelectuais e políticas envolvidas diretamente na administração do estado imperial (ALBUQUERQUE JÚNIOR, 2007, p.44-5).

$\mathrm{Na}$ tentativa de se forjar uma identidade nacional para o país recém-criado, recorreu-se à pesquisa, ao ensino e à divulgação da História. Esta tarefa coube, inicialmente, ao IHGB e ao Colégio Pedro $\mathrm{II}^{131}$, ambos criados no ano de $1838^{132}$, na então capital do Império brasileiro, o Rio de Janeiro.

\subsubsection{O IHGB e a produção didática no século XIX}

A criação do Instituto Histórico e Geográfico Brasileiro deu-se num momento particular da história do País (GUIMARÃES, 1988). Logo após a independência do Brasil (1822) e o reinado de D. Pedro I (1822-1831), o País viu sua unidade territorial ser ameaçada em meio à eclosão de uma série de movimentos e rebeliões, algumas de cunho separatista, que colocavam em xeque a própria integridade física da Nação. Havia, pois, a necessidade premente de se formular uma interpretação do País que mantivesse sua extensa unidade territorial e que, ao mesmo tempo, fortalecesse o processo de centralização políticoadministrativa do Estado monárquico.

Nesse sentido, o IHGB promoveu um concurso para a escolha de um projeto de escrita da história nacional. O vencedor foi o naturalista alemão Karl Friedrich Philipp Von Martius, com o ensaio Como se escreve a História do Brasil. Segundo Nelson Schapochnik (1993, p.70),

\footnotetext{
${ }^{131}$ O Colégio Pedro II, ainda hoje existente na cidade do Rio de Janeiro, originou-se da antiga Casa dos Meninos Órfãos, depois Seminário de São Joaquim. Em 1837, "o seminário transformou-se em colégio de instrução secundária e, em seguida, foi elevado à condição de Imperial Colégio Pedro II. O colégio é reinaugurado em 25 de março de 1838 pelo imperador, e em 27 de abril do mesmo ano recebe os primeiros alunos. De orfanato humilde, o 'Pedro II' - como era chamado - se transformaria na 'glória' do nosso ensino; uma espécie de ‘símbolo da civilidade', de um lado, e de pertencimento a uma elite, de outro.” (SCHWARCZ, Lília M. 1998, p. 150). Sobre o Colégio Pedro II e seu papel na configuração do saber histórico escolar na escola secundária, consultar GASPARELLO, Arlette M. Construtores de Identidades: a pedagogia da nação nos livros didáticos da escola secundária brasileira. São Paulo: Iglu Editora, 2004.

${ }^{132}$ Em 1838 foi criado, também, o Arquivo Nacional, já previsto na primeira Constituição do Império (1824), que tinha como tarefa básica a sistematização da documentação indispensável à construção da história do País.
} 
[...] o plano delineado por Von Martius se afastava da tentativa de compor uma visão orgânica da História do Brasil através da justaposição das histórias provinciais. Do seu ponto de vista, a História do Brasil deveria ser apreendida sob uma perspectiva capaz de produzir uma identidade que seria assegurada pelo exame do movimento característico e particular, donde confluiriam as três raças formadoras da nacionalidade brasileira.

O IHGB $^{133}$ forneceu as bases da historiografia brasileira no séc. XIX, ao reunir intelectuais ${ }^{134}$ (escritores, bacharéis, médicos, professores etc.), responsáveis pela produção de obras e textos, pautados numa "história oficial". Vários de seus membros foram responsáveis pela produção de livros escolares. Muitos deles exerciam também o magistério no Colégio Pedro II. É o caso, por exemplo, de Joaquim Manoel de Macedo (1820-1882).

Dr. Macedinho, como era mais conhecido, era médico, mas dedicou-se, sobretudo, à literatura. Escreveu o romance A Moreninha, considerado o primeiro best-seller da literatura nacional. Embora se dedicasse ao ensino secundário na Corte, Macedo produziu um livro escolar para a instrução primária:

\begin{abstract}
De todas estas atividades intelectuais, Macedo destacou-se como professor do Imperial Colégio Pedro II, o qual foi nomeado em abril de 1849, tendo sido o primeiro professor responsável pela cadeira de História do Brasil criada em 1858. Macedo chegou também a ser professor das princesas D. Isabel e D. Leopoldina Seu prestígio, no entanto, não ficou apenas na prática docente. Influenciado pela obra História Geral do Brasil, de 1854, do historiador e membro-fundador do IHGB, Francisco Adolfo Varnhagen, Macedo redigiu dois manuais didáticos, a saber: Lições de História do Brasil para uso dos alunos do Imperial Colégio Pedro II (1861/1863) - o primeiro destinado aos alunos do Colégio Pedro II e Lições de História do Brasil para uso das escolas de Instrução Primária (1865) (FERNANDES, 2005, p. 131, grifo nosso).
\end{abstract}

\footnotetext{
${ }^{133}$ Alguns membros do IHGB produziram obras de cunho histórico-educacional que hoje se constituem em importantes fontes para a História da Educação Brasileira. Entre elas, podemos citar: A Instrução Pública do Brasil: história e legislação (1500-1889), de autoria de José Ricardo Pires de Almeida, publicada originalmente em francês, no ano de 1889, na qual o autor faz um elogio à atuação do Império brasileiro no setor educacional, e os sete volumes de uma grande obra de compilação das leis das províncias do Império e início da República no País, sob responsabilidade de Primitivo Moacyr (VIDAL; FARIA FILHO, 2003).

${ }^{134}$ Concordo com a posição de Jean-Paul Sartre ao afirmar que todo escritor é também um intelectual: "Definimos a situação do intelectual pela contradição, nele, entre o saber prático (verdade, universalidade) e a ideologia (particularismo). A definição se aplica aos professores, aos cientistas, aos médicos etc." (SARTRE, Jean-Paul. Em Defesa dos Intelectuais. São Paulo: Ática, 1994, p. 54). Ver também BOTO, Carlota. O professor primário português como intelectual: eu ensino, logo existo In: LINHAS, Florianópolis, v. 6, n. 1, p. 79-130, jan./jun. 2005.
} 
Importante destacar o trabalho de outro membro do IHGB - o Cônego Fernandes Pinheiro - na produção de livros didáticos para a escola primária. Ele escreveu o livro Episódios da história pátria contados à infância (1860), que circulou durante trinta anos, chegando a 13 edições, com tiragens de 5 a 6 mil exemplares (BITTENCOURT, 2008). Usando o pseudônimo de Estácio de Sá e Menezes, escreveu também o livro História do Brasil contada aos meninos (1870), conforme veremos no item 5.3.1 deste trabalho.

Sylvio Romero, João Ribeiro, Rocha Pombo e Max Fleiuss foram outros membros ligados à tradição historiográfica do IHGB que, imbuídos do espírito nacionalista, dedicaramse também à escrita de livros escolares para crianças, em momentos posteriores.

É preciso ressalvar que até então, sob a forte influência da Igreja Católica, o Estado garantira, no período monárquico, a presença do ensino de História Sagrada no currículo escolar, tanto nas escolas primárias quanto nas secundárias.

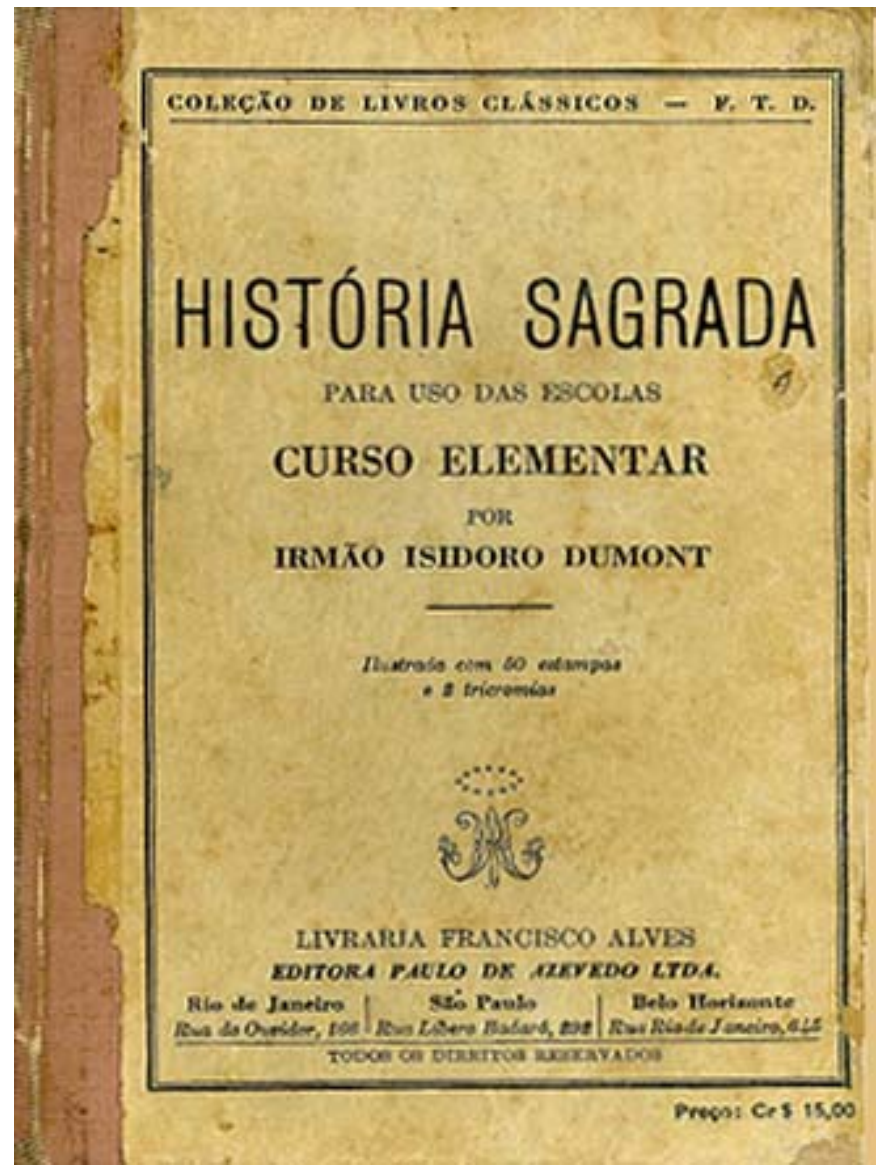

Figura 63 - Livro didático de História Sagrada - capa (Ed. FTD). Fonte: Acervo BLD-FEUSP. 
Além disso, o modelo de ensino de História era pautado no currículo humanístico clássico, de inspiração francesa, e havia predominância do ensino de História Universal em detrimento da História Nacional - esta um mero apêndice daquela.

Foi nesse contexto que, ao final do séc. XIX, houve intenso debate em torno da necessidade de reformulação da escola primária no Brasil (BOTO, 1999). Designado como relator pela Comissão de Instrução Pública da Câmara dos Deputados, Rui Barbosa ofereceu, em 1883, parecer à proposta que contém aspectos inovadores do ponto de vista metodológico para esse nível de ensino ${ }^{135}$.

Rui Barbosa era defensor da adoção do método intuitivo na escola primária, também conhecido como "lições de coisas". Por esse método, o ensino deveria sempre partir do particular para o geral, do conhecido para o desconhecido, do concreto para o abstrato. Para Rui, somente a adoção desse método possibilitaria acabar com o ensino verbalista, repetitivo e memorizador, com abstrações inúteis para as crianças, ainda presente, àquele momento, na escola primária brasileira.

Para o ensino de História, adotando-se o método intuitivo, Rui advogava o uso de fontes historiográficas na construção do passado histórico, a partir da própria história de vida do aluno, o que bem revela seu caráter inovador:

O sentimento da realidade na história pode, para o menino, derivar da idéia da história dele mesmo. Está nas mãos do professor induzi-lo a pesquisar os fatos de sua vida pessoal, levando-o a entender o modo como esse passado é o que constitui a história. [...] O professor não enarrará ele mesmo, mandará investigar por todos os modos. Incumbirá os alunos de fixarem uma data. Um livro de per si não aceitará como prova suficiente; mas se quererá o depoimento de pessoas que hajam sido testemunhas, medalhas, inscrições monumentais etc. Exercícios desta natureza inclinarão o menino para o verdadeiro sentimento da história (BARBOSA apud Souza, 2000, p. 23, grifo nosso).

135 "Inúmeros trabalhos mais recentes são unânimes em concordar que os pareceres de Rui Barbosa representam para a História da Educação talvez o primeiro grande diagnóstico da situação real do ensino no país." (BOTO, 1999, p. 259). 
Preconizava, ainda, que o professor deveria dar ênfase à lição oral, à narrativa eloqüente dos grandes fatos da história nacional, bem como ao uso do método anedótico ${ }^{136}$, que se tornou bastante recorrente no ensino de História, na escola primária. Para ele, a forma anedótica não se resumia exclusivamente ao uso de biografias, mas o professor deveria escolher dentre os fatos mais memoráveis de nossa história aqueles que melhor se adequassem à dramatização, como forma de despertar no aluno o interesse pelo passado da Pátria (SOUZA, 2000).

Essa proposta de reforma da escola primária estabelecia, também, o ensino da Educação Moral e da Educação Cívica, não de forma isolada, mas articulada com outros conteúdos, com o objetivo de desenvolver nas crianças uma educação patriótica, fundada em valores morais e intimamente relacionada com a história e a geografia do Brasil.

\subsubsection{As primeiras décadas republicanas}

Com a implantação do regime republicano, a adoção de uma nova carta constitucional para o País (1891) e a conseqüente separação entre Igreja e Estado, o princípio da laicidade fez-se presente no sistema educacional brasileiro. O ensino de História Sagrada foi substituído pela Instrução Moral e Cívica. Em particular, o ensino de História para a escola primária pautou-se por um exacerbado viés cívico-patriótico, com a exaltação de heróis nacionais e a realização de festas cívicas no espaço escolar, em torno das efemérides que serviram também para o fortalecimento do sentimento de identidade nacional (BITTENCOURT, 1990) ${ }^{137}$.

Contraditoriamente, no momento em que a República tentava moldar uma nova identidade para o País, consentânea com o ideário do progresso e da modernidade e às vésperas das comemorações do quarto centenário do descobrimento do Brasil, ocorreu, em 1899, a anexação da cadeira de História do Brasil ao ensino de História Universal. Tal medida provocou protestos de historiadores, a exemplo de Capistrano de Abreu. O historiador cearense recusou-se a ensinar a nova disciplina, o que provocou seu afastamento do ensino

\footnotetext{
136 Método anedótico refere-se ao uso de aspectos pitorescos de nosso passado, bem como de lendas e curiosidades como forma de despertar na criança o interesse pela disciplina escolar História.

${ }^{137}$ Cf. capítulo As Tradições Nacionais e o ritual das festas cívicas. In: BITTENCOURT, Circe. Pátria, Civilização e Trabalho: o ensino de história nas escolas paulistas (1917-1939). São Paulo: Edições Loyola, 1990.
} 
secundário $^{138}$. A disciplina História do Brasil só retornaria ao currículo oficial da escola secundária, de forma autônoma, em 1942, com a reforma empreendida por Gustavo Capanema, à frente do Ministério da Educação e Saúde, já em pleno Estado Novo (SCHWARTZMAN et al., 1984).

A única reforma empreendida na escola primária nesse período deu-se logo após a instalação do governo provisório da República (1889-1891), em que Benjamin Constant era Ministro dos Correios e Telégrafos e Instrução Pública. Trata-se do Decreto ${ }^{\circ}$ 981, de 8 de novembro de 1890. Em síntese, essa reforma dividiu a escola primária em duas categorias: $1^{\circ}$ grau (para a faixa etária dos 7 a 13 anos) e $2^{\circ}$ grau (dos 13 aos 15 anos). Tanto na escola de $1^{\circ}$ grau quanto na de $2^{\circ}$ grau, estava previsto o ensino de "elementos de geographia e historia, especialmente do Brazil" (art. $3^{\circ}$ do referido decreto).

Entretanto, logo no início do período republicano, houve tentativas de se escrever um outro projeto para o ensino de História. Manoel Bomfim, então Diretor da Instrução Pública do Distrito Federal, propôs uma reforma curricular no ensino, com a introdução do estudo da História da América na escola primária e nos cursos de formação de professores. Disso resultou a publicação do primeiro livro didático de História da América, de autoria de Rocha Pombo $^{139}$ (1900), que ganhara concurso promovido pela Instrução Pública do Distrito Federal. Esse projeto pretendia romper com a visão eurocêntrica de nossa história, ao mesmo tempo em que apontava para maior aproximação com os países americanos, na tentativa de se forjar uma nova identidade nacional.

Pombo também escreveu um livro destinado ao ensino primário - História da América para escolas primárias (1903). Logo na introdução, o autor tecia considerações sobre como deveriam ser os livros escolares de História para crianças.

\footnotetext{
${ }^{138}$ Mesmo referindo-se ao ensino secundário, a disputa pela introdução autônoma do ensino de História do Brasil é bastante elucidativa dos embates políticos sobre as questões educacionais do período. Após a criação do Ministério da Educação e Saúde (1931), quando se deu a primeira reforma do ensino secundário, empreendida por Francisco Campos, a disciplina História do Brasil figurava apenas como anexa às unidades de História da América. Surgiram, então, vários protestos contra essa decisão. Várias instâncias da sociedade manifestaram-se a favor do retorno da História do Brasil ao currículo oficial: a congregação do Colégio Pedro II, o IHGB, deputados eleitos à Assembléia Constituinte de 1933-34, bem como participantes do III Congresso de História Nacional, que propuseram uma moção aos poderes da República para que voltasse aos programas de ensino secundário a cadeira de História Pátria (LACOMBE, 1973). Houve, também, intenso debate na imprensa carioca, capitaneada pelo jornal "Correio da Manhã”, que fez uma campanha pelo retorno de História do Brasil ao ensino secundário (VIANA, 1965).

${ }^{139}$ POMBO, Rocha. Compêndio de História da América. Rio de Janeiro: Laemmert \& C. Editores, 1900.
} 
Livros destinados à infância devem preencher, antes de tudo, as seguintes condições: - devem ser divididos em capítulos ou lições iguaes, e escriptas em estilo conciso, nobre e elegante; - dar a maior somma de instrucção no menor número possível de palavras; - entreter a curiosidade do menino, estimulando-lhe a intelligência e o coração; - mover no seu espírito o gosto pelo estudo e o desejo de saber; - devem, em summa, obrigar, por assim dizer, o mestre - a fazer explanações, e o alumno - a pensar, a inquirir, a controverter $[\ldots]$.

Grandes modelos, grandes noções - eis o que é preciso dar, desde cedo, ante os olhos da infância: modelos reaes e legítimos como são os da História; noções verdadeiras e úteis como são as das sciencias e das artes. Só assim tornaremos o primeiro ensino fecundo, como fundamento de mais largo preparo futuro (POMBO, 1903, p. 5).

Objetivando, ainda, atender à demanda do ensino da história local, surgiu, a partir da década de 1910, uma importante coleção de livros destinados à formação do professor primário, versando sobre conteúdos regionais. A Editora Melhoramentos convidou o então historiador e diretor do Museu Paulista, Afonso D'Escragnolle Taunay, para coordenar a coleção "Resumo Didactico"140. Vários historiadores pertencentes ao IHGB (Rocha Pombo, Pedro Calmon, Max Fleiuss) e outros ligados aos institutos históricos regionais (Cruz Filho, Craveiro Costa, Mario de Mello) escreveram manuais didáticos sobre a história de alguns estados brasileiros. Embora constituindo-se uma coleção de história regional, o objetivo maior desses livros era acentuar o papel de cada estado na formação da nacionalidade:

Estudar a história de cada província ou do seu estado foi preocupação constante dos educadores, considerando que os alunos deveriam 'conhecer seu local' para que pudessem adquirir sentimentos patrióticos, inicialmente em escala de 'território local'. Este sentimento patriótico local se estenderia para o nacional uma vez que cada estado contribui para a constituição da nação. A história da nação é a somatória das histórias dos estados (OLIVEIRA, 2006, p. 147, grifo nosso).

\footnotetext{
${ }^{140}$ Segundo Oliveira (2006), essa coleção foi pensada para ser uma produção didática que contemplasse a história de todos os estados brasileiros. No entanto, foram publicados 12 livros entre os anos de 1918 a 1932 : História de Santa Catharina (Henrique Boiteaux, 1930); História do Pará (Teodoro Braga, 1932); História da Bahia (Pedro Calmon, 1929); História de Alagoas (Craveiro Costa, 1930); História do Ceará (Cruz Filho, s/d); História da Cidade do Rio de Janeiro (Max Fleiuss, 1928); História de Pernambuco (Mario de Mello, s/d); História de São Paulo (Rocha Pombo, 1918); História do Paraná (Rocha Pombo, 1929); História de Minas Geraes (Lúcio José Santos, 1926); História do Rio Grande do Sul (Doca Sousa, s/d) e História do Estado do Rio de Janeiro (Clodomiro Vasconcelos, 1928).
} 


\subsubsection{O ensino de História na Era Vargas}

Após 1930, com a criação do Ministério da Educação e Saúde, houve aprofundamento de uma organização educacional com forte tendência centralizadora. À frente dessa pasta ministerial, o mineiro Francisco Campos realizou as primeiras reformas educacionais que modificaram a estrutura do ensino secundário ${ }^{141}$. Trata-se do Decreto $\mathrm{n}^{\mathrm{o}} 19.890$, de 18 de abril de 1931. A reforma do ensino secundário foi consolidada pelo Decreto $\mathrm{n}^{\circ} 21.241$, de 4 de abril de 1932. Para Romanelli,

a Reforma Francisco Campos teve o mérito de dar organicidade ao ensino secundário, estabelecendo definitivamente o currículo seriado, a freqüência obrigatória, dois ciclos, um fundamental e outro complementar, e a exigência de habilitação neles para o ingresso no ensino superior (ROMANELLI, 2007, p. 135).

Por outro lado, houve críticas quanto ao caráter elitista dessa reforma, que deixou praticamente ignorados os ensinos primário e normal ${ }^{142}$, além de vários ramos do ensino médio profissional ${ }^{143}$.

Não se pode deixar de registrar a experiência realizada na gestão de Anísio Teixeira à frente do Departamento de Educação, da Secretaria da Educação e Cultura do Distrito Federal, quando chamou Delgado de Carvalho ${ }^{144}$ para elaborar uma nova proposta para o ensino de História, no contexto de um Programa de Ciências Sociais para a escola primária ${ }^{145}$ (1934). A proposta, inspirada na pedagogia pragmática norte-americana, determinava que o

\footnotetext{
${ }^{141} \mathrm{O}$ chamado ensino secundário compreendia dois cursos seriados: fundamental (5 séries) e complementar (2 séries). Esse último era pré-requisito para os candidatos que pleiteavam matrícula em determinados institutos de ensino superior.

${ }^{142} \mathrm{O}$ Ensino Normal tinha como finalidade básica "prover a formação do pessoal docente necessário às escolas primárias" (art. $1^{\circ}$, inc. I do Decreto-Lei ${ }^{\circ} 8.530$, de 1946).

${ }^{143}$ O Ensino Médio Profissional foi regulamentado pela Lei Orgânica do Ensino Industrial (Decreto-Lei n ${ }^{\circ} 4.073$ de 1942).

${ }^{144}$ Delgado de Carvalho foi o principal educador a defender a introdução de Estudos Sociais na escola primária brasileira. Para ele, enquanto as Ciências Sociais visavam essencialmente à pesquisa, à experiência e à descoberta, os Estudos Sociais eram um campo de estudos destinado ao ensino do conhecimento produzido pelas Ciências Sociais e Morais (CARVALHO, Delgado de. Introdução metodológica aos estudos sociais. Rio de Janeiro: Livraria Agir Editora, 1959).

${ }^{145}$ Para uma análise da proposta de Estudos Sociais para a escola primária no contexto da reforma empreendida por Anísio Teixeira, consultar: DEPARTAMENTO DE EDUCAÇÃO DO DISTRITO FEDERAL. Programa de Ciências Sociais. Escola Elementar. Volume Primeiro, $1^{\circ}, 2^{\circ}$ e $3^{\circ}$ Anos. Série C. Programas e Guias de Ensino, n. 4. Edição Preliminar. São Paulo: Companhia Editora Nacional, 1934.
} 
ensino de Estudos Sociais seria ministrado nos cinco primeiros anos da escola elementar, agregando conhecimentos históricos, geográficos, econômicos e morais. Na prática, o que se observou foi que a História e a Geografia continuaram sendo tratadas de forma autônoma (tratadas como disciplinas independentes), mesmo porque, para o ingresso no secundário, havia a necessidade de o aluno da escola primária ter de se preparar pelo programa do exame de admissão, em que se exigiam dele conteúdos das duas disciplinas (PIRES, 1996).

E assim chegamos ao Estado Novo (1937-1945), quando se aprofundou um modelo de nacionalismo centrado na figura da Pátria unificada e de seu principal e único gestor - o ditador Getúlio Vargas.

Para reforçar o nacionalismo, o Estado Novo destacou, no currículo dos cursos elementares e secundários, a importância da educação física, do ensino da moral católica e da educação cívica pelo estudo da História e da Geografia do Brasil, do canto orfeônico e das festividades cívicas, como a "Semana da Pátria". Ecoando Comte - uma das mais importantes matrizes do pensamento de Vargas -, no ensino primário o objetivo da formação era dar 'sentimento patriótico' e no secundário, a 'consciência patriótica' (HILSDORF, 2005, p. 100, grifo nosso).

Vargas serviu-se de um modelo educacional centralizador e de instâncias governamentais de propaganda política ${ }^{146}$, que se encarregaram da construção de sua imagem como "Pai dos pobres"147 e amigo das crianças. Neste sentido,

uma intensa bibliografia foi produzida pela imprensa oficial para cultuar a personalidade de Vargas. Várias 'histórias de Vargas para crianças ${ }^{148}$ chegaram às bibliotecas, demonstrando como, desde o nascimento, Getúlio estaria fadado a liderar seu povo em um grande projeto (D’ARAÚJO, 2000, p. 36, grifo nosso).

\footnotetext{
${ }^{146}$ A propaganda política estadonovista estava a cargo do Departamento de Imprensa e Propaganda (DIP), que se encarregava de organizar e controlar todas as manifestações públicas e divulgar as ações governamentais: "A propaganda, além de enaltecer a figura do líder e sua relação direta com as massas, demonstrava a preocupação do governo com a formação de uma identidade nacional coletiva. O sentimento de agregação e pertencimento foi muito valorizado através da associação entre Estado, Pátria, Nação e povo [...] " (CAPELATO, 2003, p. 124).

${ }^{147}$ Para melhor compreensão do mito em torno da figura de Getúlio Vargas na história brasileira, consultar LEVINE, Robert M. Pai dos Pobres? O Brasil e a era Vargas. São Paulo: Companhia das Letras, 2001.

${ }^{148}$ Vários livros e cartilhas foram publicados, nesse período, pelo Departamento Nacional de Propaganda (DNP) e pelo Departamento de Imprensa e Propaganda (DIP), e chegaram até os bancos escolares. Podemos citar as seguintes publicações: Catecismo cívico do Brasil Novo, s/d; O Brasil é bom (série produzida pelo DNP); Getúlio Vargas e sua vida (DIP, 1941, Coleção Brasil Novo para a criança brasileira); Getúlio Vargas para crianças (DIP, 1942, Volume especial da Biblioteca da Pátria) (CAPELATO, 1998).
} 
Durante o Estado Novo, houve tentativas de elaboração de um currículo uniforme, centralizador e homogêneo para a escola primária. Em 1938, foi criada a Comissão Nacional para a Organização do Ensino Primário (Decreto-Lei no 868, de 18 de novembro de 1938). Uma de suas atribuições era "nacionalizar"149 o ensino elementar e promover uma campanha nacional de combate ao analfabetismo, que contaria com a colaboração das diferentes esferas estatais (União, estados e municípios), bem como de iniciativas do setor privado.

Em síntese, o que se observa, na verdade, é que, apesar de várias reformas educacionais terem sido feitas nos estados durante a década de 1920, com algumas experiências inovadoras, e apesar de Vargas ter demonstrado interesse em alterar-lhe o currículo, o ensino primário nunca foi considerado prioridade do Governo Federal. O que já não ocorria exatamente com o secundário e o superior, já que, logo após a criação do Ministério da Educação e Saúde em 1931, o governo tratou de legislar sobre ambos. Na realidade, pela legislação vigente, era a administração estadual que cuidava do ensino primário e, conseqüentemente, do currículo das escolas, o que pode explicar, em parte, o "descaso" da esfera federal.

Foi, enfim, somente com a Lei Orgânica do Ensino Primário que se estabeleceram as primeiras diretrizes gerais traçadas pela União para esse nível de ensino. Pelo Decreto-Lei $\mathrm{n}^{\circ}$ 8.529, de 02 de janeiro de 1946, o ensino primário passou a ter a seguinte estrutura, subdividido em duas categorias: 1) o ensino primário fundamental destinado às crianças na faixa etária dos 7 aos 12 anos, compreendendo o primário elementar, de quatro anos, e o primário complementar, de um ano apenas; 2) ensino primário supletivo de duração de dois anos, destinado à educação de jovens e adultos que não receberam esse nível de ensino na idade adequada (ROMANELLI, 2007).

Nesse novo contexto normativo, determinou-se quais disciplinas obrigatórias fariam parte do currículo da escola primária. O ensino de História teve seu lugar assegurado na grade curricular.

\footnotetext{
${ }^{149}$ Os motivos pelos quais o Estado adotou tal procedimento foram decorrentes da desnacionalização do ensino primário nas áreas de colonização estrangeira, sobretudo alemã, presente nos estados do Rio Grande do Sul, Santa Catarina e Paraná. Posteriormente, o Ministério da Educação e da Saúde elaborou legislação específica para esses núcleos coloniais, obrigando o estabelecimento de escolas primárias em número suficiente, regidas apenas por brasileiros natos (NUNES, 2001).
} 
Quadro 1 - Currículo escolar do curso primário (1946)

\begin{tabular}{|c|c|}
\hline ESTRUTURA DO ENSINO PRIMÁRIO & DISCIPLINAS \\
\hline Curso primário elementar (4 anos) & $\begin{array}{ll}- & \text { Leitura e linguagem oral e escrita; } \\
\text { - } & \text { Matemática; } \\
- & \text { Geografia e História do Brasil; } \\
\text { - } & \text { Conhecimentos gerais aplicados à vida social, à } \\
& \text { educação para a saúde e ao trabalho; } \\
\text { - } & \text { Desenho e Trabalhos Manuais; } \\
\text { - } & \text { Canto Orfeônico; } \\
\text { - } & \text { Educação Física. }\end{array}$ \\
\hline Curso primário complementar (1 ano) & $\begin{array}{ll}- & \text { Disciplinas anteriores e } \\
- & \text { Noções de Geografia Geral e História das } \\
& \text { Américas; } \\
- & \text { Ciências Naturais e Higiene. }\end{array}$ \\
\hline Curso primário supletivo ( 2 anos) & $\begin{array}{ll}- & \text { Leitura e linguagem oral e escrita; } \\
- & \text { Aritmética e Geometria; } \\
- & \text { Geografia e História do Brasil; } \\
- & \text { Ciências Naturais e Higiene; } \\
- & \text { Noções de direito usual (legislação do trabalho, } \\
& \text { obrigações da vida civil e militar); } \\
- & \text { Desenho; } \\
- & \text { Economia Doméstica e Puericultura (alunos do } \\
& \text { sexo feminino). }\end{array}$ \\
\hline
\end{tabular}

Fonte: Decreto-Lei no 8.529, de 02.01.1946 (artigos 7, 8 e 9).

Para o ensino primário, mais uma vez, o currículo estabelecido por lei determinava o estudo da História do Brasil. No curso primário suplementar, além da História do Brasil, estava previsto o ensino de História das Américas.

\subsubsection{O ensino de História na segunda metade do século $\mathrm{XX}$}

Até a década de 40 do século passado, podemos constatar que a identidade nacional alicerçou-se em uma história com passado único, homogêneo, que escamoteava os conflitos e contradições de um país com gritantes desigualdades sociais.

Nos anos 50, houve intenso debate intelectual entre os liberais que pretendiam uma escola pública, laica e gratuita e os católicos que defendiam o modelo confessional de ensino, que resultou, posteriormente, na edição da primeira Lei de Diretrizes e Bases da Educação Nacional (Lei $\mathrm{n}^{\circ} 4.024$, de 1961). 
Como essa lei não contemplou nem mesmo as grandes linhas norteadoras de uma matriz curricular, praticamente não houve mudanças para o ensino primário. Na maioria das escolas primárias nos estados e municípios continuaram a prevalecer as determinações emanadas do Decreto-Lei n 8.529, de 1946 (Lei Orgânica do Ensino Primário). A LDB apenas estabelecia que os currículos e programas das escolas eram atribuição dos estados, municípios e Distrito Federal, com a finalidade de atender as peculiaridades e necessidades de cada região do País.

Já no final dos anos 60, Miriam Moreira Leite constatava que "o ensino de História no curso primário obedece a um programa de História do Brasil, do descobrimento aos dias atuais" $(1969$, p. 25) e que

na realidade, os programas desenvolvidos na escola primária são os mesmos de há dez anos atrás [...] e quando a professora consegue chegar ao fim do programa, encerra-o com uma lista de presidentes e de personagens que se destacaram na política, nas letras e na ciência. Dois terços do programa são dedicados ao período colonial que é, de fato, o mais bem estudado. Embora o programa procure acrescentar a História social e econômica à História política, isso é feito com muita parcimônia. O programa gira basicamente em torno de dois temas: a ocupação da terra pelos europeus, e os tipos de governo (LEITE, 1969, p. 26, grifo nosso).

Já em pleno regime de exceção, sob o governo dos militares (1964-1985), ocorreu uma mudança substancial na estrutura curricular do ensino primário que afetou diretamente o ensino de História, através de dois atos normativos, a saber: o Decreto $\mathrm{n}^{\mathrm{o}}$ 869/69, que tornou obrigatório o ensino de Educação Moral e Cívica, e a Lei no 5.692, de 1971 (Lei de Diretrizes e Bases do Ensino de $1^{\circ}$ e $2^{\circ}$ graus), que introduziu Estudos Sociais na escola de $1^{\circ}$ grau, em substituição ao estudo da História e da Geografia, com repercussões negativas para a qualidade do ensino brasileiro. 


\subsection{Que História ensinar às crianças?}

\subsubsection{Currículos, programas e métodos de ensino}

O ensino de História sempre esteve presente nas escolas primárias brasileiras, desde o século XIX. Assim, conteúdos de História, principalmente, a do País - a chamada "História Pátria" - eram ministrados às crianças, seja através da própria disciplina História, seja no ensino de Instrução Moral e Cívica, seja na Geografia e, até mesmo, nas aulas de Língua Portuguesa.

Por sua vez, não eram apenas os livros didáticos de História que traziam conteúdos dessa disciplina. Livros de leituras, seletas e antologias escolares, com excertos de textos históricos, veiculavam também um conhecimento histórico a ser apropriado pelas crianças e jovens na escola. Entretanto, diferentemente dos compêndios didáticos que primavam pela seqüência cronológica e periodização já consagrada (Brasil-Colônia, Brasil-Império e BrasilRepública), os livros de leitura e antologias escolares traziam conteúdos históricos de forma fragmentária, pois seus objetivos estavam mais ligados ao desenvolvimento da capacidade do aluno no domínio da leitura e da escrita.

E é também essencial lembrar que o saber histórico permeava o universo escolar e tinha nas datas comemorativas o momento supremo para perpetuar certa memória nacional, calcada no culto aos heróis nacionais. Muitas escolas primárias chegavam a elaborar seus currículos tomando como referência as datas comemorativas que serviam de conteúdo programático para as aulas. Era o chamado currículo por efemérides. Datas nacionais, como o descobrimento do Brasil (22 de abril), a morte de Tiradentes (21 de abril), a abolição da escravatura (13 de maio), a independência do Brasil (7 de setembro) e a proclamação da República (15 de novembro), eram amplamente comemoradas nas aulas e fora do espaço escolar (OLIVEIRA, 1989).

Nessas datas ou próximo a elas, uma vez que muitas se constituíram, com o passar dos anos, em feriados nacionais, eram realizadas solenidades cívicas na escola com o hasteamento da Bandeira e canto do Hino Nacional, apresentação de jograis e encenação de fatos históricos 
referentes à data comemorada e, até mesmo, desfiles dos alunos em estilo militar - muito comuns nas paradas de 7 de setembro, nossa data nacional por excelência ${ }^{150}$.

Ao analisar o ensino de História nas escolas paulistas, Bittencourt faz uma radiografia do modo como essa disciplina escolar era concebida e ensinada às crianças, desde as primeiras décadas da República, e que perdurou durante muitos anos. Tomando como referência os programas curriculares de 1918 e 1934 para o ensino da História na escola primária paulista, constatou-se que o viés cívico-patriótico permaneceu:

[...] a partir do $1^{\circ}$ ano o aluno aprendia a conhecer a Pátria, por descrições que garantissem despertar no espírito das crianças o interesse e o sentimento de entusiasmo pela Pátria. Estudavam-se então os vultos mais notáveis da nossa história, empreendendo, por este caminho, a construção da imagem da pátria para se buscar a identidade nacional, a qual só poderia se constituir com agentes sociais únicos produtores do passado histórico. Os heróis eram descritos no $1^{\circ}$ ano em História como nas aulas de Instrução Moral e Cívica, disciplina encarregada de fazer o aluno incorporar os valores de um bom cidadão. No $2^{\circ}$ ano, repetiam-se historietas, narradas pelo professor, encerrando fatos de patriotismo, heroísmo e abnegação (BITTENCOURT, 1990, p. 132).

No $3^{\circ}$ ano primário, era dada ênfase a capítulos de História Regional, articulando-se com o estudo mais geral da História do Brasil, o que bem demonstra que sempre houve certo espaço curricular para o ensino da história local, seja através do estudo meramente políticoadministrativo, partindo-se do local onde o aluno vive - o município - e ampliando-se para espaços maiores - o estado, a região e o país.

No $4^{\circ}$ ano, voltava-se novamente ao estudo da História do Brasil. Dessa vez, na tentativa de consolidar todo o programa da disciplina, que normalmente ia do descobrimento do Brasil, passando por nossa emancipação política, até a proclamação da República. Com

\footnotetext{
${ }^{150}$ Desde o início do governo republicano, houve o interesse de se criar uma memória nacional por meio de comemorações e festas em torno das datas históricas. O Decreto n. 155-B, de 14 de janeiro de 1890, do Governo Provisório, considera: "que o regime republicano se baseia no profundo sentimento de fraternidade universal; que esse sentimento não se pode desenvolver convenientemente sem um sistema de festas públicas, destinadas a comemorar a continuidade e a solidariedade de todas as gerações humanas; que cada pátria deve instituir tais festas segundo os laços especiais que prendem os seus destinos aos de todos os povos". Assim, pelo Decreto, eram considerados dias de festa nacional: 1 de janeiro - comemoração da fraternidade universal; 21 de abril comemoração dos precursores da independência brasileira, resumidos a Tiradentes; 3 de maio - descoberta do Brasil; 13 de maio - fraternidade dos brasileiros; 14 de julho - República, liberdade e independência dos povos americanos; 7 de setembro - Independência do Brasil; 12 de outubro - Descoberta da América; 2 de novembro Finados; 15 de novembro - comemoração da pátria brasileira (Cf. OCTÁVIO, 1893).
} 
tanto conteúdo a ser ministrado pelo professor, aliado a uma carga horária diminuta, restava ao aluno o exercício da memorização para assimilar a matéria exigida por ocasião dos exames.

Tendo em vista esse contexto e por tratar-se do ano em que foi lançado o livro História do Brasil para crianças, de Viriato Corrêa, vejamos com mais atenção o programa de História e Instrucção Cívica para o $4^{\circ}$ ano primário, no ano de 1934, adotado na rede pública de São Paulo.

Quadro 2 - Currículo escolar e História do Brasil para crianças (1934).

\begin{tabular}{|c|c|}
\hline $\begin{array}{l}\text { HISTÓRIA E INSTRUCÇÃO CÍVICA (Programa de 1934, } 4^{\circ} \\
\text { ano primário) }\end{array}$ & $\begin{array}{l}\text { HISTÓRIA DO BRASIL PARA CRIANÇAS (capítulos do livro e } \\
\text { seus respectivos conteúdos) }\end{array}$ \\
\hline $\begin{array}{l}\text { 1. O descobrimento da América e do Brasil. Início de sua } \\
\text { colonização. Os indígenas, os africanos e os europeus. A acção dos } \\
\text { jesuítas. }\end{array}$ & $\begin{array}{ll}- & \text { Cap. III - O louco (Cristóvão Colombo); } \\
- & \text { Cap. IV - A Pindorama; } \\
- & \text { Cap. V - Na terra das palmeiras; } \\
- & \text { Cap. VII - A gente da Pindorama; } \\
- & \text { Cap. VIII - O navegador espanhol; } \\
- & \text { Cap. IX - O navegador português; } \\
- & \text { Cap. XVII - Os padres jesuítas; } \\
- & \text { Cap. XVIII - Os fundadores da civilização brasileira; } \\
- & \text { Cap. XXVIII - Os negros; } \\
- & \text { Cap. XXIX - Palmares. } \\
\end{array}$ \\
\hline $\begin{array}{l}\text { 2. Os governos geraes. As invasões estrangeiras. As bandeiras e as } \\
\text { minas. }\end{array}$ & $\begin{array}{ll}- & \text { Cap. XIII - A desgraça das capitanias; } \\
- & \text { Cap. XXII - A França Antártica; } \\
- & \text { Cap. XXXV - O corsário que vencemos; } \\
- & \text { Cap. XXXVI - O corsário que nos venceu; } \\
- & \text { Cap. XXIV - A conquista dos holandeses; } \\
- & \text { Cap. XXV - O Príncipe de Nassau; } \\
- & \text { Cap. XXVI - A queda dos flamengos; } \\
- & \text { Cap. XXX - Bandeiras e bandeirantes; } \\
- & \text { Cap. XXXI - Antônio Raposo e Fernão Dias; } \\
- & \text { Cap. XXXII - As minas de ouro; } \\
- & \text { Cap. XXXIII - As pedras maravilhosas. } \\
\end{array}$ \\
\hline $\begin{array}{l}\text { 3. As luctas internas: emboabas, mascates e palmares. Aspirações à } \\
\text { independência. Tiradentes. A transmigração da família real para o } \\
\text { Brasil e suas conseqüências. }\end{array}$ & $\begin{array}{ll}- & \text { Cap. XXXIV - Paulistas e emboabas; } \\
- & \text { Cap. XXXVIII - O sentimento da independência; } \\
- & \text { Cap. XXXIX - A figura maravilhosa de Tiradentes; } \\
- & \text { Cap. XL - A morte de Tiradentes; } \\
- & \text { Cap. XLIV - A chegada da corte portuguesa. } \\
- & \text { Cap. XLVI - O Fico }\end{array}$ \\
\hline $\begin{array}{l}\text { 4. O grito do Ypiranga e o governo de D. Pedro I. As regências. O } \\
\text { reinado de D. Pedro II. As guerras externas. A abolição da } \\
\text { escravatura. }\end{array}$ & $\begin{array}{ll}- & \text { Cap. XLVII - Na colina do Ipiranga; } \\
- & \text { Cap. XLVII - A dissolução da Constituinte; } \\
- & \text { Cap. XLIX - Os republicanos de 1824; } \\
- & \text { Cap. L - Sete de abril; } \\
- & \text { Cap. LI - Nove anos de sangue; } \\
- & \text { Cap. LII - O reinado do homem pacífico; } \\
- & \text { Cap. LIII - A Guerra do Paraguai; } \\
- & \text { Cap. LIV - Riachuelo e Tuiutí; } \\
- & \text { Cap. LVII - 13 de maio. }\end{array}$ \\
\hline $\begin{array}{l}\text { 5. A proclamação da República. Estudo sucinto do período } \\
\text { republicano. }\end{array}$ & $\begin{array}{ll}- & \text { Cap. LVIII - } 15 \text { de novembro; } \\
- & \text { Cap. LIX - Palavras do fim. }\end{array}$ \\
\hline $\begin{array}{l}\text { 6. Vantagens de nossa forma de governo. O voto e a sua importância. } \\
\text { As attribuições dos poderes do Estado. As forças armadas: o } \\
\text { exército, a marinha e a polícia. O serviço militar. O jury e o dever } \\
\text { dos jurados. A necessidade dos impostos. }\end{array}$ & \\
\hline 7. Os direitos e deveres do cidadão brasileiro. & \\
\hline 8. A Bandeira Brasileira e o Hymno Nacional. & \\
\hline
\end{tabular}


Assim, quase todos os conteúdos do programa de História para o $4^{\circ}$ ano primário estavam presentes no livro de Viriato Corrêa. Embora não houvesse conteúdos específicos de instrução cívica, havia a veiculação de valores morais e cívicos, no decorrer dos capítulos de História do Brasil para crianças, através das lições do vovô. Aliás, considerando-se a diversidade de escolas existentes no País e a relativa autonomia que os estados e municípios tinham para estabelecer seus currículos e programas curriculares, podemos verificar, como se disse, que o livro História do Brasil para crianças contemplava, em grande parte, os conteúdos programáticos do currículo escolar de todo o ensino primário, a partir dos anos 1930.

O mesmo pode-se constatar em relação ao programa exigido para o ingresso no ensino ginasial ou secundário - o chamado "exame de admissão". A obrigatoriedade da realização desse exame foi fruto de uma decisão normativa oriunda da primeira reforma educacional empreendida pelo governo Vargas (Art. 18 do Decreto 19.890/1931). 
Quadro 3 - Comparativo: Exame de Admissão e História do Brasil para crianças.

\begin{tabular}{|c|c|}
\hline PROGRAMA PARA O EXAME DE ADMISSÃO & HISTÓRIA DO BRASIL PARA CRIANÇAS \\
\hline 1. Descobrimento da América; Colombo. & - Cap. III - O louco (Cristóvão Colombo). \\
\hline 2. Descobrimento do Brasil; Cabral. & $\begin{array}{ll}- & \text { Cap. VIII - O navegador espanhol; } \\
- & \text { Cap. IX - O navegador português. }\end{array}$ \\
\hline 3. Capitanias Hereditárias. & - Cap. XIII - A desgraça das capitanias. \\
\hline 4. Os três primeiros governadores gerais. & $\begin{array}{ll}- & \text { Cap. XVII - Os padres jesuítas; } \\
- & \text { Cap. XX - Cidades que eram aldeias. }\end{array}$ \\
\hline $\begin{array}{l}\text { 5. Invasão do Rio de Janeiro pelos franceses. } \\
\text { Fundação da Cidade; Estácio de Sá. }\end{array}$ & $\begin{array}{ll}\text { - } & \text { Cap. XXII - A França Antártica; } \\
- & \text { Cap. XXXV - O corsário que vencemos; } \\
- & \text { Cap. XXXVI - O corsário que nos venceu. }\end{array}$ \\
\hline $\begin{array}{l}\text { 6. Invasões holandesas; Matias de Albuquerque, } \\
\text { Henrique Dias e Felipe Camarão. }\end{array}$ & $\begin{array}{ll}- & \text { Cap. XXIV - A conquista dos holandeses; } \\
- & \text { Cap. XXV - O Príncipe de Nassau; } \\
- & \text { Cap. XXVI - A queda dos flamengos. }\end{array}$ \\
\hline $\begin{array}{l}\text { 7. Entradas e bandeiras; Antônio Raposo Tavares e } \\
\text { Fernão Dias Paes. }\end{array}$ & $\begin{array}{ll}- & \text { Cap. XXX - Bandeiras e bandeirantes; } \\
- & \text { Cap. XXXI - Antônio Raposo e Fernão Dias. }\end{array}$ \\
\hline $\begin{array}{l}\text { 8. Conjuração Mineira; Tiradentes. Transmigração } \\
\text { da família real de Portugal para o Brasil; D. João } \\
\text { VI. }\end{array}$ & $\begin{array}{ll}- & \text { Cap. XXXVIII - O sentimento da } \\
\text { independência; } \\
\text { - } \\
\text { Cap. XXXIX - A figura maravilhosa de } \\
\text { Tiradentes; } \\
-\quad \text { Cap. XL - A morte de Tiradentes; } \\
-\quad \text { Cap. XLIV - A chegada da corte portuguesa. }\end{array}$ \\
\hline $\begin{array}{l}\text { 9. Independência; D. Pedro I. José Bonifácio, } \\
\text { Gonçalves Ledo. }\end{array}$ & $\begin{array}{ll}- & \text { Cap. XLVI - O Fico; } \\
- & \text { Cap. XLVII - Na colina do Ipiranga; } \\
- & \text { Cap. XLVIII - A dissolução da Constituinte; } \\
- & \text { Cap. XLIX - Os republicanos de 1824; } \\
- & \text { Cap. L - Sete de abril. }\end{array}$ \\
\hline 10. Período regencial; Padre Feijó. & - $\quad$ Cap. LI - Nove anos de sangue; \\
\hline 11. O segundo reinado; D. Pedro II. & - Cap. LII - O reinado do homem pacífico. \\
\hline 12. Guerra do Paraguai; Osório e Caxias. & $\begin{array}{ll}- & \text { Cap. LIII - A Guerra do Paraguai; } \\
- & \text { Cap. LIV - Riachuelo e Tuiutí. }\end{array}$ \\
\hline $\begin{array}{l}\text { 13. Abolição do cativeiro; Princesa Isabel, José do } \\
\text { Patrocínio e Joaquim Nabuco. }\end{array}$ & - Cap. LVII - 13 de maio \\
\hline $\begin{array}{l}\text { 14. Proclamação da República; Deodoro, Floriano } \\
\text { Peixoto, Benjamim Constant, Rui Barbosa. }\end{array}$ & $\begin{array}{ll}- & \text { Cap. LVIII - } 15 \text { de novembro; } \\
- & \text { Cap. LIX - Palavras do fim. }\end{array}$ \\
\hline $\begin{array}{l}\text { 15. Governos republicanos; contribuição ao } \\
\text { progresso do Brasil. }\end{array}$ & $\begin{array}{l}\text { Embora publicado em 1934, o livro termina com } \\
\text { a implantação da República no Brasil e não } \\
\text { analisa os primeiros anos da história } \\
\text { republicana. }\end{array}$ \\
\hline
\end{tabular}

Da análise dos programas curriculares para o ensino de História na escola primária, observa-se que, no decorrer dos anos, embora se tenham verificado algumas mudanças na estrutura organizacional do ensino primário, os conteúdos programáticos da disciplina permaneceram quase os mesmos. 
Podemos, pois, concluir, após análise dos currículos escolares do período, que, mesmo diferenciando-se no estilo da narrativa histórica em relação a outros livros didáticos, História do Brasil para crianças, com suas explicações dialogadas entre o vovô e as crianças, contemplava, perfeitamente, o programa de História para a escola primária ou até mesmo serviria como preparação ao exame de admissão. Isso explica, em grande parte, o fato de que, surgindo como um livro infantil, História do Brasil para crianças foi o único livro de Viriato Corrêa a receber o registro da Comissão Nacional do Livro Didático do MEC ( $\mathrm{n}^{\circ}$ 966), no ano de 1961.

\subsubsection{O ensino da História no Brasil: relatos e críticas}

Quem de nós não se lembra de seus tempos de escola, em que éramos obrigados a responder perguntas infindáveis nos questionários e a memorizar datas, fatos e nomes de personagens históricos, por ocasião das provas, exames e as tão temidas argüições, que nos obrigavam a ter tudo memorizado "na ponta da língua" ou de "cor e salteado"? Relacionado ao estudo de História, isso faz parte de uma cultura escolar de décadas passadas, mas que ainda persiste no imaginário coletivo de grande parte da população escolarizada.

No senso comum, a História tem sido considerada, por excelência, "matéria decoreba", para esquecer e jogar fora, sem nenhuma importância maior para a formação do aluno, ainda que pesem os discursos oficiais e os atuais programas curriculares, que vêem, no conhecimento histórico, um componente fundamental na construção de uma pedagogia cidadã $(\text { KNAUSS, 2005) })^{151}$.

Já nos primeiros anos da República, o educador e crítico literário José Veríssimo, ao escrever sobre os problemas da educação nacional, fazia críticas à forma como era ministrada a História do Brasil nas escolas. Dizia ele:

\footnotetext{
151 Para o historiador Paulo Knauss, "mais recentemente, ao se ratificar cada dia mais o compromisso democrático da sociedade nacional, a pedagogia do civismo tendeu a ser substituída por uma pedagogia da cidadania, que atribui à história um destaque especial. O conhecimento histórico legitima a conquista dos direitos sociais e o reconhecimento de camadas sociais desfavorecidas historicamente. Contudo, também nesse caso a história surge como matéria moral, ainda que legitimada e justificada pelo engajamento na construção de uma sociedade que respeita diferenças e rejeita injustiças." (KNAUSS, Paulo. O desafio da ciência: modelos científicos no ensino de História. Cadernos Cedes, Campinas, vol. 25, n. 67, p. 279-295, set./dez. 2005, p. 282).
} 
O ensino da história pátria, além de escassamente feito, é pessimamente dado. Os compêndios, insisto, são em geral despidos de qualquer merecimento didático. São pesados, indigestos e mal escritos.

Para o ensino primário os poucos que há são inspirados na velha pedagogia jesuítica das perguntas e respostas e limitam-se a uma enfadonha e estúpida nomenclatura de governadores, de reis, capitães-mores ou de fatos áridos de nenhum modo úteis ao ensino primário da história pátria. Na escola primária, afora a decoração e bruta repetição desses péssimos compêndios, nada mais auxilia e completa o estudo da história nacional. $\mathrm{O}$ mestre, que as mais das vezes a ignora, e que em geral é pouco zeloso, limita-se a tomar a lição, isto é, a fazer ao menino as perguntas indicadas no compêndio, e a exigir dele a resposta. Não há uma explicação, não há uma lição oral, um trabalho de composição sobre a história pátria. Tomada a lição está satisfeita a obrigação oficial, quando a não descuram de todo, que é o que mais vezes acontece (VERÍSSIMO, 1906, p. 180-1, grifo nosso).

Críticas como essa ao modelo de ensino de História vigente na maior parte das escolas brasileiras eram feitas por intelectuais, impregnados do ideário nacionalista. Um deles era o paulista e acadêmico Paulo Setúbal ${ }^{152}$, que escreveu relatos romanceados de personagens e fatos da História do Brasil, entre os quais podemos citar: A Marquesa de Santos (1925), O Príncipe de Nassau (1926) e As Maluquices do Imperador (1927) ${ }^{153}$. Esses seus romances históricos foram sucesso absoluto, com uma tiragem média de 15 mil cada um dos títulos publicados pela CEN.

Setúbal, na introdução do livro O Príncipe de Nassau, já demonstrava o porquê de se dedicar ao romance histórico como forma de divulgação de nosso passado, ao mesmo tempo em que criticava a forma como se ministrava o ensino de História na escola primária. Dizia ele:

\footnotetext{
${ }^{152}$ Paulo Setúbal (1893-1937), paulista de Tatuí, foi advogado, jornalista, poeta e romancista. A partir dos anos 20, inicia a principal fase de sua produção literária, que o levaria a ser o escritor mais lido do país, destacandose, sobretudo, pelo gênero do romance histórico. "Os sucessivos livros que escreveu sobre o ciclo das bandeiras, a começar com 'O ouro de Cuiabá' (1933) até 'O sonho das esmeraldas' (1935), tinham o sentido social de levantar o orgulho do povo bandeirante na fase pós-Revolução Constitucionalista (1932) em São Paulo, trazendo o passado em socorro do presente.” Em 1935, é eleito para a Academia Brasileira de Letras na sucessão de João Ribeiro (Biografia de Paulo Setúbal In: www.academia.org.br. Acesso em 10.11.2008. Ver também JORGE, Fernando. Vida, obra e época de Paulo Setúbal: um homem de alma ardente. $2^{\mathrm{a}}$ ed., São Paulo: Geração Editorial, 2008).

${ }^{153}$ Essa obra serviu de inspiração para a minissérie da Rede Globo, intitulada O Quinto dos Infernos (2002) e foi recentemente relançada no mercado editorial no bojo das comemorações alusivas aos 200 anos da vinda da família real para o Brasil. Na capa, há uma epígrafe, como forma de atrair o leitor e que sintetiza o enredo da obra: "A incrível história de como D. Pedro I chegou ao Brasil em 1808 com o pai, Dom João VI, cresceu no meio de aventureiros e cortesãs, proclamou a independência em 1822, aos 23 anos, regressou a Portugal para guerrear contra o próprio irmão, Dom Miguel, e coroou rainha a filha de 15 anos, Dona Maria II, antes de morrer idolatrado e tuberculoso, aos 35 anos." (SETÚBAL, Paulo. As maluquices do imperador (1808-1934). São Paulo: Geração Editorial, 2008).
} 
Todos nós trazemos da meninice uma quasi aversão por coisas de historia patria. É natural. Nas escolas, propositadamente, despojam a Historia do Brasil de todos os atavios que seduzem: a lenda, o facto curioso, a anedocta interessante, o episodio novellesco. Apresentam-na desgraciosamente, ouriçada de datas, núa de galantarias e feitiços. Não há nada mais árido, tal como nos ensinam, do que este estafante ról de capitanias hereditárias, donatários, Thomés de Souza, Mens de Sá, emboabas, e não sei quantas outras massadas com que nos atulham a cabeça em vésperas de exame. A conseqüência disso é que, feitos os preparatorios, conseguida a approvaçãozinha simples, o brasileiro fecha irremissivelmente a Historia do Brasil. Resultado: essa vastíssima ignorância nacional sobre as mais rudimentares ninharias do nosso passado. A não ser os benedictinos dos Institutos, a não ser meia-dúzia de eruditos de boa-vontade, não há ninguém mais no Brasil que se preocupe com taes estudos.

Sacudir um pouco essa indifferença, contribuir com qualquer esforço, um grão de areia que seja, para que o povo se interesse pela sua historia, eis o ferrão que me aguilhoa a publicar este novo romance (SETÚBAL, 1926, p. 5, grifo nosso).

Em um de seus livros de crônicas históricas, Viriato fez também críticas à forma como a História era produzida e concebida:

A historia do Brasil é a historia enfadonha de capitães-mores, de governadoresgeraes, de vice-reis circunspectos, de cartas regias, de sesmarias.

É uma historia pesada, porque toda ella gravita em derredor de homens. Falta-lhes a centelha romanesca de tantas outras historias porque lhes faltam mulheres (CORRÊA, 1936, p. 121-2, grifo nosso).

Para Viriato Corrêa a História tal como era produzida na Academia e ensinada nos bancos escolares era uma sucessão enfadonha de nomes de personagens históricos e atos administrativos ligados ao poder instituído. Por outro lado, e nesse ponto ele se tornava inovador, Viriato pretendia uma História não restrita ao segmento masculino ${ }^{154}$. Ele queria uma História que contemplasse aspectos do cotidiano e da vida privada, pois, até então, a escrita da história era a "genealogia da nação" (FURET, s/d), com a exaltação dos feitos político-administrativos dos governantes.

\footnotetext{
${ }^{154}$ Viriato Corrêa era defensor do ingresso de mulheres na ABL, conforme matéria publicada na imprensa: "Viriato Corrêa declarou-se favorável à eleição de mulheres para aquela Casa, em virtude de achar que no Brasil existem mulheres tão inteligentes quanto os homens. Aceito a decisão da Academia de não elegê-las, mas reconheço que a Casa de Machado de Assis deve evoluir desse seu ponto de vista." (Correio da Manhã, Rio de Janeiro-RJ, 22.1.1967).
} 
A historia não é somente feita de heroísmo, de fragor de armas, de torrentes de sangue, de golpes diplomáticos, de acertos e desacertos políticos. É também feita de amor. É também feita de intrigas, de ciúmes, de mexericos, de escândalos.

Desencadeia-se tanto entre as rendas e os perfumes das alcovas, como se desencadeia nos campos de batalha ou nos gabinetes dos governantes. Vive também no bojo peccador das saias como pode viver na espada heróica dos generaes (CORRÊA, 1936, p. 121, grifo nosso).

A crítica ao ensino de História não era exclusiva de intelectuais, mas fez parte também das memórias de infância de muitos brasileiros:

Governadores-gerais, holandeses e franceses começaram a importunar-me. Esquartejavam-se períodos, subdividiam-se e rotulavam-se as peças em medonha algazarra. Os meus amigos guardavam maquinalmente façanhas portuguesas, francesas e holandesas, regras de síntese - e brilhavam nas sabatinas. Segunda-feira estavam esquecidos, e no fim da semana precisavam repetir o exercício, decorar provisoriamente a matéria. À medida que avançavam, a tarefa ia se tornando mais penosa: ficavam apenas, algum tempo, as últimas lições.

Eu achava estupidez pretenderem obrigar-me a papaguear de oitiva (RAMOS, 1979, p. 219, grifo nosso).

O uso excessivo da memorização de datas-fatos-nomes levava a situações jocosas quando da realização de argüições, conforme o seguinte relato:

A História do Brasil era decorada do livro de Lacerda, Pequena História do Brasil por perguntas e respostas. Líamos também os livros de Olavo Bilac e Coelho Neto, A Pátria Brasileira e Contos Pátrios [...]. As perguntas eram distribuídas uma após outra, aos alunos da classe, e cada um memorizava especialmente a sua, mas alguns de nós memorizávamos todas. É daí que vem a conhecida anedota escolar do menino que, argüido por um visitante sobre quem tinha descoberto o Brasil, respondeu: Eu sou o '22 de abril de 1500'; o 'Pedro Álvares Cabral precisou ir lá fora' [...] (SALUM apud LEITE, 1969, p. 52).

Lembrando os seus tempos de escola, em que particularmente preferia as aulas de História a outras disciplinas, Frei Betto não deixa de fazer uma crítica à escrita da história repassada aos alunos: 
Agradavam-me, entretanto, as aulas de história. Tudo era Minas na História do Brasil: bandeirantes e emboabas, esmeraldas e ouro, Fernão Dias e Borba Gato, Felipe dos Santos e Tiradentes, Cláudio Manoel da Costa e Tomás Antonio Gonzaga, Alvarenga Peixoto e sua Bárbara bela, a Eliodora que, como todas as mulheres, incluindo Xica da Silva e dona Beja, figuravam nos registros históricos como meras sombras de empreitadas masculinas (BETTO, 2002, p. 81, grifo nosso).

Outros memorialistas retratam sua experiência como professores de História e mostram as práticas pedagógicas usadas na escola por ocasião dos exames: sorteio do ponto, provas discursivas e o uso da "cola" diante de tantos nomes e fatos históricos a serem memorizados por estudantes, no caso, alunas.

Parcial de junho. Sentadas, porém buliçosas, nervosas, as pequenas da 32. Sobre as carteiras, o papel branco de tênues pautas azuis, o lápis-tinta, a borrachinha de apagar. Momento de atenção e de tensão: sorteio do ponto. [...]

- Alunas, escrevam no cabeçalho da prova: Ponto 2. Caminho das Índias, Vasco da Gama.

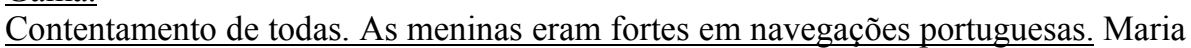
voltou ao seu lugar, triunfante. Judite franziu a testa de inteligente e logo depois rabiscava, ligeira, sem hesitação. As outras iam começando também. Só Inês que demorou, a coçar a cabeça, a assoar o nariz, a mordiscar o lápis-tinta. Decidiu-se finalmente, como ao efeito de súbita inspiração.

Desconfiei, resolvi passear nos dois corredorezinhos que separavam as carteiras. Cola, não havia. Ou não se via. Alguém mexeu os lábios. Se perguntou alguma coisa, foi baixinho demais. Ouvi, porém, o murmúrio de uma resposta: "Cabo da Boa Esperança, boba".

Não reclamei. Valia mais um bom coleguismo carioca do que uma ponta de terra, mar adentro, nos confins da África." (AMADO, 1971, p. 45, grifo nosso).

A leitura desses depoimentos, seja de intelectuais, seja das reminiscências dos próprios alunos, leva-me a concluir que, na prática pedagógica da sala de aula, apesar das mudanças nos currículos e programas de ensino e da diversidade de escolas existentes para esse nível de ensino (públicas, privadas, grupos escolares, escolas confessionais, rurais, profissionalizantes), o ensino de História na escola primária pouco mudou entre os anos 30 e 60 do século passado. Assim, no decorrer desses anos, a construção do saber histórico escolar "sacralizou" alguns conteúdos que, ainda hoje, fazem parte de qualquer livro didático de História. Muda-se apenas a forma de abordagem dos temas, com a incorporação de novas questões suscitadas pela historiografia brasileira. 


\subsection{A escrita da história para crianças: outros livros didáticos}

\subsubsection{A produção didática do século XIX}

Diferentemente de outras disciplinas escolares em que, muitas vezes, eram feitas traduções ou adaptações de livros estrangeiros à realidade brasileira, para a disciplina História, sobretudo no que se refere à História do Brasil, foi preciso escrever livros específicos, destinados a esse ensino na escola primária (BITTENCOURT, 2008).

Assim, desde meados do séc. XIX, já dispúnhamos de livros escolares destinados ao ensino dessa disciplina. Editados pela B.L. Garnier, pelos irmãos Laemmert ou pela Livraria Francisco Alves, muitos desses livros escolares tiveram ampla aceitação nas escolas de primeiras letras. Exemplo disso foram os livros Pequena História do Brasil por perguntas e respostas para uso da infância brasileira, de Joaquim Maria de Lacerda (Livraria Francisco Alves, 1887); Primeiras lições de História do Brasil: perguntas e respostas (coleção de livros didáticos da FTD); História do Brasil contada aos meninos, de Estácio de Sá e Menezes (B.L. Garnier Livreiro-Editor, 1870); História do Brasil (resumo didactico), de R. Villa-Lobos (Laemmert Editores, 1891) e História do Brasil ensinada pela biographia de seus heróes (livro para as classes primárias), de Silvio Romero (Livraria Francisco Alves, 1890).

Desses livros, alguns foram usados durante muito tempo nas escolas. É o caso, por exemplo, de Pequena história do Brazil por perguntas e respostas para uso da infância brasileira do Dr. Joaquim Maria de Lacerda ${ }^{155}$. Editado pela Livraria Francisco Alves e tendo circulado até o ano de 1957, numa edição atualizada pelo professor Luís Leopoldo Fernandes Pinheiro, seu sobrinho, o livro adotava o método de perguntas e respostas, bastante usado nos catecismos da Igreja Católica para o aprendizado da doutrina cristã.

\footnotetext{
155 Joaquim Maria de Lacerda (1838-1886) era "formado em Direito, membro da arcadia de Roma e de várias associações literárias da Europa, dedicou-se com inexcedível applicação à educação da mocidade, escrevendo e dando à publicidade muitas obras nesse sentido" (BLAKE, p. 193, vol. 1). Escreveu outros livros dedicados à infância brasileira: Pequena geographia da infância para uso das escolas primárias. Rio de Janeiro, 1887; Resumo de choreographia do Brazil, Rio de Janeiro, 1887; Arithmetica da infância. Paris, 1881; Encyclopedia primaria ou manual completo e methodico de instrucção primaria. Paris, 1882 e Thesouro da infância ou novo manual das escolas primárias. Havre, 1885.
} 


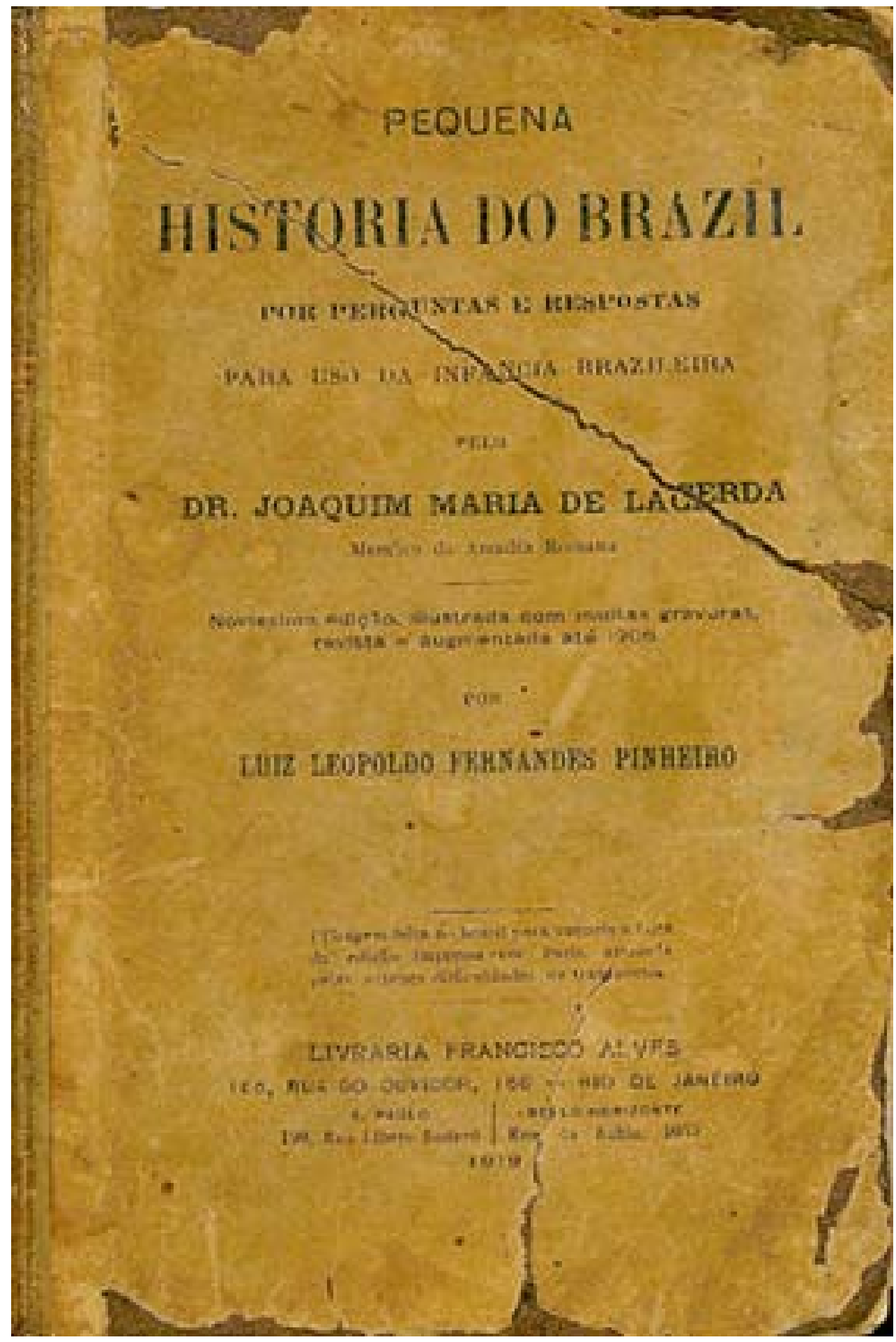

Figura 64 - Pequena História do Brasil para uso da infância brasileira - capa. Fonte: LACERDA, 1919. Acervo BLD-FEUSP. 


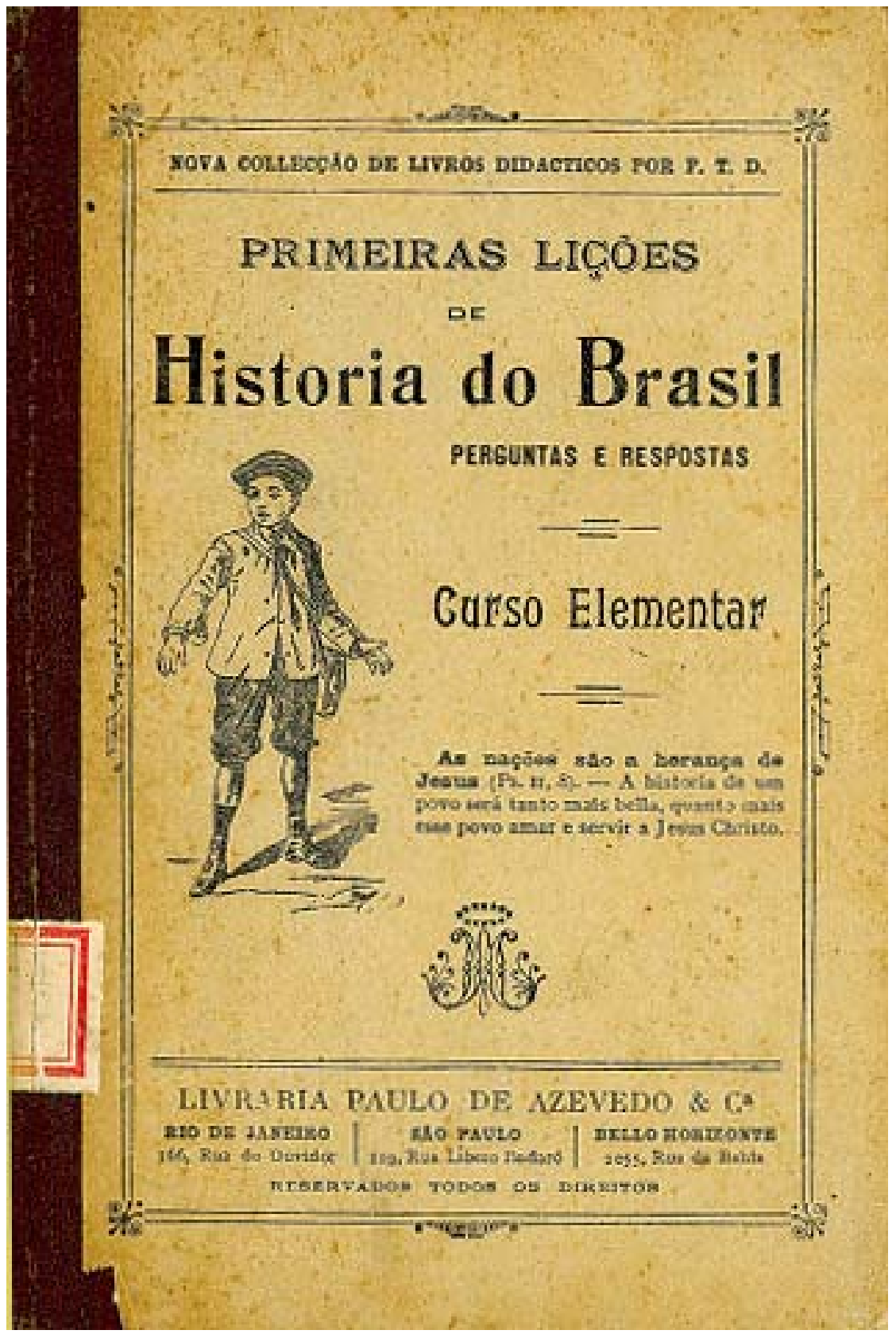

Figura 65 - Primeiras lições de Historia do Brasil: perguntas e respostas (Edições FTD, s/d). Fonte: Acervo BLD-FEUSP.

O livro História do Brasil contada aos meninos, de Estácio de Sá e Menezes, pseudônimo usado pelo Cônego Fernandes Pinheiro, difere dos demais por trazer uma pequena lição sobre um tema da História que era explicado pelo Sr. Maurício, um militar reformado, viúvo, pai de dois filhos e residente na província de Minas Gerais. Ao final da lição, havia uma seção intitulada "dúvidas e explanações", na qual os filhos Sophia e Eugenio formulavam perguntas que eram esclarecidas pelo pai. 
Sylvio Romero, escritor sergipano e crítico literário, membro-fundador da ABL, também foi autor de um livro didático destinado ao ensino de História e Instrução Cívica - a História do Brasil ensinada pela biographia de seus heróes (livro para as classes primárias). Nele, como o próprio título sugere, o estudo da história pátria é permeado pela biografia de brasileiros ilustres, de acordo com o período histórico a ser estudado: século do descobrimento e da conquista (destaque para as biografias de Colombo, Pedro Álvares Cabral e José de Anchieta); século da expansão e da resistência (biografia dos heróis Vidal de Negreiros, Fernandes Vieira, Camarão e Henrique Dias no contexto da Invasão Holandesa, bem como as figuras do padre Antonio Vieira e do escritor Gregório de Matos, como expressão das letras); século do desenvolvimento autonômico (biografia de Tiradentes e de outros inconfidentes) e século da independência e da república (vida de José Bonifácio, Evaristo da Veiga, Diogo Feijó, Duque de Caxias, Deodoro da Fonseca e Benjamin Constant, além dos "heróes das letras no século XIX", como Gonçalves Dias).

Importante é destacar a produção de dois livros didáticos escritos por mulheres em pleno séc. XIX, época em que a maioria delas não tinha acesso ao sistema de educação formal e numa sociedade em que "escrever era um verbo conjugado no masculino" (NUNES, 2007, p. 408).

Herculana Firmina Vieira de Souza exercia o magistério público como professora de primeiras letras na Villa de Cururupu, na então província do Maranhão, e escreveu um livro destinado ao ensino primário. Trata-se do Resumo da história do Brazil desde seu descobrimento até a aclamação de Sua Majestade Imperial (1500-1840). O livro, editado em 1868, tinha 151 páginas, no formato in $-8^{\circ}$ e era de perguntas e respostas, tendo obtido aprovação do governo para uso nas escolas. Segundo Blake, esse livro foi bem recebido pela imprensa, principalmente pelo Semanário Maranhense, e teve uma segunda edição em 1880, e talvez outras posteriores (BLAKE, 1970). 


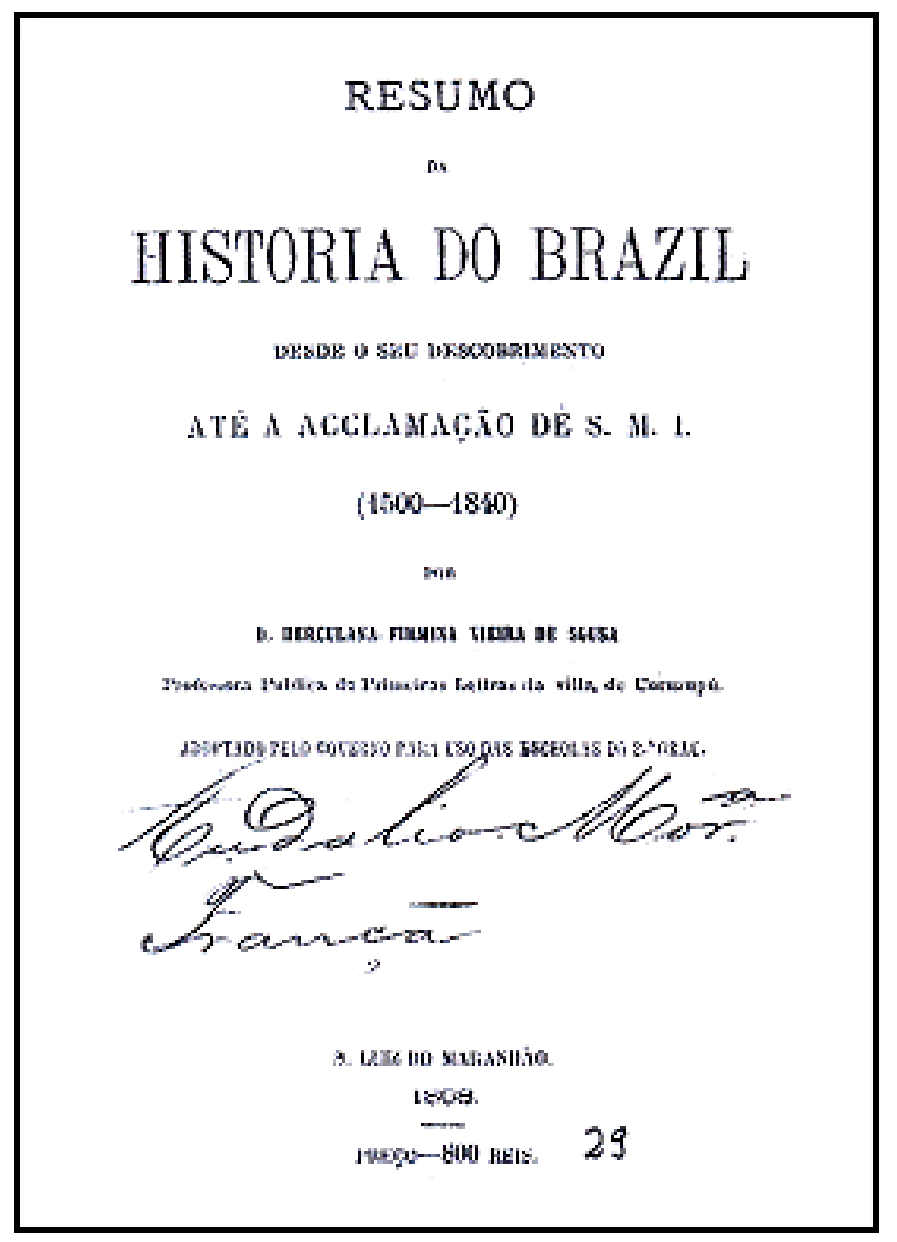

Figura 66 - Resumo da História do Brazil desde seu descobrimento até...(1500-1840). Fonte: SOUZA, 1868. Acervo IEB-USP.

A educadora mineira Maria Guilhermina Loureiro de Andrade havia fundado um colégio para meninas, na capital do País, na Rua do Riachuelo. Ela também escreveu o seguinte livro escolar: Resumo da História do Brasil para uso das escolas primárias. O livro foi editado em Boston, Estados Unidos, no ano de 1888, com 231 páginas, no formato in- $8^{\circ}$, com 22 estampas coloridas. O referido manual teve outras edições, sendo uma de 1895 (BLAKE, 1970).

\subsubsection{Os livros de maior circulação no século $X X$}

No período que tomei para a análise da História do Brasil para crianças, outros livros didáticos circularam na escola primária brasileira. Levantei, através de pesquisa junto ao banco de dados LIVRES e no acervo da Biblioteca do Livro Didático (BLD) da FEUSP, os 
livros que foram publicados e até mesmo os que, já editados em outro período, ainda circulavam na escola brasileira de então (ver em ANEXOS).

É o caso, por exemplo, do livro de autoria do historiador paranaense Rocha Pombo ${ }^{156}$, publicado pela Editora Melhoramentos, em 1917. Trata-se de Nossa Pátria: narração dos fatos da História do Brasil, através da sua evolução com muitas gravuras explicativas, que teve 63 edições e circulou até o final dos anos 60, em edição atualizada pelo educador Lourenço Filho ${ }^{157}$.

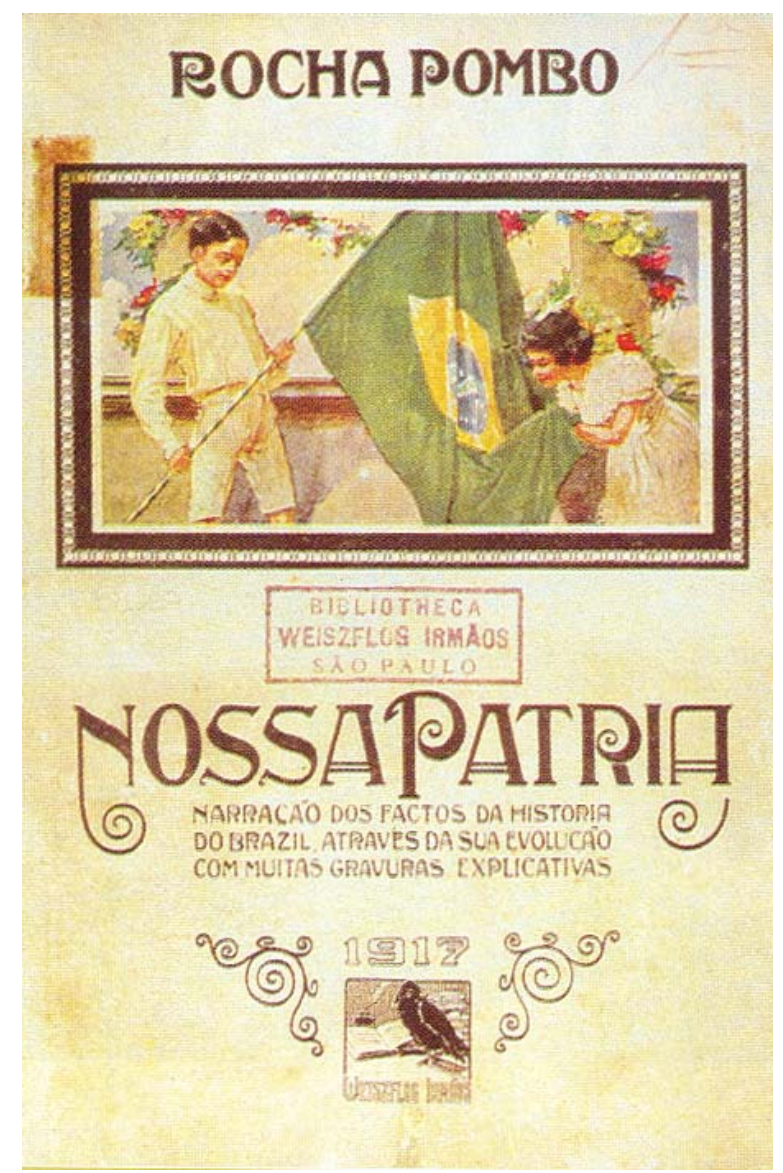

Figura 67 - Nossa Pátria - capa.

Fonte: POMBO, 1917. Acervo BLD-FEUSP.

\footnotetext{
${ }^{156}$ José Francisco da Rocha Pombo (1857-1933) nasceu na cidade de Morretes, no Paraná. Sendo o filho mais velho de uma família numerosa, teve de trabalhar aos dezessete anos, dedicando-se, a exemplo do pai, à atividade do magistério. Aos dezoito anos, fundou seu primeiro jornal, "O Povo", em que passou a defender o ideário abolicionista e republicano. Em 1886, foi eleito deputado provincial pelo Partido Conservador. No Rio de Janeiro, ingressou por concurso no Colégio Pedro II e na Escola Normal e foi admitido como sócio no IHGB no ano de 1900 .

${ }^{157}$ Segundo dados da própria Editora Melhoramentos, na página de rosto, o livro Nossa Pátria era adotado em todos os estados do Brasil. Sua última edição foi do ano de 1967 ( $85^{\mathrm{a}}$ edição revista e atualizada pelo Prof. Lourenço Filho) e teve uma tiragem de 430 mil exemplares (POMBO, 1967).
} 
Esse manual didático pode ser considerado o "petite lavisse" brasileiro, pelas sucessivas edições e por ser um dos livros que, já nas primeiras lições, fornece aos alunos conceitos como pátria, patriotismo e a significação de nossos símbolos nacionais. Esse livro traz algumas inovações que o fazem diferente das demais obras publicadas no período e que merecem ser analisadas, além do fato de que Rocha Pombo era um dos interlocutores de Viriato Corrêa ${ }^{158}$, tendo sido o autor do prefácio da primeira obra de crônicas históricas de Viriato - Histórias da nossa História (1921).

Logo na apresentação, o autor salienta que o culto à pátria deve ser feito mediante o conhecimento da ação de nossos antepassados na história. Ele diz, também, que o livro foi feito

[...] para a inteligência das crianças e dos homens simples do povo. Nestes dias, que alvorecem tão novos, em que se procura criar o culto da pátria, penso que o primeiro trabalho para isso é fazer a pátria conhecida daqueles que a devem amar. [...] Sentir o que fizeram de grande nossos antepassados equivale a tomar o compromisso de os continuar na história. [...] Fixá-los, em suas linhas gerais, na alma das gerações, é, pois, o processo mais prático e seguro de nela criar e nutrir o sentimento da pátria[...] (POMBO, s/d, p. 3).

O livro se inicia com uma exortação cívica à Pátria e prossegue com o estudo dos símbolos nacionais, por conferirem "uma representação quase totêmica ao patriotismo" (CATROGA, 2005, p. 154). A partir do capítulo 3, inicia-se o conteúdo de História do Brasil propriamente dito. Diferentemente de outros livros que normalmente começam nossa história com a chegada dos portugueses, esse capítulo trata da emancipação política e da figura do Patriarca da Independência, José Bonifácio, considerado pelo autor o grande artífice da Nação, devendo ser cultuado por todos os brasileiros:

\footnotetext{
${ }^{158}$ Há muitas semelhanças entre a trajetória pessoal e intelectual de Viriato Corrêa e Rocha Pombo. A exemplo de Viriato, Rocha Pombo veio do interior do estado (Morretes-PR) e fez seu nome na então capital da República. No Rio de Janeiro, produziu grande parte de sua obra historiográfica, destacando-se, sobretudo, na publicação de livros escolares, sendo, portanto, considerado "o historiador oficial da República Velha" (BEGA, 2003, p. 481). Exerceu, como Viriato Corrêa, mandato político, tendo sido eleito Deputado Federal pelo Estado do Paraná. Tentou por três vezes ingressar nos quadros da ABL, só conseguindo eleger-se no ano de 1933, mas morreu antes de tomar posse na cadeira de $\mathrm{n}^{\circ} 39$, posteriormente ocupada por outro historiador - Rodolfo Garcia - em 1935.
} 
Houve, naquele grande momento da nossa vida, muitos homens notáveis que se puseram à frente do povo, tomando a causa da pátria.

Entre todos esses homens, destaca-se, porém, a nobre figura de José Bonifácio de Andrada e Silva. [...] era um sábio conhecido no mundo, passou a fazer-se na América um criador de povo.

A sua obra aí está - o Brasil feito nação.

No culto dos antepassados, é ele o Patriarca - que deve estar mais vivo em nossos corações. Os seus restos mortais lá estão no seio de uma igreja de Santos (POMBO, s/d, p. 8, grifo nosso).

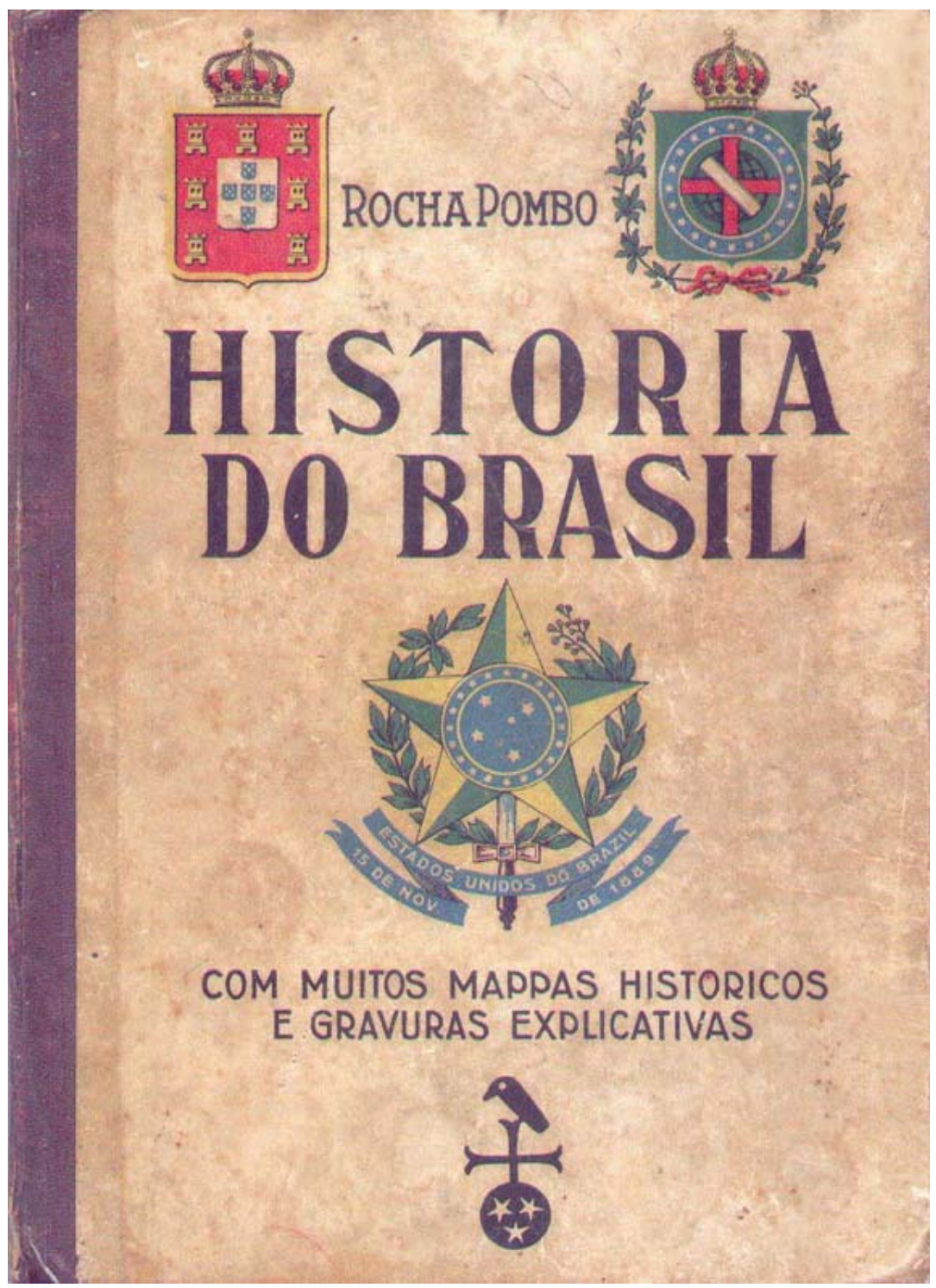

Figura 68 - História do Brasil - capa.

Fonte: POMBO, s/d. Acervo BLD-FEUSP.

Embora o livro priorize a história política, nele estão presentes, de forma inovadora, conteúdos relacionados ao cotidiano das populações urbanas (“Como se vivia nas vilas") e do homem do campo (“A vida nos sítios”). Veremos no próximo capítulo, inclusive, que Viriato 
Corrêa influenciou-se pela escrita do historiador Rocha Pombo, principalmente em "Os costumes de nossos avós", de História do Brasil para crianças.

Quanto à sua materialidade, o livro Nossa Pátria, com 169 páginas, apresenta-se em capa dura e traz como imagem colorida duas crianças: um menino empunhando a bandeira nacional e uma menina beijando-a de forma reverente. Há alguns mapas coloridos encartados no livro. As demais imagens são em preto e branco e muitas delas são reproduções de quadros de pintores famosos (Debret, Pedro Américo, Benedito Calixto, Henrique Bernardelli) e fotos de personagens históricos (D. Pedro II, D. Teresa Cristina, políticos e presidentes). O livro traz ao final uma "sinopse dos cinco séculos da nossa História" (antes de 1500 até o ano de 1922).

No mesmo ano da publicação do livro de Viriato Corrêa ${ }^{159}$, História do Brasil para crianças (1934), a Companhia Editora Nacional colocou no mercado o livro didático produzido pelo historiador baiano Pedro Calmon ${ }^{160}$. Trata-se da História da Civilização Brasileira para a escola primária, pertencente à Série II - Livros Didáticos, da BPB, dirigida por Fernando de Azevedo.

Quanto ao conteúdo, o livro difere da literatura escolar produzida no período. Isso se explica, conforme disse o próprio autor em carta dirigida às professoras, porque o mesmo foi feito para atender à demanda do Programa de Ciências Sociais do Departamento de Educação

\footnotetext{
${ }^{159}$ Houve uma contenda historiográfica entre Pedro Calmon e Viriato Corrêa, ambos pertencentes aos quadros da $\mathrm{ABL}$, sobre questões alusivas a fatos históricos relacionados à Independência do Brasil. "Numa conferência sobre 'Erros da História do Brasil', o Reitor da Universidade do Brasil, disse que D. Pedro I foi o verdadeiro patrono, relegando José Bonifácio a plano inferior e considerando a nossa independência como um negócio de pai para filho. O historiador Viriato Corrêa, disse ao DC, ontem, que de modo algum pode concordar com a opinião do seu colega da Academia. - A nossa independência só foi reconhecida na Europa devido ao prestígio de sábio de José Bonifácio. Se a independência tivesse sido proclamada unicamente por D. Pedro I, dificilmente teria sido reconhecida. Quanto à afirmação de que a independência foi um negócio de pai para filho, Viriato achou graça." ("Imortais acham que Patriarca é Bonifácio: Viriato Corrêa contra Pedro Calmon", Diário Carioca, Rio de Janeiro-RJ, de 09.11.1958).

${ }^{160}$ Pedro Calmon (1902-1985) foi professor, político, historiador. Iniciou seus estudos acadêmicos na Faculdade de Direito da Bahia, mas cursou apenas dois anos. A convite de Miguel Calmon, transferiu-se para a Capital em 1922, onde foi secretário da Comissão Promotora dos Congressos do Centenário da Independência. Concluiu seus estudos na Universidade do Rio de Janeiro, em 1924. Desde o início, mostrou grande interesse pelos estudos históricos e, no Museu Histórico Nacional, onde trabalhava como conservador, criou a cadeira de História da Civilização Brasileira, no Curso de Museus, escrevendo posteriormente um livro com o mesmo título da disciplina. Foi Deputado Estadual na Bahia, sendo um dos responsáveis pela primeira lei de proteção ao patrimônio histórico. Foi também eleito Deputado Federal, em 1935, e chegou a ocupar a pasta da Educação e Saúde, no Governo de Dutra (1946-1950). Foi eleito para a ABL em 1936 e exerceu o cargo de Reitor da Universidade do Brasil em dois períodos consecutivos (1948-1950; 1951-1966).
} 
do Distrito Federal, na gestão do educador Anísio Teixeira. Segundo Calmon, o referido programa entende e discrimina a História do Brasil por um método perfeitamente moderno e
racional. Esse livro é uma síntese, em traços largos, de duas obras de maior tomo,
que o precederam: História da Civilização Brasileira (para o curso superior.
Companhia Editora Nacional, 1933), e Espírito da Sociedade Colonial (Companhia
Editora Nacional, 1934) (CALMON, 1934, p. 13-4).

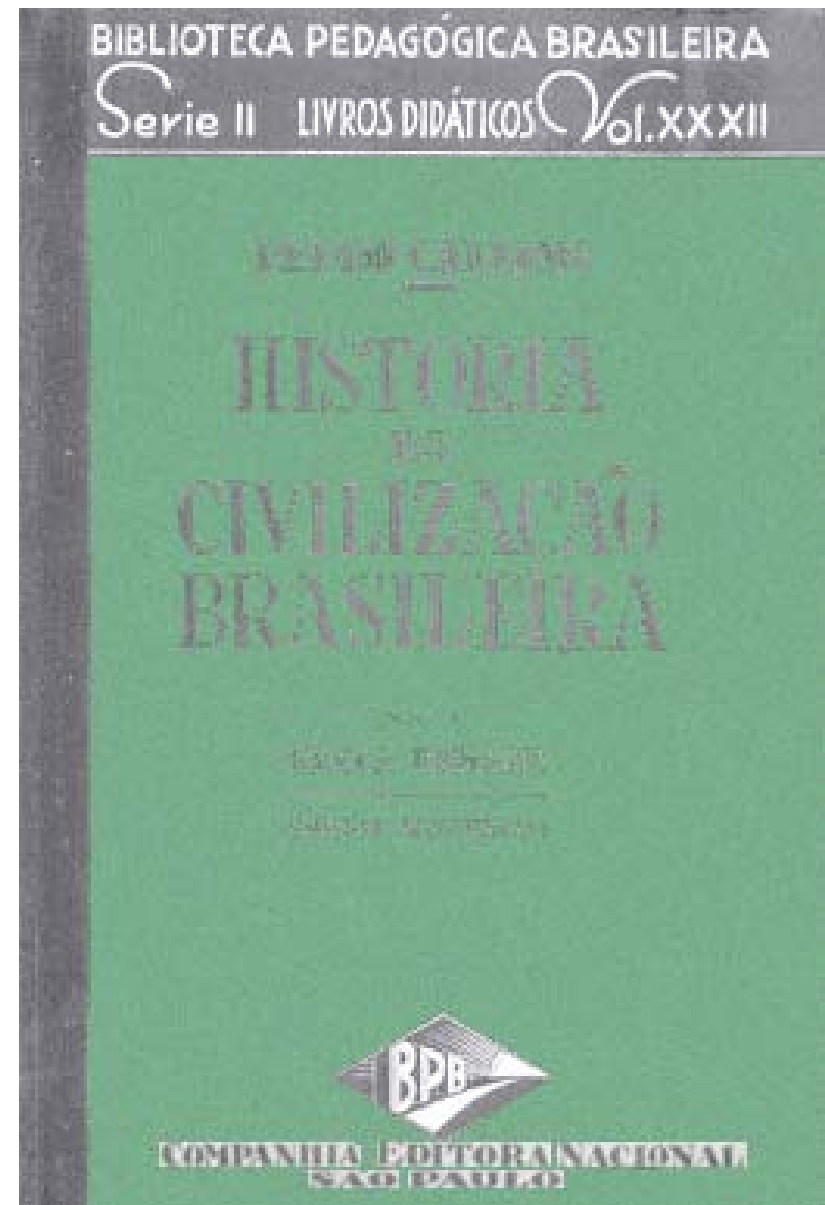

Figura 69 - Historia da Civilização Brasileira para a escola primária - capa. Fonte: CALMON, 1934.

$\mathrm{Na}$ verdade, o referido livro dá muita ênfase à história econômica e social, em detrimento dos aspectos político-institucionais tão comuns na literatura escolar do período. Assim, professor e alunos vão encontrar, logo nos primeiros capítulos, assuntos relacionados aos ciclos econômicos: a extração do pau-brasil, a conquista através do açúcar, os caminhos do gado, a procura do ouro, ao lado de capítulos sobre a vida cotidiana na colônia ("Como surgiu o sertanejo. As comunicações”; “A casa do colono”, “A instrução dos jesuítas”, entre outros). 
O livro termina em tom ufanista, exaltando o progresso econômico do País, ao tempo em que relaciona algumas realizações históricas que nos fazem ser uma "civilização brasileira".

Em 1922, numa época de prosperidade econômica, de intensa vida industrial e de progresso generalizado, o Brasil celebrou o primeiro centenário da sua Independência.

Uma exposição internacional, que reuniu no Rio de Janeiro representantes das principais nações do mundo, comemorou esse século de 'civilização brasileira', no qual realizamos:

- a emancipação política (1822),

- a organização nacional centralizada (1824),

- a organização descentralizada (1834),

- a experiência republicana da Regência,

- os melhoramentos materiais do Império,

- o prestígio internacional,

- o desenvolvimento das ciências, letras e artes,

- a eleição direta,

- a abolição da escravatura,

- a federação, com a República,

- a Constituição republicana,

- a ordem civil,

- o surto industrial de S. Paulo; a expansão da agricultura; a primazia brasileira do café, da borracha e do cacau; a transformação das cidades; a remodelação do Rio de Janeiro; a construção de estradas de ferro e de rodagem, dos telégrafos e correios, dos portos, das obras contra as secas etc.

Em cem anos conseguimos ser uma grande nação (CALMON, 1934, p. 141-2, grifo nosso).

Quanto à materialidade, o livro apresenta-se em capa dura, nas cores verde e preta, possui 143 páginas, ilustrado com estampas e reproduções de pintores e artistas consagrados (Chamberlain, Debret, Rugendas, Bernardelli) e fotografias de presidentes do período republicano - todas em preto e branco. Ao final do texto, encontramos uma cronologia da história do País.

Diferentemente do livro didático de Rocha Pombo, História da Civilização Brasileira para a escola primária só teve uma edição, no âmbito da BPB, da Companhia Editora Nacional. Isso se explica pelo fato de que o livro foi pensado para uma dada proposta de renovação do ensino de História, na gestão de Anísio Teixeira ${ }^{161}$, no Distrito Federal. Com a saída de Anísio em 1935, não foi dada continuidade a essa proposta de um programa de Ciências Sociais para a escola primária, nos moldes estabelecidos por Delgado de Carvalho.

\footnotetext{
${ }^{161}$ Anísio Teixeira permaneceu na gestão da Secretaria de Educação do Distrito Federal até o final de 1935, quando teve que se demitir do cargo em função de injunções políticas em nível nacional, que levaram, posteriormente, ao golpe do Estado Novo. A partir dessa experiência inovadora na educação do Distrito Federal, Anísio escreveu a obra Educação para a democracia: introdução à administração educacional (SAVIANI, 2007).
} 
CAPÍTULO 6 - HISTÓRIA DO BRASIL PARA CRIANÇAS: ENTRE TEXTOS E IMAGENS

HISTÓRIA PÁTRIA

Lá vai uma barquinha carregada de Aventureiros

Lá vai uma barquinha carregada de Bacharéis

Lá vai uma barquinha carregada de

Cruzes de Cristo

Lá vai uma barquinha carregada de

Donatários

Lá vai uma barquinha carregada de

Espanhóis

Paga prenda.

Prenda os espanhóis!

Lá vai uma barquinha carregada de Flibusteiros.

Lá vai uma barquinha carregada de Governadores

Lá vai uma barquinha carregada de Holandeses

Lá vai uma barquinha cheiinha de índios

Outra de degredados

Outra de pau de tinta

Até que o mar inteiro

Se coalhou de transatlânticos

$E$ as barquinhas ficaram

Jogando prenda com a raça misturada

No litoral azul de meu Brasil.

Oswald de Andrade 
6.1 A história e seus personagens: vovô e as crianças

16

VIRIATO CORR E A

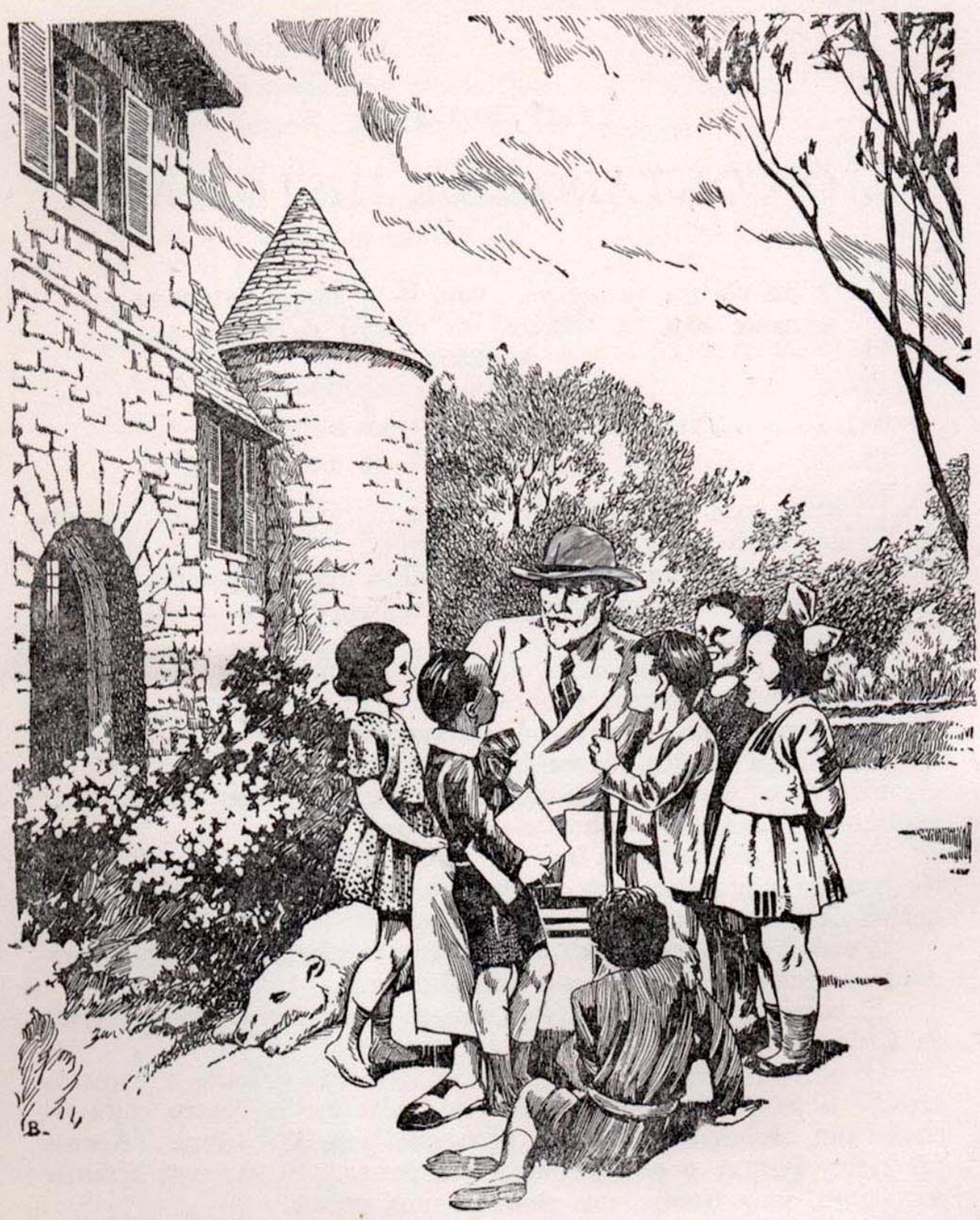

O contador de bistórias

Figura 70 - História do Brasil para crianças (reprodução em tamanho original).

Fonte: CORRÊA, 1957, p. 16. 
A primeira ilustração do livro História do Brasil para crianças permite-nos fazer algumas considerações sobre o modelo de escrita da história adotado por Viriato Corrêa.

$\mathrm{Na}$ figura, vê-se a imagem de um senhor idoso rodeado por seis crianças, em um espaço bucólico, cheio de plantas e dois animais - um gato e um cão. A imagem traz a legenda "O contador de histórias" que, por sua vez, é o título do primeiro capítulo do livro.

$\mathrm{O}$ ato de contar histórias remonta às sociedades tradicionais, que desconheciam o código da escrita e que recorrem à tradição oral, para estabelecer os vínculos necessários à sua sobrevivência física e cultural. Geralmente, um indivíduo mais velho conta histórias, repassando a memória de seu grupo social, para que esta não se perca. A narrativa torna-se, portanto, uma atividade geracional e de importância fundamental para a coesão e identidade desse grupo social. Através dos relatos narrados, calcados na memória e na experiência, o grupo social se fortalece, ao estabelecer elos de pertencimento entre seus membros (BENJAMIN, 1985).

$\mathrm{O}$ ato de narrar é, pois, uma atividade cultural bastante antiga e podemos até afirmar que o homem é o único animal contador de histórias:

[...] Crianças, só os animais vivem inteiramente no Aqui e Agora. Só a natureza não conhece memória nem história. Mas o homem - deixem-me dar-lhes uma definição - é o animal contador de histórias. Aonde quer que vá, quer deixar atrás não uma esteira caótica, não um espaço vazio, mas as reconfortantes bóias de sinalização e as indicações de estrada das histórias. Tem de continuar contando histórias, tem de continuar inventando-as. Enquanto houver histórias, está tudo bem. Mesmo em seus últimos momentos, dizem, na fração de segundo de uma queda fatal - ou quando está se afogando - ele vê, passando rapidamente à sua frente, a história de toda a sua vida (SWIFT, 1992, p. 63).

Muitas das histórias narradas passaram a fazer parte da dita cultura erudita ao serem transplantadas para o código da escrita, porém, mesmo assim, ainda permanece hoje o hábito de se contarem histórias ou "causos", em povoados e vilarejos, durante os serões noturnos. As crianças, por exemplo, mesmo com todo o suporte tecnológico da sociedade da informação à sua disposição, ainda gostam de ouvir histórias antes de dormir, fazendo com que seus narradores repitam-nas diversas vezes. E multiplicam-se também, pelo País afora, grupos de “contação de histórias", que narram e dramatizam contos infantis em escolas, livrarias, 
hospitais e clubes, como forma de incentivar a prática da leitura antes mesmo de a criança ingressar na vida escolar.

Na literatura infantil, é muito recorrente a inclusão de um personagem idoso que conta história às crianças. Tal estratégia já havia sido adotada por Monteiro Lobato, ao criar a figura de Dona Benta, proprietária do sítio do Pica-pau Amarelo, que conta história para seus netos (Narizinho e Pedrinho). Na década de 1940, o escritor mineiro Vicente Guimarães (19061981), tio de Guimarães Rosa, usou do pseudônimo "Vovô Felício", para escrever diversas histórias infantis, que foram publicadas na revista infantil Sesinho (1947-1960), do Serviço Social da Indústria (SESI). Ainda hoje, essa fórmula literária é usada, principalmente em se tratando de obras de cunho histórico ${ }^{162}$.

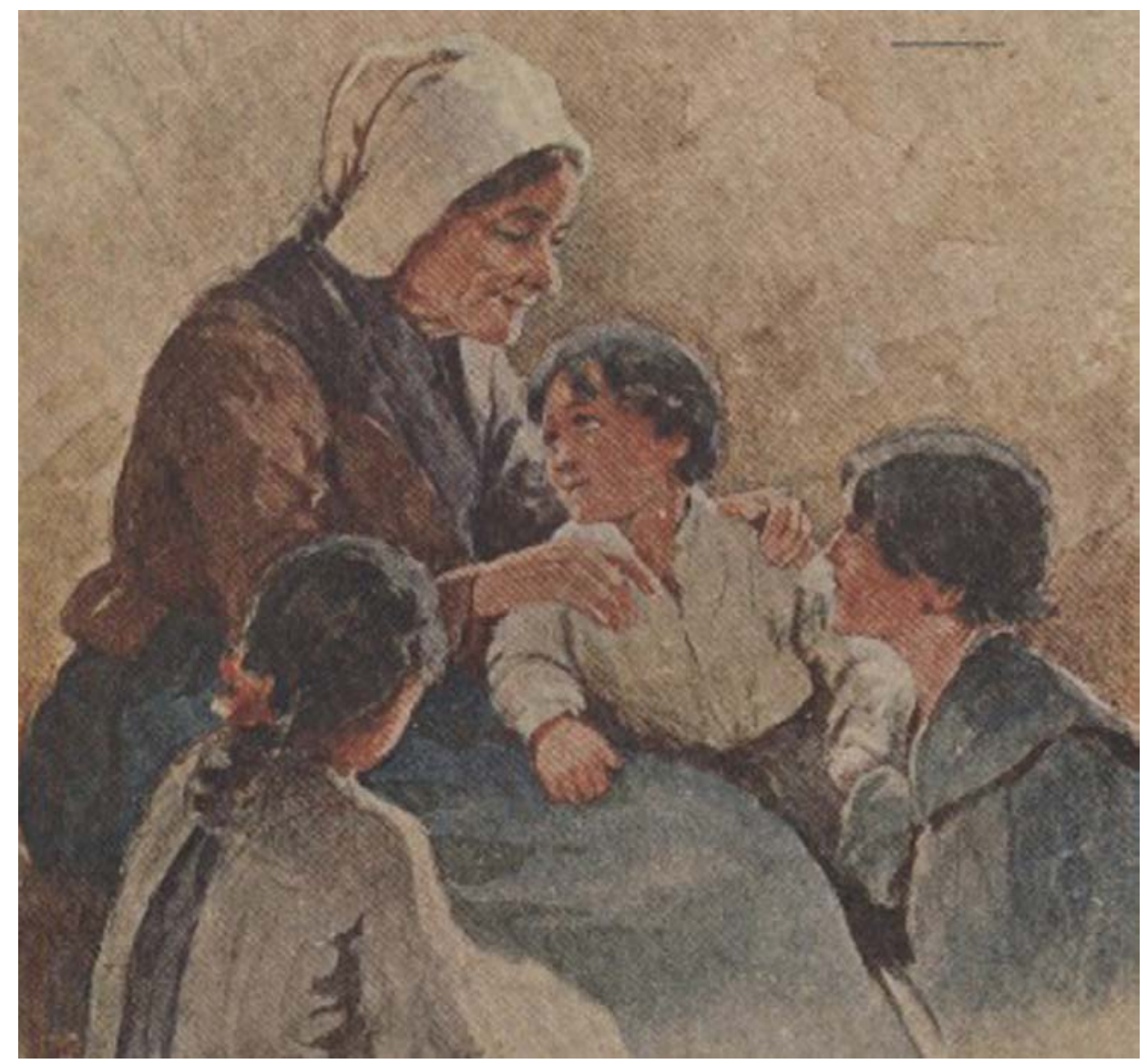

Figura 71 - A contadora de histórias - capa do primeiro livro infantil colorido, publicado no Brasil. Fonte: O Patinho Feio - Edições Melhoramentos, 1915.

\footnotetext{
${ }^{162}$ Ver VOVELLE, Michel. A Revolução Francesa explicada à minha neta. São Paulo: Editora UNESP, 2007 e LE GOOF, Jacques. A Idade Média explicada aos meus filhos. Rio de Janeiro: Agir, 2007. No Brasil, a historiadora Isabel Lustosa retomou a idéia de Viriato Corrêa, ao escrever, recentemente, o livro História do Brasil explicada aos meus filhos.
} 
Viriato recorreu também a essa fórmula, ao criar uma narrativa, em que se destaca a figura do ancestral - o vovô, que conta histórias às crianças, em um local aprazível, na sua chácara da Gávea, cidade do Rio de Janeiro, então capital do Brasi1 ${ }^{163}$.

Uma vez, pela manhã, ele (vovô) nos disse que tinha uma história bonita e muito comprida para nos contar. Não era, porém, historia de bichos nem de princesas e príncipes encantados.

- Que história é? perguntamos.

- É a Historia do Brasil, afirmou (CORRÊA, 1957, p. 17, grifo nosso).

O vovô, segundo descrição do próprio Viriato, era:

[...] um velho de setenta e quatro anos, a quem nós tratávamos por Vovô. Velho alto, magro, cabeça branca, barba branca, vestido de branco, desde os sapatos até o chapéu. Muita saúde, maneiras finas e uma doce expressão de bondade brilhando no rosto. Não sei o que havia na sua figura que, para nós (crianças), ele não era velho, mas um menino como nós, com a diferença apenas de ter a cabeça e as barbas brancas (CORRÊA, 1957, p. 15).

O vovô é uma espécie de "testemunha ocular da história", ao narrar às crianças fatos importantes de nosso passado, como o dia da assinatura da Lei Áurea pela Princesa Isabel, que ele mesmo presenciara.

O dia 13 de maio, data em que a princesa assinou a grande lei da abolição, foi o mais bonito dia de festa que já houve no Rio de Janeiro. Nunca se tinha visto tanta alegria, tanta música, tantas flores.

A cidade inteira veio para a rua festejar a liberdade dos nossos irmãos negros. A cidade inteira iluminou-se e embandeirou-se. Passeatas de manhã à noite, bandos e bandos de gente cantando hinos pelas ruas. Os negros choravam de alegria diante da alegria do povo.

A princesa desceu de Petrópolis para assinar a lei. Foi no paço da cidade (onde está atualmente a Repartição dos Telégrafos) que se realizou a cerimônia.

Vovô, como narrador da história, recorre à memória:

\footnotetext{
${ }^{163}$ No texto Tiradentes, o que morreu pela liberdade do Brasil, publicado na Coleção "Para você, Meu Filho: Grandes Vocações (Vol. 1 - Libertadores)", Viriato criou a figura da Vovó Vicência, para narrar às crianças o papel de Tiradentes na Inconfidência Mineira, e a denominou "A contadeira de histórias": "Vovó Vicência era uma velha de seus oitenta e tantos anos, durinha, espigadinha, muito doce e muito risonha e sempre bem vestida e bem calçada. Não havia ninguém que melhor contasse uma história." (CORRÊA, s/d, p. 91).
} 
- Vovó assistiu a ela? - interroguei.

- Assisti. Não posso descrever o que foi a solenidade. Há coisas que ninguém descreve. A praça e as ruas vizinhas do palácio estavam assim de gente. Na sala ninguém podia mover-se. Ao terminar a assinatura, Isabel chegou à porta do palácio. Ao me lembrar disto sinto ainda os cabelos arrepiados. A praça inteira, a uma só voz, aclamou o nome da princesa que acabava de tornar os brasileiros iguais (CORRÊA, 1957, p. 226-7, grifo nosso).

As crianças são assim descritas:

- Pedrinho, "um menino bem educado, sempre bem vestido, que na escola cursava a minha classe e se sentava junto a mim";

- Neco, "que estava a mudar os dentes e tinha a voz fanhosa e fungava muito";

- Quiquita, "fina, ajuizada, a mais adiantada da nossa escola";

- Nhonhô, "o menor de todos nós, gago e mais calado que falador";

- Mariazinha, "gorda como uma foca, baixota como um barril, voz grossa, papada imensa, ar espantado, gestos de quem mata e esfola, mas, no íntimo, excelente criatura, incapaz de fazer mal a um mosquito.” (CORRÊA, 1957, p. 17).

A descrição anterior revela certos estereótipos em um grupo de crianças: há sempre a bem-comportada, modelo de conduta para as demais (Pedrinho); a mais inteligente, considerada a melhor aluna da escola (Quiquita); o menino extrovertido e curioso (o narrador); a criança introvertida e calada, devido à gagueira (Nhonhô) e a criança que chamava mais atenção por ser gorda e feia, diferente das demais (Mariazinha).

Fazendo companhia às crianças, estão dois animais de estimação do vovô: o cachorro chamado "Barão" e um gato angorá de nome "Damasco". Até os animais não se estranhavam e viviam em perfeita harmonia, na chácara do vovô.

Vale ressaltar que, embora o livro se constitua numa narrativa histórica voltada para crianças, como o próprio título indica, não há em nenhum momento relatos envolvendo a participação de crianças e jovens na História do Brasil. Tudo parece indicar que a história é feita apenas por adultos, cabendo às crianças apenas aprendê-la e seguir os bons exemplos dos mais velhos e experientes. Assim, às crianças não lhes cabe o papel de sujeitos da história, mas de meros expectadores de um passado alheio que não lhes diz respeito, mas que deve ser aprendido através das lições do vovô. 


\subsubsection{A narrativa histórica ${ }^{164}$}

Em 59 capítulos, vovô conta praticamente toda a História do Brasil, desde a expansão marítimo-comercial européia no séc. XV, que resultou no descobrimento do Brasil, até o 15 de novembro, quando o país se tornou uma República (ver Anexo 1). Nesse aspecto, o livro assemelha-se bastante a um manual didático usado nas escolas primárias da época e, mais ainda, está de acordo com os programas curriculares para o ensino de História.

Embora publicado em 1934, o livro não aborda os primeiros anos da vida republicana brasileira. Há ênfase nos períodos colonial (45 capítulos) e monárquico (11 capítulos), com apenas 01 capítulo referindo-se ao período republicano de nossa história. Os outros dois capítulos constituem, respectivamente, a introdução (“O contador de histórias”) e a conclusão ("Palavras do fim") da narrativa.

As lições de história do vovô procuram reforçar os conteúdos a serem assimilados pelas crianças, mediante a repetição. Vovô, muitas vezes, assume ar professoral e age como tal, instituindo prêmios e recompensas a quem souber responder suas perguntas corretamente: "Há pratos que nos foram trazidos pelo branco, pratos que recebemos dos negros, pratos que herdamos do selvagem. Cada um de vocês que disser com exatidão a procedência de cada prato terá de prêmio um livro infantil com ilustrações” (CORRÊA, 1957, p. 173, grifo nosso).

Vovô diz: “ - Só a Quiquita ganhou prêmios. Só ela respondeu às perguntas que fiz.” (CORRÊA, 1957, p. 177).

A narrativa de Viriato, através das lições do vovô, é perpassada por valores morais e de conduta, com exemplos que devem ser seguidos pelas crianças. As lições do vovô possuem, assim, um duplo aspecto de aprendizagem: o conteúdo histórico propriamente dito e o conteúdo moral, muitas vezes subjacente àquele. Nesse aspecto, como já vimos, História do Brasil para crianças assemelha-se a um livro de leitura. Condena-se o uso do fumo e da

\footnotetext{
${ }^{164}$ A partir de História do Brasil para crianças (1934), em que Viriato cria a simpática figura do vovô, o mesmo estará presente, contando história para as crianças, em sua chácara na Gávea, em outros livros que foram publicados posteriormente, a saber: A Bandeira das Esmeraldas (1943), As belas histórias da História do Brasil (1948) e Curiosidades da História Brasileira (1952).
} 
bebida, como vícios de pessoas inferiores, mas, logo no primeiro capítulo, contraditoriamente, vovô aparece fumando seu cachimbo.

Naquele tempo, a não serem os índios, só as criaturas inferiores fumavam. Ele adquiriu o vício de fumar. Dizem até que deu para beber (CORRÊA, 1957, p. 67, grifo nosso).

[...] a figura amiga de Vovô, sentado à sombra de um largo tamarindeiro, fumando o seu cachimbo, livro aberto entre as pernas, aos pés o Barão, um bonito galgo, e, ao alcance do carinho de suas mãos, o Damasco, um lindo gato Angorá (CORRÊA, 1957, p. 15).

$\mathrm{O}$ vovô demonstra paciência em explicar às crianças o significado das palavras e expressões para melhor compreensão dos conteúdos históricos, conforme diálogo abaixo:

Vovô fixou em nós os óculos de cristal e perguntou:

- Sabem vocês o que é um governo constitucional?

- Eu não sei, declarou Pedrinho.

- Nenhum de nós, acrescentou o Neco.

- Sabem vocês o que é um governo absoluto?

- Não, respondemos todos.

O velho explicou:

- Governo constitucional é o que obedece a uma constituição.

- Fiquei na mesma, confessou o Neco. Pois se eu não sei o que é constituição!

- Constituição, disse Vovô, é uma lei, a principal das leis, na qual estão declarados os direitos e os deveres do povo e da pessoa ou pessoas que governam o povo. Compreenderam?

- Não compreendi nada...

Vovô ficou pensando um instante e depois falou:

- Constituição é uma espécie de regulamento pelo qual não só o povo, como os que governam o povo, fica sabendo o que podem fazer e o que não podem fazer (CORRÊA, 1957, p. 185). 


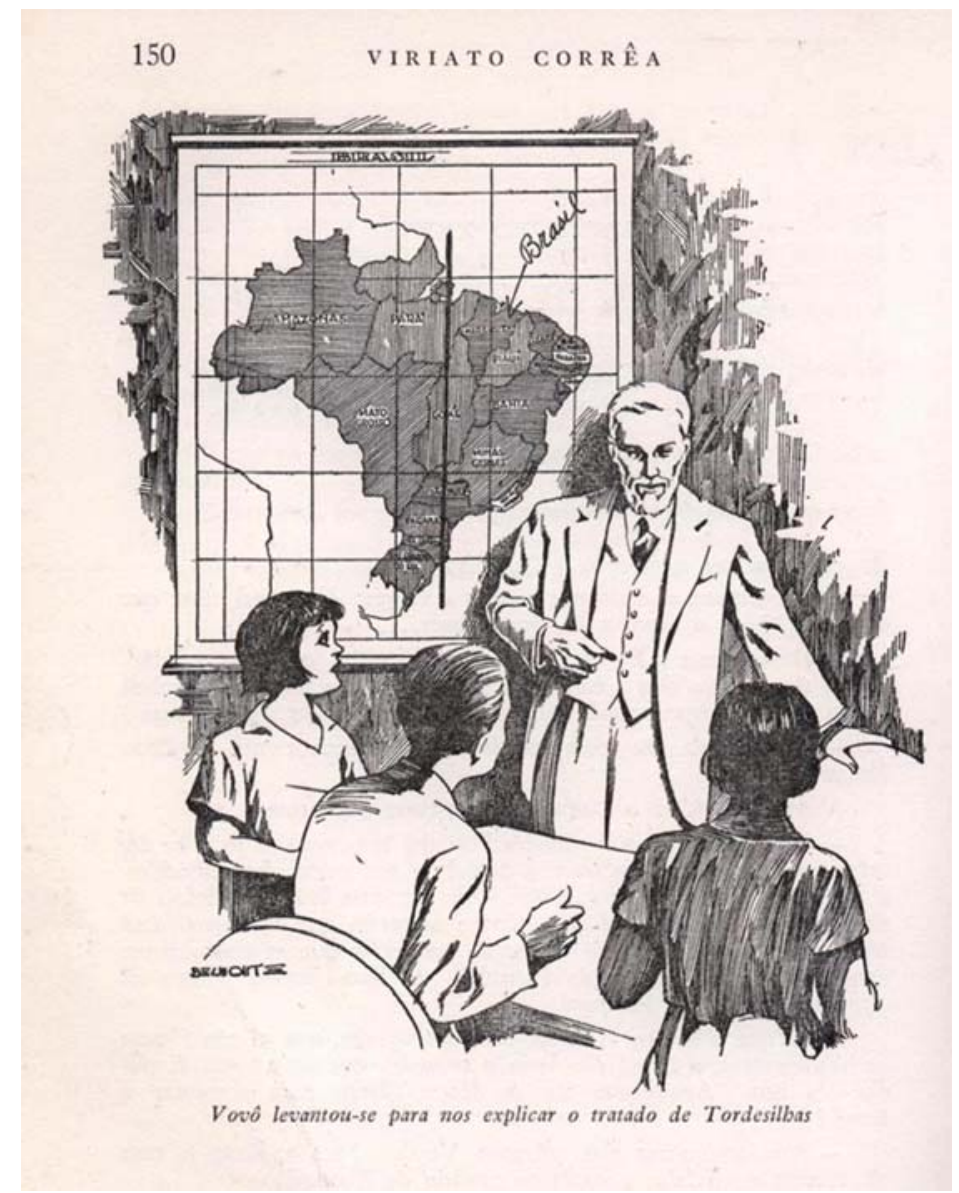

Figura 72 - História do Brasil para crianças. Fonte: CORREAA, 1957, p. 150.

Viriato Corrêa considera que a história é fonte de infinitas lições para as novas gerações, que deveriam se espelhar no exemplo de brasileiros patriotas que, em vida, dedicaram-se à causa nacional. Reforça também uma idéia bastante recorrente, no nível do senso comum, de que "a criança é o futuro do País":

\footnotetext{
A grandeza do Brasil depende de vocês, meus meninos. As crianças é que são o futuro de um pais. Se vocês seguirem o exemplo dos grandes homens que eu acabei de nomear, se trabalharem, se estudarem, se cultivarem a inteligência, o Brasil amanhã poderá ser a mais bela, a mais rica, a primeira nação do mundo (CORRÊA, 1957, p. 236).
}

Assim, a história, através das "lições do vovô", possui caráter formativo, ao fornecer elementos que servem para a construção de valores morais e cívicos, calcados no culto à Pátria e no exemplo edificante de alguns brasileiros. 
Para Viriato Corrêa, "aprender a História é fortificar o caráter, ilustrar o espírito e encher o coração com a esperança de melhores dias para a pátria, pelo aproveitamento dos sadios exemplos." (CORRÊA, 1934, orelha do livro).

Um outro aspecto interessante do livro está no estilo da narrativa, o que o diferencia dos demais livros escolares do mesmo período. Vejamos, pois, o quadro abaixo, que mostra a diferença de estilo na narrativa, a partir de um mesmo conteúdo:

Quadro 4 - Estilo comparativo entre dois livros escolares.

\begin{tabular}{|c|c|}
\hline $\begin{array}{l}\text { NOSSA PATRIA - Rocha Pombo } \\
\text { Cap. XV - Como se vivia nas vilas } \\
\text { Cap. XVI - A vida nos sítios. }\end{array}$ & $\begin{array}{l}\text { HISTÓRIA DO BRASIL PARA CRIANÇAS - } \\
\text { Viriato Corrêa } \\
\text { Cap. XLI - Os costumes de nossos avós }\end{array}$ \\
\hline $\begin{array}{l}\text { "As vilas e as cidades, naqueles tempos, não eram } \\
\text { como hoje. Além de mal construídas as casas, eram } \\
\text { muito tortas as ruas; não eram calçadas, nem } \\
\text { tinham iluminação. } \\
\text { Por isso, de noite quase nunca saíam os moradores; } \\
\text { e quando saíam, levavam sempre adiante um rapaz } \\
\text { com uma lanterna, ou mesmo com um facho aceso." } \\
(p .45-6) .\end{array}$ & $\begin{array}{l}\text { “- Não havia iluminação pública nas ruas? Atalhei. } \\
\text { - Não, não havia. Às } 7 \text { da noite rezava-se e, às } 8 \text {, já } \\
\text { todo mundo roncava na cama. Quem tivesse } \\
\text { necessidade de sai à rua levava uma lanterna para } \\
\text { não se perder na escuridão.” (p. 166-7). }\end{array}$ \\
\hline $\begin{array}{l}\text { "As mulheres viviam quase fechadas no interior das } \\
\text { casas, cuidando dos serviços domésticos" (p. 46). }\end{array}$ & $\begin{array}{l}\text { "Antigamente, uma casa de família podia ser } \\
\text { comparada a uma prisão. As janelas não se abriam, } \\
\text { as mulheres não punham a cabeça nas janelas. Mães } \\
\text { e filhas viviam trancadas lá dentro, como se tivessem } \\
\text { cometido algum crime.” (p. 165). }\end{array}$ \\
\hline $\begin{array}{l}\text { "Os caminhos eram ruins; e só se podia viajar a } \\
\text { cavalo ou a pé. } \\
\text { Os ricos faziam-se conduzir em bangüês, ou em } \\
\text { redes por escravos. Mesmo na vila, as senhoras } \\
\text { ricas não andavam a pé, senão às vezes, quando iam } \\
\text { à igreja. } \\
\text { Fazendo compras, ou visitando algum parente, iam } \\
\text { sempre levadas numa cadeirinha, espécie de maca } \\
\text { transportada por dois rapazes. } \\
\text { Mas a gente do sítio, que não tem cavalo ao menos, } \\
\text { andava sempre a pé." (p. 51-2). }\end{array}$ & $\begin{array}{l}\text { “- E como andavam os nossos avós? A pé? } \\
\text { Perguntei. } \\
\text { - A pé, os pobres, respondeu o velho. Uma rica } \\
\text { senhora, que se prezava, só saía à rua de cadeirinha } \\
\text { ou de liteira. Cadeirinha era uma cadeira coberta de } \\
\text { pano, na qual uma pessoa se sentava para ser } \\
\text { conduzida por dois homens. Liteira era mais ou } \\
\text { menos a mesma cadeirinha, mas levada por animais. } \\
\text { Havia cadeirinhas e liteiras lindíssimas e de alto } \\
\text { preço. O fazendeiro rico viajava em rede, } \\
\text { atravessada de um pau e suspensa nos ombros dos } \\
\text { escravos. O comum, porém, era o cavalo. Cada um } \\
\text { tinha o seu cavalo para andar nos povoados, nas } \\
\text { vilas e nas próprias cidades.” (p. 167). }\end{array}$ \\
\hline
\end{tabular}

Como se vê, enquanto o estilo do livro de Rocha Pombo é mais direto, com o uso de frases curtas e concisas, o de Viriato é um pouco mais "literário", embora também se utilize de uma linguagem coloquial permeada por um diálogo entre vovô e as crianças.

Às vezes, Viriato utiliza-se de linguagem lírica e rebuscada, mesmo em se tratando da narração de um fato histórico: 


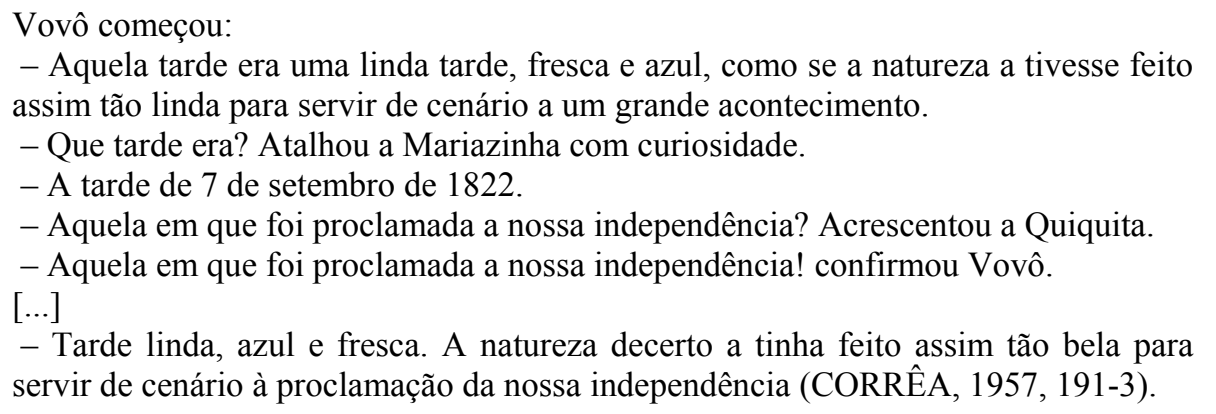

Diferentemente da grande maioria dos livros didáticos de História que, ao final de cada capítulo, traziam exercícios a serem feitos pelos alunos, na forma de perguntas e respostas - os tais "questionários" - em História do Brasil para crianças, o autor não propõe nenhum tipo de atividade para o aluno. O objetivo de Viriato não é avaliar o conhecimento histórico aprendido pelas crianças, mas fazer com que elas gostem do passado de seu País e se interessem por ele.

Com o objetivo de facilitar a leitura das crianças e ampliar seu vocabulário, há, no decorrer do texto de História do Brasil para crianças, a explicação e o significado de palavras, colocadas ao pé da página.

\subsubsection{A iconografia em História do Brasil para crianças}

Livros infantis sempre tiveram ilustrações, sobretudo nas capas, que serviam para despertar nas crianças o interesse por esse objeto cultural. No que concerne ao livro de História, já no séc. XIX, o historiador Ernest Lavisse preconizava o uso de imagens em obras didáticas como instrumento de facilitação da aprendizagem da criança: "Les enfants ont besoin de voir les scenes historiques pour comprendre l'histoire. C'est porquoi les livres d'instruction sont à present remplis d'images. Nous avons voulu forcer les enfants à bien regarder les images"165 (LAVISSE, 1894, p. 2).

\footnotetext{
${ }^{165}$ Tradução livre: "As crianças têm necessidade de ver as cenas históricas para compreenderem a história. É por esta razão que os livros de instrução que vos apresento estão repletos de imagens. Desejamos forçar os alunos a fixarem as imagens."
} 
No Brasil, livros escolares de História possuíam imagens, mesmo em preto e branco, que reproduziam quadros já consagrados de pintores que retrataram o País, sobretudo os viajantes estrangeiros, tais como Debret, Rugendas, Chamberlain, Victor Frond, e pintores nacionais, como Pedro Américo, Victor Meireles, Henrique Bernadelli, Benedito Calixto, entre outros.

Em História do Brasil para crianças, como já citei anteriormente, as imagens foram todas produzidas por Belmonte, especialmente para a obra. Apenas a capa e contracapa trazem ilustrações coloridas; as demais ilustrações são em preto e branco.

As imagens desenhadas na capa dão destaque a sujeitos históricos, ligados ao poder instituído (Estado e Igreja) em diferentes momentos históricos (Colônia, Império e República). Há figuras de soldados, governadores-gerais, vice-reis, bandeirantes, índios (dois adultos e uma criança), padre jesuíta (presumivelmente José de Anchieta), revolucionários ligados à Revolução Pernambucana de 1817 e à Confederação do Equador de 1824 e um escravo liberto dos grilhões da escravidão, sorridente por sua nova condição social. Há também figuras de animais que compõem a fauna brasileira: cavalos, aves, arara e onça. 


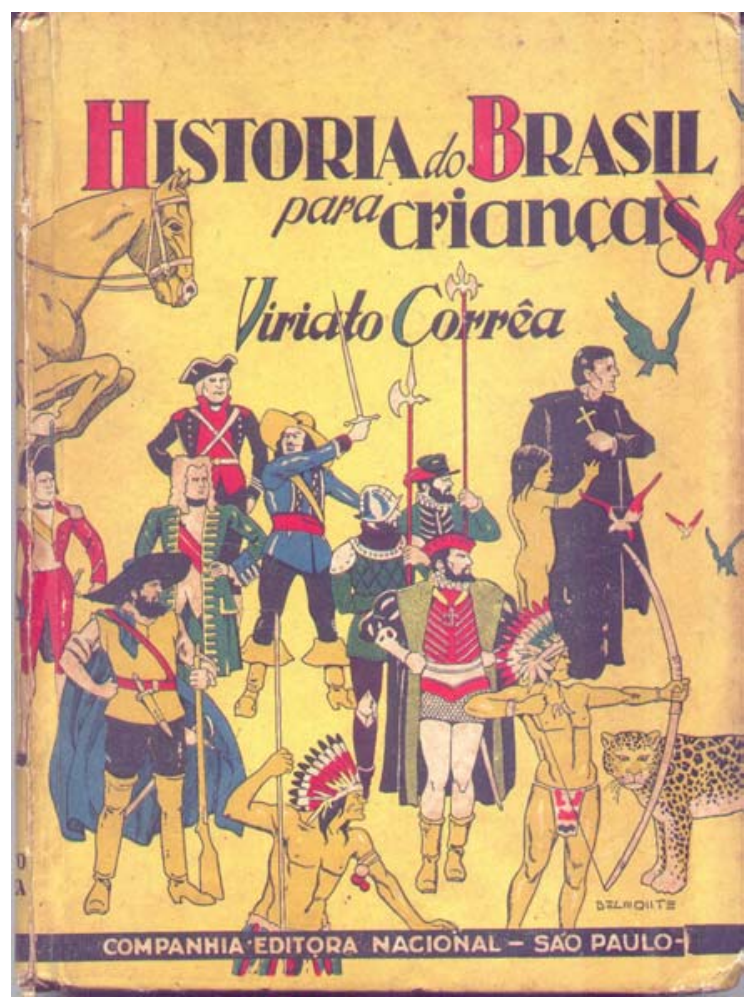

Figura 73 - História do Brasil para crianças - capa. Fonte: CORRÊA, 11ª ed., 1944.

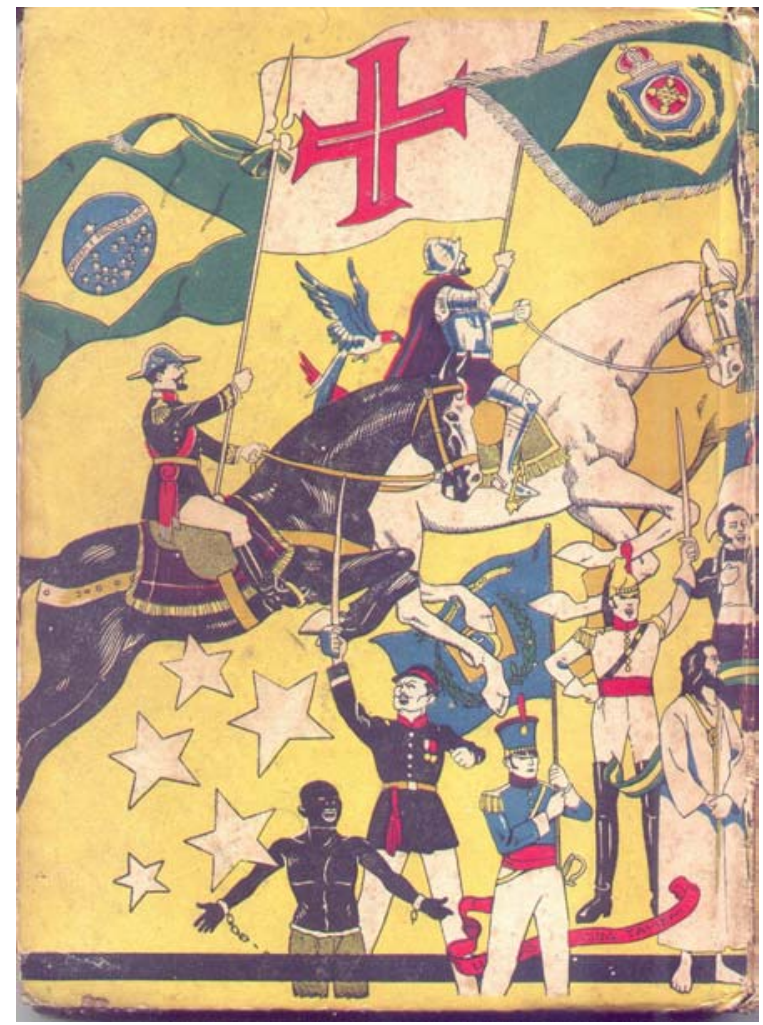

Figura 74 - História do Brasil para crianças - contracapa. Fonte: CORRÊA, $11^{\mathrm{a}}$ ed., 1944. 

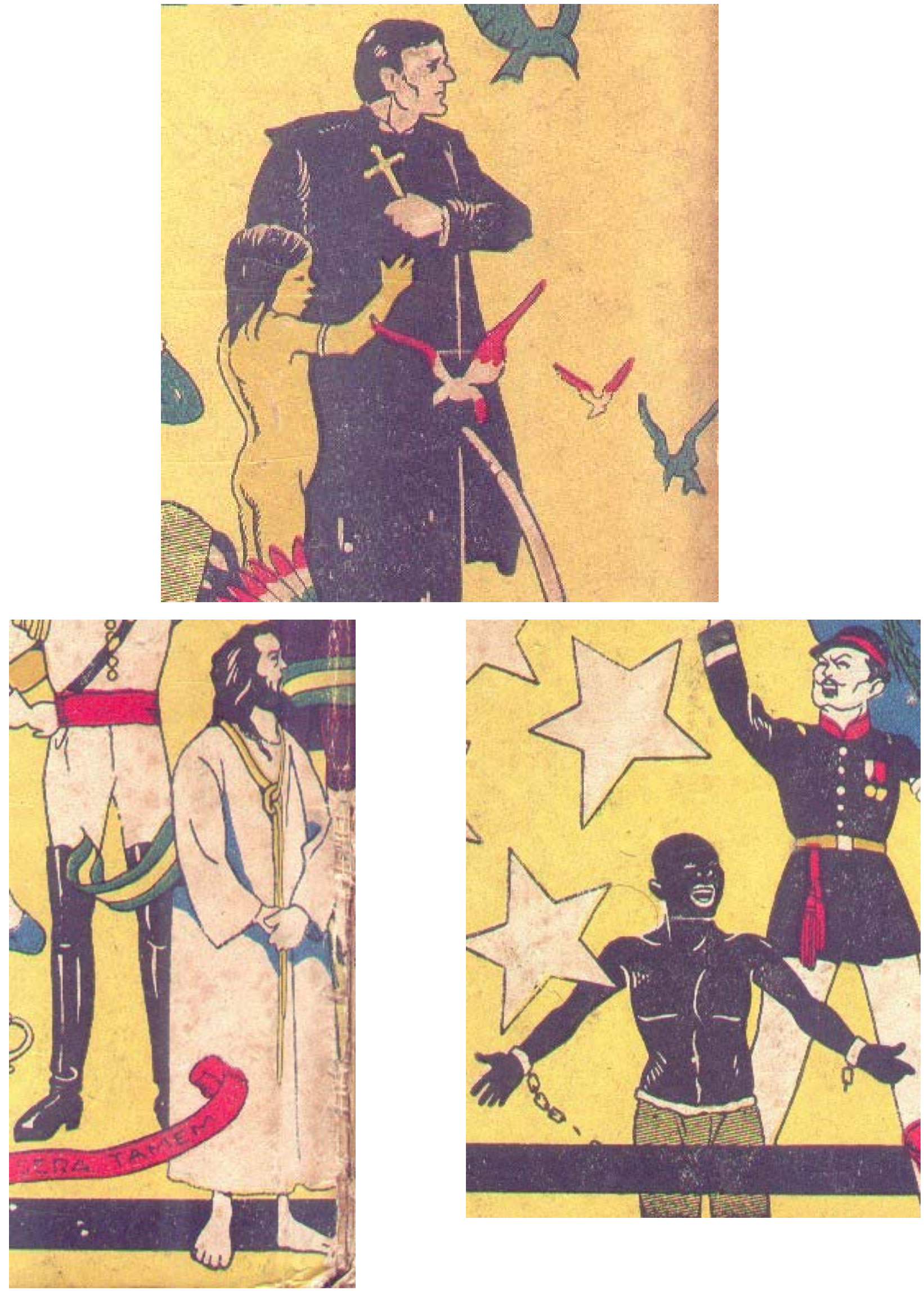

Figuras 75, 76 e 77 - História do Brasil para crianças.

Fonte: CORRÊA, $11^{\mathrm{a}}$ ed., 1944. 
O único personagem da História do Brasil identificável, através de uma imagem canônica (SALIBA, 1999) já consagrada no imaginário popular é Tiradentes, em seu camisolão branco, seu rosto, a barba e os cabelos compridos assemelhando-se a um Cristo cívico (CARVALHO, 1990) e a corda ao pescoço, denotando o martírio a que fora submetido - o enforcamento. Aos pés de Tiradentes, uma fita de cor vermelha com o dístico da Inconfidência Mineira, incorporado, posteriormente, à bandeira de Minas Gerais (“Libertas quae será tamem”).

Destaque especial é dado à bandeira brasileira, símbolo nacional, em diferentes períodos de nossa história. Da esquerda para a direita, vê-se a bandeira nacional atual levada por um soldado republicano, montado sob um cavalo preto.

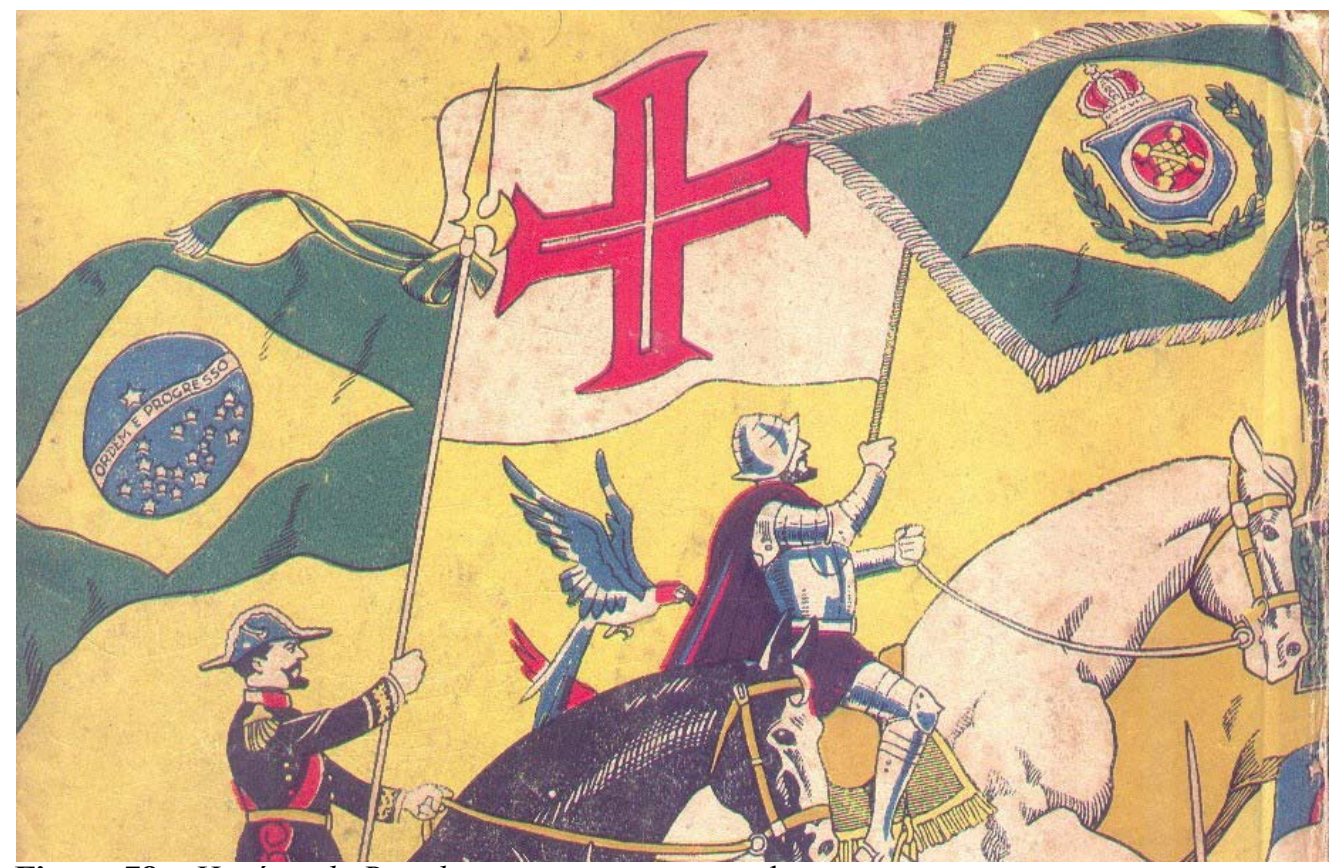

Figura 78 - História do Brasil para crianças - parte da contracapa.

Fonte: CORREAA, $11^{\mathrm{a}}$ ed., 1944.

Em seguida, temos um soldado em seu corcel branco, com a respectiva bandeira do período colonial de nossa história. Conhecida como "Bandeira da Ordem de Cristo", foi criada por El-Rei D. Diniz, em 1320, e, segundo especialistas, era pintada em todas as naus portuguesas que cruzavam os mares, no contexto da expansão comercial européia dos séculos XV e XVI. Essa bandeira foi usada quando da celebração da missa pontifical rezada antes da partida de Pedro Álvares Cabral, em Belém, Portugal. Consta que, ao chegar a terras brasileiras, Cabral teria tomado a bandeira logo após desembarcar. Foi, assim, o primeiro símbolo da terra recém-descoberta. 
Por fim, um soldado em trajes de um Dragão da Independência, montado em um cavalo marrom empunha a bandeira do Império do Brasil. A partir dela, foram definidas as cores nacionais - o verde e o amarelo. ${ }^{166}$

Na lombada, também conhecida como dorso, o destaque é dado novamente ao título da obra e ao nome do autor. Há duas imagens bem nítidas: um Dragão da Independência montado em um cavalo, com a respectiva bandeira do Império do Brasil e um militar que empunha a bandeira do movimento da Insurreição Pernambucana de 1817 - que, posteriormente, transformou-se na bandeira do estado de Pernambuco. Perpassando a imagem por trás, há uma fita com as cores verde e amarela. Na contracapa, há uma outra imagem de um soldado, portando uma bandeira que se presume ser da Confederação do Equador (1824).

A análise das imagens da capa já nos permite concluir que personagens e fatos históricos serão priorizados nos capítulos do livro, dando ênfase a uma história político-institucional, na qual o Estado configura-se como sujeito privilegiado do fazer histórico nacional.

No decorrer do texto, aparecem ilustrações - uma para cada capítulo do livro. Todas elas em preto e branco. Fazendo uma amostragem das imagens do livro, podemos identificar, no quadro abaixo, os personagens históricos mais retratados:

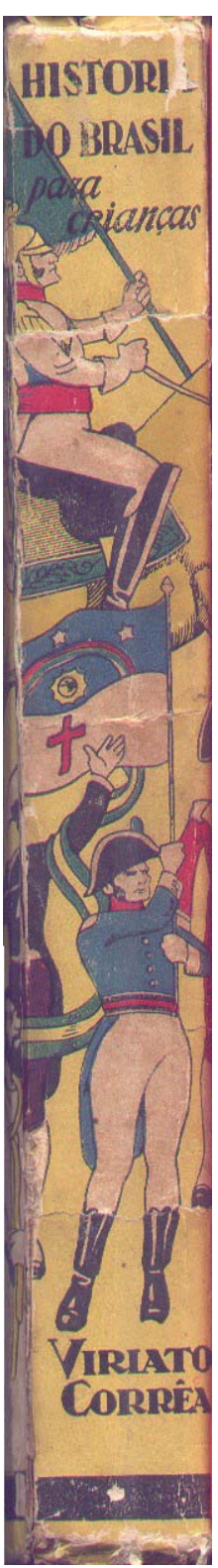

Figura 79 - História do Brasil para crianças - lombada. Fonte: CORRÊA, 11 a ed., 1944.

\footnotetext{
${ }^{166}$ Não há consenso sobre o real significado das cores nacionais. Tradicionalmente, as cores de nossa bandeira são referidas como representando o verde de nossas matas e o amarelo do nosso ouro. No entanto, essas cores foram escolhidas por D. Pedro que "pensou dotar o Brasil com a cor verde, cor de sua Casa Real de Bragança; e o amarelo, a cor da Casa de Habsburgo-Lorena de Áustria, de onde provinha sua primeira esposa, a Arquiduquesa Dona Leopoldina." (COSTA FILHO, 1989). Para Ribeiro, "a escolha das cores imperiais deverse-ia à preferência pessoal de D. Pedro I. No que concerne à emblemática, o decreto de 18 de setembro de 1822 fala do verde primavera. Mais recentemente, os manuais escolares para crianças assinalavam o verde como a evocação das florestas do país e o amarelo como a lembrança das minas de ouro, ou seja, símbolos das riquezas vegetais e minerais do Brasil. Se pensarmos que, desde o século XVI, os portugueses impressionaram-se com a densidade das florestas brasileiras - onde buscavam ouro - , tal explicação pode vir a ser aceita." (RIBEIRO, 1995, p. 88)
} 
Quadro 5: Imagens dos sujeitos históricos privilegiados em HBC

\begin{tabular}{|c|c|c|}
\hline SUJEITO HISTÓRICO & $\begin{array}{l}\text { QUANTIDADE } \\
\text { DE IMAGENS }\end{array}$ & LOCALIZAÇÃO DAS IMAGENS \\
\hline TIRADENTES & 3 & Capa, p. 158; p. 162 \\
\hline PEDRO I & 3 & p. $188 ; 192 ; 202$ \\
\hline PEDRO II & 2 & p. $206 ; 209$ \\
\hline ANCHIETA & 2 & Capa, p. 78 \\
\hline CAXIAS & 1 & p. 216 \\
\hline OSÓRIO & 1 & p. 211 \\
\hline MAURÍCIO DE NASSAU & 1 & p. 106 \\
\hline DOMINGOS JORGE VELHO & 1 & p. 120 \\
\hline CRISTÓVÃO COLOMBO & 1 & p. 24 \\
\hline PEDRO ÁLVARES CABRAL & 1 & p. 48 \\
\hline JOÃO RAMALHO & 1 & p. 52 \\
\hline VASCO COUTINHO & 1 & p. 66 \\
\hline VILLEGAGNON & 1 & p. 94 \\
\hline HENRIQUE DIAS, CAMARÃO E NEGREIROS & 1 & p. 102 \\
\hline AMADOR BUENO & 1 & p. 112 \\
\hline FERNÃO DIAS & 1 & p. 126 \\
\hline D. JOÃO V & 1 & p. 154 \\
\hline BARTOLOMEU DE GUSMÃO & 1 & p. 170 \\
\hline D. JOÃO VI & 1 & p. 180 \\
\hline ANTONIO CARLOS DE ANDRADA & 1 & p. 196 \\
\hline FREI CANECA & 1 & p. 200 \\
\hline PADRE FEIJÓ & 1 & p. 206 \\
\hline FRANCISCO DE MELO PALHETA & 1 & p. 219 \\
\hline DEODORO DA FONSECA & 1 & p. 230 \\
\hline RUI BARBOSA & 1 & p. 236 \\
\hline BANDEIRANTES & 3 & Capa, p. 74, 122; \\
\hline ÍNDIOS & 7 & Capa; p. 30; 40; 42; 56; 58; 62; 76; 174 \\
\hline JESUÍTAS & 2 & Capa; p. 76 \\
\hline AMAZONAS & 1 & p. 90 \\
\hline MULHERES & 3 & p. $138 ; 146 ; 219$ \\
\hline NEGROS & 5 & Capa; p. 86; 116; 132; 174;227 \\
\hline CRIANÇAS & 3 & p. $162 ; 166 ; 184$ \\
\hline
\end{tabular}

Do quadro acima, conclui-se que os sujeitos históricos mais privilegiados são Tiradentes e D. Pedro I (3 imagens). D. Pedro II aparece logo em seguida, com duas imagens (todas de quando criança), ao lado de Anchieta (2 imagens).

De forma genérica, no decorrer do texto, os índios são retratados nove vezes; os negros em seis imagens, e mulheres e crianças, em três imagens. Não há imagem exclusiva de nenhum personagem histórico feminino.

Belmonte, ao ilustrar o livro, utiliza-se de uma técnica de adaptação de quadros históricos e os recria em alguns trechos do livro. A reprodução dessas pinturas históricas sempre foi bastante utilizada nos livros didáticos, tornando-as imagens canônicas no ensino de História. Vieram a ser, portanto, a "memória visual da nação" (SIMAN, 2001, p. 94). Segundo Zamboni, 
As noções de identidade nacional e nação, também, foram trabalhadas e divulgadas em telas que representam fatos históricos como a Independência do Brasil, a primeira missa, a morte de Tiradentes, a Batalha de Guararapes, pintadas por artistas que receberam todo o apoio do governo imperial, como Pedro Américo, Vítor Meireles, considerados pintores oficiais de Monarquia. Portanto, a formação de uma identidade nacional e do conceito de nação é um processo ideológico que na escola passa necessariamente pela conservação de uma memória nacional e pela formação de uma consciência política (ZAMBONI, 2003, p. 374).

Assim, no capítulo XLVII - "Na colina do Ipiranga" - o desenho de Belmonte faz uma leitura de parte do célebre quadro de Pedro Américo (1843-1905) - "Independência ou Morte!"167. A legenda do referido capítulo recebe o mesmo título do famoso quadro.

${ }^{167}$ Uma análise minudente do processo de elaboração do quadro de Pedro Américo é feita em OLIVEIRA, Cecília Helena de Salles e MATTOS, Cláudia Valladão de (orgs.). O Brado do Ipiranga. São Paulo: Editora da Universidade de São Paulo: Museu Paulista da Universidade de São Paulo, 1999. 


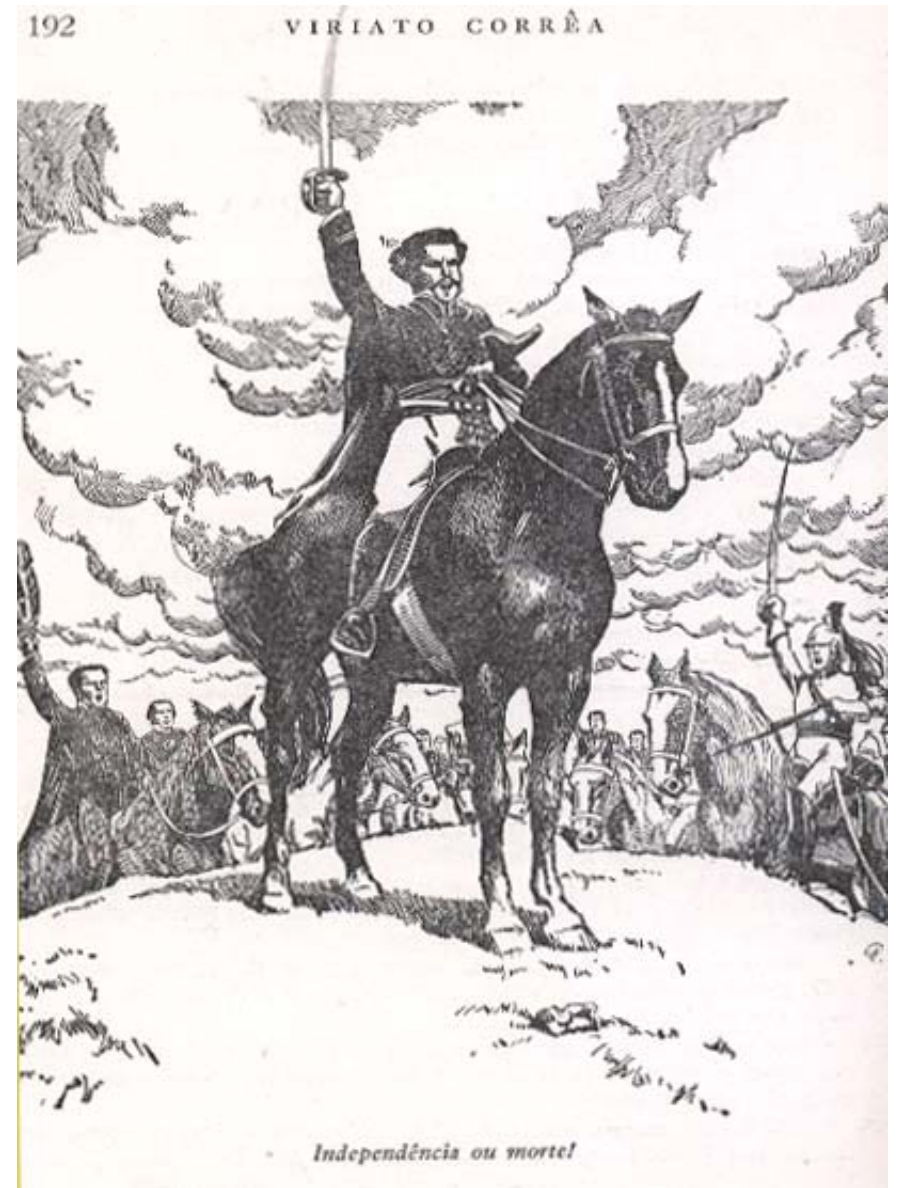

Figura 80 - História do Brasil para crianças - capítulo "Na Colina do Ipiranga". Fonte: CORRÊA, 1944, 11 a ed., p. 192.

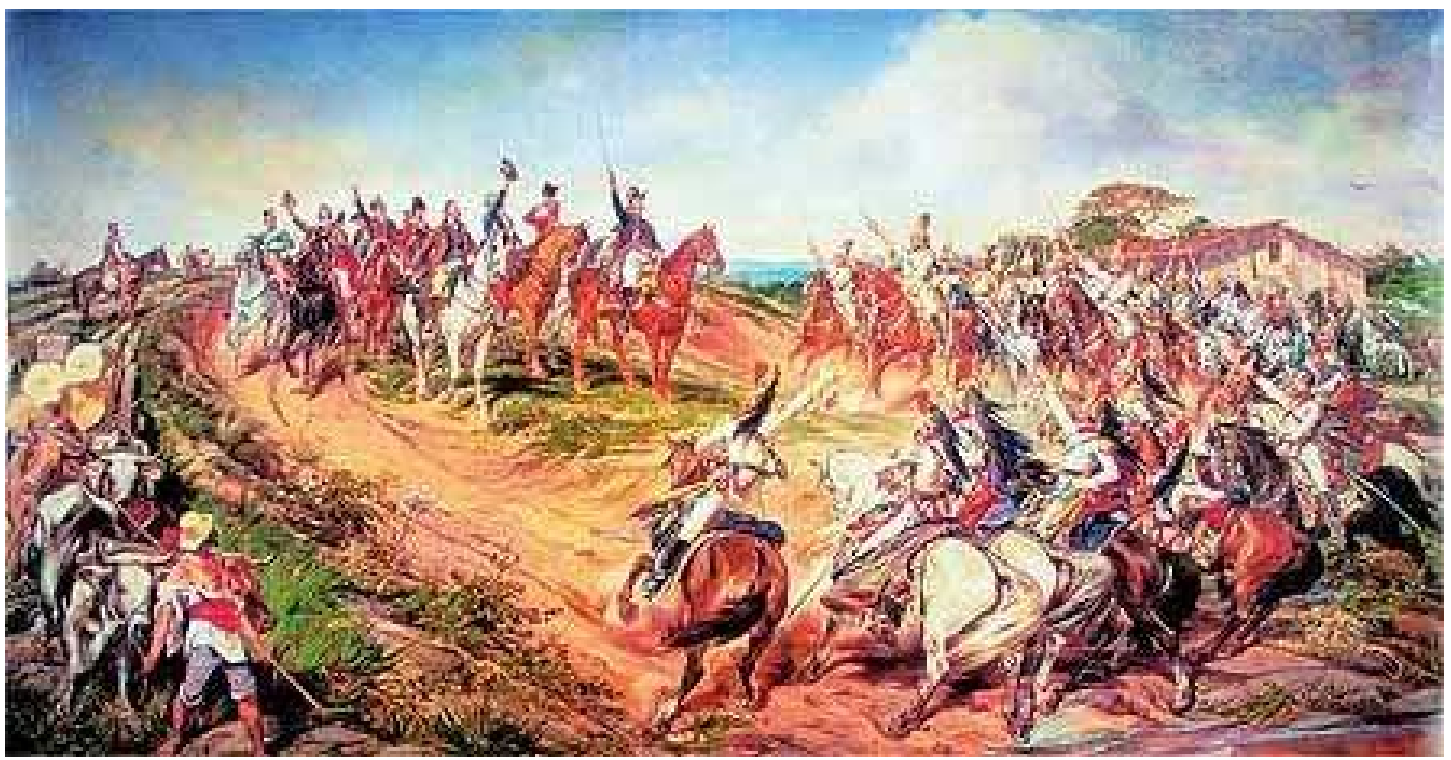

Figura 81 - "Independência ou Morte!" - Quadro a óleo pertencente ao acervo do Museu Paulista. Fonte: PEDRO AMÉRICO (1843-1905). 


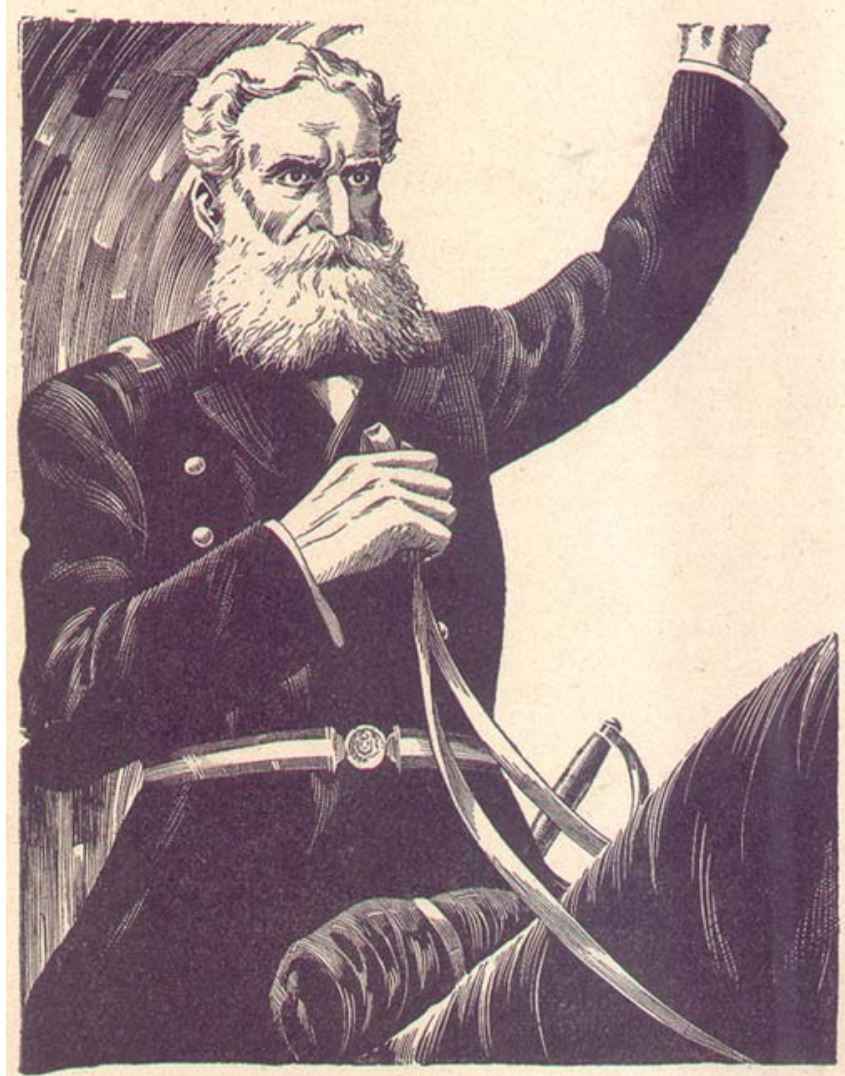

O marechal Deodoro

Figura 82 - História do Brasil para crianças.

Fonte: CORRÊA, 1944, 11ª ed., p. 230.

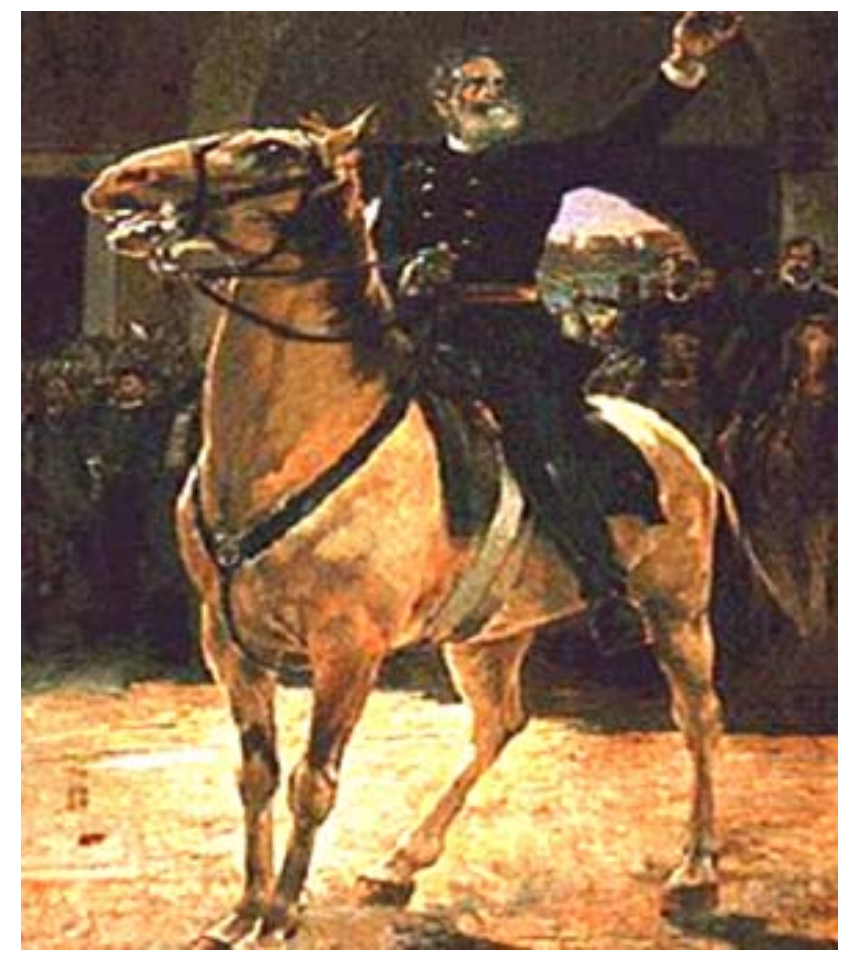

Figura 83 - Quadro “República 1889”.

Fonte: HENRIQUE BERNADELLI. 
Um outro quadro histórico, bastante reproduzido nos livros didáticos, é a pintura histórica de Henrique Bernadelli (1857-1936), que retrata a proclamação da República. Mais uma vez, Belmonte faz uma ilustração tomando como referência um quadro:

\title{
6.2 Concepção de História
}

\subsubsection{A história de chinelo: entre o pitoresco e o anedótico}

Viriato Corrêa considerava que fazia uma História diferente daquela produzida pelos historiadores, vinculados à tradição historiográfica do IHGB.

\begin{abstract}
Existem no Brasil, como em toda parte, dois ramos bem distintos de história: a história de coturno e a história de chinelo.

A de coturno enobrecida pela profunda erudição de Capistrano de Abreu, de Porto Seguro, de Teodoro Sampaio, Basílio Magalhães, Rocha Pombo, Rodolfo Garcia, etc. A de chinelo trabalhada por Vieira Fazenda, Macedo, Luis Edmundo e tantos outros mais. [...] Os seus livros históricos são feitos com a única intenção de levar os conhecimentos ao conhecimento dos elementos populares. Sem explicações e atavios filosóficos. História pura, nua, acessível a todas as inteligências e que, por toda vida, fica na memória da criatura.

Parece, à primeira vista, que a modalidade - de chinelo - seja uma modalidade inferior. Mas não é. A grande História se faz com os mosaicos da pequena história e é na composição desses mosaicos que a história vai quase sempre encontrar a razão e a explicação dos grandes acontecimentos (grifo nosso) ${ }^{168}$.
\end{abstract}

A expressão "História de chinelo(as)" foi empregada pela primeira vez por Monteiro Lobato em uma carta de 9 de maio de 1913, endereçada ao amigo Godofredo Rangel. Dizia Lobato:

\footnotetext{
A história dos historiadores coroados pelas academias mostra-nos só a sala de visitas dos povos. Mas as memórias são a alcova, as anáguas, as chinelas, o pinico, o quarto dos criados, a sala de jantar, a privada, o quintal [...] da humanidade, a grande humanidade com h minúsculo (LOBATO apud CAMARGOS, 2007, p. 9-10).
}

\footnotetext{
${ }^{168}$ Viriato louva livro de Nelson Costa, Correio da Manhã, Rio de Janeiro, RJ, 6.8.1965.
} 
O historiador português Luís Reis Torgal, ao analisar o ensino de História para crianças, faz uma análise procedente da obra de Viriato Corrêa:

\begin{abstract}
No Brasil, a história tradicionalista de Viriato Corrêa, não obstante relevar o fenômeno de formação da independência (menos contra Portugal do que de Portugal), embora salientando a miscigenação brasileira (um dos mitos culturais da visão histórica do Brasil) e apesar de conceber a história num processo antropológico, cultural, e geográfico americano, não deixa de se ligar a uma concepção europocêntrica, de onde faz derivar as raízes cristãs da civilização brasileira, que procura salientar (TORGAL, 1992, p. 38-9).
\end{abstract}

Embora Viriato tenha construído uma narrativa histórica pautada no eurocentrismo, ao exaltar o papel do colonizador português em detrimento de outros sujeitos históricos, ele dá destaque a determinados personagens que não faziam parte do "Panteão dos heróis nacionais", tão presentes em livros e cartilhas escolares. Assim, Bartira, Paraguaçu, Caramuru, Zumbi, Chica da Silva, Francisco de Melo Palheta aparecem em capítulos da História do Brasil para crianças, ao lado dos jesuítas, bandeirantes, governantes e outros filhos ilustres da Pátria.

Ao narrar os acontecimentos que levaram à proclamação da República, Viriato Corrêa mostra-nos outro aspecto de sua concepção de história, referente à noção de tempo. Para ele, o processo histórico é uma sucessão linear de fatos que levou o País, inevitavelmente, à tão sonhada República, desejo de todos os brasileiros. "Tinham-se realizado todos os sonhos de Tiradentes e dos mártires de 1817 e de 1824. Estava feita a independência. Estava feita a constituição. Estava feita a abolição da escravatura. Só a república não fora feita." (CORRÊA, 1957, p. 229).

Assim, o Brasil estava predestinado, desde o período colonial de sua história, com os movimentos da Inconfidência Mineira, da Revolução Pernambucana e da Confederação do Equador, a ser uma República, faltando apenas a adesão de alguns militares e civis à causa republicana. Com a mudança do regime de governo, o Brasil se tornaria, inevitavelmente, uma Nação feliz. 
O partido republicano procurou então mostrar ao país que só com a república, ou melhor, só quando o povo tivesse o direito de escolher diretamente os seus governantes, o Brasil seria feliz.

Os republicanos conseguiram ganhar a simpatia da gente moça, principalmente nos quartéis e nas escolas militares (CORRÊA, 1957, p. 229).

Uma questão fundamental da concepção de história do autor refere-se às noções básicas de tempo e espaço. Viriato compôs uma narrativa na qual não há uma preocupação com a cronologia. Seu texto, ao enfocar os fatos históricos, não prioriza a enumeração de datas. Isso denota que o autor não está preocupado com que as crianças memorizem datas, mas sim, com que compreendam o processo histórico e, acima de tudo, que gostem da história de seu País.

Para Viriato, a história não se desenrola apenas no espaço do poder instituído, mas também no cotidiano, do qual emerge a ação de homens e mulheres comuns. Ao abordar o cotidiano, Viriato procura tornar mais interessante sua narrativa, ao mostrar os costumes, hábitos e modos de vida dos brasileiros em diferentes momentos de nossa história.

Em síntese, podemos afirmar que a concepção de história de Viriato Corrêa é eurocêntrica, linear, prioriza a abordagem político-institucional, exalta os feitos dos grandes homens, mas para torná-la prazerosa aos ouvidos das crianças, usa aspectos do cotidiano, do pitoresco e até mesmo da lenda e do anedótico.

Múcio Leão, ao recepcionar o ingresso de Viriato na ABL, sintetiza de forma muito apropriada, que tipo de História foi produzida pela sua escrita:

[...] dois são os elementos que exigis nos fatos históricos. O primeiro é o heroísmo; o segundo é o pitoresco.

Vosso conceito da história é um conceito carlyleano ${ }^{169}$. "A História Universal (dizia o autor de Os Heróis) a historia do que o homem tem realizado no mundo, é, no fundo, apenas a história dos grandes homens que têm trabalhado na terra. Eles foram os condutores dos povos, esses grandes homens: os formadores, os modelos, e, num sentido mais amplo, os criadores de tudo o que a massa dos homens, tomada em conjunto, conseguiu realizar ou chegou a alcançar. Todas as coisas que nós vemos de pé no mundo são propriamente o resultado material exterior, a realização prática

\footnotetext{
169 Alusão ao trabalho do historiador escocês Tomás Carlyle (1795-1881), Os Heróis, escrito em 1840, sobre a vida ética e épica através do herói como divindade (Odin), como profeta (Maomé), como poeta (Shakespeare), como sacerdote (Lutero), como literato (Rousseau) ou como estadista (Napoleão). "A noção carlyliana do herói fez escola no pensamento contemporâneo” (CARLYLE, Tomás. Os Heróis. 2a ed., Lisboa: Guimarães Editores, 2002, orelha do livro).
} 
e a encarnação dos pensamentos que residiram nos grandes homens enviados ao mundo. A alma da história inteira do mundo seria a história deles."

A esse elemento do heroísmo, a história, tal como a concebeis, deve juntar o elemento da anedota.

Vossa história é, assim, um tecido de narrativas heróicas e narrativas cômicas, ou, pelo menos, graciosas. E ainda bem que é assim é! Nada pode revelar melhor um temperamento do que uma anedota. [...].

Realmente, em cada um dos vossos estudos históricos é sempre o heroísmo ou o pitoresco que encontramos [...].

Igualmente vos atraem todos os que viveram, conduzidos por uma ardente flama do amor humano. É para eles - para um Tiradentes, oferecendo a vida ao sonho da liberdade do Brasil - que vão as vossas admirações [...].

Mas, ao lado dos feitos de gigantescas proporções, como vos seduzem as indiscreções saborosas e grotescas, os simples episódios divertidos, que mostrem a fragilidade de qualquer soberbo figurão da história!

Com efeito, às vezes é-nos bastante uma situação pitoresca, ou um dito de espírito, para termos revelada a alma de um homem e até toda a psicologia de um povo (LEÃO, 1938, p. 11-2, grifo nosso).

\subsubsection{O ufanismo patriótico: "Sem história não há pátria!”}

Como vimos anteriormente (Capítulo II), o livro de leitura Por que me ufano do meu país (1900), de autoria do Conde Affonso Celso, deu início à nacionalização da literatura escolar, cujo objetivo maior era, através da descrição de nossas riquezas naturais e a dos fatos históricos mais relevantes, desenvolver nas crianças o sentimento de amor à Pátria.

O brazilianista Thomas Skidmore considera que a visão de Affonso Celso é a de um ufanismo ingênuo, mas que "fez a cabeça de muitas gerações": "Milhares de escolares futuros membros da elite - aprenderam no compêndio de Afonso Celso que seu país era um paraíso geográfico escolhido por Deus como nação mais favorecida na idade moderna." (SKIDMORE, 1989, p. 117).

Viriato Corrêa segue essa mesma tradição dos livros de leitura, ao adotar um tom ufanista. Vovô conclui sua narrativa histórica do Brasil:

- Aí tem, meus meninos, a história comprida que eu queria contar a vocês. É bonita? É feia? Não sei. O que sei é que devemos prezá-la, porque ela é a história da nossa pátria.

Amemos o mundo inteiro, mas amemos particularmente a terra em que nascemos (CORRÊA, 1957, p. 235). 
Mais uma vez, Quiquita, uma das crianças, questiona o vovô sobre qual a melhor forma de amar a nossa terra. Vovô responde, ressaltando valores que devem ser seguidos pela infância brasileira:

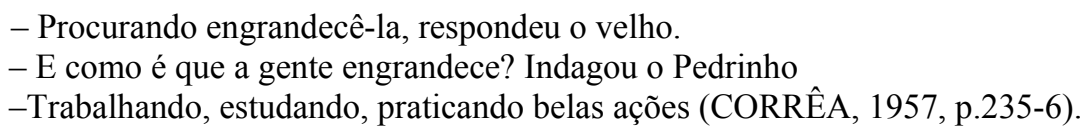

E ainda em tom ufanista, vovô dita mais uma importante lição cívica, mostrando o que faz uma Nação grandiosa é o trabalho e não as suas riquezas naturais:

\begin{abstract}
Muita gente por aí vive a dizer que o Brasil é o mais rico país do mundo. Rico por quê? Porque possui um território colossal. Mas não é porque tenham imensas terras que os povos são grandes. O que engrandece os povos é o trabalho, a inteligência, o caráter, o estudo [...] (CORRÊA, 1957, p. 236).
\end{abstract}

No entanto, o ufanismo de Viriato Corrêa, presente na História do Brasil para crianças e em outros livros seus, difere totalmente do de Affonso Celso. Enquanto Affonso Celso exaltava as riquezas naturais e a dimensão continental de nosso território, Viriato Corrêa procura mostrar às crianças que o futuro do País reside no trabalho, no estudo e no caráter dos brasileiros: "Se vocês seguirem o exemplo dos grandes homens que eu acabei de nomear, se trabalharem, se estudarem, se cultivarem a inteligência, o Brasil amanhã poderá ser a mais bela, a mais rica, a primeira nação do mundo" (CORRÊA, 1957, p. 236)

No mesmo ano da publicação de História do Brasil para crianças, Viriato lança um novo livro de crônicas históricas - Alcovas da História (cantinhos, esceninhos e recesso da vida histórica do Brazil). Nele, há a reprodução de trecho de uma conferência literária proferida pelo autor e intitulada "São Paulo e a riqueza pastoril do Brazil". Percebe-se, nesse texto, mais uma vez, sua concepção de pátria: 
Não ha pátrias physicas. Só existem pátrias moraes. Ninguém se ufana de um paiz pela immensidade territorial que elle possua, pela generosidade de seu clima, pela formosura de seus cêos, pela maravilha de suas terras. Isso é obra da natureza, que não nos pede licença para ser mesquinha ou fulgurante.

O que nos desvanece é a tradição de glórias, são os feitos radiosos, é a radiosidade da historia. Isso é que é obra humana. É isso que, em cada região reservada pelo destino a cada povo, constitue a seiva nutridora do orgulho das almas, a labareda incendiante do patriotismo. Sem historia não há pátria (CORRÊA, 1934, p. 158-9, grifo nosso).

Viriato transfere da natureza para o mundo da cultura e do trabalho a sua visão ufanista do País, ressaltando fatos marcantes de nossa história que devem ser motivo de orgulho para todos os brasileiros:

O Brasil não é o mediteraneo doce Amazonas com a galhada liquida de seus tributários; não é a Mantiqueira, com a doçura de ares e culminância de seus picos. Nem os campos de Matto Grosso, com a eterna opulência de suas pastagens. Nem a cachoeira de Paulo Affonso, com o espetáculo milenar do fragor de suas águas. Nem o Corcovado. Nem o Pão d'Assucar (CORRÊA, 1934, p. 159).

Mais uma vez, Viriato enumera os fatos históricos que ele considera marcantes, dignos de registro à posteridade:

O Brasil é a catechese civilizadora dos jesuítas; a obra realizada para a vastidão das suas fronteiras geographicas; a expulsão dos francezes, a expulsão dos holandezes. É a cana de assucar. São as bandeiras. É o devastamento dos desertos e o esplendor aurífero do século XVIII. É a riqueza pastoril. A independência. O café. O trabalho livre. A republica (CORRÊA, 1934, p.159).

\subsection{Temas de História do Brasil para crianças}

\subsubsection{O mito fundador de nossa História: a democracia racial}

Para a filósofa Marilena Chauí, “um mito fundador é aquele que não cessa de encontrar novos meios para exprimir-se, novas linguagens, novos valores e idéias, de tal 
modo que, quanto mais parece ser outra coisa, tanto mais é a repetição de si mesmo." (CHAUÍ, 2000, p. 9). Para a autora, nosso mito fundador foi construído desde os tempos da colonização, quando o Brasil era visto como "paraíso terreal". Esse discurso foi sendo reelaborado e ressignificado em diferentes momentos de nossa história, sendo a ele agregado o discurso de uma história sem conflitos sociais e de natureza inter-étnica. O Brasil é quase sempre definido a partir de sua marcante miscigenação racial.

Em História do Brasil para crianças, o tema da miscigenação racial está presente em vários capítulos e isso é mostrado de forma positiva, embora seja dado ao colonizador português o papel de "civilizador" da Nação, imputando à natureza e ao destino um papel na história:

\footnotetext{
- Vejam vocês como a natureza é sábia. Descoberto o Brasil entendeu ela que devia povoá-la, mas povoá-lo com brasileiros civilizados.

Por onde começar o povoamento? Pelo norte? Pelo sul? Pelo meio? Por qualquer das zonas em que se começasse, as outras ficavam prejudicadas, porque só muito e muito tarde, a população civilizada se estenderia as outras duas. Que fez o destino? Pegou três mulheres indígenas e três portugueses e colocou um casal em São Paulo, outro casal na Bahia e outro em Pernambuco e começou o povoamento ao mesmo tempo no sul, no meio e no norte (CORRÊA, 1957, p. 59, grifo nosso).
}

Assim, a história do País tem início com a constituição de três famílias que iniciam o processo de miscigenação e povoamento do território, resultado da união de três índias (Bartira, em São Paulo; Paraguaçu, na Bahia e Maria do Espírito Santo, em Pernambuco) com três portugueses (João Ramalho; Diogo Álvares, o "Caramuru”, e Jerônimo de Albuquerque, respectivamente): "Bartira, Paraguaçu e Maria do Espírito Santo Arcoverde são as primeiras mulheres indígenas que se casam com europeus. São, portanto, as que dão os primeiros filhos civilizados ao País." (CORRÊA, 1957, p.51).

Entre índios e negros, o autor considera que os últimos estavam em estágio cultural mais adiantado, quando chegaram do continente africano, em relação aos nativos, que sempre habitaram o território nacional: "O negro, quando chegou ao Brasil, estava muito mais adiantado que o indígena." (CORRÊA, 1957, p. 176). 
De certa forma, Viriato compartilha da tese da democracia racial brasileira, tão bem explicitada na obra do sociólogo pernambucano Gilberto Freyre - Casa-Grande e Senzala (1933) e Interpretação do Brasil (1947) ${ }^{170}$. Viriato chega a afirmar que, após a assinatura da Lei Áurea pela Princesa Isabel, negros e brancos tornaram-se iguais, omitindo o difícil processo de integração dos ex-escravos à sociedade brasileira: “A praça inteira, a uma só voz, aclamou o nome da princesa que acabava de tornar os brasileiros todos iguais." (CORRÊA, 1957, p. 228).

O mito da democracia racial assenta-se em alguns princípios, presentes na escrita de Viriato:

1. o índio era selvagem, não se adaptando ao trabalho imposto pelo branco. Já o negro não teve problemas de integração, adaptando-se ao trabalho escravo, por sua índole mansa: "O índio brasileiro é rebelde, difícil de ser amansado. O negro da África é obediente, pacífico." (CORRÊA, 1957, p.115);

2. o fato de que, comparada a outras regiões do mundo onde também foi implantado o trabalho escravo, nossa escravidão foi relativamente branda, pois aqui houve intenso processo de miscigenação entre brancos e negros, resultando na figura do mulato ou mestiço;

3. a miscigenação racial democratizou nossas relações sociais.

\footnotetext{
${ }^{170}$ Segundo a historiadora Emília Viotti da Costa, o mito da democracia racial no Brasil foi melhor explicitado na obra Interpretação do Brasil, constante de uma série de palestras que Gilberto Freyre proferiu nos Estados Unidos da América: "[...] sob o título de Interpretação do Brasil, o sociólogo brasileiro Gilberto Freyre descreveu o idílico cenário da democracia racial brasileira. Embora reconhecesse que os brasileiros não foram inteiramente isentos de preconceito racial, Freyre argumentava que a distância social, no Brasil, fora resultado de diferenças de classe, bem mais do que de preconceitos de cor ou raça." (COSTA, 2007, p. 367).
} 


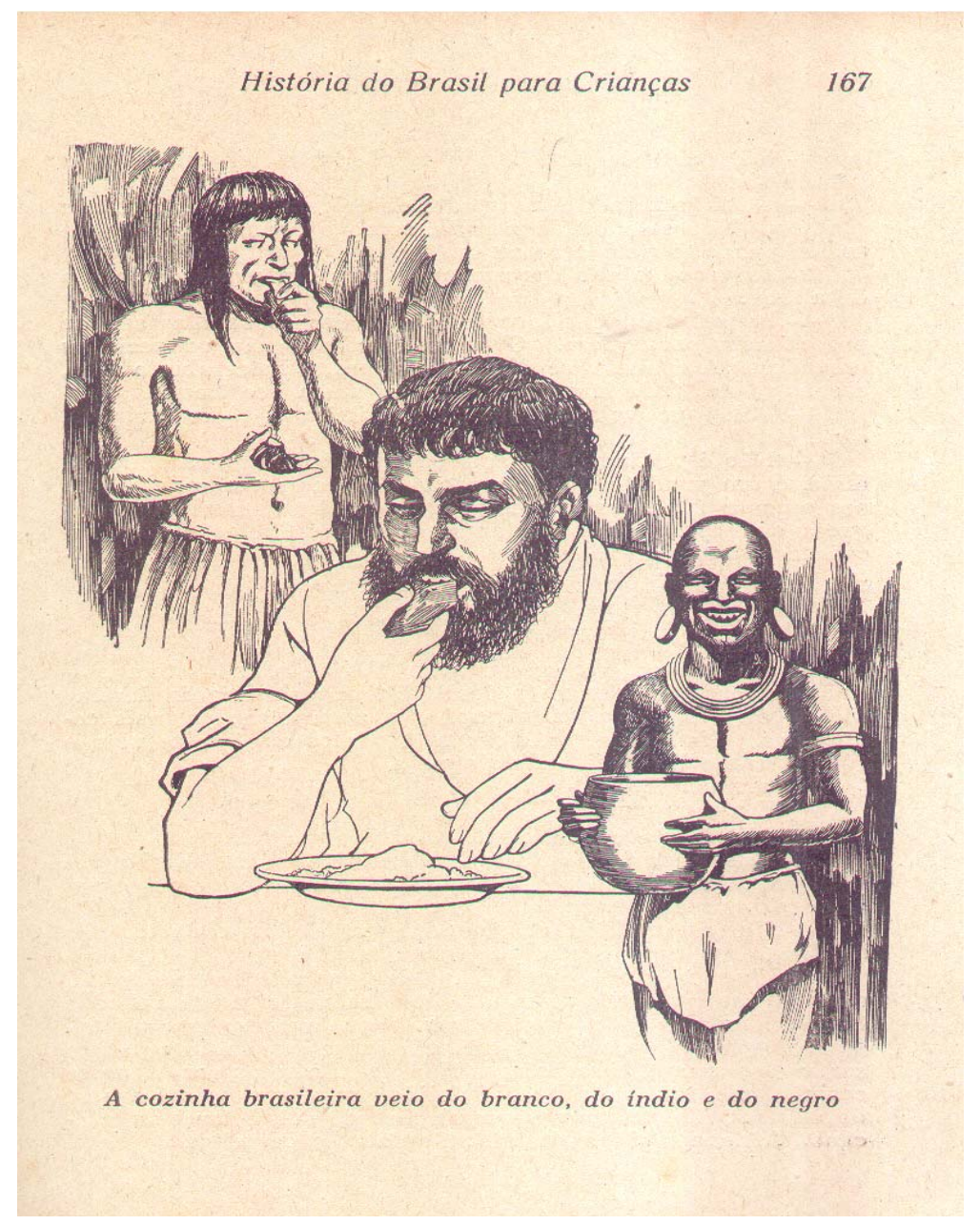

Figura 84 - História do Brasil para crianças.

Fonte: CORRÊA, $11^{\mathrm{a}}$ ed., 1944, p. 167.

Sabe-se que o mito da democracia racial, tal qual formulado por Gilberto Freyre, oculta o processo de luta e resistência do negro e a sua condição de escravo. Minimiza os conflitos sociais e de classe, ainda hoje presentes na sociedade brasileira, marcada pelo preconceito racial, desigualdade econômica e exclusão social.

De forma mais analítica e detalhada, vejamos como o autor tratou dos seguintes sujeitos históricos: índios, jesuítas e negros. 


\section{Os índios}

Como já ressaltei anteriormente, História do Brasil para crianças veicula uma concepção eurocêntrica de nossa história. Vejamos a fala do vovô, ensinando em mais uma de suas lições:

É de agora por diante, disse Vovô, que vai começar propriamente a história do nosso país. Sim, porque, de agora por diante, principia a nossa história civilizada. [...]

- Antes do descobrimento, já eu disse a vocês, não havia Brasil, havia a Pindorama indígena. Não havia brasileiros, havia selvagens. O Brasil começou com a chegada dos civilizados. Os primeiros brasileiros já não são selvagens, são filhos da gente da Europa com a gente da antiga Pindorama." (CORRÊA, 1957, p. 51, grifo nosso).

Os índios são vistos como selvagens. O Brasil apenas tem uma história a partir da chegada dos portugueses, considerados símbolos da civilização, portadores de uma cultura superior à dos índios.

[...] De agora por diante chamaremos aos habitantes da Pindorama índios, indígenas, silvícolas, isso para lhes não chamar unicamente selvagens (CORRÊA, 1957, p.31, grifo nosso).

O descobridor, imaginando que estava nas Índias, chamou índios às criaturas que encontrou à beira da praia.

E aí está por que até hoje se chamam índios os selvagens da América (CORRÊA, 1957, p.23).

- E tinham escolas?

- Não. Os povos da Pindorama eram selvagens e os selvagens não sabem o que é instrução.

- Então não sabiam ler, nem escrever, nem contar?

- Ler e escrever não. Contar sabiam, muito pouco, pois só contavam até dez (CORRÊA, 1957, p. 38, grifo nosso).

Apesar de seres selvagens, inferiores e sem nenhuma instrução, os índios eram dóceis, hospitaleiros e inofensivos: "Apesar de selvagens, os nossos índios tinham virtudes raras. Uma delas - a hospitalidade -, hospitalidade mais bela que a dos próprios civilizados" (CORRÊA, 1957, p. 38). 
Em outros momentos, os índios eram vistos como inocentes crianças, o que justificava a necessidade de tutelá-los:

[...] Os selvagens são verdadeiras crianças (CORRÊA, 1957, p. 61).

- Não nos envergonhemos dos nossos antepassados indígenas. Eles não tinham culpa do estado selvagem em que viviam. E, apesar de selvagens, possuíam virtudes que nós hoje, com a nossa civilização, não possuímos (CORRÊA, 1957, p. 39, grifo nosso).

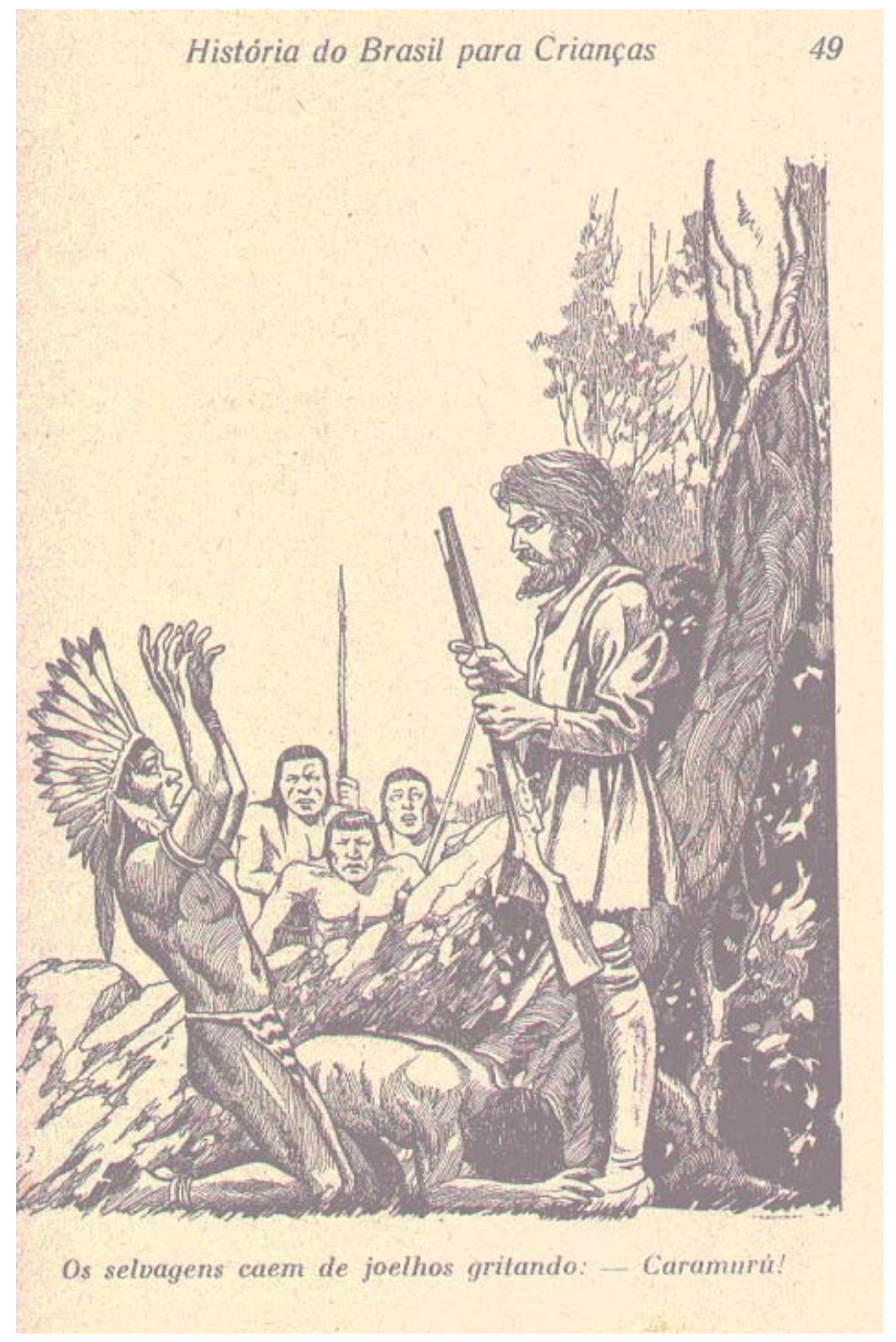

Figura 85 - História do Brasil para crianças.

Fonte: CORREAA, $11^{\mathrm{a}}$ ed., 1944, p. 49. 
Para justificar o processo de miscigenação racial entre brancos e índios, Viriato omite o processo de resistência do nativo, mostrando que tudo se deu de forma pacífica e consensual, sem conflitos: "Ao pisarem no Brasil, os europeus não conquistaram apenas a terra. Conquistaram principalmente o coração das moças selvagens. Todas elas viviam sonhando com um homem branco para esposo.” (CORRÊA, 1957, p. 59).

Mesmo no decorrer do processo de colonização, há sempre a dicotomia entre índios e brancos. Os índios são selvagens, portadores de uma cultura inferior e os portugueses são sempre "os civilizados": "Os campos de Piratininga pouco a pouco se foram enchendo de touros, vacas e bezerros. Tanto os civilizados como os índios queriam ter o seu curral para criar os seus bois." (CORRÊA, 1957, p. 72).

Aos índios é imputado um dos motivos que levou ao fracasso da adoção do sistema de capitanias hereditárias: "O desastre teve várias razões, mas três são as razões principais. Primeira: os índios. Os índios eram donos disto tudo, e, quando os capitães-mores aqui chegaram como senhores da terra, eles se levantaram em guerra, dificultando-lhes a vida" (CORRÊA, 1957, p. 64).

Segundo Rocha (1984, p. 30-1), “o livro didático opera com a categoria generalizadora índio perdendo toda a possibilidade de conhecer o homem concreto e o tipo de vida que se esconde por trás da generalização”. Para esse antropólogo, ao se analisarem as representações das sociedades indígenas na literatura didática, percebe-se que:

[...] as categorias mais recorrentes que se articulam em torno de um índio, já agora generalizado, são as que se referem a primitivo, primário, selvagem, não-civilizado e atraso.

São estas noções de selvagem e primitivo que, paralelamente à colocação do índio como uma categoria genérica, marcam os dois eixos centrais que formam a base onde se constrói a representação do índio (ROCHA, 1984, p. 33).

Em História do Brasil para crianças, os indígenas são vistos como uma categoria étnica genérica, sem especificidades lingüísticas ou culturais. Todos são índios e possuem os mesmos costumes e condições de vida iguais: 
Onde moravam os filhos da Pindorama? Perguntei.

[...] Uma cidade da Pindorama era inteiramente diferente das cidades que conhecemos. Não havia ruas, nem casas de um lado e do outro, nem lampiões, nem luz elétrica, etc. Uma cidade da "terra das palmeiras" começava por não se chamar cidade. Chamava-se taba, que significa aldeia.

A taba compunha-se de uma ocara. A ocara era uma vasta praça circulada por uma cerca de paus pontudos, a que se dava o nome de caiçara. Dentro da praça havia três, quatro ou seis palhoças grandes, que se chamavam ocas.

[...] Cada tribo obedecia a um chefe.

- O chefe era uma espécie de rei, disse a Quiquita.

- Disse bem. E rei tem todo o poder, com todas as honras. Apenas não tinha o qualificativo de rei, mas sim o qualificativo de cacique ou morubixaba (CORRÊA, 1957, p. 29).

No livro História do Brasil para crianças (1934), Viriato Corrêa dá destaque a alguns personagens de nossa história ${ }^{171}$, o que comprova que as lições de vovô estavam em consonância com o discurso da identidade nacional dos anos 30/40 e com a ideologia do trabalho e do nacionalismo patriótico, tão caros ao Estado Novo (1937-1945).

Um desses personagens é o jesuíta, a quem cabe o papel de fundador da civilização brasileira.

\section{Os Jesuítas}

"É aos jesuítas, aos primeiros que aqui chegaram, que devemos a nossa civilização." (CORRÊA, 1957, p.77).

Essa afirmação é reiterada inúmeras vezes, como forma de deixar bem claro o papel dos jesuítas na colonização portuguesa:

[...] Vovô prosseguiu:

- Eu disse a vocês que é aos jesuítas que devemos nossa civilização. É verdade. Sem eles nada seríamos hoje, sem eles Portugal não teria civilizado o nosso país (CORRÊA, 1957, p. 80, grifo nosso).

"Vovô calou-se. Segundos depois continuou:

\footnotetext{
${ }^{171}$ Não só nesse livro, mas em outros, sobretudo os de crônicas históricas, Viriato prioriza alguns sujeitos: "Viriato gosta de História, mas dentro dela há determinados personagens a quem reserva especial simpatia. D. Pedro I, a Marquesa de Santos, Tiradentes são vultos que não se cansa de estudar.” (PINTO, 1966, p. 205).
} 
- Não tenham dúvida, meus meninos, os jesuítas foram os verdadeiros fundadores da civilização brasileira (CORRÊA, 1957, p. 81, grifo nosso).

Aos jesuítas coube também o trabalho de moralização de nossos costumes e não apenas a tarefa de evangelização dos índios:

Quando os jesuítas aqui chegaram, o Brasil era uma vergonha. Entre os europeus predominavam a desordem, a falta de moral, o crime. Roubar, saquear, matar eram crimes corriqueiros. Muitos civilizados já viviam vida mais selvagem do que os próprios selvagens (CORRÊA, 1957, p. 79).

Os jesuítas também defenderam os índios da escravidão imposta pelo homem branco.

- [...] Para os civilizados daqueles tempos, fossem eles bandidos ou homens de bem, os selvagens não eram criaturas humanas como nós, mas sim bichos do mato que a gente podia prender e matar.

Os padres logo que chegaram procuraram impedir que se escravizassem os índios (CORRÊA, 1957, p. 79).

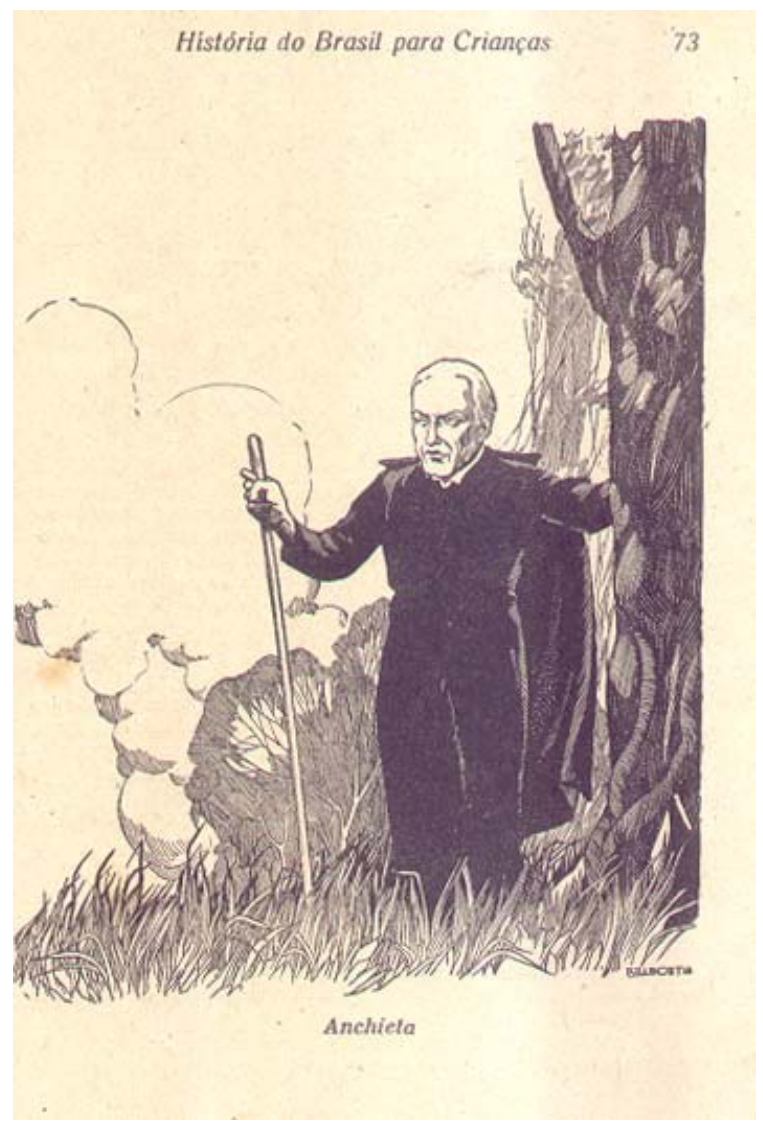

Figura 86 - História do Brasil para crianças.

Fonte: CORRÊA, $21^{\mathrm{a}}$ ed., 1957, p. 78. 
Na sua narrativa, sempre valorizando esses padres missionários, Viriato recorre, ainda, a lendas e mitos na explicação da história:

Um dia, na enseada de São Vicente, perseguido pela tempestade, naufragou o navio em que o padre Manuel da Nóbrega viajava. E, quando o navio ia afundando, viu-se o padre nadar tranqüilamente sobre as ondas, como se estivesse em terra.

Uma vez, o padre José de Anchieta atravessava numa embarcação a baía de Guanabara. Era um dia de sol infernal e o padre, bastante doente, sofria muito com o calor. Então as aves, que voavam no céu, foram descendo, descendo e, por cima da cabeça de Anchieta, formavam, com as asas, um toldo para protegê-lo contra o sol (CORRÊA, 1957, p. 75).

Diante dessa narrativa, uma das meninas do grupo - a Quiquita - questionou:

- Que é isso, vovô? É a História do Brasil ou conto da Carochinha?

- É a História do Brasil, respondeu ele. São duas lendas da História do Brasil. Duas das muitas lendas que existem sobre os padres Manuel da Nóbrega e José de Anchieta (CORRÊA, 1957, p.75).

Considero que o uso de lendas para explicar determinados fatos de nossa história é um recurso pedagógico de que se utiliza Viriato para tornar mais interessante a narrativa e, com isso, despertar nas crianças a curiosidade e o gosto pelo passado nacional. Faz parte também de sua concepção de história, calcada no aspecto pitoresco.

Em outro capítulo do livro (Capítulo XXI - O Eldorado e as amazonas), por exemplo, ele se utiliza de mais uma lenda para explicar a ocupação da Amazônia:

Foi a ambição do ouro que criou a lenda brilhante do Eldorado, disse Vovô.

Os aventureiros europeus que chegaram à América nas primeiras viagens, imaginando que a América fosse a Ásia, como o próprio Colombo imaginou, esperaram encontrar as ricas cidades de pontes de mármore e palácios de tetos de ouro descritos por Marco Pólo.

A esperança nunca se apaga da cabeça do homem. Não encontrando as tais riquezas maravilhosas, os aventureiros criaram a lenda do Eldorado.

O Eldorado era um país fabuloso, onde tudo era de ouro.

$[\ldots]$

- Foi andando à procura do Eldorado que Orellana descobriu o Amazonas. [...]

Como os índios tivessem os cabelos compridos, Orellana julgou que estava combatendo com mulheres e não com homens. [...]

A descrição feita do rio colossal deixou os europeus surpreendidos. Mas, o que mais surpreendeu a Europa foi o caso do combate com as amazonas. As amazonas eram 
mulheres gregas que formavam um país lendário, onde só elas mandavam. Essas mulheres guerreavam montadas a cavalo e tinham vencido poderosos exércitos de homens (CORRÊA, 1957, p. 89-92).

Além de destacar o papel da religião católica no processo de colonização do Brasil, Viriato Corrêa transmite, em sua narrativa, a idéia de que a história dos homens é moldada pelos desígnios de Deus, o que bem revela uma visão providencialista da história: “- Isso mostra, meus filhos, que, acima da vontade dos homens, há uma vontade inteligente e poderosa que tudo prevê e tudo determina - a vontade de Deus" (CORRÊA, 1957, p.59).

\section{Os negros}

O elemento africano enquanto etnia formadora da nacionalidade brasileira só aparece no capítulo XXVIII do livro, com o título OS NEGROS. É preciso lembrar que a ênfase na narrativa de vovô é dada ao branco colonizador, sobretudo na figura dos padres jesuítas, como vimos anteriormente.

Logo no início desse capítulo, o autor tenta justificar a escravidão negra dizendo que “existe escravidão desde que a terra existe" (CORRÊA, 1957, p. 115) e mostrando que o uso da mão-de-obra escrava no Brasil deveu-se à rebeldia do índio e que "o negro da África é obediente, pacífico" (CORRÊA, 1957, p. 115), reforçando, assim, estereótipos acerca do negro e do índio.

Fala também dos maus tratos a que eram submetidos os negros desde sua captura no continente africano até o seu transporte ao Brasil: “A viagem dos negros para o Brasil é um quadro horrível que não se descreve. Os infelizes eram atirados aos grupos para os porões dos navios." (CORRÊA, 1957, p. 116). E prossegue na explicação: "O enjôo do mar, o cansaço, a fome, a falta de ar, as doenças faziam com que só chegasse a terça parte dos que embarcavam." (CORRÊA, 1957, p. 117).

Aspecto interessante do capítulo é que o autor mostra a fuga de escravos como um das formas de resistência do negro à escravidão imposta pelo colonizador até a formação de quilombos: 
Os negros então compreendiam que uma criatura só pouco vale, e que muitas criaturas unidas podem valer muito. Passaram então a fugir para a floresta, aos bandos. Nas florestas formavam agrupamentos que resistiam à caça que os senhores lhes faziam. A esses agrupamentos dava-se o nome de quilombos.

De norte a sul do Brasil houve muitos quilombos e alguns resistentes e perigosos. $\mathrm{O}$ mais importante, porém, o que passou à história pela sua longa vida de heroísmo, foi o de Palmares (CORRÊA, 1957, p. 117).

Não por acaso, destaque especial foi dado à formação do Quilombo de Palmares, que merece um capítulo do livro: "Palmares, o quilombo dos negros que fugiram da escravidão, prosseguiu Vovô, foi uma verdadeira nação dentro do Brasil. Durou mais de 50 anos. Durante mais de 50 anos os fazendeiros e o próprio governo lutaram para destruí-lo" (CORRÊA, 1957, p. 118).

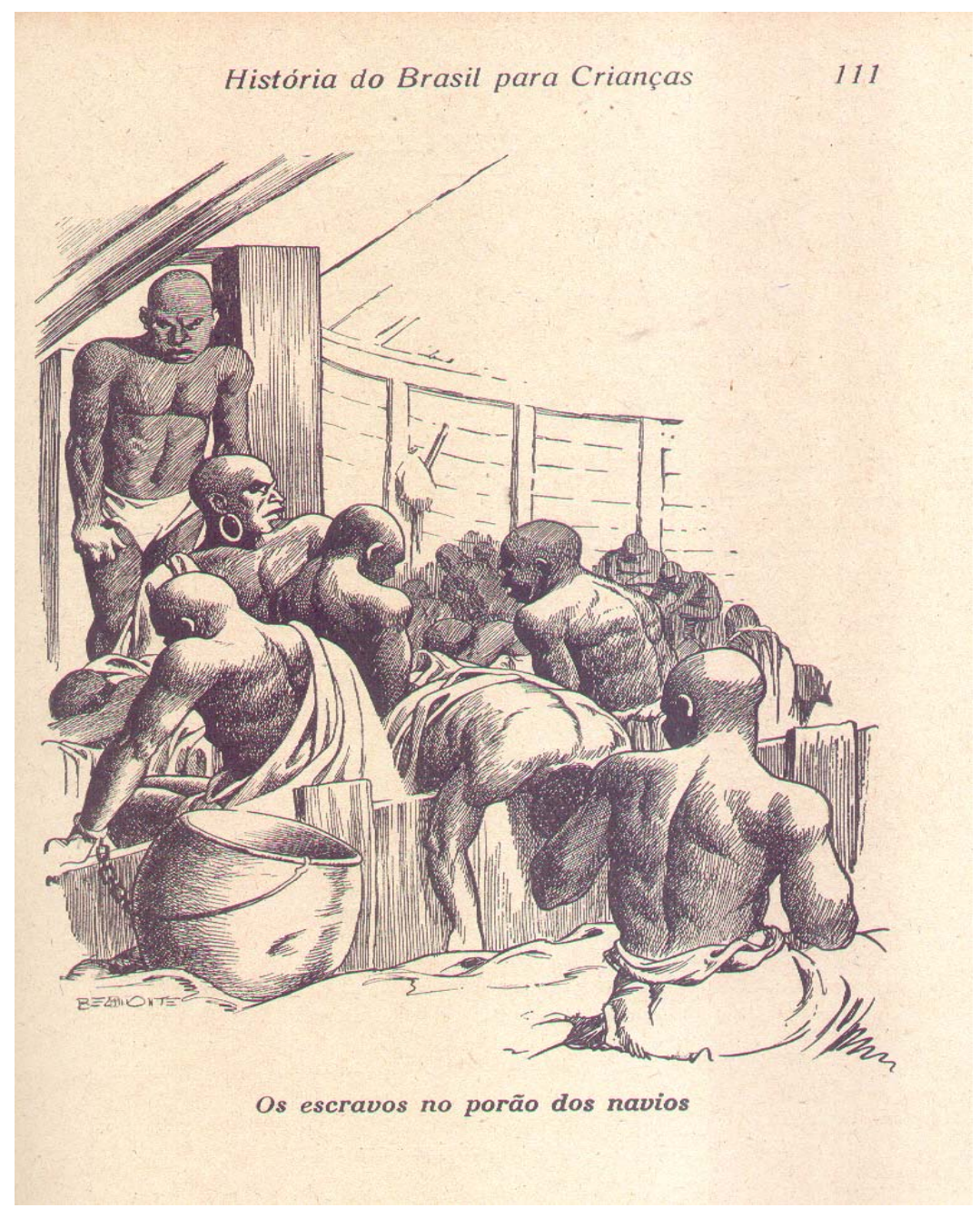

Figura 87 - História do Brasil para crianças.

Fonte: CORRÊA, 21ª ed., 1957, p. 111. 
Mas, como costuma acontecer na literatura didática para o ensino de História, os negros só aparecem na História do Brasil em dois momentos específicos, a saber: quando se fala da formação do povo brasileiro e o processo de miscigenação racial que caracterizou nossa colonização (sécs. XVII e XVIII) e só reaparecem quando se trata da abolição da escravatura, já na segunda metade do séc. XIX.

Para Viriato Corrêa a escravidão é em nossa história uma mancha, que deveria ser apagada em nome do ideário da civilização:

Em menos de 70 anos de independência tínhamos progredido mais do que nos 3 séculos em que estivemos sob o domínio alheio.

Mas, continuou, existia ainda uma grande mancha sobre nós - a escravidão dos negros. Nós, que nos dizíamos civilizados, nós, que nos dizíamos um povo amante da liberdade, tínhamos escravos (CORRÊA, 1957, p. 225).

O processo de abolição da escravatura é mostrado às crianças como uma ação de associações e clubes, do qual participavam jornalistas, escritores, advogados e políticos. Em nenhum momento, é colocada a participação dos próprios negros na luta contra a escravidão:

Compreendeu-se afinal em todo o país que se devia acabar com a escravidão. E em todo o país se formaram associações e clubes para trabalhar a favor dos escravos.

$\grave{A}$ frente dos que mais trabalhavam estavam homens de grande inteligência como Rui Barbosa, José do Patrocínio, Joaquim Nabuco, Luiz Gama, André Rebouças, José Mariano e outros. Falando, escrevendo, esses homens procuravam mostrar ao governo que era necessário fazer a abolição, isto é, fazer uma lei abolindo, acabando com a escravidão (CORRÊA, 1957, p. 225-6).

A questão dos negros e seu papel na história do País foi retomada por Viriato, de forma mais contundente, no livro de leitura Cazuza. Vale a pena ler este trecho, pois mostra a identificação do autor - mulato - com a condição social dos negros escravizados, na voz do Prof. João Câncio: 
- O Brasil deve ter pelo negro uma grande afeição e um grande carinho. Porque, se o Brasil é o que é, muita e muita coisa deve ao negro. Para esse progresso que aí está, o negro concorreu com o suor de seu rosto, com o trabalho de seu braço, com a bondade do seu coração e com o sacrifico de sua liberdade.

[...]

- Desde que o Brasil começou a dar os primeiros passos para a frente, o negro está ao lado do Brasil. Nos primeiros engenhos de cana-de-açúcar, no século do descobrimento, lá está o negro trabalhando. Quando é preciso repelir os holandeses da terra pernambucana, da terra maranhense, de quase toda a terra nortista, o peito do negro é uma de nossas maiores fortalezas. Nas bandeiras que entram pelos sertões a fundo, à procura do ouro, ao lado do bandeirante, que é o senhor de tudo, está o negro, sempre trabalhador, sempre leal e sempre bom, sem ser senhor de nada. [...]

- Houve um tempo em que Pernambuco foi o maior mercado de açúcar do mundo; houve um tempo em que Minas se abarrotou de ouro e de diamantes; em que o Maranhão enriqueceu com o algodão; em que a província do Rio de Janeiro teve magnificência com o café; em que São Paulo, com o café, teve os primeiros esplendores. Tudo isso se fez à custa do suor do negro. Ao negro, o Brasil deve grande parte de sua riqueza, da sua grandeza e da sua tranqüilidade. E, em paga disso, que foi que se deu ao negro? A escravidão (CORRÊA, 2004, p. 172, grifo nosso).

Para Dória (2008, p. 54), Viriato Corrêa

foi o primeiro autor de literatura infanto-juvenil a abraçar a causa do negro. Em sua obra não há estereótipos, e a figura do negro "inteligente" combate tudo o que havia sido dito sobre ele [...] Viriato Corrêa pode, com todos os méritos, ser considerado um precursor desse movimento, ou postura, a que demos o nome de antipreconceito.

Além dos jesuítas (Manuel da Nóbrega e Anchieta), Viriato Corrêa exalta o papel dos bandeirantes, de Tiradentes, de D. Pedro II e de Rui Barbosa.

\subsubsection{A expansão do território: os bandeirantes}

A exaltação ao papel dos bandeirantes, identificados com os paulistas, está presente em várias partes do texto e na própria imagem da capa do livro. Os bandeirantes constituem uma "raça de gigantes", pois devemos a eles a expansão de nossas fronteiras territoriais: “[...] Não tenham dúvida, meus meninos: o Brasil só tem o tamanho que vocês sabem porque houve os bandeirantes" (CORRÊA, 1957, p. 124). 
Ao se referir à união da índia Bartira com João Ramalho, o autor faz uma apologia dos paulistas: "Daquele lar erguido nos primeiros dias do Brasil, nasceu a grande raça dos paulistas, a quem o escritor francês, mais tarde, chamou de raça de gigantes" (CORREAA, 1957, p. 53). Em outro capítulo, mais uma vez, ele ressalta o caráter aventureiro dos bandeirantes: "A gente mais aventureira, mais ousada e mais ativa do Brasil - os paulistas" (CORRÊA, 1957, p. 121).

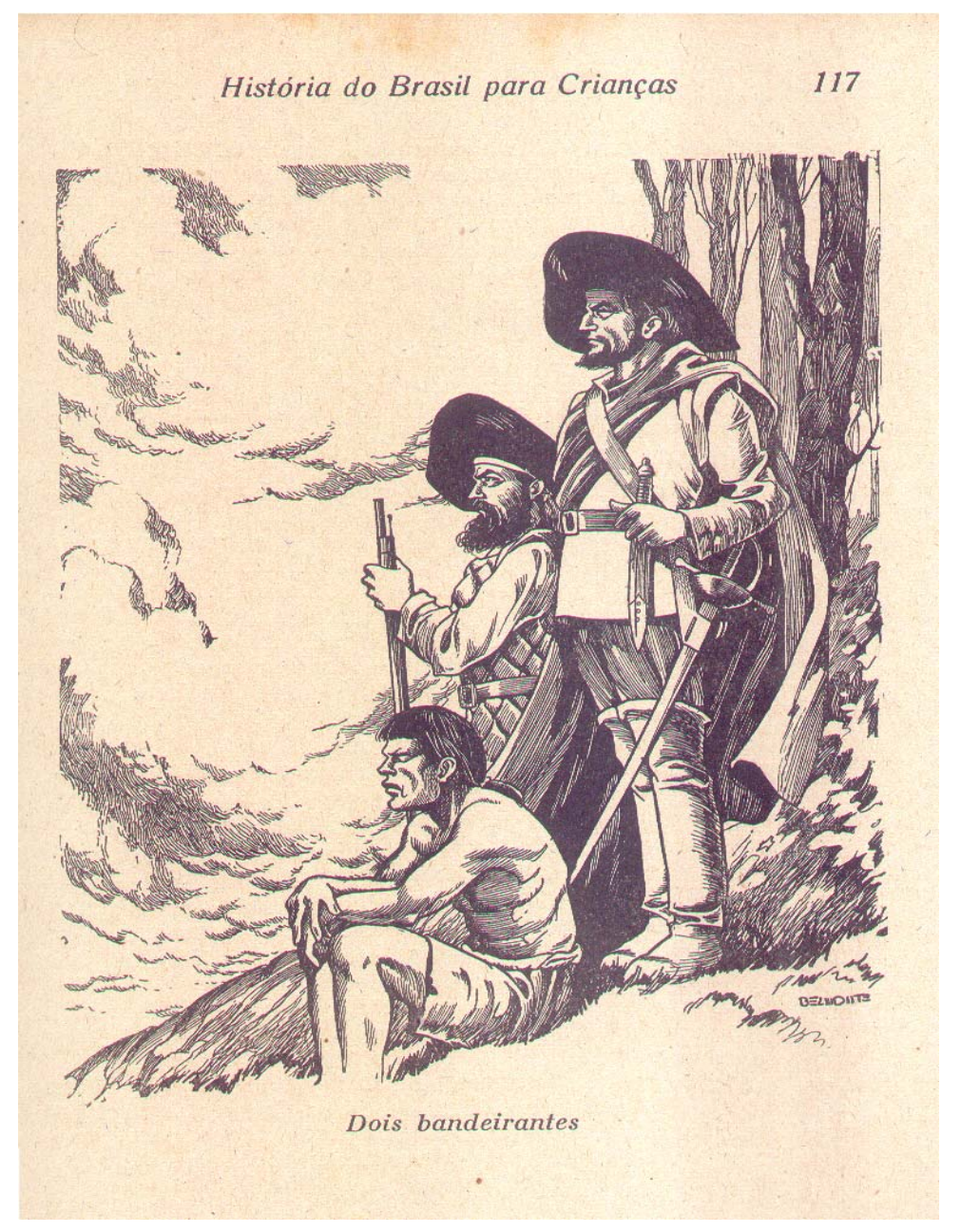

Figura 88 - História do Brasil para crianças - Ilustração da $1^{\text {a }}$ até a $11^{\mathrm{a}}$ edição. Fonte: CORRÊA, $11^{\mathrm{a}}$ ed., 1944, p. 117.

A própria dimensão da imagem do bandeirante passa às crianças a idéia de força, robustez e grandeza física. 
VIRIATO GOHAEA

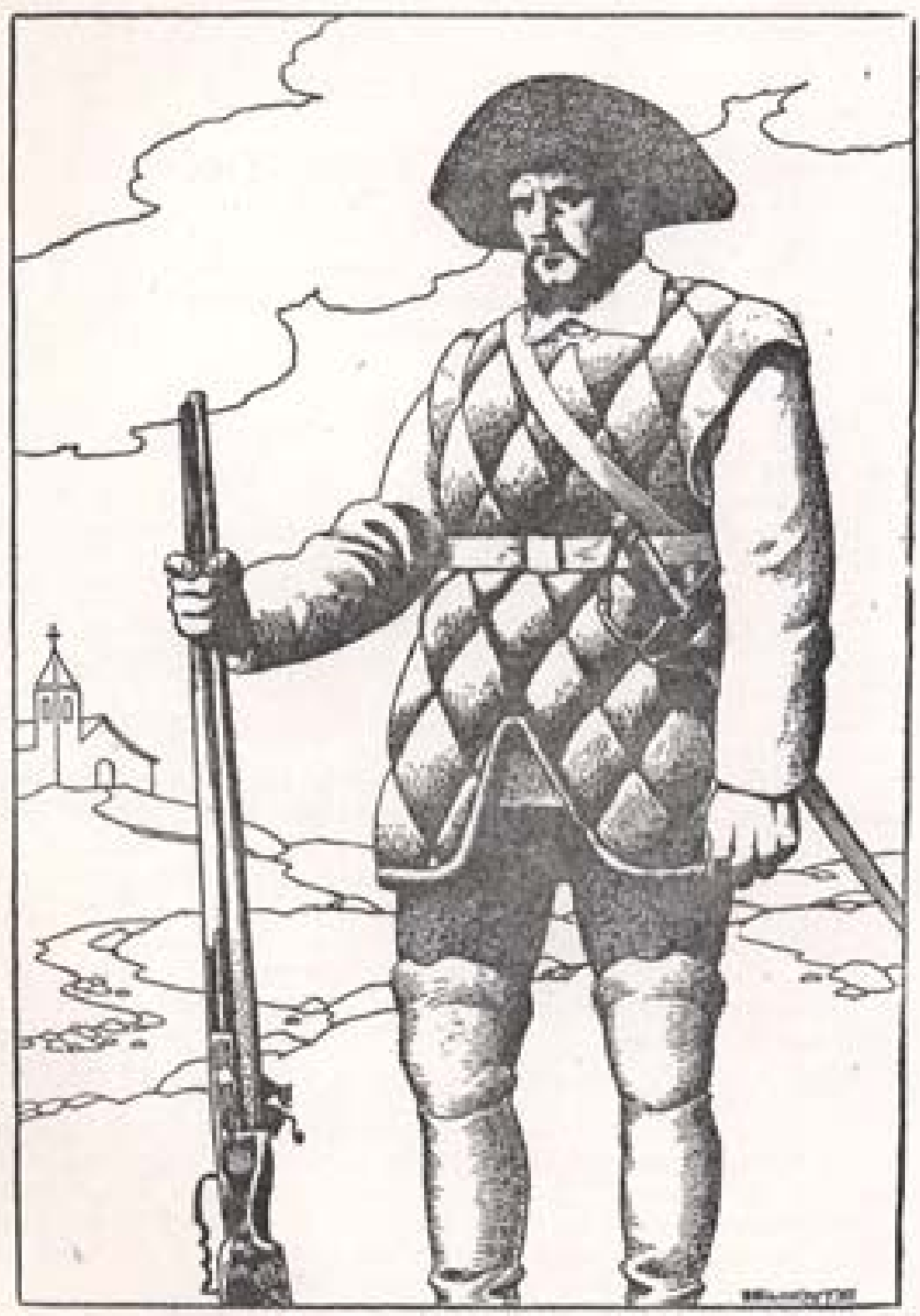

Moldebaie

Figura 89 - História do Brasil para crianças.

Fonte: CORRÊA, 21 ${ }^{\mathrm{a}}$ ed., 1957, p. 122. 
Reforçando essa imagem, Viriato assim descreve o bandeirante:

- Um bandeirante, para resistir a semelhante vida, deveria ser então uma criatura forte.

- Não há dúvida, concordou Vovô. Um bandeirante tinha de ser uma fortaleza maior que os outros homens. [...] Era preciso, portanto, ter muita coragem para resistir aos sofrimentos. [...]

$\mathrm{O}$ que comandava a bandeira devia ser um homem de qualidades ainda maiores que os outros, porque o que comandava a bandeira era tudo: o general, o disciplinador, o juiz e até a criatura que dava esperanças quando as outras desanimavam.

E mais do que isso, devia ter uma energia indomável (CORRÊA, 1957, p. 124).

Tal qual semideuses, os bandeirantes têm seu papel histórico sempre justificado pelo autor:

- Eram homens diferentes dos outros homens os grandes bandeirantes: Fernão Dias teve forças para mandar enforcar o próprio filho. A bem da disciplina da bandeira, ergueu a força no arraial e, diante da multidão aterrada, mandou matar aquele elemento de desordem e traição" (CORRÊA, 1957, p. 128).

De modo geral, os bandeirantes são identificados como "heróis" pelo desbravamento de nossas fronteiras territoriais.

As costas brasileiras foram descobertas pelos portugueses, mas os sertões do Brasil foram os bandeirantes que os descobriram. As bandeiras, penetrando nas florestas, nos campos e nas montanhas, nos chapadões até ali nunca pisados, tornaram o Brasil mais conhecido de norte a sul, de leste a oeste (CORRÊA 1957, p. 121).

Apenas uma única vez, o autor fez menção à escravidão da mão-de-obra indígena pelas bandeiras: “- As bandeiras de Antônio Raposo não andaram à procura de minas de ouro. Andaram pelo sertão escravizando índios. Naquele tempo a mina era aprisionar os selvagens e vendê-los." (CORRÊA, 1957, p. 125). 
Até a figura de Domingos Jorge Velho, o bandeirante que destruiu o quilombo de Palmares, merece destaque em uma das ilustrações do livro, em que Belmonte se baseou no quadro de Benedito Calixto, de 1903, pertencente ao acervo do Museu Paulista.

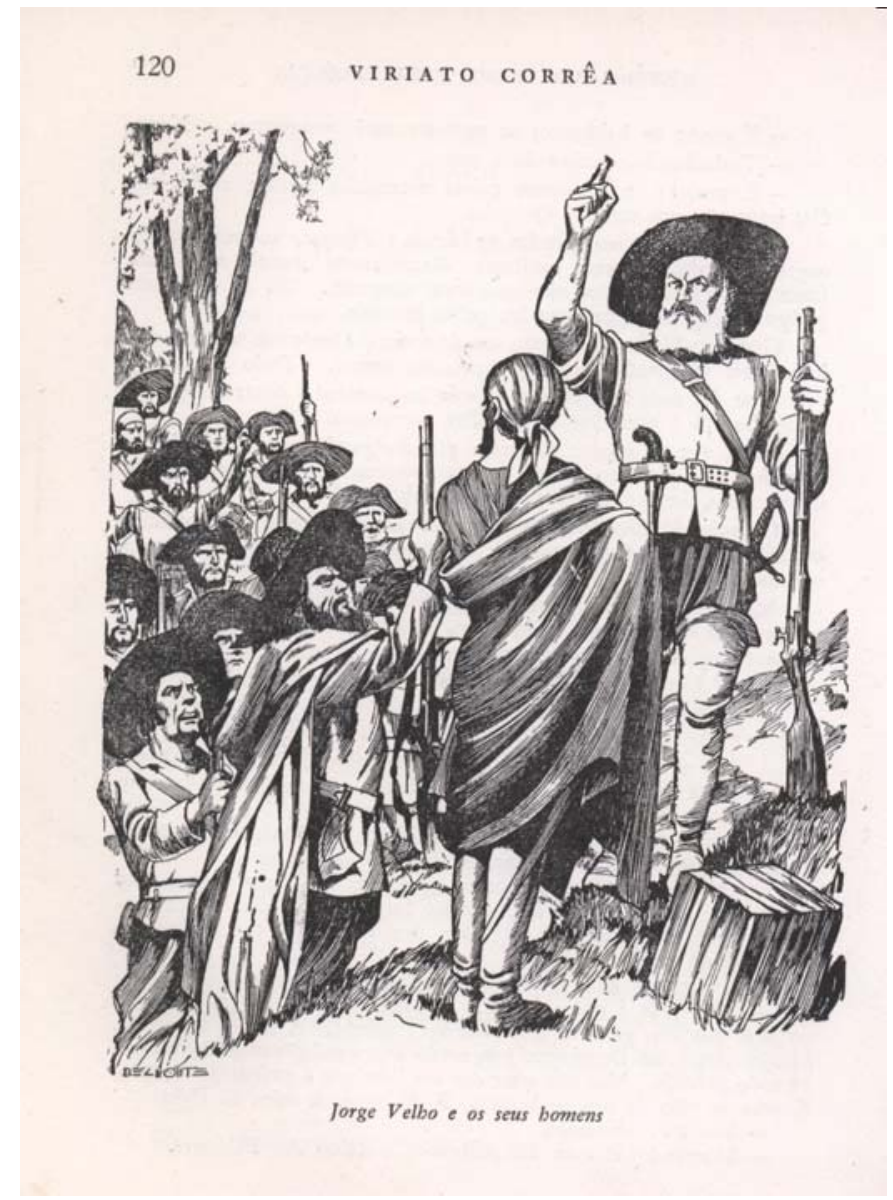

Figura 90 - História do Brasil para crianças Fonte: CORRÊA, $21^{\text {a }}$ ed., 1957, p. 120

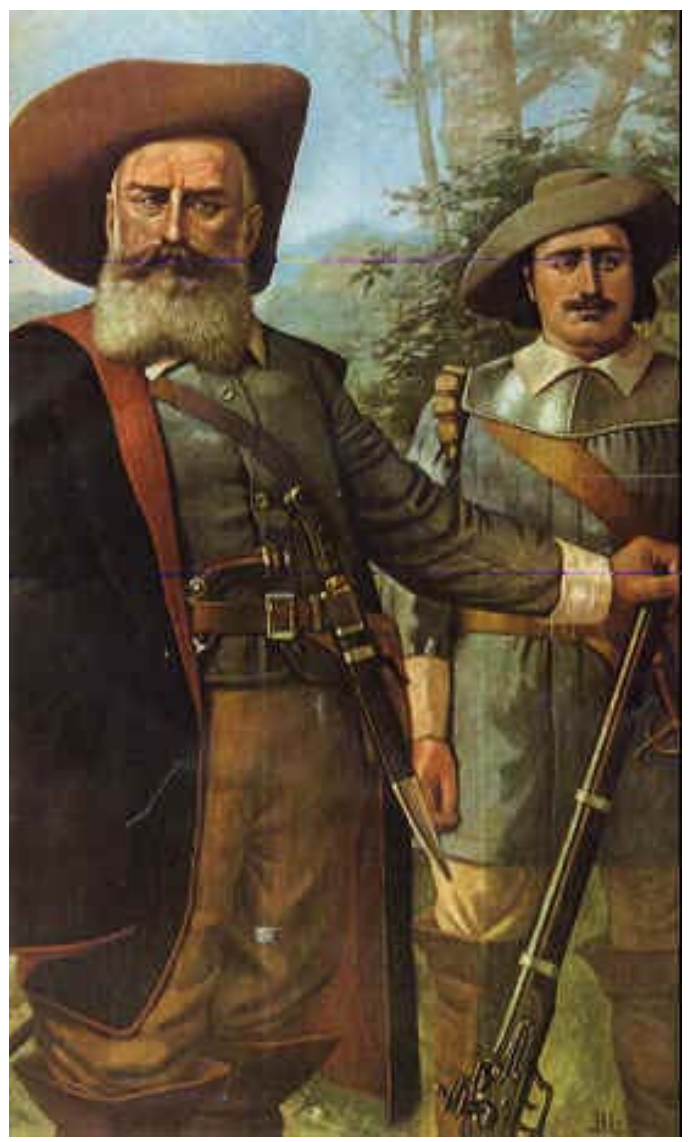

Figura 91 - Domingos Jorge Velho e seu ajudante de campo Antonio Fernandes de Abreu, 1903.

Fonte: BENEDITO CALIXTO (1853-1927). Acervo Museu Paulista. 
Sabe-se que essa imagem do bandeirante foi fruto de uma construção histórica feita pelo Instituto Histórico e Geográfico de São Paulo, no final do séc. XIX, com o intuito de inserir a história do estado na história nacional.

\begin{abstract}
Se cada instituto selecionou imagens diversas para uma mesma história, no exemplo paulista houve um claro predomínio temático do fenômeno do bandeirantismo. $\underline{\text { Os }}$ historiadores paulistas foram os responsáveis pela valorização e popularização da figura do bandeirante, introduzindo uma interpretação ainda presente na historiografia oficial. Nesta se estabelece uma relação entre a atitude valente e laboriosa daqueles primeiros aventureiros e um suposto perfil do estado e de sua trajetória vitoriosa (SCHWARCZ, 1993, p. 132-3, grifo nosso).
\end{abstract}

A imagem do bandeirante é sempre retomada, de tempos em tempos, quando se necessita de uma justificativa ideológica para ressaltar o papel de São Paulo no contexto nacional. Assim foi feito, por exemplo, quando da Revolução Constitucionalista de 1932: o soldado constitucionalista que lutava contra o governo de Vargas encarnava a figura do bandeirante e essa figura heróica do bandeirante estava presente em volantes, cartazes e panfletos usados durante a revolta. Nas comemorações alusivas aos 450 anos de São Paulo, em 1954, mais uma vez, a figura do bandeirante foi usada para mostrar a pujança econômica do estado no contexto da federação brasileira, ressaltando que, desde tempos imemoriais, São Paulo já estava predestinado ao progresso e ao desenvolvimento industrial (ABUD, 1999).

No entanto, essa imagem de homem forte, bem vestido, com botas de cano alto, gibão, colete e o chapéu de abas largas, tal qual um nobre ou um cavaleiro medieval, não condiz com a realidade de vida do bandeirante, segundo salienta o escritor Alcântara Machado, na sua obra Vida e morte de um bandeirante (1929). Machado, utilizando-se de inventários familiares como fonte documental, mostra o bandeirante como um homem, em geral, analfabeto e pobre, com costumes pouco refinados e que enfrentava dificuldades na conquista do sertão: ataques de índios, animais selvagens e peçonhentos e, até mesmo, fome. Descalços, avançando a pé pelas trilhas abertas pelos índios e portando arcos e flechas, os bandeirantes estavam distantes da imagem projetada na literatura didática e que ainda hoje povoa o imaginário popular. 
Já para o historiador Sérgio Buarque de Holanda (1957), o bandeirante deve muito de sua empreitada pela conquista da terra à presença indígena nas expedições: o bandeirante adentrava as matas e aprendia com os índios a luta pela sobrevivência no sertão.

A temática das bandeiras é bastante recorrente na obra de Viriato Corrêa, seja em livros de crônicas históricas, seja na literatura infantil (A Bandeira das Esmeraldas, 1945) e, até mesmo, em sua produção teatral (O Caçador de Esmeraldas, 1940).

Vale ressaltar também que o ilustrador da obra - o paulista Belmonte - escrevera um livro $^{172}$ sobre o tema das bandeiras, no qual também exalta o papel do bandeirante na história nacional, além de seu único livro infantil - A cidade de ouro - que também trata do mesmo tema. Assim, autor e ilustrador comungam do mesmo compromisso de exaltação desse personagem histórico.

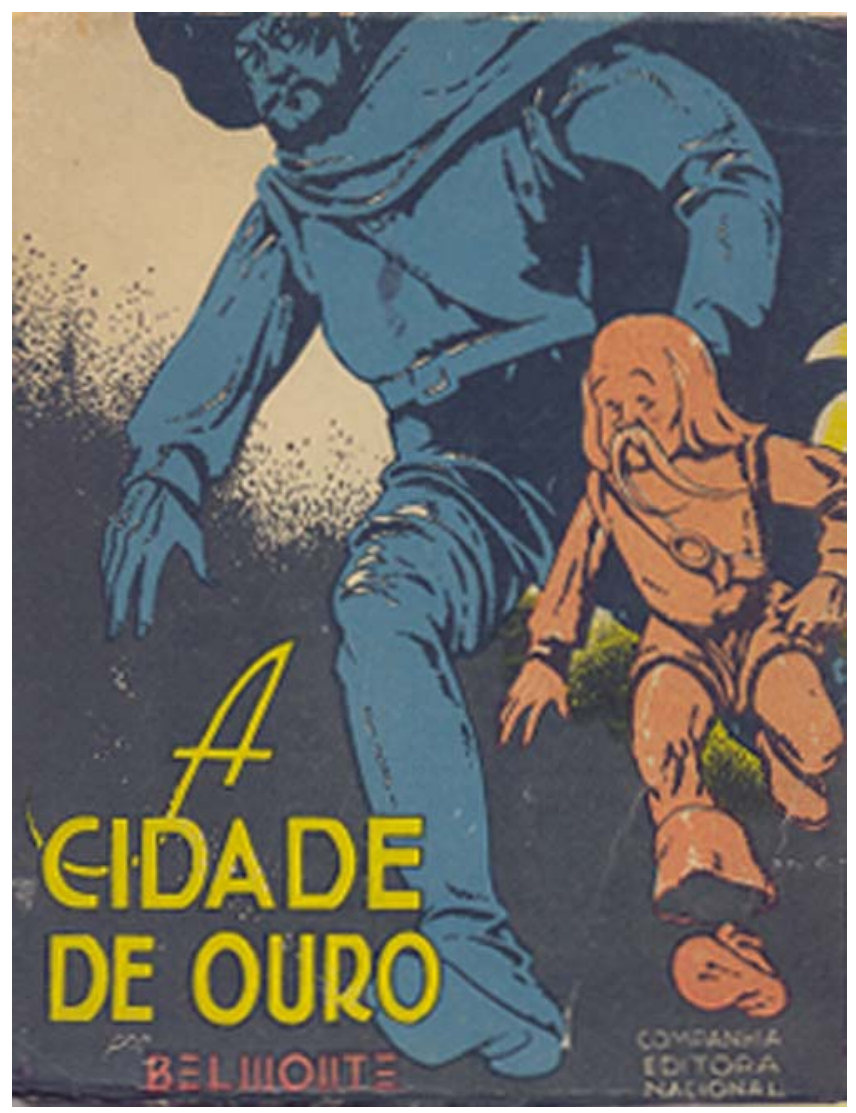

Figura 92 - A cidade de ouro.

Fonte: BELMONTE, 1940.

${ }^{172}$ BELMONTE. No tempo dos bandeirantes. $4^{\text {a }}$ ed (revista, aumentada e definitiva, com desenhos do autor). São Paulo: Edições Melhoramentos, s/d. 


\subsubsection{A defesa do território e o sentimento nativista}

$\mathrm{Na}$ literatura escolar, um dos assuntos mais recorrentes para o ensino de História era a questão relativa à defesa do território nacional contra os inimigos estrangeiros: piratas, contrabandistas, espanhóis, franceses e holandeses. A definição de nossas fronteiras era algo importante para a construção de nossa identidade nacional.

Nesse contexto, em um país de dimensões continentais, que precisava ser conhecido para ser melhor governado de forma centralizadora, alguns temas estarão presentes na literatura escolar, durante o Estado Novo:

[...] a questão da soberania nacional, da expansão territorial e política, do papel dos jesuítas na formação moral, as lutas dos nativos contra os exploradores estrangeiros, os heróis impessoais e pessoais, todos esses elementos constituíam ingredientes importantes na formação da identidade nacional e por isso ganham destaque nos livros de História do Brasil, onde a história nacional foi recontada e adaptada aos propósitos dos novos tempos (CAPELATO, 1998, p. 230).

$\mathrm{Na}$ expulsão dos estrangeiros do território, constata-se também um tema bastante difundido na historiografia brasileira - o desenvolvimento do sentimento nativista e o congraçamento das três raças formadoras do povo brasileiro, o que também reforça o mito da democracia racial.

A expulsão dos holandeses do Nordeste foi assim retratada por Viriato:

Começa então o grande heroísmo dos pernambucanos. Ninguém se conforma com o domínio dos invasores. E aqui, ali, formaram-se "redutos", ou melhor, fortalezas para impedir que os invasores se apoderem da terra toda. O mais famoso desses redutos é o Arraial do Bom Jesus, onde se reúnem os grandes patriotas como André Vidal de Negreiros, Filipe Camarão, Henrique Dias e outros (CORRÊA, 1957, p. 103, grifo nosso).

Segundo Viriato, o domínio holandês no Nordeste é visto como uma oportunidade ímpar em nossa história. Primeiro, porque o governo de Maurício de Nassau representou um momento de progresso e desenvolvimento na capitania de Pernambuco. 
No governo de Nassau, continuou o velho, houve justiça em Pernambuco. Entre brasileiros, portugueses e holandeses não havia diferença nenhuma. Pagavam todos os mesmos impostos e as leis eram as mesmas para todos. Havia também liberdade de crença: católicos, protestantes, judeus, praticavam as suas cerimônias religiosas como entendiam e o governo fazia respeitar os seus templos. Houve também liberdade de comércio: qualquer navio de qualquer nação podia entrar e sair dos portos, vender e comprar mercadorias.

Querem saber mais? Foi Nassau que introduziu a imprensa no Brasil. Foi ele que criou o descanso aos domingos para os escravos. Foi ele que fez o Recife. [...] (CORRÊA, 1957, p. 107, grifo nosso).

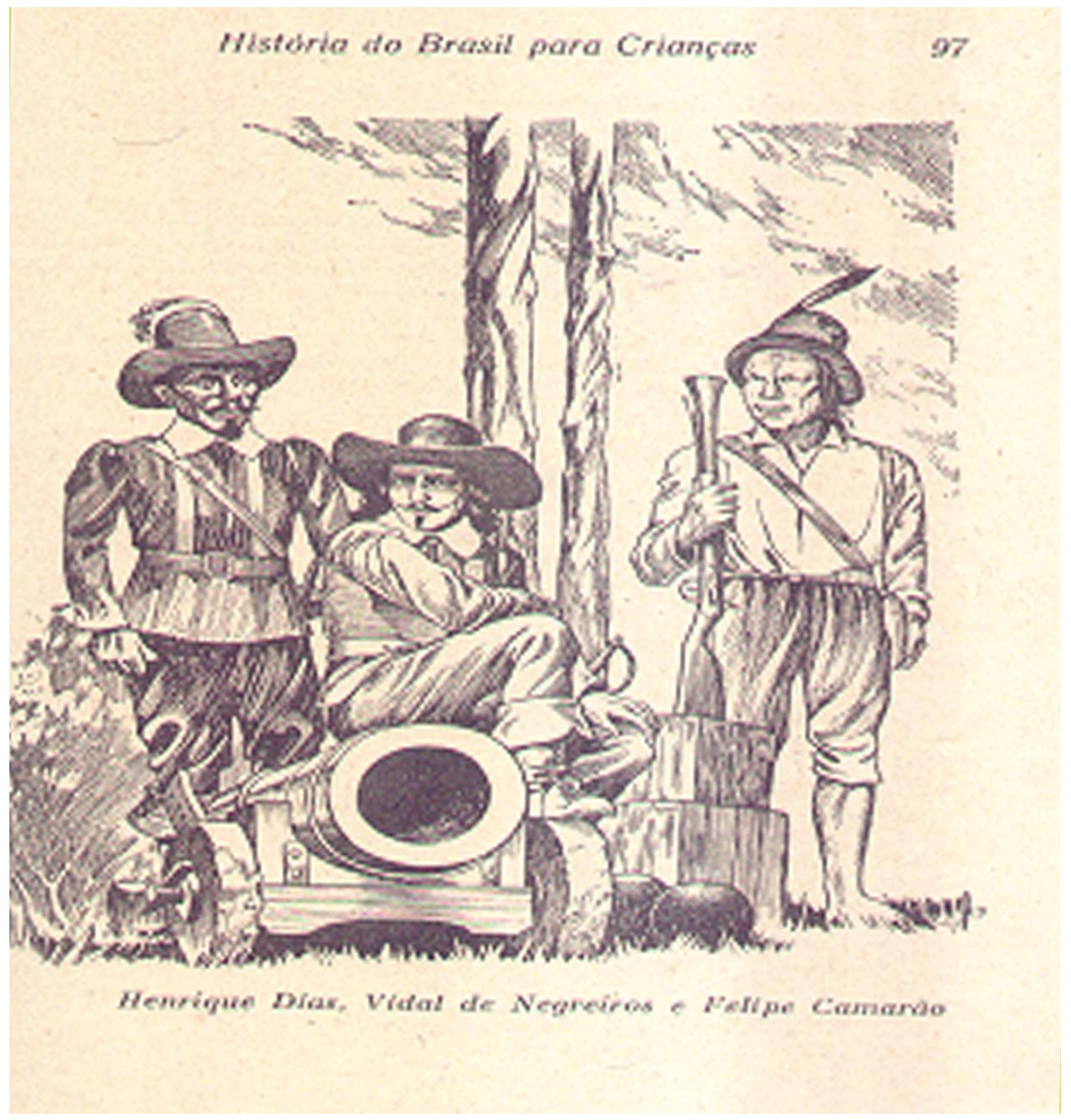

Figura 93 - História do Brasil para crianças.

Fonte: CORRÊA, $11^{\text {a }}$ ed., 1944, p. 97. 
Em segundo lugar, porque foi através da ocupação holandesa que se criou o sentimento de amor à terra. Os brasileiros das três raças (Filipe Camarão - o índio; Henrique Dias - o negro - e André Vidal de Negreiros - o branco) uniram-se para a defesa do território e expulsão do inimigo invasor:

Só faltava um homem para dar um grito de guerra.

Esse homem apareceu. Foi André Vidal de Negreiros, herói dos tempos do Arraial do Bom Jesus. Vidal de Negreiros reuniu os homens de fortuna, os grandes senhores de engenho, os guerreiros da época da invasão, entregou a chefia de tudo a Fernandes Vieira, o homem mais rico da capitania e, no ano de 1645, fez estalar a revolução (CORRÊA, 1957, p. 108).

- O domínio dos holandeses no Brasil não foi inútil. Além do período brilhante de Nassau, ele serviu para apurar as nossas qualidades de bravura, serviu para despertar dentro do coração dos brasileiros o amor à terra que Deus lhe reservou no mundo (CORRÊA, 1957, p. 109, grifo nosso).

\subsubsection{O cotidiano}

Apesar de centrar sua narrativa nos grandes fatos e personagens de nossa história, Viriato inovou em seu livro - característica que o diferencia da maioria dos manuais didáticos do período -, ao trazer aspectos relacionados ao cotidiano da população e à história da vida privada de determinados grupos sociais. Merecem destaque os capítulos "Os costumes dos nossos avós" e "A mesa brasileira".

Neles, estão presentes os seguintes temas:

\section{A família patriarcal}

A família de outrora não vivia como a família atual. [...] A esposa não valia nada, era quase uma escrava. O marido parecia um rei, dirigia tudo, sem ouvir ninguém. Ele é que escolhia os noivos para as filhas e as noivas para os filhos. Governava até os filhos casados (CORRÊA, 1957, p. 164).

Antigamente, uma casa de família podia ser comparada a uma prisão. As janelas não se abriam, as mulheres não punham a cabeça nas janelas. Mães e filhas viviam trancadas lá dentro, como se tivessem cometido algum crime. Quando saíam à rua, isso nos dias das grandes festas de igrejas, iam acompanhadas dos maridos e dos pais. Aí saía a família toda - marido, mulher, filhos, parentes, escravos, uns atrás dos outros, formando filas (CORRÊA, 1957, p. 165). 


\section{A instrução}

- Uma moça de família, antigamente, nem ao menos sabia ler. Os pais deixavam-nas analfabetas, para que não lessem cartas dos namorados (CORRÊA, 1957, p. 165).

\section{O lazer}

Vida enfadonha, a vida de nossos avós. Nem festas, nem cinemas, nem teatros, como hoje. Só existiam as festas religiosas [...].

Figuravam nas festividades várias danças e entre elas o sapateado e o côco, de origem indígena, o fandango e a caninha verde de origem portuguesa e a congada e o tambor genuinamente africanos (CORRÊA, 1957, p. 165).

Uma das diversões curiosas daqueles tempos tinha o nome de entrudo.

- Entrudo? O que é isso? Inquiriu Mariazinha.

- O entrudo fazia-se pelo Carnaval. Hoje não se usa confete e lança-perfumes? Antigamente era diferente. Usava-se a água, água limpa, água suja, água de todas as qualidades. Pelo carnaval a brincadeira consistia em molhar as criaturas. Quem saía de casa voltava molhado como um pinto. Andavam bandos e bandos de homens e mulheres pelas ruas, com vasilhas d'água, ensopando os que passavam e invadindo as casas para molhar as pessoas amigas. Esse costume tornou-se depois menos grosseiro: apareceram os limões de cheiro - limõezinhos feitos de cera e cheios d'água perfumada que arrebentavam atirados às criaturas (CORRÊA, 1957, p. 167). 


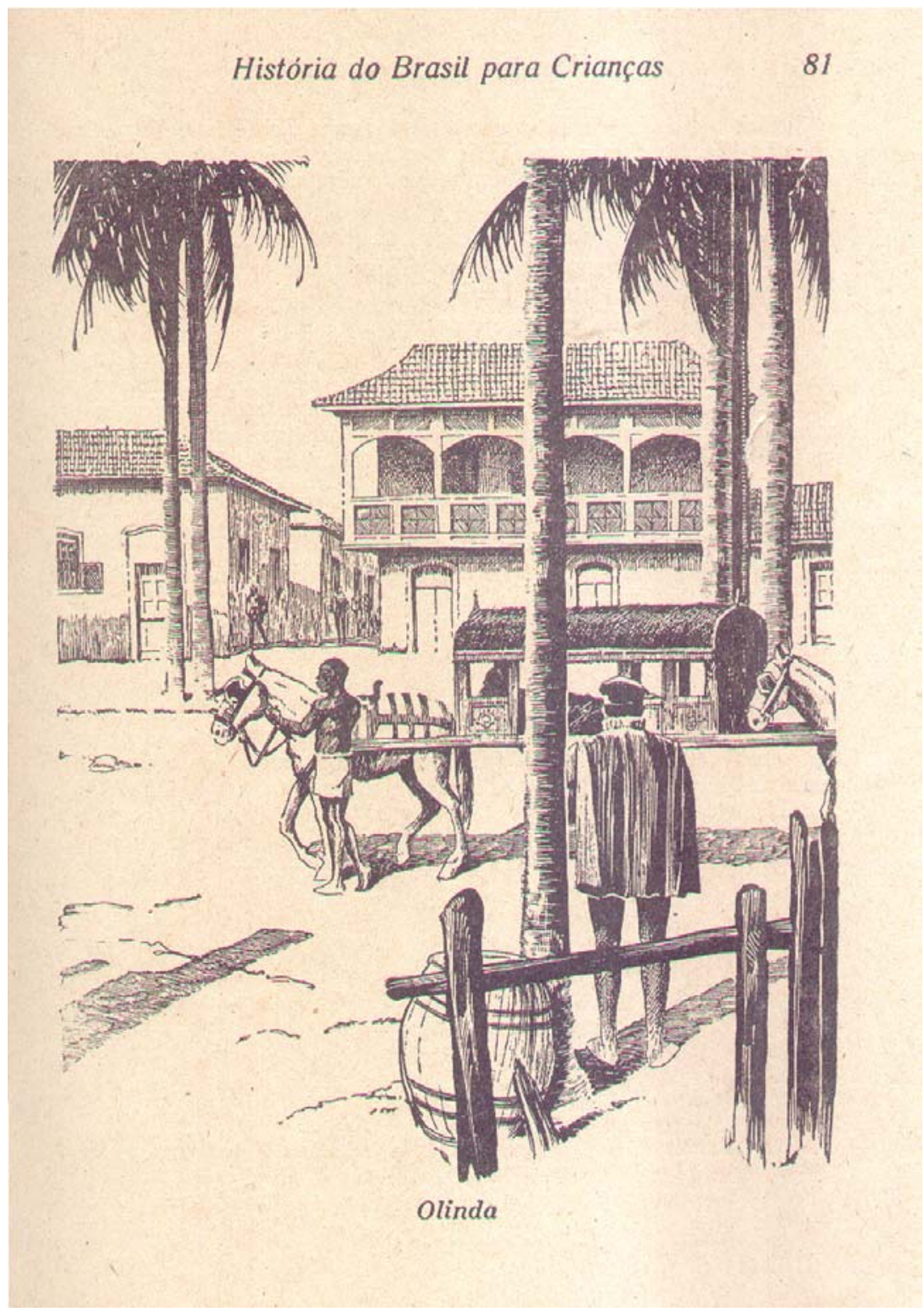

Figura 94 - História do Brasil para crianças. Capítulo "Cidades que eram aldeias". Fonte: CORRÊA, $11^{\mathrm{a}}$ ed., 1944, p. 81.

\section{A infra-estrutura urbana}

[...] Mal anoitecia, a vila ou a cidade ficava às escuras.

- Não havia iluminação pública nas ruas? Atalhei

- Não, não havia. Às 7 da noite rezava-se e, às 8 , já todo mundo roncava na cama. Quem tivesse necessidade de sair à rua levava uma lanterna para não se perder na escuridão (CORRÊA, 1957, p. 167). 


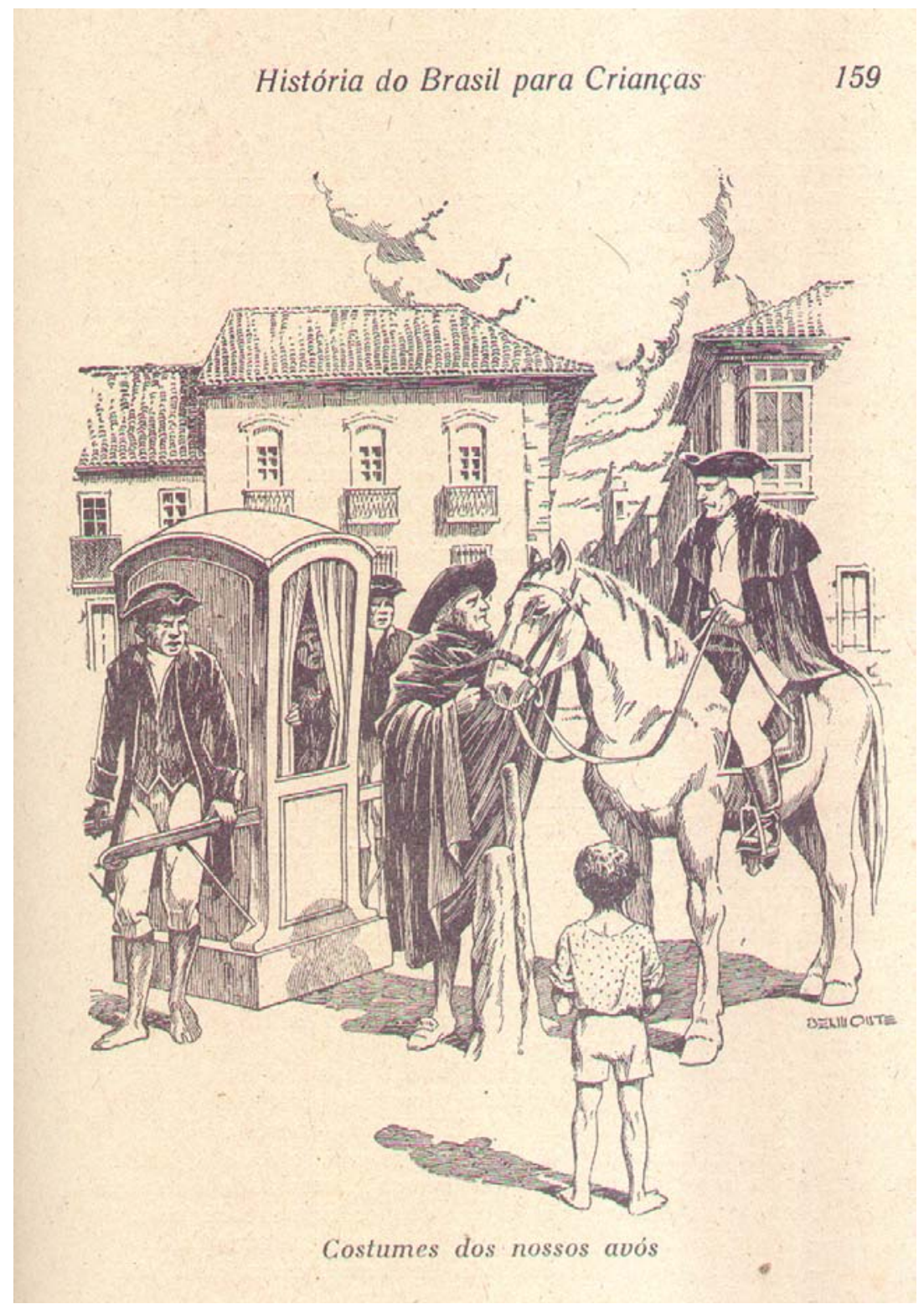

Figura 95 - História do Brasil para crianças. Capítulo "Costumes dos nossos avós". Fonte: CORREAA, 11ª ed., 1944, p. 159.

\section{O transporte}

- E como andavam os nossos avós? A pé? Perguntei.

- A pé, os pobres, respondeu o velho. Uma rica senhora, que se prezava, só saía à rua de cadeirinha ou liteira. Cadeirinha era uma cadeira coberta de pano, na qual uma pessoa se sentava para ser conduzida por dois homens. Liteira era mais ou menos a mesma cadeirinha, mas levada por animais.

Havia cadeirinhas e liteiras lindíssimas e de alto preço. O fazendeiro rico viajava em rede, atravessada por um pau e suspensa nos ombros dos escravos. O comum, porém, era o cavalo. Cada um tinha o seu cavalo para andar nos povoados, nas vilas e nas próprias cidades (CORRÊA, 1957, p. 167). 


\section{A alimentação}

Mais uma vez, ao falar sobre a mesa brasileira, Viriato remete-nos à formação do povo brasileiro, mostrando a influência de cada uma das etnias na culinária de nosso País.

- O Brasil, como vocês já sabem, é um país formado pela raça indígena, a branca e a negra. A cozinha brasileira deve ser, portanto, um produto dessas três raças (CORRÊA, 1957, p. 173).

- Pelo que vejo a cozinha brasileira é toda européia, disse eu.

- Não é verdade, replicou Vovô. A cozinha brasileira, já disse, é um produto das três raças que nos formaram. Salta aos olhos a influência de cada uma delas. A cozinha portuguesa destaca-se pelas gorduras; a africana pelos azeites esquisitos e pelos apimentados e a selvagem, pelos caldos excitantes e perigosos para a saúde (CORRÊA, 1957, p. 175).

\section{$[\ldots]$}

A influência do africano na cozinha brasileira é enorme. O negro, quando chegou ao Brasil, estava muito mais adiantado que o indígena. E tanto mais atrasado é um povo quanto mais pobre é a sua cozinha. A mesa dos antigos habitantes de Pindorama, já mostrei a vocês, era paupérrima. Pequena foi, portanto, a sua influência na cozinha brasileira (CORRÊA, 1957, p. 176).

Assim, Viriato inseriu na literatura didática aspectos já presentes em suas crônicas históricas, filiadas à noção de petite histoire. Para ele,

[...] a história não são unicamente os acontecimentos bellicos, o heroísmo da espada e o choque das batalhas. História é a aventura no bom sentido, é a audácia, é o desenvolvimento da capacidade de trabalho, é a ascenção para a posteridade, é a bravura do labor, é o descortínio do futuro, é a inquietação fecunda da intelligencia, é a realização (CORRÊA, 1934, p. 159).

Ao abordar, na narrativa histórica, o cotidiano de alguns grupos sociais, Viriato inova a literatura escolar da época, caracterizada, muitas vezes, por uma análise reducionista que enfoca somente a história político-institucional, em que o Estado e os detentores do poder, em diferentes momentos (donatários, vice-reis, monarcas, presidentes), são os sujeitos privilegiados do fazer histórico. 


\subsection{O Panteão da Pátria na escola: os heróis nacionais}

A idéia de glorificar os feitos e realizações dos governantes remonta às primeiras civilizações da Antigüidade. Em Roma, construiu-se um templo com o objetivo de que fosse consagrado a todos os deuses. Era o Pantheon. No decorrer da história, "Panteão" passou a designar o local onde se depositavam os restos mortais de homens ilustres e notáveis - os "heróis nacionais" - que prestaram grandes serviços à Pátria.

Na França, em 1791, o processo revolucionário transformou a Igreja de Santa Genoveva no Panteão moderno, como forma de cultuar os grandes homens, com a legenda "Aos grandes homens, a Pátria reconhecida". Assim, ocorreu uma laicização dos costumes, sendo os deuses e santos substituídos pelos "heróis nacionais"

Além do Panteão, os heróis encontraram nos livros didáticos, mediante reprodução de suas fotos ou quadros, local privilegiado em que pudessem ser vistos e suas ações, enaltecidas, servindo de modelo às novas gerações. Na verdade, o culto aos heróis nacionais também é instrumento de afirmação da identidade nacional.

História do Brasil para crianças traz, ao longo de sua narrativa, uma série de heróis nacionais. Veremos, agora, alguns deles, no contexto dessa obra de Viriato Corrêa.

\subsubsection{Tiradentes: o herói por excelência ${ }^{174}$}

O ardor mineiro refletia-se na estampa de Tiradentes ao lado do quadro-negro. De perfil, cabelos e barba longos, a túnica de réu entreaberta ao peito, evocava Jesus Cristo que dormitava, de rosto pendido e braços abertos, no pequeno crucifixo ao centro da sala de aula (BETTO, 2002, p. 81)

\footnotetext{
${ }^{173}$ Sobre a história do Panteão na cultura ocidental, em especial na França, consultar BONNET, Jean-Claude. Naissance du Panthéon: essai sur le culte des grands hommes. Paris: Fayard, 1998.

${ }^{174}$ Tiradentes foi um dos personagens históricos mais recorrentes na produção literária de Viriato Corrêa. Em quase todos seus livros infantis há referência ao Mártir da Independência e herói republicano por excelência. Na coleção de livros Para você, meu filho, Viriato escreveu o capítulo Tiradentes, o que morreu pela liberdade do Brasil (CORRÊA, s/d, p. 90-159.)
} 
Tiradentes é abordado em três capítulos do livro, a saber: "O sentimento da independência"; "A figura maravilhosa de Tiradentes" e "A morte de Tiradentes". Em todos eles, seu papel é exaltado como verdadeiro mártir de nossa Independência. Isso estava de acordo com o ideário dos primeiros anos da República e, posteriormente, com o Estado Novo (1937-1945), que elegeu Tiradentes o herói republicano de nossa história por excelência. ${ }^{175}$

Dando continuidade à tradição republicana, Getúlio Vargas promoveu o culto à figura de Tiradentes e ao movimento da Inconfidência Mineira, ao elevar Ouro Preto, antiga Vila Rica e palco histórico dos acontecimentos, à categoria de Monumento Nacional (1933), bem como ao transformar a antiga Casa de Câmara e Cadeia da cidade em "Museu da Inconfidência", onde estão os restos mortais de alguns inconfidentes.

\begin{abstract}
Durante o Estado Novo a comemoração do 21 de abril expandiu-se e diversificou-se quanto às atividades incorporadas à celebração. Tornou-se, no entanto, monolítica, repetindo-se todos os anos, em praticamente todos os lugares, segundo a mesma estrutura. [...] Sua função primordial era a de formar a consciência cívica do cidadão trabalhador, moldá-lo de modo a transformá-lo em uma barreira eficaz às ameaças do regime, tanto internas quanto externas. Essa homogeneidade observada entre 1937 e 1945 era também resultante da concepção de uma nação una e coesa, que deveria reconhecer de maneira unânime uma só história, compartilhar uma mesma memória, cultuar os mesmos heróis. [...], o Estado Novo definiu a comemoração aos grandes vultos da nação como um dos principais sustentáculos de sua política cultural e educacional e, em função disso, o Ministério da Educação assumiu a gestão do calendário cívico (FONSECA, 2001, p. 191).
\end{abstract}

Nesse contexto estadonovista, Viriato ainda chegou a escrever uma peça teatral a pedido do Serviço Nacional de Teatro (SNT), do Ministério da Educação, sobre o personagem histórico - Tiradentes (1941), uma comédia histórica em 3 atos e 7 quadros, com música do maestro Heitor Villa-Lobos.

Porém, vale salientar que nem sempre o tema da Inconfidência Mineira e o papel "heróico" de Tiradentes estiveram presentes na literatura escolar:

\footnotetext{
${ }^{175}$ Sobre a construção simbólica da figura de Tiradentes como mártir da República e sua elevação à categoria de "herói nacional", consultar os trabalhos dos historiadores: CARVALHO, José Murilo de. A Formação das Almas: o imaginário da República no Brasil. São Paulo: Cia. das Letras, 1990, em especial o capítulo Tiradentes: um herói para a República; LARA, Sílvia Hunold. Tiradentes e a Nação Esquartejada. In: SECRETARIA MUNICIPAL DE CULTURA. DEPARTAMENTO DE PATRIMÔNIO HISTÓRICO. Pátria Amada Esquartejada. São Paulo: DPH, 1992 e MILLIET, Maria Alice. Tiradentes: o corpo do herói. São Paulo: Martins Fontes, 2001.
} 
Até a proclamação da República, o tema não aparecia nos manuais didáticos. No entanto as festas alusivas ao 21 de abril só começaram a aparecer a partir da segunda metade do séc. XIX, com a propagação do movimento republicano.

Após 1889, Tiradentes foi entronizado à categoria de herói nacional e mártir, com profunda conotação religiosa, já que sua figura era identificada com o sofrimento de Jesus Cristo. A imagem de Tiradentes é reapropriada com o Estado Novo, atribuindo-se a ela a idéia de que o seu sacrifício pela Pátria não foi em vão. $\mathrm{O}$ Estado Novo vai valorizar a idéia de sacrifício pela Pátria em sua pedagogia escolar: os brasileiros deveriam, portanto, se espelhar no exemplo de virtude e abnegação de Tiradentes (FONSECA, 2006, p. 73-4).

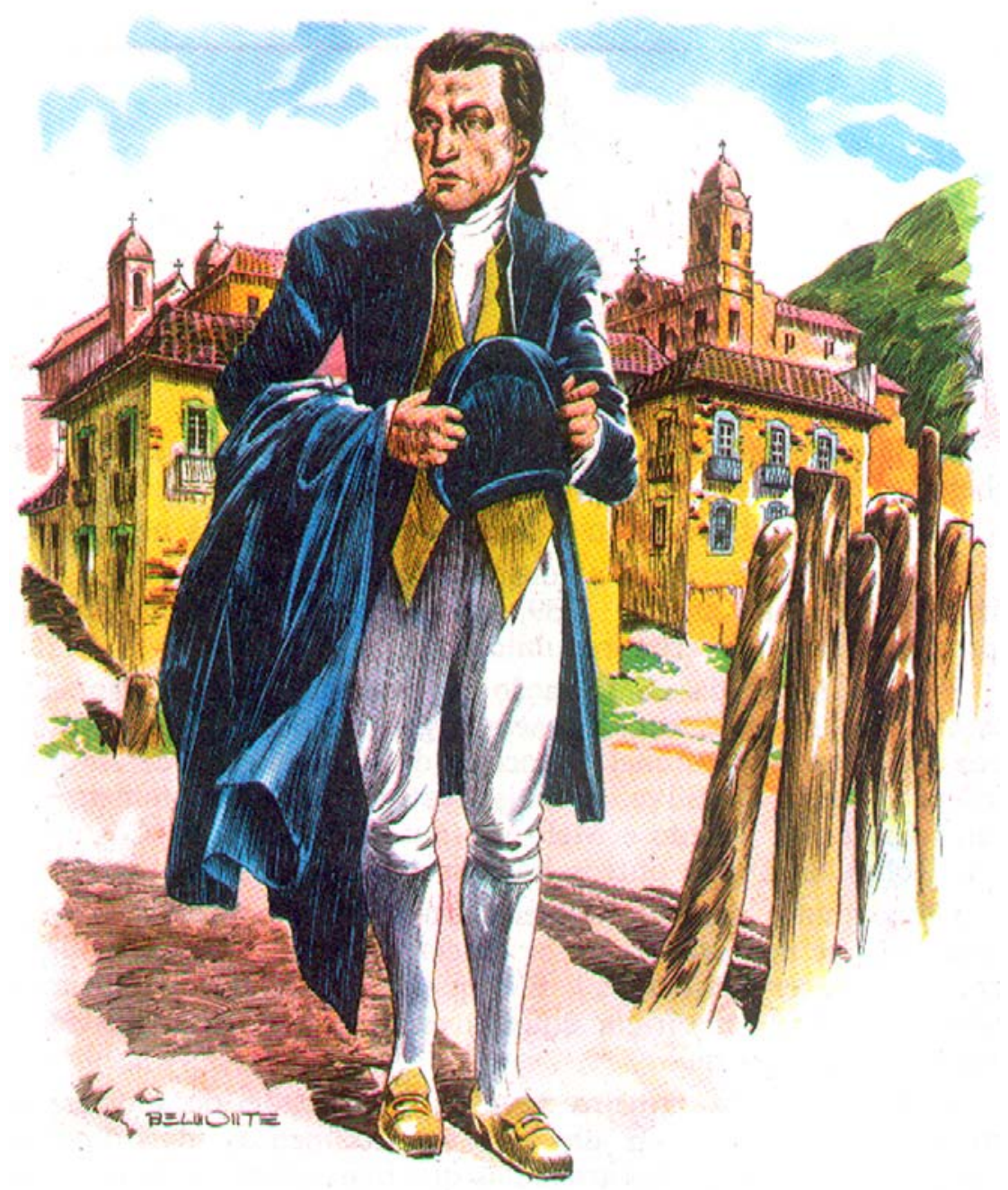

Tiradentes antes da prisão

Figura 96: História do Brasil para crianças. Tiradentes como alferes. Fonte: CORRÊA, 24 ${ }^{\mathrm{a}}$ ed., 1961. 


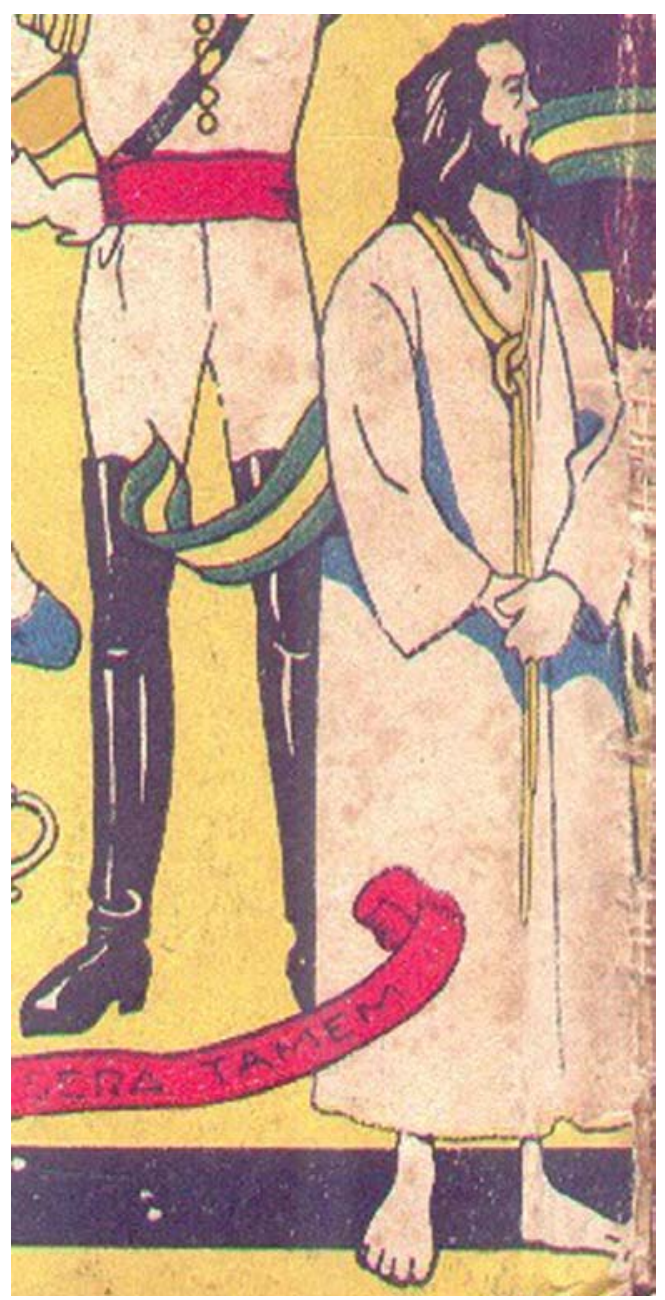

Figura 97: Tiradentes na contracapa do livro. Fonte: CORRÊA, $11^{\mathrm{a}}$ ed., 1944.

Saliba considera que a imagem de Tiradentes com barba é mais uma imagem canônica bastante recorrente na literatura escolar:

Todos nós lidamos, a todo momento, com imagens canônicas. Os livros didáticos são quase que infinitamente ilustrados com imagens canônicas. Na história brasileira, a imagem de Tiradentes com barba é uma daquelas imagens canônicas, com as quais nos acostumamos tanto, que sequer imaginaríamos outra possibilidade. A imagem de Tiradentes sem barba, veiculada em alguns raros quadros que tentam quebrar um pouco a imagem de mártir [...] já é desmistificadora, pois sabemos que a barba de Tiradentes foi uma criação bem mais tardia, da república brasileira, na época de sua fundação.(SALIBA, 2007, p. 88). 


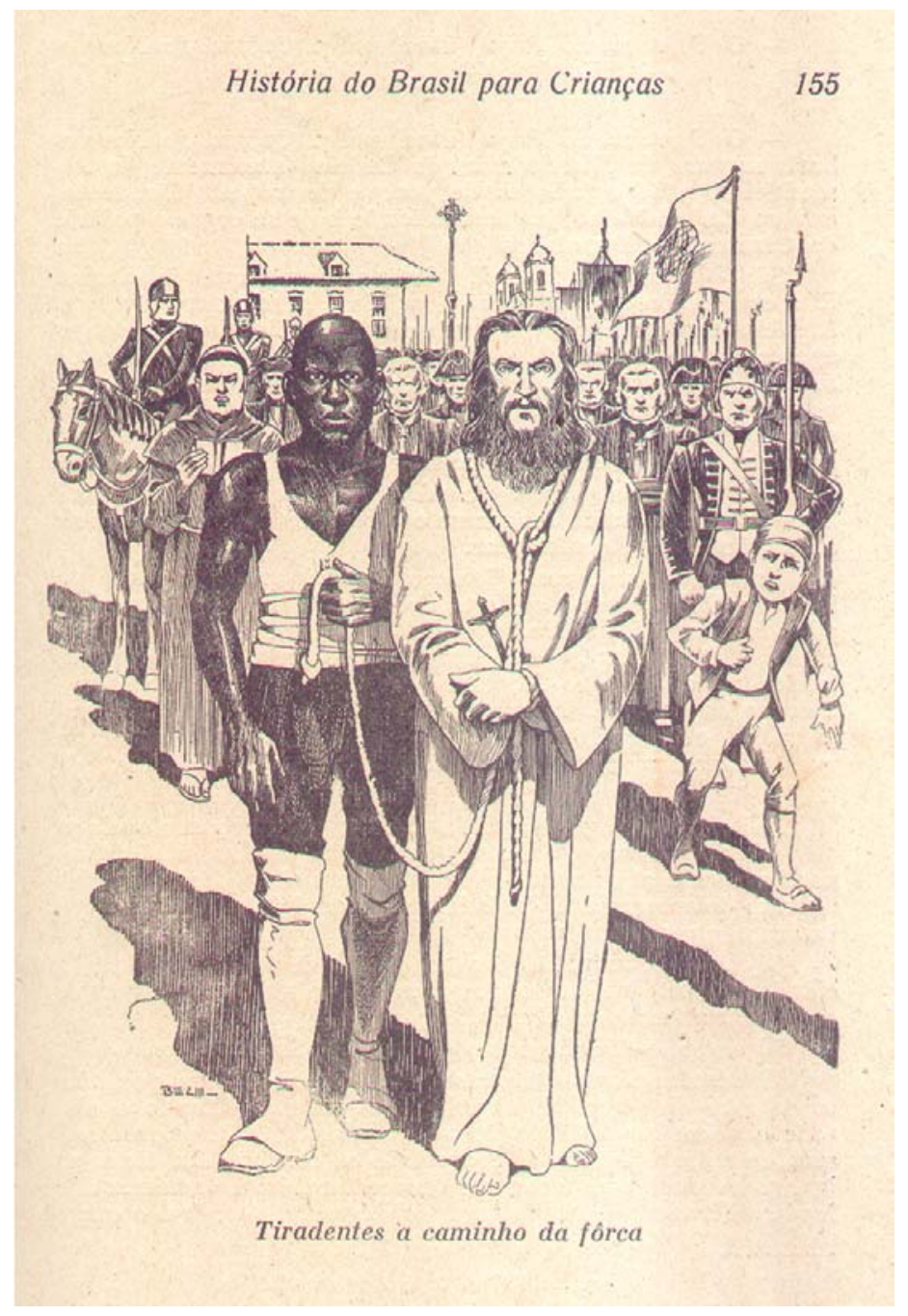

Figura 98 - História do Brasil para crianças. Tiradentes assemelhando-se a um "Cristo cívico".

Fonte: CORRÊA, $11^{\mathrm{a}}$ ed., 1944, p. 155.

Vejamos o que diz Viriato sobre Tiradentes, no livro História do Brasil para crianças:

Só uma alma ficou de pé, sem se arrepender, sem acusar ninguém- a de Tiradentes. Tiradentes se conservou digno até o fim, até o fim mostrou que a morte não lhe metia medo, até o fim mostrou que pela liberdade do Brasil seria capaz de dar a própria vida.

Tiradentes é a figura nobre da Inconfidência Mineira.

$[\ldots]$

Vovô calou-se e, depois, com voz trêmula:

- Tiradentes, meus meninos, é a mais bela e mais grandiosa figura patriótica da história brasileira. Foi o primeiro homem que morreu pela independência e pela liberdade do Brasil, foi o que melhor soube morrer pela nossa liberdade (CORRÊA, 1957 , p. 159 , grifo nosso).

- A forca, meus meninos, mata os homens, mas não mata a alma. Ao subir à forca, Tiradentes não era apenas um homem, era um sonho da liberdade brasileira. A forca matou-lhe o corpo, mas não lhe matou a idéia. A idéia, essa ficou, espalhada pelo Brasil. 
O sacrifício de Tiradentes não se perdeu. Trinta anos depois, a independência que ele sonhou e pela qual morreu foi proclamada no Brasil. E mais tarde proclamou-se a república (CORRÊA, 1957, p. 163, grifo nosso).

Em outros capítulos do livro, Viriato não deixa de mencionar o nome de Tiradentes como símbolo da liberdade e fonte de inspiração para outros movimentos revolucionários ocorridos em diferentes contextos e épocas.

O sangue de Tiradentes, derramado na fôrca, não se perdeu, disse Vovô. Ao contrário, deu mais vida à idéia de liberdade que se ia espalhando pelo Brasil. De norte a sul os brasileiros viviam a sonhar uma pátria livre.

No ano de 1817, era em Pernambuco que se reuniam os homens que mais sonhavam com a liberdade da pátria. Os que mais sonhavam e os que mais trabalhavam para realizar o sonho (CORRÊA, 19757, p. 182).

-Meus meninos: Tiradentes havia ensinado aos brasileiros como se morria por uma idéia. Domingos José Martins, o padre Roma, o padre Miguelinho, o padre Tenório, Domingos Teotônio, Barros Lima, enfim, todos os revolucionários de 1817, morreram com dignidade, com a dignidade com que se deve morrer pelo bem da pátria e da humanidade.

Guardem na memória e na alma o nome de todos, porque foi do sangue que eles derramaram que nasceu a liberdade que hoje gozamos (CORRÊA, 1957, p. 186).

O exemplo de Tiradentes, mártir da Pátria, aquele que morreu pela liberdade, é sempre lembrado e exaltado pelo autor. Parece até que Tiradentes reencarna em novos personagens históricos, também considerados heróis nacionais, a exemplo de Frei Caneca.

[...] Nada menos de 21 republicanos sofrem a pena de morte. Uns são enforcados, outros fuzilados.

- Vinte e um! Exclamamos surpreendidos.

- Vinte e um, confirmou Vovô. Frei Caneca, o padre Mororó, etc.

- E morreram todos como Tiradentes?

- Morrem, sim, respondeu Vovô, morrem todos serenos, orgulhosos de morrer pela liberdade brasileira (CORRÊA, 1957, p. 199, grifo nosso).

Além dos jesuítas (Manuel da Nóbrega, José de Anchieta e Antônio Vieira), dos bandeirantes (Antonio Raposo Tavares e Fernão Dias - o "Caçador de esmeraldas") e da figura de Tiradentes, no decorrer do livro, Viriato exalta outras personagens históricas que formam, a meu ver, um verdadeiro Panteão da Pátria, constituído pelos "grandes homens". São eles: 
- Gregório de Matos, "considerado o nosso maior poeta humorístico" (CORRÊA, 1957, p. 169).

- Eusébio de Matos e Antônio de Sá (prosadores).

- Frei Vicente do Salvador e Rocha Pita (historiadores).

- Antônio José, conhecido pela alcunha de "Judeu" (teatro).

- Basílio da Gama, Frei Santa Rita Durão, Cláudio Manuel da Costa, Silva Alvarenga, Alvarenga Peixoto, Tomás Antonio Gonzaga (poesia).

- Mestre Valentim (pintor e escultor).

- Aleijadinho (escultor).

- Padre Bartolomeu de Gusmão (cientista, inventor da "Passarola").

No último capítulo do livro, intitulado "Palavras do Fim", Viriato, mais vez, enumera os "grandes homens" que devem ter assento no Panteão da Pátria, para que sirvam de exemplo às crianças e à posteridade. São eles, de acordo com a área de atuação em que se destacaram:

- Na prosa, “os mais notáveis são: João Francisco Lisboa, Machado de Assis, Rui Barbosa, João Ribeiro e Coelho Neto" (CORRÊA, 1957, p. 233).

- Na poesia, destacam-se os nomes de Gonçalves Dias, Fagundes Varela, Álvares de Azevedo, Castro Alves, Casimiro de Abreu, Luís Delfino, Olavo Bilac, Alberto de Oliveira, Raimundo Correia, Vicente de Carvalho, Augusto de Lima, Luís Murat.

- Pintores: Vitor Meireles e Pedro Américo.

- Romancistas: José de Alencar, Machado de Assis, Aluísio de Azevedo, Adolfo Caminha, Raul Pompéia e, única mulher citada, a escritora Júlia Lopes de Almeida.

- Músicos: Padre José Maurício, Carlos Gomes, Henrique Osvaldo, Francisco Braga.

- Jornalistas: Hipólito da Costa, Evaristo da Veiga, Quintino Bocaiúva, Rui Barbosa, Ferreira de Araújo, Alcindo Guanabara e Medeiros e Albuquerque.

- Oradores: Joaquim Nabuco, Silva Jardim, Rui Barbosa, José do Patrocínio, Silveira Martins.

- No Direito: Teixeira de Freitas, Lafayette, Rui Barbosa, Clóvis Beviláqua.

- Escritores de teatro: Martins Pena, Joaquim Manuel de Macedo, França Júnior, Artur Azevedo. 
- Industriais: Mariano Procópio e Barão de Mauá.

- Soldados: "os dois maiores soldados do Brasil: o duque de Caxias e o general Osório" (CORRÊA, 1957, p. 235, grifo nosso).
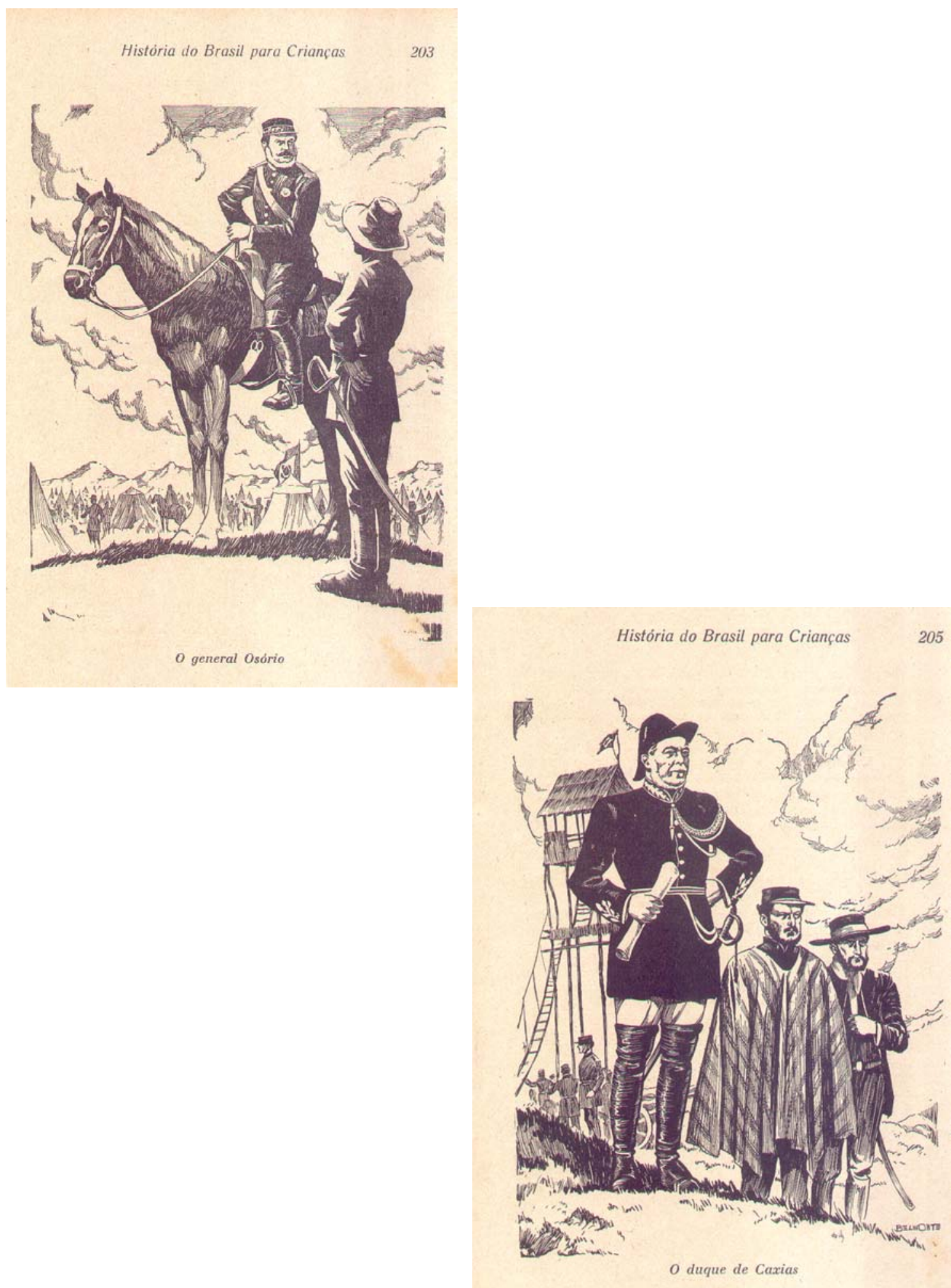

Figuras 99 e 100 - Osório e Caxias - heróis militares.

Fonte: CORRÊA, 11 a ed., 1944, p. 203, 205. 


\subsubsection{Pedro II: "o reinado do homem pacífico"}

Mais uma vez, vovô utiliza-se de um personagem histórico para passar uma lição moral às crianças: o valor do estudo e da obediência.

Pedro II nunca foi menino de andar fazendo estrepolias e de se esquecer de suas obrigações. Foi sempre uma criança estudiosa, aplicada, ajuizada. Quando começou a governar era um rapazote muito fino, muito sério, muito bem educado.

$[\ldots]$

- [...] Pedro II era um homem bom e principalmente homem de bem e uma das criaturas mais dignas que o Brasil tem tido. Era incapaz de prejudicar quem quer que fosse, incapaz de fazer uma injustiça, incapaz de tocar um vintém da nação.

Os homens inteligentes, os homens estudiosos tinham dele tudo. Durante o tempo do seu governo houve justiça, houve honestidade, houve paz no Brasil.

$[\ldots]$

O reinado de D. Pedro II pode-se chamar o reinado do homem pacífico. Todos viviam felizes. Onde há felicidade não há discórdia. Os brasileiros deixaram de brigar.

- Foi então uma época de absoluta felicidade, disse Pedrinho.

- O reinado de D. Pedro II seria uma época de absoluta felicidade para o Brasil se não tivéssemos tido guerras com três nações estrangeiras (CORRÊA,1957, p. 209210 , grifo nosso).

No paraíso tropical que era o Brasil de Pedro II, o autor esqueceu de mencionar o problema da escravidão e os conflitos daí decorrentes, sobretudo após a Guerra do Paraguai (1864-1870), quando se intensifica a campanha abolicionista, bem como a introdução da mãode-obra imigrante.

Enquanto D. João VI é visto como um governante indeciso e D. Pedro I aparece como um monarca autoritário e prepotente, o modelo de homem público e governante de nosso País é representado por D. Pedro II.

Naquele tempo, quem se sentava no trono português era a rainha D. Maria I. Mas, como a rainha tivesse enlouquecido, o seu filho D. João governava o reino, em nome dela, com o título de regente.

D. João (que, depois da morte de sua mãe, foi o rei D. João VI) era uma criatura indecisa e medrosa. Ao receber a imposição do imperador francês, ficou sem saber se se devia colocar ao lado da França ou da Inglaterra (CORRÊA, 1957, p. 179).

- Um ano depois de 7 de setembro já os brasileiros estavam arrependidos de ter confiado a D. Pedro I o papel de proclamador da independência. Arrependidos porque D. Pedro não cumpria as promessas que havia feito ao país (CORRÊA, 1957, p. 201). 
Diferentemente das imagens consagradas nos livros didáticos, que mostram um soberano velho, de barbas brancas, com ar de sapiência, uma espécie de "rei filósofo" (CALMON, 1975, p. 8), conhecedor das artes e das ciências, as duas ilustrações presentes no livro mostram D. Pedro II criança, ao lado do regente Padre Feijó, e aos sete anos de idade. 

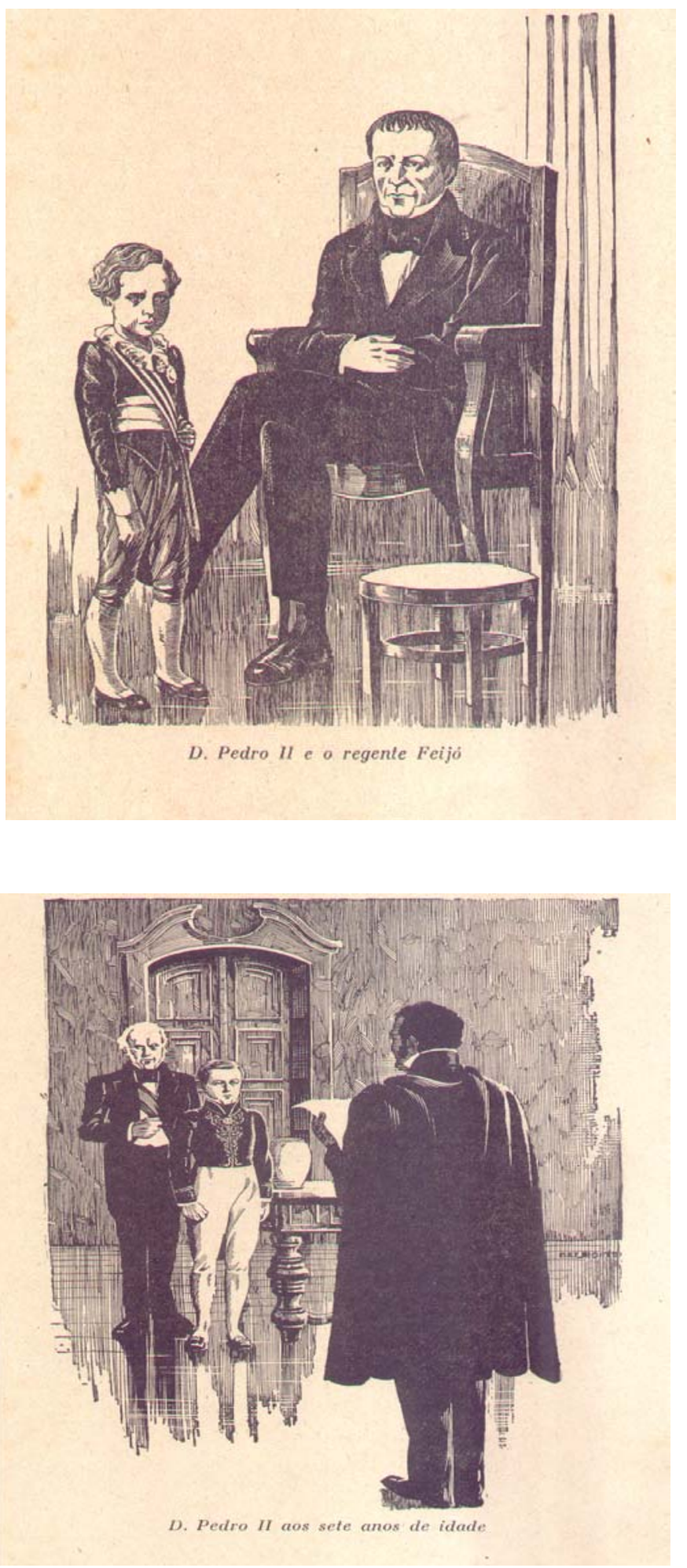

Figuras 101 e 102 - História do Brasil para crianças. Imagens de D. Pedro II.

Fonte: CORRÊA, 11 a ed., 1944, p. 199, 201. 
Viriato tinha verdadeira admiração pela figura de D. Pedro II. No seu discurso de posse na ABL, em 1938, teceu elogios ao $2^{\circ}$ Reinado de nossa história:

\begin{abstract}
No Brasil, quem abriu os olhos no reinado de D. Pedro II teve a ventura de ser contemporâneo de uma grande época. $\underline{O \text { segundo reinado é o período máximo da }}$ história nacional.

$\mathrm{O}$ domínio de $\mathrm{D}$. Pedro I é amargo. A Regência tem cunho de tragédia. O governo de D. Pedro II é a tranqüilidade, a preparação da ordem, o remanso, o equilíbrio, como the chamou Euclides da Cunha.

O primeiro reinado é a luta da independência que, de fato, só se conclui com o 7 de abril. A Regência é o caldeamento da nacionalidade, sanguinolento como todos os caldeamentos de povos. O segundo reinado não é apenas a organização da vida nacional, é também sua floração radiosa.

$[\ldots]$

Quase tudo o que temos de grande, de belo e de sólido á obra imperial.

É no segundo reinado que se lançam os fundamentos de tudo que uma nação constrói de eterno para a eternidade de sua existência (CORRÊA, 1938, p. 119-120, grifo nosso).
\end{abstract}

\title{
6.4.3 Rui Barbosa: o modelo de conduta para as crianças
}

Após a enumeração dos nomes dos grandes homens, a menina Quiquita pergunta ao vovô por que ele citou quatro vezes o nome de Rui Barbosa, como prosador, jornalista, jurista e orador. Assim, vovô responde: “- Sim, porque ele era tudo isso. Rui Barbosa foi o homem de maior inteligência e de maior saber que o Brasil já teve em todos os tempos." (CORRÊA, 1957, p. 235).

A figura de Rui Barbosa (1849-1923) é um exemplo paradigmático da construção do herói nacional. Segundo Gonçalves (2000), antes mesmo de sua morte, Rui Barbosa era visto como exemplo de homem público que dedicou o melhor de seus esforços à Nação brasileira. Exemplar único em nossa história de construção de um herói em vida.

Quando o senador, jurista, jornalista e diplomata Rui Barbosa morreu, em $1^{\mathrm{o}}$ de março de 1923, em Petrópolis, já era tratado como herói nacional. Em suas campanhas políticas, suas derrotas eleitorais foram recompensadas pela inaudita aclamação das ruas; Rui havia muito acumulara os mais prestigiosos títulos do Brasil da época (como presidente da Academia Brasileira de Letras e do Instituto dos Advogados do Brasil), e no final da vida se tornara um nome internacionalmente reconhecido, o que aumentava o gigantesco prestígio de que gozava em seu país. 
Em agosto de 1918, realizara-se em todo o Brasil, mas com especial concentração no Rio e em Salvador, o Jubileu Cívico-Literário de Rui Barbosa que comemorava o suposto cinqüentenário de seu primeiro discurso público. Nunca o país parara de tal forma para celebrar um personagem vivo e consagra-lo de forma tão grandiosa. Consolidou-se, então a prática de tratar Rui como "gênio", "semideus", "apóstolo", "super-homem" e outros epítetos do gênero. Rui consolidara na ocasião seu prestígio de prócer da civilização nacional e de ápice da cultura brasileira, por ser o homem que trazia o Brasil para o nível daquelas que então se chamavam as nações adiantadas (GONÇALVES, 2000, p. 135-136, grifo nosso).

Para reforçar o mito ruiano ${ }^{176}$, a última imagem do livro traz a figura de uma criança estudando, tendo ao fundo e em proporção muito maior, tal como um anjo a inspirar-lhe as lições, a imagem de Rui Barbosa. A legenda "estudar sempre!” reforça para as crianças a mensagem de que o estudo dignifica o homem e de que Rui Barbosa serve de inspiração e modelo para todas elas.

\footnotetext{
${ }^{176}$ Por ocasião do centenário do nascimento de Rui Barbosa, em 1959, a Casa de Rui Barbosa, no Rio de Janeiro, patrocinou edição comemorativa de um livro para crianças sobre sua vida e obra: MEIRELES, Cecília. Rui: pequena história de uma grande vida. São Paulo: Ed. Revista dos Tribunais, 1959. Pelo título, percebe-se a finalidade do livro: leitura dirigida às crianças ("pequena história") sobre um personagem ilustre de nossa história ("grande vida").
} 
VIRIATO CORREA

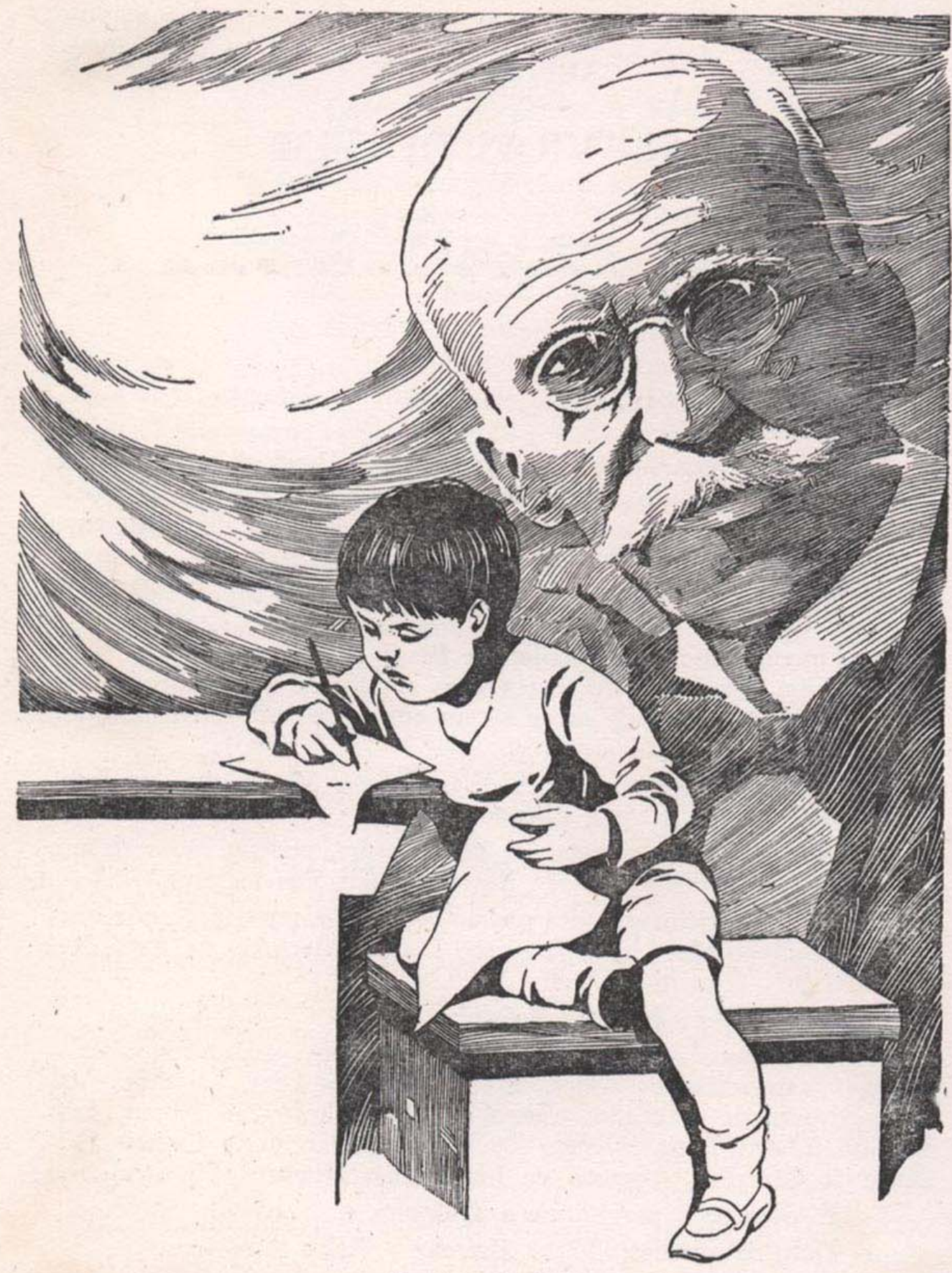

Estudar sempre!

Figura 103 - História do Brasil para crianças.

Fonte: CORRÊA, 21 ${ }^{\mathrm{a}}$ ed., 1957, p. 234. 
Por fim, embora Viriato já tenha destacado em seus livros de crônicas históricas a importância de se mostrar o papel feminino na História e, apesar de ele ser um dos mais entusiastas defensores do ingresso de mulheres na $\mathrm{ABL}^{177}$, o Panteão da Pátria - reproduzido no livro, através de textos e imagens - não reserva lugar para as mulheres e as crianças. Não há imagem com nenhuma mulher de destaque da nossa história, nem mesmo ligada à elite política como, por exemplo, a Princesa Isabel. As crianças, com exceção das personagens da narrativa, aparecem apenas como coadjuvantes da imagem principal a que se quer dar destaque. Temos, assim, uma história assexuada, na qual os heróis são todos homens. Não há lugar também para índios e negros.

O Panteão da Pátria a ser lembrado e cultuado na escola é composto quase exclusivamente por elementos pertencentes à elite branca letrada.

\footnotetext{
${ }^{177}$ Em discurso proferido, na ocasião em que recepcionou Raimundo Magalhães Júnior, Viriato destacou: “A intelectualidade feminina, no Brasil, ganhou tão grande avanço que, em nada, se mostra inferior a intelectualidade masculina. Possui figuras de tão alto relevo nacional que dariam relevo as estas cadeiras azuis [...] $\mathrm{Na}$ literatura feminina brasileira não falta nada. E, o que existe, é da melhor substância e da mais pura essência. E por que as mulheres não estão aqui dentro? Há uma explicação aceitável: Esta casa foi feita por homens e na época, as mulheres não haviam entrado nas lides literárias. Mas a Academia não é um sarcófago habitado por múmias. A Academia Brasileira de Letras é um corpo vivo que caminha para a frente, que evolui, que se aperfeiçoa. Amanhã, inevitavelmente, ela eliminará essa falha de sua organização. Amanhã, para a honra nossa, e para a glória do Brasil (vamos pedir a Deus que assim seja), amanhã teremos, nestas cadeiras tão ambicionadas pelos homens as mulheres proeminentes que dignificam a mentalidade e a nacionalidade brasileira" (DISCURSO DE VIRIATO CORRÊA NA RECEPÇÃO DE RAIMUNDO MAGALHÃES JÚNIOR. Fonte: Academia Brasileira de Letras. Discursos Acadêmicos [...]. Vol. XXII. Rio de Janeiro: Publicações da Academia Brasileira, 1961, p. 63-4).
} 


\title{
CONSIDERAÇÕES FINAIS
}

Em 1965, por ocasião do IV centenário da cidade do Rio de Janeiro, o jornal $O$ Globo fez uma enquete junto aos escritores residentes na cidade. Viriato Corrêa foi um dos escolhidos. Perguntado por que, sendo maranhense, havia escolhido essa cidade para morar, ele assim respondeu:

\begin{abstract}
Namoro o Rio como se namora uma mulher. Nele tudo me agrada: a paisagem maravilhosa, a alegria contagiante da população, a simplicidade acolhedora de suas criaturas, a beleza das mulheres, a intuição democrática, a intuição patriótica e os seus braços abertos a quem chega. Minha prova de amor só pode ser escrita.

Por que escrevo? E quem me influenciou na minha obra? Só as crianças e a pátria influenciaram minha obra, pois dediquei toda a minha vida a mostrar aos meus pequenos um pouco do Brasil, utilizando uma linguagem que eles entendessem e que retratasse com fidelidade os nossos tipos regionais e a nossa História. [...] (grifo nosso) ${ }^{178}$.
\end{abstract}

O texto acima nos dá a dimensão precisa sobre a obra literária de Viriato Corrêa, sobretudo àquela dedicada ao universo infanto-juvenil. Realmente, o mérito maior desse autor, apesar das críticas existentes, está no interesse que ele tinha pela história nacional, ao ponto de ter escrito com essa temática 9 livros de crônicas, 1 romance, 9 livros infantis, 3 peças teatrais e 1 novela radiofônica. Em toda essa sua obra, havia algo em comum: a "vulgarização" da história pátria, como ele mesmo declarava. Seu único objetivo: tirar a história presa dos arquivos empoeirados, dos compêndios massudos e tediosos, do discurso acadêmico e divulgá-la ao grande público, através de um estilo narrativo que ia do anedótico ao pitoresco, sem esquecer os heróis de nossa nacionalidade. Queria uma história "pra todo mundo entender" e que não causasse bocejos nas crianças - seu público maior.

No âmbito da literatura infantil, seus maiores destaques e campeões de venda no mercado editorial brasileiro foram Cazuza (1938), ainda hoje editado, e História do Brasil para crianças, publicado em 1934. Sobre esse último livro recaiu nossa análise neste trabalho, por ter sido aquele que mais se assemelhava a um livro didático de História para a escola primária, tendo recebido, posteriormente, a chancela do MEC.

\footnotetext{
${ }^{178}$ A cidade e seus autores. O Globo, Rio de Janeiro - RJ, 6.2.1965.
} 
Tentamos mostrar que, embora surgindo como livro infantil, no contexto de uma coleção da Companhia Editora Nacional - a Biblioteca Pedagógica Brasileira (BPB), História do Brasil para crianças pode ser considerado um livro didático, na acepção mais ampla do que seja esse importante material de nossa cultura escolar. Tanto Viriato como seus editores (Monteiro Lobato e Octalles Ferreira) tinham pretensões pedagógicas ao inseri-lo na série $1^{\mathrm{a}}$ da BPB. Queriam também que o livro chegasse a um maior número de leitores e sabia que isso passava, necessariamente, pelos bancos escolares: "livro delicioso, [...], de um alcance educativo e destinado a realizar por si só, nas escolas, uma grande obra de brasilidade e de espírito nacional.” (CEN, Catálogo Geral, 1935, p. 30).

O próprio Lobato defendia a criação de uma literatura genuinamente brasileira que contemplasse as diferentes disciplinas do currículo escolar. Prova disso foram seus livros Emília no país da gramática, Aritmética da Emília, Geografia da Dona Benta, História do mundo para crianças, entre outros. Faltava, pois, um livro destinado à infância que tratasse da história pátria. Viriato respondeu a esse desafio.

Lançado como livro de literatura infantil, podendo ser lido sem a mediação do professor; transformou-se, no entanto, também em manual didático, face a seu uso na escola. Foi, ainda, bastante indicado como leitura complementar para os alunos, constante nos manuais de Didática e Metodologia do Ensino de História direcionados aos professores do ensino primário.

Viriato Corrêa, ao escrever o livro, ateve-se ao programa de ensino da disciplina História para a escola primária da época. Os conteúdos nele abordados, em que pese seu estilo mais literário, contemplavam a História do Brasil desde o processo de sua ocupação pelos portugueses até a implantação da República no País. Muitas crianças da geração dos anos 1930 a 1970 leram esse livro, seja na escola ou mesmo fora dela, uma vez que História do Brasil para crianças também costumava ser livro-presente que os pais e familiares davam a seus filhos em ocasiões festivas. Na escola, às vezes, o livro constituía-se em prêmio destinado aos melhores alunos que se destacavam no ano letivo.

Como, então, caracterizar História do Brasil para crianças no âmbito da literatura escolar brasileira? 
Numa análise dos gêneros didáticos existentes, História do Brasil para crianças é um livro de leitura de história por veicular conteúdos da disciplina escolar História, bem como valores morais, cívicos e patrióticos, imprescindíveis nesse tipo de literatura escolar. Por contemplar os conteúdos de história necessários à aprendizagem das crianças na escola primária e estar de acordo com a legislação educacional vigente, o livro recebeu a autorização e respectivo registro do MEC como manual didático, a partir de 1961, podendo ser adotado nas escolas públicas do País.

Na elaboração desse livro, Viriato estabeleceu contato e interlocução com diferentes nomes ligados ao movimento escolanovista. Fernando de Azevedo coordenava a BPB, na qual o livro estava incluído; Anísio Teixeira, então Secretário de Educação do Distrito Federal (1931-1935), teceu elogios sobre essa obra quando de seu lançamento, e Paulo de Albuquerque Maranhão, assessor de Anísio naquele órgão e um dos signatários do Manifesto dos Pioneiros da Educação Nova (1932), que convenceu Viriato a escrevê-lo, tendo sido agraciado, em suas páginas, com uma dedicatória.

A autoria de livros didáticos nas primeiras décadas republicanas concentrava-se na figura dos intelectuais (bacharéis em Direito, jornalistas, historiadores, literatos, médicos, etc.) ligados ao Instituto Histórico e Geográfico Brasileiro, sendo muitos deles também membros da Academia Brasileira de Letras ou professores do Colégio Pedro II. Esses intelectuais, movidos pelo nacionalismo e diante da necessidade de suprir a carência de manuais didáticos para a escola primária e secundária, escreveram importantes obras. Algumas delas, como vimos no decorrer do trabalho, tornaram-se verdadeiros cânones literários escolares, a exemplo de Por que me ufano do meu país (Affonso Celso, 1900), Contos Pátrios (Olavo Bilac e Coelho Netto, 1904) e Através do Brasil (Olavo Bilac e Manuel Bomfim, 1914).

Viriato não era membro do IHGB, nem professor de História em escolas. Mesmo assim, como bacharel em Direito, jornalista e, principalmente, um "homem de letras", e já tendo escrito várias crônicas históricas e livros infantis, sentiu-se motivado a escrever um livro de História do Brasil destinado ao segmento infantil. Relembrando seu tempo de infância, Viriato considerava o ensino dessa disciplina enfadonho e cansativo. No processo de produção do livro e antes de publicá-lo, submeteu os capítulos ao crivo das próprias crianças, com o auxílio de uma professora em uma escola do Rio de Janeiro. 
$\mathrm{Na}$ elaboração do texto de História do Brasil para crianças, Viriato buscou legitimação para seu trabalho, na interlocução, direta ou indiretamente, com a obra historiográfica de Rocha Pombo, Sylvio Romero, Max Fleiuss, João Ribeiro, entre outros. Submeteu o livro à análise e crítica de Rodolfo Garcia, historiador renomado, considerado um grande nome da historiografia brasileira, ao lado de Adolfo Varnhagen e Capistrano de Abreu.

Nesse livro como em outras suas produções (crônicas, contos, novelas e peças teatrais), Viriato deixou explicitado sua concepção de História - uma "história de chinelo", filiada à noção francesa da petite histoire, que procurava dar conta de aspectos pitorescos do passado, sem esquecer os nomes que dignificaram a Nação, com seus atos de heroísmo, abnegação e trabalho. Assim, embora se pautasse por uma história de cunho tradicional, eurocêntrica, linear e etapista, procurava mostrar a vida cotidiana de alguns segmentos da sociedade. E, fundamentalmente, Viriato retomou uma tradição da literatura escolar brasileira, consubstanciada nos chamados livros de leitura, que, numa visão ufanista de nosso País, veiculavam valores cívico-patrióticos, indispensáveis ao fortalecimento de uma identidade nacional.

Ainda no âmbito da autoria desse livro, não podemos deixar de considerar que o caricaturista e escritor Benedito Carneiro de Bastos Barreto - o Belmonte - é também co-autor de História do Brasil para crianças. Suas ilustrações, feitas exclusivamente para o livro, reforçam a concepção de História de Viriato, ao tempo em que inovam a produção editorial infantil, ao desenhar capas coloridas e vistosas. Do ponto de vista gráfico, o livro História do Brasil para crianças traz uma inovação logo na sua capa. Além das cores muito vivas e chamativas, pela primeira vez na edição de livros infantis brasileiros, o desenho começa na contracapa, atravessa a lombada e termina na capa. Belmonte também foi escritor que se dedicou à divulgação da história, através de dois livros - No tempo dos bandeirantes, para o público adulto, e um livro infantil, A Cidade de ouro. Ambos, ao abordarem a temática das bandeiras na expansão territorial brasileira, contribuíram para a construção mítica e heróica da figura do bandeirante, consagrada no imaginário popular.

A partir dos anos 30 do século passado, as "lições do vovô" de Viriato, ao abordarem temas da história pátria, "fizeram a mente e o coração" de nossas crianças, fortalecendo nelas o caráter cívico-patriótico. $\mathrm{Na}$ tentativa de se forjar uma identidade cultural, o livro serviu 
perfeitamente aos preceitos ideológicos do Estado Novo que pretendia a construção de uma memória nacional una, coesa, homogênea e monolítica, sem conflitos, polêmicas e contradições sociais.

Ao produzir livros destinados ao público infanto-juvenil sobre fatos e personagens de nossa história, considero que Viriato Corrêa contribuiu para a construção do saber histórico escolar. Seus livros infantis foram tão importantes quanto os manuais didáticos de autores do período. Mesmo não sendo educador e não tendo proposto nenhuma renovação metodológica para o ensino da disciplina, Viriato queria uma história prazerosa na escola, que despertasse o interesse das crianças pelo seu país.

Até o final da década de 1960, História do Brasil para crianças teve tiragens surpreendentes, chegando a ser publicados mais de 150 mil exemplares, em cinqüenta anos de circulação no mercado editorial, o que dá uma média de 3 mil exemplares/ano - número bastante expressivo quando se sabe que, ainda hoje, as tiragens não passam de 2 mil exemplares.

$\mathrm{Na}$ introdução crítica de um dos seus primeiros livros de crônicas históricas - Terra de Santa Cruz -, por ocasião da reedição, na década de 1970, o escritor e crítico literário Afrânio Coutinho fez algumas considerações pertinentes, que sintetizam a concepção de História de seu autor:

Viriato Corrêa procura retirar dos fatos analisados a lição de heroísmo que descreve com um sabor de comicidade. Dessa forma, alcança atingir o público, despertando nele, sobretudo entre os adolescentes, o gosto do passado nacional. Para ele, $\underline{\text { a }}$ História é uma escola, onde devemos abeberar-nos para enriquecer nosso patriotismo e o amor das nossas coisas (CORRÊA, s/d, p. 9, grifo nosso).

Realmente, Viriato Corrêa soube como ninguém explorar um veio literário fértil e de ampla aceitação junto ao público, através de suas crônicas históricas e livros infantis com temas ligados ao passado nacional. Ele reconhecia que a história tinha um papel fundamental no desenvolvimento de uma consciência cívico-patriótica. Dizia ele: "Sem história, não há pátria!” Não queria uma história tão-somente presa aos bancos escolares, apesar de considerála uma verdadeira escola. Parecia querer indicar que a história era algo muito importante para 
ficar restrita ao saber erudito de historiadores ligados às academias literárias e institutos históricos.

Viriato Corrêa não se julgava um historiador. Assemelhava-se mais a um "contador de histórias”. Mesmo assim, conseguiu fazer o que muitos historiadores não conseguiram divulgar o conhecimento histórico a um maior número de brasileiros. Nisso reside seu mérito maior: usou da literatura infantil para levar a História às crianças, por entender que elas eram o futuro do País e que esse conhecimento era imprescindível à construção da Nação brasileira.

Quando ingressou na Academia Brasileira de Letras (ABL), em 1938, após quatro tentativas frustradas, Viriato foi recepcionado pelo acadêmico Múcio Leão. Esse escritor, ao receber o novo imortal que ocuparia a cadeira de $n^{0} 32$, fez uma saudação que, antes de ser mero protocolo cerimonial da solenidade, revelou o que a obra de Viriato Corrêa tem de maior - o amor pelas coisas do Brasil:

[...] Sr. Viriato Corrêa, tudo em vós está impregnado do Brasil [...].

Do Brasil estão impregnados os vossos livros de história, os livros em que evocais os heróis que fizeram a nossa nacionalidade, que lutaram contra o estrangeiro para defender o território de nossa pátria, que invadiram florestas, atravessaram rios e cordilheiras, dominaram índios selvagens e feras espantosas, para criarem o milagre do nosso país.

Do Brasil está impregnada a vossa obra destinada à infância, toda ela povoada das lendas do nosso folclore, dos bichos das nossas matas, das crendices dos nossos homens simples, da ingenuidade, da ternura da nossa gente [...].

Do Brasil está impregnada, enfim, a vossa vida, dispersa, desenrolando-se em vários ambientes, ora em Pirapemas, ora em São Luiz, ora no Recife, ora no Rio, ora em Manaus, ora em São Paulo, - mas sempre una, sempre iluminada por um sonho: o da perfeição de uma vasta obra literária.

A Academia vos sente e vos compreende, no evolver de vossa personalidade, tão profundamente brasileira.

E foi por isso que vos chamou para o seu seio, confiante em que aqui podereis dar uma realização cada vez mais ampla às vossas altas qualidades de escritor.

Pela minha voz ela vos saúda, convidando-vos a tomar, sob a proteção das venerandas sombras de Porto-Alegre, Carlos de Laet e Ramiz Galvão, a cadeira que, como o vosso patrono e os vossos antecessores, vindes enobrecer (LEÃO, 1938, p. 171-2).

O espírito de brasilidade estava, pois, presente na vida e na obra literária de Viriato Corrêa, o primeiro escritor de livros infantis a ingressar no quadro dos "imortais" da Academia Brasileira de Letras. 


\section{REFERÊNCIAS BIBLIOGRÁFICAS}

ABUD, Kátia. Formação da Alma e do Caráter Nacional: ensino de história na Era Vargas. In: Revista Brasileira de História, v. 18, nº 36, 1998.

. A idéia de São Paulo como formador do Brasil. In: FERREIRA, Antonio Celso; LUCA, Tânia Regina de; IOKOI, Zilda Grícoli (orgs.). Encontros com a História: percursos históricos e historiográficos de São Paulo. São Paulo: Editora UNESP, 1999.

ACADEMIA BRASILEIRA DE LETRAS. Arquivo dos Acadêmicos: guia geral. Rio de Janeiro: Academia Brasileira de Letras, 2003.

AGUIAR, Ronaldo Conde. O Rebelde esquecido: tempo, vida e obra de Manoel Bomfim. Rio de Janeiro: Topbooks Editora, 2000.

ALBUQUERQUE JÚNIOR, Durval M. Preconceito contra a origem geográfica e de lugar: as fronteiras da discórdia. São Paulo: Cortez, 2007.

AMADO, Genolino. O reino perdido: histórias de um professor de História. Rio de Janeiro: Livraria José Olympio Editora, 1971.

AMORIM, Galeno (org.). Retratos da leitura no Brasil. São Paulo: Imprensa Oficial: Instituto Pró-Livro, 2008.

ANDERSON, Benedict. Comunidades Imaginadas: reflexões sobre a origem e a difusão do nacionalismo. São Paulo: Companhia das Letras, 2008.

ARAÚJO, Emanuel. A construção do livro: princípios da técnica de editoração. $2^{\mathrm{a}}$ edição revista e atualizada com o novo acordo ortográfico. Rio de Janeiro: Lexikon Editora Digital; São Paulo: Fundação Editora da UNESP, 2008.

ARIÉS, Philippe. História social da criança e da família. Rio de Janeiro: Editora Guanabara, 1978.

ARROYO, Leonardo. A criança em todos nós. In: Folha de São Paulo, São Paulo-SP, 14.11.1962.

Literatura Infantil Brasileira. São Paulo: Melhoramentos, 1968.

ASSOCIAÇÃO NACIONAL DE HISTÓRIA (ANPUH). História em quadro-negro: escola, ensino e aprendizagem. Revista Brasileira de História nº 19, São Paulo: ANPUH / Editora Marco Zero, setembro de 1989/fevereiro de 1990.

Memória, História e Historiografia: Dossiê Ensino de História. Revista Brasileira de História $n^{0}$ 25/26. São Paulo: ANPUH / Editora Marco Zero, setembro de 1992/agosto de 1993.

Ensino de História: novos problemas. Revista Brasileira de História $n^{0} 36$, São Paulo: ANPUH / Humanitas Publicações, 1998. 
AZEVEDO, Carmem Lúcia de; CAMARGOS, Márcia; SACHETTA, Vladimir. Monteiro Lobato: furacão na Botocúndia. São Paulo: SENAC, 1997.

AZEVEDO, Fernando de. História de minha vida. Rio de Janeiro: Livraria José Olympio Editora, 1971.

BÁEZ, Fernando. História universal da destruição dos livros: das tábuas sumérias à guerra do Iraque. Rio de Janeiro: Ediouro, 2006.

BARBOSA, Francisco de Assis. Monteiro Lobato e o direito de sonhar. In: LOBATO, Monteiro. A menina do narizinho arrebitado. $1^{a}$ edição. Monteiro Lobato \& Cia, 1920. Edição fac-similar em comemoração ao centenário de nascimento de Monteiro Lobato. São Paulo: Metal Leve, 1982.

BARBOSA, Rui. Didática da História. Parecer apresentado na Câmara do Império (1882). In: La educación. Revista Interamericana de Desarrollo Educativo. Washington, D.C.: Departamento de Assuntos Educativos. Secretaria General da Organización de los Estados Americanos, 1987.

BASE DE DATOS MANES. Manuales escolares europeos y latinoamericanos. Guía para catalogación. Madrid: UNED, 2007.

BASTOS, Maria Helena C. Leituras de formação. Coração, de Edmundo De Amicis. Anais eletrônicos do I Seminário Brasileiro sobre Livro e História Editorial. Rio de Janeiro: Fundação Casa de Rui Barbosa, 8 a 11 de novembro de 2004.

BATISTA, Antônio Augusto Gomes. Recomendações para uma política pública de livros didáticos. Brasília, DF: Ministério da Educação, Secretaria de Educação Fundamental, 2001.

BATISTA, Antônio Augusto Gomes et al. Livros escolares de leitura: uma morfologia. Revista Brasileira de Educação, Rio de Janeiro: ANPED, n. 20, maio/jun/jul/ago 2002.

BATISTA, Antônio Augusto Gomes; GALVÃO, Ana Maria de O. Manuais escolares e pesquisa em História. In: VEIGA, Cynthia Greive; FONSECA, Thaís Nívia de Lima (orgs.). História e Historiografia da Educação no Brasil. Belo Horizonte, MG: Autêntica, 2003.

BEGA, Maria Tarcisa Silva. No centro e na periferia: a obra histórica de Rocha Pombo. In: LOPES, Marcos Antônio (org.). Grandes nomes da História Intelectual. São Paulo: Contexto, 2003.

BELMONTE. No tempo das bandeirantes. $4^{\text {a }}$ ed. (revista, aumentada e definitiva, com desenhos do autor). São Paulo: Edições Melhoramentos, s/d.

BELMONTE. A cidade de ouro. São Paulo: Companhia Editora Nacional, 1940.

BENEDETTI, Lúcia. Viriato Corrêa. In: Última Hora, Rio de Janeiro-RJ, 18.12.1958.

BENITO, Agustín Escolano. El libro escolar como espacio de memória. In: OSSENBACH, Gabriela; RODRIGUEZ, Miguel Somoza. Los manuales escolares como fuente para la 
historia de la educación en América Latina. Madrid: Universidad Nacional de Educación a Distancia, 2001.

BENJAMIN, Walter. O narrador. In: Magia e técnica, arte e política (obras escolhidas, vol. 1). São Paulo: Brasiliense, 1985.

BETTO, Frei. Alfabeto: autobiografia escolar. Memórias. São Paulo: Ática, 2002.

BILAC, Olavo; BONFIM, Manoel. Atravez do Brazil: prática da língua portugueza (narrativa). $4^{\mathrm{a}}$ ed. Rio de Janeiro: Francisco Alves \& Cia, 1918.

BILAC, Olavo; COELHO NETO, Paulo. Contos Pátrios. Educação Moral e Cívica (para crianças) $49^{\mathrm{a}}$ ed., Rio de Janeiro: Livraria Francisco Alves, s/d.

A Pátria Brazileira (para alumnos das escolas primarias) 2a ed., Rio de Janeiro: Livraria Francisco Alves, 1910, Coleção Bibliotheca dos Jovens Brazileiros.

Contos Pátrios: educação moral e cívica (para as crianças). Belo Horizonte, MG: Livraria Garnier, 2001. Biblioteca de Autores Célebres da Literatura Infantil.

BITTENCOURT, Circe (org.) O saber histórico na sala de aula. São Paulo: Contexto, 1997.

BITTENCOURT, Circe (coord.). Relatório Científico. Projeto Temático: Educação e Memória - organização de acervos de livros didáticos. São Paulo: FAPESP, 2007.

BITTENCOURT, Circe Maria F. Pátria, civilização e trabalho: o ensino de História nas escolas paulistas (1917-1930). São Paulo: Loyola, 1990.

Livro Didático e Conhecimento Histórico: uma história do saber escolar. Tese (Doutorado em História Social). Faculdade de Filosofia, Letras e Ciências Humanas, Universidade de São Paulo (USP), 1993.

Propostas curriculares de História: continuidades e transformações. In: BARRETO, Elba S. de Sá (org.). Os currículos do ensino fundamental para as escolas brasileiras. Campinas, SP: Autores Associados; São Paulo: Fundação Carlos Chagas, 1998.

Disciplinas escolares: história e pesquisa. In: OLIVEIRA, Marco A. T. de. História das disciplinas escolares no Brasil. Bragança Paulista, SP: EDUSF, 2003.

Identidade Nacional e Ensino de História do Brasil. In: KARNAL, Leandro (org.). História na sala de aula: conceitos, práticas e propostas. São Paulo: Contexto, 2003.

. Em Foco: História, produção e memória do livro didático. In: Educação e Pesquisa. Educação e Pesquisa. São Paulo: v. 30, nº 3, set./dez. 2004.

Autores e editores de compêndios e livros de leitura (1810-1910). Educação e Pesquisa. Educação e Pesquisa. São Paulo: v. 30, nº 3, set./dez. 2004.

Ensino de História: fundamentos e métodos. São Paulo: Cortez, 2004 (Coleção docência em formação. Série Ensino Fundamental). 
. Identidades e ensino de história no Brasil. In: CARRETERO, Mario; ROSA, Alberto; GONZÁleZ, Maria Fernanda (orgs.). Ensino da História e Memória Coletiva. Porto Alegre, RS: Artmed, 2007.

. Livro didático e saber escolar (1810-1910). Belo Horizonte, MG: Autêntica, 2008, Col. História da Educação.

BLAKE, Augusto Victorino Alves Sacramento. Diccionario Bibliographico Brazileiro. Rio de Janeiro: Conselho Federal de Cultura, 1970, edição fac-similar.

BLOCH, Marc. Apologia da História ou o ofício de historiador. Rio de Janeiro: Jorge Zahar Ed., 2001.

BOLETIM DE ARIEL (mensário crítico-bibliográfico). Lettras, Artes, Sciencias. Rio de Janeiro: Dezembro de 1934. Anno IV, n. 3;

BONAZZI, Mari; ECO, Umberto. Mentiras que parecem verdades. São Paulo: Summus Editorial, 1980.

BONNET, Jean-Claude. Naissance du Panthéon: essai sur le culte des grands hommes. Paris: Fayard, 1998.

BORGES, Jorge Luis. O Livro. In: Cinco visões pessoais. $4^{\mathrm{a}}$ ed., Brasília, DF: Editora da UnB, 2002.

BOTELHO, André. Aprendizado do Brasil: a nação em busca dos seus portadores sociais. Campinas, SP: Editora da UNICAMP, 2002.

BOTO, Carlota. A escola primária brasileira como debate político às vésperas da República. Revista Brasileira de História. São Paulo: v. 19, nº 38, p. 253-281, 1999.

O professor primário português como intelectual: "eu ensino, logo existo". In: LINHAS, Florianópolis, SC: v. 6, n. 1, p. 79-130, jan./jun. 2005.

BRAGANÇA, Aníbal. A política editorial de Francisco Alves e a profissionalização do escritor no Brasil. In: ABREU, Márcia (org.). Leitura, História e História da Leitura. Campinas, SP: Mercado de Letras: Associação da Leitura no Brasil; São Paulo: FAPESP, 1999.

. Sobre o editor: notas para sua história. In: Em Questão. Porto Alegre, RS: v. 11, n. 2, p. 219-237, jul./dez. 2005.

A transmissão do saber, a educação e a edição de livros escolares. In: DUTRA, Eliana de Freitas; MOLLIER, Jean-Yves (orgs.). Política, Nação e Edição: o lugar dos impressos na construção da vida política. Brasil, Europa e Américas nos sécs. XVIII-XX. São Paulo: Annablume, 2006.

BRASIL, Padre Sales. A literatura infantil de Monteiro Lobato ou comunismo para crianças. Bahia: Aguiar \& Sousa, 1957. 
BROCA, Brito. A Vida literária no Brasil. 1900. 4ª ed., Rio de Janeiro: José Olympio Editora, Academia Brasileira de Letras, 2004.

BRUNO, G. Le Tour de la France par deux enfants: devoir e patrie. Livre de lecture courante. Paris: Librairie Classique Eugene Belin, 2006.

BRUTER, Annie. Um exemplo de pesquisa sobre a história de uma disciplina escolar: a História ensinada no século XVII. História da Educação, ASPHE/FAE/UFPel, Pelotas, RS: n.19, p. 7-21, abr. 2006.

BURGUIÈRE, André (org.). Dicionário das Ciências Históricas. Rio de Janeiro: Imago Editora, 1993.

CABRINI, Conceição et al. O ensino de História: revisão urgente. São Paulo: Brasiliense, 1986.

CALMON, Pedro. História da Civilização Brasileira para a escola primária. São Paulo: Companhia Editora Nacional, 1934, Biblioteca Pedagógica Brasileira, Série II - Livros Didáticos, vol. XXXII.

CALVINO, Ítalo. Por que ler os clássicos. São Paulo: Companhia das Letras, 2007. Col. Companhia de Bolso.

CAMARgOS, Márcia. Juca e Joyce: memórias da neta de Monteiro Lobato. São Paulo: Moderna, 2007.

CAMPOS, Humberto de. Diário secreto (vol. I) Rio de Janeiro: Edições O Cruzeiro, s/d.

CAPELATO, Maria Helena R. Multidões em cena: propaganda política no varguismo e no peronismo. Campinas, SP: Papirus, 1998.

O Estado Novo: o que trouxe de novo? In: FERREIRA, Jorge; DELGADO, Lucilia de Almeida Neves (orgs.). O Brasil Republicano: o tempo do nacional-estatismo (livro 2). Rio de Janeiro: Civilização Brasileira, 2003.

CARDOSO, Rafael. O início do design de livros no Brasil. In: (org.). O Design brasileiro antes do design. Aspectos da história gráfica, 1870-1960. São Paulo: Cosac \& Naify, 2005.

CARDOSO, Vicente Licínio (org.). À Margem da História da República. $3^{\mathrm{a}}$ ed. rev. e atual. Recife, PE: FUNDAJ: Editora Massangana, 1990.

CARLYLE, Tomás. Os Heróis. 2ª ed., Lisboa: Guimarães Editores, 2002.

CARRETERO, Mario; GONZÁLEZ, Maria Fernanda. Imagénes históricas y construcción de la identidad nacional: uma comparación entre la Argentina, Chile y Espana. In: CARRETERO, Mario; VOSS, James F. (comps.). Aprender y pensar la historia. Buenos Aires: Amorrortu, 2004. 
CARVALHO, Anelise M. M. Pregadores de idéias, animadores de vontades: livros didáticos nos anos 1930-40. Dissertação de mestrado. São Paulo: Pontifícia Universidade Católica (PUC-SP), 1992.

CARVALHO, Delgado. Introdução Metodológica aos Estudos Sociais. Rio de Janeiro: Livraria Agir Editora, 1959.

CARVALHO, José Murilo de. Tiradentes: um herói para a República. In: A Formação das Almas: o imaginário da República no Brasil. São Paulo: Companhia das Letras, 1990.

. Cidadania no Brasil: o longo caminho. Rio de Janeiro: Civilização Brasileira, 2001.

. Nação imaginária: memória, mitos e heróis. In: NOVAES, Adauto (org.). A Crise do Estado-Nação. Rio de Janeiro: Civilização Brasileira, 2003.

CARVAlHO, Marta M. Chagas de. A Escola e a República. São Paulo: Brasiliense, 1989, Col. Tudo é História.

Molde Nacional e forma cívica: higiene, moral e trabalho no projeto da Associação Brasileira de Educação (1924-1931). Bragança Paulista, SP: EDUSF, 1998.

CARVALL (org.). Belmonte: 100 anos. São Paulo: Editora SENAC São Paulo, 1996.

CASSIANO, Célia Cristina de F. O mercado do livro didático no Brasil: da criação do PNLD à entrada do capital internacional espanhol (1985-2007). Tese de Doutoramento. São Paulo: Pontifícia Universidade Católica (PUC-SP), 2007.

CASTRO, Josephina de; GAUDENZI, Silva. Estudos Sociais na escola primária. Rio de Janeiro: Ministério da Educação e Cultura, 1962, Biblioteca do Professor Brasileiro.

CATÁlogo Geral. Companhia Editora Nacional. São Paulo: $n^{\circ} 12$ de setembro de 1935.

CATROGA, Fernando. Nação, mito e rito. Fortaleza, CE: NUDOC-UFC, 2005.

CAVALCANTI, Waldemar. História em Miúdos, na seção Jornal Literário do Jornal, Rio de Janeiro-RJ, 30.11.1961.

CAZUZA abre projeto de reedição da obra de Viriato Corrêa. Jornal O Estado de São Paulo. Caderno 2. Ano XVII. 01 de junho de 2002.

CELSO, Affonso. Por que me ufano do meu país. $2^{\text {a }}$ ed., Rio de Janeiro: Expressão e Cultura, 1997 (edição comemorativa ao centenário da Academia Brasileira de Letras).

CENTENÁRIO de Viriato Corrêa. São Paulo: Centro de Estudos de Literatura Infantil e Juvenil. $8^{\text {a }}$ Bienal Internacional do Livro, 1984.

CHARTIER, Roger (org.). A aventura do livro: do leitor ao navegador. São Paulo: Unesp, Imprensa Oficial, 1999. 
A Ordem dos Livros: leitores, autores e bibliotecas na Europa entre os séculos XIV e XVIII. Brasília: Editora da Universidade de Brasília, 1999.

Práticas da Leitura. 2a ed., São Paulo: Estação Liberdade, 2001.

A mediação editorial. In: Os desafios da escrita. São Paulo: Editora $\overline{\text { UNESP, }} 2002$.

CHAUÍ, Marilena. Brasil: mito fundador e sociedade autoritária. São Paulo: Fundação Perseu Abramo, 2000.

CHERVEL, André. História das disciplinas escolares: reflexões sobre um campo de pesquisa. In: Teoria\&Educação, nº 2, Porto Alegre, RS: Pannonica, 1990.

CHOPIN, Alain. Les manuels scolaires: histoire et actualitè. Paris: Hachette, 1992.

Manuels scolaires, états et sociétes (XIXe- XXe siècles). Paris: INRP, 1993.

Os manuais escolares na França e a formação do cidadão. In: Veritas, Porto Alegre, RS: v. 43 no especial, 1998.

. Los manuales escolares de ayer a hoy: el ejemplo de Francia. In: Historia de la educación - Revista interuniversitaria. $\mathrm{n}^{\circ}$ 19, 2000.

. O historiador e o livro escolar In: História da Educação/ASPHE (Associação Sulrio-grandense de Pesquisadores em História da Educação) FAE/UFPel. nº 11, abril 2002.

. História dos livros e das edições didáticas: sobre o estado da arte. Educação e Pesquisa, v. 30, nº 3, set./dez. 2004.

COELHO NETTO, Paulo. Breviário Cívico. $3^{\mathrm{a}}$ ed., Rio de Janeiro: Organização Simão Editora, 1957.

COELHO, Nely Novaes. Dicionário Crítico da Literatura Infantil e Juvenil Brasileira. 5 a ed. rev. atual. São Paulo: Companhia Editora Nacional, 2006.

CONDE, José. Escritores e livros. Correio da Manhã. 13.08.1961., s.p.

CONY, Carlos Heitor. A rara solidariedade no mundo das letras. In: LEAL, Carlos (org.). Francisco Alves: 150 anos. Rio de Janeiro: Livraria Francisco Alves Editora, 2004.

CORREAA, Viriato e DO RIO, João. Era uma vez...contos infantis. Rio de Janeiro: Livraria Francisco Alves, 1908.

CORRÊA, Viriato. Contos da Historia do Brasil (para uso das escolas). Rio de Janeiro: A. J. de Castilho Editor, 1921.

. Histórias da nossa História. $2^{\mathrm{a}}$ ed. Aumentada. Rio de Janeiro: Livraria Castilho/A. J. de Castilho Editor, 1923. 
Nacional, 1927.

A Balaiada: romance do tempo da regência. São Paulo: Companhia Editora . O Brasil dos meus avós. São Paulo: Companhia Editora Nacional, 1927.

. Bahú velho: roupas antigas da historia brasileira. São Paulo: Companhia Editora Nacional, 1927.

. No reino da bicharada. São Paulo: Companhia Editora Nacional, 1931.

A macacada. São Paulo: Companhia Editora Nacional, 1931.

. Alcovas da História (cantinhos, esceninhos e recesso da vida histórica do Brazil). São Paulo: Companhia Editora Nacional, 1934.

. Uma saia histórica In: Casa de Belchior. Rio de Janeiro: Civilização Brasileira, 1936.

. No paiz da bicharada. São Paulo: Companhia Editora Nacional, 1937.

. País do Pau de Tinta (crônicas históricas da terra do pau-brasil). Rio de Janeiro: Civilização Brasileira S/A, 1938.

Terra de Santa Cruz (biografia, introdução e notas de Afrânio Coutinho). São Paulo: Ediouro, s/d, Col. Prestígio.

A bandeira das esmeraldas. São Paulo: Companhia Editora Nacional, 1945.

A bandeira das esmeraldas. $4^{\text {a }}$ ed., São Paulo: Companhia Editora Nacional, 1957.

A bandeira das esmeraldas. $9^{\text {a }}$ ed., São Paulo: Companhia Editora Nacional, 2004.

1948.

As belas histórias da História do Brasil. São Paulo: Companhia Editora Nacional,

. As belas histórias da História do Brasil. $3^{\mathrm{a}}$ ed., São Paulo: Companhia Editora Nacional, 1955.

. As belas histórias da História do Brasil. $5^{\text {a }}$ ed., São Paulo: Companhia Editora Nacional, 1957.

As belas histórias da História do Brasil. $6^{a}$ ed., São Paulo: Companhia Editora Nacional, 1964.

. As belas histórias da História do Brasil. Rio de Janeiro: Expressão e Cultura, 2001. Col. Páginas Amarelas.

As belas histórias da História do Brasil. São Paulo: Companhia Editora Nacional, 
Nacional, 1938.

Cazuza (memórias de um menino de escola). $1^{\mathrm{a}}$ ed., São Paulo: Companhia Editora . Cazuza. 13ª ed., São Paulo: Companhia Editora Nacional, 1965.

. Cazuza. 19a ed., São Paulo: Companhia Editora Nacional, 1968.

Cazuza. 29a ed., São Paulo: Companhia Editora Nacional, 1981.

. Cazuza. 42ª ed., São Paulo: Companhia Editora Nacional, 2004.

. Curiosidades da história brasileira (para crianças). São Paulo: Companhia Editora Nacional, 1952.

Curiosidades da história brasileira (para crianças). São Paulo: Companhia Editora Nacional, 2002.

Discurso de posse de Viriato Corrêa em 29 de outubro de 1938. In: Revista da Academia Brasileira de Letras. Anais de 1938. Julho a dezembro. Rio de Janeiro. Ano 31, vol. 56.

Discurso de Viriato Corrêa na recepção de Raimundo Magalhães Júnior. In: Academia Brasileira de Letras. Discursos Acadêmicos [...]. Vol. XXII. Rio de Janeiro: Publicações da Academia Brasileira, 1961.

. Fala de Viriato Corrêa, na sessão póstuma em homenagem a Monteiro Lobato. In: Revista da Academia Brasileira de Letras. Anais de 1948 (julho a dezembro). Rio de Janeiro: Edições ABL, Ano 47, vol. 76. 1962.

História da Liberdade no Brasil. Rio de Janeiro: Editora Civilização Brasileira,

. História da Liberdade no Brasil. $2^{\mathrm{a}}$ ed. Rio de Janeiro: Civilização Brasileira, Brasília: INL, 1974.

História do Brasil para crianças. $11^{\mathrm{a}}$ ed. São Paulo: Companhia Editora Nacional, 1944. Biblioteca Pedagógica Brasileira - Literatura Infantil (Série 1ª, vol. 18).

1946.

História do Brasil para crianças $13^{\mathrm{a}}$. ed. São Paulo: Companhia Editora Nacional,

História do Brasil para crianças. $14^{\mathrm{a}}$. ed. São Paulo: Companhia Editora Nacional, 1950.

História do Brasil para crianças. $21^{\mathrm{a}}$. ed. São Paulo: Companhia Editora Nacional, 1957. 1967.

História do Brasil para crianças. $24^{\mathrm{a}}$. ed. São Paulo: Companhia Editora Nacional, 
1982.

. História do Brasil para crianças. $27^{\mathrm{a}}$. ed. São Paulo: Companhia Editora Nacional,

Histórias da história brasileira (para crianças). $2^{\mathrm{a}}$ ed. São Paulo: Companhia Editora Nacional, 1967.

Histórias da história brasileira (para crianças). $3^{a}$ ed. São Paulo: Companhia Editora Nacional, 1982.

. Histórias da história brasileira (para crianças). $4^{\mathrm{a}}$ ed. São Paulo: Companhia Editora Nacional, 1983.

. Meu Torrão (contos da História Pátria). $2^{\mathrm{a}}$ ed. São Paulo: Companhia Editora Nacional, 1939.

Meu torrão (contos da História Pátria). $7^{\mathrm{a}}$ ed. São Paulo: Companhia Editora Nacional, 1962.

Meu torrão (contos da História Pátria). $8^{\mathrm{a}}$ ed. São Paulo: Companhia Editora Nacional, 1966.

Tiradentes, o que morreu pela liberdade do Brasil. In: DONATO, Mário e REY, Marcus. Para Você, Meu Filho: Grandes Vocações (Vol. 1- Libertadores). São Paulo: Donato Editora, s/d.

À sombra dos laranjais. Rio de Janeiro: Bels, 1977.

CORRESPONDÊNCIA de Viriato Corrêa a Ribeiro Couto (1934-1950) In: Arquivo Museu de Literatura Brasileira. Rio de Janeiro: Fundação Casa de Rui Barbosa (fontes manuscritas).

COSTA FILHO, Sebastião Pereira da (coord.). Cem anos de República. Centenário da Bandeira (1889-1989). Brasília, DF: Ministério da Educação/FAE, 1989.

COSTA, Emília Viotti. Da monarquia à república: momentos decisivos. São Paulo: Editora da UNESP, 2007.

. Da Senzala à Colônia: quarenta anos depois. In: FERREIRA, Antonio Celso; BEZERRA, Holien G.; DE LUCA, Tânia R (orgs.). O historiador e seu tempo: encontros com a história. São Paulo: Editora UNESP: ANPUH, 2008.

D’ÂNGELO, Newton. Ouvindo o Brasil: o ensino de História no rádio - décadas de 1930/40. Revista Brasileira de História, v. 18, n. 36. São Paulo: 1998.

D’ARAÚJO, Maria Celina. O Estado Novo. Rio de Janeiro: Jorge Zahar Ed., 2000.

DARNTON, Robert. História da leitura. In: BURKE, Peter (org.). A Escrita da História: novas perspectivas. São Paulo: Editora da UNESP, 1992.

O que é a História dos Livros? In: O Beijo de Lamourette: mídia, cultura e revolução. São Paulo: Cia. das Letras, 1990. 
DE AMICIS, Edmundo. Coração: diário de um aluno. $2^{\mathrm{a}}$. ed. São Paulo: Hemus Livraria Editora Ltda, 1982.

Corazon: diário de um niño. Buenos Aires: Ediciones Peuser, 1947.

Cuore: a heart of a boy. Dufon Editions, Inc., 2005.

DE CERTEAU, Michel. A invenção do cotidiano. v.1 Artes de fazer. $11^{\mathrm{a}}$ ed. Petrópolis, RJ: Vozes, 2005.

DE LORENZO, Helena Carvalho; COSTA, Wilma Peres. A década de 20 e as origens do Brasil moderno. São Paulo: Fundação Editora da UNESP, 1997.

DEBUS, Eliane. Monteiro Lobato e o leitor esse conhecido. Itajaí, SC: UNIVALI Ed.; Florianópolis, SC: Ed. UFSC, 2004.

DECRETO $\mathrm{n}^{\mathrm{o}}$ 155-B, que declara os dias de festa nacional. Disponível em $<$ http:\|www.camara.gov.br/legislação>. Acesso em: 20.11.2008.

DECRETO $\mathrm{n}^{\mathrm{o}}$ 981, de 8 de novembro de 1890, que aprova o regulamento da instrução primária e secundária do Distrito Federal. Disponível em: $<$ http:॥www.camara.gov.br/legislação>. Acesso em: 20.11.2008.

DECRETO n ${ }^{\circ} 19.890$, de 18 de abril de 1931, que dispõe sobre a organização do ensino secundário. Disponível em: <http: \|www.camara.gov.br/legislação>. Acesso em: 20.11.2008.

DECRETO n $^{\text {0 }}$ 21.241, de 4 de abril de 1932, que consolida as disposições sobre a organização do ensino secundário e dá outras providências. Disponível em: <http:\www.camara.gov.br/legislação>. Acesso em: 20.11.2008.

DECRETO-LEI n ${ }^{\circ}$ 868, de 18 de novembro de 1938, que cria, no Ministério da Educação e Saúde, a Comissão Nacional de Ensino Primário. Disponível em: <http: \wwww.camara.gov.br/legislação>. Acesso em: 20.11.2008.

DECRETO-LEI $\mathrm{n}^{\circ} 1.006$, de 30 de dezembro de 1938, que estabelece as condições de produção, importação e utilização do livro didático. Disponível em: <http:\www.camara.gov.br/legislação>. Acesso em: 20.11.2008.

DECRETO-LEI $n^{0}$ 4.073, de 30 de janeiro de 1942 (Lei Orgânica do Ensino Industrial). Disponível em: <http:\www.camara.gov.br/legislação>. Acesso em: 20.11.2008.

DECRETO-LEI n ${ }^{\circ}$ 8.460, de 26 de dezembro de 1945, que consolida a legislação sobre as condições de produção, importação e utilização do livro didático. Disponível em: $<$ http: \|www.camara.gov.br/legislação>. Acesso em: 20.11.2008.

DECRETO-LEI $\mathrm{n}^{\circ}$ 8.529, de 2 de janeiro de 1946 (Lei orgânica do ensino primário). Disponível em: <http:॥www.camara.gov.br/legislação>. Acesso em: 20.11.2008. 
DECRETO-LEI $n^{\circ}$ 8.530, de 2 de janeiro 1946 (Lei orgânica do ensino normal). Disponível em: <http:\|www.camara.gov.br/legislação>. Acesso em: 20.11.2008.

DECRETO-LEI n ${ }^{\circ}$ 869, de 12 de setembro de 1969, que dispõe sobre a inclusão da educação moral e cívica como disciplina obrigatória, nas escolas de todos os graus e modalidades dos sistemas de ensino do pais, e da outras providências. Disponível em: $<$ http: \www.camara.gov.br/legislação>. Acesso em: 20.11.2008.

DELGADO, Márcia Cristina. Cartografia Sentimental de sebos e livros. Belo Horizonte, MG: Autêntica, 1999.

DEPARTAMENTO DE EDUCAÇÃO DO DISTRITO FEDERAL. Programa de Ciências Sociais. Escola Elementar. Volume Primeiro, $1^{\circ}, 2^{\circ}$ e $3^{\circ}$ Anos. Série C. Programas e Guias de Ensino, n. 4. Edição Preliminar. São Paulo: Companhia Editora Nacional, 1934.

DE ROSSI, Vera Lúcia Zabongi; ZAMBONI, Ernesta (orgs.). Quanto tempo o tempo tem! Campinas, SP: Alínea, 2003.

DIMAS, Antonio. Bilac, o jornalista. São Paulo: Imprensa Oficial, 2006.

DONATO, Hernani. 100 Anos da Melhoramentos: 1890-1990. São Paulo: Melhoramentos, 1990.

DÓRIA, Antonio Sampaio. O preconceito em foco: análise das obras literárias infantojuvenis: Reflexões sobre história e cultura. São Paulo: Paulinas, 2008.

DUTRA, Eliana de Freitas. A nação nos livros: a biblioteca ideal na coleção Brasiliana. In: DUTRA, Eliana de Freitas; MOLLIER, Jean-Yves (orgs.). Política, Nação e Edição: o lugar dos impressos na construção da vida política. Brasil, Europa e Américas nos sécs. XVIII-XX. São Paulo: Annablume, 2006.

Companhia Editora Nacional: tradição editorial e cultura nacional no Brasil dos anos 30. In: I Seminário Brasileiro sobre o Livro e História Editorial. Rio de Janeiro: FCRB, UFF/PPGCOM/LIHED. Disponível em <http://www.livrohistoriaeditorial.pro.br $>$. Acesso em 24.09.2008.

EDMUNDO, Luiz. O Rio de Janeiro do meu tempo. $2^{\text {a }}$ ed., Rio de Janeiro: Conquista, $1957,5^{\circ}$ vol.

EDREIRA, Marco Antonio Branco. Monteiro Lobato e seus leitores: livros para ensinar, ler para aprender. In: Revista Brasileira de História da Educação. Campinas, SP: Editora Autores Associados Ltda., $1^{\mathrm{o}}$ número, 2001.

EL FAR, Alessandra. "A Presença dos ausentes": a tarefa acadêmica de criar e perpetuar vultos literários. In: Estudos Históricos, Rio de Janeiro: vol. 14, nº 25, 2000, p. 119-134.

A Encenação da Imortalidade: uma análise da Academia Brasileira de Letras nos primeiros anos da República (1897-1924). Rio de Janeiro: Editora FGV, 2000.

ENEIDA. Encontro Matinal. Diário de Notícias. Rio de Janeiro-RJ. 31.10.1962, s.p. 
FARIA, Maria Isabel; PERICÃO, Maria da Graça. Dicionário do Livro: da escrita ao livro eletrônico. São Paulo: EDUSP, 2008.

FÁVERO, Maria de Lourdes de A.; BRITTO, Jader de Medeiros de. Dicionário de Educadores no Brasil: da colônia aos dias atuais. Rio de Janeiro: Editora da UFRJ/MECINEP, 1999.

FERNANDES, Antonia Terra de Calazans. Estudos Sociais no contexto da história brasileira nas primeiras décadas do século XX In: Anais eletrônicos do VIII Encontro Nacional dos Pesquisadores do Ensino de História (ENPEH). São Paulo: Faculdade de Educação. Universidade de São Paulo, 2008.

FERNANDES, J. Ricardo Oriá. Entre a história sagrada e a moral cívica: o "Livro do Povo" e a instrução popular no nordeste brasileiro (séc. XIX) In: Cultura escolar, migrações e cidadania: livro de resumos/ VII Congresso Luso-Brasileiro de História da Educação. Porto, 2008.

O Livro didático e a pedagogia do cidadão: o papel do Instituto Histórico e Geográfico Brasileiro no ensino de história. In: SAECULUM - Revista e História (13); João Pessoa, PB, jul/dez. 2005, p. 121-131.

FERREIRA, Marieta de Moraes; FRANCO, Renato. Desafios do ensino de história. In: Estudos Históricos, Rio de Janeiro: vol. 21, nº 41, janeiro-junho de 2008, p. 79-93.

FERRO, Marc; JEAMMET, Philippe e GUILBERT, Daniele. Que herança terão nossos filhos? São Paulo: Edições Loyola, 2001.

FERRO, Marc. A manipulação da História no ensino e nos meios de comunicação. São Paulo: IBRASA, 1983.

FERRO, Maria do Amparo Borges. Literatura Escolar e História da Educação: cotidiano, ideário e práticas pedagógicas. Tese de Doutoramento. Faculdade de Educação, Universidade de São Paulo (USP), 2000.

FONSECA, Selva Guimarães. Caminhos da História ensinada. Campinas, SP: Papirus, 1993.

FONSECA, Thais Nivia de Lima e. Da Infâmia ao Altar da Pátria: memória e representações da Inconfidência Mineira e de Tiradentes. Tese de doutoramento. São Paulo: Faculdade de Filosofia, letras e Ciências Humanas da Universidade de São Paulo, 2001.

História e ensino de História. $2^{\text {a }}$ ed. Belo Horizonte, MG: Autêntica Editora, 2006.

Historiografia do Ensino de História no Brasil. In: RIBEIRO, Renilson et al (orgs.).

Ensino de História: trajetórias em movimento. Cáceres, MT: Editora UNEMAT, 2007.

FRANCO, Maria Laura P.B. O livro didático de História no Brasil: a versão fabricada. São Paulo: Global Editora, 1982. 
FREITAG, Bárbara; MOTTA, Valéria R; COSTA, Wanderley Ferreira da. O livro didático em questão. São Paulo: Cortez: Autores Associados, 1989.

FREITAS, Itamar. A pedagogia da História de Jonathas Serrano para o ensino secundário brasileiro (1913-1935). Tese de Doutoramento em Educação. Pontifícia Universidade Católica de São Paulo (PUC-SP), 2006.

FRIAS, J.M.C. de. Memória sobre a tipografia maranhense (apresentada à Comissão Diretora da Exposição Provincial do Maranhão de 1866 e exposta como prova tipográfica pelo tipógrafo). $3^{\text {a }}$ ed., São Paulo: Editora Siciliano, 2001.

FURET, François. O nascimento da história. In A oficina da história. Lisboa: Gradiva, s/d.

GANDRA, José R. Homens e Livros. São Paulo: Edições IBEP, 2005 (edição comemorativa dos 40 anos do IBEP e dos 80 anos da Companhia Editora Nacional).

GASPARELLO, Arlette M. Construtores de Identidades: a pedagogia da nação nos livros didáticos da escola secundária brasileira. São Paulo: Iglu Editora, 2004.

GATTI JÚNIOR, Décio. A escrita escolar da História: livro didático e ensino no Brasil (1970-1990). Bauru, SP: EDUSC; Uberlândia, MG: EDUFU, 2004.

GEBRIM, Nabiha (coord.) Guia de Livros Didáticos 2005: vol. 5. Brasília, DF: Ministério da Educação, Secretaria de Educação Infantil e Fundamental, 2004.

GINSBURG, Carlo. Sinais: raízes de um paradigma indiciário. In: e sinais: morfologia e história. São Paulo: Companhia das Letras, 1989. Mitos, emblemas

GLÉNISSON, Jean. Le livre pour la jeunesse. In: Histoire de l'edition française. Le temps dês éditeurs: du romantisme à la belle époque (Tome III). Paris: Fayard, 1985.

GOMES, Ângela de Castro. As Aventuras de Tibicuera: literatura infantil, História do Brasil e política cultural na Era Vargas. In: Revista USP, São Paulo: n. 59, p. 116-133, setembro/novembro 2003.

GONÇALVES, João Felipe. Enterrando Rui Barbosa: um estudo de caso da construção fúnebre de heróis na Primeira República. Estudos Históricos. Heróis Nacionais. $N^{0} 25$. Rio de Janeiro: CPDOC-FGV, 2000/1.

GOODSON, Ivor. Currículo: teoria e história. 8ª ed., Petrópolis, RJ: Vozes, 2008.

GUIA LIVRES. Livros escolares brasileiros (1810-2005). São Paulo. Faculdade de Educação. Universidade de São Paulo, 2005.

GUIBERNAU, M. Monteserrat. Nacionalismos: o estado nacional e o nacionalismo no século XX. Rio de Janeiro: Jorge Zahar Ed., 1997.

GUIMARÃES, Manoel L. S. Nação e Civilização nos Trópicos: o Instituto Histórico e Geográfico Brasileiro. In: Estudos Históricos, v. 1, nº 1, 1988. 
HALLEWELL, Laurence. O Livro no Brasil: sua história. São Paulo: T.A. Queiroz: Ed. da Universidade de São Paulo, 1985.

HANSEN, Patrícia Santos. Feições \& Fisionomia: A História do Brasil de João Ribeiro. Rio de Janeiro: Acess Editora, 2000.

HAROCHE, Claudine. O que é um povo? Os sentimentos coletivos e o patriotismo do final do século XIX. In: SEIXAS, Jacy Alves et al (orgs.). Razão e paixão na política. Brasília, DF: Editora UnB, 2002.

HÉBRARD, Jean. Três figuras de jovens leitores: alfabetização e escolarização do ponto de vista da História Cultural. In: ABREU, Márcia (org.). Leitura, História e História da Leitura. Campinas, SP: Mercado de Letras: Associação de Leitura do Brasil; São Paulo: FAPESP,1999.

HERMIDA, Borges. História do Brasil. $5^{\text {a }}$ série. São Paulo: Companhia Editora Nacional, 1983.

HERSCHMANN, Micael M.; PEREIRA, Carlos Alberto Messeder. O imaginário moderno no Brasil. In: HERSCHMANN, Micael M; PEREIRA, Carlos Alberto Messeder (orgs.). A Invenção do Brasil Moderno: medicina, educação e engenharia nos anos 20-30. Rio de Janeiro: Rocco, 1994.

HILlYER, V.M. Pequena história do mundo para crianças. Tradução e adaptação de Godofredo Rangel. $3^{\mathrm{a}}$ ed., São Paulo: Companhia Editora Nacional, s/d.

HILSDORF, Maria Lúcia Spedo. História da Educação Brasileira: leituras. São Paulo: Pioneira Thomson Learning, 2005.

HOBSBAWN, Eric; RANGER, Terence. A Invenção das Tradições. Rio de Janeiro: Paz e Terra, 1984.

HOBSBAWN, Eric. Nações e nacionalismo desde 1870. São Paulo: Paz e Terra, 1989.

HÖFFLING, Eloísa de Mattos. A trajetória do Programa Nacional do Livro Didático do Ministério da Educação no Brasil. In: FRACALANZA, Hilário; MEGID NETO, Jorge (orgs.). O Livro Didático de Ciências no Brasil. Campinas, SP: Editora Komedi, 2006.

HOLLANDA, Guy de. Um quarto de século de programas e compêndios de História para o ensino secundário (1931-1956). Rio de Janeiro: Instituto Nacional de Estudos Pedagógicos, 1957.

HOLANDA, Sérgio Buarque de; SOUSA, Octávio Tarquínio de. História do Brasil ( $3^{\text {a }}$ série do ciclo ginasial). Rio de Janeiro: Editora José Olympio, 1940.

HOLANDA, Sérgio Buarque de. Caminhos e Fronteiras. São Paulo: Edições Melhoramentos, 1957. 
. Visão do paraíso: os motivos edênicos do descobrimento e colonização do Brasil. São Paulo: Brasiliense, 1992.

HOUAISS, Antonio. Elementos de Bibliologia. São Paulo: Hucitec, 1983.

JAGUAR. O maior desenhista do mundo. In: Revista de História. Rio de Janeiro: Biblioteca Nacional, 2007.

JOHNSEN, Egil Borre. Libros de texto en el calidoscópio: estúdio crítico de la literatura y la investigación sobre los textos escolares. Barcelona: Ediciones Pomares-Corredor, S.A., 1996.

JORGE, Fernando. A Academia do Fardão e da Confusão: a Academia Brasileira de Letras e os seus "imortais" mortais. São Paulo: Geração Editorial, 1999.

Vida, obra e época de Paulo Setúbal: um homem de alma ardente. $2^{\mathrm{a}}$ ed., São Paulo: Geração Editorial, 2008.

JULIA, Dominique. A cultura escolar como objeto histórico. In: Revista Brasileira de História da Educação (publicação semestral da Sociedade Brasileira de História da Educação-SBHE). Campinas, SP: Autores Associados, nº 1, jan./jun. 2001.

. Disciplinas escolares: objetivos, ensino e apropriação. In: LOPES, A.R.C. e MACEDO, E. (orgs.). Disciplinas e integração curricular: história e políticas. Rio de Janeiro: DP\&A, 2002.

KNAUSS, Paulo. O desafio da ciência: modelos científicos no ensino de história. Cadernos Cedes, Campinas, SP: vol. 25, n. 67, p. 279-295, set./dez. 2005.

KOSHIYAMA, Alice Mitika. Monteiro Lobato: intelectual, empresário, editor. São Paulo: EDUSP: Com-Arte, 2006, Col. Memória Editorial.

LACERDA, Joaquim Maria de. Pequena História do Brazil por perguntas e respostas para uso da infância brasileira. Rio de Janeiro: Livraria Francisco Alves, 1957 (novíssima edição, ilustrada com muitas gravuras, revista e aumentada até 1919 por Luís Leopoldo Fernandes Pinheiro).

LACOMBE, Américo Jacobina. Introdução ao estudo da História do Brasil. São Paulo: Companhia Editora Nacional/Editora da Universidade de São Paulo, 1973, Coleção Brasiliana, vol. 350.

LAJOLO, Marisa. Usos e abusos da literatura na escola: Bilac e a literatura escolar na República Velha. Rio de Janeiro: Globo, 1982.

. Monteiro Lobato: um brasileiro sob medida. São Paulo: Moderna, 2000.

Infância de papel e tinta. In: FREITAS, Marcos Cezar de (org.). História social da infância no Brasil. $3^{a}$ ed., São Paulo: Cortez Editora; USF-IFAN, 2001. 
LAJOLO, Mariza; ZILBERMAN, Regina. Um Brasil para crianças: para conhecer a literatura infantil brasileira: histórias, autores e textos. $4^{\mathrm{a}}$ ed., São Paulo: Golbal, 1986.

. A Formação da Leitura no Brasil. São Paulo: Ática, 1999.

2002.

Literatura Infantil Brasileira: história \& histórias. 6a edição, São Paulo: Ática,

LARA, Sílvia Hunold. Tiradentes e a Nação Esquartejada. In: SECRETARIA MUNICIPAL DE CULTURA. DEPARTAMENTO DE PATRIMÔNIO HISTÓRICO. Pátria Amada Esquartejada. São Paulo: DPH, 1992.

LAVISSE, Ernest. La nouvelle 1re. Année d'Histoire de France. Paris: Armando Colin, 1894.

LE GOOF, Jacques. A Idade Média explicada aos meus filhos. Rio de Janeiro: Agir, 2007.

LEAL, Carlos. Francisco Alves. 150 Anos. Rio de Janeiro: Francisco Alves, 2004.

LEÃO, Andréa Borges. A Magia da Civilização: uma sociologia do livro para crianças na República das Letras. In: SERRA, Elizabeth D’Angelo (org.). Ética, Estética e Afeto na Literatura para crianças e jovens. São Paulo: Global, 2001.

LEÃO, Múcio (org.). Crítica. João Ribeiro. Historiadores. Rio de Janeiro: Publicações da Academia Brasileira, 1961, vol. VI.

LEÃO, Múcio. Discurso de recepção a Viriato Corrêa. In: Revista da Academia Brasileira de Letras. Anais de 1938. Julho a dezembro. Rio de Janeiro. Ano 31, vol. 56.

LEE, Ana. O sorriso da sociedade: intriga e crime no mundo literário da belle époque. Rio de Janeiro: Objetiva, 2006.

LEI de 15 de outubro de 1827, que manda crear escolas de primeiras letras em todas as cidades, villas e logares mais populosos do Império. Disponível em: $<$ http:॥www.camara.gov.br/legislação>. Acesso em: 20.11.2008.

LEI $\mathrm{n}^{\circ}$ 4.024, de 20 de dezembro de 1961, que estabelece as diretrizes e bases da educação nacional. Disponível em: <http: $\mid{ }_{w w w}$.camara.gov.br/legislação>. Acesso em: 20.11.2008.

LEI $\mathrm{n}^{\circ}$ 5.692, de 11 de agosto de 1971, que estabelece as diretrizes e bases do ensino de primeiro e segundo graus e dá outras providências. Disponível em: $<$ http: \|www.camara.gov.br/legislação>. Acesso em: 20.11.2008.

LEI $\mathrm{n}^{\mathrm{o}} 10.402$, de 8 de janeiro de 2002, institui o Dia Nacional do Livro Infantil. Disponível em: <http:॥www.camara.gov.br/legislação>. Acesso em: 20.11.2008.

LEI $n^{\circ} 10.753$, de 30 de outubro de 2003, que institui a política nacional do livro. Disponível em: <http:॥www.camara.gov.br/legislação>. Acesso em: 20.11.2008. 
LEITE, Dinara. Metodologia da Geografia e da História (de acordo com o programa do curso de formação do professor primário). $5^{\mathrm{a}}$ ed. Rio de Janeiro: Editora Conquista, 1959.

LEITE, Miriam Moreira. O Ensino da História no primário e no ginásio. São Paulo: Editora Cultrix, 1969.

LEN, Eduardo (org.). O Futuro do livro: sessenta visões. São Paulo: Estúdio Substância: Editora Olhares: IPSIS Gráfica e Editora, 2007.

LEVINE, Robert M. Pai dos Pobres? O Brasil e a era Vargas. São Paulo: Companhia das Letras, 2001.

LIMA, Herman. História da Caricatura no Brasil. Rio de Janeiro: Livraria José Olympio Editora, 1963, vol. 4.

LINS, Guto. Livro Infantil?: projeto gráfico, metodologia, subjetividade (Coleção Textos Design). São Paulo: Edições Rosari, 2003.

LIVROS da Semana. Correio da Manhã, 10.11.1962, s.p.

LOBATO, Monteiro. A menina do narizinho arrebitado. Segundo livro de leitura para uso das escolas primárias. Ilustrado por Voltolino. São Paulo: Monteiro Lobato \& Cia, 1921.

A barca de Gleyre (vol. 2). $7^{\mathrm{a}}$ ed., São Paulo: Brasiliense, 1956.

A profissão do livreiro. Disponível em: $<<\mathrm{http}: /$ www.estantevirtual.com.br $>>$. Acesso em: 25.09.2008.

LONTRA, Hilda O. Hartmann. Labirintos da memória: travessias. In: (org.). Histórias de leitores. Brasília, DF: Editora da Universidade de Brasília: Oficina Editorial do Instituto de Letras UnB, 2006.

LUGARINHO, Airton. No mundo dos livros. Brasília, DF: Editora Universa, 2005.

LUSTOSA, Isabel. A História do Brasil explicada aos meus filhos. Rio de Janeiro: Agir, 2007.

MACHADO, Alcântara. Vida e morte do Bandeirante. Rio de Janeiro: Editora Nova Aguilar, 2000. Coleção Intérpretes do Brasil.

MACIEL, Francisca Isabel P.; FRADE, Isabel Cristina A. S. Cartilhas de Alfabetização e Nacionalismo. In: PERES, Eliane; TAMBARA, Elomar (orgs.). Livros Escolares e ensino da leitura e da escrita no Brasil (séculos XIX-XX). Pelotas, RS: Seiva Publicações \& FAPERGS, 2003.

MACIEL, Francisca Isabel Pereira. O PNBE e o CEALE: de como semear leituras. In: PAIVA, Aparecida; SOARES, Magda (orgs.). Literatura Infantil: políticas e concepções. Belo Horizonte, MG: Autêntica Editora, 2008. Coleção Literatura e Educação. 
MAGALHÃES JÚNIOR, Raimundo. O Império em chinelos. Rio de Janeiro: Editora Civilização Brasileira S/A, 1957.

Olavo Bilac e sua época. Rio de Janeiro: Editora Americana, 1974.

MAGALHÃES, Justino. O manual escolar no quadro da história cultural: para uma historiografia do manual escolar português. In: Sísifo. Revista de Ciências da Educação, I, p. 5-14. Disponível em: $<<$ http://sisifo.fpce.ul.pt $>>$. Acesso em: 28.6.2008.

MAIOR, Armando Souto. História do Brasil para o curso colegial. $2^{\text {a }}$ ed. São Paulo: Companhia Editora Nacional, 1965.

MARTIN, Henry-Jean; FEBVRE, Lucien. O aparecimento do livro. São Paulo: Editora Universidade Estadual Paulista; Hucitec, 1992.

MARTINS, Maria do Carmo. A História prescrita e disciplinada nos currículos escolares: quem legitima esses saberes? Bragança Paulista, SP: EDUSF, 2000.

MARTINS FILHO, Plínio (org.). Ex-Libris: coleção Livraria Sereia de José Luis Garaldi. Cotia, SP: Ateliê Editorial, 2008 (artes do livro: 6).

MATTOS, Selma Rinaldi de. O Brasil em lições: a história como disciplina escolar em Joaquim Manuel de Macedo. Rio de Janeiro: Acess Editora, 2000.

MÁSCUlO, José Cássio. A coleção Sérgio Buarque de Holanda: livros didáticos e ensino de História. Tese de doutorado defendida no Programa de Estudos Pós-Graduados em Educação da PUC-SP, 2008.

MEIRELES, Cecília. Rui: pequena história de uma grande vida. São Paulo: Ed. Revista dos Tribunais, 1959.

Problemas da Literatura Infantil. 4ª ed., Rio de Janeiro: Nova Fronteira, 1984.

MELO, Ciro Flávio de C. Bandeira de. Senhores da história e do esquecimento: a construção do Brasil em dois manuais didáticos da História na segunda metade do século XIX. Belo Horizonte, MG: Argvmentvm, 2008.

MELO, Elizabete Amorim de Almeida. Estudo de uma coleção paradidática de Língua Portuguesa. In: FERREIRA, Norma Sandra de Almeida (org.). Livros, catálogos, revistas e sites para o universo escolar. Campinas, SP: Mercado de Letras: Associação de leitura do Brasil , 2006 (Coleção Leituras do Brasil).

MENEZES, Estácio de Sá e. História do Brasil contada aos meninos. Rio de Janeiro: B.L. Garnier Livreiro-Editor, 1870.

MENEZES, Raimundo de. Dicionário literário brasileiro. $2^{\mathrm{a}}$ ed. Rio de Janeiro: Livros Técnicos e Científicos, 1978.

MILLIET, Maria Alice. Tiradentes: o corpo do herói. São Paulo: Martins Fontes, 2001. 
MINDLIN, José; ANTUNES, Cristina. Brasiliana: obras e coleções publicadas. In: LAUERHASS, Ludwig; NAVA, Carmen. Brasil: uma identidade em construção. São Paulo: Ática, 2007, p. 86.

MINISTÉRIO DA CULTURA (MinC). Diretrizes Gerais para o Plano Nacional de Cultura. Brasília, DF: MinC/Câmara dos Deputados, 2007.

MOACYR, Primitivo. A instrução e as províncias (vol. 2). São Paulo: Cia. Editora Nacional, 1939.

MOLLIER, Jean-Yves. A leitura e seu público no mundo contemporâneo : ensaios sobre história cultural. Belo Horizonte, MG : Autêntica Editora, 2008. Coleção História e Historiografia.

MONIOT, Henri (org.). Enseigner l'histoire: des manuels à la mémoire. Berne; FrancfortS. Main; Nancy; New York: Lang, 1984.

MONTEllo, Josué. Pequeno Anedotário da Academia Brasileira de Letras. São Paulo: Livraria Martins Editora, s/d.

Diário Completo: edição organizada pelo autor. Rio de Janeiro: Nova Aguilar, 1998.

MORAES, Rubens Borba de. A Impressão Régia do Rio de Janeiro: origens e produção. In: MORAES, Rubens Borba de; CAMARGO, Ana Maria de Almeida. Bibliografia da Impressão Régia do Rio de Janeiro (vol. 1). São Paulo: Editora da Universidade de São Paulo/Livraria Kosmos Editora, 1993.

MUNAKATA, Kazumi. Produzindo livros didáticos e paradidáticos. Tese de Doutoramento em História e Filosofia da Educação. Pontifícia Universidade Católica de São Paulo (PUC-SP), 1997.

. Brasil. Apéndice Bibliográfico. In: OSSENBACH, Gabriela; RODRIGUEZ, Miguel Somoza. Los manuales escolares como fuente para la historia de la educación em América Latina. Madrid: Universidad Nacional de Educación a Distancia, 2001.

NADAI, Elza. O ensino de história no Brasil: trajetórias e perspectivas. Revista Brasileira de História, São Paulo, v. 13, n. 25/26, p. 143-162, set. 1992/ ago. 1993.

NAGLE, Jorge. Educação na Primeira República. In: FAUSTO, Boris (org.). História Geral da Civilização Brasileira. O Brasil republicano: sociedade e instituições. $2^{\mathrm{a}}$ ed., Rio de Janeiro: Difel, 1983.

NAVA, Carmen. Formando futuros cidadãos nas escolas públicas brasileiras (1937-1945). In: LAUERHASS, Ludwig; NAVA, Carmen. Brasil: uma identidade em construção. São Paulo: Ática, 2007, p. 109.

NEEDELL, Jeffrey D. Belle Époque Tropical: sociedade e cultura de elite no Rio de Janeiro na virada do século. São Paulo: Companhia das Letras, 1993. 
NERES, Júlio Maria. A produção didática de história em quadrinhos: Julierme e a História para a escola moderna (1969-1975). Dissertação de mestrado. Faculdade de Educação da USP, 2005.

NORA, Pierre. Entre Memória e História: a problemática dos lugares. In: Projeto História: Revista do Programa de Pós-Graduação em História da PUC-SP. São Paulo, nº 10, dez. 1993.

Lavisse, instituteur national. In: (org.). Les Lieux de Mémoire (vol. 1). Paris: Editora Gallimard, 1997.

NOSELlA, Maria de Lourdes Chagas Deiró. As Belas Mentiras: a ideologia subjacente aos textos didáticos. $4^{\mathrm{a}}$ ed., São Paulo: Moraes, 1981.

NOVA COLLECÇÃO DE LIVROS DIDACTICOS POR F.T.D. Primeiras lições de História do Brasil: perguntas e respostas. $3^{\mathrm{a}}$ ed., Rio de Janeiro: Livraria Paulo de Azevedo \& Cia., 1922.

NUNES, Cassiano (coord.). Monteiro Lobato vivo: seleção e organização de cartas variadas. Rio de Janeiro: MPM Propaganda: Record, 1986.

NUNES, Clarice. As políticas públicas de educação de Gustavo Capanema no governo Vargas. In: BOMENY, Helena (org.). Constelação Capanema: intelectuais e políticas. Rio de Janeiro: Editora FGV, 2001.

Dilemas da modernidade latino-americana: autoria feminina e discurso pedagógico. In: BENCOSTTA, Marcus Levy (org.). Culturas escolares, saberes e práticas educativas: itinerários históricos. São Paulo: Cortez, 2007.

OCTÁVIO, Rodrigo. Festas Nacionaes. Rio de Janeiro: F. Briguiet \& Cia. Editores, 1893.

OLIVEIRA, Cecília Helena de Salles; MATTOS, Cláudia Valladão de (orgs.). O Brado do Ipiranga. São Paulo: Editora da Universidade de São Paulo: Museu Paulista da Universidade de São Paulo, 1999.

OLIVEIRA, João Batista de Araújo ; GUIMARÃES. Sonia Dantas P.; BOMÉNY, Helena Maria Bousquet. A política do livro didático. São Paulo: Summus; Campinas: Ed. da Universidade Estadual de Campinas, 1984.

OLIVEIRA, Lúcia Lippi. As festas que a República manda guardar. Estudos Históricos. Rio de Janeiro, vol. 2, n. 4, 1989.

A questão nacional na Primeira República. São Paulo: Brasiliense, 1990.

A construção do herói no imaginário brasileiro de ontem e de hoje. In: PESAVENTO, Sandra Jatahy. História Cultural: experiências de pesquisa. Porto Alegre, RS: UFRGS, 2003.

OLIVEIRA, Luiz Eduardo M. de. Entre a História Cultural e a Teoria Literária: rumo a uma história dos cânones escolares no Brasil. In: Revista Brasileira de História da Educação, Sociedade Brasileira de História da Educação (SBHE), nº 8, jul./dez. 2004. 
OLIVEIRA, Marco Antonio de. Os intelectuais e a produção da série Resumo Didactico pela Companhia Melhoramentos de S. Paulo (1918-1936). Tese de Doutoramento. Faculdade de Educação, Universidade de São Paulo (USP), 2006.

OLIVEIRA, Rui de. Pelos Jardins Boboli: reflexões sobre a arte de ilustrar livros para crianças e jovens. Rio de Janeiro: Nova Fronteira, 2008.

ORIÁ, Ricardo. 18 de abril. Dia do livro infantil In: BITTENCOURT, Circe (org.). Dicionário de datas da História do Brasil. São Paulo: Contexto, 2007.

OSSENBACH, Gabriela; RODRIGUEZ, Miguel Somoza. Los manuales escolares como fuente para la historia de la educación em América Latina. Madrid: Universidad Nacional de Educación a Distancia, 2001.

OZOUF, Jacques e Mona. "Le Tour de la France par deux enfants": le petit livre rouge de la Republique. In: NORA, Pierre (org.). Les Lieux de Mémoire (vol. 1). Paris: Editora Gallimard, 1997.

PAIXÃO, Fernando (org.). Momentos do livro no Brasil. São Paulo: Ática, 1996 (edição comemorativa aos 30 anos da Editora Ática).

PALLOTTA, Miriam Giberti Páttaro. Uma história meio ao contrário: um estudo sobre História do Mundo para as Crianças de Monteiro Lobato. Tese de Doutoramento. Faculdade de Ciências e Letras de Assis, UNESP, 2001.

. História do mundo para crianças: uma obra inovadora. In: LAJOLO, Marisa; CECCANTINI, João Luís (orgs.). Monteiro Lobato, livro a livro: obra infantil. São Paulo: Editora da UNESP, Imprensa Oficial de São Paulo, 2008.

PENNAC, Daniel. Como um romance. Porto Alegre, RS: LP\&M; Rio de Janeiro: Rocco, 2008.

PENTEADO, Ana Elisa de Arruda. Literatura Infantil, História e Educação: um estudo da obra Cazuza, de Viriato Corrêa. Dissertação de Mestrado. Faculdade de Educação, Universidade Estadual de Campinas (UNICAMP), 2001.

PEREGRINO JÚNIOR (João P. J. da Rocha Fagundes). Sessão de saudade dedicada à memória do acadêmico Viriato Corrêa. Sessão em 13 de abril de 1967. In: Revista da Academia Brasileira de Letras. Anais de 1967. Janeiro a Junho.

PETIT, Michele. Os jovens e a leitura: uma nova perspectiva. São Paulo: Ed. 34, 2008.

PFROMM NETO, Samuel et al. O Livro na Educação. Rio de Janeiro: Primor, INL, 1974.

PINGEL, Falk. UNESCO Guidebook on textbook research and textbook revision. Hannover: George Eckert Institute dor International Textbook Research, 1999.

PINHEIRO, Lúcia M.; PINHEIRO, Maria do Carmo M. Com que finalidade devemos levar a criança ao estudo da História do Brasil? In: Prática na formação e no aperfeiçoamento do magistério primário. São Paulo: Companhia Editora Nacional, 1969, (vol. 1). 
PINTO, G. Hércules. Viriato Corrêa (a modo de biografia). Rio de Janeiro: Editora Alba Ltda., 1966.

PIRES, Veríssimo Lopes. O ensino de História nas escolas primárias (1940-1950). Dissertação de mestrado. São Paulo: Faculdade de Educação - USP. São Paulo, 1996.

PIZA, Daniel. Academia Brasileira de Letras: histórias e revelações. São Paulo: Dezembro Editorial, 2003.

POMBO, Rocha. Compêndio de História da América. Rio de Janeiro: Laemmerrt \& C. Editores, 1900.

. História da América para escolas primárias. Rio de Janeiro: H. Garnier, LivreiroEditor, 1903, Biblioteca da Infância.

. Nossa Pátria: narração dos fatos da História do Brasil, através da sua evolução com muitas gravuras explicativas. $79^{\mathrm{a}}$ ed., São Paulo: Companhia Melhoramentos de São Paulo, $\mathrm{s} / \mathrm{d}$.

Nossa Pátria: pequena História do Brasil. $85^{a}$ edição revista e atualizada pelo Prof. Lourenço Filho, São Paulo: Edições Melhoramentos, 1967.

PORTARIA no 1.422, de 2006 que cria, no âmbito do Ministério da Cultura e da Educação, o Programa Nacional do Livro e da Leitura, e dá outras providências. Disponível em:

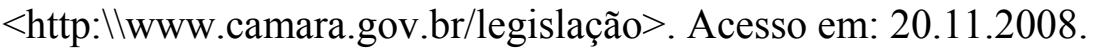

PORTARIA $\mathrm{n}^{\circ}$ 501, de 19 de maio de 1952, que estabelece o programa do exame de admissão, de que trata o art. 18 do Decreto $\mathrm{n}^{\circ} 19.890$, de 18 de abril de 1931, que dispõe sobre a organização do ensino secundário. Disponível em: $<$ http: $\mid$ www.camara.gov.br/legislação>. Acesso em: 20.11.2008.

POWERS, Alan. Era uma vez uma capa: história ilustrada da literatura infantil. São Paulo: Cosac Naify, 2008.

PREVOST, Nicole. Livres de prix et distributions de prix dans l'enseignement primaire (1870-1914). In: Positions des thèses. Paris: École des Chartes, 1979.

PROUST, Marcel. Sobre a leitura. $4^{\text {a }}$ ed.: Campinas, SP: Pontes, 2003.

RAMOS, Graciliano. Infância. 15ª ed., Rio de Janeiro: Record, 1979.

. Pequena História da República. In: Alexandre e outros heróis. $20^{\mathrm{a}}$ ed., Rio de Janeiro: Record, 1981.

RAZZINI, Márcia de Paula Gregório. Livros e leitura na escola brasileira do século XX. In: BASTOS, Ma. Helena Câmara; STEPHANOU, Maria (orgs.). Histórias e memórias da educação no Brasil (vol. III: século XX). Petrópolis, RJ: Vozes, 2005.

REGO, José Lins do. Doidinho. Rio de Janeiro: J. Olympio; Brasília, DF: INL, 1980. 
REIS, José Carlos. Civilização Brasileira e otimismo ultraconservador (ingênuo): Pedro Calmon e a visão romântica e cristã da nação brasileira. In: . As Identidades do

Brasil: de Calmon a Bomfim: a favor do Brasil: direita ou esquerda? Rio de Janeiro: Editora FGV, 2006.

RIBEIRO, Maria Eurydice de Barros. Os símbolos do poder. Cerimônias e imagens do estado monárquico no Brasil. Brasília, DF: Editora Universidade de Brasília, 1995.

ROCHA, Everardo P.G. Um índio didático: nota para o estudo de representações. In: ROCHA, E. et al. Testemunha ocular: textos de antropologia social do cotidiano. São Paulo: Brasiliense, 1984.

RODRIGUES, Antônio Marques. O Livro do Povo (obra recommendada e approvada pelos Exmos. Srs. D. Manoel, Arcebispo da Bahia, e D. Luiz, Bispo do Maranhão, e adoptada nas escolas primarias das províncias do Amazonas, Pará, Maranhão, Piauhy, Ceará, Parayba e Pernambuco). $4^{\mathrm{a}}$ ed., São Luis, MA: Typ. do Frias, 1865.

RODRIGUES, João Paulo Coelho de Souza. A dança das cadeiras: literatura e política na Academia Brasileira de Letras (1896-1913). 2a ed., Campinas, SP: Editora da UNICAMP, CECULT, 2003.

RODRIGUES, José Honório. História e Historiografia. Petrópolis, RJ: Vozes, 1970.

ROMANELLI, Otaíza de Oliveira. História da Educação no Brasil (1930-1973). 32a ed., Petrópolis, RJ: Vozes, 2007.

ROMERO, Sylvio. História do Brasil ensinada pela biographia de seus heróes (livro para as classes primárias). $4^{\mathrm{a}}$ ed. correcta e augmentada. Rio de Janeiro: Livraria Francisco Alves, 1895.

RÖSSIN, Tânia M. K. (org.). Do livro ao CD-Rom: novas navegações. Passo Fundo, RS: EDIUPF, 1999.

SALIBA, Elias Thomé. As imagens canônicas e o ensino de História. In: SCHMIDIT, Maria Auxiliadora; CAINELLI, Marlene (orgs.). III Encontro Perspectivas do Ensino de História. Curitiba, PR: Aos Quatro Ventos, 1999.

. As imagens canônicas e a História. In: CAPELATO, Maria Helena et al. História e Cinema: dimensões históricas do audiovisual. São Paulo: Alameda, 2007.

SANDES, Noé Freire. A invenção da nação: entre a monarquia e a república. Goiânia, GO: Editora UFG, 2000.

SANTOS, João Brígido. Resumo da História do Ceará. Ceará: Imprensa Econ., s.d.

SANTOS, Theobaldo de Miranda. Seleta Brasileira: pequena antologia da cultura brasileira (curso de admissão). $2^{\mathrm{a}}$ ed., Rio de Janeiro: Livraria Agir Editora, 1951. 
. Contos Cívicos do Brasil. São Paulo: Companhia Editora Nacional, 1955, Coleção Brasiliana Infantil, vol. 4.

SARTRE, Jean-Paul. Em Defesa dos Intelectuais. São Paulo: Ática, 1994.

SATUÉ, Enric. Aldo Manuzio: editor, tipógrafo, livreiro. O design do livro do passado, do presente e, talvez, do futuro. Cotia, SP: Ateliê Editorial, 2004, Col. Artes do Livro, vol. 4.

SCHAPOCHINIK, Nelson. Como se escreve a História? In: Revista Brasileira de História. São Paulo (v. 13), nº 25/26, pp. 67-80, set. 92/ago. 93.

. João do Rio: um dândi na Cafelândia. São Paulo: Boitempo Editorial, 2004, Coleção Paulicéia-Letras.

SCHWARCZ, Lília Moritz. O Espetáculo das raças: cientistas, instituições e questão racial no Brasil (1870-1930). São Paulo: Companhia das letras, 1993.

. Um monarca nos trópicos: o Instituto Histórico e Geográfico Brasileiro, a Academia Imperial de Belas-Artes e o Colégio Pedro II. In: As Barbas do Imperador: D. Pedro II, um monarca nos trópicos. São Paulo: Companhia das Letras, 1998.

SCHWARTZMAN, Simon et al. Tempos de Capanema. Rio de Janeiro/São Paulo: Paz e Terra/EDUSP, 1984.

SCLIAR, Moacyr. Memórias de um aprendiz de escritor. Memórias de um menino apaixonado por livros. 2a . ed. São Paulo: Companhia Editora Nacional, 2005.

A mulher que escreveu a Bíblia. São Paulo: Companhia das Letras, 2007.

O texto, ou: a vida. Uma trajetória literária. Rio de Janeiro: Bertrand Brasil, 2007.

SECCHIN, Antonio Carlos. Guia dos Sebos das cidades do Rio de Janeiro e São Paulo. $3^{\text {a }}$ ed., Rio de Janeiro: Nova Fronteira, 2001.

SECRETARIA DA EDUCAÇÃO DO ESTADO DE MINAS GERAIS. Programas (ensino primário elementar). $3^{\mathrm{a}}$ ed., Belo Horizonte: Imprensa Oficial, 1961.

SENNA, Ernesto. O Velho comércio do Rio de Janeiro. $2^{\mathrm{a}}$ ed., Rio de Janeiro: G. ErmaKoff casa Editorial, 2006.

SERRANO, Jonathas. Methodologia da História na aula primária. Rio de Janeiro: Francisco Alves, 1917.

Como se ensina História. São Paulo: Comp. Melhoramentos, 1935. Bibliotheca de Educação, vol. XXV.

SETÚBAL, Paulo. O Príncipe de Nassau (romance histórico). São Paulo: Companhia. Editora Nacional, 1926.

As maluquices do imperador (1808-1934). São Paulo: Geração Editorial, 2008. 
SEVCENKO, Nicolau. Literatura como missão: tensões sociais e criação cultural na Primeira República. $2^{a}$ ed., São Paulo: Companhia das Letras, 2003.

SILVA, Joaquim. História do Brasil ( $1^{\mathrm{a}}$ série ginasial). São Paulo: Companhia Editora Nacional, 1961.

SILVA, Marco Antonio (org.) Repensando a História. Rio de Janeiro: Marco Zero, 1984.

SILVA, Paulo Vinicius Baptista da. Racismo em livros didáticos: estudo sobre negros e brancos em livros de Língua Portuguesa. Belo Horizonte, MG: Autêntica Editora, 2008 (Coleção Cultura Negra e Identidades).

SKIDMORE, Thomas. Preto no branco. $2^{\text {a }}$ ed., São Paulo: Paz e Terra, 1989.

SOARES, Gabriela Pellegrino. Semear Horizontes: uma história da formação de leitores na Argentina e no Brasil, 1915-1954. Belo Horizonte, MG: Editora UFMG, 2007.

SOARES, Magda Becker. Um olhar sobre o livro didático. In: Presença Pedagógica (vol. 2), $\mathrm{n}^{\mathrm{o}} 12$, nov./dez. 1996.

SOUSA, Ana Paula. A História como ela é. O pote de ouro do livro didático motiva uma guerra ideológica e comercial em torno de um compêndio de historia. In: Revista Carta Capital, edição ${ }^{\circ}$ 464, 2007.

SOUSA, Herculana Firmina Vieira de. Resumo da História do Brasil: desde seu descobrimento até a aclamação de Sua Majestade Imperial (1500-1840). São Luiz, MA: Belarmino de Mattos, 1868.

SOUSA, Rosa Fátima. Inovação educacional no século XIX: a construção do currículo da escola primária no Brasil. In: Cadernos CEDES, ano XX, nº 51, novembro/2000.

SPOSITO, Maria Encarnação Beltrão. A avaliação de livros didáticos no Brasil - por quê? In: . Livros Didáticos de História e Geografia: avaliação e pesquisa. São Paulo: Cultura Acadêmica, 2006.

SUASSUNA, Ariano. "Eu sou é imperador!". In: Revista Nossa História (editada com o Conselho de Pesquisa da Biblioteca Nacional). Ano 2, nº 14, dezembro de 2004.

SWIFT, Graham. Do animal contador de histórias. In: Terra D’Água. São Paulo: Companhia das Letras, 1992.

TAMBARA, Elomar. Trajetórias e natureza do livro didático nas escolas de ensino primário no século XIX no Brasil. In: História da Educação. ASPHE/FaE/UFPel, Pelotas, RS: (11): 25-52, Abr.02.

. Bosquejo de um ostensor do repertório de textos escolares utilizados no ensino primário e secundário no século XIX no Brasil. Pelotas, RS: Seiva Publicações, 2003.

TELLES, Norma Abreu. Cartografia brasílis ou esta história está mal contada. São Paulo: Edições Loyola, 1984. 
TOLEDO, Maria Rita de Almeida. Coleção atualidades pedagógicas: do projeto político ao projeto editorial (1931-1981). Tese de Doutoramento. São Paulo: Pontifícia Universidade Católica de São Paulo (PUC-SP), 2001.

TORGAL, Luís Reis. A História contada às crianças. In: Primeiro Encontro sobre o Ensino da História. Comunicações. Lisboa: Fundação Calouste Gulbenkian, 1992.

TRAVASSOS, Nelson. Minhas memórias dos Monteiros Lobatos. São Paulo: Edart, 1964. Livro sobre livros. São Paulo: HUCITEC, 1978.

VERGUEIRO, Waldomiro; SANTOS, Roberto Elísio (orgs.). O Tico-Tico: centenário da primeira revista de quadrinhos do Brasil. Vinhedo, SP: Opera Graphica Editora, 2005.

VERÍSSIMO, Érico. As aventuras de Tibicuera que são também as aventuras do Brasil. $4^{\mathrm{a}}$ ed., Porto Alegre: Edição da Livraria do Globo, 1947.

VERÍSSIMO, José. A Educação Nacional. $2^{\mathrm{a}}$ ed., Rio de Janeiro: Livraria Francisco Alves, 1906.

A História Pátria e a Educação Nacional. In: A Educação Nacional. $2^{a}$ ed., Rio de Janeiro: Livraria Francisco Alves, 1906.

VIANNA, Hélio. O ensino da História do Brasil. In: História do Brasil (vol. I período colonial). $3^{\mathrm{a}}$ ed., São Paulo: Edições Melhoramentos, 1965.

VIANA, Marfa Barbosa. Sugestões Literárias. A Noite. Rio de Janeiro-RJ, de 19.12.1962, s.p.

VIDAL, Diana G.; FARIA FILHO, Luciano Mendes de. História da Educação no Brasil: a constituição histórica do campo (1880-1970). In: Revista Brasileira de História. São Paulo: v. $23, n^{\circ} 45$, pp. 37-70, 2003.

VIEIRA, Cleber Santos. Entre as coisas do mundo e o mundo dos livros: prefácios cívicos e impressos escolares no Brasil republicano. Tese de doutorado. Faculdade de Educação da USP, 2008.

VILLA-LOBOS, R. História do Brasil (resumo didactico). $4^{\text {a }}$ ed., Rio de Janeiro: Laemmert e Cia, 1896.

VIRIATO Corrêa passou a limpo a História do Brasil: fórmula simples (entrevista de Viriato Corrêa ao O Jornal, Rio de Janeiro: 17.12.1960).

VIRIATO é enredo do Salgueiro. Jornal do Brasil, Rio de Janeiro-RJ, 18.8.1966.

VOVELLE, Michel. A Revolução Francesa explicada à minha neta. São Paulo: Editora UNESP, 2007.

WALSH, Rev. Robert. Notícia do Brasil (1828-1829). Belo Horizonte, MG: Itatiaia; São Paulo: Edusp, 1985. 
ZAMBONI, Ernesta (org.). A prática de ensino de História. Campinas, SP: Cadernos CEDES nº 10, 1985.

ZAMBONI, Ernesta et al. (orgs.) Memórias e Histórias da Escola. Campinas, SP: Mercado de Letras, 2008.

ZAMBONI, Ernesta. Que História é essa? - uma proposta analítica dos livros paradidáticos de História. Tese de Doutoramento. Faculdade de Educação. Universidade de Campinas, 1991.

Projeto pedagógico dos parâmetros curriculares nacionais: identidade nacional e consciência histórica. In: Cadernos CEDES, Campinas, SP: v. 23, n. 61, p. 367-377, dezembro 2003.

ZILBERMAN, Regina. Começos da literatura para crianças no Brasil. In: PAULINO, Graça (org.). O jogo do livro infantil. Belo Horizonte, MG: Editora Dimensão, 1997. Futuro; 3).

Fim do livro, fim dos leitores? São Paulo: Editora SENAC São Paulo, 2001 (Ponto Como e por que ler a literatura infantil brasileira. Rio de Janeiro: Objetiva, 2005. 
ANEXOS 
ANEXO 1 - HISTÓRIA DO BRASIL PARA CRIANÇAS ${ }^{179}$ - VIRIATO CORRÊA (1934)

\begin{tabular}{|c|c|c|c|c|}
\hline $\begin{array}{l}\text { CAPÍTULO/ } \\
\text { TÍTULO }\end{array}$ & TÓPICOS $^{180}$ & ASSUNTO & $\begin{array}{c}\text { PERÍODO } \\
\text { HISTÓRICO }\end{array}$ & $\begin{array}{c}\text { IMAGENS - } \\
\text { DESCRIÇÃO }\end{array}$ \\
\hline $\begin{array}{l}\text { I- O contador de } \\
\text { histórias }\end{array}$ & $\begin{array}{l}\text { A rua em que eu } \\
\text { morava. Vovô - a } \\
\text { criança de setenta e } \\
\text { tantos anos. A } \\
\text { Chácara. As crianças } \\
\text { do meu amigo. A } \\
\text { história }\end{array}$ & $\begin{array}{l}\text { Introdução à } \\
\text { narrativa. } \\
\text { Apresentação dos } \\
\text { personagens. } \\
\text { Vovô, as seis } \\
\text { crianças }^{181} \text { e os } \\
\text { animais (cão e } \\
\text { gato) }\end{array}$ & & $\begin{array}{l}\text { "O contador de } \\
\text { histórias" (vovô } \\
\text { contando histórias } \\
\text { para as seis crianças } \\
\text { em sua chácara na } \\
\text { Gávea) }\end{array}$ \\
\hline $\begin{array}{l}\text { II- O mundo } \\
\text { antigo }\end{array}$ & $\begin{array}{l}\text { A pobreza da } \\
\text { Europa. Marco Pólo. } \\
\text { Os turcos. A } \\
\text { navegação a vela; a } \\
\text { bússola; a imprensa. } \\
\text { Mistérios do mar. O } \\
\text { infante D. Henrique }\end{array}$ & $\begin{array}{l}\text { A expansão } \\
\text { marítimo- } \\
\text { comercial } \\
\text { européia }\end{array}$ & Brasil Colônia & $\begin{array}{l}\text { "Toda a gente } \\
\text { acreditava que no } \\
\text { oceano viviam } \\
\text { monstros } \\
\text { apavorantes" } \\
\text { (imagem em alto } \\
\text { mar, com caravela e } \\
\text { monstros) }\end{array}$ \\
\hline III- O louco & $\begin{array}{l}\text { A caminho do } \\
\text { Ocidente. Aos pés de } \\
\text { D. João II. Aos pés } \\
\text { de Isabel, a Católica. } \\
\text { Os sábios de } \\
\text { Salamanca. A } \\
\text { viagem. A revolta a } \\
\text { bordo. Nas Antilhas. } \\
\text { Os índios }\end{array}$ & $\begin{array}{l}\text { Cristóvão } \\
\text { Colombo e a } \\
\text { descoberta da } \\
\text { América. }\end{array}$ & Brasil Colônia & $\begin{array}{l}\text { "Os sábios de } \\
\text { Salamanca riram-se } \\
\text { de Colombo" } \\
\text { (imagem de } \\
\text { Colombo em } \\
\text { destaque) }\end{array}$ \\
\hline IV- A Pindorama & $\begin{array}{l}\text { A terra das } \\
\text { palmeiras. Os rios. } \\
\text { As montanhas. Os } \\
\text { tupis e os tapuias. } \\
\text { Como se vestiam os } \\
\text { índios }\end{array}$ & Os índios & Brasil Colônia & $\begin{array}{l}\text { "A Pindorama" } \\
\text { (imagem idílica e } \\
\text { exuberante, com } \\
\text { montanhas, mar, } \\
\text { palmeiras, aves e } \\
\text { embarcação com } \\
\text { índio) }\end{array}$ \\
\hline $\begin{array}{l}\text { V-Na terra das } \\
\text { palmeiras }\end{array}$ & $\begin{array}{l}\text { Uma cidade da } \\
\text { Pindorama. O } \\
\text { cacique. As tribos. } \\
\text { Os deuses. Os } \\
\text { mortos. As armas. }\end{array}$ & Os índios & Brasil Colônia & $\begin{array}{l}\text { "Os primeiros } \\
\text { habitantes do Brasil" } \\
\text { (grupo de quatro } \\
\text { índios na taba) }\end{array}$ \\
\hline $\begin{array}{l}\text { VI- Plantas e } \\
\text { bichos da } \\
\text { Pindorama }\end{array}$ & $\begin{array}{l}\text { Os frutos que } \\
\text { existiam e os frutos } \\
\text { que não existiam. O } \\
\text { açúcar. Os animais } \\
\text { da terra das } \\
\text { palmeiras. A } \\
\text { galinha. A vaca, o } \\
\text { cavalo, o porco, a } \\
\text { cabra etc. O que se } \\
\text { comia. }\end{array}$ & $\begin{array}{l}\text { Flora e fauna } \\
\text { brasileiras }\end{array}$ & Brasil Colônia & $\begin{array}{l}\text { "Alguns animais do } \\
\text { Brasil" (arara, } \\
\text { macaco, preguiça, } \\
\text { anta, tatu e outros) }\end{array}$ \\
\hline
\end{tabular}

\footnotetext{
${ }^{179}$ História do Brasil para crianças, de autoria de Viriato Corrêa e ilustrações de Belmonte, foi publicado em 1934 pela Companhia Editora Nacional, tendo circulado até o ano de 1984 (28 edições).

${ }^{180}$ Os tópicos assemelham-se aos itens das unidades de um programa de ensino.

181 As crianças são Pedrinho, Neco, Quiquita, Nhonhô, Mariazinha e o narrador. Os animais são o gato "Damasco" e o cão "Barão".
} 


\begin{tabular}{|c|c|c|c|c|}
\hline $\begin{array}{l}\text { CAPÍTULO/ } \\
\text { TÍTULO }\end{array}$ & TÓPICOS $^{182}$ & ASSUNTO & $\begin{array}{c}\text { PERÍODO } \\
\text { HISTÓRICO }\end{array}$ & $\begin{array}{l}\text { IMAGENS - } \\
\text { DESCRIÇÃO }\end{array}$ \\
\hline $\begin{array}{l}\text { VII- A gente de } \\
\text { Pindorama }\end{array}$ & $\begin{array}{l}\text { A mesa indígena. } \mathrm{O} \\
\text { faro dos selvagens. } \\
\text { A cerimônia do } \\
\text { casamento. A } \\
\text { hospitalidade } \\
\text { cabocla. }\end{array}$ & Os índios & Brasil Colônia & $\begin{array}{l}\text { "Prova de } \\
\text { habilitação ao } \\
\text { casamento" (dois } \\
\text { índios numa } \\
\text { competição, um } \\
\text { correndo com tronco } \\
\text { de madeira) }\end{array}$ \\
\hline $\begin{array}{l}\text { VIII- O } \\
\text { navegador } \\
\text { espanhol }\end{array}$ & $\begin{array}{l}\text { Vicente Pinson. O } \\
\text { cabo de Santo } \\
\text { Agostinho. O rio } \\
\text { Mearim e a } \\
\text { pororoca. A } \\
\text { embocadura do } \\
\text { Amazonas. O rio } \\
\text { gambá. Os trinta } \\
\text { escravos }\end{array}$ & Vicente Pinson & Brasil Colônia & $\begin{array}{l}\text { "O navegador } \\
\text { espanhol" (imagem } \\
\text { com índio preso e } \\
\text { outro sentado e dois } \\
\text { espanhóis. Ao fundo, } \\
\text { índios acorrentados } \\
\text { pelo pescoço) }\end{array}$ \\
\hline $\begin{array}{l}\text { IX- O navegador } \\
\text { português }\end{array}$ & $\begin{array}{l}\text { O caminho das } \\
\text { Índias. A frota de } \\
\text { Cabral. As calmarias } \\
\text { e as correntezas do } \\
\text { mar. O monte } \\
\text { Pascoal. Porto } \\
\text { Seguro. A primeira e } \\
\text { a segunda missa. O } \\
\text { papa e a divisão do } \\
\text { mundo }\end{array}$ & $\begin{array}{l}\text { A expansão } \\
\text { marítima } \\
\text { portuguesa. Pedro } \\
\text { Álvares Cabral e } \\
\text { a descoberta do } \\
\text { Brasil }\end{array}$ & Brasil Colônia & $\begin{array}{l}\text { "O navegador } \\
\text { português" (imagem } \\
\text { de um português } \\
\text { supostamente lendo } \\
\text { a carta de Pero Vaz } \\
\text { de Caminha ao rei de } \\
\text { Portugal) }\end{array}$ \\
\hline $\begin{array}{l}\text { X-O lar de } \\
\text { Bartira }\end{array}$ & $\begin{array}{l}\text { As nossas primeiras } \\
\text { avós. João Ramalho. } \\
\text { A filha de Tibiriçá. } \\
\text { Os mamelucos. A } \\
\text { raça de gigantes }\end{array}$ & $\begin{array}{l}\text { Formação do } \\
\text { povo brasileiro. } \\
\text { Os mamelucos }\end{array}$ & Brasil Colônia & $\begin{array}{l}\text { "João Ramalho" } \\
\text { (João Ramalho } \\
\text { comunicando-se } \\
\text { com dois índios) }\end{array}$ \\
\hline $\begin{array}{l}\text { XI- O lar de } \\
\text { Paraguaçu }\end{array}$ & $\begin{array}{l}\text { Caramuru e a sua } \\
\text { espingarda. A linda } \\
\text { filha de Taparica. Na } \\
\text { corte francesa. A } \\
\text { grande mulher }\end{array}$ & $\begin{array}{l}\text { Formação do } \\
\text { povo brasileiro }\end{array}$ & Brasil Colônia & $\begin{array}{l}\text { "Os índios caíram de } \\
\text { joelhos" (Caramuru } \\
\text { e os índios } \\
\text { ajoelhados em } \\
\text { reverência) }\end{array}$ \\
\hline $\begin{array}{l}\text { XII- O lar de } \\
\text { Maria do Espírito } \\
\text { Santo }\end{array}$ & $\begin{array}{l}\text { Na taba dos } \\
\text { tabajaras. Jerônimo } \\
\text { de Albuquerque. A } \\
\text { hora da morte. O } \\
\text { romance de amor da } \\
\text { filha de Arcoverde }\end{array}$ & $\begin{array}{l}\text { Formação do } \\
\text { povo brasileiro }\end{array}$ & Brasil Colônia & $\begin{array}{l}\text { "A índia ameaça } \\
\text { suicidar-se" (Maria } \\
\text { do Espírito Santo } \\
\text { tenta salvar } \\
\text { Jerônimo de } \\
\text { Albuquerque) } \\
\end{array}$ \\
\hline $\begin{array}{l}\text { XIII- A desgraça } \\
\text { das capitanias }\end{array}$ & $\begin{array}{l}\text { O Brasil } \\
\text { abandonado. } \\
\text { Traficantes, } \\
\text { contrabandistas e } \\
\text { piratas. O pau-brasil. } \\
\text { Os doze canteiros. } \\
\text { Os capitães-mores. } \\
\text { Pernambuco e São } \\
\text { Vicente }\end{array}$ & $\begin{array}{l}\text { Colonização do } \\
\text { Brasil. As } \\
\text { capitanias } \\
\text { hereditárias }\end{array}$ & Brasil Colônia & $\begin{array}{l}\text { "Traficantes, } \\
\text { contrabandistas e } \\
\text { piratas negociando } \\
\text { com os índios" (o } \\
\text { escambo realizado } \\
\text { entre os índios e os } \\
\text { europeus) }\end{array}$ \\
\hline
\end{tabular}

${ }^{182}$ Os tópicos assemelham-se aos itens das unidades de um programa de ensino. 


\begin{tabular}{|c|c|c|c|c|}
\hline $\begin{array}{l}\text { CAPÍTULO/ } \\
\text { TíTULO }\end{array}$ & TÓPICOS $^{183}$ & ASSUNTO & $\begin{array}{c}\text { PERÍODO } \\
\text { HISTÓRICO }\end{array}$ & $\begin{array}{l}\text { IMAGENS - } \\
\text { DESCRIÇÃO }\end{array}$ \\
\hline $\begin{array}{l}\text { XIV- A triste } \\
\text { sorte de Vasco } \\
\text { Coutinho }\end{array}$ & $\begin{array}{l}\text { Na bela baía de } \\
\text { Vitória. A desordem } \\
\text { da capitania. Na } \\
\text { igreja de Olinda. A } \\
\text { morte de Vasco }\end{array}$ & $\begin{array}{l}\text { Colonização do } \\
\text { Brasil }\end{array}$ & Brasil Colônia & $\begin{array}{l}\text { "A triste sorte de } \\
\text { Vasco Coutinho" } \\
\text { (imagem de penúria } \\
\text { de Vasco Coutinho) }\end{array}$ \\
\hline $\begin{array}{l}\text { XV - A cana-de- } \\
\text { açúcar }\end{array}$ & $\begin{array}{l}\text { Os primeiros } \\
\text { canaviais. Os } \\
\text { primeiros engenhos } \\
\text { de açúcar. As } \\
\text { gulodices } \\
\text { açucaradas. O luxo } \\
\text { de Olinda }\end{array}$ & $\begin{array}{l}\text { Colonização do } \\
\text { Brasil. O ciclo do } \\
\text { açúcar }\end{array}$ & Brasil Colônia & $\begin{array}{l}\text { "O navio que trouxe } \\
\text { as primeiras mudas } \\
\text { de cana-de-açúcar" }\end{array}$ \\
\hline $\begin{array}{l}\text { XVI- As } \\
\text { primeiras boiadas }\end{array}$ & $\begin{array}{l}\text { A segunda viagem } \\
\text { de Colombo. Nos } \\
\text { campos de } \\
\text { Piratininga. O povo } \\
\text { paulista. O gado na } \\
\text { Bahia. A grande } \\
\text { riqueza }\end{array}$ & $\begin{array}{l}\text { Colonização do } \\
\text { Brasil. O ciclo da } \\
\text { pecuária }\end{array}$ & Brasil-Colônia & $\begin{array}{l}\text { "Os primeiros bois" } \\
\text { (imagem com gado e } \\
\text { com dois homens } \\
\text { que se assemelham } \\
\text { aos bandeirantes) }\end{array}$ \\
\hline $\begin{array}{l}\text { XVII- Os padres } \\
\text { jesuítas }\end{array}$ & $\begin{array}{l}\text { A Companhia de } \\
\text { Jesus. Os primeiros } \\
\text { jesuítas. A } \\
\text { dissolução dos } \\
\text { costumes. A } \\
\text { escravidão dos } \\
\text { selvagens. Os } \\
\text { escravizadores. A } \\
\text { água do batismo }\end{array}$ & $\begin{array}{l}\text { Colonização do } \\
\text { Brasil. O papel } \\
\text { civilizatório dos } \\
\text { jesuítas }\end{array}$ & Brasil Colônia & $\begin{array}{l}\text { "Os civilizados } \\
\text { dispunham os índios } \\
\text { contra os jesuítas, } \\
\text { convencendo-os de } \\
\text { que a água do } \\
\text { batismo era a causa } \\
\text { das pestes" }\end{array}$ \\
\hline $\begin{array}{l}\text { XVIII- Os } \\
\text { fundadores da } \\
\text { civilização } \\
\text { brasileira }\end{array}$ & $\begin{array}{l}\text { Os grandes jesuítas. } \\
\text { Manuel da Nóbrega. } \\
\text { José de Anchieta. } \\
\text { Antônio Vieira. }\end{array}$ & $\begin{array}{l}\text { Colonização do } \\
\text { Brasil. O papel } \\
\text { civilizatório dos } \\
\text { jesuítas }\end{array}$ & Brasil Colônia & "Anchieta" \\
\hline $\begin{array}{l}\text { XIX-As } \\
\text { primeiras cidades }\end{array}$ & $\begin{array}{l}\text { Palácios de palha. } \\
\text { Como se fundaram } \\
\text { as cidades. São } \\
\text { Vicente. Olinda. } \\
\text { Bahia. S. Paulo. Rio } \\
\text { de Janeiro }\end{array}$ & $\begin{array}{l}\text { Colonização do } \\
\text { Brasil. As } \\
\text { primeiras cidades. }\end{array}$ & Brasil Colônia & $\begin{array}{l}\text { "E surgiu a primeira } \\
\text { igreja..." }\end{array}$ \\
\hline $\begin{array}{l}\text { XX- Cidades que } \\
\text { eram aldeias }\end{array}$ & $\begin{array}{l}\text { A cerimônia de } \\
\text { fundação do Rio de } \\
\text { Janeiro. São Paulo } \\
\text { nos primeiros dias. } \\
\text { O berimbau do padre } \\
\text { Barnabé. O } \\
\text { esplendor de Olinda }\end{array}$ & $\begin{array}{l}\text { Colonização do } \\
\text { Brasil. A } \\
\text { fundação do Rio } \\
\text { de Janeiro e São } \\
\text { Paulo }\end{array}$ & Brasil Colônia & "Olinda" \\
\hline $\begin{array}{l}\text { XXI- O Eldorado } \\
\text { e as amazonas }\end{array}$ & $\begin{array}{l}\text { O país do ouro. O } \\
\text { reino da ilusão. } \\
\text { Francisco Orellana. } \\
\text { O grande rio. Os } \\
\text { índios uaupés. As } \\
\text { amazonas. As duas } \\
\text { mentiras }\end{array}$ & $\begin{array}{l}\text { Colonização do } \\
\text { Brasil. } \\
\text { Exploração do } \\
\text { Amazonas }\end{array}$ & Brasil Colônia & "As amazonas" \\
\hline
\end{tabular}

${ }^{183}$ Os tópicos assemelham-se aos itens das unidades de um programa de ensino. 


\begin{tabular}{|c|c|c|c|c|}
\hline $\begin{array}{l}\text { CAPÍTULO/ } \\
\text { TÍTULO }\end{array}$ & TÓPICOS $^{184}$ & ASSUNTO & $\begin{array}{c}\text { PERÍODO } \\
\text { HISTÓRICO }\end{array}$ & $\begin{array}{l}\text { IMAGENS - } \\
\text { DESCRIÇÃO }\end{array}$ \\
\hline $\begin{array}{l}\text { XXII- A França } \\
\text { Antártica }\end{array}$ & $\begin{array}{l}\text { Lutero e o papa. O } \\
\text { protestantismo. } \\
\text { Villegagnon e a } \\
\text { cidade dos } \\
\text { protestantes. } \\
\text { Villegagnon no Rio } \\
\text { de Janeiro }\end{array}$ & $\begin{array}{l}\text { Invasão francesa } \\
\text { no Rio de Janeiro }\end{array}$ & Brasil Colônia & "Villegagnon" \\
\hline $\begin{array}{l}\text { XXIII- O } \\
\text { Maranhão e os } \\
\text { franceses }\end{array}$ & $\begin{array}{l}\text { A jornada milagrosa. } \\
\text { O filho de Maria do } \\
\text { Espírito Santo. A } \\
\text { batalha de } \\
\text { Guaxenduba. La } \\
\text { Ravardière }\end{array}$ & $\begin{array}{l}\text { Invasão francesa } \\
\text { no Maranhão }\end{array}$ & Brasil Colônia & $\begin{array}{l}\text { "A esquadra } \\
\text { francesa aproxima- } \\
\text { se arrogantemente" }\end{array}$ \\
\hline $\begin{array}{l}\text { XXIV-A } \\
\text { conquista dos } \\
\text { holandeses }\end{array}$ & $\begin{array}{l}\text { A Holanda contra a } \\
\text { Espanha. A invasão } \\
\text { da Bahia. A invasão } \\
\text { de Pernambuco. O } \\
\text { heroísmo dos } \\
\text { pernambucanos. As } \\
\text { vitórias flamengas }\end{array}$ & $\begin{array}{l}\text { Invasão } \\
\text { holandesa no } \\
\text { Nordeste }\end{array}$ & Brasil Colônia & $\begin{array}{l}\text { "Henrique Dias, } \\
\text { Camarão e } \\
\text { Negreiros" (imagem } \\
\text { que reproduz o } \\
\text { nativismo na junção } \\
\text { das três raças contra } \\
\text { os holandeses) }\end{array}$ \\
\hline $\begin{array}{l}\text { XXV-O príncipe } \\
\text { de Nassau }\end{array}$ & $\begin{array}{l}\text { O esplendor de } \\
\text { Pernambuco. Os } \\
\text { palácios e as festas. } \\
\text { A obra de Nassau. } \\
\text { Por que o príncipe se } \\
\text { desgosta }\end{array}$ & $\begin{array}{l}\text { Governo holandês } \\
\text { em Pernambuco }\end{array}$ & Brasil Colônia & $\begin{array}{l}\text { "O príncipe de } \\
\text { Nassau" }\end{array}$ \\
\hline $\begin{array}{l}\text { XXVI- A queda } \\
\text { dos flamengos }\end{array}$ & $\begin{array}{l}\text { A ganância dos } \\
\text { flamengos. André } \\
\text { Vidal de Negreiros. } \\
\text { A guerra de } \\
\text { expulsão. O cerco de } \\
\text { Recife. As vitórias } \\
\text { brasileiras. A derrota } \\
\text { dos holandeses }\end{array}$ & $\begin{array}{l}\text { Insurreição } \\
\text { Pernambucana }\end{array}$ & Brasil Colônia & $\begin{array}{l}\text { "Compraram ratos } \\
\text { para matar a fome" }\end{array}$ \\
\hline $\begin{array}{l}\text { XXVII- O } \\
\text { primeiro ensaio }\end{array}$ & $\begin{array}{l}\text { O que não quis ser } \\
\text { rei. Amador Bueno } \\
\text { da Ribeira. A } \\
\text { aclamação. O } \\
\text { primeiro grito de } \\
\text { separação. }\end{array}$ & $\begin{array}{l}\text { A aclamação de } \\
\text { Amador Bueno } \\
\text { em SP }\end{array}$ & Brasil Colônia & $\begin{array}{l}\text { "Amador Bueno } \\
\text { chega à porta do } \\
\text { mosteiro de São } \\
\text { Bento" }\end{array}$ \\
\hline $\begin{array}{l}\text { XXVIII- Os } \\
\text { negros }\end{array}$ & $\begin{array}{l}\text { Os negreiros. A } \\
\text { viagem através do } \\
\text { mar. O martírio do } \\
\text { Brasil. Os } \\
\text { quilombos. }\end{array}$ & $\begin{array}{l}\text { Exploração da } \\
\text { mão-de-obra } \\
\text { escrava africana. }\end{array}$ & Brasil Colônia & $\begin{array}{l}\text { "Os escravos no } \\
\text { porão dos navios" }\end{array}$ \\
\hline XXIX- Palmares & $\begin{array}{l}\text { O rei Gangazuma. A } \\
\text { importância de } \\
\text { Palmares. Tentativas } \\
\text { para destruí-lo. O rei } \\
\text { Zambi. O exército de } \\
\text { Domingos Jorge } \\
\text { Velho. A destruição }\end{array}$ & $\begin{array}{l}\text { Resistência à } \\
\text { escravidão. O } \\
\text { quilombo de } \\
\text { Palmares e } \\
\text { Zumbi. }\end{array}$ & Brasil Colônia & $\begin{array}{l}\text { "Jorge Velho e seus } \\
\text { homens" }\end{array}$ \\
\hline
\end{tabular}

\footnotetext{
${ }^{184}$ Os tópicos assemelham-se aos itens das unidades de um programa de ensino.
} 


\begin{tabular}{|c|c|c|c|c|}
\hline $\begin{array}{c}\text { CAPÍTULO/ } \\
\text { TÍTULO }\end{array}$ & TÓPICOS $^{185}$ & ASSUNTO & $\begin{array}{c}\text { PERÍODO } \\
\text { HISTÓRICO }\end{array}$ & $\begin{array}{c}\text { IMAGENS - } \\
\text { DESCRIÇÃO }\end{array}$ \\
\hline $\begin{array}{l}\text { XXX- } \\
\text { Bandeirantes e } \\
\text { bandeiras }\end{array}$ & $\begin{array}{l}\text { Os paulistas. O que } \\
\text { era uma bandeira. } \\
\text { Em busca de } \\
\text { tesouros. A figura do } \\
\text { bandeirante. Os } \\
\text { grandes chefes de } \\
\text { bandeiras. }\end{array}$ & $\begin{array}{l}\text { O papel dos } \\
\text { bandeirantes na } \\
\text { expansão } \\
\text { territorial } \\
\text { brasileira }\end{array}$ & Brasil Colônia & "Bandeirante" \\
\hline $\begin{array}{l}\text { XXXI- Antonio } \\
\text { Raposo e Fernão } \\
\text { Dias }\end{array}$ & $\begin{array}{l}\text { O homem de aço. A } \\
\text { escravização dos } \\
\text { índios. Na } \\
\text { cordilheira dos } \\
\text { Andes. O caçador de } \\
\text { esmeraldas. A } \\
\text { traição. As pedras } \\
\text { verdes }\end{array}$ & $\begin{array}{l}\text { A bandeira de } \\
\text { Fernão Dias - o } \\
\text { caçador de } \\
\text { esmeraldas }\end{array}$ & Brasil Colônia & $\begin{array}{l}\text { "Fernão Dias manda } \\
\text { enforcar o próprio } \\
\text { filho" }\end{array}$ \\
\hline $\begin{array}{l}\text { XXXII- As minas } \\
\text { de ouro }\end{array}$ & $\begin{array}{l}\text { A transformação por } \\
\text { que passou o Brasil. } \\
\text { O formigueiro. A } \\
\text { loucura. O luxo. Os } \\
\text { nababos. A } \\
\text { decadência }\end{array}$ & O ciclo do ouro & Brasil Colônia & $\begin{array}{l}\text { "Até as negras } \\
\text { usavam sedas e } \\
\text { jóias" }\end{array}$ \\
\hline $\begin{array}{l}\text { XXXIII- As } \\
\text { pedras } \\
\text { maravilhosas }\end{array}$ & $\begin{array}{l}\text { O frade } \\
\text { desconhecido. Os } \\
\text { tentos dos jogos. } \\
\text { João Fernandes de } \\
\text { Oliveira e Chica da } \\
\text { Silva. Um navio em } \\
\text { pleno sertão mineiro. }\end{array}$ & $\begin{array}{l}\text { O ciclo do ouro e } \\
\text { a figura de Chica } \\
\text { da Silva }\end{array}$ & Brasil Colônia & $\begin{array}{l}\text { "Os tentos eram } \\
\text { diamantes" }\end{array}$ \\
\hline $\begin{array}{l}\text { XXXIV- } \\
\text { Paulistas e } \\
\text { emboabas }\end{array}$ & $\begin{array}{l}\text { Pinto calçudo. } \\
\text { Nunes Viana. O } \\
\text { frade diabólico e a } \\
\text { traição da meia- } \\
\text { noite. Bento do } \\
\text { Amaral Coutinho e a } \\
\text { carnificina do } \\
\text { "Capão da Traição". } \\
\text { As mulheres } \\
\text { paulistas. }\end{array}$ & $\begin{array}{l}\text { A guerra dos } \\
\text { emboabas }\end{array}$ & Brasil Colônia & $\begin{array}{l}\text { "As mulheres não } \\
\text { receberam os } \\
\text { maridos" }\end{array}$ \\
\hline $\begin{array}{l}\text { XXXV-O } \\
\text { corsário que } \\
\text { vencemos }\end{array}$ & $\begin{array}{l}\text { O trono de Espanha. } \\
\text { A invasão de } \\
\text { Duclerc. A moleza } \\
\text { do governador. A } \\
\text { cidade atacada. A } \\
\text { bravura dos } \\
\text { estudantes. A vitória }\end{array}$ & $\begin{array}{l}\text { A invasão dos } \\
\text { franceses no Rio } \\
\text { de Janeiro }\end{array}$ & Brasil Colônia & $\begin{array}{l}\text { "Os estudantes } \\
\text { investem sobre os } \\
\text { invasores" }\end{array}$ \\
\hline $\begin{array}{l}\text { XXXVI- O } \\
\text { corsário que nos } \\
\text { venceu }\end{array}$ & $\begin{array}{l}\text { A esquadra de } \\
\text { Duguay-Trouin. O } \\
\text { bombardeio da } \\
\text { cidade. O dilúvio. } \\
\text { Noite infernal. O que } \\
\text { se pagou ao corsário, } \\
\text { A deposição do } \\
\text { governador }\end{array}$ & $\begin{array}{l}\text { A invasão dos } \\
\text { franceses no Rio } \\
\text { de Janeiro }\end{array}$ & Brasil Colônia & $\begin{array}{l}\text { "A multidão que } \\
\text { fugia foi colhida } \\
\text { pelo temporal" }\end{array}$ \\
\hline
\end{tabular}

${ }^{185}$ Os tópicos assemelham-se aos itens das unidades de um programa de ensino. 


\begin{tabular}{|c|c|c|c|c|}
\hline $\begin{array}{l}\text { CAPÍTULO/ } \\
\text { TÍTULO }\end{array}$ & TÓPICOS $^{186}$ & ASSUNTO & $\begin{array}{c}\text { PERÍODO } \\
\text { HISTÓRICO }\end{array}$ & $\begin{array}{c}\text { IMAGENS - } \\
\text { DESCRIÇÃO }\end{array}$ \\
\hline $\begin{array}{l}\text { XXXVII- A linha } \\
\text { de Tordesilhas }\end{array}$ & $\begin{array}{l}\text { A partilha feita pelo } \\
\text { papa. As } 380 \text { léguas. } \\
\text { A linha divisória. Os } \\
\text { bandeirantes } \\
\text { aumentam nosso } \\
\text { território }\end{array}$ & $\begin{array}{l}\text { A expansão } \\
\text { territorial do } \\
\text { Brasil }\end{array}$ & Brasil Colônia & $\begin{array}{l}\text { "Vovô levantou-se } \\
\text { para nos explicar o } \\
\text { tratado de } \\
\text { Tordesilhas" }\end{array}$ \\
\hline $\begin{array}{l}\text { XXXVIII- O } \\
\text { sentimento da } \\
\text { independência }\end{array}$ & $\begin{array}{l}\text { As exigências de } \\
\text { Portugal. Tudo } \\
\text { proibido. O } \\
\text { desespero do povo. } \\
\text { Ânsias de liberdade. } \\
\text { Tiradentes. }\end{array}$ & $\begin{array}{l}\text { A crise do } \\
\text { sistema colonial }\end{array}$ & Brasil Colônia & $\begin{array}{l}\text { "D. João V examina } \\
\text { o ouro do Brasil"" }\end{array}$ \\
\hline $\begin{array}{l}\text { XXXIX- A figura } \\
\text { maravilhosa de } \\
\text { Tiradentes }\end{array}$ & $\begin{array}{l}\text { A Inconfidência } \\
\text { Mineira. A derrama. } \\
\text { Joaquim Silvério, o } \\
\text { traidor. A prisão de } \\
\text { Tiradentes. O } \\
\text { martírio dos } \\
\text { inconfidentes. A } \\
\text { alma que não se } \\
\text { abate. }\end{array}$ & $\begin{array}{l}\text { Tiradentes e a } \\
\text { Inconfidência } \\
\text { Mineira }\end{array}$ & Brasil Colônia & $\begin{array}{l}\text { "Tiradentes antes da } \\
\text { prisão" }\end{array}$ \\
\hline $\begin{array}{l}\text { XL- A morte de } \\
\text { Tiradentes }\end{array}$ & $\begin{array}{l}\text { O luxo da festa. O } \\
\text { mártir da liberdade. } \\
\text { A caminho da forca. } \\
\text { Na escada do } \\
\text { patíbulo. Idéia que } \\
\text { não morre }\end{array}$ & Tiradentes & Brasil Colônia & $\begin{array}{l}\text { "Tiradentes a } \\
\text { caminho da forca" }\end{array}$ \\
\hline $\begin{array}{l}\text { XLI- Os } \\
\text { costumes dos } \\
\text { nossos avós }\end{array}$ & $\begin{array}{l}\text { A família antiga. As } \\
\text { festas. O entrudo. } \\
\text { Cadeirinhas e } \\
\text { liteiras. Os enterros. } \\
\text { Bailes nas igrejas }\end{array}$ & $\begin{array}{l}\text { O cotidiano da } \\
\text { família patriarcal } \\
\text { brasileira }\end{array}$ & Brasil Colônia & $\begin{array}{l}\text { "Costumes dos } \\
\text { nossos avós" }\end{array}$ \\
\hline $\begin{array}{l}\text { XLII- Grandes } \\
\text { homens }\end{array}$ & $\begin{array}{l}\text { A Bahia no século } \\
\text { XVII. Minas do } \\
\text { século XVIII. O } \\
\text { maior acontecimento } \\
\text { científico. } \\
\text { Bartolomeu de } \\
\text { Gusmão e a } \\
\text { Passarola } \\
\end{array}$ & $\begin{array}{l}\text { Grandes nomes } \\
\text { que contribuíram } \\
\text { para o } \\
\text { desenvolvimento } \\
\text { sociocultural da } \\
\text { Colônia }\end{array}$ & Brasil Colônia & $\begin{array}{l}\text { "Bartolomeu de } \\
\text { Gusmão e a } \\
\text { Passarola" }\end{array}$ \\
\hline $\begin{array}{l}\text { XLIII- A mesa } \\
\text { brasileira }\end{array}$ & $\begin{array}{l}\text { Os pratos herdados } \\
\text { do branco e do índio. } \\
\text { O leitão assado. O } \\
\text { leite de coco. Os } \\
\text { azeites e as } \\
\text { pimentas. As } \\
\text { moquecas. O piracuí. }\end{array}$ & $\begin{array}{l}\text { A culinária } \\
\text { brasileira }\end{array}$ & Brasil Colônia & $\begin{array}{l}\text { "A cozinha brasileira } \\
\text { veio do índio, do } \\
\text { negro e do branco" }\end{array}$ \\
\hline
\end{tabular}

\footnotetext{
${ }^{186}$ Os tópicos assemelham-se aos itens das unidades de um programa de ensino.
} 


\begin{tabular}{|c|c|c|c|c|}
\hline $\begin{array}{l}\text { CAPÍTULO/ } \\
\text { TÍTULO }\end{array}$ & TÓPICOS $^{187}$ & ASSUNTO & $\begin{array}{c}\text { PERÍODO } \\
\text { HISTÓRICO }\end{array}$ & $\begin{array}{c}\text { IMAGENS - } \\
\text { DESCRIÇÃO }\end{array}$ \\
\hline $\begin{array}{l}\text { XLIV- A chegada } \\
\text { da corte } \\
\text { portuguesa }\end{array}$ & $\begin{array}{l}\text { As festas da } \\
\text { chegada. Napoleão I } \\
\text { e a invasão de } \\
\text { Portugal. A fuga } \\
\text { para o Brasil. As } \\
\text { vantagens que } \\
\text { obtivemos. De } \\
\text { colônia a Reino }\end{array}$ & $\begin{array}{l}\text { O governo } \\
\text { joanino. }\end{array}$ & $\begin{array}{l}\text { Brasil Reino } \\
\text { Unido }\end{array}$ & "O rei D. João VI" \\
\hline $\begin{array}{l}\text { XLV- Os } \\
\text { sonhadores de } \\
1817\end{array}$ & $\begin{array}{l}\text { Domingos José } \\
\text { Martins e outros } \\
\text { revolucionários. } \\
\text { Como rebentou a } \\
\text { revolução. A derrota } \\
\text { dos republicanos. A } \\
\text { cabeça do padre } \\
\text { João Ribeiro. Os que } \\
\text { morreram pela } \\
\text { República }\end{array}$ & $\begin{array}{l}\text { Revolução de } \\
1817\end{array}$ & $\begin{array}{l}\text { Brasil Reino } \\
\text { Unido }\end{array}$ & $\begin{array}{l}\text { "Vencera a } \\
\text { revolução" }\end{array}$ \\
\hline XLVI- O Fico & $\begin{array}{l}\text { Governo } \\
\text { constitucional e } \\
\text { governo absoluto. A } \\
\text { revolução } \\
\text { portuguesa. A } \\
\text { partida do rei. Os } \\
\text { patriotas brasileiros } \\
\text { e a independência. } \\
\text { Diga ao povo que } \\
\text { fico. Os batalhões e } \\
\text { o povo }\end{array}$ & $\begin{array}{l}\text { Regência de } \\
\text { Pedro }\end{array}$ & $\begin{array}{l}\text { Brasil Reino } \\
\text { Unido }\end{array}$ & $\begin{array}{l}\text { "Como é para o bem } \\
\text { de todos e felicidade } \\
\text { geral da nação, diga } \\
\text { ao povo que fico" }\end{array}$ \\
\hline $\begin{array}{l}\text { XLVII- Na colina } \\
\text { do Ipiranga }\end{array}$ & $\begin{array}{l}\text { De Santos a São } \\
\text { Paulo. A chegada de } \\
\text { Paulo Bergaro. As } \\
\text { ordens de Portugal. } \\
\text { Independência ou } \\
\text { Morte! Laços fora! }\end{array}$ & $\begin{array}{l}\text { A Independência } \\
\text { do Brasil, no } \\
\text { Ipiranga }\end{array}$ & $\begin{array}{l}\text { Brasil Reino } \\
\text { Unido }\end{array}$ & $\begin{array}{l}\text { "Independência ou } \\
\text { Morte!" }\end{array}$ \\
\hline $\begin{array}{l}\text { XLVIII- A } \\
\text { dissolução da } \\
\text { Constituinte }\end{array}$ & $\begin{array}{l}\text { A briga de José } \\
\text { Bonifácio com o } \\
\text { imperador. O } \\
\text { farmacêutico do } \\
\text { Largo da Carioca. A } \\
\text { prisão de José } \\
\text { Bonifácio e de seus } \\
\text { amigos. }\end{array}$ & $\begin{array}{l}\text { Convocação e } \\
\text { dissolução da } 1^{\mathrm{a}} \\
\text { Assembléia } \\
\text { Constituinte }\end{array}$ & Brasil Império & $\begin{array}{l}\text { "Antonio Carlos } \\
\text { cumprimenta o } \\
\text { canhão" }\end{array}$ \\
\hline $\begin{array}{l}\text { XLIX- Os } \\
\text { republicanos de } \\
1824\end{array}$ & $\begin{array}{l}\text { A revolução de } \\
\text { Pernambuco. A } \\
\text { infelicidade das } \\
\text { forças republicanas. } \\
\text { Na fazenda "Juiz". } \\
\text { Os patriotas } \\
\text { sacrificados. A } \\
\text { morte de Frei } \\
\text { Caneca }\end{array}$ & $\begin{array}{l}\text { A Confederação } \\
\text { do Equador }\end{array}$ & Brasil Império & $\begin{array}{l}\text { "A execução de Frei } \\
\text { Caneca" }\end{array}$ \\
\hline
\end{tabular}

${ }^{187}$ Os tópicos assemelham-se aos itens das unidades de um programa de ensino. 


\begin{tabular}{|c|c|c|c|c|}
\hline $\begin{array}{l}\text { CAPÍTULO/ } \\
\text { TÍTULO }\end{array}$ & TÓPICOS $^{188}$ & ASSUNTO & $\begin{array}{c}\text { PERÍODO } \\
\text { HISTÓRICO }\end{array}$ & $\begin{array}{l}\text { IMAGENS - } \\
\text { DESCRIÇÃO }\end{array}$ \\
\hline L- Sete de abril & $\begin{array}{l}\text { Pedro I repelido pelo } \\
\text { povo. Sinos } \\
\text { dobrando a finados. } \\
\text { A "noite das } \\
\text { garrafadas". A } \\
\text { demissão dos } \\
\text { ministros queridos } \\
\text { do povo. A } \\
\text { revolução. A } \\
\text { abdicação }\end{array}$ & $\begin{array}{l}\text { A abdicação de } \\
\text { D. Pedro I }\end{array}$ & Brasil Império & $\begin{array}{l}\text { "Pedro I assina a } \\
\text { abdicação" }\end{array}$ \\
\hline $\begin{array}{l}\text { LI- Nove anos de } \\
\text { sangue }\end{array}$ & $\begin{array}{l}\text { A Regência. } \\
\text { Brasileiros contra } \\
\text { brasileiros. Guerras } \\
\text { e guerras. Os } \\
\text { salvadores do País. } \\
\text { A grande figura do } \\
\text { padre Feijó. }\end{array}$ & $\begin{array}{l}\text { O período } \\
\text { regencial e as } \\
\text { rebeliões } \\
\text { provinciais }\end{array}$ & Brasil Império & $\begin{array}{l}\text { "D. Pedro II e o } \\
\text { regente Feijó" }\end{array}$ \\
\hline $\begin{array}{l}\text { LII- O reinado do } \\
\text { homem pacífico }\end{array}$ & $\begin{array}{l}\text { A maioridade de D. } \\
\text { Pedro II. } \\
\text { Governando aos } 14 \\
\text { anos. A nobre figura } \\
\text { do imperador. A paz } \\
\text { entre os brasileiros. }\end{array}$ & $\begin{array}{l}\text { O governo de D. } \\
\text { Pedro II }\end{array}$ & Brasil Império & $\begin{array}{l}\text { "D. Pedro II aos sete } \\
\text { anos de idade" }\end{array}$ \\
\hline $\begin{array}{l}\text { LIII- A guerra do } \\
\text { Paraguai }\end{array}$ & $\begin{array}{l}\text { Solano Lopez, o } \\
\text { presidente dos } \\
\text { paraguaios. A } \\
\text { provocação da } \\
\text { guerra. O } \\
\text { aprisionamento do } \\
\text { "Marquês de } \\
\text { Olinda". Cinco anos } \\
\text { de sangue. Os heróis } \\
\text { brasileiros. }\end{array}$ & $\begin{array}{l}\text { A Guerra do } \\
\text { Paraguai (1864- } \\
1870)\end{array}$ & Brasil Império & "O general Osório" \\
\hline $\begin{array}{l}\text { LIV- Riachuelo e } \\
\text { Tuiuti }\end{array}$ & $\begin{array}{l}\text { "O Brasil espera que } \\
\text { cada um cumpra o } \\
\text { seu dever". } \\
\text { "Sustentem o fogo } \\
\text { que a vitória é } \\
\text { nossa". A } \\
\text { canhoneira Parnaíba. } \\
\text { A luta em Tuiuti. } \\
\text { Cinco horas de fogo. }\end{array}$ & $\begin{array}{l}\text { A Guerra do } \\
\text { Paraguai (1864- } \\
1870)\end{array}$ & Brasil Império & $\begin{array}{l}\text { "O Duque de } \\
\text { Caxias" }\end{array}$ \\
\hline $\begin{array}{l}\text { LV- Um figurão } \\
\text { da nossa história }\end{array}$ & $\begin{array}{l}\text { Na África e na } \\
\text { Arábia. Como } \\
\text { chegou à América o } \\
\text { primeiro pé de café. } \\
\text { Francisco de Melo } \\
\text { Palheta em Caiena. } \\
\text { As sementes de café } \\
\text { e a mulher do } \\
\text { governador }\end{array}$ & $\begin{array}{l}\text { A introdução do } \\
\text { café no Brasil }\end{array}$ & Brasil Império & $\begin{array}{l}\text { "Palheta gostou do } \\
\text { café" }\end{array}$ \\
\hline
\end{tabular}

\footnotetext{
${ }^{188}$ Os tópicos assemelham-se aos itens das unidades de um programa de ensino.
} 


\begin{tabular}{|c|c|c|c|c|}
\hline $\begin{array}{l}\text { CAPÍTULO/ } \\
\text { TÍTULO }\end{array}$ & TÓPICOS ${ }^{189}$ & ASSUNTO & $\begin{array}{c}\text { PERÍODO } \\
\text { HISTÓRICO }\end{array}$ & $\begin{array}{c}\text { IMAGENS - } \\
\text { DESCRIÇÃO }\end{array}$ \\
\hline $\begin{array}{l}\text { LVI- Ainda o } \\
\text { figurão }\end{array}$ & $\begin{array}{l}\text { O café no Pará. O } \\
\text { café no Rio de } \\
\text { Janeiro. O } \\
\text { desembargador } \\
\text { Castelo Branco. O } \\
\text { padre Couto. Na } \\
\text { terra paulista. } \\
\text { Benditas as mãos de } \\
\text { Mme. Claudel. }\end{array}$ & $\begin{array}{l}\text { A expansão da } \\
\text { cultura cafeeira. }\end{array}$ & Brasil Império & $\begin{array}{l}\text { "Os frades } \\
\text { barbadinhos } \\
\text { plantaram o cafeeiro } \\
\text { no quintal do } \\
\text { convento" }\end{array}$ \\
\hline LVII- 13 de maio & $\begin{array}{l}\text { A mancha da } \\
\text { escravidão. Os } \\
\text { grandes } \\
\text { abolicionistas. O } \\
\text { jangadeiro do Ceará. } \\
\text { A lei da abolição. A } \\
\text { princesa Isabel. As } \\
\text { festas }\end{array}$ & $\begin{array}{l}\text { Abolição da } \\
\text { escravidão (1888) }\end{array}$ & Brasil Império & $\begin{array}{l}\text { "A alegria foi } \\
\text { intensa" }\end{array}$ \\
\hline $\begin{array}{l}\text { LVIII- } 15 \text { de } \\
\text { novembro }\end{array}$ & $\begin{array}{l}\text { Os chefes } \\
\text { republicanos. } \\
\text { Deodoro da Fonseca. } \\
\text { O boato do major } \\
\text { Solano. A revolução } \\
\text { nos quartéis. No } \\
\text { quartel general. A } \\
\text { república. O } \\
\text { Ministério } \\
\end{array}$ & $\begin{array}{l}\text { A Proclamação } \\
\text { da República }\end{array}$ & Brasil Império & $\begin{array}{l}\text { "O marechal } \\
\text { Deodoro" }\end{array}$ \\
\hline $\begin{array}{l}\text { LIX- Palavras do } \\
\text { fim }\end{array}$ & $\begin{array}{l}\text { Da Inconfidência } \\
\text { Mineira à República, } \\
\text { Os grandes } \\
\text { brasileiros. A } \\
\text { história que devemos } \\
\text { prezar. O Brasil de } \\
\text { amanhã }\end{array}$ & $\begin{array}{l}\text { Os grandes } \\
\text { homens que } \\
\text { integram o } \\
\text { Panteão da Pátria. } \\
\text { Exemplo a ser } \\
\text { seguido pelas } \\
\text { crianças }\end{array}$ & & "Estudar sempre!" \\
\hline
\end{tabular}

${ }^{189}$ Os tópicos assemelham-se aos itens das unidades de um programa de ensino. 


\section{ANEXO 2 - LIVROS DIDÁTICOS PARA O ENSINO DE HISTÓRIA NA ESCOLA PRIMÁRIA (1930-1960) ACERVO: BIBLIOTECA DO LIVRO DIDÁTICO - FEUSP}

\begin{tabular}{|c|c|c|c|c|}
\hline AUTOR & TÍTULO & $\begin{array}{l}\text { EDIÇÃO/ } \\
\text { ANO }\end{array}$ & EDITORA & OBSERVAÇÕES \\
\hline $\begin{array}{l}\text { CORRÊA, } \\
\text { Viriato }\end{array}$ & $\begin{array}{l}\text { História do Brasil } \\
\text { para crianças }\end{array}$ & $\begin{array}{l}19 \text { ed ( } 110 \\
\text { milheiros), } \\
1955\end{array}$ & $\begin{array}{l}\text { Companhia Editora } \\
\text { Nacional }\end{array}$ & $\begin{array}{l}\text { Exemplar integrante da } \\
\text { BLD (série 1- v. 13) }\end{array}$ \\
\hline $\begin{array}{l}\text { POMBO, José } \\
\text { Francisco } \\
\text { Rocha }\end{array}$ & $\begin{array}{l}\text { História do Brasil } \\
\text { para o ensino } \\
\text { elementar }\end{array}$ & $22^{a}$ ed., 1943 & Melhoramentos & $\begin{array}{l}\text { Contém sinopse dos } \\
\text { Cinco séculos da nossa } \\
\text { História, além de mapas } \\
\text { históricos e gravuras } \\
\text { explicativas }\end{array}$ \\
\hline POMBO, Rocha & $\begin{array}{l}\text { Nossa Pátria } \\
\text { (narração dos } \\
\text { factos da História } \\
\text { do Brasil, através } \\
\text { de sua evolução } \\
\text { com muitas } \\
\text { gravuras } \\
\text { explicativas) }\end{array}$ & $67^{\mathrm{a}}$ ed., 1925 & Melhoramentos & $\begin{array}{l}\text { Este livro, cuja primeira } \\
\text { edição é de } 1917, \\
\text { circulou até o final da } \\
\text { década de } 60, \text { numa } \\
\text { edição revista e } \\
\text { atualizada por Lourenço } \\
\text { Filho. }\end{array}$ \\
\hline $\begin{array}{l}\text { LOBO, } \\
\text { Esmeralda A. }\end{array}$ & $\begin{array}{l}\text { História do Brasil } \\
\text { (série de mapas e } \\
\text { quadros sinóticos) }\end{array}$ & $5^{\mathrm{a}}$ ed., 1938 & $\begin{array}{l}\text { J.R. de Oliveira \& } \\
\text { Cia Editores }\end{array}$ & $\begin{array}{l}\text { Desenhos históricos do } \\
\text { Prof. Magalhães Corrêa, } \\
\text { aprovados pelos } \\
\text { Conselho de Educação } \\
\text { do DF, Conselho de } \\
\text { Instrução Pública do } \\
\text { Estado de Minas Gerais e } \\
\text { Diretoria de Instrução } \\
\text { Pública dos Estados de } \\
\text { Pernambuco, Ceará e } \\
\text { Pará. }\end{array}$ \\
\hline $\begin{array}{l}\text { TAUNAY, } \\
\text { Alfredo D'E e } \\
\text { ACCIOLI, } \\
\text { Roberto }\end{array}$ & $\begin{array}{l}\text { História do Brasil } \\
\text { para o exame de } \\
\text { admissão (de } \\
\text { acordo com o } \\
\text { programa } \\
\text { elaborado pela } \\
\text { Congregação do } \\
\text { Colégio Pedro II, } \\
\text { aos } 29 \text { de } \\
\text { dezembro de } \\
\text { 1959, e aprovado } \\
\text { pelo Ministro da } \\
\text { Educação e } \\
\text { Cultura, em } \\
\text { 13/01/1960 }\end{array}$ & 1961 & $\begin{array}{l}\text { Companhia Editora } \\
\text { Nacional }\end{array}$ & $\begin{array}{l}\text { O livro traz o programa } \\
\text { de História do Brasil para } \\
\text { o exame de admissão no } \\
\text { Colégio Pedro II }(*)\end{array}$ \\
\hline $\begin{array}{l}\text { LIMA, } \\
\text { Hildebrando de }\end{array}$ & $\begin{array}{l}\text { Lições do Tio } \\
\text { Emílio }\end{array}$ & $39^{\mathrm{a}}$ ed., 1953 & $\begin{array}{l}\text { Companhia Editora } \\
\text { Nacional }\end{array}$ & $\begin{array}{l}\text { Livro destinado ao quarto } \\
\text { grau primário, com } \\
\text { apêndice de História, } \\
\text { Geografia, Ciências } \\
\text { Naturais e Aritmética. } \\
\text { Autorizado pelo MEC } \\
\text { (registro no } 2.106 \text { ) }\end{array}$ \\
\hline
\end{tabular}




\begin{tabular}{|c|c|c|c|c|}
\hline AUTOR & TÍTULO & $\begin{array}{c}\text { EDIÇÃO/ } \\
\text { ANO }\end{array}$ & EDITORA & OBSERVAÇÕES \\
\hline $\begin{array}{l}\text { MARTINEZ, } \\
\text { César }\end{array}$ & $\begin{array}{l}\text { A linda história } \\
\text { do meu paiz }\end{array}$ & $4^{\mathrm{a}}$ ed., 1932 & $\begin{array}{l}\text { Livraria Francisco } \\
\text { Alves (série vida } \\
\text { escolar) }\end{array}$ & $\begin{array}{l}\text { Obra aprovada pela } \\
\text { Diretoria Geral de } \\
\text { Instrução Pública de SP, } \\
\text { destinada ao } 4^{\circ} \text { ano do } \\
\text { curso primário. }\end{array}$ \\
\hline SILVA, J. Pinto & $\begin{array}{l}\text { Minha Pátria }\left(3^{\circ}\right. \\
\text { anno) }\end{array}$ & $20^{\mathrm{a}}$ ed., 1930 & Typografia Siqueira & $\begin{array}{l}\text { Obra approvada e } \\
\text { adoptada pelos governos } \\
\text { do Estado de SP, outros } \\
\text { estados e escolas } \\
\text { particulares. }\end{array}$ \\
\hline $\begin{array}{l}\text { CALMON, } \\
\text { Pedro }\end{array}$ & $\begin{array}{l}\text { Pequena História } \\
\text { da Civilização } \\
\text { Brasileira para a } \\
\text { escola primária }\end{array}$ & $3^{\mathrm{a}}$ ed., 1938 & $\begin{array}{l}\text { Companhia Editora } \\
\text { Nacional }\end{array}$ & $\begin{array}{l}\text { O livro integra a } 2^{\text {a }} \text { Série } \\
\text { Livros Didáticos } \\
\text { (manuais, livros de texto } \\
\text { e livros-fontes) da BPB } \\
\text { (vol. 32), sob a direção } \\
\text { de Fernando de Azevedo. } \\
\text { O autor dirige uma } \\
\text { "Carta aos professores" } \\
\text { em que mostra a } \\
\text { inovação trazida pelo } \\
\text { livro, ajustado ao } \\
\text { Programa de Ciências } \\
\text { Sociais do Departamento } \\
\text { de Educação do DF. }\end{array}$ \\
\hline $\begin{array}{l}\text { THOMAS, } \\
\text { Cláudio Maria }\end{array}$ & $\begin{array}{l}\text { Primeiras Lições } \\
\text { de História do } \\
\text { Brasil (perguntas } \\
\text { e respostas) }\end{array}$ & $\begin{array}{l}\text { Não consta } \\
\text { edição. } 1952\end{array}$ & $\begin{array}{l}\text { O livro pertence à } \\
\text { Coleção de Livros } \\
\text { Didáticos da FTD, } \\
\text { pertencente aos Irmãos } \\
\text { Maristas, mas foi } \\
\text { impresso pela Livraria } \\
\text { Francisco Alves }\end{array}$ & $\begin{array}{l}\text { Por ser livro pertencente } \\
\text { a uma congregação } \\
\text { religiosa, possui o } \\
\text { REIMPRIMATUR(autor } \\
\text { ização da Igreja Católica } \\
\text { para circulação e adoção) }\end{array}$ \\
\hline $\begin{array}{l}\text { SANTOS, } \\
\text { Theobaldo de } \\
\text { Miranda }\end{array}$ & $\begin{array}{l}\text { Vamos estudar? } \\
\left(2^{\mathrm{a}} \text { série primária }\right)\end{array}$ & $5^{\mathrm{a}}$ ed., 1952 & Livraria Agir Editora & $\begin{array}{l}\text { Livro rigorosamente de } \\
\text { acordo com os programas } \\
\text { oficiais. O autor foi } \\
\text { membro da Comissão } \\
\text { Nacional do Livro } \\
\text { Didático. }\end{array}$ \\
\hline $\begin{array}{l}\text { SILVA, } \\
\text { Joaquim e } \\
\text { PENTEADO, } \\
\text { José de Arruda } \\
\text { (História do } \\
\text { Brasil), } \\
\text { AZEVEDO, } \\
\text { Aroldo de } \\
\text { (Geografia), } \\
\text { CRETELLA } \\
\text { JÚNIOR, José } \\
\text { (Português) e } \\
\text { SANGIORGI, } \\
\text { Osvaldo } \\
\text { (Matemática) }\end{array}$ & $\begin{array}{l}\text { Programa de } \\
\text { Admissão } 190\end{array}$ & $4^{\mathrm{a}}$ ed., 1958 & $\begin{array}{l}\text { Companhia Editora } \\
\text { Nacional }\end{array}$ & $\begin{array}{l}\text { Obra de acordo com os } \\
\text { novos programas, } \\
\text { conforme Portaria } \\
\text { Ministerial } \mathrm{n}^{\circ} 501 \text {, de } \\
19.05 .1952^{191}\end{array}$ \\
\hline
\end{tabular}

${ }^{190}$ O livro traz orientações para o aluno de como se preparar para o exame de admissão: “a) orientação para prova escrita: a prova escrita de História do Brasil constará de 20 (vinte) questões simples e objetivas sobre o programa da disciplina. Dez dessas questões devem versar sobre o Brasil independente. No julgamento em conjunto da prova serão atribuídos até 10 (dez) pontos; b) orientação para a prova oral: a prova oral constará de argüição sobre um ponto sorteado dentre 20 (vinte) formulados sobre a matéria constante do programa." (p. 143) 


\begin{tabular}{|c|c|c|c|c|}
\hline AUTOR & TÍTULO & $\begin{array}{c}\text { EDIÇÃO/ } \\
\text { ANO }\end{array}$ & EDITORA & OBSERVAÇÕES \\
\hline $\begin{array}{l}\text { RANGEL, Luís } \\
\text { Cardoso e } \\
\text { RANGEL, } \\
\text { Artur Cardoso }\end{array}$ & $\begin{array}{l}\text { Exames de } \\
\text { Admissão (síntese } \\
\text { de matéria) }\end{array}$ & $18^{\mathrm{a}}$ ed., 1958 & $\begin{array}{l}\text { Editora Livraria } \\
\text { Católica }\end{array}$ & \\
\hline $\begin{array}{l}\text { PEIXOTO, } \\
\text { Vicente }\end{array}$ & $\begin{array}{l}\text { Coração Infantil } \\
\text { (quinto ano e } \\
\text { admissão ao } \\
\text { ginásio) }\end{array}$ & 1957 & $\begin{array}{l}\text { Edições } \\
\text { Melhoramentos }\end{array}$ & $\begin{array}{l}\text { O livro é uma coletânea } \\
\text { de textos de Língua } \\
\text { Portuguesa, com pontos } \\
\text { de História, Geografia, } \\
\text { Ciências Naturais e } \\
\text { Higiene, ao final de cada } \\
\text { lição. }\end{array}$ \\
\hline
\end{tabular}

${ }^{191}$ Programa Oficial (segundo Portaria Ministerial no 501, de 19.05.1952), p. 12.

\section{HISTÓRIA:}

- Descobrimento da América; Colombo.

- Descobrimento do Brasil; Cabral.

- Capitanias Hereditárias.

- Os três primeiros governadores gerais.

- Invasão do Rio de Janeiro pelos franceses. Fundação da Cidade; Estácio de Sá.

- Invasões holandesas; Matias de Albuquerque, Henrique Dias e Felipe Camarão.

- Entradas e bandeiras; Antônio Raposo Tavares e Fernão Dias Paes.

- Conjuração Mineira; Tiradentes. Transmigração da família real de Portugal para o Brasil; D. João VI.

- Independência; D. Pedro I. José Bonifácio, Gonçalves Ledo.

- Período regencial; Padre Feijó.

- O segundo reinado; D. Pedro II.

- Guerra do Paraguai; Osório e Caxias.

- Abolição do cativeiro; Princesa Isabel, José do Patrocínio e Joaquim Nabuco.

- Proclamação da República; Deodoro, Floriano Peixoto, Benjamim Constant, Rui Barbosa.

- Governos republicanos; contribuição ao progresso do Brasil. 


\section{ANEXO 3 - CRONOLOGIA DA PRODUÇÃO LITERÁRIA DE VIRIATO CORRÊA (1884-1967)}

- 1903

- Minaretes (contos).

- 1907

- Fafazinho (periódico infantil, em colaboração com Osmundo Pimentel).

- 1908

- Era uma vez... contos infantis (em co-autoria com Paulo Barreto - o João do Rio - , literatura infantil).

- 1912

- Contos do sertão (contos).

- 1915

- Sertaneja (teatro).

- 1916

- Manjerona (teatro).

- 1917

- Morena (teatro).

- 1918

- Sol do sertão (teatro).

- 1920

- Sapequinha (teatro).

- 1921

- Novelas doidas (contos);

- Histórias da nossa História (crônica histórica);

- Terra de Santa Cruz (crônica histórica);

- Contos da História do Brasil (livro infantil).

- 1924

- Nossa gente (teatro);

- Zuzu (teatro).

- 1926

- Uma noite de baile (teatro). 
- 1927

- Balaiada (romance histórico);

- Baú velho (crônica histórica);

- Brasil dos meus avós (crônica histórica);

- Pequetita (teatro).

- 1928

- Histórias ásperas (conto);

- Varinha de condão (literatura infantil).

- 1930

- Arca de Noé (literatura infantil);

- A descoberta do Brasil (literatura infantil).

- 1931

- Bombonzinho (teatro);

- A macacada (literatura infantil);

- Os meus bichinhos (literatura infantil);

- No reino da bicharada (literatura infantil);

- Quando Jesus nasceu (literatura infantil).

- 1932

- Gaveta de sapateiro: miudezas desarrumadas da história nacional (crônica histórica);

- Sansão (teatro).

- 1933

- Maria (teatro).

- 1934

- Alcovas da história (crônica histórica);

- Mata galego (crônica histórica);

- História do Brasil para crianças (literatura infantil).

- 1935

- Meu torrão (contos da História Pátria) (literatura infantil).

- 1936

- Bico papão (teatro);

- Casa de Belchior (crônica histórica);

- O homem da cabeça de ouro (teatro). 
- 1938

- Bichos e bichinhos (literatura infantil);

- Carneiro de batalhão (teatro);

- A Marquesa de Santos (teatro);

- Cazuza (literatura infantil).

- 1939

- História de Caramuru (literatura infantil);

- O país do pau de tinta (crônica histórica).

- 1940

- O caçador de esmeraldas (teatro).

- 1941

- Rei de papelão (teatro);

- Tiradentes (comédia histórica).

- 1942

- Caxias, o pacificador do Brasil (crônica histórica);

- Pobre diabo (teatro).

- 1943

- O gato comeu (teatro);

- O príncipe encantado (teatro).

- 1944

- À sombra dos laranjais ${ }^{192}$ (teatro).

- 1945

- A Bandeira das esmeraldas (literatura infantil);

- Estão cantando as cigarras (teatro).

- 1946

- Venha a nós (teatro).

- 1948

- As belas histórias da História do Brasil (literatura infantil).

- 1949

- Dinheiro é dinheiro (teatro).

192 Esta peça de teatro foi adaptada para novela e transmitida pela Rede Globo de Televisão, com título homônimo, em 1977, no horário das 18 h. 
- 1955

- Curiosidades da História do Brasil (literatura infantil).

- 1956

- Discursos na Academia Brasileira de Letras, em colaboração de Josué Montello.

- 1959

- O grande amor de Gonçalves Dias (teatro).

- 1962

- O mistério de MMM (romance);

- História da liberdade no Brasil (literatura infantil). 